Prepared in cooperation with (in alphabetical order) Antero Resources, Bureau of Land Management, Bureau of Reclamation, Chevron Corporation, City of Grand Junction and City of Rifle, Colo., Colorado Department of Agriculture, Colorado Department of Natural Resources, Colorado Department of Public Health and Environment, Colorado Division of Wildlife-River Watch, Colorado Oil and Gas Conservation Commission, Colorado River Water Conservation District, Delta County, Colo., EnCana Oil \& Gas (USA) Inc., Garfield County, Colo., Gunnison Energy Corp., National Park Service, Natural Soda, Inc., North Fork River Improvement Association, Oxy Petroleum Corporation, Petroleum Development Corp., Rio Blanco County, Shell Oil Company, Solvay Chemicals, Towns of Carbondale, De Beque, Palisade, Parachute, Rangely, and Silt, Colo., U.S. Forest Service, West Divide Water Conservancy District, and Williams Companies, Inc.

\title{
Characterization and Data-Gap Analysis of Surface-Water Quality in the Piceance Study Area, Western Colorado, 1959-2009
}

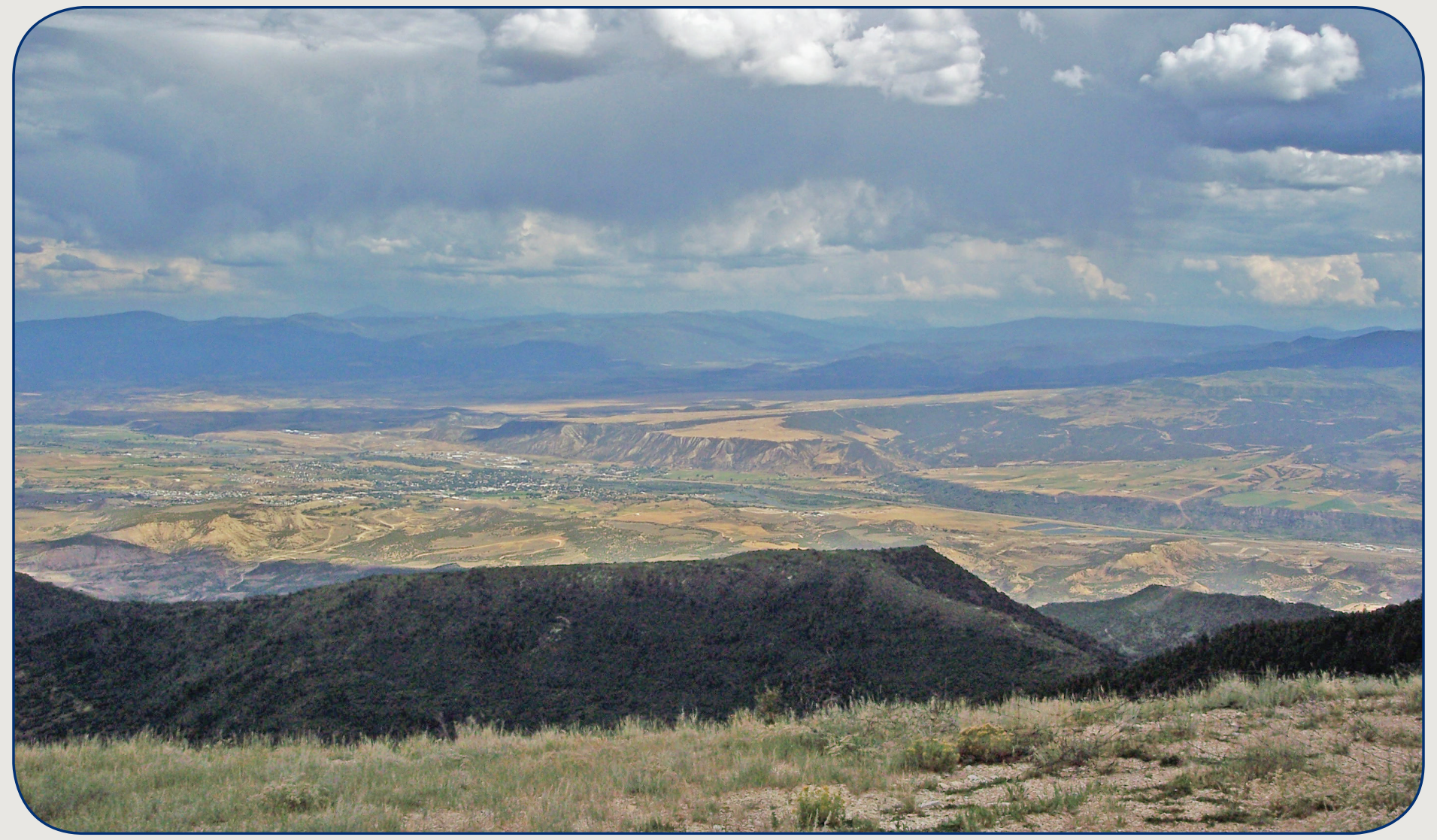

Scientific Investigations Report 2013-5015 
Cover. View of the Colorado River valley from the Roan Cliffs near Rifle, Colorado. Photo by Kirby Wynn, U.S. Geological Survey. 


\title{
Characterization and Data-Gap Analysis of Surface-Water Quality in the Piceance Study Area, Western Colorado, 1959-2009
}

By Judith C. Thomas, Jennifer L. Moore, Keelin R. Schaffrath, Jean A. Dupree, Cory A. Williams, and Kenneth J. Leib

Prepared in cooperation with (in alphabetical order) Antero Resources, Bureau of Land Management, Bureau of Reclamation, Chevron Corporation, City of Grand Junction and City of Rifle, Colo., Colorado Department of Agriculture, Colorado Department of Natural Resources, Colorado Department of Public Health and Environment, Colorado Division of Wildlife-River Watch, Colorado Oil and Gas Conservation Commission, Colorado River Water Conservation District, Delta County, Colo., EnCana Oil \& Gas (USA) Inc., Garfield County, Colo., Gunnison Energy Corp., National Park Service, Natural Soda, Inc., North Fork River Improvement Association, Oxy Petroleum Corporation, Petroleum Development Corp., Rio Blanco County, Shell Oil Company, Solvay Chemicals, Towns of Carbondale, De Beque, Palisade, Parachute, Rangely, and Silt, Colo., U.S. Forest Service, West Divide Water Conservancy District, and Williams Companies, Inc.

Scientific Investigations Report 2013-5015

\author{
U.S. Department of the Interior \\ U.S. Geological Survey
}




\title{
U.S. Department of the Interior SALLY JEWELL, Secretary
}

\section{U.S. Geological Survey Suzette M. Kimball, Acting Director}

\author{
U.S. Geological Survey, Reston, Virginia: 2013
}

For more information on the USGS - the Federal source for science about the Earth, its natural and living resources, natural hazards, and the environment, visit http://www.usgs.gov or call 1-888-ASK-USGS.

For an overview of USGS information products, including maps, imagery, and publications, visit http://www.usgs.gov/pubprod

To order this and other USGS information products, visit http://store.usgs.gov

Any use of trade, firm, or product names is for descriptive purposes only and does not imply endorsement by the U.S. Government.

Although this information product, for the most part, is in the public domain, it also may contain copyrighted materials as noted in the text. Permission to reproduce copyrighted items must be secured from the copyright owner.

Suggested citation:

Thomas, J.C., Moore, J.L., Schaffrath, K.R., Dupree, J.A., Williams, C.A., and Leib, K.J., 2013, Characterization and datagap analysis of surface-water quality in the Piceance study area, western Colorado, 1959-2009: U.S. Geological Survey Scientific Investigations Report 2013-5015, 300 p., http://pubs.usgs.gov/sir/2013/5015/. 


\section{Contents}

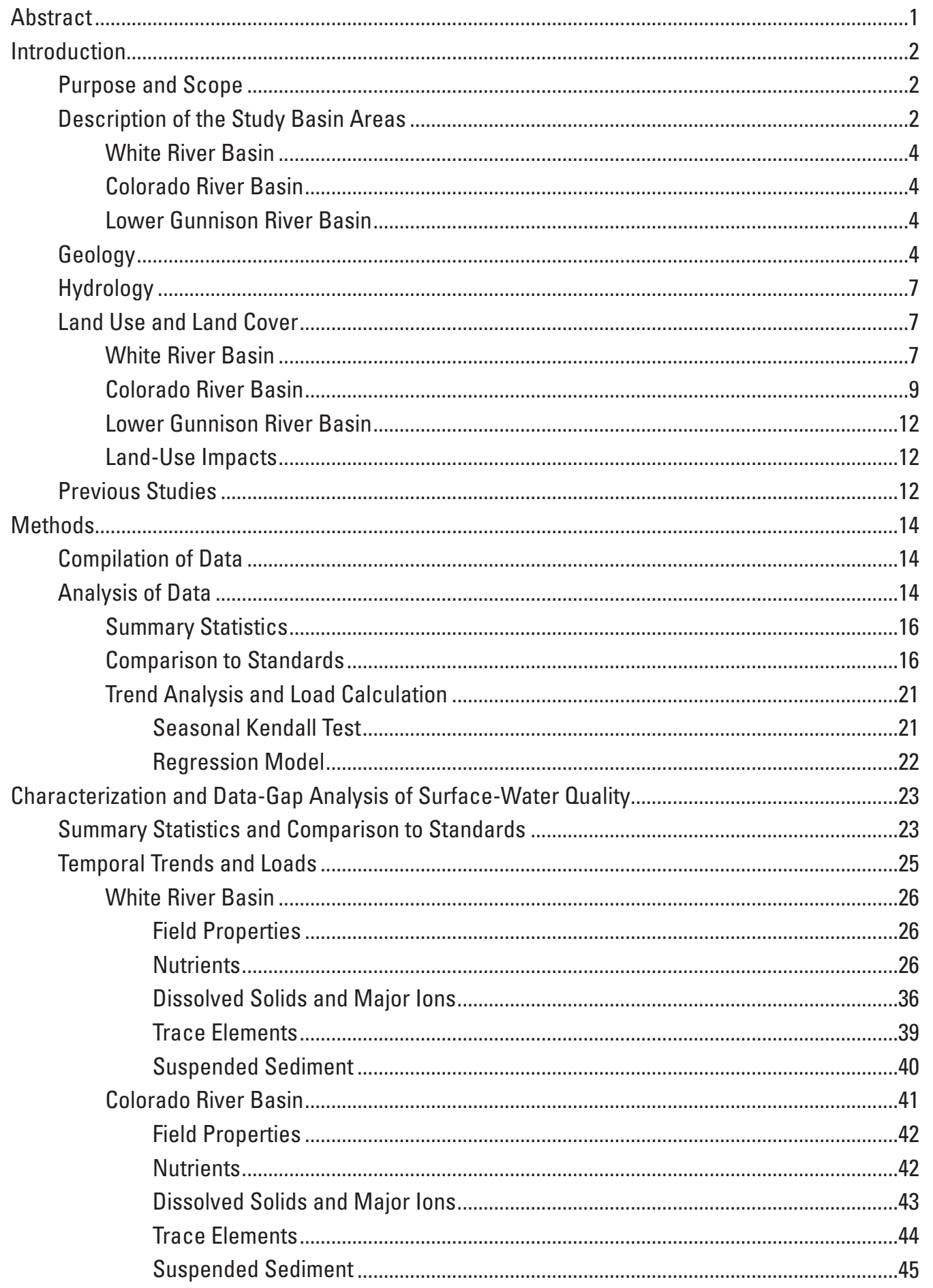


Lower Gunnison River Basin ........................................................................................4

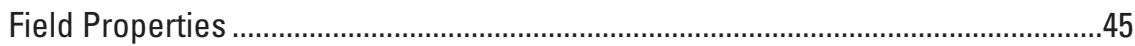

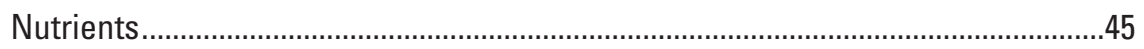

Dissolved Solids and Major lons............................................................................45

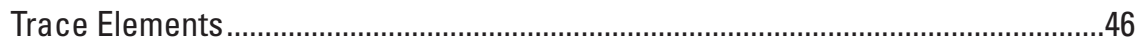

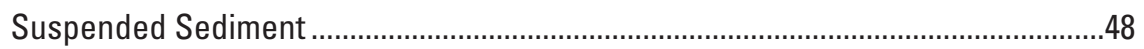

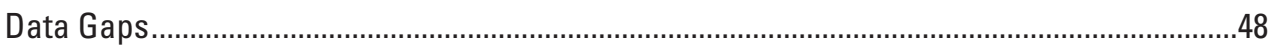

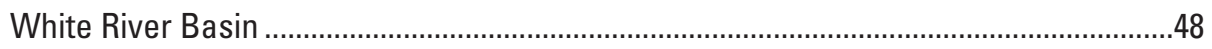

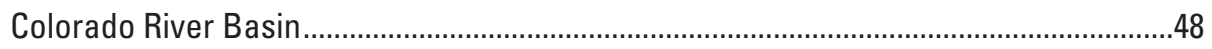

Lower Gunnison River Basin.........................................................................................48

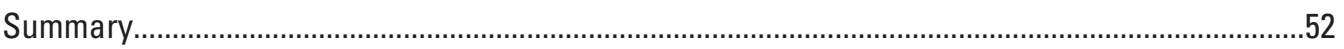

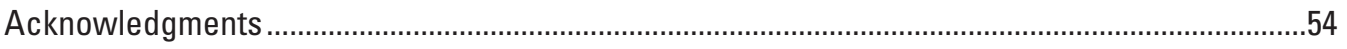

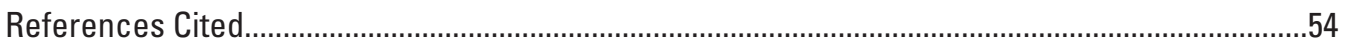

Appendix 1. Summary of Surface-Water-Quality Data by Site, by Constituent, Piceance Study Area, Western Colorado .........................................................................................61

Appendix 2. Model Coefficients and Statistical Diagnostics from Regression Models Used for Trend Analysis in the Piceance Study Area, Colorado .......................................281

Appendix 3. Schematic Diagrams of the Model Line without Streamflow or Seasonality Terms To Facilitate the Determination of Zero-Slope Year, Net Trend Direction, and Direction of the Trend Before and After the Zero-Slope Year...

\section{Plates (located at back of report)}

1. Map showing water-quality sites with downstream order number from appendix 1 in the Piceance study area, western Colorado.

2. Map showing exceedances of water-quality standards for temperature, $\mathrm{pH}$, and dissolved oxygen from appendix 1 in the Piceance study area, western Colorado

3. Map showing exceedances of water-quality standards for nitrate and phosphorus from appendix 1 in the Piceance study area, western Colorado

4. Map showing exceedances of water-quality standards for chloride and sulfate from appendix 1 in the Piceance study area, western Colorado

5. Map showing exceedances of water-quality standards for copper, iron (total and dissolved), lead, zinc, and selenium from appendix 1 in the Piceance study area, western Colorado

\section{Figures}

1. Location of the Piceance study area, western Colorado.....................................................

2. Generalized geologic structures of the Piceance study area, western Colorado.............5

3. Generalized geologic map of the Piceance study area, western Colorado ........................

4. The hydrology of the Piceance study area, western Colorado.........................................8 
5. Annual-mean streamflows for selected U.S. Geological Survey streamflow-gaging stations in the Piceance study area for 1990 through 2009, western Colorado ...................10

6. Land cover of the Piceance study area, western Colorado ..............................................11

7. Location of the sites where trend analysis was completed, western Colorado...............27

8. Loading profile for nitrate and orthophosphate in the White River Basin, western Colorado

9. Loading profile for dissolved solids, iron, and selenium in the White River Basin, western Colorado

10. Loading profile for nitrate and orthophosphate in the Colorado River Basin, western Colorado.

11. Loading profile for dissolved solids, iron, and selenium in the Colorado River Basin, western Colorado

12. Loading profile for dissolved solids and selenium in the Lower Gunnison River Basin, western Colorado...

13. Locations of continuous streamflow, physical parameter data trend, concentration data trend, and summary statistic sites in the White River Basin, western Colorado

14. Locations of continuous streamflow, physical parameter data trend, concentration data trend, and summary statistic sites in the Colorado River Basin, western Colorado

15. Locations of continuous streamflow, physical parameter data trend, concentration data trend, and summary statistic sites in the Lower Gunnison River Basin, western Colorado

\section{Tables}

1. Annual-mean streamflow, in cubic feet per second, for selected U.S. Geological Survey streamflow-gaging stations in the Piceance study area for the period 1990 through 2009, western Colorado .

2. Colorado Department of Public Health and Environment section 303(d) list of impaired waters and monitoring and evaluation list for the Piceance study area, western Colorado, 2011

3. Selected Colorado Department of Public Health and Environment instream water-quality standards for stream segments in the Piceance study area, western Colorado

4. Summary of the seasonal Kendall test trend analysis results for field properties, Piceance study area, western Colorado, 1990-2009.

5. Summary of regression model trend analysis results for nutrients and Escherichia coli, Piceance study area, western Colorado, 1990-2009

6. Summary of regression model trend analysis results for dissolved solids and major ions, Piceance study area, western Colorado, 1990-2009

7. Summary of regression model trend analysis results for trace elements and suspended sediment, Piceance study area, western Colorado, 1990-2009. 


\section{Conversion Factors}

Inch/Pound to SI

\begin{tabular}{|c|c|c|}
\hline Multiply & By & To obtain \\
\hline \multicolumn{3}{|c|}{ Length } \\
\hline foot $(\mathrm{ft})$ & 0.3048 & meter (m) \\
\hline mile (mi) & 1.609 & kilometer $(\mathrm{km})$ \\
\hline \multicolumn{3}{|c|}{ Area } \\
\hline acre & 4,047 & square meter $\left(\mathrm{m}^{2}\right)$ \\
\hline acre & 0.4047 & hectare (ha) \\
\hline acre & 0.4047 & square hectometer $\left(\mathrm{hm}^{2}\right)$ \\
\hline acre & 0.004047 & square kilometer $\left(\mathrm{km}^{2}\right)$ \\
\hline square foot $\left(\mathrm{ft}^{2}\right)$ & 929.0 & square centimeter $\left(\mathrm{cm}^{2}\right)$ \\
\hline square foot $\left(\mathrm{ft}^{2}\right)$ & 0.09290 & square meter $\left(\mathrm{m}^{2}\right)$ \\
\hline square mile $\left(\mathrm{mi}^{2}\right)$ & 259.0 & hectare (ha) \\
\hline square mile $\left(\mathrm{mi}^{2}\right)$ & 2.590 & square kilometer $\left(\mathrm{km}^{2}\right)$ \\
\hline \multicolumn{3}{|c|}{ Volume } \\
\hline cubic foot $\left(\mathrm{ft}^{3}\right)$ & 28.32 & cubic decimeter $\left(\mathrm{dm}^{3}\right)$ \\
\hline cubic foot $\left(\mathrm{ft}^{3}\right)$ & 0.02832 & cubic meter $\left(\mathrm{m}^{3}\right)$ \\
\hline acre-foot (acre-ft) & 1,233 & cubic meter $\left(\mathrm{m}^{3}\right)$ \\
\hline acre-foot (acre-ft) & 0.001233 & cubic hectometer $\left(\mathrm{hm}^{3}\right)$ \\
\hline \multicolumn{3}{|c|}{ Flow rate } \\
\hline foot per second $(\mathrm{ft} / \mathrm{s})$ & 0.3048 & meter per second $(\mathrm{m} / \mathrm{s})$ \\
\hline cubic foot per second $\left(\mathrm{ft}^{3} / \mathrm{s}\right)$ & 0.02832 & cubic meter per second $\left(\mathrm{m}^{3} / \mathrm{s}\right)$ \\
\hline cubic foot per day $\left(\mathrm{ft}^{3} / \mathrm{d}\right)$ & 0.02832 & cubic meter per day $\left(\mathrm{m}^{3} / \mathrm{d}\right)$ \\
\hline gallon per minute (gal/min) & 0.06309 & liter per second $(\mathrm{L} / \mathrm{s})$ \\
\hline \multicolumn{3}{|l|}{ 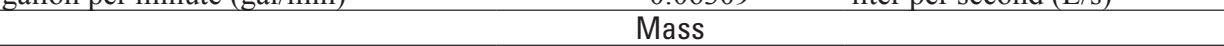 } \\
\hline tons per day & 0.9072 & metric ton per day \\
\hline tons per year (ton/yr) & 0.9072 & metric ton per day \\
\hline
\end{tabular}

Temperature in degrees Celsius $\left({ }^{\circ} \mathrm{C}\right)$ may be converted to degrees Fahrenheit $\left({ }^{\circ} \mathrm{F}\right)$ as follows: ${ }^{\circ} \mathrm{F}=\left(1.8 \times{ }^{\circ} \mathrm{C}\right)+32$

Vertical coordinate information is referenced to the North American Vertical Datum of 1988 (NAVD 88).

Horizontal coordinate information is referenced to the North American Datum of 1983 (NAD 83).

Elevation, as used in this report, refers to distance above the vertical datum.

Concentrations of chemical constituents in water are given either in milligrams per liter ( $\mathrm{mg} / \mathrm{L}$ ) or micrograms per liter $(\mu \mathrm{g} / \mathrm{L})$. 


\author{
Abbreviations Used in This Report \\ BLM Bureau of Land Management \\ BTEX benzene, toluene, ethylbenzene, and xylene \\ CDPHE Colorado Department of Public Health and Environment \\ CFU colony forming units \\ DS dissolved solids \\ ESTREND Estimate Trend computer program \\ GMUG Grand Mesa Uncompahgre and Gunnison (National Forests) \\ LOADEST Load Estimation computer program \\ MCL maximum contaminant level \\ $\mu \mathrm{g} / \mathrm{L} \quad$ micrograms per liter \\ $\mathrm{mg} / \mathrm{L} \quad$ milligrams per liter \\ NIWQP National Irrigation Water Quality Program \\ NWIS National Water Information System \\ PRESS prediction sum of squares \\ TMDL total maximum daily loads \\ TPH total petroleum hydrocarbons \\ TVS table-value standards \\ USEPA U.S. Environmental Protection Agency \\ USGS U.S. Geological Survey
}





\title{
Characterization and Data-Gap Analysis of Surface-Water Quality in the Piceance Study Area, Western Colorado, 1959-2009
}

\author{
By Judith C. Thomas, Jennifer L. Moore, Keelin R. Schaffrath, Jean A. Dupree, Cory A. Williams, \\ and Kenneth J. Leib
}

\section{Abstract}

The U.S. Geological Survey, in cooperation with Federal, State, county, and industry partners, developed a Webaccessible common data repository to provide access to historical and current (as of August 2009) water-quality information (available on the Internet at http://rmgsc.cr.usgs.gov/cwqdr/ Piceance/index.shtml). Surface-water-quality data from public and private sources were compiled for the period 1931 to 2009 and loaded into the common data repository for the Piceance Basin. A subset of surface-water-quality data for 1959 to 2009 from the repository were compiled, reviewed, and checked for quality assurance for this report. This report contains data summaries, comparisons to water-quality standards, trend analyses, a generalized spatial analysis, and a data-gap analysis for select water-quality properties and constituents.

Summary statistics and a comparison to standards were provided for 347 sites for 33 constituents including field properties, nutrients, major ions, trace elements, suspended sediment, Escherichia coli, and BTEX (benzene, toluene, ethylbenzene, and xylene). When sufficient data were available, trends over time were analyzed and loads were calculated for those sites where there were also continuous streamflow data.

The majority of sites had information on field properties. Water temperature data was available for 316 sites where data were collected between 1959 and 2009. The only trend that was detected in temperature was an upward trend at the Gunnison River near Grand Junction, Colorado. There were 326 values out of a total of 32,006 values in the study area that exceeded the aquatic-life standard for daily maximum water temperature. For the entire study area, 196 sites had dissolved-oxygen data collected between 1970 and 2009, and median dissolved-oxygen concentrations ranged from 6.8 to 11.2 milligrams per liter $(\mathrm{mg} / \mathrm{L})$. There were 185 concentrations that exceeded the dissolved oxygen aquatic-life standard out of a total of 11,248 values. The $\mathrm{pH}$ data were available for 276 sites, and median $\mathrm{pH}$ values ranged from 7.5 to 9.0. There were 241 values that exceeded the high $\mathrm{pH}$ standard and 13 values that were less than the low $\mathrm{pH}$ standard of the 16,790 values in the study area.
Nutrients within the study area were not well represented in each basin and were often not being sampled currently. For the entire study area, 62 sites had nitrate data collected between 1958 and 2009, and median nitrate concentrations ranged from less than detection to $3.72 \mathrm{mg} / \mathrm{L}$ as nitrogen. The maximum contaminant level for domestic water supply for nitrate is $10 \mathrm{mg} / \mathrm{L}$ and was exceeded once in 3,736 samples. Total phosphorus was collected at 113 sites between 1974 and 2009, and median total phosphorus concentrations ranged from less than detection to $5.04 \mathrm{mg} / \mathrm{L}$. The U.S. Environmental Protection Agency recommendation for phosphorus is less than $0.1 \mathrm{mg} / \mathrm{L}$, and 1,469 of 4,842 samples exceeded this recommended standard. An upward trend in both nitrate and total phosphorus was detected in the White River above Coal Creek near Meeker, Colo.

Standards for major ions exist only for chloride and sulfate. For the entire study area, 118 sites had both chloride and sulfate concentration data collected between 1958 and 2009. Median chloride concentrations ranged from $0.085 \mathrm{mg} / \mathrm{L}$ to $280 \mathrm{mg} / \mathrm{L}$. Median sulfate concentrations ranged from $4.57 \mathrm{mg} / \mathrm{L}$ to $15,000 \mathrm{mg} / \mathrm{L}$. Both chloride and sulfate domestic water-supply standards are $250 \mathrm{mg} / \mathrm{L}$. There were 120 chloride concentrations and 1,111 sulfate concentration samples that exceeded these standards. A downward trend in dissolved solids was detected at the Colorado River near the Colorado-Utah state border and could be a result of salinity control work near Grand Junction, Colo.

Trace elements were relatively well represented both temporally and spatially in the study area though the number of trace element samples per site was not typically enough to compute trends or loads except for selenium. There were 127 sites that had dissolved iron concentration data collected between 1961 and 2009, and median iron concentrations ranged from less than detection to 1,100 micrograms per liter $(\mu \mathrm{g} / \mathrm{L})$. The 30-day drinking-water standard for iron is $300 \mu \mathrm{g} / \mathrm{L}$, and 203 samples exceeded the standard. Selenium was the best represented trace element with selenium concentration data collected at 197 sites between 1973 and 2009, and median selenium concentrations range from less than detection to $181 \mu \mathrm{g} / \mathrm{L}$. The chronic standard of $4.6 \mu \mathrm{g} / \mathrm{L}$ for 
selenium concentrations was exceeded in 899 samples, and the acute aquatic-life standard of $18.4 \mu \mathrm{g} / \mathrm{L}$ for selenium was exceeded in 629 samples. High concentrations of selenium are of concern in the Lower Gunnison River Basin because of the combination of geologic formations and land use. There were significant downward trends in selenium at both main-stem sites on the Gunnison River at Delta, Colo., and the Gunnison River near Grand Junction, Colo. High selenium concentrations correlate with high salinity concentrations; thus, when salinity control efforts are conducted in selenium-rich areas in the Lower Gunnison River Basin, both salinity and selenium have the potential to decrease.

Spatial, temporal, and analytical data gaps were identified in the study area. The spatial coverage of sampling sites could be expanded in the White River Basin by adding more tributary sites. No water-quality data exist for tributary streams in the area north of Rangely, Colo., where extensive energy development has occurred in a complex geologic setting. Douglas Creek has a drainage area of 425 square miles and has limited historic water-quality and water-quantity data. Limited data were available for field properties, major ions, nutrients, and trace elements on the main stem of the Colorado River between Glenwood Springs and Cameo, Colo. Nutrient data were minimally collected upstream from Colorado River at the Colorado-Utah state border and on the Gunnison River (major tributary in the reach). Approximately 30 percent of the samples for total phosphorus in the Lower Gunnison River Basin exceeded the recommended standard, yet there were insufficient data to do trends analysis in the Lower Gunnison River Basin except at the Gunnison near Grand Junction site. There is limited trace element data except for selenium in the Lower Gunnison River Basin. Additional sampling is necessary to understand the occurrence, concentrations, and loads of these constituents.

\section{Introduction}

Water resources can be affected by natural and human factors. Human factors can include activities such as urbanization, agriculture, and multiple types of development and changes in land use, including energy development and infrastructure. Northwestern Colorado is experiencing many of these types of changes in land use, which can result in short- and long-term changes in the water resources in the study area. Ongoing monitoring and assessment are required to periodically reestablish our understanding of baseline conditions and to detect changes. Substantial water-resource datasets, publications, and other materials have been developed in past years and can be used to assess baseline conditions and to evaluate land-use effects. However, these data are generally stored in disparate formats among numerous agencies, energy companies, private consulting firms, universities, and stakeholder groups. A publically accessible common data repository was needed to compile water-quality data collected by various entities. Compilation and quality assurance of existing water-quality data from the currently disparate sources and formats provides a useful contribution to public and private entities tasked with planning, oversight, conservation, and management of water resources. The U.S. Geological Survey (USGS), in cooperation with Federal, State, county, and industry partners, developed a Web-accessible common data repository to provide energy operators, researchers, consultants, agencies, and interested stakeholders equal access to historical and current (as of August 2009) water-quality information (available on the Internet at http://rmgsc.cr.usgs.gov/cwqdr/ Piceance/index.shtml). The following is an alphabetical list of cooperators involved in this study: Antero Resources, Bureau of Land Management, Bureau of Reclamation, Chevron Corporation, City of Grand Junction and City of Rifle, Colo., Colorado Department of Agriculture, Colorado Department of Natural Resources, Colorado Department of Public Health and Environment, Colorado Division of Wildlife-River Watch, Colorado Oil and Gas Conservation Commission, Colorado River Water Conservation District, Delta County, Colo., EnCana Oil \& Gas (USA) Inc., Garfield County, Colo., Gunnison Energy Corp., National Park Service, Natural Soda, Inc., North Fork River Improvement Association, Oxy Petroleum Corporation, Petroleum Development Corp., Rio Blanco County, Shell Oil Company, Solvay Chemicals, Towns of Carbondale, De Beque, Palisade, Parachute, Rangely, and Silt, Colo., U.S. Forest Service, West Divide Water Conservancy District, and Williams Companies, Inc.

\section{Purpose and Scope}

This report provides an analysis of select surface-water data for 1959-2009 from the common data repository for the Piceance study area. Data were summarized to identify available data and evaluate temporal and spatial patterns in the study area. These data were analyzed to provide a baseline assessment of available water-resource data and aid in the development of regional monitoring strategies. The report contains data summaries, comparisons to standards, trend analyses, and a generalized spatial analysis for selected waterquality properties and constituents. Gaps in available data were identified from these analyses.

\section{Description of the Study Basin Areas}

The Piceance study area refers to an area of approximately 9,500 square miles $\left(\mathrm{mi}^{2}\right)$ in western Colorado extending from north of Rangely to south of Delta and east to west from Glenwood Springs, Colorado (Colo.) to the ColoradoUtah state border (fig. 1). The study area was delineated based on hydrology, geology, and political boundaries. The Piceance study area is subdivided into three study basin areas: the White River Basin, the Colorado River Basin, and the Lower Gunnison River Basin (fig. 1). The climate of the Piceance study area is arid to semiarid with the exception of higher elevations of the Grand Mesa and the Roan Plateau, which are considered subalpine zones (fig. 1). The majority 


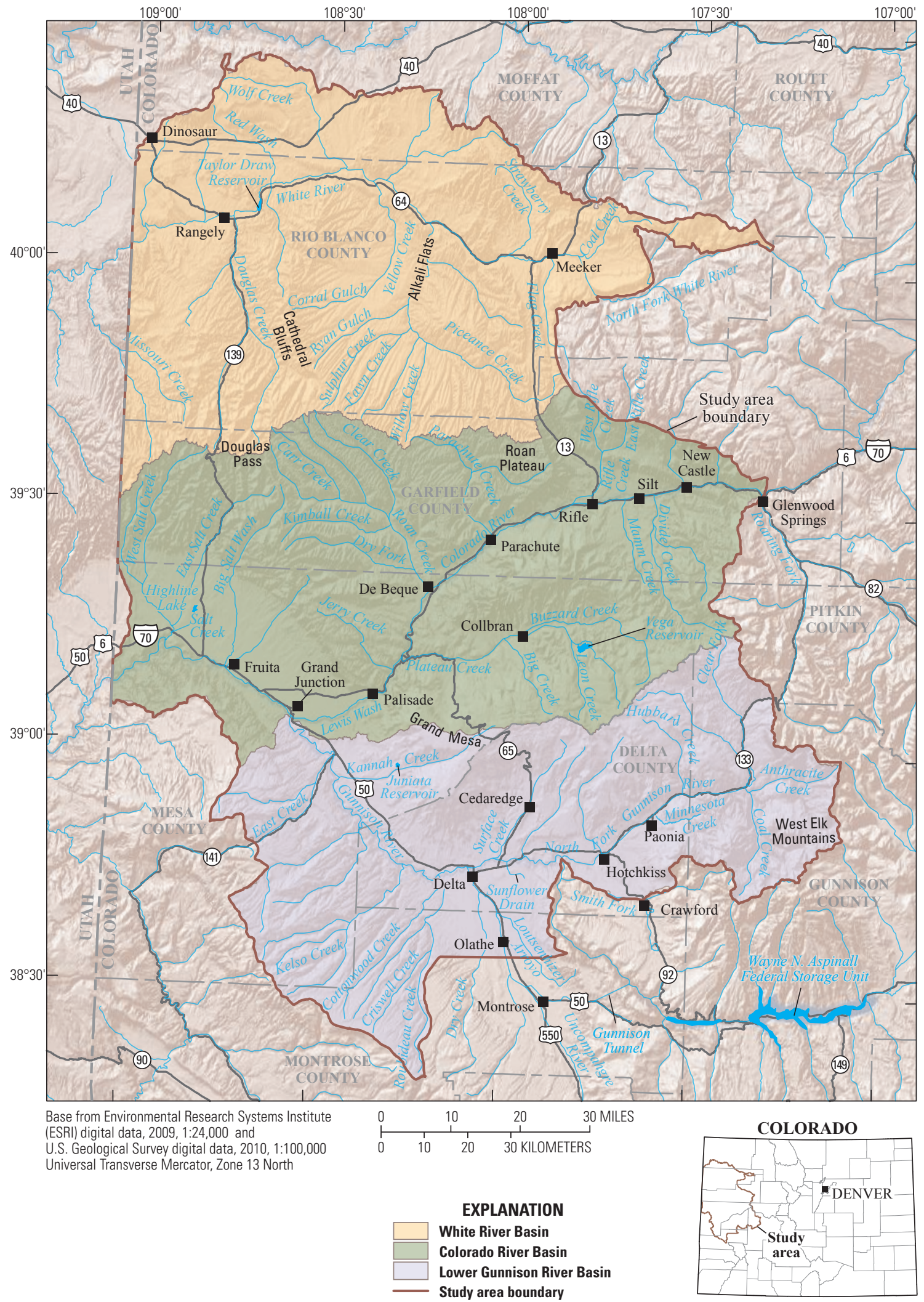

Figure 1. Location of the Piceance study area, western Colorado. 
of precipitation in the lower elevations falls as rain during the late summer and early fall. The majority of precipitation in the higher elevations falls as snow and accumulates in a seasonal snowpack (Western Regional Climate Center, 2012).

\section{White River Basin}

The White River Basin is partially defined by the Piceance Structural Basin boundary and begins near the mouth of Coal Creek and extends downstream to the White River at the Colorado-Utah state border. Elevations range from more than 8,675 feet (ft) at Cathedral Bluffs to about 5,200 ft on the White River near the Colorado-Utah state border. The basin is located in Rio Blanco, Garfield, and Moffat Counties (fig. 1). The towns of Meeker and Rangely are the two largest population centers in the basin (fig. 1). Meeker had a population of 2,475 in 2010, and Rangely had a population of 2,365 in 2010 (U.S. Census Bureau, 2011).

\section{Colorado River Basin}

The Colorado River Basin includes the drainage area from Glenwood Springs, Colo., to the Colorado-Utah state border (fig. 1). Elevations range from more than $11,000 \mathrm{ft}$ on the Grand Mesa (fig. 1) down to about $4,300 \mathrm{ft}$ on the Colorado River at the Colorado-Utah border. The basin is located in Garfield and Mesa Counties (fig. 1). The primary population centers in this basin (from east to west) are Glenwood Springs, New Castle, Silt, Rifle, Parachute, Collbran, De Beque, Palisade, Grand Junction, and Fruita, Colo. (fig. 1). The largest population center in the basin is Grand Junction, which had a population of 58,566 in 2010 (U.S. Census Bureau, 2011). In comparison, Collbran had a population of 708 in 2010 (U.S. Census Bureau, 2011).

\section{Lower Gunnison River Basin}

The Lower Gunnison River Basin is the southernmost section of the Piceance study area (fig. 1). The Lower Gunnison River Basin is only a part of the entire Gunnison River Basin; the Gunnison River is the largest tributary to the Colorado River in Colorado. The Lower Gunnison River Basin, for this study, included the entire drainage area of the North Fork of the Gunnison River and the drainage area beginning slightly downstream from the Gunnison Tunnel on both the Gunnison River and the Uncompahgre River. The Gunnison Tunnel diverts irrigation water from the Gunnison River to the Uncompahgre River. Elevations in the Lower Gunnison River Basin range from about 13,000 ft in the West Elk Mountains (fig. 1) located in the southeast corner of the basin to 4,600 $\mathrm{ft}$ near the confluence of the Gunnison River and Colorado River. The basin is located in Delta, Mesa, Gunnison, and Montrose Counties (fig. 1). The largest population center in the basin is Delta which had a population of 8,915 in 2010 (U.S. Census Bureau, 2011). The smallest population center in the basin is Hotchkiss, which had a population of 944 in 2010 (U.S. Census Bureau, 2011).

\section{Geology}

The Piceance study area lies within the Piceance Structural Basin, which is a downwarped region surrounded by uplifted regions including the Axial Basin Arch to the north, the Grand Hogback to the east, the Gunnison Uplift to the southeast, the Uncompahgre Uplift to the southwest, and the Douglas Creek Arch to the west (fig. 2). Outcropping bedrock units in the center of the downwarped region are Tertiary sedimentary rocks (fig. 3). Uplifted regions at the boundaries of the structural basin are primarily Cretaceous sedimentary rocks (figs. 2 and 3).

The surface geology of the study area ranges from Quaternary to Jurassic age (Tweto, 1979; Green, 1992) (fig. 3). Alluvial, terrace, and valley-fill deposits of Quaternary age form the unconsolidated materials in the valleys. The Green River Formation, of early Tertiary age, rests conformably on the Wasatch Formation (older Tertiary rock). The Green River Formation is well known for rich oil-shale deposits. The Green River Formation also contains natural resources of economic interest including nacholite, dawsonite, potable groundwater, natural gas, and crude oil, depending on location in the basin. The Wasatch Formation consists of a varied colored mudstone with sandstone lenses (Johnson and Flores, 2003). Some of the sandstone lenses, such as the Wasatch " $G$ " interval of the Wasatch Formation, are appreciable reservoirs of natural gas in or near Parachute and Rulison, Colo. (Nelson and Santus, 2010). The Wasatch Formation is also a source of potable water.

Cretaceous sedimentary rocks of primary interest in the study area were the Mesaverde Group, the Mancos Shale, and the Dakota Sandstone (fig. 3). The Mesaverde Group was formed by a series of marine transgressions and regressions with later periods of fluvial deposition (Johnson, 1989) resulting in a sequence of marine shales, siltstones, and sandstones capped by a thick sequence of terrestrial fluvial deposits. The fluvial deposits of the Mesaverde Group consist almost entirely of lenticular channel sandstones and fine-grained flood-plain deposits. The channel sandstones are the primary reservoirs for natural gas and require a dense pattern of drilling to recover the gas from these sandstones (Nelson and Santus, 2010). The Mesaverde Group consists of the Iles Formation and the Williams Fork Formation. The Iles Formation contains the Corcoran, Cozzette, and Rollins Members (Reinecke and others, 1991). The Williams Fork Formation is an important natural gas producing unit within the study area. The Mancos Shale is of Late Cretaceous age and is composed of massive, fossiliferous marine shale with interbedded sandstone, siltstone, and devitrified volcanic ash layers. The Mancos Shale is a major source of dissolved solids and selenium in the study area. The Mancos Shale is the lateral equivalent to the Niobrara Shale, Cody Shale, and Pierre Shale in Colorado, Montana, Nebraska, South Dakota, and Wyoming (Tweto, 1979; Green, 1992; Wright and Butler, 1993). The Dakota Sandstone, of Early Cretaceous age, is composed of interbedded, hard sandstone, conglomerates, shale, and coal (Brune, 1953); it is a potential source of potable water as well as a source of dissolved solids in the study area. 


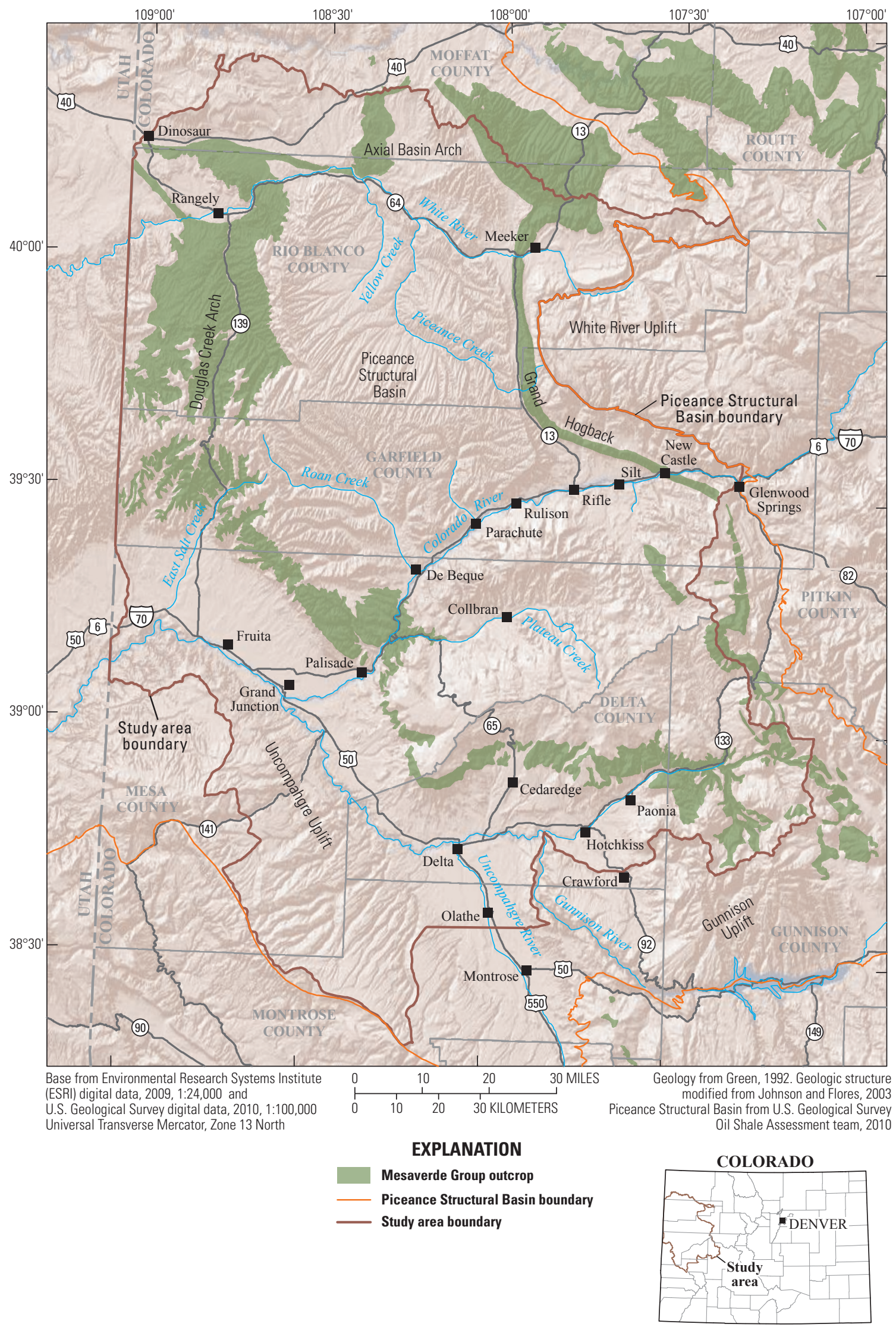

Figure 2. Generalized geologic structures of the Piceance study area, western Colorado. 


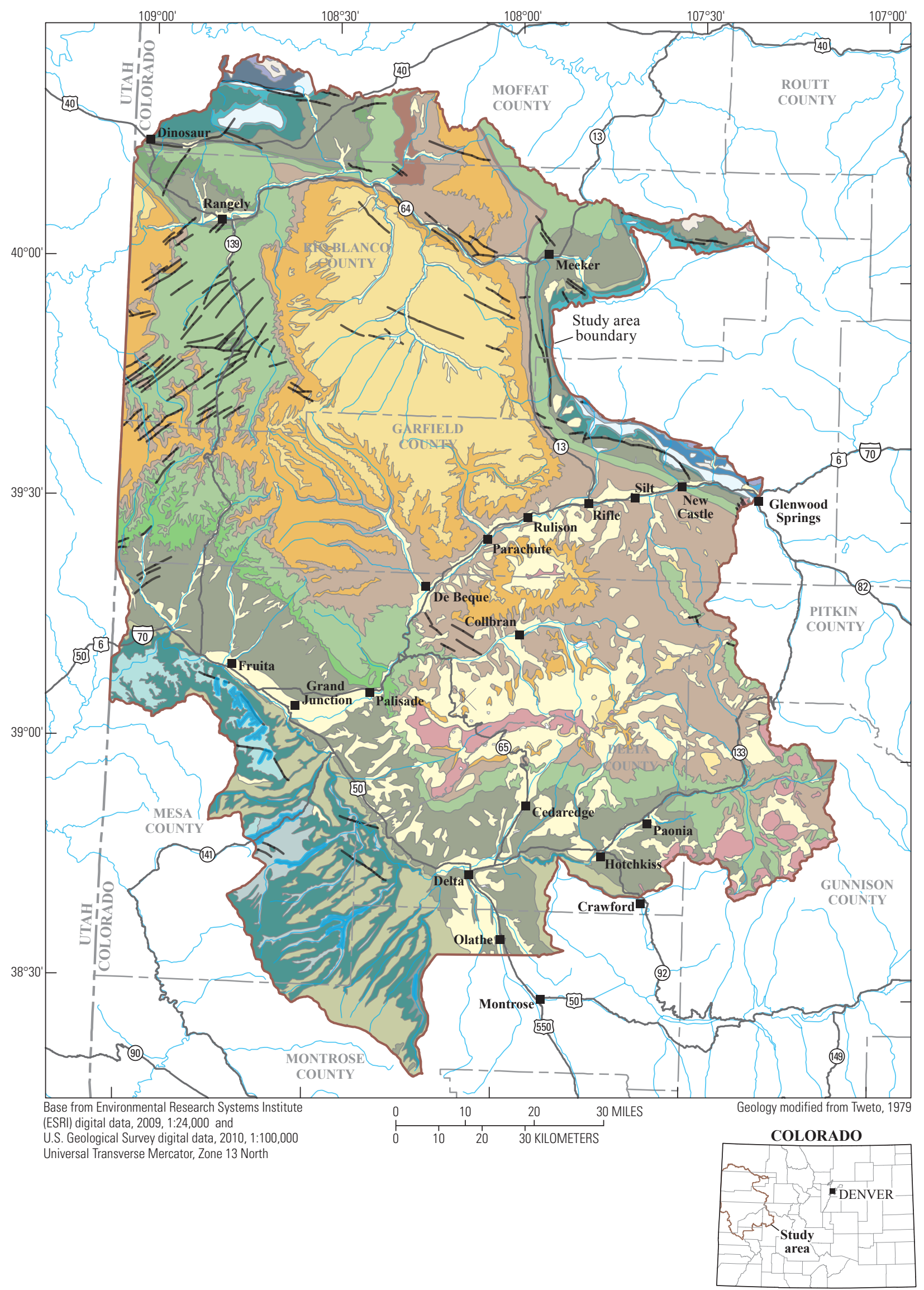

Figure 3. Generalized geologic map of the Piceance study area, western Colorado. 


\section{EXPLANATION}

Geologic unit

Quaternary sedimentary units, undifferentiated

Quaternary-Tertiary ancient alluvium

Tertiary volcanic and plutonic units

Tertiary Browns Park Formation

Tertiary Uinta Formation

Oligocene sedimentary rocks

Tertiary Green River Formation

Tertiary Lower Green River and Wasatch Formation

Tertiary Wasatch Formation

Tertiary Fort Union Formation

Mesozoic rocks, undifferentiated

Cretaceous-Jurassic Dakota, Burro Canyon, Morrison, Wanakah, and Entrada Formations

Cretaceous Dakota Sandstone and Burro Canyon Formation

Cretaceous Mesaverde Group

Cretaceous Mount Garfied Formation and Sego Sandstone

Cretaceous Sego Sandstone, Buck Tongue of Mancos Shale, and Castlegate Sandstone

Cretaceous Mancos Shale

Jurassic units, undifferentiated

Triassic Kayenta Formation

Triassic Wingate Sandstone and Chinle Formations

Triassic-Permian Chinle, Moenkopi, Park City, and State Bridge Formations

Triassic Chinle Formation

Pennsylvanian Maroon Formation and Weber Sandsone

Pennsylvanian Minturn

Pennsylvanian Belden Formation

Pennsylvanian evaporitic facies

Pennsylvanian Morgan Valley Formation and Round Valley Limestone

Mississippian-Cambrian units, undifferentiated

Precambrian, undifferentiated

Fault

Study area boundary

\section{Hydrology}

The Piceance study area has three study basin areas: the White River, Colorado River, and the Lower Gunnison River (fig. 4). The annual streamflow cycle in the study area is marked by spring snowmelt, which causes water levels in the river to rapidly rise. Low-flow conditions are characteristic of the late summer through winter seasons. Annual-mean streamflows at 10 USGS streamflow-gaging stations were calculated (1990 through 2009) to represent effects such as the construction of major diversions or storage facilities and climatic effects such as wet and dry hydrologic cycles (table 1, fig. 5). Streamflow data were obtained from the National Water Information System (NWIS) website (http://waterdata.usgs.gov). Generally, the annual-mean streamflows were variable based on basin area. Annual-mean streamflows in the Piceance study area demonstrated a wet period from approximately 1997 through 1999 followed by a dry period from approximately 2002 through 2004.

\section{Land Use and Land Cover}

Land use and land cover in the Piceance study area are varied, including forested land, rangeland/shrubland, agricultural land, barren land, and developed/urban land, which includes ski resorts and energy development (fig. 6). The total study area is almost 9,500 $\mathrm{mi}^{2}$ and includes $4,600 \mathrm{mi}^{2}$ (about 50 percent) of forested land and 3,800 $\mathrm{mi}^{2}$ (about 40 percent) of rangeland (Homer and others, 2004). Natural gas development has increased in the study area since 2000, in part because of advancements in the application of hydraulic fracturing, which has allowed successful extraction of natural gas from previously inaccessible sources (Nelson and Santus, 2010).

\section{White River Basin}

The area of the White River Basin is 3,160 $\mathrm{mi}^{2}$. The Bureau of Land Management (BLM) owns 2,176 mi ${ }^{2}$ (69 percent), and private entities own $837 \mathrm{mi}^{2}$ (26 percent) (Bureau of Land Management, 2009). The dominant land cover in the basin in 2001 was rangeland/shrubland (48 percent) (Homer and others, 2004). Much of the BLM land serves multiple uses, including ranching of sheep and cattle, natural gas development, and oil shale research development and demonstration leases (Bureau of Land Management, 2009). Part of the BLM land is managed for wild horse and burro herds (Bureau of Land Management, 2011a). Natural gas development on public lands in Rio Blanco County has increased from 58 permits in 2001 to 200 permits in 2006, and a total of 2,556 multiple well pads are projected during the next 20 years (Bureau of Land Management, 2011b).

The White River Basin is located primarily in Rio Blanco County (fig. 1) and is a tributary to the Green River, which then flows into the Colorado River in Utah. The White River Basin includes the White River and other major tributaries such as Piceance Creek, Yellow Creek, and Douglas Creek (fig. 1). Sedimentary rocks of Tertiary age including the Uinta Formation and the Green River Formation outcrop in the eastern and central part of the White River Basin (fig. 3). Cretaceous Mesaverde Group rocks outcrop in the western part of the White River Basin (fig. 3), specifically within the Douglas Creek drainage area (figs. 1 and 3). The White River has no major transbasin diversions or diversions for agricultural use. Oil shale and natural gas development have been and continue to be one of the most important land uses in the White River Basin. Conventional and unconventional natural gas extraction and the associated infrastructure are becoming increasingly prevalent in the basin. Rio Blanco County is one 


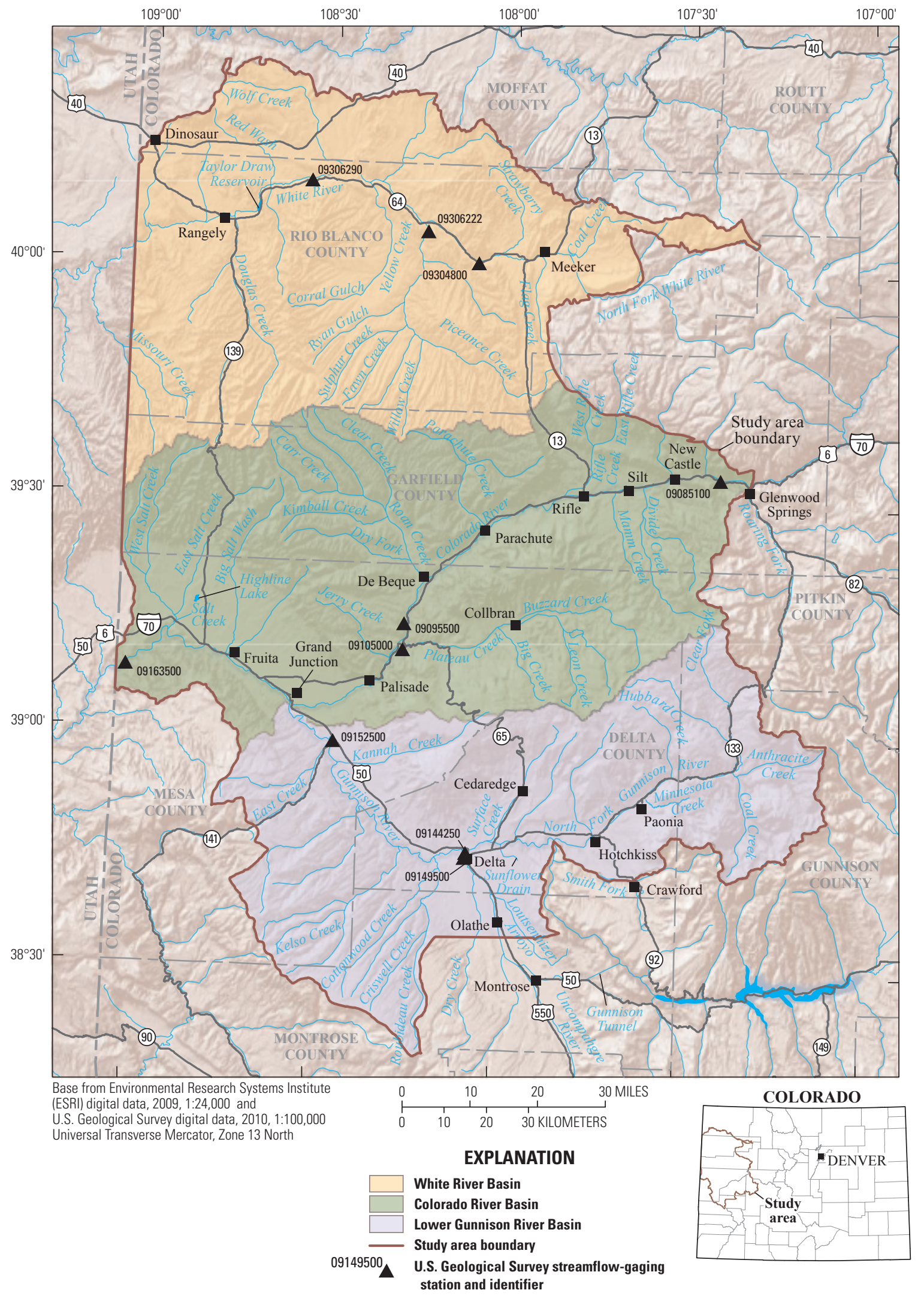

Figure 4. The hydrology of the Piceance study area, western Colorado. 
Table 1. Annual-mean streamflow, in cubic feet per second, for selected U.S. Geological Survey streamflow-gaging stations in the Piceance study area for the period 1990 through 2009, western Colorado.

[Mean annual streamflow caclulated using data from 1990 through 2009]

\begin{tabular}{|c|c|c|c|}
\hline $\begin{array}{c}\text { Site } \\
\text { identification } \\
\text { number } \\
\text { (fig. 4) } \\
\end{array}$ & Station name & $\begin{array}{l}\text { Mean annual } \\
\text { streamflow, } \\
\text { in cubic feet } \\
\text { per second }\end{array}$ & $\begin{array}{l}\text { Drainage area, } \\
\text { in square miles }\end{array}$ \\
\hline \multicolumn{4}{|c|}{ White River Basin } \\
\hline 09304800 & White River below Meeker, Colo. & 614 & 1,024 \\
\hline 09306222 & Piceance Creek at White River, Colo. & 38 & 652 \\
\hline 09306290 & White River below Boise Creek, near Rangely, Colo. & 723 & 2,530 \\
\hline \multicolumn{4}{|c|}{ Colorado River Basin } \\
\hline 09085100 & Colorado River below Glenwood Springs, Colo. & 3,344 & 6,014 \\
\hline 09095500 & Colorado River near Cameo, Colo. & 3,854 & 7,986 \\
\hline 09105000 & Plateau Creek near Cameo, Colo. & 194 & 592 \\
\hline 09163500 & Colorado River near Colorado-Utah State Line & 6,465 & 17,849 \\
\hline \multicolumn{4}{|c|}{ Lower Gunnison River Basin } \\
\hline 09149500 & Uncompahgre River at Delta, Colo. & 335 & 1,114 \\
\hline 09144250 & Gunnison River at Delta, Colo. & 1,964 & 5,636 \\
\hline 09152500 & Gunnison River near Grand Junction, Colo. & 2,600 & 7,923 \\
\hline
\end{tabular}

of the six counties in Colorado that have the greatest number of actively operating gas wells; there were 2,906 active gas wells in Rio Blanco County as of October 2011 (Colorado Oil and Conservation Commission, 2011).

\section{Colorado River Basin}

The area of the Colorado River Basin (study area) is $3,560 \mathrm{mi}^{2}$, and the area of the drainage area of the Colorado River upstream from the site at the Colorado-Utah state border is $17,843 \mathrm{mi}^{2}$. About 1,600 $\mathrm{mi}^{2}$ (45 percent) of the study area are managed by the Bureau of Land Management (Bureau of Land Management, 2009). About 1,400 mi (39 percent) of the basin were privately owned and $500 \mathrm{mi}^{2}$ (14 percent) were managed by the U.S. Forest Service (Bureau of Land Management, 2009). The dominant land cover (48 percent) in the basin during 2001 was deciduous and evergreen forest. More than $230 \mathrm{mi}^{2}$ (6.5 percent) had an agricultural land cover in 2001 (Homer and others, 2004) and $220 \mathrm{mi}^{2}$ were irrigated (Techni Graphics Systems, Inc., 2004).

The Colorado River drains watersheds from seven states, and the headwaters originate in Colorado. Large diversions of water from the Colorado River are used for agricultural irrigation and by municipalities for drinking water. There are thermal hot springs adjacent to the Colorado River in Glenwood Springs. The water chemistry of the springs comprises up to 22,200 milligrams per liter ( $\mathrm{mg} / \mathrm{L}$ ) dissolved solids, 7,600 mg/L of sodium, $11,000 \mathrm{mg} / \mathrm{L}$ of chloride, and $2,450 \mathrm{mg} / \mathrm{L}$ of sulfate (Lund and Hunter, 2009). The springs also contain significant quantities of fluoride, silica, barium, iron, lithium, and boron. Water temperatures from the springs flowing to the river are approximately $32-49^{\circ} \mathrm{C}$ (Lund and Hunter, 2009). Uranium and vanadium mining and milling operations took place in Rifle, Colo., in the 1920s and again from 1947 to 1957 (U.S. Energy Information Administration,
2011). During the latter time period, the mill processed ore at about 200 tons/day. A second mill was built in 1958 with an ore processing capacity of 400 tons/day. Both mill locations were remediated by the U.S. Department of Energy starting in 1989 (U.S. Energy Information Administration, 2011).

The economy of the basin is dominated by agriculture, energy development, industry, real estate development, tourism, and recreation (Leib and Bauch, 2008). The Colorado River is home to 14 native species of fish, of which four are endemic and endangered: the Colorado pikeminnow, razorback sucker, bonytail chub, and humpback chub (U.S.Fish and Wildlife Services, 2011). The Roan Plateau (fig. 1) provides habitat to a native, genetically diverse population of cutthroat trout (Bureau of Land Management, 2002). The Grand Mesa has more than 200 lakes and reservoirs. The Grand Mesa, as part of the Grand Mesa Uncompahgre and Gunnison National Forests (GMUG), has unique natural peatforming wetlands called fens that are considered an aquatic resource of national importance by the U.S. Environmental Protection Agency (USEPA) (U.S. Forest Service, 2011). The Roan Plateau is leased for the drilling of natural gas. Based on estimates from the BLM management plan for the Roan Plateau Planning area, Federal lands on the Roan Plateau could provide 3,630 billion cubic feet $\left(\mathrm{ft}^{3}\right)$ of natural gas during the next 20 years (Bureau of Land Management, 2002). The estimated technically recoverable gas resource within the Roan Plateau Planning Area of Federal lands is approximately 8,900 billion $\mathrm{ft}^{3}$. Colorado Oil and Gas Conservation Commission issued 13,775 application permits to develop natural gas since 2004 in Garfield County (fig. 6) (Colorado Oil and Gas Conservation Commission, 2011). The Roan Plateau area also is a potential region for the development of oil shale. The Parachute Creek Member of the Green River Formation is about 900 to $1,200 \mathrm{ft}$ thick in the Roan Plateau area and is generally considered the primary oil shale unit of interest (Bureau of Land Management, 2002). 

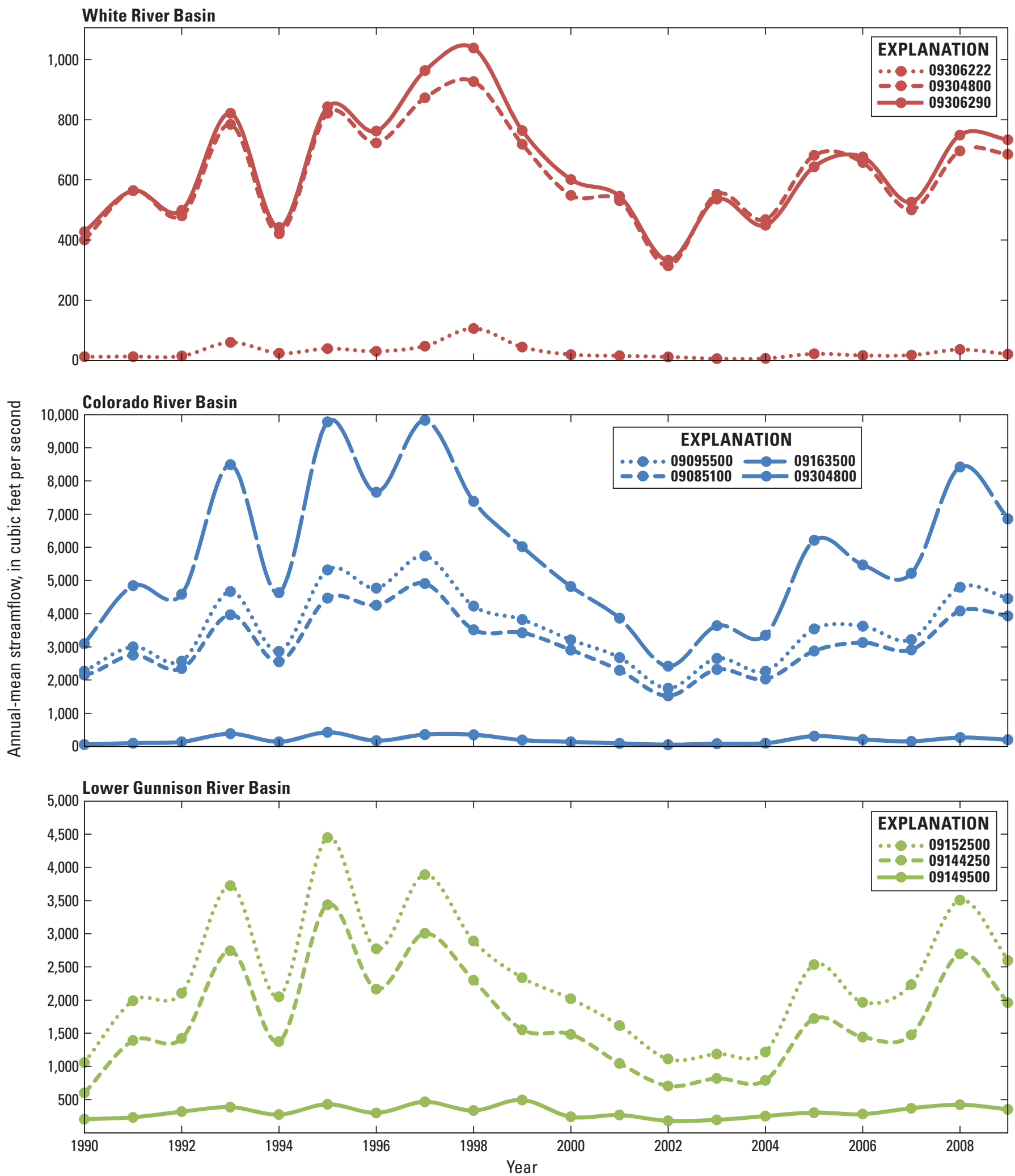

Figure 5. Annual-mean streamflows for selected U.S. Geological Survey streamflow-gaging stations in the Piceance study area for 1990 through 2009, western Colorado. 


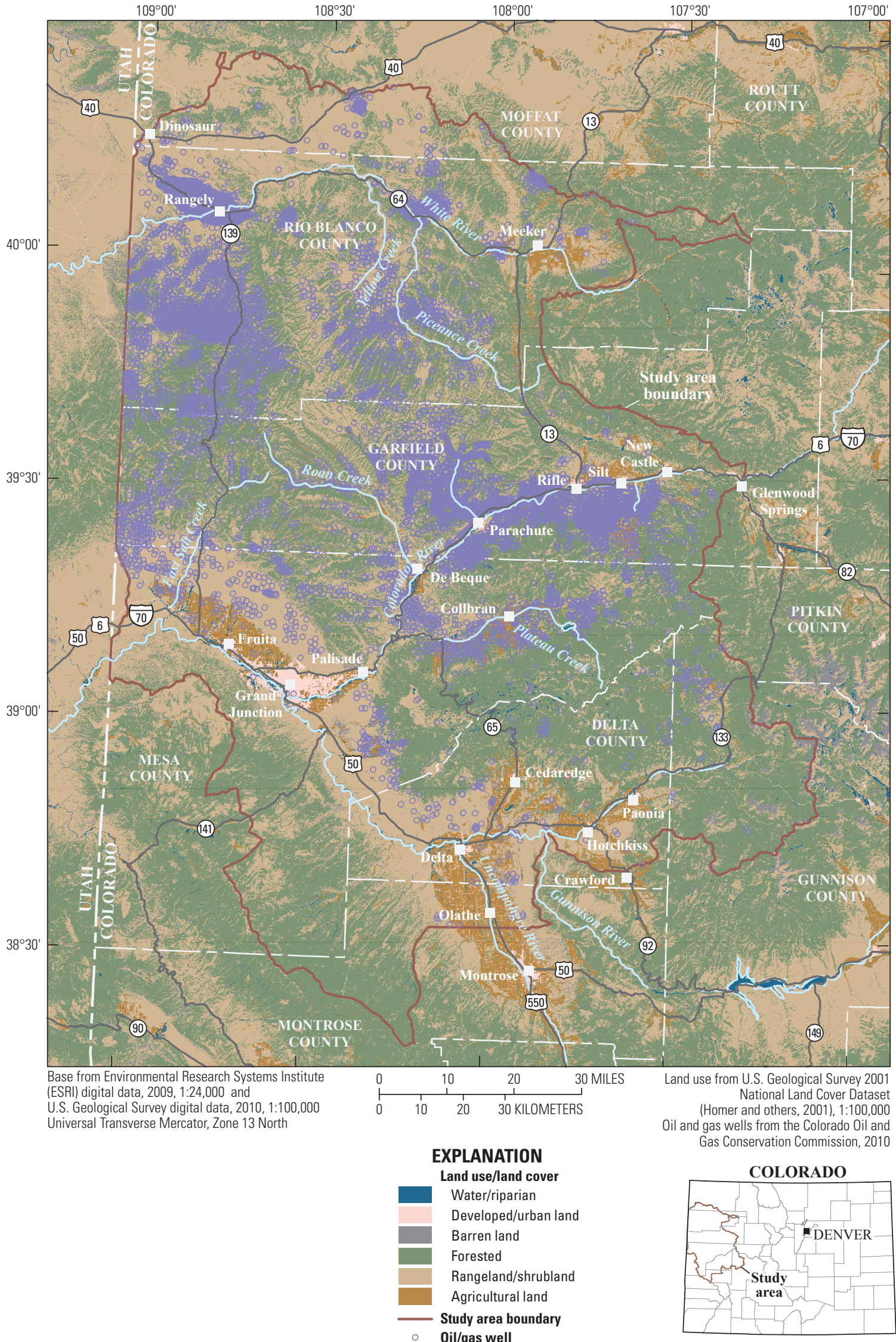

Figure 6. Land cover of the Piceance study area, western Colorado. 


\section{Lower Gunnison River Basin}

The area of the Lower Gunnison River Basin is 2,700 $\mathrm{mi}^{2}$, and the entire drainage area (measured from where the Gunnison River enters the Colorado River) is 7,900 $\mathrm{mi}^{2}$. The U.S. Forest Service manages the GMUG National Forests, which comprise $1,100 \mathrm{mi}^{2}$ (about 41 percent) within the basin. The BLM manages public lands with an area of about $790 \mathrm{mi}^{2}$ (29 percent) of public land; private ownership accounts for about $780 \mathrm{mi}^{2}$ (29 percent) (Bureau of Land Management, 2009). The land cover in the Lower Gunnison River Basin is dominated by forest (48 percent), rangeland (33 percent), and agriculture (8 percent) (Homer and others, 2004). Throughout the lower elevations in the Lower Gunnison River Basin, about 6 percent $\left(173 \mathrm{mi}^{2}\right)$ of the land is irrigated agriculture (Techni Graphic Systems, Inc., 2004). Coal mining occurs within the national forest in the North Fork of the Gunnison River. The GMUG has approximately $25 \mathrm{mi}^{2}$ of Federal coal leases (U.S. Forest Service, 2011).

The Gunnison River is the largest tributary to the Colorado River in Colorado. Major storage facilities such as the Wayne N. Aspinall Federal Storage Unit (fig. 1; outside the study area) are situated in line with the main channel of the Gunnison River (Bureau of Reclamation, 2011). There are multiple beneficial uses of Aspinall Project water, including irrigation and domestic supplies, hydropower generation, and essential environmental and recreational uses in Colorado. The Gunnison Tunnel (fig. 1) delivers about 320,000 acre-ft per year from the Gunnison River to the Uncompahgre River during the irrigation season (April through October) (Colorado Department of Public Health and Environment, 2010). Nearly $173 \mathrm{mi}^{2}$ of land are irrigated in the Lower Gunnison River Basin (Techni Graphic Systems, 2004). The complex geology, combined with various landuse types such as irrigation and residential development, can greatly impact water-quality conditions in the Lower Gunnison River Basin.

The source water for the City of Grand Junction comes from Juniata Reservoir and Kannah Creek (fig. 1), which drain the western slopes of the Grand Mesa into the Lower Gunnison River Basin. Energy development (gas drilling) is increasing in scale on the slopes of the Grand Mesa (Bureau of Land Management, 2004). This type of development has the potential to affect groundwater and surface-water quality running off the Grand Mesa.

\section{Land-Use Impacts}

Agricultural land use in the study area is largely irrigated where $440 \mathrm{mi}^{2}$ of the $540 \mathrm{mi}^{2}$ of agricultural land cover was irrigated in 2001 (Techni Graphic Systems, Inc., 2004; Homer and others, 2004). Irrigated agriculture is a main concern to water managers because of the additional dissolved solids (DS) that enter the watershed. Natural sources of DS include seeps or springs that originate from geological formations with high salt content. Salts are mobilized through dissolution, surface runoff, and deep percolation into the groundwater system that discharges to the river system as base flow (Kanzer and Merritt, 2008). The application of irrigation water to these agricultural lands increases the rate at which salts in the bedrock are dissolved and transported to streams (Prairie and others, 2005; Kenney and others, 2009). The history of salinity control efforts in the Gunnison and Colorado River Basins dates back to the 1970s when the Salinity Control Act, Public Law 93-320, prompted the creation of the Colorado River Basin Salinity Control Forum to investigate, plan, and construct projects to reduce salinity loading to the Colorado River (Bureau of Reclamation, 2009). Investigations and projects completed by the Colorado River Basin Salinity Control Forum refer to the entire drainage area of the Gunnison River or Colorado River, rather than the parts of the basins presented in this report. The Bureau of Reclamation (2011a) estimated that 47 percent of the salinity load in the entire Colorado River Basin is derived from natural sources, including geological formations, saline springs, and surface runoff; 37 percent results from irrigation; and the remaining 16 percent results from reservoir-storage effects and municipal and industrial activities.

Selenium is another concern in the Lower Gunnison and Colorado River Basins. The National Irrigation Water Quality Program (NIWQP) is a multiagency program within the Department of the Interior that has performed investigations of various irrigation projects in the Western United States to determine whether irrigation drainage was having adverse effects on water quality and on fish and wildlife (Butler and Leib, 2002). NIWQP studies were initiated in the Lower Gunnison River Basin in 1988. In 1997 the Colorado State Water Quality Control Commission revised the chronic aquatic-life criterion for dissolved selenium from 17 micrograms per liter $(\mu \mathrm{g} / \mathrm{L})$ to $4.6 \mu \mathrm{g} / \mathrm{L}$. In response to this action and in cooperation with NIWQP, the Gunnison Basin Selenium Task Force was established in 1998 as a group of private, local, State, and Federal interests to develop ideas and projects for reducing selenium in the Lower Gunnison River Basin.

\section{Previous Studies}

The Piceance study area in western Colorado contains energy, mineral, and other natural resources that have been the subject of numerous studies and publications. Selected publications that relate to water resources within the study area are summarized herein.

The relationship between groundwater and surface water in the White River Basin has been evaluated in several studies. A study of simulated effects of oil shale development used digital models to evaluate the hydrologic system (Weeks and others, 1975). The study, specifically in the Piceance and Yellow Creek drainage areas, concluded that proposed oil shale development would have significant effects on the surface-water and groundwater systems. A study from 1977 to 1981 of Piceance and Yellow Creeks collected physical and chemical data at perennial and intermittent streams 
(Tobin and others, 1985). The study indicated that groundwater contributions to streams during medium and low flow result in increases in fluoride, sulfate, dissolved solids, arsenic, boron, lithium, and strontium. A study conducted during December 2000 used tracer-dilution techniques and synoptic-water-quality sampling to evaluate mass loading in Piceance Creek (Ortiz, 2002). Groundwater upwelling in the Alkali Flats area (fig. 1) contributed substantially to observed increases in constituent concentrations; however, losses in streamflow resulted in small increases in loads downstream on the study reach.

Trends and loads of DS, suspended sediment, and other constituents in the White River Basin have been conducted. A study from 1975 to 1988 of sediment transport, water-quality characteristics, and loads on the White River determined that snowmelt runoff from the headwaters of the White River dilutes and transports large concentrations of suspended sediment and dissolved solids in the central part of the basin (Tobin, 1993). A study of characteristics and trends of streamflow and dissolved solids in the White River Basin reported a decrease in annual-median-flow-adjusted concentrations of dissolved solids in the White River below Meeker from 1974 through 1983 (Liebermann and others, 1989).

Water quality has been studied in springs and surface water in the Colorado River Basin. A study in the Colorado River Basin from 1981 to 1983 of discharge, water-quality, and radiochemical data collected at springs in the oil shale regions of the Roan and Parachute Creek Basins reported that springs were mixed-cation bicarbonate water types (Butler, 1985). The study also concluded that springs located near oil shale mines or processing plants could be used for monitoring groundwater quality and quantity. In 2008, the USGS published a report of DS trends (1986-2003) in the Upper Colorado River Basin upstream from the Grand Valley Salinity Control Unit (Leib and Bauch, 2008). The report details results for trends in concentrations and loads of DS and selected major ions near the Grand Valley Salinity Control Unit. The largest decrease in salinity load was 6,590 tons per year (ton/yr) and occurred in the area between the Colorado River at Cameo, Colo., and the Colorado River above Glenwood Springs, Colo. Downward trends in DS load (11,200 ton/yr) were detected at the Gunnison River near Grand Junction, Colo., streamflow-gaging station. A USGS study from 2004 to 2006 analyzed DS and selenium trends (concentrations and loads) in the Upper Colorado River Basin, specifically, in three tributaries to the Colorado River in the Grand Valley (Leib, 2008). The report states that the reduction in annual DS load at Lewis Wash (fig. 1) could be the result of either salinitycontrol work or land-use change, particularly the conversion of agricultural land to residential development. A USGS study from 2000 to 2004 collected and analyzed water-quality data for the Government Highline Canal and Highline Lake, which are located in the Grand Valley area (Ortiz, 2005). Data were used to characterize the seasonal stratification patterns, waterquality chemistry, bacteria populations, and phytoplankton community structure in the lake. Highline Lake was reported as having strong thermal and dissolved-oxygen stratification patterns during the summer months, which likely released ammonia from the bottom sediments. Generally, the seasonal succession of phytoplankton was similar to that of other lakes in similar climates.

The importance and complexity of DS and selenium in the Gunnison River is reflected in the abundance of studies and publications on the topics. These efforts have included quantifying the natural component of the DS load as well as identifying trends over time in DS and selenium concentrations and loads. Salt loading from natural sources in the Gunnison River Basin was 542,000 ton/yr for water years 1914-1957 (a water year is from October 1 through the following September 30 and is designated by the year in which it ends), assuming the 1957 level of water-resources development (Iorns and others, 1965). Another study for the same period used a mass balance approach and reported that $431,000-463,000$ tons of DS load were caused by natural sources (Mueller and Osen, 1988). The DS concentration and load results were reported in both studies for the site Gunnison River near Grand Junction, Colo. (streamflow-gaging station 09152500).

Studies that quantified DS trends over time relative to land-use changes have reported downward trends in DS at the Gunnison River near Grand Junction, Colo. (09152500) for different study periods. Liebermann and others (1989) quantified the DS trends at the Gunnison River near Grand Junction (streamflow-gaging station 09152500) based on the completion of the Blue Mesa Dam in 1965, the uppermost of the three dams that make up the Aspinall Unit. The Aspinall Unit is located outside of the study area upstream from the Lower Gunnison River Basin (fig. 1). The pre-reservoir period was 1934-1965 and the post-reservoir period was 1966-1983, and they performed a step trend test to determine whether there were significant differences between the pre- and post-dam periods as well as trend tests within each of the two periods. A downward step trend of 119,000 tons (pre- and post-dam comparison) was reported at the Gunnison River near Grand Junction, Colo., site as a result of the construction and operation of Blue Mesa reservoir, but there were no significant trends within each of the two periods (Liebermann and others, 1989). Streamflow and DS concentrations in the Gunnison River decreased during high flow (May-June) and increased during the low-flow period (August-March) as a result of Blue Mesa Reservoir. Butler and others (1996) reported a net downward trend of 146,000 tons of DS at Gunnison River near Grand Junction (streamflow-gaging station 09152500) from 1970 to 1993. Butler and others (1996) concluded that the measured decreases were not the result of DS control projects implemented by the Bureau of Reclamation and the Natural Resources Conservation Service. Leib and Bauch (2008) showed a downward trend of 201,600 tons in the Gunnison River near Grand Junction, Colo., for water years 1986-2003. Schaffrath (2012) quantified trends at 15 sites in the Gunnison River Basin. Results indicated a downward trend of 247,000 tons from 1989 to 2004 . The downward trend was smaller at 190,000 tons from 1989 to 2007, potentially indicating that DS concentration and load are leveling off. 
The effect of converting previously irrigated agricultural land to urban land use was investigated during two recent studies (Mayo, 2008; Moore, 2011) in western Colorado. The Grand Valley study measured irrigation-water application and deep percolation on urban sites in Grand Junction, Colo., where deep percolation was defined as infiltration of water below the top 12 inches of soil (Mayo, 2008). The measurements were compared to water application and deep percolation data from agricultural sites provided by the Natural Resources Conservation Service. The study results indicated that conversion of land from agricultural use to urban residential use can result in a decrease in salt loading of 90 percent per developed acre. The second study compared DS concentrations and load between two sites on the Montrose Arroyo near Montrose, Colo. (Moore, 2011). One site was upstream and the other was downstream from increased urbanization. The previous land use was dominated by irrigated agriculture but included other land-use categories. There were no significant differences between DS at the two sites, which implies that urbanization had no effect on DS concentration or load at that scale.

A study in 2007 analyzed selenium load from 1978 to 2005 in the Lower Gunnison River Basin in support of the development of total maximum daily loads (TMDLs) for selenium (Thomas and others, 2008). Results for the Uncompahgre River indicated that a reduction of 69 percent of the mean annual load of selenium for water years 2001-2005 was necessary to meet the water-quality standard for the Uncompahgre River at Delta, Colo., streamflow-gaging station.

\section{Methods}

The data compiled in the Web-accessible common data repository were analyzed to provide a baseline assessment of available water-resource data and aid in the development of regional monitoring strategies. Selected water-quality properties and constituents were compared to Federal and State standards or previous studies where applicable. When sufficient data were available, trends over time were analyzed and loads were calculated for those sites where there were also continuous streamflow data.

\section{Compilation of Data}

A repository of available water-quality data was compiled from local, State, and Federal agencies and private entities (consulting firms, energy, and mining companies). The data repository is accessible on the Internet at http://rmgsc.cr.usgs.gov/cwqdr/Piceance/index.shtml. Not all known data sources were loaded into the data repository for a variety of reasons, such as non-participation, non-electronic format, insufficient metadata, and late data submission.
However, the repository represents the most comprehensive set of surface-water-quality data for the study area available as of August 2009. Data were evaluated for duplication (the same site, sample, or result submitted to the repository under two or more source agencies) and removed prior to analysis. Sites and water-quality data were evaluated to determine if it was appropriate to aggregate data if sites were within a 50-ft buffer of one another. The USGS NWIS Water-Quality User Manual was consulted for evaluating properties and constituents that can be recensored (assigned the value of "less than the censoring level") if the stored value is zero and for properties and constituents that allow negative values (U.S. Geological Survey, 2011).

The data repository contained 1,433 surface-water sites, 45,008 samples, and 1,144,808 water-quality results for the period from 1931 to 2009 . A subset of data from the repository was extracted and checked for quality assurance for this report using the following criteria. Only water-quality data from the most recent 50 water years (1959 to 2009) were included, so data had to be collected after September 30, 1958. Sites were required to have five or more samples, collected over at least 13 months so that seasonality would be represented. USEPA water-quality standards and guidelines were used to analyze a subset of the available constituents. Additionally, specific constituents of interest were analyzed based on stakeholder input, land-use factors, recommendations from the Colorado Department of Public Health and Environment (CDPHE) 303d (table 2), and monitoring and evaluation lists (Colorado Department of Public Health and Environment, 2010). Lake sites were not included because of the lack of depth information associated with samples. When multiple samples were collected in a single day, such as stormwater sampling, the first sample was included and the remaining data were removed from the analysis. The final dataset used in this report included 347 surface-water sites, 35,970 samples, and 228,242 waterquality results (app. 1). Limited metadata were available for much of the data, which limited the ability to evaluate the quality of the water-quality data. No distinctions between water-quality data collection methods or laboratory-analytical techniques were made owing to this limited metadata. Disparities between data from various sources resulting from these differences may bias the statistical results. Robust statistical methods were employed to limit these sources of bias on the statistical results.

\section{Analysis of Data}

The final dataset that resulted from the compilation of the data contained 347 sites and 33 constituents. These data were summarized using summary statistics and compared to USEPA and CDPHE recommendations and standards. Additional criteria were applied to select data for analysis of time trends and load calculations. 
Table 2. Colorado Department of Public Health and Environment section 303(d) list of impaired waters and monitoring and evaluation list for the Piceance study area, western Colorado, 2011.

[CDPHE, Colorado Department of Public Health and Environment; WBID, water-body identifier; E. coli, Escherichia coli; Fe, iron; Se, selenium; Trec, total recoverable; USFS, U.S. Forest Service; USGS, U.S. Geological Survey. Data from Colorado Department of Public Health and Environment (2011b)]

\begin{tabular}{|c|c|c|c|c|c|}
\hline Segment & $\begin{array}{l}\text { CDPHE } \\
\text { WBID }\end{array}$ & Segment description & Segment portion & $\begin{array}{l}\text { Clean Water } \\
\text { Act Section 303(d) } \\
\text { impairment }\end{array}$ & $\begin{array}{l}303(d) \\
\text { priority }\end{array}$ \\
\hline LGunn 2 & COGULG02 & Gunnison River, Uncompahgre River to Colorado River & all & $\mathrm{Se}$ & high \\
\hline LGunn_8 & COGULG08 & Tributaries to Gunnison River, Kannah Creek & $\begin{array}{l}\text { Kannah Creek below } \\
\text { USGS station } 09152000\end{array}$ & $\mathrm{Se}$ & high \\
\hline NFkGunn_3 & COGUNF03 & $\begin{array}{l}\text { North Fork of the Gunnison from Black Bridge above Paonia to the confluence within } \\
\text { the Gunnison }\end{array}$ & all & $\mathrm{Se}$ & high \\
\hline NFkGunn_5 & COGUNF05 & $\begin{array}{l}\text { Hubbard, Terror, Minnesota and Leroux Creeks from USFS boundary to N. Fork. main stem } \\
\text { of Jay Creek and main stem and tributaries of Roatcap Creek to the N. Fork }\end{array}$ & $\begin{array}{l}\text { Leroux Creek, } \\
\text { Jay Creek, }\end{array}$ & $\mathrm{Se}$ & high \\
\hline L_Gunn_8 & COGUNF06a & Tributaries to the North Fork of the Gunnison River not on USFS lands & Short Draw & $\mathrm{Se}$ & high \\
\hline NFkGunn_6b & COGUNF06b & $\begin{array}{l}\text { Bear Creek, Reynolds Creek, Bell Creek, McDonald Creek, Cottonwood Creek, Love } \\
\text { Gulch, Cow Creek, Dever Creek, German Creek, Miller Creek, Stevens Gulch, Big Gulch, } \\
\text { Stingley Gulch and Alum Gulch not on national forest lands from the source to the North } \\
\text { Fork of the Gunnison River }\end{array}$ & Cottonwood Creek & $\mathrm{Se}$ & high \\
\hline Uncom_4b & COGUUN04b & Uncompahgre River, La Salle Road to Confluence Park & all & $\mathrm{Se}$ & high \\
\hline Uncom_4c & COGUUN04c & Uncompahgre River, Confluence Park to Gunnison River & all & $\mathrm{Se}$ & high \\
\hline Uncom_12 & COGUUN12 & Tributaries to Uncompahgre River, South Canal to Gunnison River & all & $\mathrm{Se}$ & high \\
\hline LCol_2 & COLCLC02b & Colorado River, Rapid Creek to Gunnison River & $\begin{array}{c}\text { Humphrey } \\
\text { Backwater area }\end{array}$ & $\mathrm{Se}$ & medium \\
\hline LCol_3 & COLCLC03 & Colorado River, Gunnison River to state line & all & $\mathrm{Se}$ & medium \\
\hline LCol_4a & COLCLC04a & Tributaries to Colorado River, Roaring Fork to Parachute Creek except for specific segments & all & $\mathrm{Se}$ & medium \\
\hline LCol_10 & COLCLC10 & $\begin{array}{l}\text { East Rifle Creek, West Rifle Creek and Rifle Creek, including tributaries from Rifle Gap to } \\
\text { the Colorado River }\end{array}$ & all & $\mathrm{Se}$ & low \\
\hline LCol_13b & COLCLC13b & Tributaries to Colorado River from Government Highline Canal Diversion to Salt Creek & Salt Creek & sediment & low \\
\hline LCol_13b & COLCLC13b & $\begin{array}{l}\text { Tributaries to Colorado River from Government Highline Canal Diversion to Salt Creek } \\
\text { except specific segments }\end{array}$ & all & $\mathrm{Se}$ & medium \\
\hline LCol_13b & COLCLC13b & $\begin{array}{l}\text { Tributaries to Colorado River from Government Highline Canal Diversion to Salt Creek } \\
\text { except specific segments }\end{array}$ & Adobe Creek & E. coli, $\mathrm{Fe}(\mathrm{Trec})$ & high \\
\hline LCol_13c & COLCLC13c & Walker Wildlife Area Ponds & all & $\mathrm{Se}$ & medium \\
\hline LCol_14c & COLCLC14c & Main stem of Roan Creek including all tributaries from Kimball Creek to the Colorado River & Dry Fork & $\mathrm{Se}$ & low \\
\hline LCol_19 & COLCLC19 & $\begin{array}{l}\text { Lakes and reservoirs tributary to the Colorado River, Parachute Creek to the Colorado/Utah } \\
\text { border }\end{array}$ & $\begin{array}{l}\text { West Pond Orchard } \\
\text { Mesa Wildlife Area }\end{array}$ & $\mathrm{Se}$ & high \\
\hline White_9d & COLCWH09d & $\begin{array}{l}\text { Sulphur Creek and tributaries from source to White River. Flag Creek and tributaries from } \\
\text { the East Fork of Flag Creek to the White River }\end{array}$ & all & $\mathrm{Se}$ & low \\
\hline White_22 & COLCWH22 & Tributaries to White River, Douglas Creek to Colorado-Utah border & $\begin{array}{l}\text { West Evacuation Wash, } \\
\text { Douglas Creek }\end{array}$ & sediment & low \\
\hline
\end{tabular}




\section{Summary Statistics}

Summary statistics were computed for each of the 347 sites and the selected constituents, including the period of record, the number of observations, the number of censored observations, and minimum, 25th percentile, median (50th percentile), 75th percentile, and maximum values (app. 1). Most of the 33 constituents are dissolved, meaning the sample was filtered, unless otherwise stated. Unfiltered samples will be referred to as total or total recoverable. In addition, certain constituents are never filtered and include field properties $(\mathrm{pH}$, temperature, dissolved oxygen, specific conductance). Constituents like E. coli and suspended sediment are also unfiltered as these are particulates carried in water. The determination of the chemical properties of waters can result in left-censored data (nondetects) because of analytical limits of the laboratory analysis. In a dataset of this breadth, there can be multiple forms of bias in nondetect data including antiquated methods for storing nondetects (zero and negative values) and changes in the meaning of less-than values (Helsel, 2005a). In an effort to reduce these sources of bias, zero-values were changed to the appropriate reporting limit for select constituents. Where multiple censoring levels exist for a single constituent, data were not edited to a common censoring level in this report (Helsel, 2005b). Instead, data were re-censored using the longterm method detection limit where applicable. This resulted in an improvement to the overall dataset but did not remove all instances of these forms of bias; therefore, these results should be considered with this in mind. Summary statistics were computed using Kaplan-Meier methods when no more than 50 percent of the observations were censored (Helsel, 2005b). Maximum likelihood estimations were computed for greater than 50 observations and where 50 to 80 percent of the observations were censored. Regression-on-order statistics were computed for less than 50 observations where 50 to 80 percent of the observations were censored. The data range, censoring levels, and maximum observation were reported where more than 80 percent of the observations were censored (Helsel, 2005b).

\section{Comparison to Standards}

Instream water-quality standards for surface water in Colorado have been established by the Water Quality Control Commission of the CDPHE to protect the beneficial uses of surface water, which include aquatic life, domestic water supply, agriculture, and recreation (Colorado Department of Public Health and Environment, 2010). The CDPHE provides basic standards (Regulation 31) and separates Colorado into 13 planning and management regions for regulatory purposes, each with standards tabulated by stream-reach segment.

Stream-segment descriptions for this study were used to assign each surface-water measurement site to a segment to apply the appropriate standards. Surface-water sites in the study area are located in one of the following three management regions: the Upper Colorado River Basin and North Platte River (Region
12, Regulation 33), the Lower Colorado River Basin (Region 11, Regulation 37), or the Gunnison and Lower Dolores River Basins (Region 10, Regulation 35). Not all constituents are regulated by established water-quality standards. The CDPHE has not established a water-quality standard for the constituent total phosphorus; therefore, the standard of $0.1 \mathrm{mg} / \mathrm{L}$ recommended by USEPA was used (U.S. Environmental Protection Agency, 2000). Data from the study area were compared to the CDPHE and USEPA standards to guide interpretation of surface-water quality, look for spatial patterns of standard exceedances, and obtain a broad understanding of waterquality conditions across the study area. The objective of this comparison was not to assess stream impairment or compliance with standards.

Each stream segment has a different standard and can be regulated for multiple beneficial uses. For example, a given segment may have a different standard for iron concentrations for drinking-water supply than for aquatic life. Standards can vary by season, elevation, or fish species believed to be present in the segment (for example, water temperature). Several segments that were matched to sites in the study area have temporary standards for certain constituents, particularly for selenium concentrations. Table 3 lists constituents and the standards for individual segments that were used to assess water-quality measurement sites in the study area.

The CDPHE has established two types of numeric waterquality standards: (1) fixed-value standards and (2) table-value standards (TVSs) (Colorado Department of Public Health and Environment, 2011). Fixed-value standards can be aquaticlife standards; USEPA maximum contaminant levels (MCLs); standards for domestic water supply; or recreation-based standards (table 3). An MCL is a legally enforceable standard that applies to drinking water from public water systems only. The TVSs are usually calculated values that are established for aquatic-life protection and include acute and chronic classifications. An acute standard is not to be exceeded by the concentration in a single sample or by the average concentration of all samples collected during a one-day period. For water temperature, the acute standard is the daily maximum, which is the highest 2-hour average temperature measured in a 24-hour period. A chronic standard is a value not to be exceeded by the concentration for either a single representative sample or by the average of all samples collected during a 30-day period. The chronic standard for water temperature is based on the average of equally spaced measurements (a minimum of three per day) made for seven consecutive days. The chronic standard is implemented in combination with a selected duration and frequency of recurrence. The TVSs for water temperature are specified for Regulation 37, the Lower Colorado River region, and are based on water temperature, fish species, and season. Acute and chronic TVSs based on $\mathrm{pH}$ and temperature have been established for total ammonia for cold- and warm-water stream segments. The TVSs have been established for trace elements based on stream hardness. The CDPHE hardness-dependent TVSs were calculated for samples analyzed for trace elements using either a hardness 
Table 3. Selected Colorado Department of Public Health and Environment instream water-quality standards for stream segments in the Piceance study area, western Colorado. Segments are listed only if a surface-water-measurement site was matched to the segment and contained data for the given constituent.

$\left[\mathrm{mg} / \mathrm{L}\right.$, milligrams per liter, ${ }^{\circ} \mathrm{C}$, degrees Celsius; col/mL, colonies per 100 milliliters; DM, daily maximum; MWAT, maximum weekly average temperature; TVS, table-value standard; MCL; maximum contaminant level; $\mu \mathrm{g} / \mathrm{L}$, micrograms per liter; sc, sculpin. Water-quality standards are from the Colorado Department of Public Health and Environment (2011) except for the recommended total phosphorus level, which is from the U.S. Environmental Protection Agency (2000)]

\begin{tabular}{cccc}
\hline Physical & \multicolumn{3}{c}{ Instream water-quality standard } \\
\cline { 2 - 3 } $\begin{array}{c}\text { property or } \\
\text { constituent } \\
\text { (units) }\end{array}$ & Type & Value' $^{1}$ & Qualification \\
\hline
\end{tabular}

\begin{tabular}{llcl}
\hline & & \\
\hline $\mathrm{pH}$ (standard units) & Aquatic life & $6.5-9.0$ & \\
$\begin{array}{l}\text { Dissolved oxygen } \\
(\mathrm{mg} / \mathrm{L})\end{array}$ & Aquatic life & 5.0 & \\
& & 6.0 & \\
& & \\
& 7.0 & spawning \\
& & & \\
& & &
\end{tabular}

\section{Water temperature}

$\left({ }^{\circ} \mathrm{C}\right)$

Aquatic life

17.0

$\left(\mathrm{MWAT}^{3}\right)$

Aquatic life, cold class 1 or 2

20.0

$\left(\mathrm{MWAT}^{3}\right)$

30.0

Aquatic life, warm class 1 or 2

Aquatic life Cold Stream Tier I

(June-September)

Aquatic life Cold Stream Tier I (October-May)

Aquatic life Cold Stream Tier II (April-October)

Aquatic life Cold Stream Tier II

(November-March)

Aquatic life Cold Lake

(April-December)

Aquatic life Cold Lake

(January-March)

Aquatic life Warm Stream Tier II

(March-November)

Aquatic life Warm Stream Tier II

(December-February)

Aquatic life Warm Stream Tier IV (March-November)

Aquatic life Warm Stream Tier IV

(December-February)

Field parameters

all

Regulation 35, Lower Gunnison River: 4a, 4b and North Fork Gunnison River: 6b and Uncompahgre River: 4b, 12 Regulation 37, Lower Colorado River: 2a, 2b, 3, 4d, 13a, 13b, 14c and White River: 11, 12, 13b, 13c, 15, 16, 21, 22 Regulation 33, Upper Colorado River: 3

Regulation 35, Lower Gunnison River: 1, 2, 3, 5, 6, 7, 8, 10 and North Fork Gunnison River: 1, 2, 3, 4, 5

Regulation 37, Lower Colorado River: 1, 5, 6, 7a, 7b, 8, 9b, 11a, 11b, 11d, 11e, 11f, 11g, 11h, 14a, 15, 16, 17a and

White River: 4, 7, 9a, 9c, 14a, 14b, 17, 18, 20

Regulation 33, Upper Colorado River: 3

Regulation 35, Lower Gunnison River: 1, 2, 3, 5, 6, 7, 8, 10 and North Fork Gunnison River: 1, 2, 3, 4, 5

Regulation 37, Lower Colorado River: 1, 5, 6, 7a, 7b, 8, 9b, 11a, 11b, 11d, 11e, 11f, 11g, 11h, 14a, 15, 16, 17a and

White River: 4, 7, 9a, 9c, 14a, 14b, 17, 18, 20

only for sites at Regulation 35, Lower Gunnison River: 3, 7, 8 and North Fork Gunnison River: 4, 5, 6a, 6b

greater than 7,000 feet

elevation in listed

segments

Regulation 35, Lower Gunnison River: 1, 3, 5, 6, 7, 8,10 and North Fork Gunnison River: 1, 2, 3, 4, 5

Regulation 35, Lower Gunnison River: 2, 4a, 4b and North Fork Gunnison River: 6a, 6b and Uncompaghre: 4b, 12

Regulation 37, Lower Colorado River: 5, 6, 7a, 8, 11a, 11b, 11d, 11e, 11f, 11g, 14a and White River: 4, 9a, 9c, 14a, 17,20

Regulation 37, Lower Colorado River: 5, 6, 7a, 8, 11a, 11b, 11d, 11e, 11f, 11g, 14a and White River: 4, 9a, 9c, 14a, 17,20

Regulation 33, Upper Colorado River: 3

Regulation 37, Lower Colorado River: 1, 4a, 4d, 7b, 10, 11h,14b, 16, 17a and White River: 7, 14b, 18

Regulation 33, Upper Colorado River: 3

Regulation 37, Lower Colorado River: 1, 4a, 4d, 7b, 10,11h,14b, 16, 17a and White River: 7, 14b, 18

Regulation 37, Lower Colorado River: 9b

Regulation 37, Lower Colorado River: 9b

Regulation 37, Lower Colorado River: 2a, 2b, 3,13b,14c and White River: 12, 13c, 15, 21

Regulation 37, Lower Colorado River: 2a, 2b, 3,13b,14c and White River: 12, 13c, 15, 21

Regulation 37, Lower Colorado River: 13a and White River: 13b, 16, 22

Regulation 37, Lower Colorado River: 13a and White River: 13b, 16, 22 
Table 3. Selected Colorado Department of Public Health and Environment instream water-quality standards for stream segments in the Piceance study area, western Colorado. Segments are listed only if a surface-water-measurement site was matched to the segment and contained data for the given constituent.-Continued

$\left[\mathrm{mg} / \mathrm{L}\right.$, milligrams per liter, ${ }^{\circ} \mathrm{C}$, degrees Celsius; col/mL, colonies per 100 milliliters; DM, daily maximum; MWAT, maximum weekly average temperature; TVS, table-value standard; MCL; maximum contaminant level; $\mu \mathrm{g} / \mathrm{L}$, micrograms per liter; sc, sculpin. Water-quality standards are from the Colorado Department of Public Health and Environment (2011) except for the recommended total phosphorus level, which is from the U.S. Environmental Protection Agency (2000)]

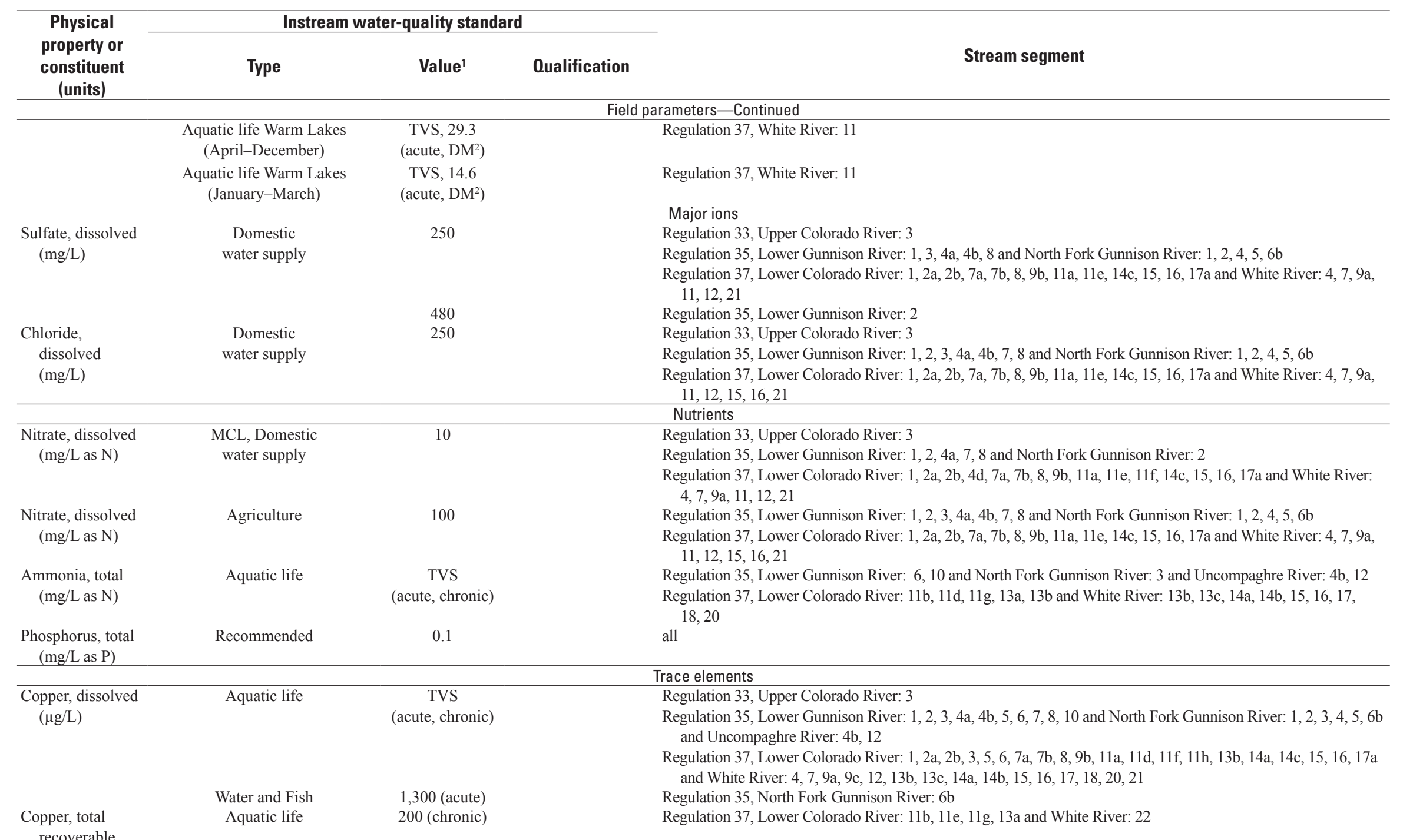


Table 3. Selected Colorado Department of Public Health and Environment instream water-quality standards for stream segments in the Piceance study area, western Colorado. Segments are listed only if a surface-water-measurement site was matched to the segment and contained data for the given constituent.-Continued

$\left[\mathrm{mg} / \mathrm{L}\right.$, milligrams per liter, ${ }^{\circ} \mathrm{C}$, degrees Celsius; col/mL, colonies per 100 milliliters; DM, daily maximum; MWAT, maximum weekly average temperature; TVS, table-value standard; MCL; maximum contaminant level; $\mu \mathrm{g} / \mathrm{L}$, micrograms per liter; sc, sculpin. Water-quality standards are from the Colorado Department of Public Health and Environment (2011) except for the recommended total phosphorus level, which is from the U.S. Environmental Protection Agency (2000)]

\begin{tabular}{|c|c|c|c|c|}
\hline \multirow{2}{*}{$\begin{array}{c}\text { Physical } \\
\text { property or } \\
\text { constituent } \\
\text { (units) } \\
\end{array}$} & \multicolumn{3}{|c|}{ Instream water-quality standard } & \multirow[b]{2}{*}{ Stream segment } \\
\hline & Type & Value $^{1}$ & Qualification & \\
\hline \multicolumn{5}{|c|}{ Trace elements-Continued } \\
\hline \multirow{3}{*}{$\begin{array}{l}\text { Iron, dissolved } \\
\quad(\mu \mathrm{g} / \mathrm{L})\end{array}$} & Domestic & 300 (chronic) & & Regulation 33, Upper Colorado River: 3 \\
\hline & water supply & & & Regulation 35, Lower Gunnison River: 1, 2, 3, 4a, 4b, 8, 10 and North Fork Gunnison River: 1, 2, 4, 5, 6b \\
\hline & & & & $\begin{array}{l}\text { Regulation 37, Lower Colorado River: 1, 2a, 2b, 4d, 5, 6, 7a, 7b, 8, 9b, 11a, 11e, 11f, 14a, 14c, 15, 16, 17a and } \\
\text { White River: 4, 7, 9a, 9c, 12, } 21\end{array}$ \\
\hline \multirow{4}{*}{$\begin{array}{l}\text { Iron, total } \\
\text { recoverable } \\
(\mu \mathrm{g} / \mathrm{L})\end{array}$} & Aquatic life & 1,000 (chronic) & & Regulation 33, Upper Colorado River: 3 \\
\hline & & & & $\begin{array}{l}\text { Regulation 35, Lower Gunnison River: 1, 2, 3, 4a, 4b, 6, 7, 8, } 10 \text { and North Fork Gunnison River: 1, 2, 3, 4, 5, 6a, } \\
6 \mathrm{~b} \text { and Uncompaghre River: 4b, } 12\end{array}$ \\
\hline & & & & $\begin{array}{l}\text { Regulation 37, Lower Colorado River: 1, 2a, 2b, 3, 4d, 5, 6, 7a, 7b, 8, 9b, 11a, 11d, 11f, 11h, 13b, 14a, 14c, 15, 16, } \\
\text { 17a and White River: 4, 7, 9a, 9c, 12, 13b, 13c, 14a, 14b, 15, 16, 17, 18, 20, } 21\end{array}$ \\
\hline & & $\begin{array}{l}\text { existing ambient } \\
\text { quality (chronic) }\end{array}$ & & Regulation 35, North Fork Gunnison River: 6b \\
\hline \multirow[t]{2}{*}{$\begin{array}{l}\text { Lead, dissolved } \\
\qquad(\mu \mathrm{g} / \mathrm{L})\end{array}$} & Aquatic life & $\begin{array}{c}\text { TVS } \\
\text { (acute, chronic) }\end{array}$ & & $\begin{array}{l}\text { Regulation 35, Lower Gunnison River: 1, 2, 3, 4a, 4b, 5, 6, 7, 8, } 10 \text { and North Fork Gunnison River: 1, 2, 3, 4, 5, 6a, } \\
6 \mathrm{~b} \text { and Uncompaghre River: 4b, } 12\end{array}$ \\
\hline & & & & $\begin{array}{l}\text { Regulation 37, Lower Colorado River: 1, 2a, 2b, 3, 5, 6, 7a, 7b, 8, 9b, 11a, 11d, 11f, 11h, 13b, 14a, 14c, 15, 16, 17a } \\
\text { and White River: 4, 7, 9a, 9c, 12, 13b, 13c, 14a, 14b, 15, 16, 17, 18, 20, } 21\end{array}$ \\
\hline $\begin{array}{l}\text { Lead, total } \\
\text { recoverable } \\
(\mu \mathrm{g} / \mathrm{L})\end{array}$ & Aquatic life & 100 (chronic) & & Regulation 37, Lower Colorado River: 11b, 11e, 11g, 13a and White River: 22 \\
\hline \multirow{9}{*}{$\begin{array}{l}\text { Selenium, } \\
\text { dissolved } \\
(\mu \mathrm{g} / \mathrm{L})\end{array}$} & Aquatic life & TVS, 18.4 & & Regulation 33, Upper Colorado River: 3 \\
\hline & & $\begin{array}{c}\text { (acute), } \\
4.6 \text { (chronic) }\end{array}$ & & $\begin{array}{l}\text { Regulation 35, Lower Gunnison River: 1, 2, 3, 4a, 4b, 5, 6, 7, 8, } 10 \text { and North Fork Gunnison River: 1, 2, 3, 4, 5, 6a, } \\
6 \mathrm{~b} \text { and Uncompaghre River: 4b, } 12\end{array}$ \\
\hline & & & & $\begin{array}{l}\text { Regulation 37, Lower Colorado River: 1, 2a, 2b, 3, 4d, 5, 6, 7a, 7b, 8, 11a, 11d, 11f, 11h, 13b, 14a, 14c, 15, 16, 17a } \\
\text { and White River: 4, 7, 9a, 9c, 12, 13b, 13c, 14a, 14b, 15, 16, 17, 18, 20, } 21\end{array}$ \\
\hline & & 5.7 (chronic) & $\begin{array}{c}\text { temporary, } \\
\text { expires } 12 / 31 / 2012\end{array}$ & Regulation 35, North Fork Gunnison River: 3 \\
\hline & & 8.4 (chronic) & $\begin{array}{l}\text { temporary, } \\
\text { expires } 12 / 31 / 2012\end{array}$ & Regulation 35, Lower Gunnison River: 2 \\
\hline & & 9.3 (chronic) & $\begin{array}{l}\text { temporary, } \\
\text { expires } 12 / 31 / 2012\end{array}$ & Regulation 35, Lower Gunnison River: 7 \\
\hline & & 20 (chronic) & $\begin{array}{c}\text { temporary, } \\
\text { expires } 12 / 31 / 2012\end{array}$ & Regulation 35, Uncompaghre River: 4b \\
\hline & Water and Fish & 170 (acute) & & Regulation 35, North Fork Gunnison River: 6b \\
\hline & Fish ingestion & 4,200 (acute) & & Regulation 37, White River: 17 \\
\hline \multirow{2}{*}{$\begin{array}{l}\text { Selenium, total } \\
\text { recoverable } \\
(\mu \mathrm{g} / \mathrm{L})\end{array}$} & Aquatic life & $\begin{array}{l}\text { existing ambient } \\
\text { quality (chronic) }\end{array}$ & $\begin{array}{c}\text { temporary, } \\
\text { expires } 12 / 31 / 2012\end{array}$ & Regulation 35, Lower Gunnison River: 4a and North Fork Gunnison River: 5, 6b and Uncompaghre River: 12 \\
\hline & & 20 (chronic) & & Regulation 37, Lower Colorado River: 11b, 11e, 11g, 13a and White River: 22 \\
\hline
\end{tabular}


Table 3. Selected Colorado Department of Public Health and Environment instream water-quality standards for stream segments in the Piceance study area, western Colorado. Segments are listed only if a surface-water-measurement site was matched to the segment and contained data for the given constituent.-Continued

$\left[\mathrm{mg} / \mathrm{L}\right.$, milligrams per liter, ${ }^{\circ} \mathrm{C}$, degrees Celsius; col/mL, colonies per 100 milliliters; DM, daily maximum; MWAT, maximum weekly average temperature; TVS, table-value standard; MCL; maximum contaminant level; $\mu \mathrm{g} / \mathrm{L}$, micrograms per liter; sc, sculpin. Water-quality standards are from the Colorado Department of Public Health and Environment (2011) except for the recommended total phosphorus level, which is from the U.S. Environmental Protection Agency (2000)]

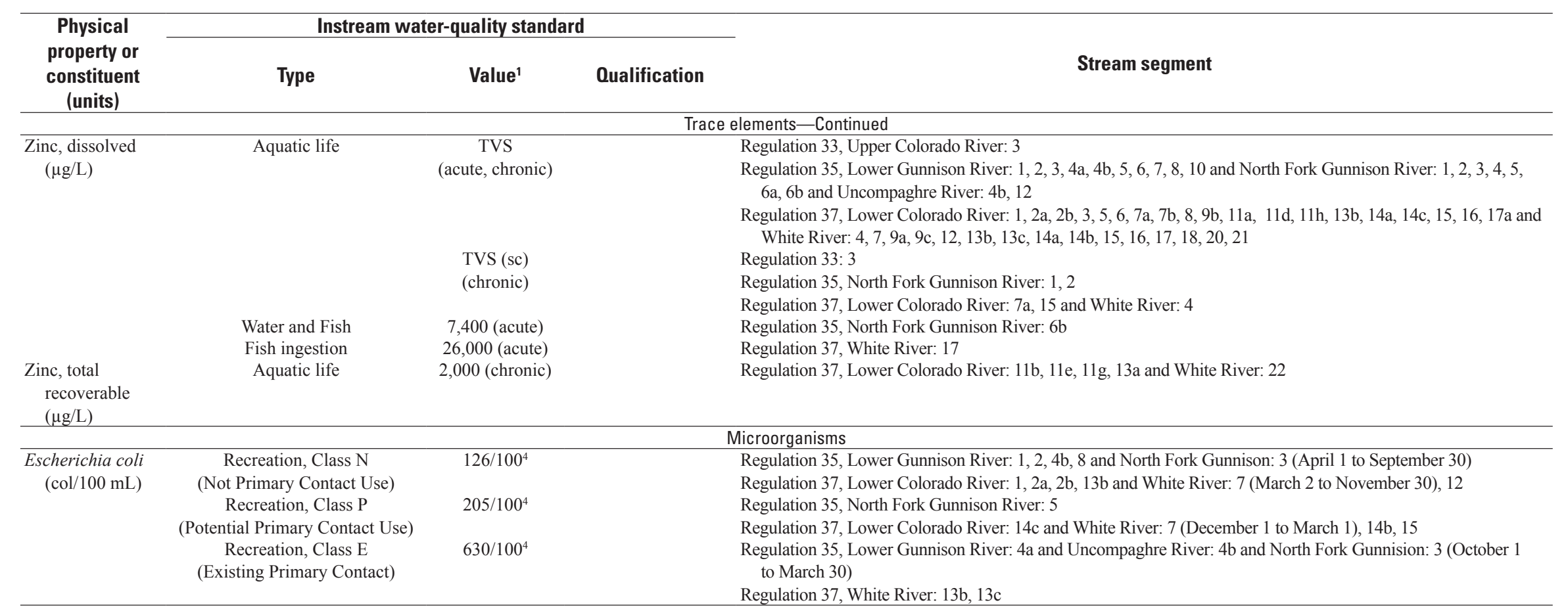

${ }^{1}$ Table value standards for trace elements vary with hardness. See Colorado Department of Public Health and Environment (2011).

${ }^{2}$ Daily maximum (DM) is the highest two-hour average water temperature recorded during a given 24-hour period (Colorado Department of Public Health and Environment, 2011).

${ }^{3}$ Maximum weekly average temperature (MWAT) is the maximum average of multiple, equally spaced, daily temperatures over seven consecutive days with a minimum of three data points spaced equally throughout the day. It is calculated from the optimum and upper temperatures tolerated by a species (Colorado Department of Public Health and Environment, 2011).

${ }^{4}$ Attainment of the standard is based on a two-month geometric mean of the data. 
value measured for the same sample or a calculated hardness derived from calcium and magnesium data for that sample. When hardness values exceed $400 \mathrm{mg} / \mathrm{L}$, a hardness of $400 \mathrm{mg} / \mathrm{L}$ (113 mg/L for zinc, sculpin standards) was used to determine trace element standards (Sarah Johnson, Colorado Department of Public Health and Environment, written commun., September 26, 2011).

\section{Trend Analysis and Load Calculation}

Data were selected from the original dataset of 347 sites for analysis of trends based on several criteria. Trend analysis using the method chosen was best for periods of 20 years or less; thus, data had to be collected after October 1, 1989, with a minimum of 8 years of continuous data. Data from 68 of the 347 sites met these criteria. Separate techniques for trends analysis were used depending on the constituent. Monotonic trends in field properties (water temperature, dissolved oxygen, and $\mathrm{pH}$ ) were assessed using the seasonal Kendall test, a nonparametric technique (Hirsch and others, 1982; Helsel and Hirsch, 2002). Regression models define the relation between the concentration of a given water-quality constituent with explanatory variables such as streamflow, seasonality, and time (Helsel and Hirsch, 2002; Cohn, 2005). The relation of concentration with time in the regression model describes the time trend.

The load of a given constituent is the mass of the constituent transported in the water. Regression models, which are parametric techniques, were used for estimating loads from the concentration data. Loads calculated from the field properties are either not possible (temperature or $\mathrm{pH}$ ) or not meaningful (dissolved oxygen).

Parametric techniques assume a normal distribution of the data, while nonparametric techniques do not require the data to be normally distributed (Helsel and Hirsch, 2002). Where there is a perfect normal distribution of the data, parametric tests have more statistical power. However, water-quality data will only approximate a normal distribution, so the statistical power in parametric and nonparametric techniques is similar for analysis of water-quality data (Helsel and Hirsch, 2002). Statistical power, in this analysis, refers to the probability of rejecting the null hypothesis that there is no time trend when there is a net trend (Alley, 1988; Hirsch and others, 1991).

\section{Seasonal Kendall Test}

Monotonic trends in temperature, dissolved oxygen, and pH data were tested using the seasonal Kendall test (Hirsch and others, 1982, 1991; Schertz and others, 1991; Helsel and Hirsch, 2002). The seasonal Kendall test accounts for seasonal variability in the field property data through the separation and comparison of data by each season. The seasonal Kendall test was applied using the computer program Estimate Trend (ESTREND) (Schertz and others, 1991), which was modified to run in the S-Plus Statistical Package (TIBCO Software, Inc., 1998-2008).
To run ESTREND, sites had to have a minimum of 8 years of record with 10 or more samples and less than 50 percent of the data could be censored. A total of 30 sites had sufficient data to meet these criteria for at least one of the three field properties. Seasonality was characterized within the ESTREND interface with input from the user. For the analysis presented in this report, a sampling frequency of 2 to 4 months was required, which allow trends to be run with 6 or 4 seasons, respectively. The choice of the number of seasons was determined using the first and last fifths of the record (Lanfear and Alexander, 1990; Schertz and others, 1991). If the site did not have at least one sample for each of at least four seasons in the first and last fifths of the record, the analysis was not completed. The user defines adequate seasonal characterization within ESTREND. For example, each season of every year for a 10 -year study period is compared to that same season for all other years. The user for this analysis required that at least 50 percent of possible seasonal comparisons were possible and that at least 3 of 4 seasons or 5 of 6 seasons must meet the 50 percent criteria to qualify for analysis (Schertz and others, 1991).

The seasonal Kendall tests for the significance of Kendall's tau, which in this case is testing time against concentration. The test is completed on each of the 4 to 6 seasons, the results are combined, and the resulting test statistic is evaluated against a standard normal distribution (Mann, 1945; Kendall, 1975; Hirsch and others, 1982; Schertz and others, 1991; Helsel and Hirsch, 2002). The p-value associated with Kendall's tau was used to determine the significance of a time trend, where the p-value is a measure of the probability of incorrectly rejecting the null hypothesis. The null hypothesis is that the probability distribution of the random concentration variable has not changed over time. The test statistic is adjusted in the ESTREND program to account for serial correlation among the seasons and compute a corrected $\mathrm{p}$-value. The trend was considered highly significant when the corrected p-value was less than 0.01 and significant when the corrected $\mathrm{p}$-value was greater than 0.01 and less than or equal to 0.05 . The trend direction from the seasonal Kendall test is the sign on the slope, which is computed as the median of all slopes between data pairs within the same season (Sen, 1968; Schertz and others, 1991; Helsel and Hirsch, 2002). The slope describes the monotonic trend observed throughout the entire trend period instead of an average annual slope, and the trend is not necessarily linear.

Trends in field properties or concentrations can be due to variability in streamflow quantity or timing. Where adequate streamflow data were available and the amount of censored water-quality data was less than 8 percent, the field property data were flow adjusted to account for the variability that was related to streamflow (Helsel and Hirsch, 2002). The flowadjustment portion of this analysis is derived from the relation between streamflow and the field property result where the flow-adjusted data are the residuals from the relation. The relation between streamflow and the field property data was significant when the p-value on the streamflow term was less 
than or equal to 0.05 . The ESTREND program has 13 flowadjustment models, and the best model was chosen based on the PRESS (prediction sum of squares) statistic (Myers, 1986; Schertz and others, 1991). The best model was the model with the minimum PRESS value, which indicates that the model has the lowest prediction error among the models compared. Residual plots were inspected qualitatively to assure that regression assumptions were met. Approximate normality of model residuals was apparent when the normal-probability plot was approximately linear relative to a 1:1 line and the plots of the residuals have no pattern and show uniformity of scatter (homoscedacity). Flow-adjusted analysis better quantifies changes in the field property over time that are not the result of changes in streamflow; therefore, where both trend tests were evaluated, preference was given to flow-adjusted trend results when the relation between streamflow and the field property was significant.

\section{Regression Model}

Additional selection criteria were applied to the dataset of 68 sites for analysis using the regression model. A total of 28 sites met the criteria of having a minimum of 8 years of record with at least 20 observations and less than 80 percent censoring of the data (Runkel and others, 2004).

Trends in concentration data were tested using regression models developed for each site, where constituent load was the response variable. The models were used to calculate annual load of each constituent. Concentrations are a mass per known volume of a constituent, and load represents the mass of the constituent in the river per unit time. Load (in tons or pounds) is computed by multiplying the concentration (milligrams or micrograms per liter) by the streamflow (cubic feet per second) and a unit conversion constant. Loads can be estimated for any day when a sample has been collected by assuming that the concentration represents the daily mean concentration. A regression model is used for the days when no sample was collected.

The regression model used for trend analysis was applied using a USGS statistical program, LOADEST (Load Estimation), that was developed by Runkel and others (2004). S-LOADEST is a version of the LOADEST software developed to run as a plug-in program to the PC-based statistical software package Spotfire S+ and was used in this study (TIBCO Software, Inc., 1998-2008). S-LOADEST uses up to six explanatory variables to build a regression model that defines the relation of a constituent load to streamflow, time, and season. The inclusion of streamflow in the regression meant that there had to be existing streamflow associated with each sample included in this part of the trend analysis. The resulting general equation form used in this analysis is similar to Runkel and others (2004), Cohn (2005), and Dalby (2006) and is represented below in equation 1 .

$$
\begin{aligned}
\ln L & =b_{0}+\left(\ln Q-\ln Q^{*}\right)+b_{2}\left(t-t^{*}\right) \\
& +b_{3}(\sin (2 \pi T))+b_{4}(\cos (2 \pi T))+e
\end{aligned}
$$

where

$L$ is the load, in tons, pounds, or million colonies;

$b_{0}$ is the regression equation intercept;

$b_{n}$ is the coefficient on the $n^{\text {th }}$ regression variable, where $n$ is 1 through 4 ;

$Q$ is a streamflow term, in cubic feet per second;

$Q^{*}$ is the streamflow centering value, in cubic feet per second;

$t$ is time, in decimal years;

$t^{*}$ is the time centering value from the calibration dataset, in decimal years;

$T$ is the decimal portion of the year starting January 1;

$e$ is the error associated with the regression equation;

$\sin$ is the sine; and

$\cos$ is the cosine.

The model is developed using a calibration dataset that includes the date of the periodic sample collection, the associated value of concentration, and a streamflow value associated with the sampling date. The input values for concentration and streamflow were log transformed to meet the assumptions of normality and constant variance (Hirsch and others, 1991). Quadratic terms for decimal time and (or) streamflow were significant variables in some of the final selected model equations. However, with both the linear and quadratic terms in the equation, the possibility of multicollinearity increases, which inflates the variance in the associated coefficients. Streamflow and decimal time were centered to reduce the likelihood of multicollinearity and to ensure orthogonality in the streamflow and decimal time variables (Cohn and others, 1992). Compensation for differences in seasonal flux was accomplished, where significant, using Fourier series (Runkel and others, 2004; Cohn, 2005; Dalby, 2006). Fourier series uses sine and cosine terms to describe continual changes over the seasonal period. Model coefficients $\left(b_{n}\right)$ were estimated using adjusted maximum likelihood estimation (Runkel and others, 2004).

The p-value associated with the model coefficient on the time parameter(s) was used to determine the significance of a time trend. The p-value associated with model coefficient(s) is the probability of obtaining the computed parameter coefficient when the null hypothesis is true, where the null hypothesis is that the coefficient is zero. The trend was considered highly significant when the p-value for the time term(s) was less than 0.01 and significant when the p-value was greater than 0.01 and less than or equal to 0.05 . The sign (positive or negative) on the model coefficient(s) was used to determine the net direction of the trend. The time term in the model represents the trend over time for concentration and load and accounts for flow and seasonal variability. The net direction was only presented when the p-value indicated that the linear time term was significant. When quadratic time was significant, the trend was referred to as parabolic. The water year when the slope of the parabola was zero was presented as the year when the direction changed. The zero-slope year and the 
directions of the trend before and after the zero-slope year were visually determined using plots of the model line without streamflow or seasonality terms. The model line describes the mean response of the concentration and load variable relative to the explanatory variables (time, streamflow, and seasonality) that were significant.

The final model equations were obtained by iteration using the option that is built into S-LOADEST that chooses the best model from nine model options made up of varying combinations of the variables listed in equation 1 . The best model has the lowest Akaike Information Criteria (Runkel and others, 2004). S-LOADEST outputs diagnostic plots and statistics that were used to determine whether the calibration data met the assumptions of normality. The plots included a normal-probability plot and plots of the standardized residuals. Normality of model residuals was apparent when the normalprobability plot was approximately linear relative to a 1:1 line and the plots of the residuals have no pattern and show uniformity of scatter (homoscedacity). The plots were assessed qualitatively by the authors of this report. The criteria for the model statistics were that the variance inflation factor had to be less than 10 for each parameter in the model; serial correlation of the residuals had to be less than 0.6 and estimated residual variance had to be less than 1 . Additionally, the p-values of the model coefficients had to be significant, or less than 0.05 , to be included in the final model (app. 2). This final criterion had two exceptions: (1) only one of the model coefficients on the sine-cosine pair of the Fourier series had to be significant for the pair to be included in the model and (2) the linear time term was included anytime quadratic time was significant, even if the linear time was not significant. If the final model failed any of these diagnostics, results from the trend analysis were not presented. This scenario may indicate that more data might be required or a more randomized sampling approach might be needed to acquire a normal distribution of data.

Annual loads were used for a regional loading analysis. Using the selected form of equation 1 that was unique for each site and an estimation dataset with daily streamflow values, daily load and concentration were estimated. Annual loads were the sum of the daily loads for the water year. Each site and constituent had different study periods for trend analysis and, in some cases, the daily streamflow record had missing years; therefore, a comparison of sites required the selection of a common year among the sites based on the average annual streamflows for each site. Discussion of the loads using a common year provided the opportunity to describe sources of the constituent of interest. For each constituent described in the regional loading analysis, the average annual streamflow was calculated for each site. The average annual streamflow was calculated for the common study period of all the sites where the same constituent was analyzed. For example, the Colorado River Basin had four DS sites that had sufficient data for trend analysis and load calculation. The longest study period was 1990 to 2009 and the shortest was 1992 to 2002. Thus, the average annual streamflow for those four sites was calculated for the period 1992 to 2002. The one year within that period was chosen that most closely matched the average annual streamflow for each site. That common year was the year that represented the common study period for that constituent and basin.

Temporal trends have both a statistical significance and an environmental significance, but this distinction is often a subjective decision based on the context of the current stream conditions. Review of trend summaries requires consideration of the specific constituent of concern and any corresponding standard.

\section{Characterization and Data-Gap Analysis of Surface-Water Quality}

Surface-water quality can be affected by natural and human factors. Natural factors affecting water quality include but are not limited to geology, soil type, vegetation, streamflow, precipitation, and climate. Human factors can include activities such as urbanization, agriculture, and other types of land development, including energy development and infrastructure. Potential effects of land-use activities on water quality may include changes in streamflow, changes in DS concentration and load, detection of chemicals associated with energy development, and increases in sediment in streams that can potentially transport chemicals that have adhered to the sediment. The relation between land use and surface-water quality is complex and often requires special monitoring efforts to identify specific sources contributing to changes in surface-water quality. Land and water-use managers need a better understanding of the relationship between land use and water quality. The descriptions of surface-water quality in this study are designed as an inclusive approach to help understand changes in the Piceance study area. Data gaps and limitations might inhibit the analysis from conveying specific conclusions that identify pollution sources or their immediate effects within the study area.

\section{Summary Statistics and Comparison to Standards}

Summary statistics and water-quality exceedances are discussed by basin to provide a general overview of water quality (app. 1). Throughout the Piceance study area, waterquality constituent sampling was variable among basins. Summary statistics and comparison to standards were provided for 347 sites. The locations of these sites are shown on plate 1 and exceedances of water-quality standards are shown on plates 2 through 5 . The constituents summarized include field properties ( $\mathrm{pH}$, temperature, dissolved oxygen), nutrients (ammonia, nitrate, orthophosphate, total phosphorus, dissolved organic carbon), major ions (calcium, magnesium, sodium, potassium, chloride, sulfate, fluoride, silica, alkalinity, bicarbonate, carbonate, dissolved solids), dissolved trace elements (copper, iron, lead, zinc, selenium), total recoverable iron, 
Escherichia coli (E. coli), suspended sediment, and BTEX compounds (benzene, toluene, ethylbenzene, xylene). The number of observations, number of censored observations, period of record, minimum, 25th percentile, median (50th percentile), 75th percentile, maximum values, and, where appropriate, information on censored values for each constituent, and comparison to water-quality standards are provided in appendix 1 .

The collection of field properties is an important component to all water-quality sampling in order to properly characterize water-quality results. The majority of sites had information on field properties (app. 1, pl. 2). For the entire study area, 316 sites had temperature data collected between 1959 and 2009: 41 sites in the White River Basin, 165 sites in the Colorado River Basin, and 110 sites in the Lower Gunnison River Basin. Median temperature values ranged from 0.5 to 17.0 degrees Celsius $\left({ }^{\circ} \mathrm{C}\right)$ in the White River Basin, from 4.0 to $19.0^{\circ} \mathrm{C}$ in the Colorado River Basin, and from 0.7 to $19.5^{\circ} \mathrm{C}$ in the Lower Gunnison River Basin. There were 326 values out of a total of 32,006 values in the study area that exceeded the aquatic-life standard for daily maximum water temperature: 220 values in the White River Basin and 106 values in the Colorado River Basin. There were 220 values that exceeded the aquatic-life standard for maximum weekly average water temperature in the study area: all 220 occurred in the Lower Gunnison River Basin. Maximum weekly average water temperature standards only exist for the Lower Gunnison in the study area (table 3). For the entire study area, 196 sites had dissolved-oxygen data collected between 1970 and 2009: 34 sites in the White River Basin, 111 sites in the Colorado River Basin, and 51 sites in the Lower Gunnison River Basin. Median dissolved-oxygen concentrations ranged from 7.6 to $11.2 \mathrm{mg} / \mathrm{L}$ in the White River Basin, from 6.8 to $10.9 \mathrm{mg} / \mathrm{L}$ in the Colorado River Basin, and from 7.0 to $11.2 \mathrm{mg} / \mathrm{L}$ in the Lower Gunnison River Basin. There were 185 concentrations that exceeded the dissolved oxygen aquatic-life standard out of a total of 11,248 values in the study area: 13 in the White River Basin, 168 in the Colorado River Basin, and 4 in the Lower Gunnison River Basin. There were 273 concentrations that exceeded the aquatic-life standard for dissolved oxygen (spawning season only) in the study area: 27 in the White River Basin, 214 in the Colorado River Basin, and 32 in the Lower Gunnison River Basin. For the entire study area, 276 sites had $\mathrm{pH}$ data collected between 1958 and 2009: 39 sites in the White River Basin, 147 sites in the Colorado River Basin, and 90 sites in the Lower Gunnison River Basin. Median pH values ranged from 7.9 to 8.9 in the White River Basin, from 7.5 to 9.0 in the Colorado River Basin, and from 7.4 to 8.7 in the Lower Gunnison River Basin. There were 241 values out of a total of 16,307 values that exceeded the high $\mathrm{pH}$ standard in the study area: 32 in the White River Basin, 191 in the Colorado River Basin, and 18 in the Lower Gunnison River Basin. There were 7 values that were less than the low $\mathrm{pH}$ standard in the study area: 1 in the White River Basin, 2 in the Colorado River Basin, and 4 in the Lower Gunnison River Basin.
Natural changes in precipitation and streamflow and anthropogenic changes in nutrient sources (such as wastewater treatment facilities, golf courses, urban runoff, agricultural fields, and septic tanks) can influence nutrient concentrations in streams (Sprague and others, 2009). Nitrogen and phosphorus inputs to the stream could be derived from fertilizer and manure applications to agricultural land areas (Puckett, 1994; Paschke and others, 2008). Nutrients within the study area were not well represented in each basin and were often not being sampled currently (August 2009) (app. 1, pl. 3). The White River Basin, in contrast to the other basins, had recent nutrient data collected in the past 5 years and historic nutrient data. For the entire study area, 62 sites had nitrate data collected between 1958 and 2009: 24 sites in the White River Basin, 22 sites in the Colorado River Basin, and 16 sites in the Lower Gunnison River Basin. Median nitrate concentrations ranged from less than detection to $1.49 \mathrm{mg} / \mathrm{L}$ as nitrogen $(\mathrm{N})$ in the White River Basin, from less than detection to $2.70 \mathrm{mg} / \mathrm{L}$ as $\mathrm{N}$ in the Colorado River Basin, and from less than detection to $3.72 \mathrm{mg} / \mathrm{L}$ as N in the Lower Gunnison River Basin. The MCL for domestic water supply for nitrate is $10 \mathrm{mg} / \mathrm{L}$ and was exceeded once in 3,736 samples. Total phosphorus data was better represented spatially throughout the study area relative to other nutrients. Total phosphorus was collected at 113 sites between 1974 and 2009: 32 sites in the White River Basin, 43 sites in the Colorado River Basin, and 38 sites in the Lower Gunnison River Basin. Median total phosphorus concentrations ranged from 0.02 to $5.04 \mathrm{mg} / \mathrm{L}$ in the White River Basin, from less than detection to $0.6 \mathrm{mg} / \mathrm{L}$ in the Colorado River Basin, and from less than detection to $0.55 \mathrm{mg} / \mathrm{L}$ in the Lower Gunnison River Basin. The USEPA recommendation for phosphorus is less than $0.1 \mathrm{mg} / \mathrm{L}$, and 1,469 of 4,842 samples exceeded this recommended standard in the study area. Overall, 400 values in the White River Basin, 586 values in the Colorado River Basin, and 483 values in the Lower Gunnison River Basin exceeded the recommended standard.

Standards for major ions exist only for chloride and sulfate (app. 1, pl. 4). For the entire study area, 118 sites had chloride and sulfate concentration data collected between 1958 and 2009: 27 sites in the White River Basin, 49 sites in the Colorado River Basin, and 42 sites in the Lower Gunnison River Basin. Median chloride concentrations ranged from 1.4 to $165 \mathrm{mg} / \mathrm{L}$ in the White River Basin, from 1.4 to $280 \mathrm{mg} / \mathrm{L}$ in the Colorado River Basin, and from 0.085 to $190 \mathrm{mg} / \mathrm{L}$ in the Lower Gunnison River Basin. There were 120 samples with chloride concentrations that exceeded the chloride domestic water-supply standard of $250 \mathrm{mg} / \mathrm{L}$ from a total of 8,817 samples with chloride concentration data: 86 in the White River Basin and 34 in the Colorado River Basin. Median sulfate concentrations ranged from 57.5 to $1,780 \mathrm{mg} / \mathrm{L}$ in the White River Basin, from 11.0 to $15,000 \mathrm{mg} / \mathrm{L}$ in the Colorado River Basin, and from 4.57 to $1,680 \mathrm{mg} / \mathrm{L}$ in the Lower Gunnison River Basin. There were 1,111 samples with sulfate concentrations that exceeded the sulfate domestic water-supply standard of $250 \mathrm{mg} / \mathrm{L}$ (477 mg/L in the Lower Gunnison River Basin) 
(table 3) from a total of 8,736 samples with sulfate concentration data in the study area: 503 in the White River Basin, 131 values in the Colorado River Basin, and 477 in the Lower Gunnison River Basin.

Many trace elements in natural waters are essential to plant and aquatic life. There are natural (geology) and anthropogenic sources of trace elements in streams. Mining can provide conduits for water and air to come in contact with the underlying geologic material, where both physical and chemical weathering can dissolve and transport these constituents into streams. River segments adjacent to urban areas are subject to mobilization of trace elements from urban runoff and treated wastewater. Trace elements were relatively well represented both temporally and spatially in the study area (app. 1, pl. 5), though the number of trace element samples per site was not typically enough to compute trends or loads except for selenium. There were 109 sites that had dissolved copper concentration data collected between 1972 and 2009: 27 sites in the White River Basin, 42 sites in the Colorado River Basin, and 40 sites in the Lower Gunnison River Basin. Median copper concentrations ranged from less than detection to $4.5 \mu \mathrm{g} / \mathrm{L}$ in the White River Basin, from 0.62 to $6 \mu \mathrm{g} / \mathrm{L}$ in the Colorado River Basin, and from 0.53 to $5 \mu \mathrm{g} / \mathrm{L}$ in the Lower Gunnison River Basin. Copper concentrations were compared to two standards: the chronic (30-day) aquatic-life standard, which ranges from 1.57 to $29.3 \mu \mathrm{g} / \mathrm{L}$, and the acute aquatic-life standard, which ranges from 1.96 to $49.6 \mu \mathrm{g} / \mathrm{L}$ in the study area (table 3). There were 69 samples with copper concentrations that exceeded the chronic standard from a total of 2,885 samples with copper concentration data: 12 in the White River Basin, 23 in the Colorado River Basin, and 34 in the Lower Gunnison River Basin. There were 29 samples with copper concentrations that exceeded the acute standard: 9 in the White River Basin, 2 in the Colorado River Basin, and 18 in the Lower Gunnison River Basin. There were 127 sites that had dissolved iron concentration data collected between 1961 and 2009: 33 sites in the White River Basin, 63 sites in the Colorado River Basin, and 31 sites in the Lower Gunnison River Basin. Median iron concentrations ranged from 7 to $78 \mu \mathrm{g} / \mathrm{L}$ in the White River Basin, from less than detection to $1,100 \mu \mathrm{g} / \mathrm{L}$ in the Colorado River Basin, and from 4 to $120 \mu \mathrm{g} / \mathrm{L}$ in the Lower Gunnison River Basin. The 30-day drinking-water standard for iron is $300 \mu \mathrm{g} / \mathrm{L}$, and 203 samples exceeded the standard from a total of 5,027 samples with iron concentration data, 196 of which occurred in the Colorado River Basin, most of which are from Divide Creek. The samples on Divide Creek were collected as part of a multiphase water-quality investigation associated with a leaking natural gas well (Papadopulos \& Associates, Inc., 2008). Selenium was the best represented trace element with selenium concentration data collected at 197 sites between 1973 and 2009: 28 sites in the White River Basin, 94 sites in the Colorado River Basin, and 75 sites in the Lower Gunnison River Basin. Median selenium concentrations range from 0.79 to $5.7 \mu \mathrm{g} / \mathrm{L}$ in the White River Basin, from less than detection to $86 \mu \mathrm{g} / \mathrm{L}$ in the Colorado River Basin, and from less than detection to
$181 \mu \mathrm{g} / \mathrm{L}$ in the Lower Gunnison River Basin. For most stream segments in the study area, the chronic (30-day) aquatic-life selenium standard is $4.6 \mu \mathrm{g} / \mathrm{L}$, but a few segments have temporary chronic standards based either on a fixed standard or on the 85th-percentile data value for a given site, which can be as high as $280 \mu \mathrm{g} / \mathrm{L}$ (table 3 ). The chronic standard for selenium concentrations was exceeded in 899 samples: 22 in the White River Basin, 741 in the Colorado River Basin, and 136 in the Lower Gunnison River Basin. The acute aquatic-life standard of $18.4 \mu \mathrm{g} / \mathrm{L}$ for selenium was exceeded in 629 samples: 202 in the Colorado River Basin and 427 in the Lower Gunnison River Basin.

Statistics for suspended sediment, E. coli, and BTEX were summarized (app. 1). The study area included 53 sites with suspended sediment data. Sediment affects macroinvertebrate and fish habitat and municipal water treatment. Where sediment is on the monitoring and evaluation list of the CDPHE 303d list, there is not an easily defined standard. Only 18 sites had E. coli concentration data that could provide an assessment of the suitability of the water for recreational use. The E. coli recreational standard is 630 colony forming units (CFU) in streams where primary contact (such as swimming or other water sports) will occur, $205 \mathrm{CFU}$ in areas of potential primary contact, and $126 \mathrm{CFU}$ where the stream is not suitable for primary contact recreation (table 3 ). Of the 18 sites, 11 sites had exceedances of the $E$. coli recreational standard (app. 1). The seasonal E. coli standard is $126 \mathrm{CFU}$ and was only exceeded once in the White River Basin. There were 5 sites in the Colorado River Basin that had BTEX concentration data, which could be a constituent of interest when looking at energy-related activities. For example, in the Divide Creek and Mamm Creek area (fig. 1), BTEX concentration data were used to evaluate the impacts from faulty natural gas production well completion where detections and elevated concentrations of BTEX were observed in surface water and groundwater (Papadopulos \& Associates, Inc., 2008). BTEX does not persist in the environment where conditions are typically well oxygenated, so BTEX might not be a constituent to add to routine monitoring of surface water, but more for use in evaluating known occurrences and persistent sources of BTEX.

\section{Temporal Trends and Loads}

The results of the trend analysis are presented for the three study basins starting with the northernmost basin (White River Basin) and ending with the southernmost basin (Lower Gunnison River Basin). Within each basin, results are presented beginning with the main-stem sites in the basin, starting with the most upstream site and ending with the most downstream site. The most downstream site on the main stem in each basin represents the entire drainage area of the basin. After the main-stem sites, tributary sites are presented from upstream to downstream. Finally, trends for lower order tributaries are presented where there were sufficient data for analysis. Only 37 sites met the final selection criteria for trend 
analysis: 31 sites had sufficient field property data for analysis using the seasonal Kendall test and 28 sites had sufficient concentration data for analysis using regression models (fig. 7).

Loads and exceedances are presented for some constituents not only to provide context to the trends analysis results, but also to identify data gaps. Additionally, the land use and geology for each basin, as it may relate to water quality, are presented in further detail. Loading profiles are presented for selected constituents for all sites where trend analysis was computed and where there were sufficient streamflow data to compute a load. The figures include both main-stem and tributary sites and are ordered from upstream to downstream (figs. 8-12).

Loads and loading profiles are presented in figures 8-12, and trend data are presented in tables 4-7. Table 4 contains the results of the trend analysis for field properties using ESTREND. Tables 5-7 present the results of the trends analysis for concentration data (nutrients, major ions and dissolved solids, and trace elements, respectively) using S-LOADEST. Tables include the study period and a trend direction (where trends were significant) when sufficient data existed for trend analysis. The code "ND" was used to indicate that there were no data for that constituent at that site. The code "IS" indicates that there were data but they did not meet the selection criteria detailed in the "Trend Analysis and Load Calculation" section presented earlier in this report (p. 21). The code "NT" was used to indicate no trend, and "F" was used to indicate the model failed diagnostics. The code "NA" was used to indicate not applicable. In the field properties table (table 4), there are also dashes (-) that were used to indicate that the dataset met the initial criteria but did not meet the internal ESTREND criteria to adequately characterize seasonality.

\section{White River Basin}

Temporal and spatial variability of water-quality data in the White River Basin were evaluated at 10 sites: 6 sites on the White River main stem and 4 sites on tributaries to the White River (tables 4-7, fig. 7). Main-stem sites on the White River were 09304200 (White River above Coal Creek), 09304500 (White River near Meeker), 09304800 (White River below Meeker), 09306224 (White River above Crooked Wash near White River City), 09306290 (White River below Boise Creek, near Rangely), and 09306305 (White River below Taylor Draw Reservoir, above Rangely) (fig. 1) in order from upstream to downstream. Tributary sites included 2 sites on Piceance Creek, 09306200 (Piceance Creek below Ryan Gulch, near Rio Blanco) and 09306222 (Piceance Creek at White River) from upstream to downstream; 09306242 (Corral Gulch near Rangely), which is tributary to Yellow Creek; and 09306255 (Yellow Creek near White River), which then flows into the White River downstream from Piceance Creek.

\section{Field Properties}

Results of the trend analysis for water temperature, $\mathrm{pH}$, and dissolved oxygen are presented in table 4 . Sufficient data were available to analyze for water temperature trends at 8 sites in the White River Basin; however, there were no significant trends in water temperature at any of these sites. Sufficient data were available to analyze for dissolved-oxygen trends at 6 sites; however, no trends were detected from 1990 to 2009 for all sites. Sufficient data existed to analyze for $\mathrm{pH}$ trends at 6 sites. An upward trend in $\mathrm{pH}$ was observed at the most upstream site, 09304200 (White River above Coal Creek), from 1990 to 2009, and no trends were detected at the remaining 5 sites for the same period.

\section{Nutrients}

Trends in nutrient concentration data were evaluated for ammonia, nitrate, orthophosphate, and total phosphorus in the White River main stem (table 5). In addition, organic carbon and E. coli are discussed in this section as well. At 09304200 (White River above Coal Creek, near Meeker), a net, upward trend was detected in nitrate from 1990 to 2009. The trend was parabolic with a zero-slope year around 2002, after which the shape of the parabola indicated a downward trend. Trends were detected in other nutrients at this site, including an upward trend in total phosphorus from 1991 to 2009 and a downward trend in orthophosphate from 1990 to 2009. A net, downward trend in orthophosphate was detected at 09304800 (White River below Meeker) from 1990 to 2009. The trend was parabolic with a zero-slope year around 1997, prior to which the shape of the parabola indicated an upward trend. Trends in orthophosphate were consistently downward throughout the main stem of the White River. All other models failed diagnostics for nutrients for this site. Downstream at site 09306290 (White River below Boise Creek, near Rangely), dissolved organic carbon had a net, downward trend from 1990 to 2009. The trend was parabolic with a zero-slope year around 1999, prior to which the shape of the parabola indicated an upward trend.

Trends were analyzed for nutrients on tributary sites to the White River Basin (table 5). Downward trends were detected for nitrate, orthophosphate, and organic carbon at site 09306200 (Piceance Creek below Ryan Gulch, near Rio Blanco) from 1990 to 2009. Downstream, at site 09306222 (Piceance Creek at White River), no trend was detected in orthophosphate and the model failed diagnostics for nitrate for the same period. It is unclear why the trend in orthophosphate is not consistent between Piceance Creek below Ryan Gulch, near Rio Blanco, and Piceance Creek at White River for the same period. All trend models failed diagnostics for nutrients at 09306255 (Yellow Creek near White River); however, no trend was detected in nitrate or orthophosphate from 1990 to 2008 at 09306242 (Corral Gulch near Rangely), a tributary to Yellow Creek. 


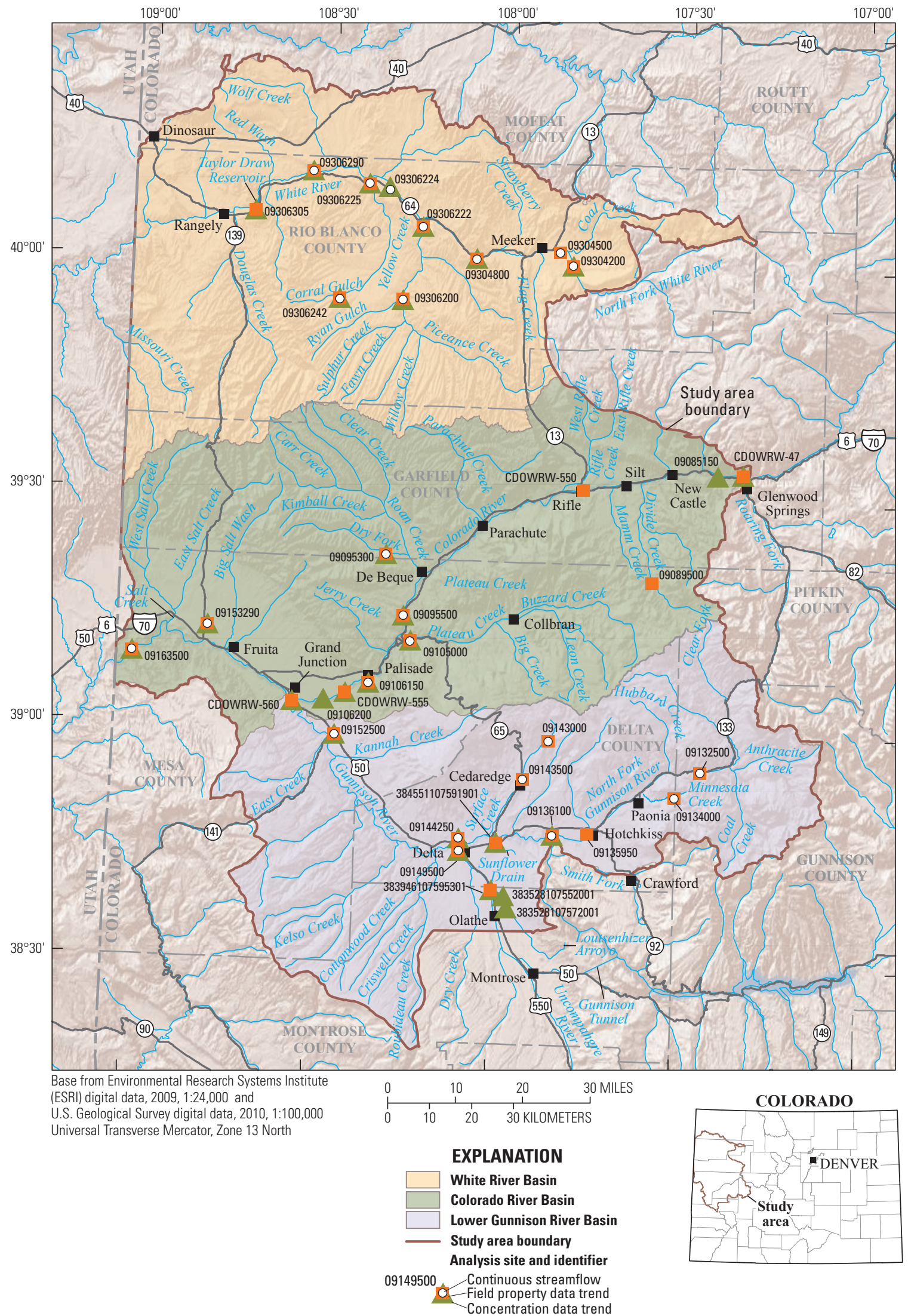

Figure 7. Location of the sites where trend analysis was completed, western Colorado. 

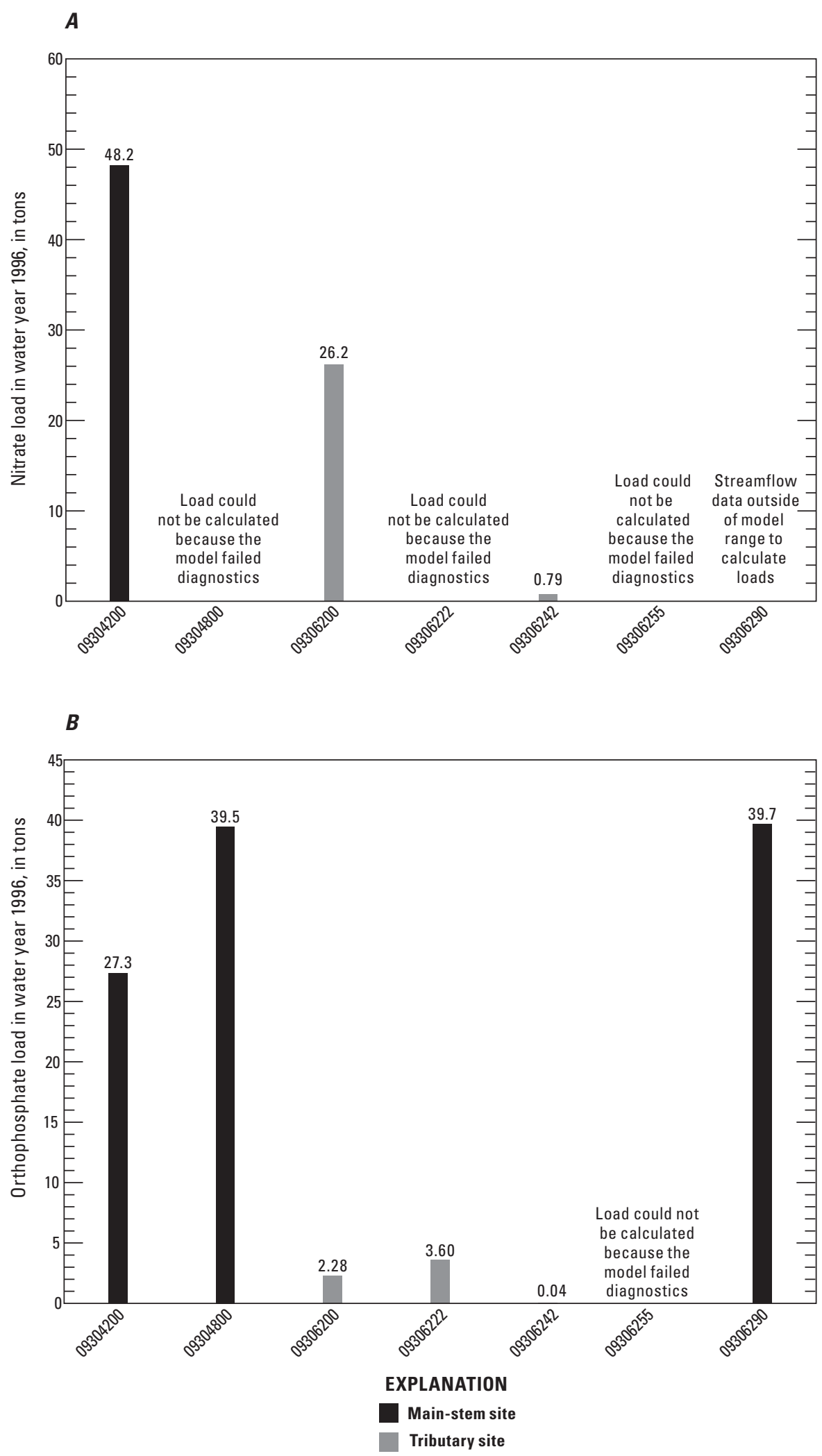

Figure 8. Loading profile for $(A)$ nitrate and $(B)$ orthophosphate in the White River Basin, western Colorado. 

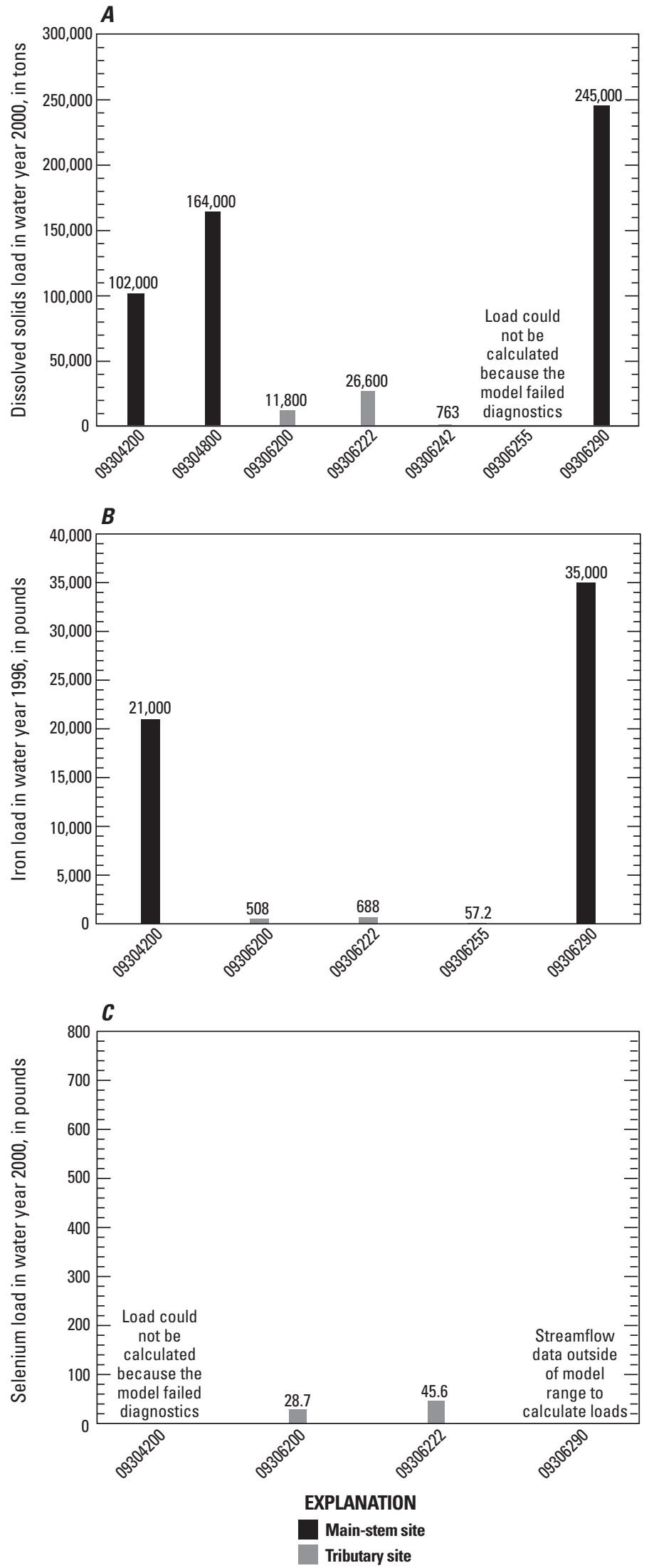

Figure 9. Loading profile for $(A)$ dissolved solids, $(B)$ iron, and $(C)$ selenium in the White River Basin, western Colorado. 

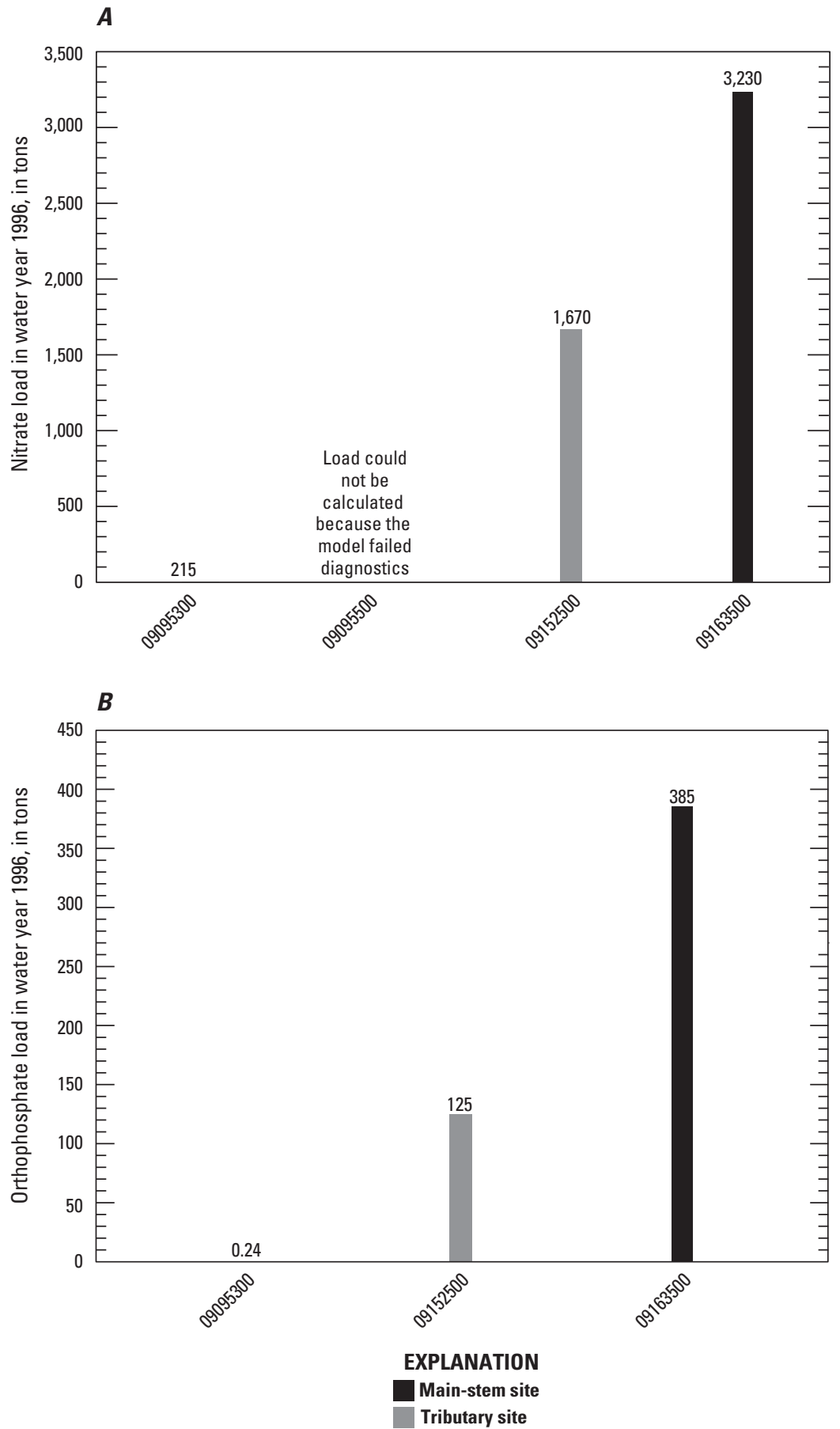

Figure 10. Loading profile for $(A)$ nitrate and $(B)$ orthophosphate in the Colorado River Basin, western Colorado. 

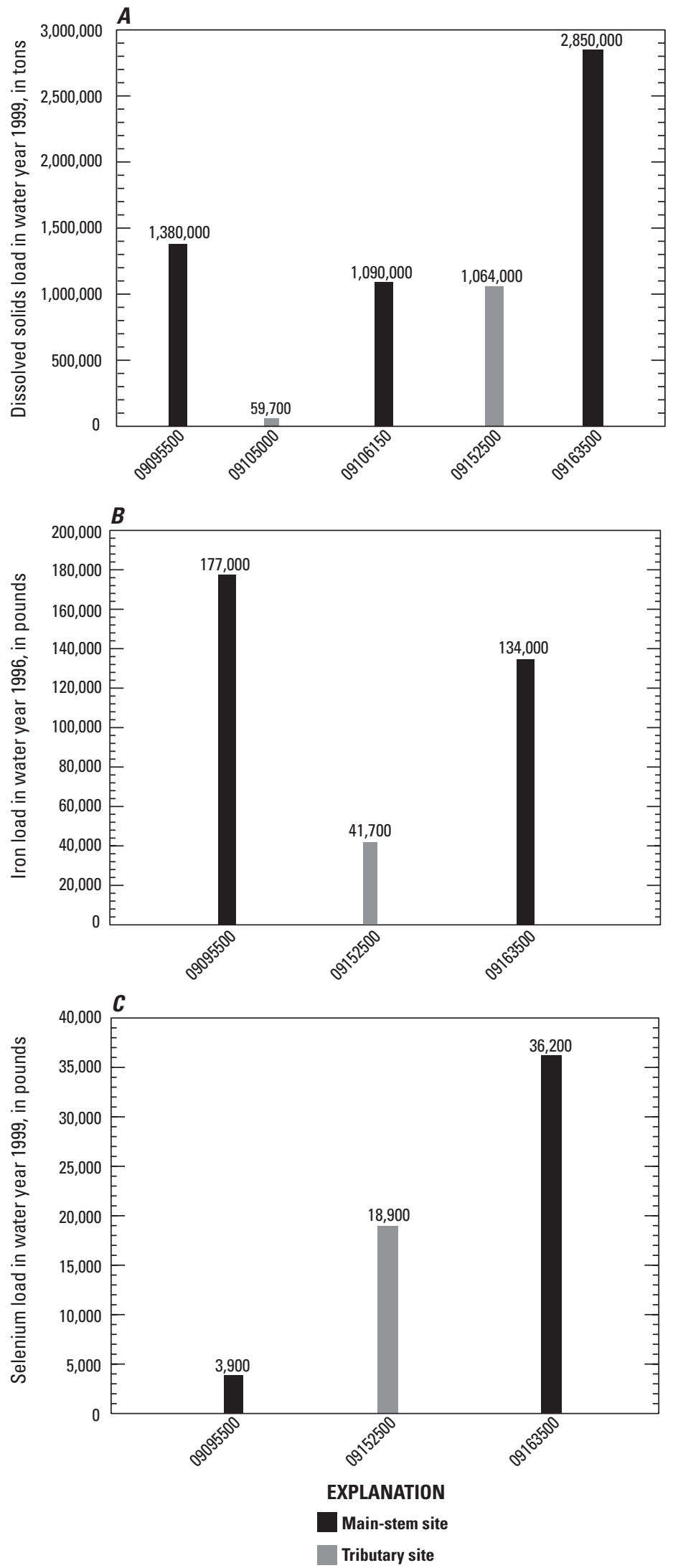

Figure 11. Loading profile for $(A)$ dissolved solids, $(B)$ iron, and $(C)$ selenium in the Colorado River Basin, western Colorado. 

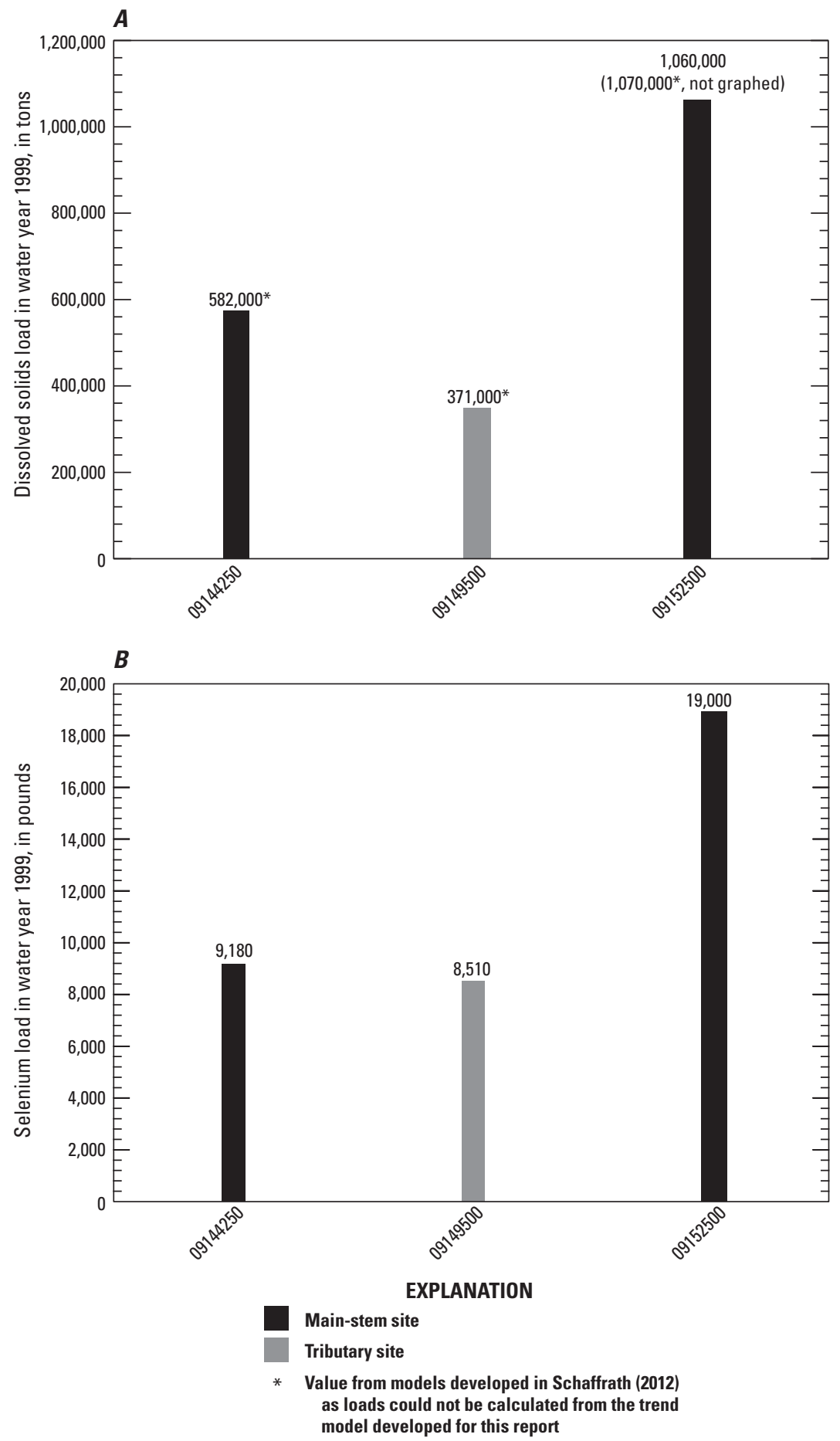

Figure 12. Loading profile for $(A)$ dissolved solids and $(B)$ selenium in the Lower Gunnison River Basin, western Colorado. 
Table 4. Summary of the seasonal Kendall test trend analysis results for field properties, Piceance study area, western Colorado, 1990-2009.

[NP, data not provided in the repository; IS, did not meet seasonal Kendall criteria due to insufficient data; - , data was not sufficient do adequately characterize seasonality; ND, no data available]

\begin{tabular}{|c|c|c|c|c|c|c|c|c|}
\hline \multirow{2}{*}{ Site name } & \multirow{2}{*}{$\begin{array}{c}\text { Site } \\
\text { identification } \\
\text { number }\end{array}$} & \multirow{2}{*}{$\begin{array}{l}\text { Drainage } \\
\text { area, } \\
\text { in square } \\
\text { miles }\end{array}$} & \multicolumn{2}{|c|}{$\begin{array}{l}\text { Water temperature, } \\
\text { in degrees Celsius }\end{array}$} & \multicolumn{2}{|c|}{$\begin{array}{l}\text { Dissolved oxygen, } \\
\text { in milligrams per liter }\end{array}$} & \multicolumn{2}{|c|}{$\begin{array}{c}\mathrm{pH}, \\
\text { in standard units }\end{array}$} \\
\hline & & & $\begin{array}{l}\text { Study } \\
\text { period }\end{array}$ & $\begin{array}{l}\text { Trend } \\
\text { type }\end{array}$ & $\begin{array}{l}\text { Study } \\
\text { period }\end{array}$ & $\begin{array}{l}\text { Trend } \\
\text { type }\end{array}$ & $\begin{array}{l}\text { Study } \\
\text { period }\end{array}$ & $\begin{array}{l}\text { Trend } \\
\text { type }\end{array}$ \\
\hline \multicolumn{9}{|c|}{ White River Basin } \\
\hline White River above Coal Creek, near Meeker, Colo. & 09304200 & 648 & 1990-2009 & no trend & 1990-2009 & no trend & 1990-2009 & upward \\
\hline White River near Meeker, Colo. & 09304500 & 755 & 1990-2005 & no trend & \multicolumn{2}{|c|}{ ND } & \multicolumn{2}{|c|}{ IS } \\
\hline White River below Meeker, Colo. & 09304800 & 1,024 & 1990-2009 & no trend & 1990-2009 & no trend & 1990-2009 & no trend \\
\hline Piceance Creek below Ryan Gulch, near Rio Blanco, Colo. & 09306200 & 506 & 1990-2009 & no trend & 1990-2009 & no trend ${ }^{1}$ & 1990-2009 & no trend \\
\hline Piceance Creek at White River, Colo. & 09306222 & 652 & 1990-2009 & no trend & 1990-2009 & no trend ${ }^{1}$ & 1990-2009 & no trend \\
\hline Corral Gulch near Rangely, Colo. & 09306242 & 32 & 1990-2009 & no trend & - & - & - & - \\
\hline Yellow Creek near White River, Colo. & 09306255 & 262 & 1990-2009 & no trend & 1990-2009 & no trend & 1990-2009 & no trend \\
\hline White River below Boise Creek, near Rangely, Colo. & 09306290 & 2,530 & 1990-2009 & no trend & 1990-2009 & no trend & 1990-2009 & no trend \\
\hline White River below Taylor Draw Reservoir, above Rangely Colo. & 09306305 & 2,776 & - & & & & - & \\
\hline \multicolumn{9}{|c|}{ Colorado River Basin } \\
\hline Colorado River Devereaux Bridge & CDOWRW-47 & NP & $1991-2007$ & no trend & $1991-2007$ & downward & - & \\
\hline West Divide Creek near Raven, Colo. & 09089500 & 65 & - & & & & Is & \\
\hline Colorado River Rifle Bridge & CDOWRW-550 & NP & - & & & & - & \\
\hline Dry Fork at Upper Station, near DeBeque, Colo. & 09095300 & 97 & - & & & & - & \\
\hline Colorado River near Cameo, Colo. & 09095500 & 8,050 & 1990-2009 & no trend & $1991-2008$ & no trend & $1990-2009$ & upward \\
\hline Plateau Creek near Cameo, Colo. & 09105000 & 592 & 1990-2009 & no trend & $1991-2008$ & no trend ${ }^{1}$ & $1991-2009$ & no trend \\
\hline $\begin{array}{l}\text { Colorado River below Grand Valley Diversion, } \\
\text { near Palisade, Colo. }\end{array}$ & 09106150 & 8,753 & - & & & & - & \\
\hline Colorado River Highway 6 & CDOWRW-555 & NP & - & & & & - & \\
\hline Colorado River Watson & CDOWRW-560 & NP & - & & & & - & \\
\hline Reed Wash near Mack, Colo. & 09153290 & 16 & 1990-2000 & no trend & & & - & \\
\hline Colorado River near Colorado-Utah state line & 09163500 & 17,843 & 1990-2009 & no trend & 1990-2008 & no trend & 1990-2009 & no trend \\
\hline \multicolumn{9}{|c|}{ Lower Gunnison River Basin } \\
\hline North Fork Gunnison River near Somerset, Colo. & 09132500 & 526 & - & & & & Is & \\
\hline Minnesota Creek near Paonia, Colo. & 09134000 & 41 & - & & & & $\mathrm{N}$ & \\
\hline $\begin{array}{l}\text { North Fork of the Gunnison River below Leroux Creek, } \\
\text { near Hotchkiss, Colo. }\end{array}$ & 09135950 & 922 & - & & & & Is & \\
\hline Smith Fork near Crawford, Colo. & 09128500 & 43 & - & & & & Is & \\
\hline Sunflower Drain at Highway 92, near Read & 384551107591901 & NP & - & & & & - & \\
\hline Surface Creek near Cedaredge, Colo. & 09143000 & 27 & - & & & & $\mathrm{N}$ & \\
\hline Surface Creek at Cedaredge, Colo. & 09143500 & 39 & 1990-2004 & no trend & & & $\mathrm{N}$ & \\
\hline Gunnison River at Delta, Colo. & 09144250 & 5,628 & 1990-2009 & no trend & & & - & \\
\hline Loutsenhizer Arroyo at North River Road & 383946107595301 & NP & - & & & & - & \\
\hline Uncompahgre River at Delta, Colo. & 09149500 & 1,115 & 1990-2009 & no trend & & & - & \\
\hline Gunnison River near Grand Junction, Colo. & 09152500 & 7,928 & 1990-2009 & upward & 1990-2009 & no trend & 1990-2009 & no trend \\
\hline
\end{tabular}

Indicates that there were not sufficient streamflow data to flow adjust the concentrations. 
Table 5. Summary of regression model trend analysis results for nutrients and Escherichia coli, Piceance study area, western Colorado, 1990-2009.

[The upward and downward columns are populated whenever there is a significant trend. If the trend was parabolic, then both columns contain the time frame of the respective trend direction, the net direction of the trend is indicated by shading. If the trend was monotonic, then the respective column contains the respective time frame and the other columns contains NA. If no significant trend was detected, then the combined columns contain an indicator of no trend and the time frame of the analysis; NT, no trend detected; F, model failed the model diagnostics; —, site did not have sufficient data for trend analysis; ND, site did not have data; IS, insufficient data for regression model analysis]

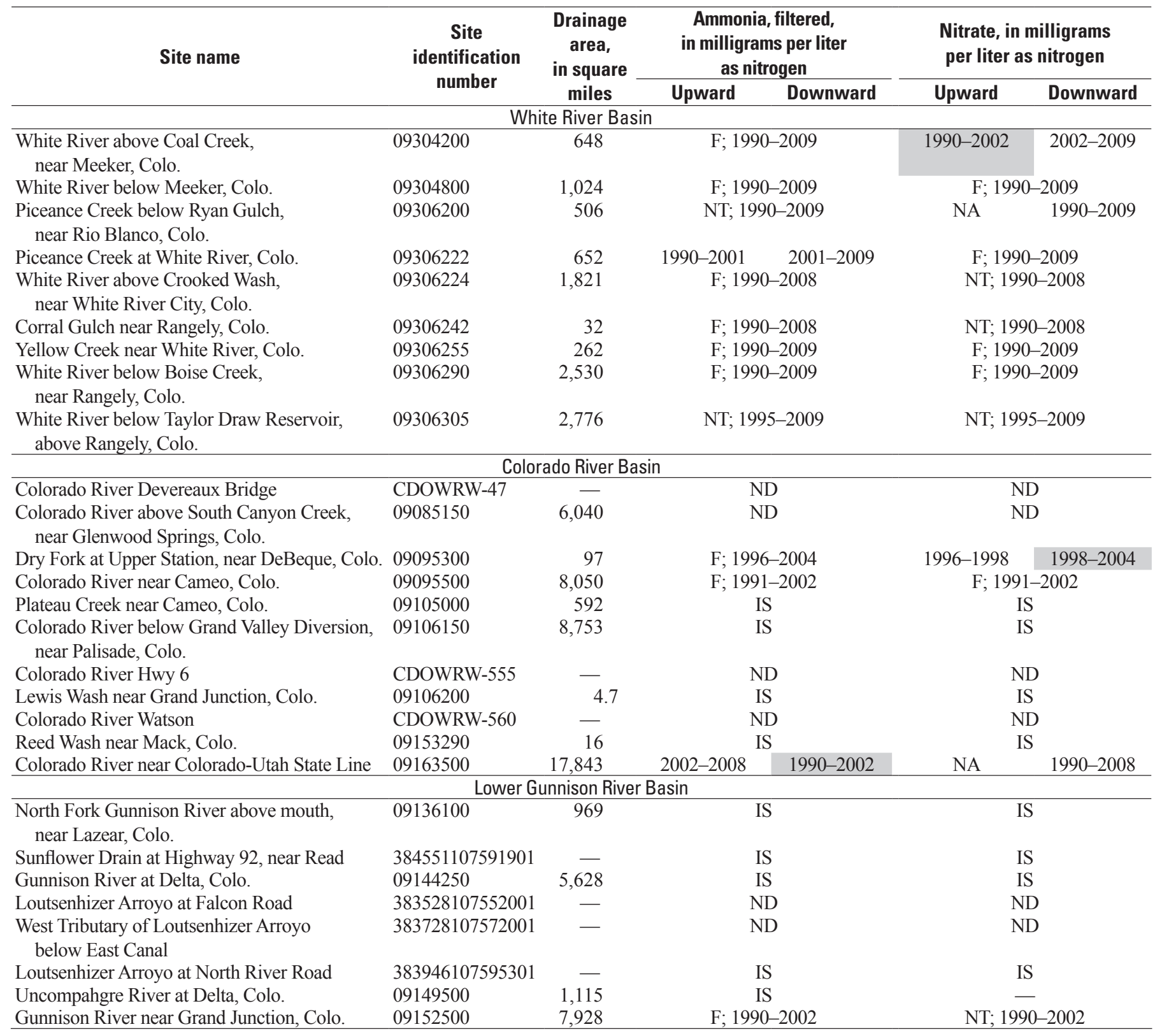


Table 5. Summary of regression model trend analysis results for nutrients and Escherichia coli, Piceance study area, western Colorado, 1990-2009.-Continued

[The upward and downward columns are populated whenever there is a significant trend. If the trend was parabolic, then both columns contain the time frame of the respective trend direction, the net direction of the trend is indicated by shading. If the trend was monotonic, then the respective column contains the respective time frame and the other columns contains NA. If no significant trend was detected, then the combined columns contain an indicator of no trend and the time frame of the analysis; NT, no trend detected; F, model failed the model diagnostics; —, site did not have sufficient data for trend analysis; ND, site did not have data; IS, insufficient data for regression model analysis]

\begin{tabular}{|c|c|c|c|c|c|c|c|}
\hline \multicolumn{2}{|c|}{$\begin{array}{l}\text { Orthophosphate, filtered, } \\
\text { in milligrams per liter }\end{array}$} & \multicolumn{2}{|c|}{$\begin{array}{l}\text { Total phosphorous, } \\
\text { in milligrams per liter }\end{array}$} & \multicolumn{2}{|c|}{$\begin{array}{l}\text { Organic carbon, filtered, } \\
\text { in milligrams per liter }\end{array}$} & \multicolumn{2}{|c|}{$\begin{array}{c}\text { Escherichia coli, } \\
\text { colonies per } 100 \text { milliliters }\end{array}$} \\
\hline \multirow{2}{*}{\multicolumn{8}{|c|}{ White River Basin }} \\
\hline & & & & & & & \\
\hline NA & 1990-2009 & 1991-2009 & NA & & & NT; & 2004 \\
\hline 1990-1997 & 1997-2009 & \multirow{2}{*}{\multicolumn{2}{|c|}{ F; 1991-2009 }} & \multicolumn{2}{|c|}{ - } & $F ; 1$ & 2003 \\
\hline NA & $1990-2009$ & & & NA & 1993-2009 & & \\
\hline \multicolumn{2}{|c|}{ NT; 1990-2009 } & \multicolumn{2}{|c|}{ - } & \multicolumn{2}{|c|}{ NT; 1991-2009 } & \multicolumn{2}{|c|}{ IS } \\
\hline \multicolumn{2}{|c|}{ NT; 1990-2008 } & \multicolumn{2}{|c|}{ IS } & \multicolumn{2}{|c|}{ IS } & & \\
\hline \multicolumn{2}{|c|}{ NT; 1990-2008 } & \multicolumn{2}{|c|}{ - } & \multicolumn{2}{|c|}{ F; 1991-2008 } & & \\
\hline \multicolumn{2}{|c|}{ F; 1990-2009 } & \multirow{2}{*}{\multicolumn{2}{|c|}{ F; $1990-2009$}} & \multicolumn{2}{|c|}{ NT; 1991-2009 } & & \\
\hline NA & 1990-2009 & & & 1990-1999 & 1999-2009 & & \\
\hline NA & 1995-2009 & 1995-2009 & NA & \multicolumn{2}{|c|}{ ND } & & \\
\hline \multicolumn{8}{|c|}{ Colorado River Basin } \\
\hline \multirow{2}{*}{\multicolumn{2}{|c|}{$\begin{array}{l}\text { ND } \\
\text { ND }\end{array}$}} & \multirow{2}{*}{\multicolumn{2}{|c|}{$\begin{array}{c}\text { IS } \\
\text { ND }\end{array}$}} & & & \\
\hline & & & & & & & \\
\hline \multicolumn{2}{|c|}{ NT; 1996-2004 } & \multicolumn{2}{|c|}{ F; 1996-2004 } & \multicolumn{2}{|c|}{ - } & & \\
\hline & & & & & & & \\
\hline & & & & & & & \\
\hline & & & & & & & \\
\hline & & & & & & & \\
\hline & & & & & & & \\
\hline & & & & & & & \\
\hline & & & & & & & \\
\hline NA & 1990-2008 & 1990-2008 & NA & NT; 1 & 2002 & & \\
\hline & & & Lower Gunn & iver Basin & & & \\
\hline & & & & & & & \\
\hline & & & & & & & \\
\hline & & & & & & & \\
\hline & & & & & & & \\
\hline & & & & & & & \\
\hline & & & & & & & \\
\hline & & & & & & & \\
\hline NT; 1 & 1998 & F; 199 & 002 & NT; 1 & 2002 & & \\
\hline
\end{tabular}


Table 6. Summary of regression model trend analysis results for dissolved solids and major ions, Piceance study area, western Colorado, 1990-2009.

[The upward and downward columns are populated whenever there is a significant trend. If the trend was parabolic, then both columns contain the time frame of the respective trend direction, the net direction of the trend is indicated by shading. If the trend was monotonic, then the respective column contains the respective time frame and the other columns contains NA. If no significant trend was detected, then the combined columns contain an indicator of no trend and the time frame of the analysis; NT, no trend detected; F, model failed the model diagnostics; —, site did not have sufficient data for trend analysis; ND, site did not have data; IS, insufficient data for regression model analysis]

\begin{tabular}{|c|c|c|c|c|}
\hline Site name & $\begin{array}{c}\text { Site } \\
\text { identification } \\
\text { number }\end{array}$ & $\begin{array}{c}\text { Drainage } \\
\text { area, in } \\
\text { square miles }\end{array}$ & \multicolumn{2}{|c|}{$\begin{array}{c}\text { Calcium, filtered, } \\
\text { in milligrams per liter }\end{array}$} \\
\hline \multicolumn{5}{|c|}{ White River Basin } \\
\hline White River below Meeker, Colo. & 09304800 & 1,024 & \multicolumn{2}{|c|}{ NT; 1990-2009 } \\
\hline Piceance Creek below Ryan Gulch, near Rio Blanco, Colo. & 09306200 & 506 & $1990-2009$ & NA \\
\hline Piceance Creek at White River, Colo. & 09306222 & 652 & $2000-2009$ & $1990-2000$ \\
\hline Yellow Creek near White River, Colo. & 09306255 & 262 & \multicolumn{2}{|c|}{ NT; 1990-2009 } \\
\hline White River below Boise Creek, near Rangely, Colo. & 09306290 & 2,530 & \multicolumn{2}{|c|}{ NT; 1990-2009 } \\
\hline White River below Taylor Draw Reservoir, above Rangely Colo. & 09306305 & 2,776 & \multicolumn{2}{|c|}{ IS } \\
\hline \multicolumn{5}{|c|}{ Colorado River Basin } \\
\hline Colorado River Devereaux Bridge & CDOWRW-47 & - & \multicolumn{2}{|c|}{ NT; 2000-2007 } \\
\hline Colorado River above South Canyon Creek near Glenwood Springs, Colo. & 09085150 & 6,040 & \multicolumn{2}{|c|}{ IS } \\
\hline Colorado River Hwy 6 & CDOWRW-555 & - & \multicolumn{2}{|c|}{ IS } \\
\hline Lewis Wash near Grand Junction, Colo. & 09106200 & 4.7 & \multicolumn{2}{|c|}{ NT; 1991-2006 } \\
\hline Colorado River Watson & CDOWRW-560 & - & \multicolumn{2}{|c|}{ IS } \\
\hline Reed Wash near Mack, Colo. & 09153290 & 16 & \multicolumn{2}{|c|}{ IS } \\
\hline Colorado River near Colorado-Utah State Line & 09163500 & 17,843 & $2001-2009$ & 1990-2001 \\
\hline \multicolumn{5}{|c|}{ Lower Gunnison River Basin } \\
\hline North Fork Gunnison River above mouth near Lazear, Colo. & 09136100 & 969 & NA & 1991-2009 \\
\hline Sunflower Drain at Highway 92, near Read & 384551107591901 & - & \multicolumn{2}{|c|}{ NT; 1991-2003 } \\
\hline Gunnison River at Delta, Colo. & 09144250 & 5,628 & \multicolumn{2}{|c|}{ F; $1991-2009$} \\
\hline Loutsenhizer Arroyo at Falcon Road & 383528107552001 & - & \multicolumn{2}{|c|}{ IS } \\
\hline West Tributary of Loutsenhizer Arroyo below East Canal & 383728107572001 & - & \multicolumn{2}{|c|}{ IS } \\
\hline Loutsenhizer Arroyo at North River Road & 383946107595301 & - & \multicolumn{2}{|c|}{ NT; 1991-2009 } \\
\hline
\end{tabular}

Nitrate and orthophosphate loads and total phosphorus standard exceedances were evaluated in the White River Basin. The White River Basin had the greatest number of nitrate concentration samples; however, use of the loading profile for nitrate was limited at the main stem of the White River because load could not be calculated for the most downstream site 09306290 (White River below Boise Creek, near Rangely) (fig. 8A). A loading profile for orthophosphate in the White River Basin indicated a slight increase in orthophosphate from upstream to downstream (fig. 8B). Between 09304800 (White River below Meeker) and 09306290 (White River below Boise Creek, near Rangely), orthophosphate increased by only 0.2 tons while tributaries between the two sites sum to more than 6 tons of additional orthophosphate. There were 29 sites that had exceedances of the recommended total phosphorus standard, with more than 402 exceedances, many of which occur prior to 2000 ( 21 sites and 323 samples had total phosphorus standard exceedances) (app. 1).

\section{Dissolved Solids and Major lons}

Dissolved solids (DS) refers to the concentration of dissolved solids in water, including calcium, magnesium, sodium, potassium, silica, chloride, sulfate, and carbonate species.

Although DS has not been a significant water-quality concern in the White River Basin, a potential source of the DS might be $55 \mathrm{mi}^{2}$ of irrigated land in the basin. Irrigation occurs primarily near Meeker, Colo., and in the Piceance Creek Basin. Prior to 1980, Meeker Dome, 3 miles east of the town of Meeker, was a point source for DS on the White River owing to highly saline water that was discharging at the surface through abandoned and improperly plugged exploration oil wells drilled during the 1920s (Liebermann and others, 1989). The wells were eventually plugged during the 1960s and 1980s and the source was mitigated. However, results from this previous study indicated that there were potentially large conduits for high DS groundwater to upwell to the surface and enter surface water. 
Table 6. Summary of regression model trend analysis results for dissolved solids and major ions, Piceance study area, western Colorado, 1990-2009.-Continued

[The upward and downward columns are populated whenever there is a significant trend. If the trend was parabolic, then both columns contain the time frame of the respective trend direction, the net direction of the trend is indicated by shading. If the trend was monotonic, then the respective column contains the respective time frame and the other columns contains NA. If no significant trend was detected, then the combined columns contain an indicator of no trend and the time frame of the analysis; NT, no trend detected; F, model failed the model diagnostics; —, site did not have sufficient data for trend analysis; ND, site did not have data; IS, insufficient data for regression model analysis]

\begin{tabular}{|c|c|c|c|c|c|c|c|}
\hline \multicolumn{2}{|c|}{$\begin{array}{l}\text { Magnesium, filtered, } \\
\text { in milligrams per liter }\end{array}$} & \multicolumn{2}{|c|}{$\begin{array}{c}\text { Sodium, filtered, } \\
\text { in milligrams per liter }\end{array}$} & \multicolumn{2}{|c|}{$\begin{array}{l}\text { Potassium, filtered, } \\
\text { in milligrams per liter }\end{array}$} & \multicolumn{2}{|c|}{$\begin{array}{c}\text { Chloride, filtered, } \\
\text { in milligrams per liter }\end{array}$} \\
\hline Upward & Downward & Upward & Downward & Upward & Downward & Upward & Downward \\
\hline \multicolumn{8}{|c|}{ White River Basin } \\
\hline \multicolumn{2}{|c|}{ NT; 1990-2002 } & 1990-1992 & $1992-2002$ & & \multicolumn{2}{|c|}{ NT; 1990-2009 } \\
\hline \multirow{2}{*}{\multicolumn{2}{|c|}{$\begin{array}{l}\text { NT; 1990-2009 } \\
\text { NT; 1990-2009 }\end{array}$}} & \multicolumn{2}{|c|}{ NT; 1990-2009 } & \multicolumn{2}{|c|}{ NT; 1990-2009 } & NA & 1990-2009 \\
\hline & & 1997-2009 & 1990-1997 & \multicolumn{2}{|c|}{ NT; 1990-2009 } & 2003-2009 & $1990-2003$ \\
\hline 1999-2009 & 1990-1999 & \multicolumn{2}{|c|}{ NT; 1990-2009 } & \multicolumn{2}{|c|}{ NT; 1990-2009 } & NA & 1990-2009 \\
\hline & & \multicolumn{2}{|c|}{-} & \multirow{3}{*}{\multicolumn{2}{|c|}{$\begin{array}{l}\text { NT; 1990-2008 } \\
\text { NT; 1990-2009 }\end{array}$}} & \\
\hline $1990-1996$ & 1996-2008 & NA & $1990-2008$ & & & 2002-2008 & 1990-2002 \\
\hline \multicolumn{2}{|c|}{ F; 1990-2009 } & \multicolumn{2}{|c|}{ NT: 1990-2009 } & & & 1999-2009 & 1990-1999 \\
\hline 1990-1999 & 1999-2009 & 1990-1998 & 1998-2009 & 1990-1999 & 1999-2009 & NA & 1990-2009 \\
\hline \multicolumn{2}{|c|}{ IS } & \multicolumn{2}{|c|}{ IS } & \multicolumn{2}{|c|}{ IS } & \multicolumn{2}{|c|}{ IS } \\
\hline \multicolumn{8}{|c|}{ Colorado River Basin } \\
\hline \multicolumn{2}{|c|}{ NT; 2000-2007 } & \multicolumn{2}{|c|}{ ND } & \multicolumn{2}{|c|}{ ND } & \multicolumn{2}{|c|}{ ND } \\
\hline \multicolumn{2}{|c|}{ IS } & & & & & & \\
\hline & & & & & & NT; 19 & -2004 \\
\hline NT; 19 & 2009 & NT; 19 & 009 & NT; 19 & 009 & 1990-2009 & NA \\
\hline NT; 19 & 2009 & NA & $1991-2009$ & NT; 19 & 009 & 1991-2002 & 2002-2009 \\
\hline NT; 19 & 2002 & NT; 19 & 002 & NT; 19 & 002 & NT; 19 & -2002 \\
\hline & & & & & & & \\
\hline NA & 1991-2006 & NT; 199 & 006 & NT; 19 & 006 & $\mathrm{~F} ; 199$ & 2006 \\
\hline & & & & & & & \\
\hline & & & & & & & \\
\hline 2004-2009 & 1990-2004 & $2002-2009$ & 1990-2002 & 1999-2009 & 1990-1999 & NT; 19 & -2009 \\
\hline & & & Lower Gunn & iver Basin & & & \\
\hline NA & 1991-2009 & NA & 1991-2009 & $\mathrm{NT} ; 19$ & 009 & $\mathrm{~F} ; 19 \mathrm{C}$ & 2009 \\
\hline NT; 19 & 2003 & NT; 199 & 003 & NT; 19 & 003 & NT; 19 & -2003 \\
\hline NA & 1991-2009 & F; 199 & & NT; 19 & 009 & $F ; 19$ & 2009 \\
\hline & & & & & & & \\
\hline & & & & & & & \\
\hline NT; 19 & 2009 & NT; 193 & 009 & NT; 19 & 009 & NT; 19 & -2009 \\
\hline $2000-2009$ & $1991-2000$ & $2000-2009$ & $1991-2000$ & NT; 19 & 009 & 2000-2009 & 1991-2000 \\
\hline 2003-2009 & 1990-2003 & 2005-2009 & 1990-2005 & 2000-2009 & 1990-2000 & 2002-2009 & 1990-2002 \\
\hline
\end{tabular}

Sufficient data were available to analyze for trends in DS and other major ions for 3 sites on the White River main stem: 09304200 (White River above Coal Creek, near Meeker), 09304800 (White River below Meeker), and 09306290 (White River below Boise Creek, near Rangely). No trends were detected from 1990 to 2002 at 09304200 (White River above Coal Creek, near Meeker) for calcium, magnesium, chloride, sulfate, silica, and DS (table 6). Sodium had a net, downward trend at 09304200 from 1990 to 2002 . The trend was parabolic with a zero-slope year around 1992, after which the shape of the parabola indicated an upward trend. No trends were detected downstream at 09304800 (White River below Meeker) from 1990 to 2009 for calcium, magnesium, sodium, potassium, sulfate, fluoride, silica, or DS. A downward trend was detected for chloride at 09304800 from 1990 to 2009. Net, downward trends were detected for DS and sodium from 1990 to 2009 at site 09306290 (White River below Boise Creek, near Rangely). The trend for both constituents was parabolic with a zero-slope year around 1998, prior to which the shape of the parabola indicated an upward trend. It is unclear what contributed to the fluctuation in DS throughout the main stem of the White River.

Trends in DS and other major ions were analyzed for 4 tributary sites to the White River. At site 09306200 (Piceance Creek below Ryan Gulch, near Rio Blanco), a net, downward trend was detected for DS from 1990 to 2009. The trend was parabolic with a zero-slope year of 2003, after which the shape indicated an upward trend (table 6). At the next site downstream, 09306222 (Piceance Creek at White River), a downward trend was detected for DS from 1990 to 2009 (table 6). No trends were detected at 09306255 (Yellow Creek near White River); however, at 09306242 (Corral Gulch near Rangely), a tributary to Yellow Creek, a net, downward trend was detected for DS from 1990 to 2008. The trend was parabolic with a zero-slope year around 1993 prior to which the shape of the parabola indicated an upward trend. 
Table 6. Summary of regression model trend analysis results for dissolved solids and major ions, Piceance study area, western Colorado, 1990-2009.-Continued

[The upward and downward columns are populated whenever there is a significant trend. If the trend was parabolic, then both columns contain the time frame of the respective trend direction, the net direction of the trend is indicated by shading. If the trend was monotonic, then the respective column contains the respective time frame and the other columns contains NA. If no significant trend was detected, then the combined columns contain an indicator of no trend and the time frame of the analysis; NT, no trend detected; F, model failed the model diagnostics; —, site did not have sufficient data for trend analysis; ND, site did not have data; IS, insufficient data for regression model analysis]

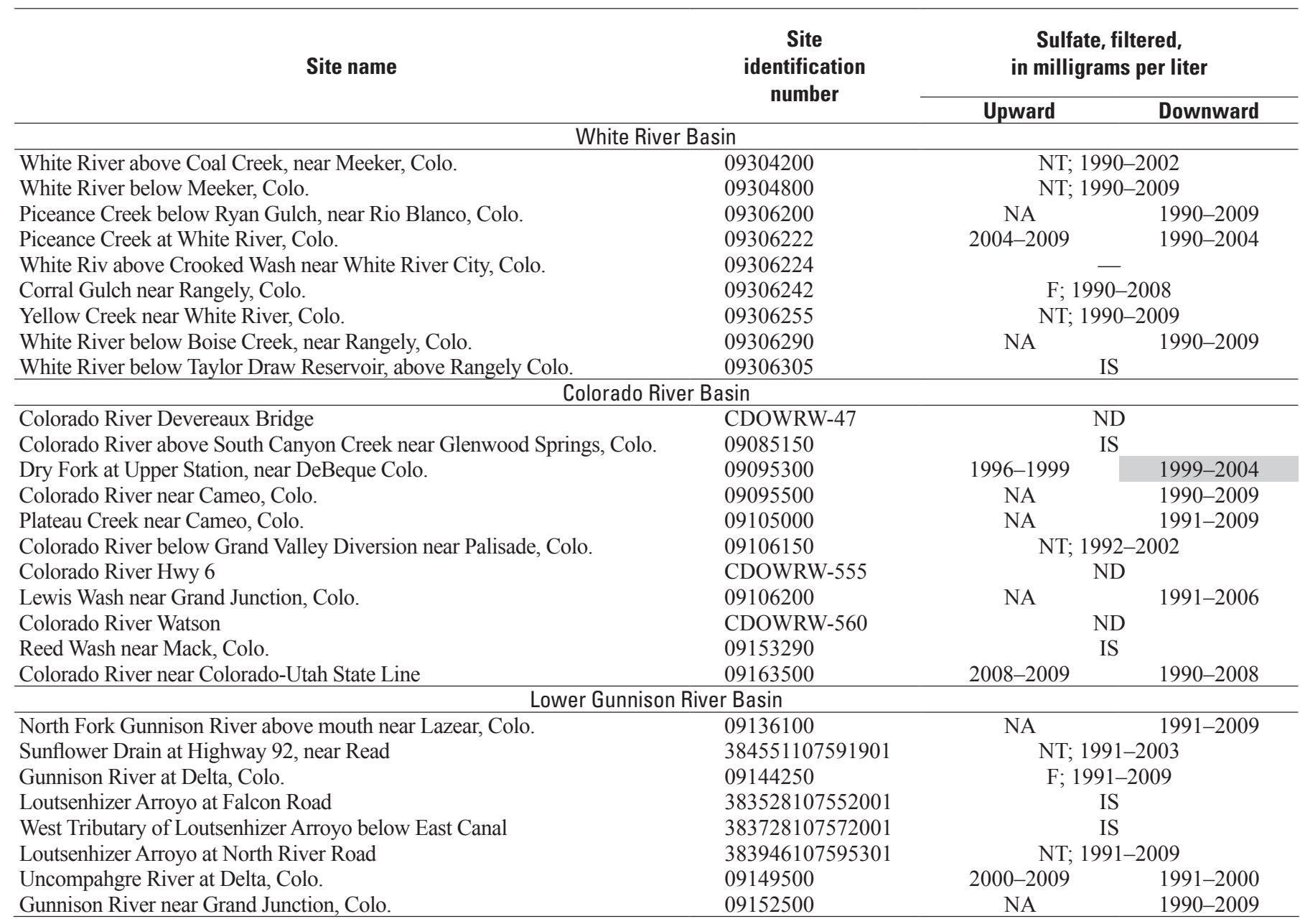

Generally, the trend analysis indicated that there was either no change or a net, downward trend in DS and other major ions. However, there were exceedances of chloride and sulfate standards in the upstream area of the basin on tributaries to the White River. Only 2 sites had exceedances of the chloride standard, most of these exceedances occurred at 09304550 (Curtis Creek), and all exceedances occurred from data sampled prior to 1985 (app. 1). There were a total of 504 exceedances of the sulfate standard at 6 sites, although most of the exceedances occurred at 09304480 (Coal Creek) and 09304550 (Curtis Creek), 196 and 294 exceedances respectively. Most exceedances occurred prior to 1986; no sampling for chloride and sulfate occurred after that time at Curtis Creek and Coal Creek (app. 1). Insufficient data were available on the remaining tributaries to further aid in the analysis of DS in the White River Basin.
A loading profile for the White River Basin indicated increasing DS loads from upstream to downstream (fig. 9A). The total DS load from the White River Basin was represented by the most downstream site, 09306290 (White River below Boise Creek, near Rangely), where the load in water year 2000 was 245,000 tons. The DS load at 09304200 for water year 2000 was 102,000 tons, which was about 41 percent of the load in the White River Basin at site 09306290. The DS load at 09304800 (White River below Meeker) for water year 2000 was 164,000 tons, which was about 67 percent of the load from the White River Basin. Between 09304200 and 09304800 more than 60,000 tons of DS load are generated that could potentially be from irrigated agriculture. Load from 09306222 (Piceance Creek at White River) for water year 2000 was about 26,600 tons, which was about 11 percent of the load from the White River Basin. Alkali Flats is an area 
Table 6. Summary of regression model trend analysis results for dissolved solids and major ions, Piceance study area, western Colorado, 1990-2009.-Continued

[The upward and downward columns are populated whenever there is a significant trend. If the trend was parabolic, then both columns contain the time frame of the respective trend direction, the net direction of the trend is indicated by shading. If the trend was monotonic, then the respective column contains the respective time frame and the other columns contains NA. If no significant trend was detected, then the combined columns contain an indicator of no trend and the time frame of the analysis; NT, no trend detected; F, model failed the model diagnostics; —, site did not have sufficient data for trend analysis; ND, site did not have data; IS, insufficient data for regression model analysis]

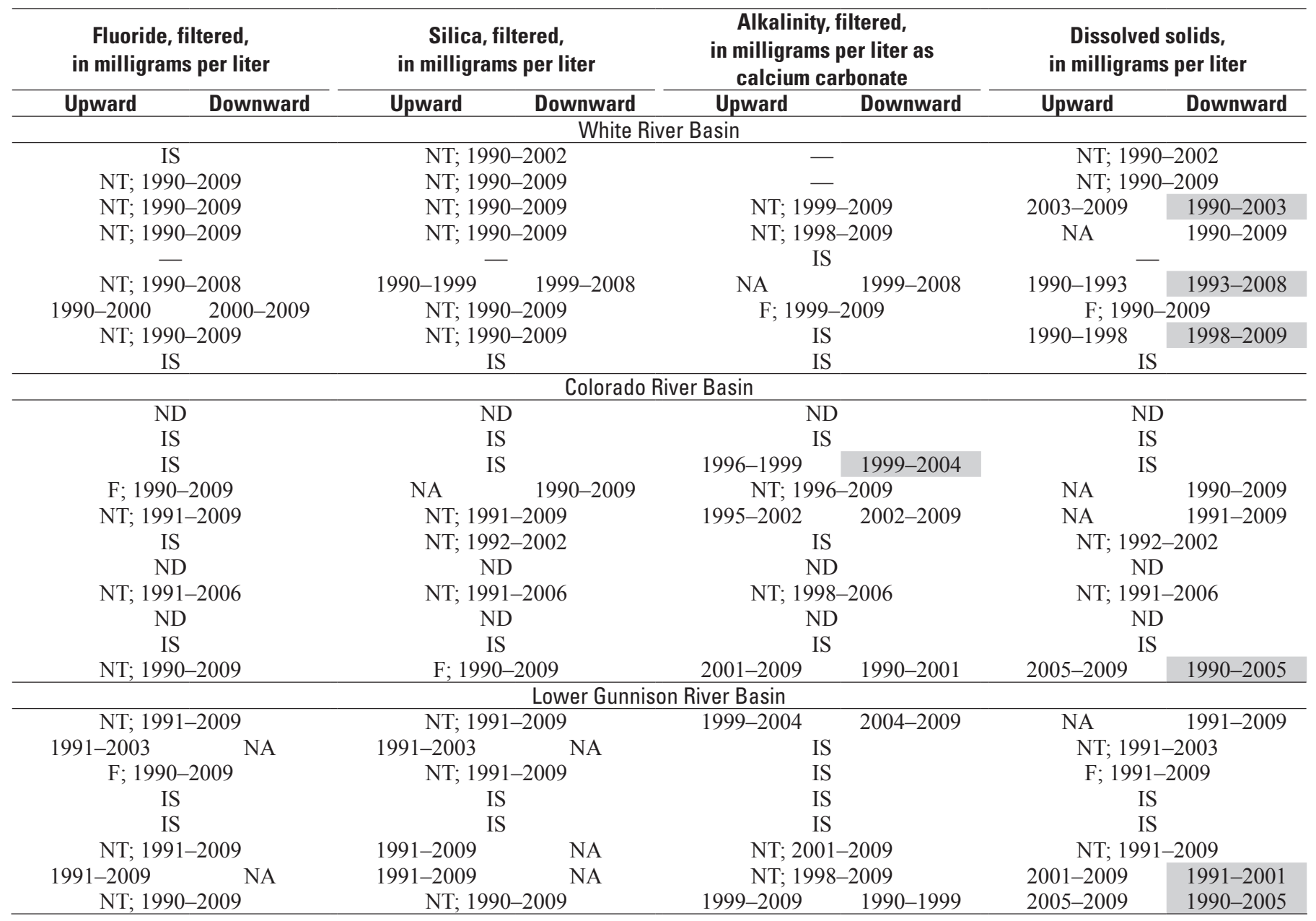

of known groundwater upwelling upstream from 09306222 (Piceance Creek at White River). The area could represent an important input of DS to surface water, though losses in streamflow in the Alkali Flats area may also be occurring (Tobin and others, 1985; Ortiz, 2002). The sum of the loads at 09304800 (White river below Meeker) and the tributary sites do not equal the load calculated at the most downstream site 09306290 (White River below Boise Creek, near Rangely). The remaining DS load measured at the gage and unaccounted for by tributary inputs might be sourced from groundwater or unsampled tributaries.

\section{Trace Elements}

Sufficient data were available to compare the results of the trends analysis only for iron and total recoverable iron in the White River Basin (table 7). Along the main stem of the
White River, no trend was detected in iron or total recoverable iron at either 09304800 (White River below Meeker) or 09306290 (White River below Boise Creek, near Rangely) for the periods 1995 to 2009 and 1990 to 2009, respectively (table 7). At site 09306200 (Piceance Creek below Ryan Gulch, near Rio Blanco), no trend was detected in iron from 1990 to 2009. Downstream at site 09306222 (Piceance Creek at White River), there was no net trend from 1991 to 2009, although there was a parabolic trend. The parabolic trend in iron was initially downward until around 2001, after which the trend was upward. An upward trend in iron was detected at 09306255 (Yellow Creek near White River) from 1991 to 2009. Only 2 of the 33 sites had exceedances of the 30-day drinking-water standard for iron; 1,871 samples had iron data (app. 1). The loading profile for the of the White River Basin indicated that iron load between the two White River sites (below Meeker and near Rangely) increased although the sampled tributaries did not 
Table 7. Summary of regression model trend analysis results for trace elements and suspended sediment, Piceance study area, western Colorado, 1990-2009.

[The upward and downward columns are populated whenever there is a significant trend. If the trend was parabolic, then both columns contain the time frame of the respective trend direction, the net direction of the trend is indicated by shading. If the trend was monotonic, then the respective column contains the respective time frame and the other columns contains NA. If no significant trend was detected, then the combined columns contain an indicator of no trend and the time frame of the analysis; NT, no trend detected; F, model failed the model diagnostics; —, site did not have sufficient data for trend analysis; ND, site did not have data; IS, insufficient data for regression model analysis]

\begin{tabular}{|c|c|c|c|c|}
\hline Site name & $\begin{array}{c}\text { Site } \\
\text { identification } \\
\text { number }\end{array}$ & $\begin{array}{c}\text { Drainage } \\
\text { area, in } \\
\text { square miles }\end{array}$ & \multicolumn{2}{|c|}{$\begin{array}{c}\text { Copper, filtered, } \\
\text { in micrograms per liter }\end{array}$} \\
\hline \multicolumn{5}{|c|}{ White River Basin } \\
\hline White River below Meeker, Colo. & 09304800 & 1,024 & \multicolumn{2}{|c|}{ F; 1991-2009 } \\
\hline Piceance Creek below Ryan Gulch, near Rio Blanco, Colo. & 09306200 & 506 & 1999-2002 & 2002-2009 \\
\hline Piceance Creek at White River, Colo. & 09306222 & 652 & $1999-2003$ & 2003-2009 \\
\hline White River above Crooked Wash, near White River City, Colo. & 09306224 & 1,821 & \multicolumn{2}{|c|}{ IS } \\
\hline Corral Gulch near Rangely, Colo. & 09306242 & 32 & \multicolumn{2}{|c|}{ - } \\
\hline Yellow Creek near White River, Colo. & 09306255 & 262 & \multicolumn{2}{|c|}{ - } \\
\hline White River below Boise Creek, near Rangely, Colo. & 09306290 & 2,530 & \multicolumn{2}{|c|}{ - } \\
\hline White River below Taylor Draw Reservoir, above Rangely, Colo. & 09306305 & 2,776 & \multicolumn{2}{|c|}{ IS } \\
\hline \multicolumn{5}{|c|}{ Colorado River Basin } \\
\hline Colorado River Devereaux Bridge & CDOWRW-47 & - & 1991-1999 & 1999-2006 \\
\hline Colorado River above South Canyon Creek, near Glenwood Springs, Colo. & 09085150 & 6,040 & \multicolumn{2}{|c|}{ ND } \\
\hline Dry Fork at Upper Station, near DeBeque Colo. & 09095300 & 97 & \multicolumn{2}{|c|}{ ND } \\
\hline Colorado River near Cameo, Colo. & 09095500 & 8,050 & \multicolumn{2}{|c|}{ IS } \\
\hline Plateau Creek near Cameo, Colo. & 09105000 & 592 & \multicolumn{2}{|c|}{ IS } \\
\hline Colorado River below Grand Valley Diversion, near Palisade, Colo. & 09106150 & 8,753 & \multicolumn{2}{|c|}{ IS } \\
\hline Colorado River Hwy 6 & CDOWRW-555 & - & \multicolumn{2}{|c|}{ IS } \\
\hline Lewis Wash near Grand Junction, Colo. & 09106200 & 4.7 & \multicolumn{2}{|c|}{ IS } \\
\hline Colorado River Watson & CDOWRW-560 & - & \multicolumn{2}{|c|}{ IS } \\
\hline Reed Wash near Mack, Colo. & 09153290 & 16 & \multicolumn{2}{|c|}{ ND } \\
\hline Colorado River near Colorado-Utah State Line & 09163500 & 17,843 & \multicolumn{2}{|c|}{ - } \\
\hline \multicolumn{5}{|c|}{ Lower Gunnison River Basin } \\
\hline North Fork Gunnison River above mouth, near Lazear, Colo. & 09136100 & 969 & \multicolumn{2}{|c|}{ IS } \\
\hline Sunflower Drain at Highway 92, near Read & 384551107591901 & - & \multicolumn{2}{|c|}{ IS } \\
\hline Gunnison River at Delta, Colo. & 09144250 & 5,628 & \multicolumn{2}{|c|}{ IS } \\
\hline Loutsenhizer Arroyo at Falcon Road & 383528107552001 & - & \multicolumn{2}{|c|}{ ND } \\
\hline West Tributary of Loutsenhizer Arroyo below East Canal & 383728107572001 & - & \multicolumn{2}{|c|}{ ND } \\
\hline Loutsenhizer Arroyo at North River Road & 383946107595301 & - & \multicolumn{2}{|c|}{ IS } \\
\hline Uncompahgre River at Delta, Colo. & 09149500 & 1,115 & & \\
\hline Gunnison River near Grand Junction, Colo. & 09152500 & 7,928 & & \\
\hline
\end{tabular}

account for the increase (fig. 9B). Load from 09304800 (White River below Meeker) for water year 1996 was 21,000 pounds per year, which is 60 percent of the load from the White River Basin (fig. 9B). The remaining load might be sourced from groundwater or unsampled tributaries.

\section{Suspended Sediment}

Suspended sediment is a water-quality concern in the White River Basin, specifically in Douglas Creek. Douglas Creek is listed on the CDPHE 303(d) list for suspended sediment (table 2), yet there were no suspended sediment data available to evaluate trends and or calculate suspended sediment load. Suspended sediment loads were previously evaluated on the White River as part of the design of the Taylor Draw Reservoir (also known as Kenney Reservoir) (Salas and Shin, 1999).

Trends in suspended sediment were analyzed for 4 sites on the White River main stem. No trends were detected from 1990 to 2001 at 09304200 (White River above Coal Creek, near
Meeker) (table 7). The suspended sediment model failed diagnostics at 09304800 (White River below Meeker) from 1990 to 2009. A downward trend was detected at 09306290 (White River below Boise Creek, near Rangely) in suspended sediment from 1990 to 2009. A net, downward trend was detected at 09306305 (White River below Taylor Draw Reservoir, above Rangely) from 1995 to 2002. The trend was parabolic with a zero-slope year around 1996, prior to which the shape of the parabola indicated a downward trend. The downward trend at 09306305 could be related to Taylor Draw Reservoir, which was constructed in 1984. The efficiency of a reservoir to retain sediment is a function of reservoir capacity, inflow volume, mean velocity of flow through the reservoir, and size composition of the sediment load (Churchill, 1948; Brune, 1953). A reservoir's ability to retain sediment can increase as the ratio of the reservoir capacity to inflow volume increases or the percent composition of silt and clay in the sediment load decreases, or both. The downward trend at 09306305 might reflect a decrease in inflow volume or changes in sources of fluvial sediment. 
Table 7. Summary of regression model trend analysis results for trace elements and suspended sediment, Piceance study area, western Colorado, 1990-2009._-Continued

[The upward and downward columns are populated whenever there is a significant trend. If the trend was parabolic, then both columns contain the time frame of the respective trend direction, the net direction of the trend is indicated by shading. If the trend was monotonic, then the respective column contains the respective time frame and the other columns contains NA. If no significant trend was detected, then the combined columns contain an indicator of no trend and the time frame of the analysis; NT, no trend detected; F, model failed the model diagnostics; - , site did not have sufficient data for trend analysis; ND, site did not have data; IS, insufficient data for regression model analysis]

\begin{tabular}{|c|c|c|c|c|c|c|c|c|c|}
\hline \multicolumn{2}{|c|}{$\begin{array}{c}\text { Iron, filtered, } \\
\text { in micrograms per liter }\end{array}$} & \multicolumn{2}{|c|}{$\begin{array}{l}\text { Iron, total recoverable, } \\
\text { in micrograms per liter }\end{array}$} & \multicolumn{2}{|c|}{$\begin{array}{c}\text { Lead, filtered, } \\
\text { in micrograms per liter }\end{array}$} & \multicolumn{2}{|c|}{$\begin{array}{c}\text { Zinc, filtered, } \\
\text { in micrograms per liter }\end{array}$} & \multicolumn{2}{|c|}{$\begin{array}{l}\text { Selenium, filtered, } \\
\text { in micrograms per liter }\end{array}$} \\
\hline Upward & Downward & Upward & Downward & Upward & Downward & Upward & Downward & Upward & Downward \\
\hline \multicolumn{10}{|c|}{ White River Basin } \\
\hline \multicolumn{2}{|c|}{ IS } & NA & 1991-2001 & & & & & & \\
\hline \multirow{2}{*}{\multicolumn{2}{|c|}{$\begin{array}{l}\text { NT; 1995-2009 } \\
\text { NT: 1990-2009 }\end{array}$}} & \multicolumn{2}{|c|}{ NT; 1991-2002 } & \multicolumn{2}{|c|}{ - } & \multicolumn{2}{|c|}{ F; 1991-2009 } & \multicolumn{2}{|c|}{ F; 1991-2009 } \\
\hline & -2009 & \multicolumn{2}{|c|}{ IS } & \multirow{2}{*}{\multicolumn{2}{|c|}{$\begin{array}{c}\text { F; 1999-2009 } \\
\text { NT; 1999-2009 }\end{array}$}} & \multicolumn{2}{|r|}{ 1990-2009 } & \multicolumn{2}{|c|}{ NT; 1999-2009 } \\
\hline $2001-2009$ & 1991-2001 & \multicolumn{2}{|c|}{ IS } & & & NA & 1991-2009 & NT; 19 & 2009 \\
\hline I & & \multicolumn{2}{|c|}{ IS } & \multicolumn{2}{|c|}{ IS } & \multicolumn{2}{|c|}{ IS } & \multicolumn{2}{|c|}{ IS } \\
\hline - & & \multirow{2}{*}{\multicolumn{2}{|c|}{ IS }} & \multicolumn{2}{|c|}{ - } & \multicolumn{2}{|c|}{ - } & \multicolumn{2}{|c|}{ - } \\
\hline 1991-2009 & NA & & & \multicolumn{2}{|c|}{ - } & \multicolumn{2}{|c|}{ F; 1991-2009 } & \multicolumn{2}{|c|}{ - } \\
\hline NT; 199 & -2009 & NT; $19 \mathrm{C}$ & -2001 & & & & & NT; 19 & 2009 \\
\hline I & & I & & & & & & & \\
\hline & & & & Colorad & ver Basin & & & & \\
\hline NA & 1991-2007 & $2000-2007$ & 1991-2000 & & & 1991-1995 & 1995-2007 & & \\
\hline $\mathrm{N}$ & & $\mathrm{N}$ & & & & & & NT; 20 & 2009 \\
\hline I & & $\mathrm{N}$ & & & & & & & \\
\hline 1999-2002 & 1995-1999 & I & & & & & & NT; 19 & 2009 \\
\hline- & & I & & & & & & & \\
\hline - & & I & & & & & & & \\
\hline I & & I & & & & & & & \\
\hline - & & $\mathrm{N}$ & & & & & & 2000-2006 & $1991-2000$ \\
\hline I & & I & & & & & & & \\
\hline I & & $\mathrm{N}$ & & & & & & & \\
\hline $1997-2002$ & $1990-1997$ & I & & & & & & NA & 1990-2009 \\
\hline & & & & Lower Gunr & n River Basin & & & & \\
\hline $\mathrm{N}$ & & I & & & & & & NT; 19 & 2009 \\
\hline I & & $\mathrm{N}$ & & & & & & NA & 1991-2003 \\
\hline $\mathrm{N}$ & & I & & & & & & NA & 1991-2009 \\
\hline $\mathrm{N}$ & & $\mathrm{N}$ & & & & & & & \\
\hline $\mathrm{N}$ & & $\mathrm{N}$ & & & & & & & \\
\hline I & & I & & & & & & 1991-2009 & NA \\
\hline - & & - & & & & & & 2002-2009 & 1991-2002 \\
\hline 1999-2002 & 1990-1999 & - & & & & & & NA & 1990-2009 \\
\hline
\end{tabular}

Trends in suspended sediment were analyzed for 4 tributary sites to the White River. A downward trend in suspended sediment was detected at 09306200 (Piceance Creek below Ryan Gulch, near Rio Blanco) from 1990 to 2009. A net, downward trend in suspended sediment was detected at 09306222 (Piceance Creek at White River) from 1990 to 2009. The trend was parabolic with a zero-slope year around 2003, prior to which the shape of the parabola indicates a downward trend. Both site 09306255 (Yellow Creek near White River) and site 09306242 (Corral Gulch near Rangely) failed model diagnostics.

\section{Colorado River Basin}

Temporal and spatial variability of water-quality data in the Colorado River Basin were evaluated at 13 sites: 8 sites on the Colorado main stem and 5 sites on tributaries to the Colorado River (tables 4-7, fig. 7). Main-stem sites on the Colorado River were CDOWRW-47 (Colorado River Deveraux Bridge), 09085150 (Colorado River above South Canyon near Glenwood Springs), CDOWRW-550 (Colorado River Rifle Bridge), 09095500 (Colorado River near Cameo), 09106150 (Colorado River below Grand Valley Diversion near Palisade), CDOWRW-555 (Colorado River Highway 6), CDOWRW-560 (Colorado River Watson), and 09163500 (Colorado River near Colorado-Utah state line). Tributary sites were 09089500 (West Divide Creek near Raven), 09095300 (Dry Fork at Upper Station, near DeBeque), 09105000 (Plateau Creek near Cameo), 09106200 (Lewis Wash near Grand Junction), and 09153290 (Reed Wash near Mack). The Gunnison River is also a tributary to the Colorado River, and it is discussed as a separate basin in this report. The most downstream site in the Lower Gunnison River Basin, 09152500 (Gunnison River near Grand Junction), is included in the figures and discussion of loading profiles for the Colorado River Basin to complete the discussion of spatial patterns. 
Table 7. Summary of regression model trend analysis results for trace elements and suspended sediment, Piceance study area, western Colorado, 1990-2009.-Continued

[The upward and downward columns are populated whenever there is a significant trend. If the trend was parabolic, then both columns contain the time frame of the respective trend direction, the net direction of the trend is indicated by shading. If the trend was monotonic, then the respective column contains the respective time frame and the other columns contains NA. If no significant trend was detected, then the combined columns contain an indicator of no trend and the time frame of the analysis; NT, no trend detected; F, model failed the model diagnostics; —, site did not have sufficient data for trend analysis; ND, site did not have data; IS, insufficient data for regression model analysis]

\begin{tabular}{|c|c|c|c|}
\hline Site name & $\begin{array}{c}\text { Site } \\
\text { identification } \\
\text { number }\end{array}$ & \multicolumn{2}{|c|}{$\begin{array}{l}\text { Suspended sediment, } \\
\text { in milligrams per liter }\end{array}$} \\
\hline \multicolumn{4}{|c|}{ White River Basin } \\
\hline White River below Meeker, Colo. & 09304800 & \multicolumn{2}{|c|}{ F; 1990-2009 } \\
\hline Piceance Creek below Ryan Gulch, near Rio Blanco, Colo. & 09306200 & NA & 1990-2009 \\
\hline Piceance Creek at White River, Colo. & 09306222 & 2003-2009 & 1990-2003 \\
\hline White River above Crooked Wash, near White River City, Colo. & 09306224 & \multicolumn{2}{|c|}{ - } \\
\hline White River below Boise Creek, near Rangely, Colo. & 09306290 & NA & 1990-2009 \\
\hline White River below Taylor Draw Reservoir, above Rangely, Colo. & 09306305 & $1995-1996$ & 1996-2002 \\
\hline \multicolumn{4}{|c|}{ Colorado River Basin } \\
\hline Colorado River Devereaux Bridge & CDOWRW-47 & \multicolumn{2}{|c|}{ ND } \\
\hline Colorado River above South Canyon Creek, near Glenwood Springs, Colo. & 09085150 & \multicolumn{2}{|c|}{ ND } \\
\hline Dry Fork at Upper Station, near DeBeque Colo. & 09095300 & \multicolumn{2}{|c|}{ F; 1996-2004 } \\
\hline Colorado River Watson & CDOWRW-560 & \multicolumn{2}{|c|}{ ND } \\
\hline Reed Wash near Mack, Colo. & 09153290 & \multicolumn{2}{|c|}{ IS } \\
\hline Colorado River near Colorado-Utah State Line & 09163500 & \multicolumn{2}{|c|}{$\mathrm{F} ; 1990-2008$} \\
\hline \multicolumn{4}{|c|}{ Lower Gunnison River Basin } \\
\hline North Fork Gunnison River above mouth, near Lazear, Colo. & 09136100 & \multicolumn{2}{|c|}{ IS } \\
\hline Sunflower Drain at Highway 92, near Read & 384551107591901 & \multicolumn{2}{|c|}{ IS } \\
\hline Gunnison River at Delta, Colo. & 09144250 & \multicolumn{2}{|c|}{ ND } \\
\hline Loutsenhizer Arroyo at Falcon Road & 383528107552001 & \multicolumn{2}{|c|}{ ND } \\
\hline West Tributary of Loutsenhizer Arroyo below East Canal & 383728107572001 & \multicolumn{2}{|c|}{ ND } \\
\hline Loutsenhizer Arroyo at North River Road & 383946107595301 & \multicolumn{2}{|c|}{ ND } \\
\hline Uncompahgre River at Delta, Colo. & 09149500 & \multicolumn{2}{|c|}{-} \\
\hline Gunnison River near Grand Junction, Colo. & 09152500 & \multicolumn{2}{|c|}{ F; 1990-2007 } \\
\hline
\end{tabular}

\section{Field Properties}

Results of the trend analysis for water temperature, $\mathrm{pH}$, and dissolved oxygen are presented in table 4 . Sufficient data were available to analyze for temperature trends at 5 sites in the Colorado River Basin. No significant trends in temperature were detected throughout the Colorado main-stem section. Sufficient data were available to analyze for $\mathrm{pH}$ trends at 3 sites in the Colorado River Basin. An upward trend in $\mathrm{pH}$ was detected at 09095500 (Colorado River near Cameo) from 1990 to 2009. Sufficient data were available to analyze for dissolved-oxygen trends at 4 sites. A downward trend in dissolved oxygen was detected at CDOWRW-47 (Colorado River Devereux Bridge) from 1991 to 2007.

\section{Nutrients}

Trends in nutrient concentration data were evaluated for ammonia, nitrate, orthophosphate, and total phosphorus. Models failed diagnostics for ammonia and nitrate at site 09095500
(Colorado River near Cameo) from 1991 to 2002 (table 5). Additionally, between 1980 and 1998, there were 16 exceedances for total phosphorus (app. 1). At 09163500 (Colorado River near Colorado-Utah state line), a downward trend was detected in nitrate and orthophosphate from 1990-2008. A net, downward trend in ammonia was detected at this site from 1990 to 2008. The trend was parabolic with a zero-slope year around 2002 , prior to which the shape of the parabola indicates a downward trend. An upward trend was detected in total phosphorus at the same site during the same time period, and there were 122 exceedances from 1979-2008 (app. 1). Without a regression model for nutrient data upstream from 09095500 (Colorado River near Cameo) on the main stem of the Colorado River, it is difficult to determine what the potential upstream sources were contributing to the observed trends at 09163500 (Colorado River near Colorado-Utah state line).

Limited nutrient data were available for tributaries to the Colorado main stem. Sufficient data were not available for trend analysis at 09153290 (Reed Wash near Mack), but 
there were 40 exceedances in total phosphorus from 1995 to 1998 (app. 1). As such, Reed Wash was a probable source of total phosphorus to the Colorado River. No trend was detected at 09095300 (Dry Fork at Upper Station, near DeBeque) for orthophosphate from 1996 to 2004, and a net, downward trend in nitrate was detected from 1996 to 2004. The total phosphorus model failed diagnostics for site 09095300 (Dry Fork at Upper Station, near DeBeque) from 1996 to 2004; 24 exceedances were observed for the same period (app. 1).

Although neither the nitrate nor the orthophosphate loading profile for the Colorado River has sufficient information for a comprehensive analysis (fig. 10), the lower Colorado River was analyzed with respect to the contributions from its principal tributary, the Gunnison River. The total nitrate load from the Gunnison River, represented by 091520500 (Gunnison River near Grand Junction), was 1,670 tons in 1996, which was 52 percent of the total load at 09163500 (Colorado River near Colorado-Utah state line) (fig. 10A). The total nitrate load from the Colorado River Basin, represented by the most downstream site 09163500 (Colorado River near Colorado-Utah state line), was 3,230 tons. Orthophosphate load from the Gunnison River in water year 1996 was 125 tons, 32 percent of the total load at the Colorado River near Colorado-Utah state line (385 tons) (fig. 10B). These results indicated that the Gunnison River is a substantial source of nitrate and orthophosphate to the Colorado River.

\section{Dissolved Solids and Major lons}

Trends in DS were evaluated at 3 sites on the Colorado main stem. A downward trend was detected in DS at 09095500 (Colorado River near Cameo) from 1990 to 2009, and no trend was detected at 09106150 (Colorado River below Grand Valley Diversion near Palisade) from 1992 to 2002 (table 6). A net, downward trend in DS was detected at 09163500 (Colorado River near Colorado-Utah state border) from 1990 to 2009. The trend was parabolic with a zero-slope year around 2005, prior to which the shape of the parabola indicates a downward trend. Salinity control work in the Grand Valley could have contributed to the downward trend at 09163500 (Colorado River near Colorado-Utah state border). Trends in other major ion concentrations may aid in identifying sources of DS based on mineral composition, where dissolution of these sources might be controlling DS contribution to the Colorado River. The trend results indicated that other major ions (sulfate, chloride, magnesium, and sodium) had similar trend patterns as DS throughout the basin.

The three tributary sites for the Colorado River that had sufficient data for trend analysis for the majority of major ions were 09095300 (Dry Fork at Upper Station, near DeBeque), 09105000 (Plateau Creek near Cameo), and 09106200 (Lewis Wash near Grand Junction) (table 6). Net, downward trends were detected for sulfate, alkalinity, and bicarbonate at site 09095300 (Dry Fork at Upper Station, near DeBeque) from 1996 to 2004. The trends were parabolic with a zeroslope year around 1999, prior to which the shape of the parabola indicated an upward trend. No trends were detected at 09095300 (Dry Fork at Upper Station, near DeBeque) for chloride and carbonate, and there were insufficient data to analyze trends in DS. A downward trend was detected at 09105000 (Plateau Creek near Cameo) from 1991 to 2009 for DS, sulfate, and sodium. A net, downward trend was detected for chloride from 1991 to 2009. The trend was parabolic with a zero-slope year around 2002, prior to which the shape of the parabola indicated an upward trend. There were no trends detected in calcium, magnesium, potassium, fluoride, or silica. An upward trend was detected for bicarbonate from 1995 to 2009, while no trend was detected for carbonate during the same period. The headwaters of Plateau Creek originate on the Grand Mesa (fig. 1) where the geology is dominated by vesicular basalt. The Grand Mesa has relatively little urban development in comparison to the Colorado River mainstem corridor, but the area is experiencing increasing energy development. Downstream, Plateau Creek flows over Tertiary sedimentary formations composed of mudstone and sandstone, which are a likely source for DS in Plateau Creek. Downward trends were detected at 09106200 (Lewis Wash near Grand Junction) for magnesium and sulfate from 1991 to 2006; no trends were detected for DS and the other major ions (table 6).

Natural sources and anthropogenic activities contribute to DS along the Colorado River main stem. The Eagle Valley Evaporite (fig. 3), present upstream from Glenwood Springs and in the Roaring Fork drainage area, is a natural source of DS in the upper part of the basin. Chafin and Butler (2002) reported that the Eagle Valley Evaporite contributed approximately 800,000 metric tons of salt per year to the Colorado River. Salts from the Eagle Valley Evaporite contributed nearly 60 percent of the annual DS load observed at the USGS gaging station Colorado River near Cameo (09095500) (Chafin and Butler, 2002). The high concentrations of DS downstream from 09095500 (Colorado River near Cameo) can be attributed to irrigation of the sedimentary formations such as the Mancos Shale and Dakota Sandstone (fig. 3). Irrigation return flows generally have a higher salinity concentration than the applied water because of the effect of salt dissolution in the soil and subsurface materials and the concentrating effect of evapotranspiration (Vaill and Butler, 1999). A loading profile for the Colorado River Basin indicated increasing DS load from upstream to downstream with the exception of the Colorado River below the Grand Valley Diversion (fig. 11A). The total DS load from the Colorado River Basin is represented by the most downstream site, 09163500 (Colorado River near Colorado-Utah state line). The load in water year 1999 was $2,850,000$ tons (fig. $11 \mathrm{~A}$ ), which is about 10 times larger than the DS load from the White River Basin in water year 2000 (fig. 9A). Load at 09095500 (Colorado River near Cameo) for water year 1999 was 1,380,000 tons, which was about 48 percent of the load from the Colorado River Basin (fig. 11A). Load from 09105000 (Plateau Creek near Cameo) for water year 1999 was 59,700 tons, which was about 2 percent of the load from the Colorado River Basin 
(fig. 11A). Load from 09106150 (Colorado River below the Grand Valley Diversion near Palisade) was 1,090,000 tons for water year 1999, which was about 38 percent of the load from the Colorado River Basin. The reduction in load from 09095500 (Colorado River near Cameo) to 09106150 (Colorado River below the Grand Valley Diversion near Palisade) indicated that DS loads were removed along with significant diversions in this area (fig. 11A). Downstream from 09095500 (Colorado River near Cameo) there are two diversions of irrigation water that have an estimated capacity of 2,380 cubic feet per second ( $\left.\mathrm{ft}^{3} / \mathrm{s}\right)$, and about $650 \mathrm{ft}^{3} / \mathrm{s}$ is returned to the Colorado River just above the site 09106150 (Colorado River below the Grand Valley Diversion near Palisade) (Butler, 1985; Kuhn and Williams, 2004). Leib and Bauch (2008) estimated an average annual DS concentration of $374 \mathrm{mg} / \mathrm{L}$ for 09095500 in water year 1999, which included both irrigated and non-irrigated seasons. Using the concentration of $374 \mathrm{mg} / \mathrm{L}$ resulted in an estimation of approximately 350,000 tons of dissolved solids that could be diverted between 09095500 and 09106150 , and this estimation would vary based on season and water availability. The Gunnison River, represented by 09152500 (Gunnison River near Grand Junction), contributed 1,064,000 tons of dissolved solids to the Colorado River in water year 1996 (fig. 11A), which was 37 percent of the most downstream site, 09163500 (Colorado River near Colorado-Utah state line).

\section{Trace Elements}

Sufficient data were available to compare the results of the trends analysis for iron in the Colorado River Basin (table 7). A downward trend for iron was detected at site CDOWRW-47 (Colorado River Devereux Bridge) from 1991 to 2007 (table 7). At 09095500 (Colorado River near Cameo), a net, downward trend in iron was detected from 1995 to 2002. The trend was also parabolic with a zero-slope year around 1999, after which the shape of the parabola indicated an upward trend. At 09163500 (Colorado River near ColoradoUtah state line), a net, downward trend was detected in iron from 1990 to 2002. The trend also was parabolic with a zeroslope year around 1997, after which the shape of the parabola indicated an upward trend. The loading profile for iron indicated a decreasing iron load downstream (fig. 11B). The iron load in water year 1996 at 09163500 (Colorado River near Colorado-Utah state line) was 134,000 pounds, which was 43,000 pounds less than the iron load from the upstream site, 09095500 (Colorado River near Cameo) (177,000 pounds). Despite the contribution of 41,700 pounds of iron in water year 1996 from 09152500 (Gunnison River near Grand Junction), there still was a loss in iron load (1,300 pounds) at 09163500 (Colorado River near Colorado-Utah state line). There are no major hard-rock mines in the Colorado River Basin that could have been potential point sources for selected trace elements like iron. Further study of iron sources and sinks in the Colorado River Basin near Grand Junction would be beneficial to better understand these results. Results for total recoverable iron throughout the Colorado River Basin reported 600 exceedances of the chronic aquatic-life standard (app. 1). There were approximately 82 exceedances observed at 4 sites on Plateau Creek, although the sampling period was from 1992 to 2004. Insufficient data were available to perform a trend analysis on any Plateau Creek site.

Similar to DS, selenium is a water-quality concern in the Colorado River Basin because of the combination of geologic formations and land use. The CDPHE has listed many stream segments from East Rifle Creek to the ColoradoUtah state border for selenium impairments (table 2). No trend was detected in selenium at 09095500 (Colorado River near Cameo) from 1991 to 2009, and a downward trend was detected at 09163500 (Colorado River near Colorado-Utah state line) from 1990 to 2009. Results for selenium in the Colorado River Basin reported 741 exceedances of the chronic aquatic-life standard and 201 exceedances of the acute standard (app. 1).

A loading profile for the Colorado River Basin indicated increased selenium load between the 09095500 (Colorado River near Cameo) and 09163500 (Colorado River near Colorado-Utah state line) sites (fig.11C). The total selenium load from the Colorado River Basin at the most downstream site 09163500 (Colorado River near Colorado-Utah state line) in water year 1999 was 36,200 pounds. Load at 09095500 (Colorado River near Cameo) for water year 1999 was 3,900 pounds, which was about 11 percent of the load from the Colorado River Basin. Load at 09152500 (Gunnison River near Grand Junction) for water year 1999 was 18,900 pounds, which was about 52 percent of the load from the Colorado River Basin, indicating that the Lower Gunnison River Basin is one of the major source of selenium in this part of the Colorado River Basin.

Insufficient data were available to analyze selenium data for trends or loads on tributaries to the Colorado River upstream from Plateau Creek. Median selenium concentration at 09095300 (Dry Fork at Upper Station, near De Beque) was $4 \mu \mathrm{g} / \mathrm{L}$, and there were 16 exceedances from 1996 to 2001 of the chronic aquatic-life standard. The site is listed on the CDPHE 303d list for selenium impairment. Additional waterquality monitoring could help land managers to identify what is causing the selenium impairment. Sites on Divide Creek (LANG2ST-LANG8ST) had a median selenium concentration of $5.6 \mu \mathrm{g} / \mathrm{L}$ and approximately 62 exceedances from 2004 to 2005 of the chronic aquatic-life standard. Other tributaries in the basin such as East Rifle Creek, West Rifle Creek, and Rifle Creek are listed on the CDPHE 303d list for selenium impairment, but insufficient data were available from this study to analyze for trends. 


\section{Suspended Sediment}

Suspended sediment data did not meet the criteria for trend analysis at most sites, and the models failed diagnostics at sites where there were sufficient data. Failed diagnostics were reported at sites 09095300 (Dry Fork at Upper Station, near DeBeque), 09095500 (Colorado River near Cameo), and 09163500 (Colorado River near Colorado-Utah state line). Sediment is listed on the $303 \mathrm{~d}$ list for Salt Creek, which is a tributary to the Colorado River (table 2).

\section{Lower Gunnison River Basin}

Temporal and spatial variability of water-quality data in the Lower Gunnison River Basin were evaluated at 14 sites: 2 sites on the Gunnison River main stem and 12 sites on tributaries to the Gunnison River (tables 4-7, fig.7). Main-stem sites on the Gunnison River were 09144250 (Gunnison River at Delta) and 09152500 (Gunnison River near Grand Junction). Tributary sites included 09132500 (North Fork Gunnison River near Somerset), 09136100 (North Fork Gunnison River above mouth near Lazear), 09134000 (Minnesota Creek near Paonia), 09135950 (North Fork of the Gunnison below Leroux Creek, near Hotchkiss), 09128500 (Smith Fork near Crawford), 384551107591901 (Sunflower Drain at Highway 92, near Read), 09143000 and 09143500 (Surface Creek near and at Cedaredge, respectively), and 09149500 (Uncompahgre River at Delta). There were 3 sites on Loutsenhizer Arroyo, which is a tributary to the Uncompahgre River: 383528107552001 (Loutsenhizer Arroyo at Falcon Road), 383728107572001 (West tributary of Loutsenhizer Arroyo below East Canal), and 383946107595301 (Loutsenhizer Arroyo at North River Road).

\section{Field Properties}

Results of the trend analysis for water temperature, $\mathrm{pH}$, and dissolved oxygen are presented in table 4. Sufficient data were available to analyze for temperature trends at 4 sites in the Lower Gunnison River Basin. No trends were detected at 3 of these sites. However, an upward trend was detected in water temperature from 1990 to 2009 at 09152500 (Gunnison River near Grand Junction), the most downstream site. This same site, 09152500, also had sufficient data to analyze for trends in dissolved oxygen and pH from 1990 to 2009 and no trends were detected.

\section{Nutrients}

There are limited nutrient data in the Lower Gunnison River Basin (table 5). Only one site, 09152500 (Gunnison River near Grand Junction), met the criteria for the trend analysis. No trend was detected in nitrate from 1990 to 2002, orthophosphate from 1990 to 1998, or organic carbon from 1995 to 2002. Comparisons to the recommended total phosphorus standard showed nearly 500 exceedances out of
1,538 samples. Additional long-term monitoring of nutrients in surface water could provide an opportunity to describe the current nutrient levels in the Lower Gunnison River Basin.

\section{Dissolved Solids and Major lons}

Dissolved solids are a water-quality concern to land and water managers in the Lower Gunnison River Basin because of the combination of geologic formations and land use. This scenario is in contrast to the Colorado River Basin where DS levels are greatly elevated from natural sources such as the Eagle Valley Evaporite Formation (Chafin and Butler, 2002). Natural sources of DS include seeps or springs that originate from geological formations with high DS content, such as the Mancos Shale and Dakota Sandstone in the Lower Gunnison River Basin (fig. 3). Another source of DS in the Lower Gunnison River Basin is the result of irrigated agriculture in areas underlain by Mancos Shale (Butler and others, 1996).

In the Lower Gunnison River Basin, trends in DS and other major ions were tested at 2 sites on the main stem and 4 tributary sites of the Gunnison River. The main-stem sites were 09152500 (Gunnison River near Grand Junction) and 09144250 (Gunnison River at Delta). The DS model failed diagnostics at 09144250 (app. 1, table 6); many of the other models for trends in major ions also failed model diagnostics for this site. However, a downward trend at 09144250 (Gunnison River at Delta) was detected in magnesium, and no trend was detected in potassium or silica from 1991 to 2009. Schaffrath (2011) reported a downward trend in DS for the period 1989 through 2004. The most downstream site in the basin was 09152500 (Gunnison River near Grand Junction), where a net, downward trend was detected from 1990 to 2009. The trend was parabolic with a zero-slope year around 2005, after which the shape of the parabola indicated an upward trend. This conclusion is supported by the findings reported by Schaffrath (2012); that is, a downward trend from 1989 through 2003 and a net, downward trend from 1989 through 2007 for DS. Other major ions analyzed for trends at this site (and study period) generally had the same result. Calcium, magnesium, sodium, and chloride all had the same general trend pattern. Parabolic trends were detected for potassium and alkalinity with zero slope years of 2000 and 1999, respectively. No net trend was detected for the time period for both of these constituents. No trend was detected for silica or bicarbonate. Downward trends were detected for sulfate and carbonate, while an upward trend was detected for fluoride from 1990 to 2009.

Trends were analyzed at 4 tributary sites: 09136100 (North Fork Gunnison River above mouth near Lazear), 384551107591901 (Sunflower Drain at Highway 92, near Read), 09149500 (Uncompahgre River at Delta), and 383946107595301 (Loutsenhizer Arroyo at North River Road) (table 6). The first three sites are tributaries to the main stem of the Gunnison River while the fourth site is tributary 
to the Uncompahgre River. A downward trend was detected for DS, calcium, magnesium, sodium, and sulfate at site 09136100 (North Fork Gunnison River above mouth near Lazear) from 1991 to 2009, and no trends were detected for potassium, fluoride, or silica. No trends were detected for DS, calcium, magnesium, sodium, potassium, chloride, or sulfate at 384551107591901 (Sunflower Drain at Highway 92, near Read) for the period from 1991 to 2003. However, upward trends were detected for fluoride and silica from 1991 to 2003 at 384551107591901 (Sunflower Drain at Highway 92, near Read). The trend analysis period for this site may not reflect the most recent condition in that area. A portion of the DS (and other major ions) load measured at site 384551107591901 (Sunflower Drain at Highway 92, near Read) was from water diverted from the Uncompahgre River Basin; however, the actual amount is unknown because of data limitations. A net, downward trend was detected for DS at site 09149500 (Uncompahgre River at Delta) from 1991 to 2009. The trend was parabolic with a zero-slope year around 2001, after which the shape of the parabola indicated an upward trend. Downward trends with significant parabolic trends similar to DS were detected for calcium, magnesium, sodium, chloride, and sulfate. An upward trend was detected for fluoride from 1991 to 2009. The shape of the major ion trends at 09149500 (Uncompahgre River at Delta) was similar to those detected at 09152500 (Gunnison River near Grand Junction), but the zero-slope years differed slightly. Both the North Fork and the Uncompahgre River Basins have similar DS and major ion trends and are the two major tributaries to the Gunnison River. This would indicate that both the North Fork and Uncompahgre River Basins were controlling the trends at the 09152500 (Gunnison River near Grand Junction) site; however, the trend at 09149500 (Uncompahgre River at Delta) may have more influence based on its similar trend slope and direction to that found for 09152500 (Gunnison River near Grand Junction). Schaffrath (2012) reported a downward trend in DS at 09149500 (Uncompahgre River at Delta) from 1989 to 2004 . The drainage area above this site is dominated by agricultural land and is underlain by Mancos Shale. Salinity-control efforts have been focused in this area since the 1980s. The site that was a tributary to the Uncompahgre River, 383946107595301 (Loutsenhizer Arroyo at North River Road), did not have a trend in DS or other major ions except for an upward trend for silica from 1991 to 2009.

The DS load from the Gunnison River Basin is represented by the most downstream site, 09152500 (Gunnison River near Grand Junction). The Gunnison River is a tributary to the Colorado River, so the loading profile was compared to 09163500 (Colorado River at the Colorado-Utah state line) (fig. 12A). Load at 09152500 (Gunnison River near Grand Junction) for water year 1999 was approximately $1,060,000$ tons (fig. 12A), which was about 37 percent of the load calculated for 09163500 (Colorado River at the Colorado-Utah state line) (fig. 11A). Load at 09136100 (North Fork Gunnison River above mouth near Lazear) could not be calculated because of an incomplete streamflow record.
The DS load in the North Fork of the Gunnison River drainage area is primarily from natural and agricultural sources based on the low levels of industrial and residential uses (Homer and others, 2004), and salinity control efforts are ongoing in the area. The models failed diagnostics for loads in DS at 09144250 (Gunnison River at Delta) and 09149500 (Uncompahgre River at Delta). However, Schaffrath (2012) developed model equations for 09144250, 09149500, and 09152500. Using those equations, the 1999 water year load calculated for 09152500 (Gunnison River near Grand Junction) was $1,070,000$ tons, which was only 10,000 tons more than the load calculated using the model equations developed in this report. The DS load in water year 1999 at 09144250 (Gunnison River at Delta), for comparison, was 582,000 tons, which was about 54 percent of the load from the Lower Gunnison River Basin. The Uncompahgre River flows into the Gunnison River just downstream from site 09149500 (Uncompahgre River at Delta). The DS load at 09144250 (Gunnison River at Delta) for water year 1999, also calculated using equations from Schaffrath (2012), was approximately 371,000 tons, which was about 35 percent of the load from the Lower Gunnison River Basin that year. Load at the Loutsenhizer Arroyo site could not be calculated because of insufficient streamflow data.

The majority of DS load and respective salinity-control efforts have occurred in the Gunnison River drainage area downstream from the Gunnison Tunnel (Lower Gunnison River Basin). Schaffrath (2012) reported no downward trends in DS in the Upper Gunnison River drainage area, defined in this report as the region of the Gunnison River upstream from the Gunnison Tunnel. Efforts to reduce DS load in the Lower Gunnison River Basin have been ongoing since the 1980s through salinity control efforts. On-farm and small irrigation ditch improvements as of 2007 had been implemented in $76 \mathrm{mi}^{2}$ in the Lower Gunnison River Basin, resulting in estimates of DS load reduction of 95,200 tons (Frank Riggle, Natural Resources Conservation Service, written commun., July 28, 2010; Schaffrath, 2011). Bureau of Reclamation also sponsors programs to reduce DS load in the Lower Gunnison River Basin; they had participated in projects that included 29 miles of canal lining and elimination of stock watering areas that resulted in estimates of DS load reduction of 49,520 tons as of 2007 (Mike Baker, Bureau of Reclamation, written commun., September 20, 2010; Schaffrath, 2012).

\section{Trace Elements}

Sufficient data were available only for trend analysis of iron at site 09152500 (Gunnison River near Grand Junction) and selenium at various other sites in the Lower Gunnison River Basin (table 7). A net, downward trend in iron was detected at 09152500 (Gunnison River near Grand Junction) from 1990 to 2002. The trend also was parabolic with a zeroslope year of 1999, prior to which the shape of the parabola indicated an upward trend. The Lower Gunnison River Basin had 326 exceedances of the chronic (30-day) aquatic-life 
standard for iron (app. 1). There were exceedances for many of the trace elements sampled in the basin. For example, 34 exceedances for the aquatic-life 30-day standard for copper, 18 exceedances for the acute copper standard, 73 exceedances of the chronic (30-day) aquatic-life standard for lead, and 4 exceedances of the acute standard for lead were observed. Zinc had no more than 7 exceedances of the chronic or acute water-quality standards. About $25 \mathrm{mi}^{2}$ of the Lower Gunnison River Basin are Federal coal leases, and Oxbow Mining and Mountain Coal Company are interested in developing approximately $3 \mathrm{mi}^{2}$ (U.S. Forest Service, 2011). The infrequent sampling for trace elements and high number of exceedances in the Lower Gunnison River Basin illustrated a data gap in the Piceance study area.

Selenium is a major water-quality concern for land and water managers in the Lower Gunnison River Basin. Similar to DS, high selenium concentrations are due to the combination of geologic formations and land use. Selenium is primarily sourced from a geologic formation known as the Mancos Shale; that is, DS is sourced from the Mancos Shale formation and a variety of sedimentary rock formations in the area. Selenium is leached from soils in a similar manner as DS by way of irrigation and natural chemical processes. Selenium is more chemically reactive than the major ions included in the DS measurements. The reactive nature of selenium can cause selenium to oxidize and reduce between mobile and immobile forms. Therefore, there is a high degree of the temporal and spatial variability in selenium concentrations. This extreme variability is complicated, and scientists and land managers often have a difficult time understanding the effects that various types of land use in the Lower Gunnison River Basin have on selenium concentrations in rivers and streams. Previous studies in the Lower Gunnison River Basin have documented that high selenium concentrations correlate with high DS concentrations. The nature of this paired occurrence means that when salinity control efforts are conducted in seleniumrich areas of the Lower Gunnison River Basin, both DS and selenium concentrations have the potential to decrease (Butler and others, 1996; Moore, 2011).

Trends in selenium were analyzed at 2 sites on the main stem of the Gunnison River and at 4 sites on tributaries to the Gunnison River. Main-stem sites were 09144250 (Gunnison River at Delta) and 09152500 (Gunnison near Grand Junction). Downward trends in selenium were detected at both main-stem sites from 1991 to 2009 at 09144250 (Gunnison River at Delta) and from 1990 to 2009 at 09152500 (Gunnison near Grand Junction) (table 7).

The 4 tributary sites to the Gunnison River were 09136100 (North Fork of the Gunnison above mouth near Lazear), 09149500 (Uncompahgre River at Delta), 384551107591901

(Sunflower Drain at Highway 92, near Read), and 383946107595301 (Loutsenhizer Arroyo at North River Road). No selenium trend was detected at site 09136100 (North Fork of the Gunnison near the mouth of Lazear) from 1991 to 2009. A net, downward trend for selenium was detected at site 09149500 (Uncompahgre River at Delta) from 1991 to 2009. The trend was also parabolic with a zero-slope year of 2002, after which the shape of the parabola indicates an upward trend. The shape of the selenium trend at this site was very similar to that of the DS trend observed at this site. A downward trend in selenium was detected at 384551107591901 (Sunflower Drain at Highway 92, near Read) from 1991 to 2003. The period of record for 384551107591901 (Sunflower Drain at Highway 92, near Read) ends in 2003; therefore, it is unknown if the downward trend for the 1991 to 2003 period is representative of current conditions. An upward trend in selenium was detected at 383946107595301 (Loutsenhizer Arroyo at North River Road), a tributary to the Uncompahgre River, from 1991 to 2009. This was the only site tested in the Lower Gunnison River Basin that had an upward trend in selenium. Selenium load reported by Butler and Leib (2002) indicated that Loutsenhizer Arroyo drainage area is one of the largest sources of selenium load in the Lower Gunnison River Basin. This may explain why there is a parabolic trend in selenium at the 09149500 (Uncompahgre River at Delta) while 09152500 (Gunnison River near Grand Junction) only had a downward trend.

The loading profile includes the two main-stem Gunnison River sites, 09144250 (Gunnison River at Delta) and 09152500 (Gunnison River near Grand Junction), and a site on the Uncompahgre River, 09149500 (Uncompahgre River at Delta) (fig. 12B). The other sites for which selenium trends were analyzed did not have sufficient streamflow data to calculate annual loads. The load at the most downstream site in the basin, 09152500 (Gunnison River near Grand Junction), was 19,000 pounds in 1999 . This basin is a tributary to the Colorado River, and 19,000 pounds is about 52 percent of the load estimated for 09163500 (Colorado River at the ColoradoUtah state line) (fig. 11C). Mayo and Leib (2012) reported a downward trend in load at this site for the period 1986 to 2008. Mayo and Leib also reported the magnitude of the trend to be an approximate decrease of $2 \mu \mathrm{g} / \mathrm{L}$, which is about 6,000 pounds annual difference between 1986 and 2008. Selenium load at 09144250 (Gunnison River at Delta) for water year 1999 was 9,180 pounds in 1999 , which was about 48 percent of the load from site 09152500 (Gunnison River near Grand Junction). Selenium load at 09144250 (Gunnison River at Delta) is sourced not only from the Gunnison River and North Fork of the Gunnison River Basins, but also from parts of the Uncompahgre River Basin as a result of multiple water diversions from the Uncompahgre River. The elevated selenium load is counterintuitive because the Uncompahgre River Basin is a tributary to the Gunnison River downstream from 09144250 (Gunnison River at Delta). The actual portion of selenium load from the Uncompahgre River Basin at 09144250 (Gunnison River at Delta) is unknown because of data limitations. Moore (2011) reported upward trends in selenium concentration and load in Montrose Arroyo. Montrose Arroyo is situated geologically in a similar manner and has similar geology as Loutsenhizer Arroyo in the Uncompahgre River Basin but is outside the study area. Moore (2011) suggested that changes in land use and possible geochemical factors could be causing the increases in selenium. 


\section{Suspended Sediment}

Sufficient data were available at 09152500 (Gunnison River near Grand Junction) to perform trend analysis, but the model failed diagnostics. Therefore, insufficient data were available and trend analysis could not be performed for the Lower Gunnison River Basin (table 7).

\section{Data Gaps}

Spatial, temporal, and analytical data gaps were identified in the study area. Spatial data gaps were identified where surface-water monitoring sites were not sufficient to characterize trends and loads, especially in areas contributing to a municipal drinking-water intake. Temporal data gaps were identified where data were collected in the past but are not being collected currently. Analytical data gaps were identified where analysis was incomplete (for example, not enough major ions to do a charge balance), entire constituent groups were omitted (for example, nutrients in the Lower Gunnison River Basin), or select constituents were not sampled for (for example, BTEX in the White River Basin).

\section{White River Basin}

The White River Basin had 45 water-quality sites of which 10 could be used for analysis of trends and loads (fig. 13). Sites where trends or loads were not analyzed included sites that were not currently being sampled, did not have sufficient data for analysis beyond summary statistics and comparison to standards, or lacked continuous streamflow data.

The spatial coverage of sampling sites could be expanded in the White River Basin by adding more tributary sites. Water-quality and streamflow data for Douglas Creek are not currently being collected. The exception is a single site located at the mouth of Douglas Creek where streamflow gaging and sampling were discontinued in 1996. Douglas Creek has a drainage area of $425 \mathrm{mi}^{2}$ of the $2,776 \mathrm{mi}^{2}$ (about 15 percent) of the White River Basin. Water-quality samples are collected on Coal, Flag, and Strawberry Creeks, but the addition of streamflow data could greatly enhance these datasets. No waterquality data exists for tributaries in the area north of Rangely, Colo., where extensive energy development has occurred in a complex geologic setting.

Analytical data gaps were identified in several constituent groups in the White River Basin. Owing to the amount of natural gas development and the potential for naturally occurring sources of BTEX, a synoptic sampling of BTEX at surface-water sites and springs could provide useful baseline information to better understand BTEX concentrations in the White River Basin, specifically in the Piceance and Yellow Creek drainage areas. Trace elements were collected at a few sites, mostly on tributaries (Piceance Creek), thus limiting the ability to understand occurrence, concentrations, and load. Selenium is identified on the 303d list for Black Sulphur Creek and Flag Creek (table 2), both tributaries to the White
River. However, sufficient data were not available at either site to obtain an understanding of the sources or sinks of selenium in the area. Furthermore, neither site has continuous streamflow to enable calculation of loads. Sediment is identified on the 303d list for Douglas Creek and West Evacuation Creek (table 2), but water-quality and quantity data are not currently being collected on Douglas Creek or West Evacuation Creek.

\section{Colorado River Basin}

Data collection has occurred at numerous sites throughout the Colorado River Basin (fig.14). The spatial and temporal continuity of these data efforts are often inconsistent. An attempt to calculate loads in the Colorado River Basin resulted in only 13 of the 179 sites meeting the criteria for trend analysis. Limited data were available for field properties, major ions, nutrients, and trace elements on the main stem of the Colorado River between Glenwood Springs and Cameo, Colo. Limited data were available on Plateau Creek for nutrients and trace elements. Urban growth, energy development, and landuse change in the Colorado River Basin increases the need to understand changes in water quality in the main stem and the respective tributaries.

The main analytical data gaps identified in the Colorado River Basin were nutrients and trace elements. The nitrate and orthophosphate trend analysis demonstrated at the Colorado River near the Colorado-Utah state line (09163500) is a downward trend from 1990 to 2008. Nutrient data were collected minimally upstream from 09163500 on the main stem of the Colorado River, and data were not collected on the Gunnison River (major tributary in the reach). Therefore, existing data are not sufficient to identify the land-use change and sources of the nutrient trends.

Iron loads decreased between 09095500 (Colorado River at Cameo) and 09163500 (Colorado River near ColoradoUtah state line), and further study is needed to understand iron sources and sinks in this area. Selenium has been identified on the $303 \mathrm{~d}$ list for all tributaries to the Colorado River between the confluence of the Roaring Fork and the Colorado River downstream to Parachute Creek (fig. 1). These tributaries have limited or no streamflow or water-quality data to complete load or trend analysis. Sediment has been identified on the 303d list for Salt Creek and E.coli and total recoverable iron for Adobe Creek (table 2, fig. 14). Salt Creek and Adobe Creek are tributaries to the Colorado River, and water-quality and water-quantity data are not being collected currently.

\section{Lower Gunnison River Basin}

There were 130 water-quality sites in the Lower Gunnison River Basin: 17 sites had sufficient data for trends analysis and 3 sites had sufficient streamflow data to calculate loads (fig. 15). Other sites were not currently being sampled, did not have sufficient data for analysis beyond summary statistics and comparison to standards, or lacked continuous streamflow. 


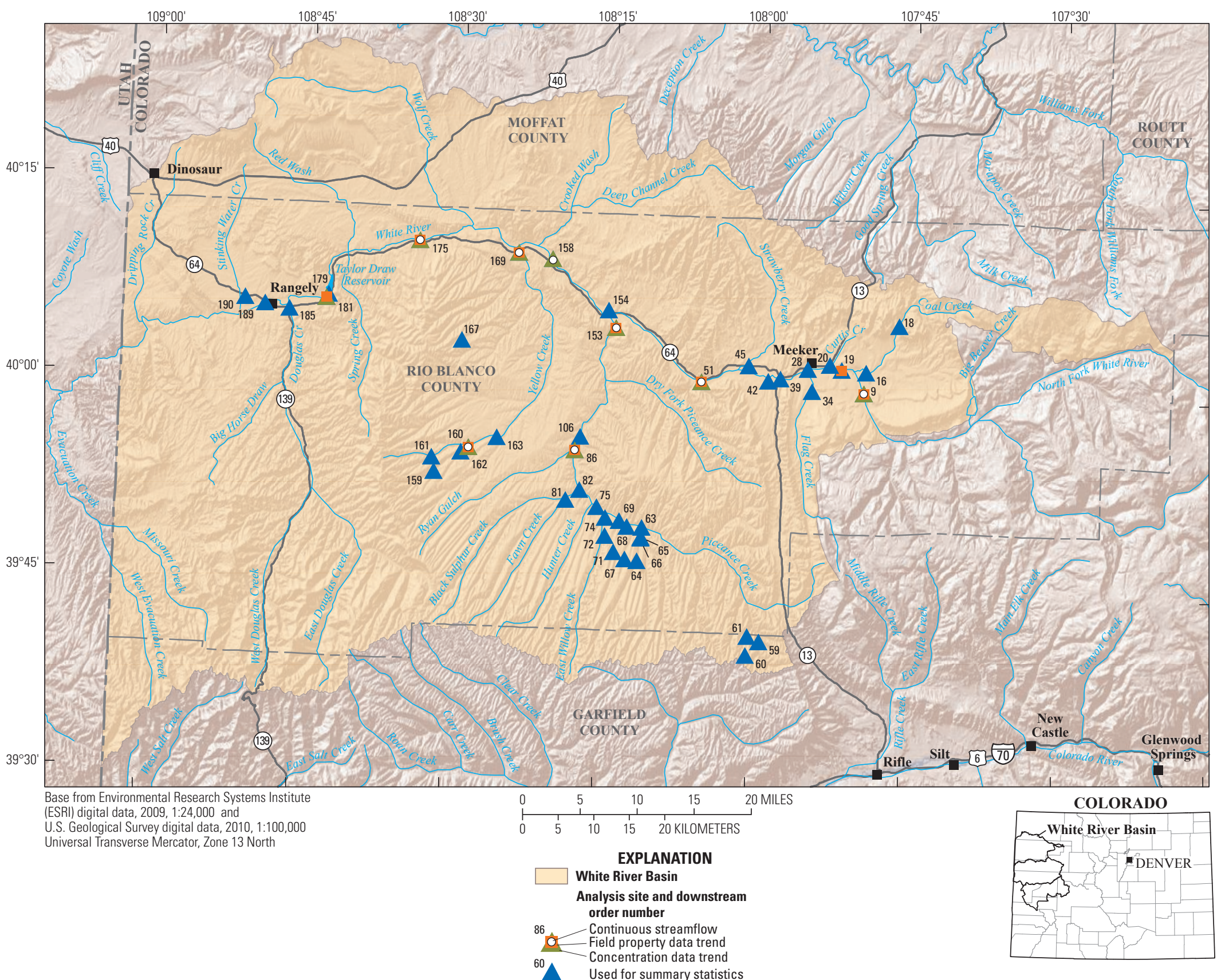

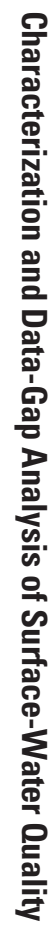

Figure 13. Locations of continuous streamflow, physical parameter data trend, concentration data trend, and summary statistic sites in the White River Basin, western Colorado. 


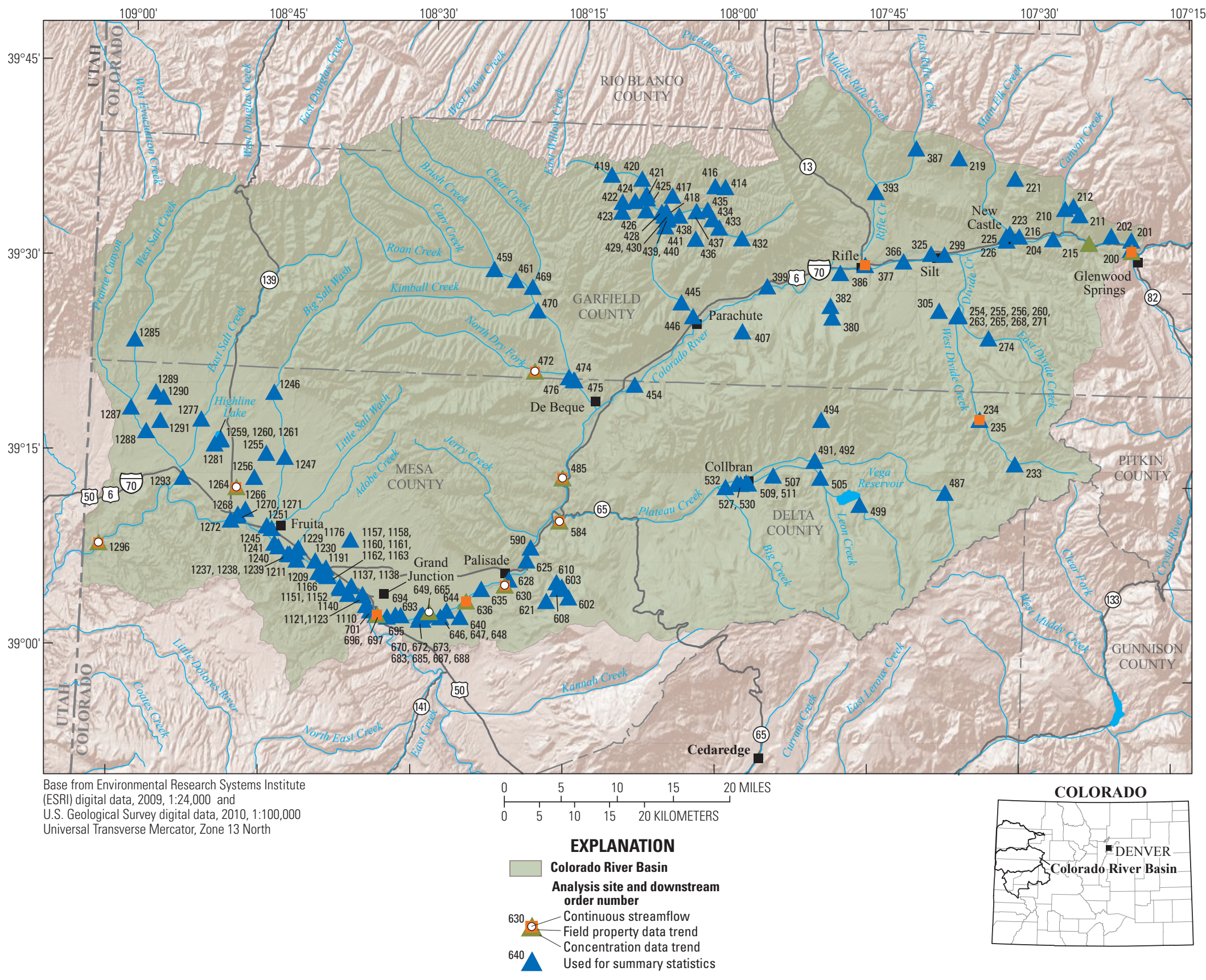

Figure 14. Locations of continuous streamflow, physical parameter data trend, concentration data trend, and summary statistic sites in the Colorado River Basin, western Colorado. 


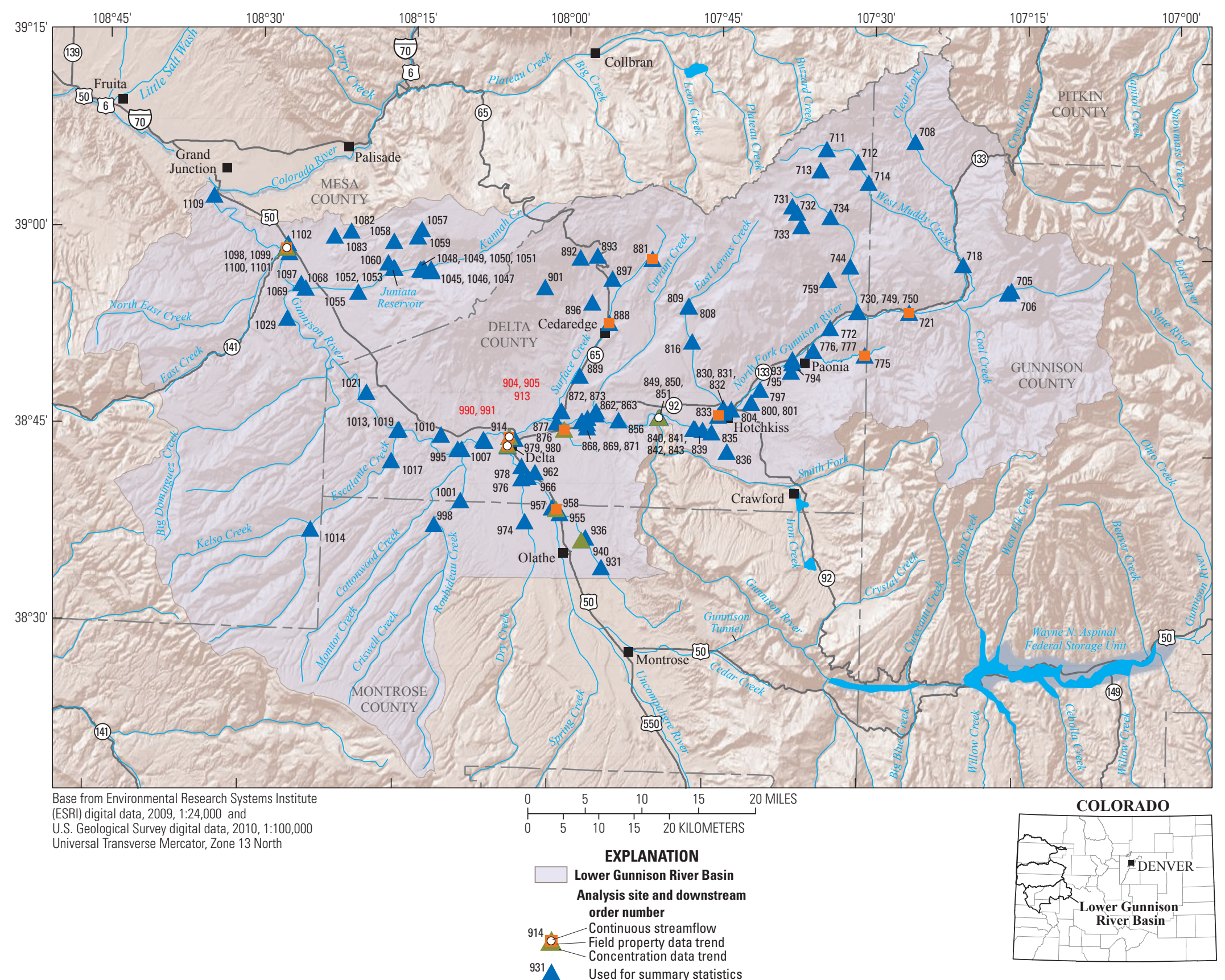

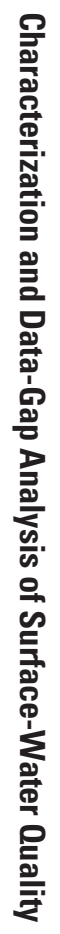

Figure 15. Locations of continuous streamflow, physical parameter data trend, concentration data trend, and summary statistic sites in the Lower Gunnison River Basin, western Colorado. 
Geographic coverage of surface-water-quality sites in the Lower Gunnison River could be enhanced to include more tributaries. The majority of sampling has occurred near Delta, Colo. Additional sampling of tributaries to the Gunnison River could enhance the existing dataset. The only data for Surface Creek and the North Fork of the Gunnison River were field properties. Downstream from Delta, Colo., to the Gunnison River near Grand Junction (09152500), no surface-water quality data were available that could be used for trends or loads. Additional measurement of streamflow at the majority of these sites could greatly enhance the dataset and provide a more complete loading profile for the basin for any constituent sampled.

Analytical data gaps were identified in several constituent groups in the Lower Gunnison River Basin. A total of 84 samples were collected for $E$. coli, and 17 samples exceeded the recommended standard (app. 1). However, insufficient data were available to do any trend analysis of E.coli. Almost 30 percent of the samples for total phosphorus in the basin exceeded the recommended standard (app. 1), yet there were insufficient data to do trend analysis at all but one site (09152500) (table 5). A better understanding of nutrient levels in the Lower Gunnison River Basin will not be possible without additional nutrient sampling in the area. The same data gap exists for trace elements. Only one site, Gunnison River near Grand Junction, had sufficient data for trend analysis in iron. There were exceedances in copper, total recoverable iron, lead, zinc, and selenium, yet data were insufficient to complete a trend analysis or calculate load. Additional sampling is necessary to understand the occurrence, concentrations, and loads of these elements. Continuous streamflow data are necessary to calculate loads for any of the constituents sampled.

\section{Summary}

Northwestern Colorado is experiencing changes in landuse including urbanization, agriculture, and increasing energy development and infrastructure. These land-use changes can result in short- and long-term changes in the water resources in the study area. Ongoing monitoring and assessment are required to periodically reestablish our understanding of baseline conditions and to detect changes. Substantial waterresource datasets, publications, and other materials have been developed in past years and can be used to assess baseline conditions and to evaluate land-use effects. The U.S. Geological Survey (USGS), in cooperation with Federal, State, county and industry partners, developed a Web-accessible common data repository to provide energy operators, researchers, consultants, agencies, and interested stakeholders equal access to historical and current (as of August 2009) water-quality information (available on the Internet at http://rmgsc.cr.usgs.gov/cwqdr/ Piceance/index.shtml).
The following is an alphabetical list of cooperators involved in this study: Antero Resources, Bureau of Land Management, Chevron Corporation, City of Grand Junction, City of Rifle, Colorado Department of Agriculture, Colorado Department of Natural Resources, Colorado Department of Public Health and Environment, Colorado Division of Wildlife-River Watch, Colorado Oil and Gas Conservation Commission, Colorado River Water Conservation District, Delta County, EnCana Oil \& Gas (USA) Inc., Garfield County, Gunnison Energy Corp, National Park Service, Natural Soda, Inc., North Fork River Improvement Association, Oxy Petroleum Corporation, Petroleum Development Corp, Rio Blanco County, Shell Oil Company, Solvay Chemicals, Town of Carbondale, Town of De Beque, Town of Palisade, Town of Parachute, Town of Rangely, Town of Silt, Bureau of Reclamation, U.S. Forest Service, West Divide Water Conservancy District, and Williams Companies, Inc. These data are analyzed to provide a baseline assessment of available water-resource data and aid in the development of regional monitoring strategies.

The Piceance study area is subdivided into three study basin areas: the White River Basin, the Colorado River Basin, and the Lower Gunnison River Basin. The White River Basin is partially defined by the Piceance Structural Basin boundary and begins roughly at the mouth of Coal Creek and extends downstream to the White River at the Colorado-Utah state border. The Colorado River Basin includes the drainage area from Glenwood Springs to the Colorado-Utah state border. The Gunnison River is the largest tributary to the Colorado River in Colorado. The Lower Gunnison River Basin is only a part of the entire Gunnison River Basin. The Lower Gunnison River Basin for this study included the entire drainage area of the North Fork of the Gunnison River and the drainage area beginning slightly downstream from the Gunnison Tunnel on both the Gunnison River and the Uncompahgre River.

The area of the White River Basin is 3,160 $\mathrm{mi}^{2}$. Land use in the White River Basin is affected by oil shale and natural gas development. Conventional and unconventional natural gas extraction and the associated infrastructure are becoming increasingly prevalent in this basin. The area of the Colorado River Basin (study area) is 3,560 $\mathrm{mi}^{2}$, and the area of the drainage area of the Colorado River upstream from the site at the Colorado-Utah state border is $17,843 \mathrm{mi}^{2}$. The economy of the Colorado River Basin is dominated by agriculture, energy development, industry, real estate development, tourism, and recreation. The area of the Lower Gunnison River Basin is $2,700 \mathrm{mi}^{2}$, and the entire drainage area (measured from where the Gunnison River enters the Colorado River) is 7,900 $\mathrm{mi}^{2}$. A primary concern of water managers in the Lower Gunnison River Basin is the presence of salinity and selenium in the surface water as a result of irrigated agriculture. The complex geology, combined with various land-use types such as irrigation and residential development, can influence water-quality conditions in the Lower Gunnison River Basin. 
Data were summarized to identify available data and evaluate temporal and spatial patterns in the Piceance study area. The report contains data summaries, comparison to water-quality standards, trend analysis, a generalized spatial analysis, and a data-gap analysis for select water-quality properties and constituents. Gaps in available data were identified from these analyses and are provided in this report. A repository of available water-quality data was compiled from local, State, and Federal agencies and private entities (consulting firms, energy, and mining companies). The data repository contained 1,433 surface-water sites, 45,008 samples, and $1,144,808$ water-quality results from 1931 to 2009 . A subset of surface-water-quality data from the repository was compiled, reviewed, and checked for quality assurance for this report.

Summary statistics and comparison to standards were provided for 347 sites for 33 constituents including field properties, nutrients, major ions, trace elements, suspended sediment, Escherichia coli, and BTEX (benzene, toluene, ethylbenzene, xylene). Data from the study area were compared to the Colorado Department of Public Health and Environment and U.S. Environmental Protection Agency standards and recommendations to guide interpretation of surface-water quality, evaluate spatial patterns, and obtain a broad understanding of water-quality conditions across the study area. When sufficient data were available, trends over time were analyzed and loads were calculated for those sites where there were also continuous streamflow data.

Summary statistics and water-quality exceedances are discussed by basin to provide a general overview of water quality. The collection of field properties is an important component to all water-quality sampling in order to properly characterize water-quality results. The majority of sites had information on field properties. For the entire study area, 316 sites had temperature data collected between 1959 and 2009. There were 326 values out of a total of 32,006 values in the study area that exceeded the aquatic-life standard for daily maximum water temperature. For the entire study area, 196 sites had dissolved-oxygen data collected between 1970 and 2009. Median dissolved-oxygen concentrations ranged from 6.8 to $11.2 \mathrm{mg} / \mathrm{L}$. There were 185 concentrations that exceeded the dissolved oxygen aquatic-life standard out of a total of 11,248 values in the study area. For the entire study area, 276 sites had $\mathrm{pH}$ data collected between 1958 and 2009. Median $\mathrm{pH}$ values ranged from 7.5 to 9.0. There were 241 values out of a total of 16,307 values that exceeded the high $\mathrm{pH}$ standard in the study area, while there were 7 values that were less than the low $\mathrm{pH}$ standard in the study area. Nutrients within the study area were not well represented in each basin and were often not being sampled currently. For the entire study area, 62 sites had nitrate data collected between 1958 and 2009, and median nitrate concentrations ranged from less than detection to $3.72 \mathrm{mg} / \mathrm{L}$ as nitrogen $(\mathrm{N})$. The maximum contaminate level for domestic water supply for nitrate is $10 \mathrm{mg} / \mathrm{L}$ and was exceeded once in 3,736 samples. Total phosphorus was collected at 113 sites between 1974 and 2009, and median total phosphorus concentrations ranged from less than detection to $5.04 \mathrm{mg} / \mathrm{L}$. The USEPA recommendation for phosphorus is less than $0.1 \mathrm{mg} / \mathrm{L}$, and 1,469 of 4,842 samples exceeded this recommended standard in the study area. Standards for major ions exist only for chloride and sulfate. For the entire study area, 118 sites had chloride and sulfate concentration data collected between 1958 and 2009. Median chloride concentrations ranged from 0.085 to $280 \mathrm{mg} / \mathrm{L}$. There were 120 of the 8,817 chloride concentration samples that exceeded the chloride domestic watersupply standard of $250 \mathrm{mg} / \mathrm{L}$. Median sulfate concentrations ranged from 4.57 to $15,000 \mathrm{mg} / \mathrm{L}$. There were 1,111 of the 8,736 sulfate concentration samples that exceeded the sulfate domestic water-supply standard of $250 \mathrm{mg} / \mathrm{L}$. Trace elements were relatively well represented both temporally and spatially in the study area, though the number of trace element samples per site was not typically enough to compute trends or loads except for selenium. There were 127 sites that had dissolved iron concentration data collected between 1961 and 2009, and median iron concentrations ranged from less than detection to $1,100 \mu \mathrm{g} / \mathrm{L}$. The 30 -day drinking-water standard for iron is $300 \mu \mathrm{g} / \mathrm{L}$, and 203 samples exceeded the standard. Selenium was the best represented trace element with selenium concentration data collected at 197 sites between 1973 and 2009, and median selenium concentrations range from less than detection to $181 \mu \mathrm{g} / \mathrm{L}$. The chronic aquatic-life standard of $4.6 \mu \mathrm{g} / \mathrm{L}$ for selenium concentrations was exceeded in 899 samples, and the acute aquatic-life standard of $18.4 \mu \mathrm{g} / \mathrm{L}$ for selenium was exceeded in 629 samples.

Natural changes in precipitation and streamflow and anthropogenic changes in nutrient sources (such as wastewater treatment facilities, golf courses, urban runoff, agricultural fields, and septic tanks) can influence nutrient concentrations in streams throughout the study area. Upward trends in nitrate and total phosphorus were detected in the White River Basin at 09304200 (White River above Coal Creek near Meeker) from 1990 to 2009 and 1991 to 2009, respectively. Downward trends in DS were detected at 09163500 (Colorado River near Colorado-Utah state line) from 1990 to 2009. Salinity control work in the Colorado River Basin near Grand Junction might have contributed to the downward trend. Field properties such as water temperature, $\mathrm{pH}$, and dissolved oxygen were tested for trends over time. An upward trend in water temperature was detected at the Gunnison River near Grand Junction (09152500). There are limited trace element data except for selenium in the Lower Gunnison River Basin. Concentrations of trace elements, and more specifically selenium, are of concern to water and land managers in the Lower Gunnison River Basin because of the combination of geologic formations and land use. Downward trends in selenium were detected at both main-stem sites, from 1991 to 2009 at 09144250 (Gunnison River at Delta) and from 1990 to 2009 at 09152500 (Gunnison River near Grand Junction). High selenium concentrations correlate with high salinity concentrations; thus, when salinity control efforts are conducted in selenium-rich areas in the Lower Gunnison River Basin, both salinity and selenium have the potential to decrease. 
Spatial, temporal, and analytical data gaps were identified in the study area. No water-quality data exist for tributaries in the area north of Rangely, Colo., where extensive energy development has occurred in a complex geologic setting. The spatial coverage of sampling sites could be expanded in the White River Basin by adding more tributary sites. Douglas Creek has a drainage area of $425 \mathrm{mi}^{2}$, and no water-quality or quantity data are currently being collected at this site. Data in the Colorado River Basin for all constituent groups were limited on the main stem of the Colorado River between Glenwood Springs and Cameo, Colo. Nutrient data were minimally collected upstream from Cameo, Colo., on the main stem of the Colorado River and were minimally collected on the Gunnison River (a major tributary in the reach). Almost 30 percent of the samples for total phosphorus in this Lower Gunnison River Basin exceeded the recommended standard, yet there were insufficient data to do trends analysis in the Lower Gunnison River Basin except at the Gunnison River near Grand Junction site. Only one site had sufficient data for trends analysis in iron (Gunnison River near Grand Junction). Additional sampling is necessary to better understand the occurrence, concentrations, and loads of these elements.

\section{Acknowledgments}

The author wished to express thanks and appreciation to the many agencies that provided data for this report. The author would like to acknowledge Berry Petroleum Company for their contribution to this project, which was undertaken in connection with the settlement of an enforcement action taken by the Colorado Department of Public Health and Environment for violations of the Water Quality Control Act. The author would like to express appreciation to David Lorenz and Alisa Mast for their technical review of the manuscript, which aided in the overall improvement of this report.

\section{References Cited}

Alley, W.M., 1988, Using exogenous variables in testing for monotonic trends in hydrologic time series: Water Resources Research, v. 24, no. 11, p. 1955-1961.

Brooks, T., and Ackerman, D.J., 1985, Reconnaissance of ground-water resources in the Lower Gunnison River Basin, southwestern Colorado: U.S. Geological Survey WaterResources Investigations Report 84-4185, 35 p.

Brune, G.M., 1953, Trap efficiency of reservoirs: American Geophysical Union Transactions, v. 34, no. 3, p. 407-418.

Bureau of Land Management, 2002, Roan Plateau Eligibility Report for the national wild and scenic rivers system: Bureau of Land Management, 28 p., accessed November 8, 2011, at http://www.saveroanplateau.org/documents/ scenicrivers.pdf.
Bureau of Land Management, 2004, Oil and gas potential and reasonable foreseeable development (RFD) scenarios in the Grand Mesa, Uncompahgre, and Gunnison (GMUG) National Forests Colorado: Bureau of Land Management, accessed December 31, 2012, at http://www.fs.fed.us/ outernet/r2/gmug/policy/plan_rev/final/comp_assess/doc2_ Oil_Gas_Potential_RFDS_8-27-04R.pdf.

Bureau of Land Management, 2009, BLM Colorado Statewide Geospatial Database, 1st conflated poly: Bureau of Land Management, Colorado State Office, Geosciences Team, Dave Taylor (ed.).

Bureau of Land Management, 2011a, BLM Colorado's Wild Horse and Burro Program: Bureau of Land Management, accessed November 8, 2011, at http://www.blm.gov/co/st/en/ BLM_Programs/wild_horse_and_burro.html/.

Bureau of Land Management, 2011b, Reasonable foreseeable development scenario for oil and gas activities in the BLM White River Field Office-Rio Blanco, Moffat And Garfield Counties, Colorado: Bureau of Land Management, accessed January 17, 2011, at http://www.blm.gov/ pgdata/etc/medialib/blm/co/programs/land_use_planning/ $\mathrm{rmp} /$ white_river/documents.Par.86610.File.dat/RFD_ Executuve_Sumnmary.pdf.

Bureau of Reclamation, 2009, Colorado River Basin salinity control program - Federal accomplishments report for fiscal year 2009: Bureau of Reclamation, accessed August 13, 2010, at http://www.usbr.gov/uc/progact/salinity/pdfs/ FedAccompRep-2009.pdf.

Bureau of Reclamation, 2011, Colorado River Storage Project-Wayne N. Aspinall Unit: Bureau of Reclamation, accessed November 14, 2011, at http://www.usbr.gov/uc/ feature/crsp/aspinall.html.

Butler, D.L., 1985, Discharge and water quality of springs in Roan and Parachute Creek Basins, northwestern Colorado, 1981-1983: U.S. Geological Survey Water-Resources Investigations Report 85-4078, $150 \mathrm{p}$.

Butler, D.L., and Leib, K.J., 2002, Characterization of selenium in the lower Gunnison River Basin, Colorado, 1988-2000: U.S. Geological Survey Water-Resources Investigations Report 02-4151, 26 p.

Butler, D.L., Wright, W.G., Stewart, K.C., Osmundson, B.C., Krueger, R.P., and Crabtree, D.W., 1996, Detailed study of selenium and other constituents in water, bottom sediment, soil, alfalfa, and biota associated with irrigation drainage in the Uncompahgre Project area and in the Grand Valley, west-central Colorado, 1991-93: U.S. Geological Survey Water-Resources Investigations Report 96-4138, 136 p. 
Chafin, D.T., and Butler, D.L., 2002, Dissolved-solids-load contributions off the Pennsylvanian Eagle Valley Evaporite to the Colorado River, west-central Colorado, in Kirkham, R.M., Scott, R.B., and Judkins, T.W., eds., Late Cenezoic evaporite tectonism and volcanism in west-central Colorado: Geological Society of America Special Paper 366, p. 149-156.

Churchill, M.A., 1948, Analysis and use of reservoir sedimentation data with discussion by L.C. Gottschalk, in Federal Inter-Agency Sedimentation Conference, Denver, Colo., 1947, Proceedings: U.S. Geological Survey, p. 139-140.

Cohn, T.A., 2005, Estimating contaminant loads in rivers-An application of adjusted maximum likelihood to type 1 censored data: Water Resources Research, v. 41, no. 7, 13 p.

Cohn, T.A., Caulder, D.L., Gilroy, E.J., Zynjuk, L.D., and Summers, R.M., 1992, The validity of a simple statistical model for estimating fluvial constituent loads-An empirical study involving nutrient loads entering Chesapeake Bay: Water Resources Research, v. 28, no. 9, p. 2353-2364.

Colorado Department of Public Health and Environment, 2010, Regulation no. 93, Colorado's Section 303(D) List of impaired waters and monitoring and evaluation list: Colorado Department of Public Health and Environment, Water Quality Control Commission, accessed October 14, 2011.

Colorado Department of Public Health and Environment, 2011, Water Quality Control Commission regulationsSurface water quality classifications and standards: Colorado Department of Public Health and Environment, accessed October 25, 2011, at http://www.cdphe.state.co.us/ regulations/wqccregs/.

Colorado Oil and Gas Conservation Commission, 2010, GIS downloads, wells: Colorado Oil and Gas Conservation Commission, accessed January 26, 2010, at http://cogcc.state.co.us/.

Colorado Oil and Gas Conservation Commission, 2011, News and media, Colorado weekly and monthly information: Colorado Oil and Gas Conservation Commission, accessed October 26, 2011, at http://cogcc.state.co.us/.

Dalby, C.E., 2006, Use of regression and time-series methods to estimate a sediment budget for Nevada Creek Reservoir, Montana: Proceedings of the 2006 AWRA Summer Specialty Conference, Adaptive Management of Water Resources, Missoula, Mont., June 26-28, 2006: American Water Resources Association, $10 \mathrm{p}$.

Green, G.N., 1992, The digital geological map of Colorado in Arc/Info format: U.S. Geological Survey Open-File Report 92-0507, scale 1:500,000.

Helsel, D.R., 2005a, Insider censoring-Distortion of data with nondetects: Human and Ecological Risk Assessment, v. 11, p. 1127-1137.
Helsel, D.R., 2005b, Non-detects and data analysis-Statistics for censored environmental data: New Jersey, John Wiley and Sons, Inc., 268 p.

Helsel, D.R., and Hirsch, R.M., 2002, Statistical methods in water resources: U.S. Geological Survey Techniques of Water-Resources Investigation, book 4, chap. A3, 523 p.

Hirsch, R.M., Slack, J.R., and Smith, R.A., 1982, Techniques of trend analysis for monthly water-quality data: Water Resources Research, v. 18, no. 6, p. 107-121.

Hirsch, R.M., Alexander, R.B., and Smith, R.A., 1991, Selection of methods for the detection and estimation of trends in water quality: Water Resources Research, v. 27, no. 5, p. 803-813.

Homer, C., Huang, C., Yang, L., Wylie, B.K., and Coan, M., 2004, Development of a 2001 National Landcover Database for the United States: Photogrammetric Engineering and Remote Sensing, v. 70, no. 7, p. 829-840.

Iorns, W.V., Hembree, C.H., and Oakland, G.L., 1965, Water resources of the Upper Colorado River Basin-Technical report: U.S. Geological Survey Professional Paper 441, $370 \mathrm{p}$.

Johnson, R.C., 1989, Geologic history and hydrocarbon potential of late Cretaceous-age, low permeability reservoirs, Piceance Basin, western Colorado: U.S. Geological Survey Bulletin 1787-E, $51 \mathrm{p}$.

Johnson, R.C., and Flores, R.M., 2003, History of the Piceance Basin from latest Cretaceous through early Eocene and the characterization of lower Tertiary sandstone reservoirs, chap. 3 in Peterson, K.M., Olson, T.M., and Anderson, D.S., eds., Piceance Basin guidebook: Denver, Colo., Rocky Mountain Association of Geologists, p. 21-61.

Kanzer, D., and Merritt, D., 2008, The TDS control story of the Upper Colorado River Basin illustrated by case studies: Adelaide, Australia, 2nd International Salinity Forum, 4 p., available online at $h t t p: / / w w w$ internationalTDSforum. org/14_final.html.

Kendall, M.G., 1975, Rank correlation methods (4th ed.): London, Charles Griffin.

Kenney, T.A., Gerner, S.J., Buto, S.G, and Spangler, L.E., 2009, Spatially referenced statistical assessment of dissolved-solids load sources and transport in streams of the Upper Colorado River Basin: U.S. Geological Survey Scientific Investigations Report 2009-5007, 50 p.

Kuhn, G., and Williams, C.A., 2004, Evaluation of streamflow losses along the Gunnison River from Whitewater downstream to the Redlands Canal Diversion Dam, near Grand Junction, Colorado, water years 1995-2003: U.S. Geological Survey Scientific Investigations Report 2004-5095, $22 \mathrm{p}$. 
Lanfear, K.J., and Alexander, R., 1990, Methodology to derive water-quality trends for use by the National Water Summary Program of the U.S. Geological Survey: U.S. Geological Survey Open-File Report 90-359, 10 p.

Leib, K.J., 2008, Concentrations and loads of selenium in selected tributaries to the Colorado River in the Grand Valley, western Colorado, 2004-2006: U.S. Geological Survey Scientific Investigations Report 2008-5036, 36 p.

Leib, K.J., and Bauch, N.J., 2008, Salinity trends in the Upper Colorado River Basin upstream from the Grand Valley Salinity Control Unit, Colorado, 1986-2003: U.S. Geological Survey Scientific Investigations Report 2007-5288, $21 \mathrm{p}$.

Liebermann, T.D., Mueller, D.K., Kircher, J.E., and Choquette, A.F., 1989, Characteristics and trends of streamflow and dissolved solids in the upper Colorado River Basin, Arizona, Colorado, New Mexico, Utah, and Wyoming: U.S. Geological Survey Water-Supply Paper 2358, 64 p.

Lund, J., and Hunter, G., 2009, A review of the geothermal resources underlying Glenwood Springs, Colorado and of the technologies appropriate for use in their potential development: City of Glenwood Springs Geothermal Task Force, $87 \mathrm{p}$.

Mann, H.B., 1945, Non-parametric test against trend: Econometrica, v. 13, p. 245-259.

Mayo, J.W., 2008, Estimating the effects of conversion of agricultural land to urban land on deep percolation of irrigation water in the Grand Valley, western Colorado: U.S. Geological Survey Scientific Investigations Report 2008-5086, $58 \mathrm{p}$.

Mayo, J.W., and Leib, K.J., 2012, Flow-adjusted trends in dissolved selenium load and concentration in the Gunnison and Colorado Rivers near Grand Junction, Colorado, water years 1986-2008: U.S. Geological Survey Scientific Investigations Report 2012-5088, 33 p.

Moore, J.L., 2011, Effects of land use change on salinity and selenium loading in Montrose Arroyo, western Colorado, from 1992 to 2010: U.S. Geological Survey Scientific Investigations Report 2011-5106.

Mueller, D.K., and Osen, L.L., 1988, Estimation of natural dissolved-solids discharge in the Upper Colorado River Basin, Western United States: U.S. Geological Survey Water-Resources Investigations Report 87-4069, 62 p.

Myers, R.H., 1986, Classical and modern regression with applications: Boston, Mass., Duxbury Press.

Nelson, P.H., and Santus, S.L., 2010, Gas, water, and oil production from Grand Valley, Parachute, Rulison, and Mamm Creek fields in the Piceance Basin, Colorado: U.S. Geological Survey Open-File Report 2010-1110, 28 p.

Ortiz, R.F., 2002, Baseline characterization of water quality and mass loading in Piceance Creek, Rio Blanco County, Colorado, December 2000: U.S. Geological Survey WaterResources Investigations Report 02-4134, 29 p.
Ortiz, R.F., 2005, Characterization of water quality in Government Highline Canal at Camp 7 Diversion and Highline Lake, Mesa County, Colorado, July 2000 through September 2003: U.S. Geological Survey Scientific Investigations Report 2004-5281, 30 p.

Papadopulos \& Associates, Inc., 2008, Phase II hydrogeologic characterization of the Mamm Creek Field area, Garfield County, Colorado: Prepared for the Board of County Commissioners, Garfield County, Colorado, 41 p.

Paschke, S.P., Schaffrath, K.R., and Mashburn, S.L., 2008, Near-decadal changes in nitrate and pesticide concentrations in the South Platte River alluvial aquifer, 1993-2004: Journal of Environmental Quality, v. 37, p. S281-S295.

Prairie, J.R., Rajagopalan, B., Fulp, T.J., and Zagona, E.A., 2005, Statistical nonparametric model for natural salt estimation: Journal of Environmental Engineering, v. 131, no. 1, p. 130-138.

Puckett, L.J, 1994, Nonpoint and point sources of nitrogen in major watersheds in the United States: U.S. Geological Survey Water-Resources Investigations Report 94-4001, 12 p.

Reinecke, K.M., Rice, D.D. and Johnson, R.C., 1991, Characteristics and development of fluvial sandstone and coalbed reservoirs of Upper Cretaceous Mesaverde Group, Grand Valley field, Colorado, in Schwochow, S.D., Murray, D.K., and Fahy, M.F., eds., Coalbed methane of western North America: Rocky Mountain Association of Geologists 1991 Guidebook, p. 209-225.

Runkel, R.L., Crawford, C.G., and Cohn, T.A., 2004, Load Estimator (LOADEST) - A FORTRAN program for estimating constituent loads in streams and rivers: U.S. Geological Survey Techniques of Water-Resources Investigations, book 4, chap. A5, 69 p.

Salas, J.D., and Shin, H., 1999, Uncertainty analysis of reservoir sedimentation: Journal of Hydraulic Engineering, v. 125 , no. 4, p. 339-350.

Schaffrath, K.R., 2012, Surface-water salinity in the Gunnison River Basin, Colorado, 1989 through 2007: U.S. Geological Survey Scientific Investigations Report 2012-5128, 82 p.

Schertz, T.L., Alexander, R.B., and Ohe, D.J., 1991, The computer program Estimate Trend (ESTREND), a system for the detection of trends in water-quality data: U.S. Geological Survey Water Resources Investigations Report 91-4040, $72 \mathrm{p}$. (Also available at http://water.usgs.gov/pubs/wri/ wri91-4040/).

Sen, P.K., 1968, Estimates of the regression coefficient based on Kendall's tau: Journal of the American Statistical Association, v. 63, no. 325, p. 1379-1389.

Sprague, L.A., Muller, D.K., Schwarz, G.E., and Lorenz, D.L., 2009, Regional nutrient trends in streams and rivers of the United States, 1993-2003: U.S. Geological Survey Scientific Investigations Report 2008-5202, 196 p. 
Techni Graphics Systems, Inc., 2004, Colorado Decision Support Systems, http://cdss.state.co.us/DNN/GIS/tabid/67/ Default.aspx, accessed September 28, 2010.

Thomas, J.C., Leib, K.J., Mayo, J.W., 2008, Analysis of dissolved selenium loading for selected sites in the Lower Gunnison River Basin, Colorado, 1978-2005: U.S. Geological Survey Scientific Investigations Report 2007-5287, 25 p.

TIBCO Software, Inc., 1998-2008, TIBCO Spotfire S+ Release 8.1 for Windows: TIBCO Software Inc.

Tobin, R.L., Stranathan, H.E., Covay, K.J., 1985, Waterquality characteristics of streams in the Piceance Creek and Yellow Creek drainage basins, northwestern Colorado, water years 1977-81: U.S. Geological Survey WaterResources Investigations Report 84-4261, 78 p.

Tobin, R.L., 1993, Sediment transport and water-quality characteristics and loads, White River, northwestern Colorado, water years 1975-88: U.S. Geological Survey WaterResources Investigations Report 92-4031, 68 p.

Tweto, Ogden, comp., 1979, Geologic map of Colorado: U.S. Geological Survey State Geologic Map, scale 1:500,000 (reprinted).

U.S. Census Bureau, 2011, Population estimates: U.S. Census Bureau, accessed October 6, 2011, at http://www.census.gov/ popest/cities/files/SUB-EST2009_8.csv.

U.S. Energy Information Administration, 2011, Rifle mills (old and new) mill sites: U.S. Energy Information Administration, Nuclear and Uranium, accessed October 24, 2011, at http://205.254.135.24/cneaf/nuclear/page/umtra/rifle_mills_ title1.html.

U.S. Environmental Protection Agency, 2000, Nutrient criteria technical guidance manual-River and streams, 2000: U.S. Environmental Protection Agency Report 822B-00-002.
U.S. Fish and Wildlife Services, 2011, Fish and aquatic species: U.S. Fish and Wildlife Service, accessed October 10, 2011, at http://www.fws.gov/mountain-prairie/fisheries/fish.htm.

U.S. Geological Survey, 2011, User's manual for the National Water Information System of the U.S. Geological Survey-Water-quality system, version 4.11: U.S. Geological Survey, accessed November 15, 2010, at http://nwis.usgs.gov/currentdocs/qw/QW.user.book.html.

U.S. Geological Survey Oil Shale Assessment Team, 2010, Oil shale and nahcolite resources of the Piceance Basin, Colorado: U.S. Geological Survey Digital Data Series DDS-69-Y, 7 chapters, pages variable.

Vaill, J.E., and Butler, D.L., 1999, Streamflow and dissolvedsolids trends, through 1996, in the Colorado River Basin upstream from Lake Powell - Colorado, Utah, and Wyoming: U.S. Geological Survey Water-Resources Investigations Report 99-4097, 47 p.

Weeks, J.B., Leavesley, G.H., Welder, F.A., and Saulnier, G.J., Jr., 1975, Simulated effects of oil-shale development on the hydrology of Piceance Basin, Colorado: U.S. Geological Survey Professional Paper 908, 84 p.

Western Regional Climate Center, 2012, Colorado climate summaries: Western Regional Climate Center, accessed December 31, 2011, at http://www.wrcc.dri.edu/summary/ climsmco.html.

Wright, W.G., and Butler, D.L., 1993, Distribution and mobilization of dissolved selenium in ground water of the irrigated Grand and Uncompahgre Valleys, western Colorado, in Allen, R.G., and Neale, C.M.U., eds., Management of irrigation and drainage systems - Integrated perspectives. Proceedings of the 1993 National Conference on Irrigation and Drainage Engineering, Park City, Utah, July 21-23, 1993: American Society of Civil Engineers, p. 770-777. 

Appendixes 

Appendix 1. Summary of surface-water-quality data and comparison to water-quality standards by site, by constituent, Piceance study area, western Colorado. Water-quality standards comparisons follow data summaries and are in blue text; standards are provided in table 3.

[CDPHE segment, Colorado Department of Health and the Environment stream segment as referred to in tables 2 and 3; latitude and longitude are in North American Datum of 1983; downstream order number assigned as part of analysis. $\mu \mathrm{g} / \mathrm{L}$, micrograms per liter; $\mu \mathrm{S} / \mathrm{cm}$, microsiemens per centimeter; $\mathrm{mg} / \mathrm{L}$, milligrams per liter; mL, milliliters; aq, aquatic; CO, Colorado; EPA, U.S. Environmental Protection Agency; Max, maximum; Min, minimum; NA, not applicable; No., number; NTU, nephelometric turbitidy units; WS, water supply; dates given in month/day/year format]

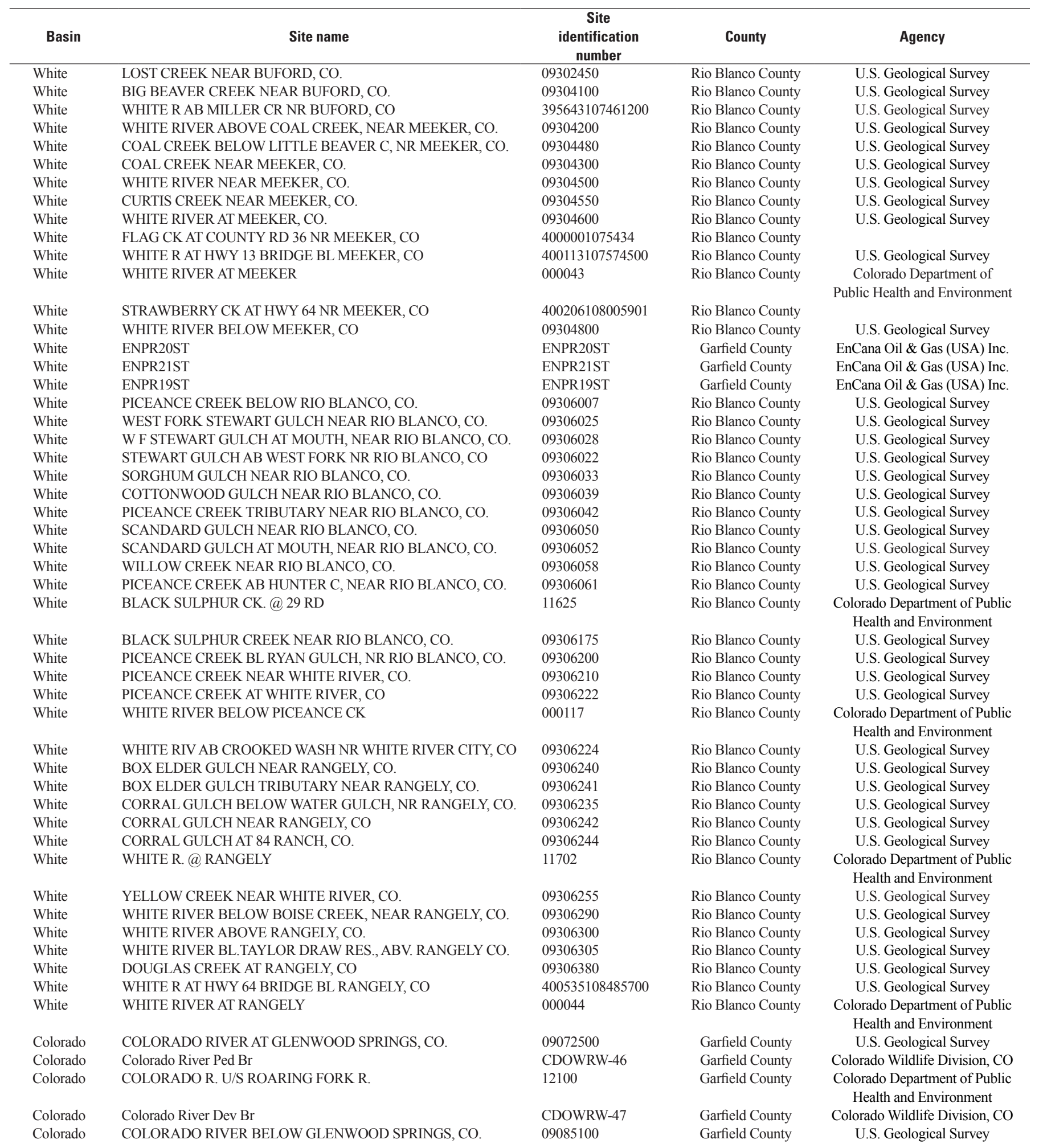


Appendix 1. Summary of surface-water-quality data and comparison to water-quality standards by site, by constituent, Piceance study area, western Colorado. Water-quality standards comparisons follow data summaries and are in blue text; standards are provided in table 3.-Continued

[CDPHE segment, Colorado Department of Health and the Environment stream segment as referred to in tables 2 and 3; latitude and longitude are in North American Datum of 1983; downstream order number assigned as part of analysis. $\mu \mathrm{g} / \mathrm{L}$, micrograms per liter; $\mu \mathrm{S} / \mathrm{cm}$, microsiemens per centimeter; $\mathrm{mg} / \mathrm{L}$, milligrams per liter; mL, milliliters; aq, aquatic; CO, Colorado; EPA, U.S. Environmental Protection Agency; Max, maximum; Min, minimum; NA, not applicable; No., number; NTU, nephelometric turbitidy units; WS, water supply; dates given in month/day/year format]

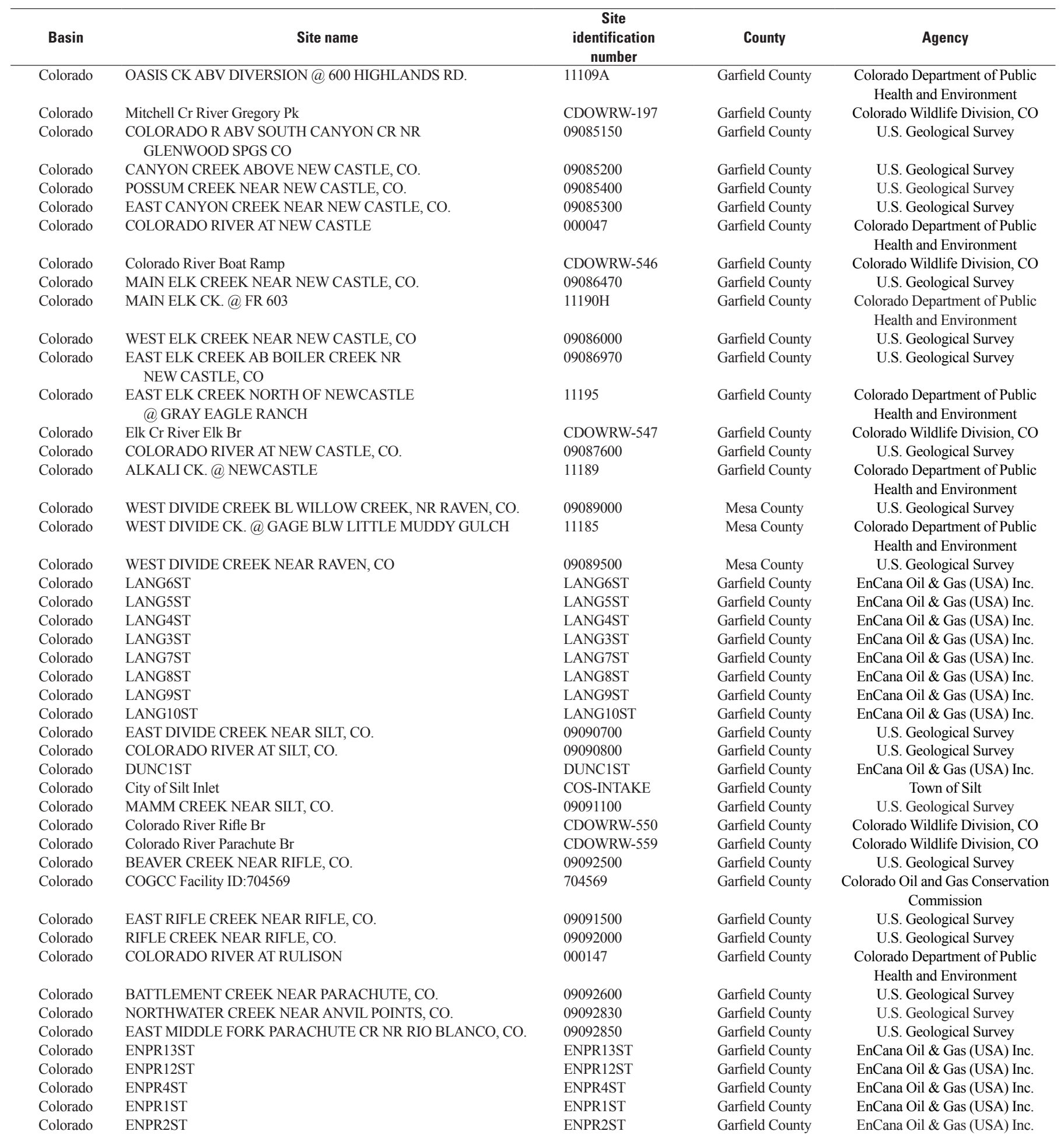


Appendix 1. Summary of surface-water-quality data and comparison to water-quality standards by site, by constituent, Piceance study area, western Colorado. Water-quality standards comparisons follow data summaries and are in blue text; standards are provided in table 3.-Continued

[CDPHE segment, Colorado Department of Health and the Environment stream segment as referred to in tables 2 and 3; latitude and longitude are in North American Datum of 1983; downstream order number assigned as part of analysis. $\mu \mathrm{g} / \mathrm{L}$, micrograms per liter; $\mu \mathrm{S} / \mathrm{cm}$, microsiemens per centimeter; mg/L, milligrams per liter; mL, milliliters; aq, aquatic; CO, Colorado; EPA, U.S. Environmental Protection Agency; Max, maximum; Min, minimum; NA, not applicable; No., number; NTU, nephelometric turbitidy units; WS, water supply; dates given in month/day/year format]

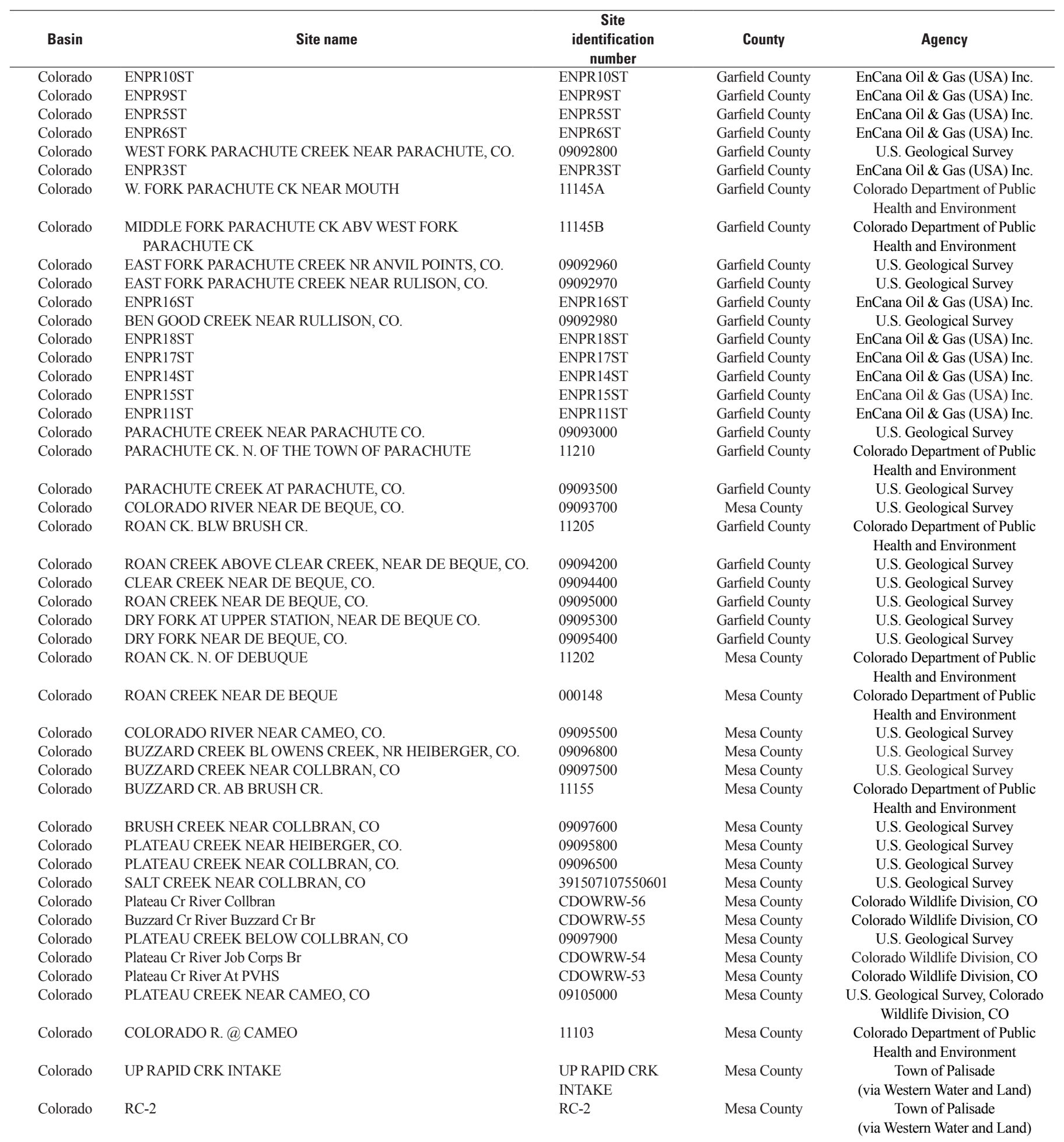


Appendix 1. Summary of surface-water-quality data and comparison to water-quality standards by site, by constituent, Piceance study area, western Colorado. Water-quality standards comparisons follow data summaries and are in blue text; standards are provided in table 3.-Continued

[CDPHE segment, Colorado Department of Health and the Environment stream segment as referred to in tables 2 and 3; latitude and longitude are in North American Datum of 1983; downstream order number assigned as part of analysis. $\mu \mathrm{g} / \mathrm{L}$, micrograms per liter; $\mu \mathrm{S} / \mathrm{cm}$, microsiemens per centimeter; $\mathrm{mg} / \mathrm{L}$, milligrams per liter; mL, milliliters; aq, aquatic; CO, Colorado; EPA, U.S. Environmental Protection Agency; Max, maximum; Min, minimum; NA, not applicable; No., number; NTU, nephelometric turbitidy units; WS, water supply; dates given in month/day/year format]

\begin{tabular}{|c|c|c|c|c|}
\hline Basin & Site name & $\begin{array}{c}\text { Site } \\
\text { identification } \\
\text { number }\end{array}$ & County & Agency \\
\hline Colorado & $\mathrm{RC}-3$ & $\mathrm{RC}-3$ & Mesa County & $\begin{array}{c}\text { Town of Palisade } \\
\text { (via Western Water and Land) }\end{array}$ \\
\hline Colorado & LOWER RAPID CRK & LOWER RAPID CRK & Mesa County & $\begin{array}{c}\text { Town of Palisade } \\
\text { (via Western Water and Land) }\end{array}$ \\
\hline Colorado & L COTTONWOOD INTAKE & $\begin{array}{l}\text { L COTTONWOOD } \\
\text { INTAKE }\end{array}$ & Mesa County & $\begin{array}{c}\text { Town of Palisade } \\
\text { (via Western Water and Land) }\end{array}$ \\
\hline Colorado & $\begin{array}{l}\text { COTTONWOOD CREEK NEAR MOUTH NORTH } \\
\text { OF PALISADE }\end{array}$ & 11151 & Mesa County & $\begin{array}{l}\text { Colorado Department of Public } \\
\text { Health and Environment }\end{array}$ \\
\hline Colorado & COLORADO RIVER AT PALISADE, CO & 390622108205400 & Mesa County & U.S. Geological Survey \\
\hline Colorado & $\begin{array}{l}\text { COLO RIVER BELOW GRAND VALLEY DIV NR } \\
\text { PALISADE, CO }\end{array}$ & 09106150 & Mesa County & U.S. Geological Survey \\
\hline Colorado & Colorado River PHS & CDOWRW-553 & Mesa County & Colorado Wildlife Division, CO \\
\hline Colorado & Colorado River Hwy 6 & CDOWRW-555 & Mesa County & Colorado Wildlife Division, CO \\
\hline Colorado & DRAIN, C 1/2 AND 33 3/4 ROADS, CEN.ORCHARD MESA & 390322108253401 & Mesa County & U.S. Geological Survey \\
\hline Colorado & DRAIN AT D AND 32 1/2 ROADS, NEAR CLIFTON & 390348108265601 & Mesa County & U.S. Geological Survey \\
\hline Colorado & Colorado River Corn Lake & CDOWRW-556 & Mesa County & Colorado Wildlife Division, CO \\
\hline Colorado & COLORADO RIVER AT CLIFTON & 390319108273200 & Mesa County & U.S. Geological Survey \\
\hline Colorado & COLORADO RIVER AT 32 ROAD NEAR CLIFTON, CO & 390318108273200 & Mesa County & U.S. Geological Survey \\
\hline Colorado & Colorado River BMS & CDOWRW-557 & Mesa County & Colorado Wildlife Division, CO \\
\hline Colorado & LEWIS WASH NEAR GRAND JUNCTION, CO. & 09106200 & Mesa County & U.S. Geological Survey \\
\hline Colorado & $\begin{array}{l}\text { HUMPHREY BACKWATER, SITE 2,POOL ABOVE } \\
\text { CRWA OUTLET }\end{array}$ & 390324108291301 & Mesa County & U.S. Geological Survey \\
\hline Colorado & COLORADO R.WILDLIFE AREA, WEST POOL OUTLET & 390326108291601 & Mesa County & U.S. Geological Survey \\
\hline Colorado & HUMPHREY BACKWATER BELOW CRWA.OUTLET & 390323108291601 & Mesa County & U.S. Geological Survey \\
\hline Colorado & THE “OM4” DRAIN AT MOUTH AT OMWA (SITE GF6) & 390303108291601 & Mesa County & U.S. Geological Survey \\
\hline Colorado & HUMPHREY BACKWATER,SITE 4,LOWER CHANNEL & 390322108292301 & Mesa County & U.S. Geological Survey \\
\hline Colorado & HUMPHREY BACKWATER BELOW DRAIN GJ3 & 390318108293301 & Mesa County & U.S. Geological Survey \\
\hline Colorado & WEST GULLY AT MOUTH (GF5), O.M.WILDLIFE AREA & 390302108293801 & Mesa County & U.S. Geological Survey \\
\hline Colorado & DRAIN AT C $1 / 2$ AND 28 1/2 ROADS & 390319108312501 & Mesa County & U.S. Geological Survey \\
\hline Colorado & INDIAN WASH AT C 1/2 ROAD & 390320108315901 & Mesa County & U.S. Geological Survey \\
\hline Colorado & Colorado River Knights & CDOWRW-558 & Mesa County & Colorado Wildlife Division, CO \\
\hline Colorado & Colorado River Watson & CDOWRW-560 & Mesa County & Colorado Wildlife Division, CO \\
\hline Colorado & COLORADO RIVER AT GRAND JUNCTION, CO & 09106500 & Mesa County & U.S. Geological Survey \\
\hline Colorado & COLORADO RIVER ABOVE GUNNISON RIVER & 390337108342800 & Mesa County & U.S. Geological Survey \\
\hline Colorado & Colorado River Grand Br & CDOWRW-563 & Mesa County & Colorado Wildlife Division, CO \\
\hline Colorado & INDIAN WASH NEAR MOUTH & $11135 \mathrm{~A}$ & Mesa County & $\begin{array}{l}\text { Colorado Department of Public } \\
\text { Health and Environment }\end{array}$ \\
\hline Colorado & Colorado River $25 \mathrm{Rd}$ & CDOWRW-749 & Mesa County & Colorado Wildlife Division, CO \\
\hline Colorado & LEACH CREEK AT DURHAM, CO. & 09152650 & Mesa County & U.S. Geological Survey \\
\hline Colorado & LEACH CREEK NEAR MOUTH & 11135 & Mesa County & $\begin{array}{l}\text { Colorado Department of Public } \\
\text { Health and Environment }\end{array}$ \\
\hline Colorado & $\begin{array}{l}\text { DUKE POND AT OUTLET CHANNEL, CONNECTED } \\
\text { LAKES PARK }\end{array}$ & 390449108364101 & Mesa County & U.S. Geological Survey \\
\hline Colorado & DRAIN ALONG REDLANDS PARKWAY, AT MOUTH & 390514108373201 & Mesa County & U.S. Geological Survey \\
\hline Colorado & $\begin{array}{l}\text { COLORADO R. AT REDLANDS PARKWAY NR } \\
\text { GRAND JCT., CO }\end{array}$ & 390521108373300 & Mesa County & U.S. Geological Survey \\
\hline Colorado & COLORADO R.DIVERSION AT WALTER WALKER SWA & 390607108384201 & Mesa County & U.S. Geological Survey \\
\hline Colorado & WALKER SWA CHANNEL, SEEPAGE SITE WWC1-SW & 390609108384701 & Mesa County & U.S. Geological Survey \\
\hline Colorado & WALKER SWA CHANNEL,SEEPAGE SITE WC4B (X-S WW6) & 390613108385603 & Mesa County & U.S. Geological Survey \\
\hline Colorado & WALKER SWA CHANNEL, SEEPAGE SITE WWC11- SW & 390625108390402 & Mesa County & U.S. Geological Survey \\
\hline Colorado & WALKER SWA CHANNEL, SEEPAGE SITE WWC10 (SW) & 390617108391001 & Mesa County & U.S. Geological Survey \\
\hline Colorado & WALKER SWA,CHANNEL OUTFLOW NR BOR GAGE & 390632108392101 & Mesa County & U.S. Geological Survey \\
\hline Colorado & $\begin{array}{l}\text { EAST DRAIN NR MOUTH, PANORAMA } \\
\text { BOTTOMLANDS AREA }\end{array}$ & 390624108394701 & Mesa County & U.S. Geological Survey \\
\hline Colorado & PERSIGO WASH AT J ROAD & 390859108364101 & Mesa County & U.S. Geological Survey \\
\hline Colorado & PERSIGO WASH AT RIVER ROAD & 390645108390101 & Mesa County & U.S. Geological Survey \\
\hline Colorado & HUNTER WASH AT RIVER ROAD & 390717108400501 & Mesa County & U.S. Geological Survey \\
\hline
\end{tabular}


Appendix 1. Summary of surface-water-quality data and comparison to water-quality standards by site, by constituent, Piceance study area, western Colorado. Water-quality standards comparisons follow data summaries and are in blue text; standards are provided in table 3.-Continued

[CDPHE segment, Colorado Department of Health and the Environment stream segment as referred to in tables 2 and 3; latitude and longitude are in North American Datum of 1983; downstream order number assigned as part of analysis. $\mu \mathrm{g} / \mathrm{L}$, micrograms per liter; $\mu \mathrm{S} / \mathrm{cm}$, microsiemens per centimeter; $\mathrm{mg} / \mathrm{L}$, milligrams per liter; mL, milliliters; aq, aquatic; CO, Colorado; EPA, U.S. Environmental Protection Agency; Max, maximum; Min, minimum; NA, not applicable; No., number; NTU, nephelometric turbitidy units; WS, water supply; dates given in month/day/year format]

\begin{tabular}{|c|c|c|c|c|}
\hline Basin & Site name & $\begin{array}{c}\text { Site } \\
\text { identification } \\
\text { number }\end{array}$ & County & Agency \\
\hline Colorado & BACKWATER SITE AT FORRESTERS,EAST OF 19 ROAD & 390718108415701 & Mesa County & U.S. Geological Survey \\
\hline Colorado & ADOBE CREEK NEAR FRUITA, CO. & 09152900 & Mesa County & U.S. Geological Survey \\
\hline Colorado & ADOBE CREEK NEAR MOUTH & 11133 & Mesa County & $\begin{array}{c}\text { Colorado Department of Public } \\
\text { Health and Environment }\end{array}$ \\
\hline Colorado & $\begin{array}{l}\text { SECONDARY CHANNEL ABOVE ADOBE C., } \\
\text { ADOBE BOTTOMLAND }\end{array}$ & 390741108424001 & Mesa County & U.S. Geological Survey \\
\hline Colorado & ADOBE CR.AT MOUTH, ADOBE CR.BOTTOMLANDS AREA & 390741108424301 & Mesa County & U.S. Geological Survey \\
\hline Colorado & $\begin{array}{l}\text { SECONDARY CHANNEL BLW ADOBE CR., } \\
\text { ADOBE BOTTOMLAND }\end{array}$ & 390741108425301 & Mesa County & U.S. Geological Survey \\
\hline Colorado & COLORADO RIVER NEAR FRUITA, CO. & 09153000 & Mesa County & U.S. Geological Survey \\
\hline Colorado & COLORADO RIVER NEAR FRUITA & 000049 & Mesa County & $\begin{array}{c}\text { Colorado Department of Public } \\
\text { Health and Environment }\end{array}$ \\
\hline Colorado & LITTLE SALT WASH AT HWY 50, AT FRUITA & 390938108443101 & Mesa County & U.S. Geological Survey \\
\hline Colorado & BIG SALT CK BELOW RUBY LEE RES. & 11110 & Mesa County & $\begin{array}{l}\text { Colorado Department of Public } \\
\text { Health and Environment }\end{array}$ \\
\hline Colorado & BIG SALT WASH AT GOVT.HIGHLINE CANAL & 391509108433001 & Mesa County & U.S. Geological Survey \\
\hline Colorado & BIG SALT WASH AT FRUITA, CO. & 09153270 & Mesa County & U.S. Geological Survey \\
\hline Colorado & GOVERNMENT HIGHLINE CAAT 16 ROAD, NR LOMA, CO. & 09095526 & Mesa County & U.S. Geological Survey \\
\hline Colorado & KIEFER EXTENSION GRAND VALLEY CA NR FRUITA, CO. & 09106104 & Mesa County & U.S. Geological Survey \\
\hline Colorado & CAMP NO. 7 SPILLWAY NEAR MACK, CO. & 09095529 & Mesa County & U.S. Geological Survey \\
\hline Colorado & GOVT HIGHLINE CAAB CAMP \#7 SPILL, NR MACK, CO. & 090955285 & Mesa County & U.S. Geological Survey \\
\hline Colorado & LATERAL NO. 48 NEAR MACK, CO. & 09095528 & Mesa County & U.S. Geological Survey \\
\hline Colorado & REED WASH NEAR MACK, CO. & 09153290 & Mesa County & U.S. Geological Survey \\
\hline Colorado & REED WASH NEAR LOMA, CO. & 09153300 & Mesa County & U.S. Geological Survey \\
\hline Colorado & LOMA DRAIN AT MOUTH & 391038108475601 & Mesa County & U.S. Geological Survey \\
\hline Colorado & COLORADOR.@LOMA & 000050 & Mesa County & $\begin{array}{l}\text { Colorado Department of Public } \\
\text { Health and Environment }\end{array}$ \\
\hline Colorado & REED WASH NEAR FRUITA, CO. & 391029108480200 & Mesa County & U.S. Geological Survey \\
\hline Colorado & COLORADOR.@HORSETHIEF SWA & 11101 & Mesa County & $\begin{array}{l}\text { Colorado Department of Public } \\
\text { Health and Environment }\end{array}$ \\
\hline Colorado & EAST SALT CREEK NEAR MACK, CO. & 09163310 & Mesa County & U.S. Geological Survey \\
\hline Colorado & MACK WASH NEAR MACK, CO. & 09163340 & Mesa County & U.S. Geological Survey \\
\hline Colorado & WEST SALT CREEK NEAR CARBONERA, CO. & 09153330 & Garfield County & U.S. Geological Survey \\
\hline Colorado & WEST SALT CREEK NEAR MACK, CO. & 09153400 & Mesa County & U.S. Geological Survey \\
\hline Colorado & WEST SALT CREEK NEAR S ROAD & 391646108572301 & Mesa County & U.S. Geological Survey \\
\hline Colorado & BADGER WASH OBSERVATION RES 2-A NEAR MACK, CO. & 09161000 & Mesa County & U.S. Geological Survey \\
\hline Colorado & BADGER WASH OBSERVATION RES 12 NEAR MACK, CO. & 09160500 & Mesa County & U.S. Geological Survey \\
\hline Colorado & BADGER WASH NEAR MACK, CO. & 09163050 & Mesa County & U.S. Geological Survey \\
\hline Colorado & SALT CREEK NEAR MACK, CO. & 09163490 & Mesa County & U.S. Geological Survey \\
\hline Colorado & COLORADO RIVER NEAR COLORADO-UTAH STATE LINE & 09163500 & Mesa County & U.S. Geological Survey \\
\hline Lower Gunnison & ANTHRACITE CK ABV ERICKSON SPRINGS CG & 10485 & Gunnison County & $\begin{array}{l}\text { Colorado Department of Public } \\
\text { Health and Environment }\end{array}$ \\
\hline Lower Gunnison & ANTHRACITE CREEK NEAR SOMERSET, CO. & 09132050 & Gunnison County & U.S. Geological Survey \\
\hline Lower Gunnison & CLEAR FORK NEAR RAGGED MOUNTAIN, CO. & 09129800 & Gunnison County & U.S. Geological Survey \\
\hline Lower Gunnison & WEST MUDDY CREEK NEAR RAGGED MOUNTAIN, CO. & 09130600 & Delta County & U.S. Geological Survey \\
\hline Lower Gunnison & WEST MUDDY CREEK NEAR BOWIE, CO. & 09130800 & Delta County & U.S. Geological Survey \\
\hline Lower Gunnison & COW CREEK NEAR PAONIA, CO. & 09131100 & Delta County & U.S. Geological Survey \\
\hline Lower Gunnison & WEST MUDDY CREEK NEAR SOMERSET, CO. & 09131200 & Delta County & U.S. Geological Survey \\
\hline Lower Gunnison & MUDDY CK ABV PAONIA RESERVOIR & 10490 & Gunnison County & $\begin{array}{l}\text { Colorado Department of Public } \\
\text { Health and Environment }\end{array}$ \\
\hline Lower Gunnison & NORTH FORK GUNNISON RIVER NEAR SOMERSET, CO. & 09132500 & Gunnison County & U.S. Geological Survey \\
\hline Lower Gunnison & NORTH FORK GUNNISON RIVER NEAR BOWIE & 000152 & Delta County & $\begin{array}{l}\text { Colorado Department of Public } \\
\text { Health and Environment }\end{array}$ \\
\hline Lower Gunnison & MAIN HUBBARD CREEK NEAR PAONIA, CO. & 09132700 & Delta County & U.S. Geological Survey \\
\hline Lower Gunnison & MIDDLE HUBBARD CREEK NEAR PAONIA, CO. & 09132800 & Delta County & U.S. Geological Survey \\
\hline Lower Gunnison & WEST HUBBARD CREEK NEAR PAONIA, CO. & 09132900 & Delta County & U.S. Geological Survey \\
\hline Lower Gunnison & HUBBARD CREEK NEAR BOWIE, CO. & 09132920 & Delta County & U.S. Geological Survey \\
\hline
\end{tabular}


Appendix 1. Summary of surface-water-quality data and comparison to water-quality standards by site, by constituent, Piceance study area, western Colorado. Water-quality standards comparisons follow data summaries and are in blue text; standards are provided in table 3.-Continued

[CDPHE segment, Colorado Department of Health and the Environment stream segment as referred to in tables 2 and 3; latitude and longitude are in North American Datum of 1983; downstream order number assigned as part of analysis. $\mu \mathrm{g} / \mathrm{L}$, micrograms per liter; $\mu \mathrm{S} / \mathrm{cm}$, microsiemens per centimeter; $\mathrm{mg} / \mathrm{L}$, milligrams per liter; mL, milliliters; aq, aquatic; CO, Colorado; EPA, U.S. Environmental Protection Agency; Max, maximum; Min, minimum; NA, not applicable; No., number; NTU, nephelometric turbitidy units; WS, water supply; dates given in month/day/year format]

\begin{tabular}{|c|c|c|c|c|}
\hline Basin & Site name & $\begin{array}{c}\text { Site } \\
\text { identification } \\
\text { number }\end{array}$ & County & Agency \\
\hline Lower Gunnison & $\begin{array}{l}\text { HUBBARD CREEK ABOVE IRON POINT GULCH NR } \\
\text { BOWIE, CO }\end{array}$ & 09132940 & Delta County & U.S. Geological Survey \\
\hline Lower Gunnison & $\begin{array}{l}\text { HUBBARD CREEK AT HIGHWAY } 133 \text { AT MOUTH NR } \\
\text { BOWIE, CO }\end{array}$ & 09132960 & Delta County & U.S. Geological Survey \\
\hline Lower Gunnison & TERROR CREEK AT MOUTH NEAR BOWIE, CO & 09132995 & Delta County & U.S. Geological Survey \\
\hline Lower Gunnison & MINNESOTA CREEK NEAR PAONIA, CO. & 09134000 & Delta County & U.S. Geological Survey \\
\hline Lower Gunnison & MINNESOTA CK NEAR MOUTH AT 41.10 DR BRIDGE & 10436 & Delta County & $\begin{array}{l}\text { Colorado Department of Public } \\
\text { Health and Environment }\end{array}$ \\
\hline Lower Gunnison & MINNESOTA CREEK AT PAONIA, CO. & 09134050 & Delta County & U.S. Geological Survey \\
\hline Lower Gunnison & ROATCAP CREEK AT HIGHWAY 133, NR MOUTH & 385144107371701 & Delta County & \\
\hline Lower Gunnison & NORTH FORK GUNNISON RIVER BELOW PAONIA, CO & 09134100 & Delta County & U.S. Geological Survey \\
\hline Lower Gunnison & SMITH FK BLW CRAWFORD & 10212 & Delta County & $\begin{array}{l}\text { Colorado Department of Public } \\
\text { Health and Environment }\end{array}$ \\
\hline Lower Gunnison & $\begin{array}{l}\text { SHORT DRAW WEST OF CTY FAIRGROUNDS, } \\
\text { AT HOTCHKISS }\end{array}$ & 384747107430501 & Delta County & U.S. Geological Survey \\
\hline Lower Gunnison & LEROUX CREEK NEAR CEDAREDGE, CO. & 09134500 & Delta County & U.S. Geological Survey \\
\hline Lower Gunnison & COW CREEK NEAR CEDAREDGE, CO. & 09134700 & Delta County & U.S. Geological Survey \\
\hline Lower Gunnison & LEROUX CK BELOW DEVER CK & 10415 & Delta County & $\begin{array}{l}\text { Colorado Department of Public } \\
\text { Health and Environment }\end{array}$ \\
\hline Lower Gunnison & LEROUX CREEK AT HOTCHKISS, CO. & 09135900 & Delta County & U.S. Geological Survey \\
\hline Lower Gunnison & LEROUX CK NR MOUTH AT J.80 RD & 10411 & Delta County & $\begin{array}{l}\text { Colorado Department of Public } \\
\text { Health and Environment }\end{array}$ \\
\hline Lower Gunnison & LEROUX CREEK AT MOUTH & 384732107434801 & Delta County & U.S. Geological Survey \\
\hline Lower Gunnison & N.F. GUNNISON R BLW LEROUX CR, NR HOTCHKISS, CO & 09135950 & Delta County & U.S. Geological Survey \\
\hline Lower Gunnison & N FK OF GUNNISON R BELOW HOTCHKISS & 000100 & Delta County & $\begin{array}{l}\text { Colorado Department of Public } \\
\text { Health and Environment }\end{array}$ \\
\hline Lower Gunnison & HOTCHKISS NFH NORTH FORK GUNISON & 231274 & Delta County & $\begin{array}{l}\text { U.S. Environmental } \\
\text { Protection Agency }\end{array}$ \\
\hline Lower Gunnison & $\begin{array}{l}\text { NORTH FK GUNNISON RIVER ABOVE MOUTH } \\
\text { NR LAZEAR, CO }\end{array}$ & 09136100 & Delta County & U.S. Geological Survey \\
\hline Lower Gunnison & NORTH FORK GUNNISON R AT MOUTH & 10400 & Delta County & $\begin{array}{l}\text { Colorado Department of Public } \\
\text { Health and Environment }\end{array}$ \\
\hline Lower Gunnison & GUNNISON RIVER NEAR LAZEAR, CO. & 09136200 & Delta County & U.S. Geological Survey \\
\hline Lower Gunnison & UNNAMED DRAINAGE BELOW OASIS POND, AT CTY ROAD & 384643107540301 & Delta County & U.S. Geological Survey \\
\hline Lower Gunnison & CURRANT CK NR MOUTH & 10587 & Delta County & $\begin{array}{l}\text { Colorado Department of Public } \\
\text { Health and Environment }\end{array}$ \\
\hline Lower Gunnison & CURRANT CREEK NEAR READ, CO. & 09137050 & Delta County & U.S. Geological Survey \\
\hline Lower Gunnison & ALFALFA RUN AT AUSTIN & 384649107570501 & Delta County & U.S. Geological Survey \\
\hline Lower Gunnison & GUNNISON RIVER AT 2200 RD BRIDGE, AT AUSTIN & 384624107570701 & Delta County & U.S. Geological Survey \\
\hline Lower Gunnison & PEACH VALLEY ARROYO NEAR MOUTH & 384604107570701 & Delta County & U.S. Geological Survey \\
\hline
\end{tabular}


Appendix 1. Summary of surface-water-quality data and comparison to water-quality standards by site, by constituent, Piceance study area, western Colorado. Water-quality standards comparisons follow data summaries and are in blue text; standards are provided in table 3.-Continued

[CDPHE segment, Colorado Department of Health and the Environment stream segment as referred to in tables 2 and 3; latitude and longitude are in North American Datum of 1983; downstream order number assigned as part of analysis. $\mu \mathrm{g} / \mathrm{L}$, micrograms per liter; $\mu \mathrm{S} / \mathrm{cm}$, microsiemens per centimeter; $\mathrm{mg} / \mathrm{L}$, milligrams per liter; mL, milliliters; aq, aquatic; CO, Colorado; EPA, U.S. Environmental Protection Agency; Max, maximum; Min, minimum; NA, not applicable; No., number; NTU, nephelometric turbitidy units; WS, water supply; dates given in month/day/year format]

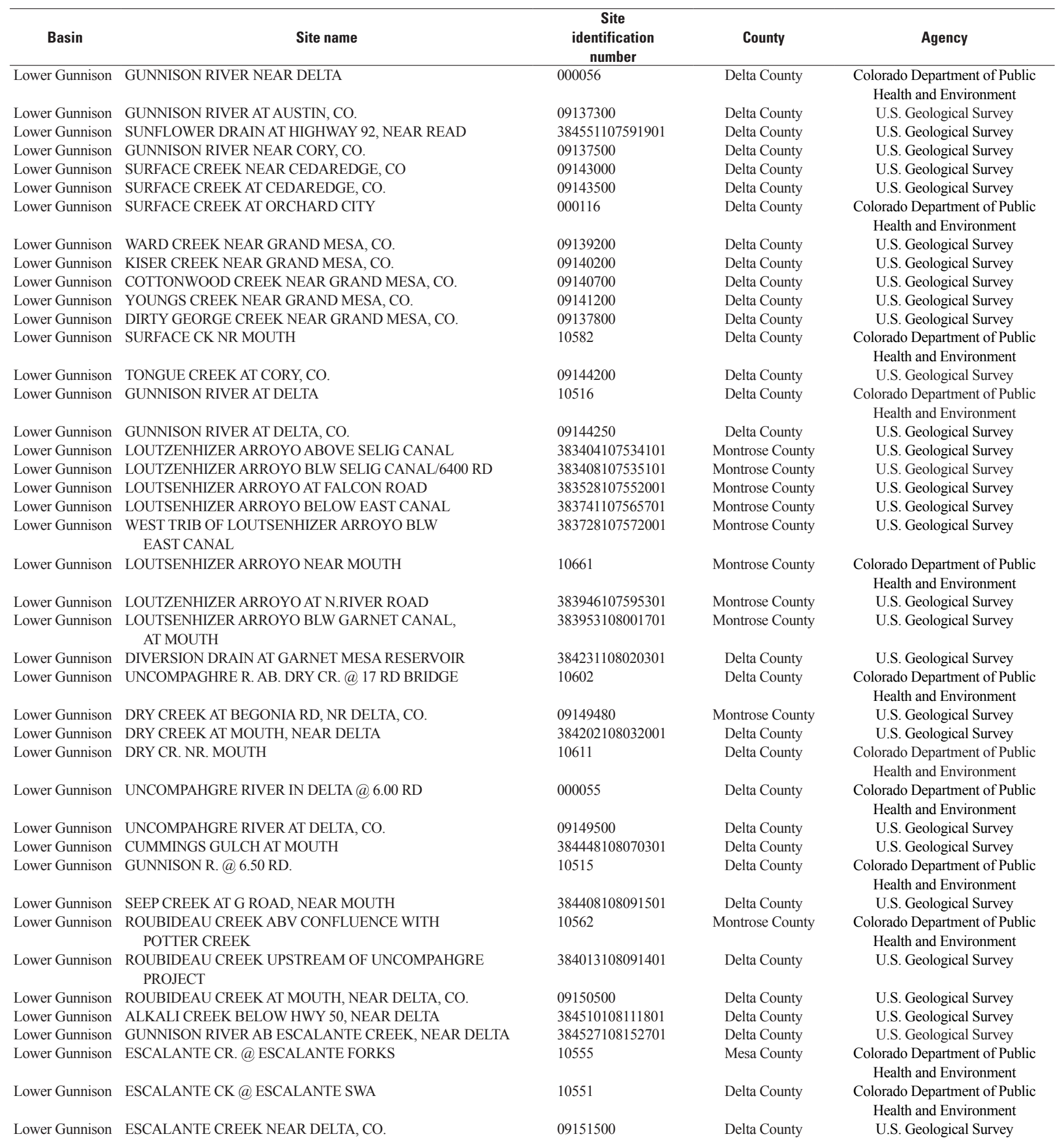


Appendix 1. Summary of surface-water-quality data and comparison to water-quality standards by site, by constituent, Piceance study area, western Colorado. Water-quality standards comparisons follow data summaries and are in blue text; standards are provided in table 3.-Continued

[CDPHE segment, Colorado Department of Health and the Environment stream segment as referred to in tables 2 and 3; latitude and longitude are in North American Datum of 1983; downstream order number assigned as part of analysis. $\mu \mathrm{g} / \mathrm{L}$, micrograms per liter; $\mu \mathrm{S} / \mathrm{cm}$, microsiemens per centimeter; $\mathrm{mg} / \mathrm{L}$, milligrams per liter; mL, milliliters; aq, aquatic; CO, Colorado; EPA, U.S. Environmental Protection Agency; Max, maximum; Min, minimum; NA, not applicable; No., number; NTU, nephelometric turbitidy units; WS, water supply; dates given in month/day/year format]

\begin{tabular}{|c|c|c|c|c|}
\hline Basin & Site name & $\begin{array}{c}\text { Site } \\
\text { identification } \\
\text { number }\end{array}$ & County & Agency \\
\hline Lower Gunnison & WELLS GULCH AT DOMINGUEZ ROAD CROSSING & 384813108184301 & Delta County & U.S. Geological Survey \\
\hline Lower Gunnison & WHITEWATER CK@32.70 RD. & $10505 \mathrm{~A}$ & Mesa County & $\begin{array}{l}\text { Colorado Department of Public } \\
\text { Health and Environment }\end{array}$ \\
\hline Lower Gunnison & W. Fork 2 Creek & WSWF2CR & Mesa County & City of Grand Junction \\
\hline Lower Gunnison & E. Fork 2 Creek & WSEF2CR & Mesa County & City of Grand Junction \\
\hline Lower Gunnison & Two Creek & WSTWOCR & Mesa County & City of Grand Junction \\
\hline Lower Gunnison & KC above CG (intake) & WSKCINTK & Mesa County & City of Grand Junction \\
\hline Lower Gunnison & KANNAH CK ABOVE DOW FISHING AREA & 10575 & Mesa County & $\begin{array}{l}\text { Colorado Department of Public } \\
\text { Health and Environment }\end{array}$ \\
\hline Lower Gunnison & KANNAH CREEK NEAR WHITEWATER, CO. & 09152000 & Mesa County & U.S. Geological Survey \\
\hline Lower Gunnison & $\mathrm{KC}$ below $\mathrm{CG}$ & WSKCBLCG & Mesa County & City of Grand Junction \\
\hline Lower Gunnison & Juniata Inlet & WSJUNNLT & Mesa County & City of Grand Junction \\
\hline Lower Gunnison & Lower JUNNLT & WSJUNNLTLO & Mesa County & City of Grand Junction \\
\hline Lower Gunnison & KANNAH CK@65.00 RD & 10572 & Mesa County & $\begin{array}{l}\text { Colorado Department of Public } \\
\text { Health and Environment }\end{array}$ \\
\hline Lower Gunnison & NF KC at WR CG & WSNFKCWR & Mesa County & City of Grand Junction \\
\hline Lower Gunnison & NF Kannah Cr at Div. & WSNFKCDV & Mesa County & City of Grand Junction \\
\hline Lower Gunnison & $\mathrm{NF} \mathrm{KC}$ at $\mathrm{SR} \mathrm{CG}$ & WSNFKCSR & Mesa County & City of Grand Junction \\
\hline Lower Gunnison & NF Kannah Cr at Inlt & WSNFKCINLT & Mesa County & City of Grand Junction \\
\hline Lower Gunnison & KANNAH CREEK ABOUT .1 MI BELOW INDIAN CREEK & 385600108250301 & Mesa County & U.S. Geological Survey \\
\hline Lower Gunnison & KANNAHCK@FS.50 RD & 10530 & Mesa County & $\begin{array}{l}\text { Colorado Department of Public } \\
\text { Health and Environment }\end{array}$ \\
\hline Lower Gunnison & Lockhart Draw & WSLOCKDRW & Mesa County & City of Grand Junction \\
\hline Lower Gunnison & Whitewater Creek & WSWHITCR & Mesa County & City of Grand Junction \\
\hline Lower Gunnison & $\begin{array}{l}\text { WHITEWATER CREEK .4 MI ABOVE MOUTH,AT } \\
\text { WHITEWATER }\end{array}$ & 385839108264401 & Mesa County & U.S. Geological Survey \\
\hline Lower Gunnison & GUNNISON R.@WHITEWATER & 10505 & Mesa County & $\begin{array}{l}\text { Colorado Department of Public } \\
\text { Health and Environment }\end{array}$ \\
\hline Lower Gunnison & Gunnison River Whitewater $\mathrm{Br}$ & CDOWRW-562 & Mesa County & Colorado Wildlife Division, CO \\
\hline Lower Gunnison & GUNNISON RIVER NEAR GRAND JUNCTION, CO. & 09152500 & Mesa County & U.S. Geological Survey \\
\hline Lower Gunnison & GUNNISON SOUTHEAST OF GRD JUNCT & 000054 & Mesa County & $\begin{array}{l}\text { Colorado Department of Public } \\
\text { Health and Environment }\end{array}$ \\
\hline Lower Gunnison & CALLOW CREEK AT WHITEWATER, CO & 09152520 & Mesa County & U.S. Geological Survey \\
\hline Lower Gunnison & ORCHARD MESA DRAIN AT GRAND JUNCTION, CO. & 09152600 & Mesa County & U.S. Geological Survey \\
\hline
\end{tabular}


Appendix 1. Summary of surface-water-quality data and comparison to water-quality standards by site, by constituent, Piceance study area, western Colorado. Water-quality standards comparisons follow data summaries and are in blue text; standards are provided in table 3.-Continued

[CDPHE segment, Colorado Department of Health and the Environment stream segment as referred to in tables 2 and 3; latitude and longitude are in North American Datum of 1983; downstream order number assigned as part of analysis. $\mu \mathrm{g} / \mathrm{L}$, micrograms per liter; $\mu \mathrm{S} / \mathrm{cm}$, microsiemens per centimeter; mg/L, milligrams per liter; mL, milliliters; aq, aquatic; CO, Colorado; EPA, U.S. Environmental Protection Agency; Max, maximum; Min, minimum; NA, not applicable; No., number; NTU, nephelometric turbitidy units; WS, water supply; dates given in month/day/year format]

\begin{tabular}{|c|c|c|c|c|c|c|c|c|c|c|c|}
\hline $\begin{array}{c}\text { Site } \\
\text { identification } \\
\text { number }\end{array}$ & $\begin{array}{c}\text { CDPHE } \\
\text { segment }\end{array}$ & $\begin{array}{l}\text { Latitude } \\
\text { (decimal } \\
\text { degrees) }\end{array}$ & $\begin{array}{l}\text { Longitude } \\
\text { (decimal } \\
\text { degrees) }\end{array}$ & $\begin{array}{c}\text { Downstream } \\
\text { order } \\
\text { number }\end{array}$ & \multicolumn{7}{|c|}{ Temperature, water, degrees Celsius } \\
\hline 09304100 & White_9a & 39.969 & -107.647 & 3 & $52 / 0$ & $\begin{array}{c}8 / 11 / 1959- \\
11 / 4 / 1964\end{array}$ & 0.5 & 5.3 & 13.3 & 18.5 & 24.5 \\
\hline 09304480 & White_9a & 40.031 & -107.822 & 16 & $296 / 0$ & $\begin{array}{l}\text { 7/6/1978- } \\
6 / 11 / 2007\end{array}$ & 0.0 & 2.0 & 7.3 & 14.0 & 22.0 \\
\hline 09304300 & White_9a & 40.091 & -107.770 & 18 & $113 / 0$ & $\begin{array}{c}8 / 12 / 1959- \\
9 / 23 / 2005\end{array}$ & 0.0 & 2.0 & 8.5 & 14.0 & 66.0 \\
\hline 09304500 & White_7 & 40.034 & -107.862 & 19 & $446 / 0$ & $\begin{array}{c}8 / 11 / 1959- \\
9 / 24 / 2005\end{array}$ & 0.0 & 3.2 & 8.5 & 12.0 & 22.0 \\
\hline 4000001075434 & & 40.005 & -107.911 & 34 & $12 / 0$ & $\begin{array}{c}10 / 19 / 1999 \\
6 / 11 / 2007\end{array}$ & 0.1 & 3.6 & 11.5 & 17.1 & 22.0 \\
\hline 400113107574500 & White_7 & 40.020 & -107.963 & 39 & & & & & & & \\
\hline 000043 & White_7 & 40.017 & -107.983 & 42 & $145 / 0$ & $\begin{array}{c}1 / 24 / 1968- \\
4 / 21 / 1992\end{array}$ & 0.0 & 2.2 & 7.2 & 11.7 & 21.1 \\
\hline 400206108005901 & & 40.0350861 & -108.0162556 & 45 & $6 / 0$ & $\begin{array}{c}6 / 24 / 2005- \\
6 / 11 / 2007\end{array}$ & 2.5 & 3.4 & 14.0 & 15.3 & 15.5 \\
\hline 09304800 & White_7 & 40.013 & -108.093 & 51 & $837 / 0$ & $\begin{array}{c}\text { 9/20/1961- } \\
\text { 9/29/2009 }\end{array}$ & -0.1 & 3.2 & 9.1 & 14.0 & 25.5 \\
\hline ENPR20ST & White_16 & 39.686 & -107.985 & 59 & & & & & & & \\
\hline ENPR21ST & White 16 & 39.668 & -108.007 & 60 & & & & & & & \\
\hline ENPR19ST & White_16 & 39.692 & -108.005 & 61 & & & & & & & \\
\hline 09306007 & White_14a & 39.826 & -108.183 & 63 & $638 / 0$ & $\begin{array}{c}4 / 23 / 1974 \\
10 / 5 / 1998\end{array}$ & 0.0 & 5.0 & 9.5 & 14.0 & 28.0 \\
\hline 09306042 & White_16 & 39.834 & -108.221 & 69 & $170 / 0$ & $\begin{array}{c}3 / 17 / 1977- \\
6 / 18 / 1991\end{array}$ & 0.0 & 11.0 & 17.0 & 23.0 & 29.5 \\
\hline 09306050 & White_16 & 39.794 & -108.228 & 71 & $6 / 0$ & $\begin{array}{l}3 / 4 / 1975- \\
2 / 19 / 1980\end{array}$ & 0.0 & 0.5 & 3.0 & 4.5 & 4.5 \\
\hline 09306052 & White_16 & 39.814 & -108.244 & 72 & $11 / 0$ & $\begin{array}{l}3 / 4 / 1975- \\
3 / 11 / 1985\end{array}$ & 0.0 & 0.0 & 0.5 & 1.5 & 6.0 \\
\hline 09306058 & White_18 & 39.837 & -108.244 & 74 & $395 / 0$ & $\begin{array}{c}4 / 23 / 1974 \\
9 / 3 / 1998\end{array}$ & 0.0 & 6.0 & 10.0 & 14.0 & 27.0 \\
\hline 09306061 & White_14a & 39.851 & -108.259 & 75 & $472 / 0$ & $\begin{array}{l}4 / 23 / 1974 \\
11 / 19 / 1993\end{array}$ & -0.5 & 5.5 & 10.0 & 14.0 & 24.0 \\
\hline 11625 & White_20 & 39.858 & -108.311 & 81 & $9 / 0$ & $\begin{array}{c}8 / 18 / 1999- \\
6 / 21 / 2007\end{array}$ & 2.7 & 8.3 & 12.4 & 14.7 & 22.2 \\
\hline 09306175 & White_20 & 39.871 & -108.288 & 82 & $336 / 0$ & $\begin{array}{c}1 / 15 / 1975- \\
8 / 17 / 1983\end{array}$ & 0.0 & 6.0 & 10.8 & 13.0 & 23.0 \\
\hline 09306200 & White_14b & 39.921 & -108.298 & 86 & $761 / 0$ & $\begin{array}{c}6 / 9 / 1964 \\
7 / 8 / 2009\end{array}$ & 0.0 & 5.0 & 10.0 & 15.0 & 26.3 \\
\hline 09306210 & White_15 & 39.939 & -108.290 & 106 & $91 / 0$ & $\begin{array}{c}10 / 13 / 1964 \\
8 / 18 / 1976\end{array}$ & 0.0 & 1.5 & 8.0 & 14.0 & 26.0 \\
\hline
\end{tabular}


Appendix 1. Summary of surface-water-quality data and comparison to water-quality standards by site, by constituent, Piceance study area, western Colorado. Water-quality standards comparisons follow data summaries and are in blue text; standards are provided in table 3.-Continued

[CDPHE segment, Colorado Department of Health and the Environment stream segment as referred to in tables 2 and 3; latitude and longitude are in North American Datum of 1983; downstream order number assigned as part of analysis. $\mu \mathrm{g} / \mathrm{L}$, micrograms per liter; $\mu \mathrm{S} / \mathrm{cm}$, microsiemens per centimeter; $\mathrm{mg} / \mathrm{L}$, milligrams per liter; mL, milliliters; aq, aquatic; CO, Colorado; EPA, U.S. Environmental Protection Agency; Max, maximum; Min, minimum; NA, not applicable; No., number; NTU, nephelometric turbitidy units; WS, water supply; dates given in month/day/year format]

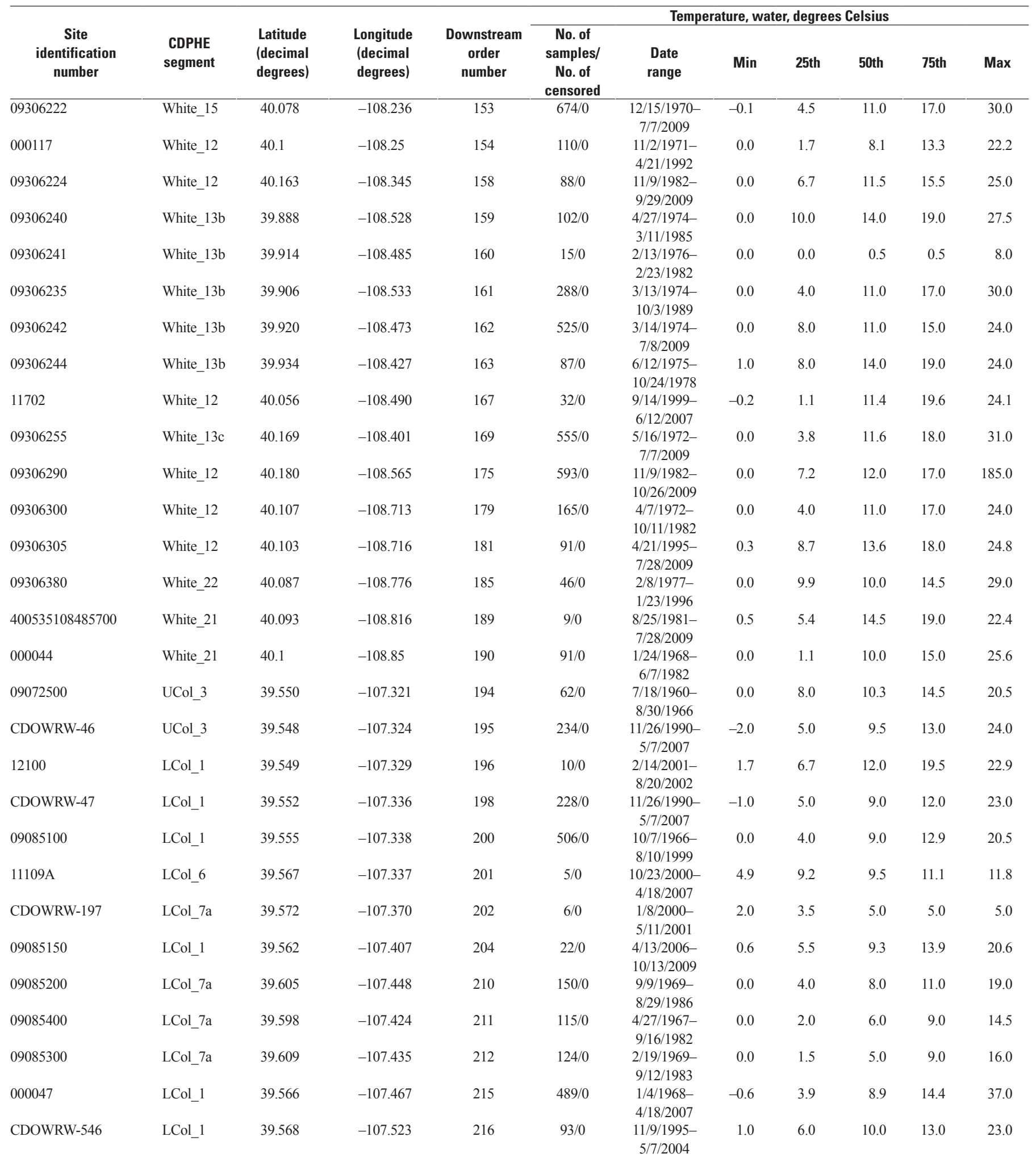


Appendix 1. Summary of surface-water-quality data and comparison to water-quality standards by site, by constituent, Piceance study area, western Colorado. Water-quality standards comparisons follow data summaries and are in blue text; standards are provided in table 3.-Continued

[CDPHE segment, Colorado Department of Health and the Environment stream segment as referred to in tables 2 and 3; latitude and longitude are in North American Datum of 1983; downstream order number assigned as part of analysis. $\mu \mathrm{g} / \mathrm{L}$, micrograms per liter; $\mu \mathrm{S} / \mathrm{cm}$, microsiemens per centimeter; mg/L, milligrams per liter; mL, milliliters; aq, aquatic; CO, Colorado; EPA, U.S. Environmental Protection Agency; Max, maximum; Min, minimum; NA, not applicable; No., number; NTU, nephelometric turbitidy units; WS, water supply; dates given in month/day/year format]

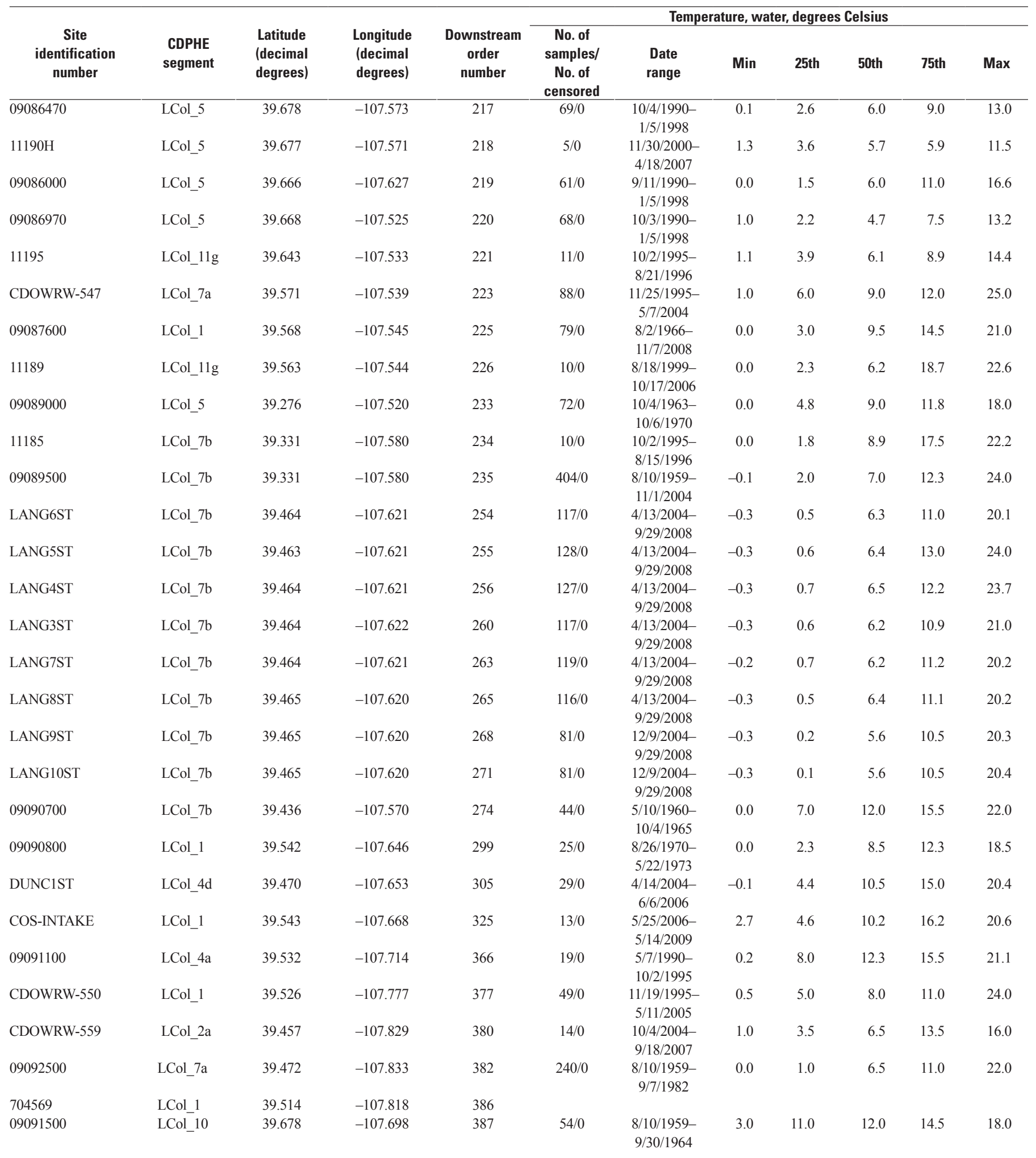


Appendix 1. Summary of surface-water-quality data and comparison to water-quality standards by site, by constituent, Piceance study area, western Colorado. Water-quality standards comparisons follow data summaries and are in blue text; standards are provided in table 3.-Continued

[CDPHE segment, Colorado Department of Health and the Environment stream segment as referred to in tables 2 and 3; latitude and longitude are in North American Datum of 1983; downstream order number assigned as part of analysis. $\mu \mathrm{g} / \mathrm{L}$, micrograms per liter; $\mu \mathrm{S} / \mathrm{cm}$, microsiemens per centimeter; $\mathrm{mg} / \mathrm{L}$, milligrams per liter; mL, milliliters; aq, aquatic; CO, Colorado; EPA, U.S. Environmental Protection Agency; Max, maximum; Min, minimum; NA, not applicable; No., number; NTU, nephelometric turbitidy units; WS, water supply; dates given in month/day/year format]

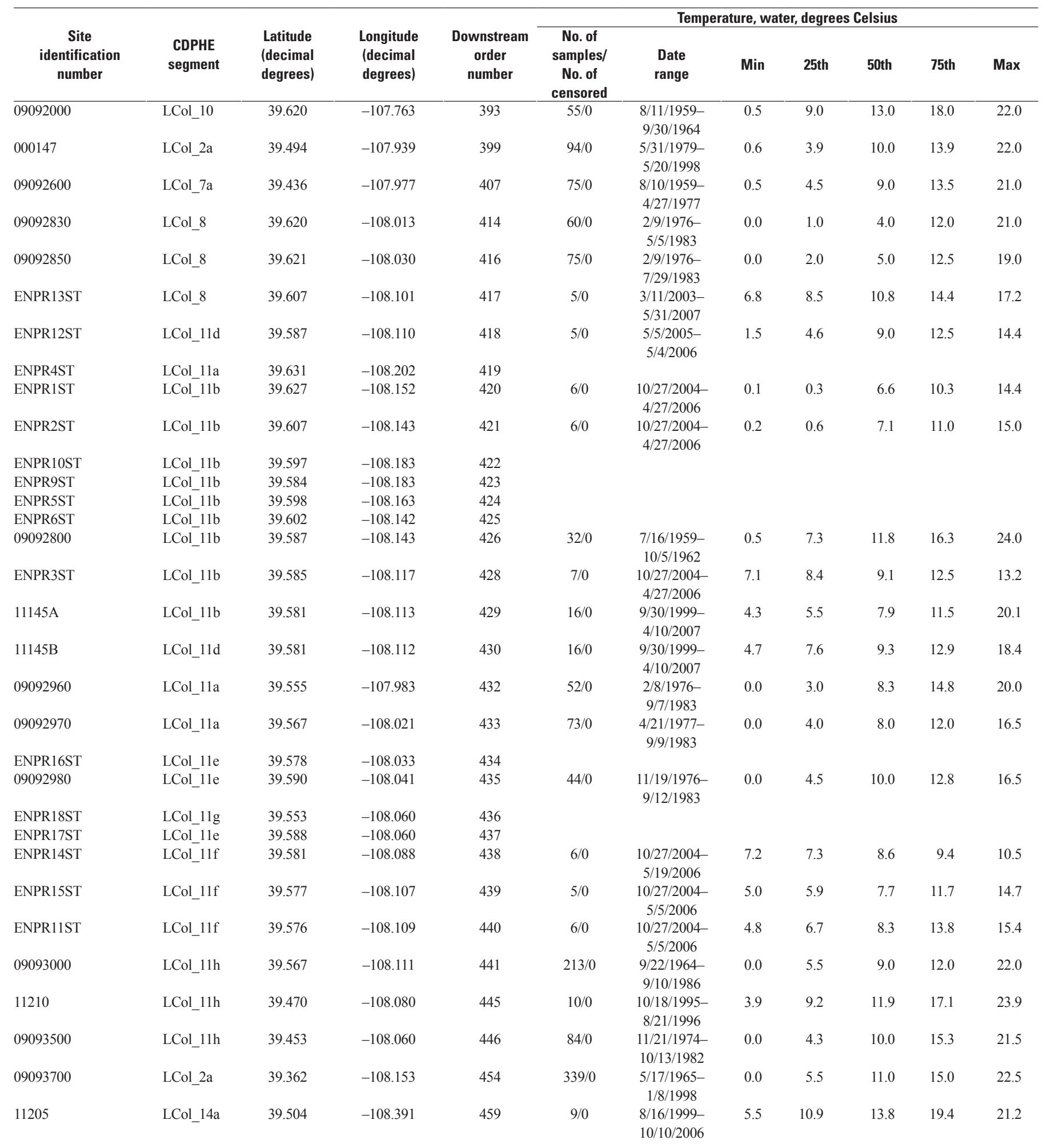


Appendix 1. Summary of surface-water-quality data and comparison to water-quality standards by site, by constituent, Piceance study area, western Colorado. Water-quality standards comparisons follow data summaries and are in blue text; standards are provided in table 3.-Continued

[CDPHE segment, Colorado Department of Health and the Environment stream segment as referred to in tables 2 and 3; latitude and longitude are in North American Datum of 1983; downstream order number assigned as part of analysis. $\mu \mathrm{g} / \mathrm{L}$, micrograms per liter; $\mu \mathrm{S} / \mathrm{cm}$, microsiemens per centimeter; mg/L, milligrams per liter; mL, milliliters; aq, aquatic; CO, Colorado; EPA, U.S. Environmental Protection Agency; Max, maximum; Min, minimum; NA, not applicable; No., number; NTU, nephelometric turbitidy units; WS, water supply; dates given in month/day/year format]

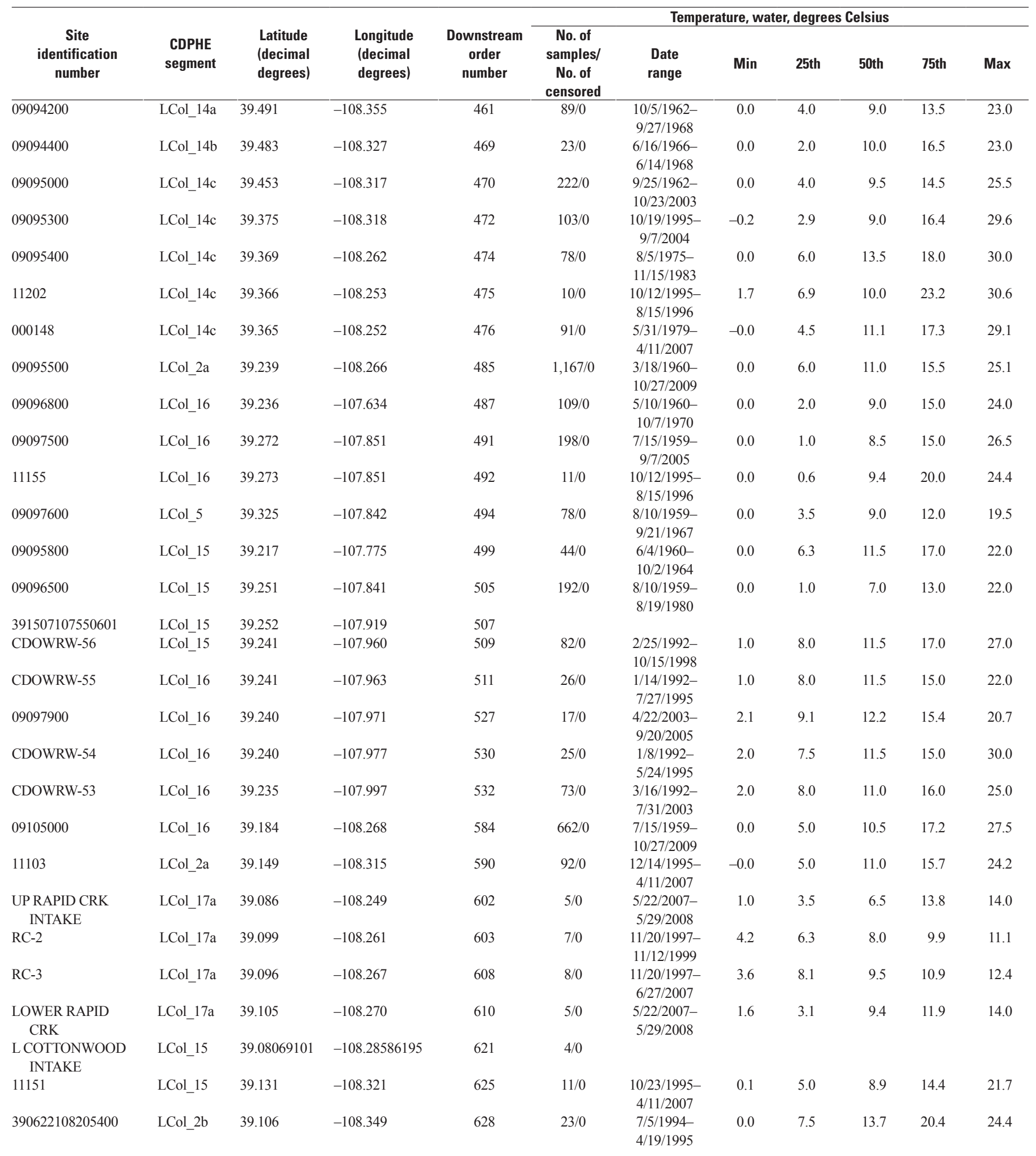


Appendix 1. Summary of surface-water-quality data and comparison to water-quality standards by site, by constituent, Piceance study area, western Colorado. Water-quality standards comparisons follow data summaries and are in blue text; standards are provided in table 3.-Continued

[CDPHE segment, Colorado Department of Health and the Environment stream segment as referred to in tables 2 and 3; latitude and longitude are in North American Datum of 1983; downstream order number assigned as part of analysis. $\mu \mathrm{g} / \mathrm{L}$, micrograms per liter; $\mu \mathrm{S} / \mathrm{cm}$, microsiemens per centimeter; $\mathrm{mg} / \mathrm{L}$, milligrams per liter; mL, milliliters; aq, aquatic; CO, Colorado; EPA, U.S. Environmental Protection Agency; Max, maximum; Min, minimum; NA, not applicable; No., number; NTU, nephelometric turbitidy units; WS, water supply; dates given in month/day/year format]

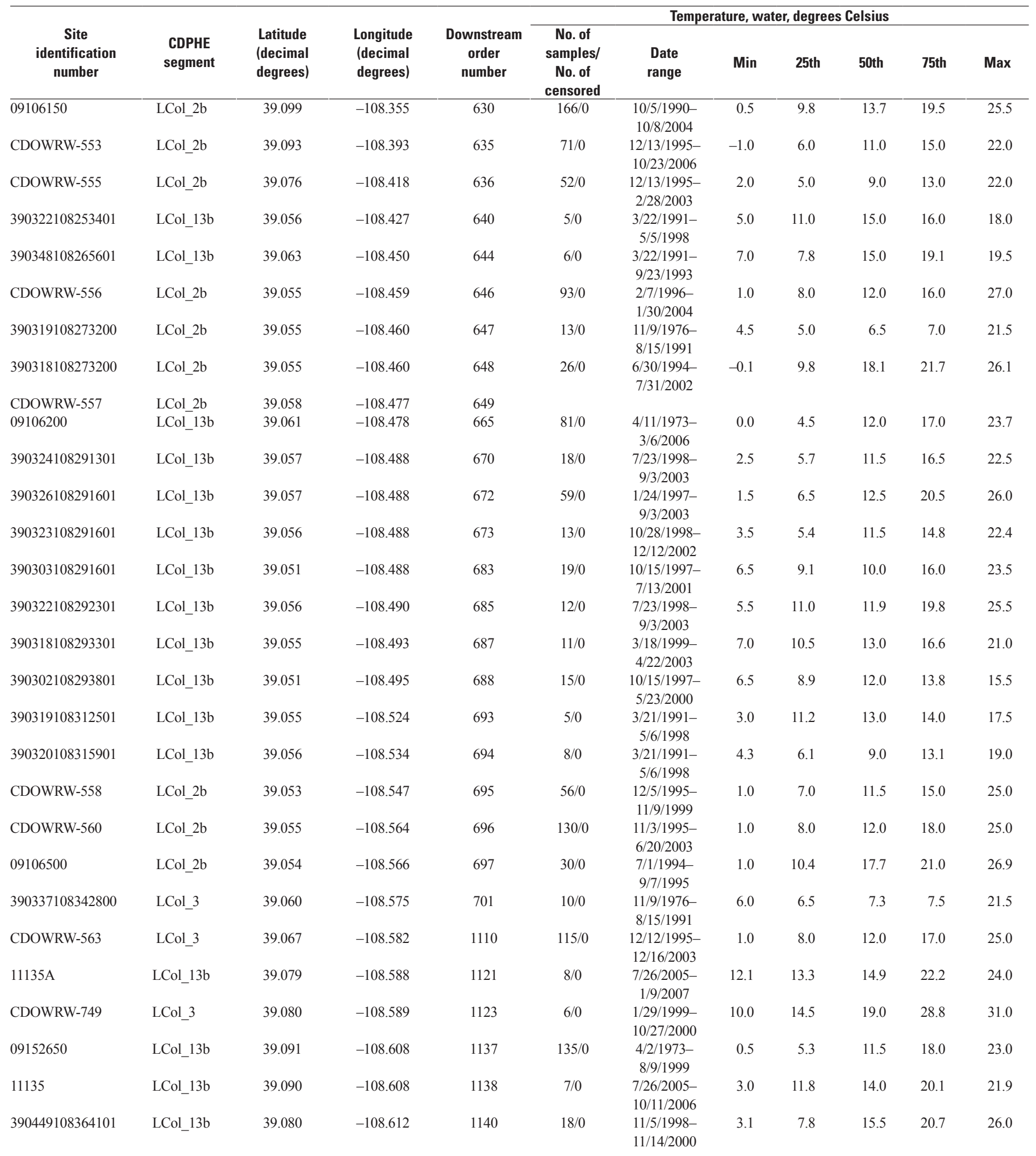


Appendix 1. Summary of surface-water-quality data and comparison to water-quality standards by site, by constituent, Piceance study area, western Colorado. Water-quality standards comparisons follow data summaries and are in blue text; standards are provided in table 3.-Continued

[CDPHE segment, Colorado Department of Health and the Environment stream segment as referred to in tables 2 and 3; latitude and longitude are in North American Datum of 1983; downstream order number assigned as part of analysis. $\mu \mathrm{g} / \mathrm{L}$, micrograms per liter; $\mu \mathrm{S} / \mathrm{cm}$, microsiemens per centimeter; mg/L, milligrams per liter; mL, milliliters; aq, aquatic; CO, Colorado; EPA, U.S. Environmental Protection Agency; Max, maximum; Min, minimum; NA, not applicable; No., number; NTU, nephelometric turbitidy units; WS, water supply; dates given in month/day/year format]

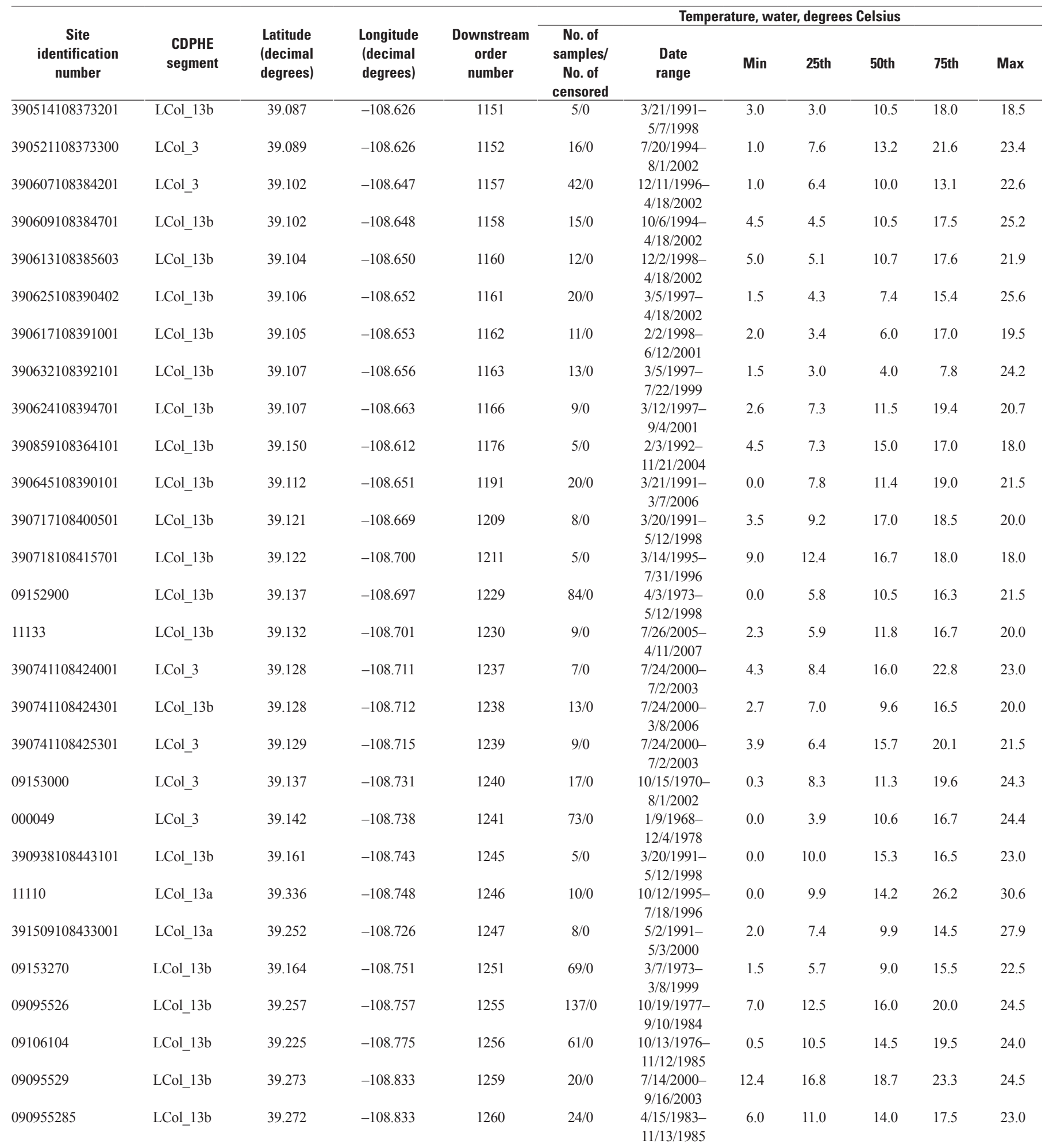


Appendix 1. Summary of surface-water-quality data and comparison to water-quality standards by site, by constituent, Piceance study area, western Colorado. Water-quality standards comparisons follow data summaries and are in blue text; standards are provided in table 3.-Continued

[CDPHE segment, Colorado Department of Health and the Environment stream segment as referred to in tables 2 and 3; latitude and longitude are in North American Datum of 1983; downstream order number assigned as part of analysis. $\mu \mathrm{g} / \mathrm{L}$, micrograms per liter; $\mu \mathrm{S} / \mathrm{cm}$, microsiemens per centimeter; $\mathrm{mg} / \mathrm{L}$, milligrams per liter; mL, milliliters; aq, aquatic; CO, Colorado; EPA, U.S. Environmental Protection Agency; Max, maximum; Min, minimum; NA, not applicable; No., number; NTU, nephelometric turbitidy units; WS, water supply; dates given in month/day/year format]

\begin{tabular}{|c|c|c|c|c|c|c|c|c|c|c|c|}
\hline $\begin{array}{c}\text { Site } \\
\text { identification } \\
\text { number }\end{array}$ & $\begin{array}{l}\text { CDPHE } \\
\text { segment }\end{array}$ & $\begin{array}{l}\text { Latitude } \\
\text { (decimal } \\
\text { degrees) }\end{array}$ & $\begin{array}{l}\text { Longitude } \\
\text { (decimal } \\
\text { degrees) }\end{array}$ & $\begin{array}{c}\text { Downstream } \\
\text { order } \\
\text { number }\end{array}$ & \multicolumn{7}{|c|}{ Temperature, water, degrees Celsius } \\
\hline 09153290 & LCol_13b & 39.211 & -108.804 & 1264 & $278 / 0$ & $\begin{array}{c}10 / 13 / 1976- \\
10 / 3 / 2000\end{array}$ & 0.0 & 8.0 & 12.0 & 16.0 & 23.0 \\
\hline 391038108475601 & LCol_13b & 39.177 & -108.800 & 1268 & $9 / 0$ & $\begin{array}{l}7 / 9 / 1993- \\
7 / 14 / 1999\end{array}$ & 2.0 & 7.0 & 9.5 & 14.0 & 19.5 \\
\hline 000050 & LCol_3 & 39.175 & -108.801 & 1270 & $479 / 0$ & $\begin{array}{l}1 / 9 / 1968- \\
7 / 29 / 1996\end{array}$ & -1.1 & 5.0 & 11.7 & 17.2 & 26.7 \\
\hline 391029108480200 & LCol_13b & 39.175 & -108.801 & 1271 & $9 / 0$ & $\begin{array}{c}11 / 10 / 1976- \\
6 / 25 / 1991\end{array}$ & 6.0 & 6.0 & 7.0 & 7.5 & 14.5 \\
\hline 11101 & LCol_3 & 39.170 & -108.811 & 1272 & $42 / 0$ & $\begin{array}{c}8 / 11 / 1999- \\
4 / 11 / 2007\end{array}$ & -0.2 & 3.6 & 14.2 & 18.7 & 25.3 \\
\hline 09153330 & LCol_13b & 39.396 & -108.981 & 1285 & $11 / 0$ & $\begin{array}{c}\text { 6/12/1979- } \\
\text { 9/14/1981 }\end{array}$ & 5.0 & 15.0 & 18.5 & 29.0 & 32.0 \\
\hline 09153400 & LCol_13b & 39.309 & -108.984 & 1287 & $32 / 0$ & $\begin{array}{c}\text { 9/12/1973- } \\
3 / 13 / 1997\end{array}$ & 2.0 & 9.0 & 12.0 & 24.5 & 33.0 \\
\hline 391646108572301 & LCol_13b & 39.279 & -108.957 & 1288 & $5 / 0$ & $\begin{array}{c}5 / 2 / 1991- \\
5 / 3 / 2000\end{array}$ & 0.9 & 7.0 & 11.0 & 19.9 & 20.4 \\
\hline 09161000 & LCol_13b & 39.329 & -108.943 & 1289 & & & & & & & \\
\hline 09160500 & LCol_13b & 39.323 & -108.931 & 1290 & $9 / 0$ & $\begin{array}{c}11 / 11 / 1978 \\
11 / 12 / 1978\end{array}$ & 5.0 & 5.0 & 5.0 & 5.0 & 5.0 \\
\hline 09163050 & LCol_13b & 39.293 & -108.934 & 1291 & $42 / 0$ & $\begin{array}{c}4 / 12 / 1973- \\
9 / 8 / 1982\end{array}$ & 5.0 & 13.0 & 15.8 & 19.5 & 24.5 \\
\hline 09163490 & LCol_13b & 39.222 & -108.893 & 1293 & $99 / 0$ & $\begin{array}{l}4 / 4 / 1973- \\
5 / 13 / 1998\end{array}$ & 0.0 & 3.8 & 12.0 & 17.0 & 23.0 \\
\hline 09130600 & NFkGunn_4 & 39.131 & -107.575 & 711 & $44 / 0$ & $\begin{array}{l}8 / 3 / 1960- \\
10 / 7 / 1965\end{array}$ & 0.0 & 5.0 & 10.8 & 16.3 & 23.0 \\
\hline 09130800 & NFkGunn_4 & 39.116 & -107.524 & 712 & $50 / 0$ & $\begin{array}{c}11 / 5 / 1968- \\
10 / 4 / 1974\end{array}$ & 0.0 & 1.0 & 6.0 & 11.0 & 21.0 \\
\hline 09131100 & NFkGunn_4 & 39.104 & -107.585 & 713 & $94 / 0$ & $\begin{array}{c}10 / 15 / 1968- \\
8 / 16 / 1983\end{array}$ & 0.0 & 1.0 & 6.8 & 12.0 & 20.0 \\
\hline 09131200 & NFkGunn_4 & 39.090 & -107.505 & 714 & $103 / 0$ & $\begin{array}{c}6 / 14 / 1961- \\
10 / 9 / 1973\end{array}$ & 0.0 & 3.0 & 9.0 & 14.5 & 24.0 \\
\hline 10490 & NFkGunn_4 & 38.988 & -107.348 & 718 & $13 / 0$ & $\begin{array}{c}10 / 11 / 1995- \\
3 / 17 / 2005\end{array}$ & 0.6 & 3.4 & 5.0 & 9.4 & 18.9 \\
\hline 09132500 & NFkGunn_2 & 38.926 & -107.434 & 721 & $472 / 0$ & $\begin{array}{l}7 / 2 / 1959- \\
7 / 21 / 2009\end{array}$ & -0.1 & 2.5 & 7.3 & 12.5 & 23.5 \\
\hline 000152 & NFkGunn_2 & 38.925 & -107.518 & 730 & $35 / 0$ & $\begin{array}{c}5 / 14 / 1979 \\
5 / 25 / 2006\end{array}$ & -0.6 & 2.6 & 7.8 & 11.9 & 19.4 \\
\hline 09132700 & NFkGunn_4 & 39.057 & -107.630 & 731 & $46 / 0$ & $\begin{array}{l}6 / 1 / 1961- \\
9 / 11 / 1968\end{array}$ & 0.0 & 1.5 & 4.5 & 8.5 & 15.5 \\
\hline 09132800 & NFkGunn_4 & 39.049 & -107.621 & 732 & $50 / 0$ & $\begin{array}{c}5 / 11 / 1961- \\
9 / 11 / 1968\end{array}$ & 0.0 & 1.5 & 3.8 & 8.0 & 16.0 \\
\hline
\end{tabular}


Appendix 1. Summary of surface-water-quality data and comparison to water-quality standards by site, by constituent, Piceance study area, western Colorado. Water-quality standards comparisons follow data summaries and are in blue text; standards are provided in table 3.-Continued

[CDPHE segment, Colorado Department of Health and the Environment stream segment as referred to in tables 2 and 3; latitude and longitude are in North American Datum of 1983; downstream order number assigned as part of analysis. $\mu \mathrm{g} / \mathrm{L}$, micrograms per liter; $\mu \mathrm{S} / \mathrm{cm}$, microsiemens per centimeter; mg/L, milligrams per liter; mL, milliliters; aq, aquatic; CO, Colorado; EPA, U.S. Environmental Protection Agency; Max, maximum; Min, minimum; NA, not applicable; No., number; NTU, nephelometric turbitidy units; WS, water supply; dates given in month/day/year format]

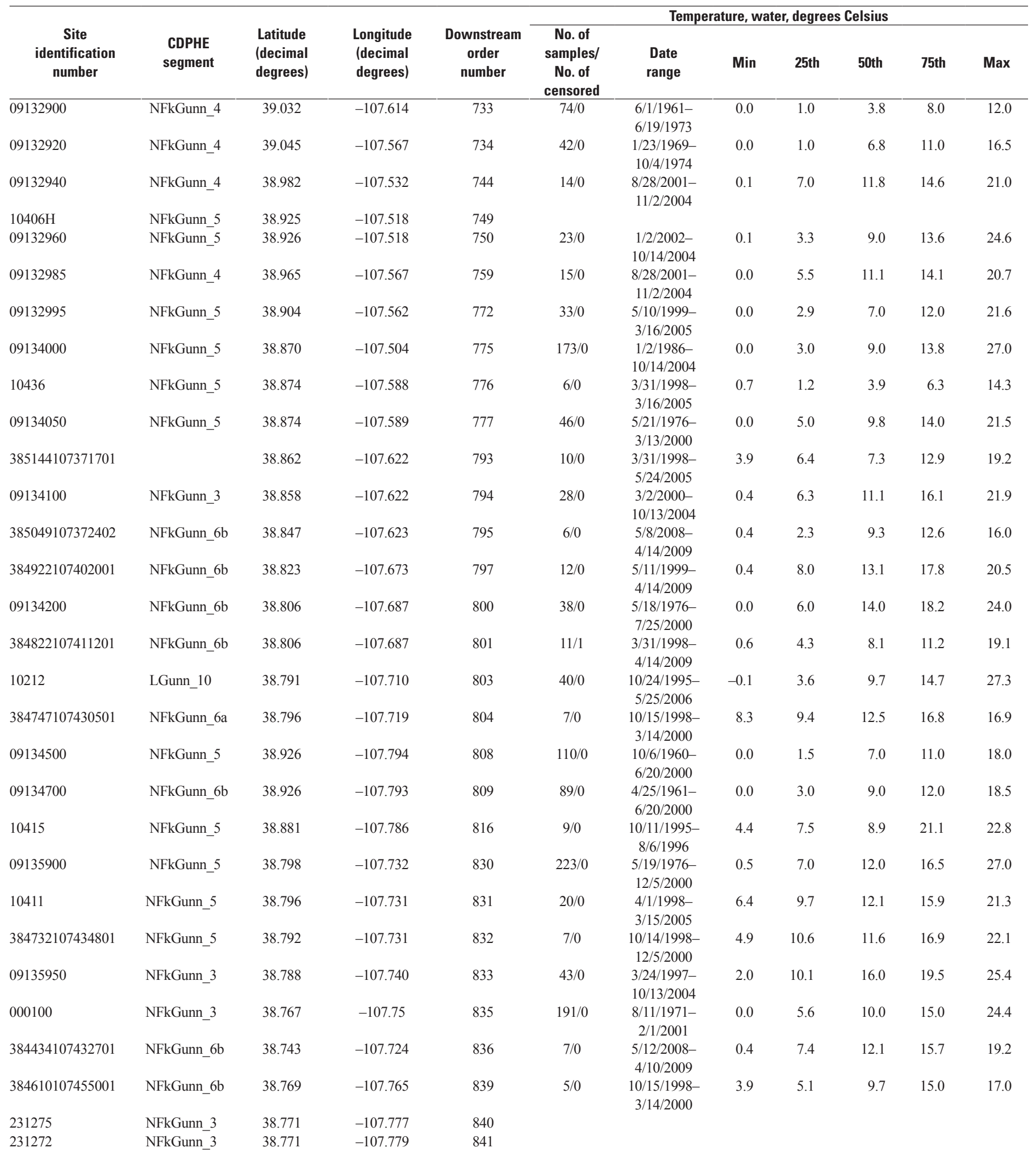


Appendix 1. Summary of surface-water-quality data and comparison to water-quality standards by site, by constituent, Piceance study area, western Colorado. Water-quality standards comparisons follow data summaries and are in blue text; standards are provided in table 3.-Continued

[CDPHE segment, Colorado Department of Health and the Environment stream segment as referred to in tables 2 and 3; latitude and longitude are in North American Datum of 1983; downstream order number assigned as part of analysis. $\mu \mathrm{g} / \mathrm{L}$, micrograms per liter; $\mu \mathrm{S} / \mathrm{cm}$, microsiemens per centimeter; $\mathrm{mg} / \mathrm{L}$, milligrams per liter; mL, milliliters; aq, aquatic; CO, Colorado; EPA, U.S. Environmental Protection Agency; Max, maximum; Min, minimum; NA, not applicable; No., number; NTU, nephelometric turbitidy units; WS, water supply; dates given in month/day/year format]

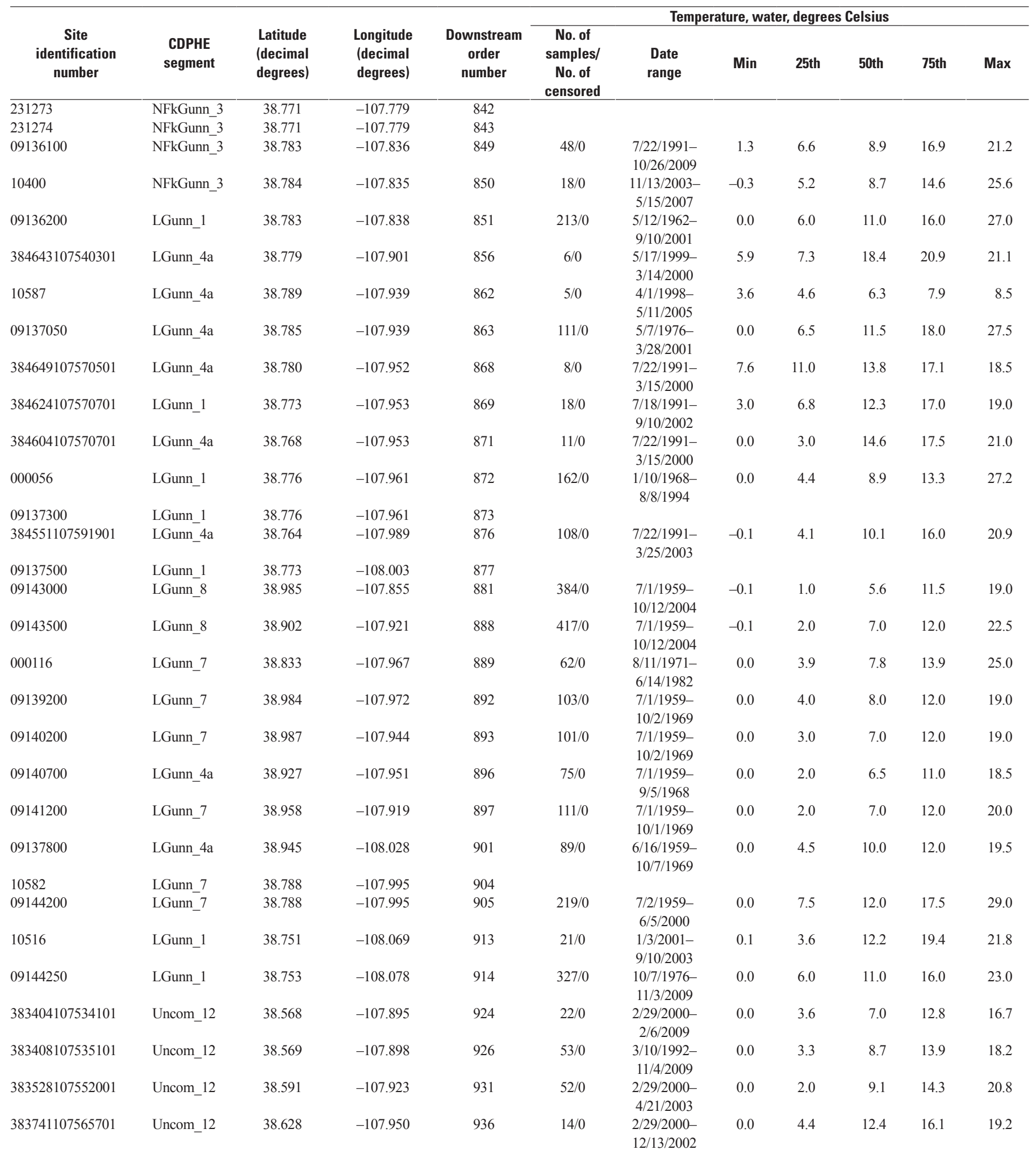


Appendix 1. Summary of surface-water-quality data and comparison to water-quality standards by site, by constituent, Piceance study area, western Colorado. Water-quality standards comparisons follow data summaries and are in blue text; standards are provided in table 3.-Continued

[CDPHE segment, Colorado Department of Health and the Environment stream segment as referred to in tables 2 and 3; latitude and longitude are in North American Datum of 1983; downstream order number assigned as part of analysis. $\mu \mathrm{g} / \mathrm{L}$, micrograms per liter; $\mu \mathrm{S} / \mathrm{cm}$, microsiemens per centimeter; mg/L, milligrams per liter; mL, milliliters; aq, aquatic; CO, Colorado; EPA, U.S. Environmental Protection Agency; Max, maximum; Min, minimum; NA, not applicable; No., number; NTU, nephelometric turbitidy units; WS, water supply; dates given in month/day/year format]

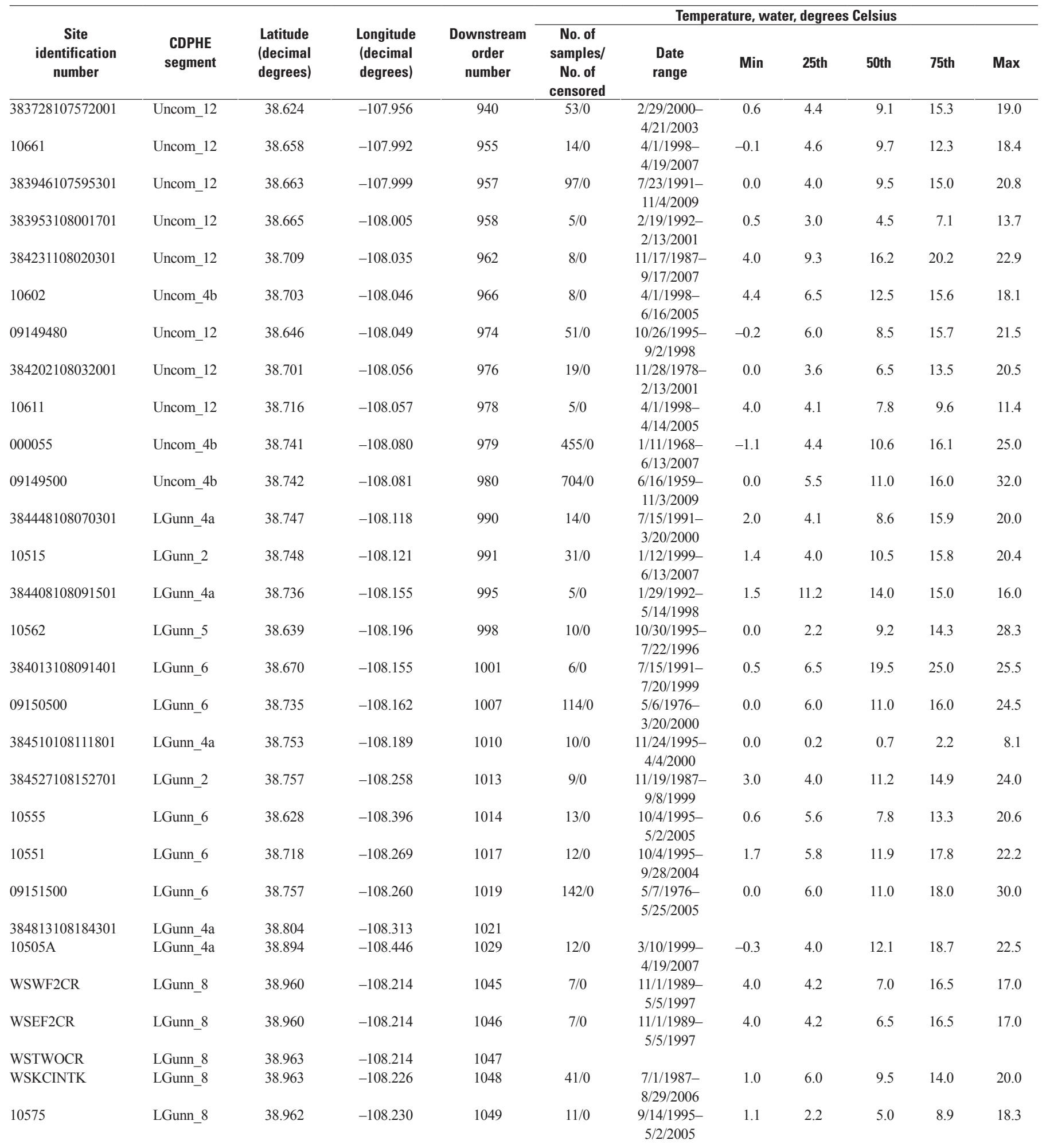


Appendix 1. Summary of surface-water-quality data and comparison to water-quality standards by site, by constituent, Piceance study area, western Colorado. Water-quality standards comparisons follow data summaries and are in blue text; standards are provided in table 3.-Continued

[CDPHE segment, Colorado Department of Health and the Environment stream segment as referred to in tables 2 and 3; latitude and longitude are in North American Datum of 1983; downstream order number assigned as part of analysis. $\mu \mathrm{g} / \mathrm{L}$, micrograms per liter; $\mu \mathrm{S} / \mathrm{cm}$, microsiemens per centimeter; $\mathrm{mg} / \mathrm{L}$, milligrams per liter; mL, milliliters; aq, aquatic; CO, Colorado; EPA, U.S. Environmental Protection Agency; Max, maximum; Min, minimum; NA, not applicable; No., number; NTU, nephelometric turbitidy units; WS, water supply; dates given in month/day/year format]

\begin{tabular}{|c|c|c|c|c|c|c|c|c|c|c|c|}
\hline $\begin{array}{c}\text { Site } \\
\text { identification } \\
\text { number }\end{array}$ & $\begin{array}{l}\text { CDPHE } \\
\text { segment }\end{array}$ & $\begin{array}{c}\text { Latitude } \\
\text { (decimal } \\
\text { degrees) }\end{array}$ & $\begin{array}{l}\text { Longitude } \\
\text { (decimal } \\
\text { degrees) }\end{array}$ & $\begin{array}{c}\text { Downstream } \\
\text { order } \\
\text { number }\end{array}$ & \multicolumn{7}{|c|}{ Temperature, water, degrees Celsius } \\
\hline WSKCBLCG & LGunn_8 & 38.962 & -108.232 & 1051 & $24 / 0$ & $\begin{array}{c}\text { 1/13/1988- } \\
7 / 1 / 1991\end{array}$ & 0.0 & 3.1 & 5.9 & 15.0 & 21.0 \\
\hline WSJUNNLTLO & LGunn_4b & 38.963 & -108.275 & 1053 & & & & & & & \\
\hline 10572 & LGunn_4b & 38.930 & -108.332 & 1055 & $10 / 0$ & $\begin{array}{c}9 / 14 / 1995- \\
5 / 2 / 2005\end{array}$ & 5.0 & 7.2 & 8.9 & 13.3 & 21.1 \\
\hline WSNFKCWR & LGunn_3 & 39.013 & -108.232 & 1057 & $17 / 0$ & $\begin{array}{c}\text { 7/1/1987- } \\
\text { 7/1/1991 }\end{array}$ & 3.0 & 7.1 & 9.0 & 10.4 & 17.2 \\
\hline WSNFKCDV & LGunn_4a & 38.997 & -108.277 & 1058 & $81 / 0$ & $\begin{array}{l}\text { 7/1/1987- } \\
10 / 8 / 2007\end{array}$ & 0.0 & 5.9 & 10.0 & 14.0 & 21.7 \\
\hline 10530 & LGunn_4b & 38.939 & -108.426 & 1069 & $5 / 0$ & $\begin{array}{l}3 / 9 / 1999 \\
4 / 26 / 2006\end{array}$ & -0.2 & 10.3 & 12.7 & 17.2 & 24.1 \\
\hline WSLOCKDRW & LGunn_4a & 39.008 & -108.346 & 1082 & $6 / 0$ & $\begin{array}{c}10 / 6 / 2003- \\
10 / 8 / 2007\end{array}$ & 5.7 & 6.3 & 9.0 & 13.2 & 17.8 \\
\hline WSWHITCR & LGunn_4a & 39.001 & -108.374 & 1083 & $41 / 0$ & $\begin{array}{c}\text { 7/1/1991- } \\
8 / 8 / 2006\end{array}$ & 4.0 & 10.0 & 13.9 & 16.5 & 20.5 \\
\hline 385839108264401 & LGunn_4a & 38.977 & -108.446 & 1097 & $21 / 0$ & $\begin{array}{c}4 / 29 / 1999 \\
5 / 23 / 2002\end{array}$ & -0.1 & 4.4 & 12.2 & 17.7 & 20.9 \\
\hline 10505 & LGunn_2 & 38.984 & -108.451 & 1098 & $65 / 0$ & $\begin{array}{c}1 / 12 / 1999 \\
5 / 15 / 2007\end{array}$ & -0.3 & 4.4 & 12.2 & 18.0 & 23.6 \\
\hline CDOWRW-562 & LGunn_2 & 38.984 & -108.451 & 1099 & $42 / 0$ & $\begin{array}{c}\text { 3/11/1997- } \\
6 / 8 / 1999\end{array}$ & 2.0 & 7.8 & 11.0 & 15.0 & 24.0 \\
\hline 09152500 & LGunn_2 & 38.983 & -108.451 & 1100 & $807 / 0$ & $\begin{array}{l}4 / 1 / 1960- \\
9 / 28 / 2009\end{array}$ & 0.0 & 6.0 & 11.9 & 17.2 & 25.5 \\
\hline
\end{tabular}


Appendix 1. Summary of surface-water-quality data and comparison to water-quality standards by site, by constituent, Piceance study area, western Colorado. Water-quality standards comparisons follow data summaries and are in blue text; standards are provided in table 3.-Continued

[CDPHE segment, Colorado Department of Health and the Environment stream segment as referred to in tables 2 and 3; latitude and longitude are in North American Datum of 1983; downstream order number assigned as part of analysis. $\mu \mathrm{g} / \mathrm{L}$, micrograms per liter; $\mu \mathrm{S} / \mathrm{cm}$, microsiemens per centimeter; $\mathrm{mg} / \mathrm{L}$, milligrams per liter; mL, milliliters; aq, aquatic; CO, Colorado; EPA, U.S. Environmental Protection Agency; Max, maximum; Min, minimum; NA, not applicable; No., number; NTU, nephelometric turbitidy units; WS, water supply; dates given in month/day/year format]

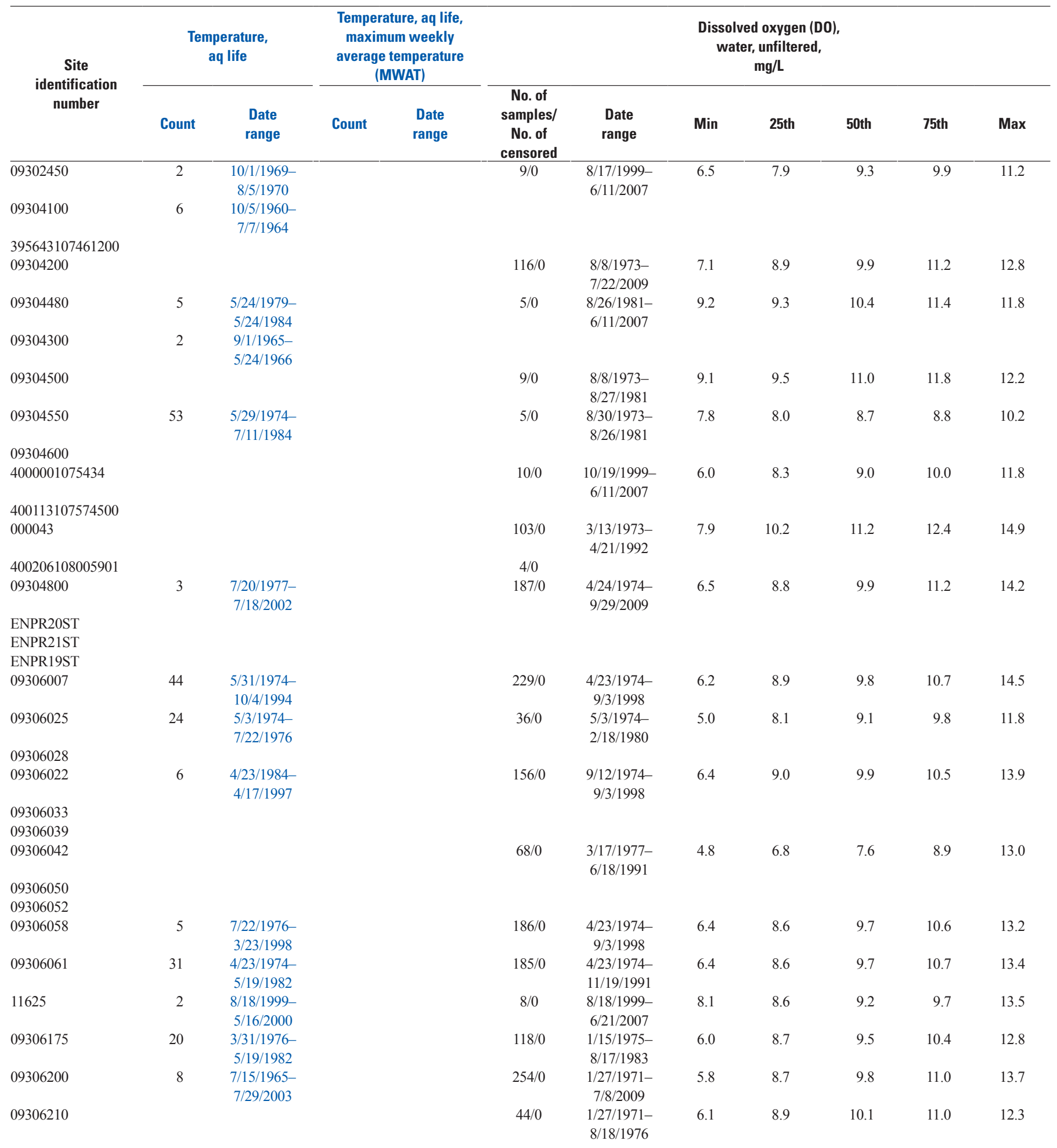


Appendix 1. Summary of surface-water-quality data and comparison to water-quality standards by site, by constituent, Piceance study area, western Colorado. Water-quality standards comparisons follow data summaries and are in blue text; standards are provided in table 3.-Continued

[CDPHE segment, Colorado Department of Health and the Environment stream segment as referred to in tables 2 and 3; latitude and longitude are in North American Datum of 1983; downstream order number assigned as part of analysis. $\mu \mathrm{g} / \mathrm{L}$, micrograms per liter; $\mu \mathrm{S} / \mathrm{cm}$, microsiemens per centimeter; $\mathrm{mg} / \mathrm{L}$, milligrams per liter; mL, milliliters; aq, aquatic; CO, Colorado; EPA, U.S. Environmental Protection Agency; Max, maximum; Min, minimum; NA, not applicable; No., number; NTU, nephelometric turbitidy units; WS, water supply; dates given in month/day/year format]

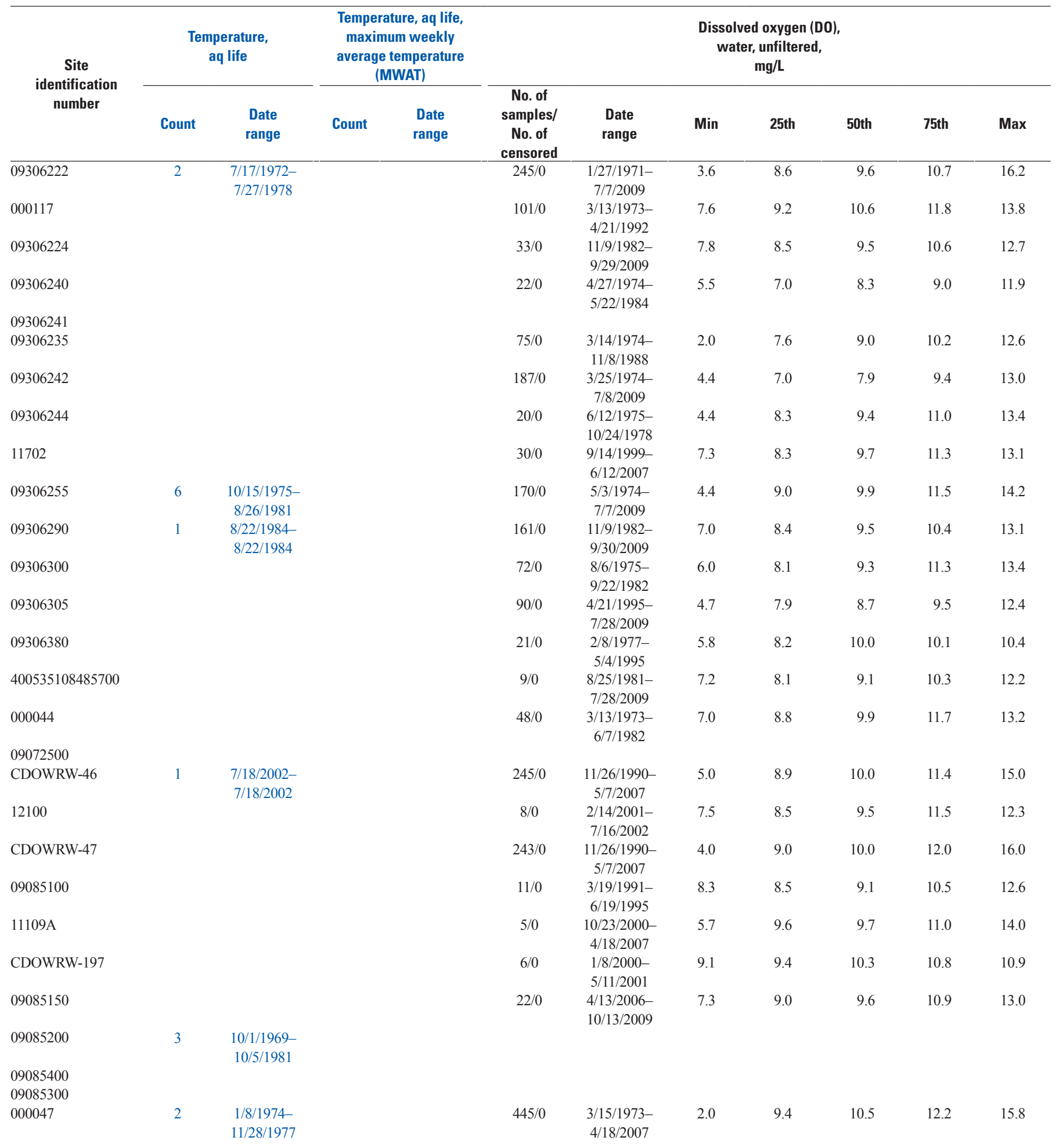


Appendix 1. Summary of surface-water-quality data and comparison to water-quality standards by site, by constituent, Piceance study area, western Colorado. Water-quality standards comparisons follow data summaries and are in blue text; standards are provided in table 3.-Continued

[CDPHE segment, Colorado Department of Health and the Environment stream segment as referred to in tables 2 and 3; latitude and longitude are in North American Datum of 1983; downstream order number assigned as part of analysis. $\mu \mathrm{g} / \mathrm{L}$, micrograms per liter; $\mu \mathrm{S} / \mathrm{cm}$, microsiemens per centimeter; $\mathrm{mg} / \mathrm{L}$, milligrams per liter; mL, milliliters; aq, aquatic; CO, Colorado; EPA, U.S. Environmental Protection Agency; Max, maximum; Min, minimum; NA, not applicable; No., number; NTU, nephelometric turbitidy units; WS, water supply; dates given in month/day/year format]

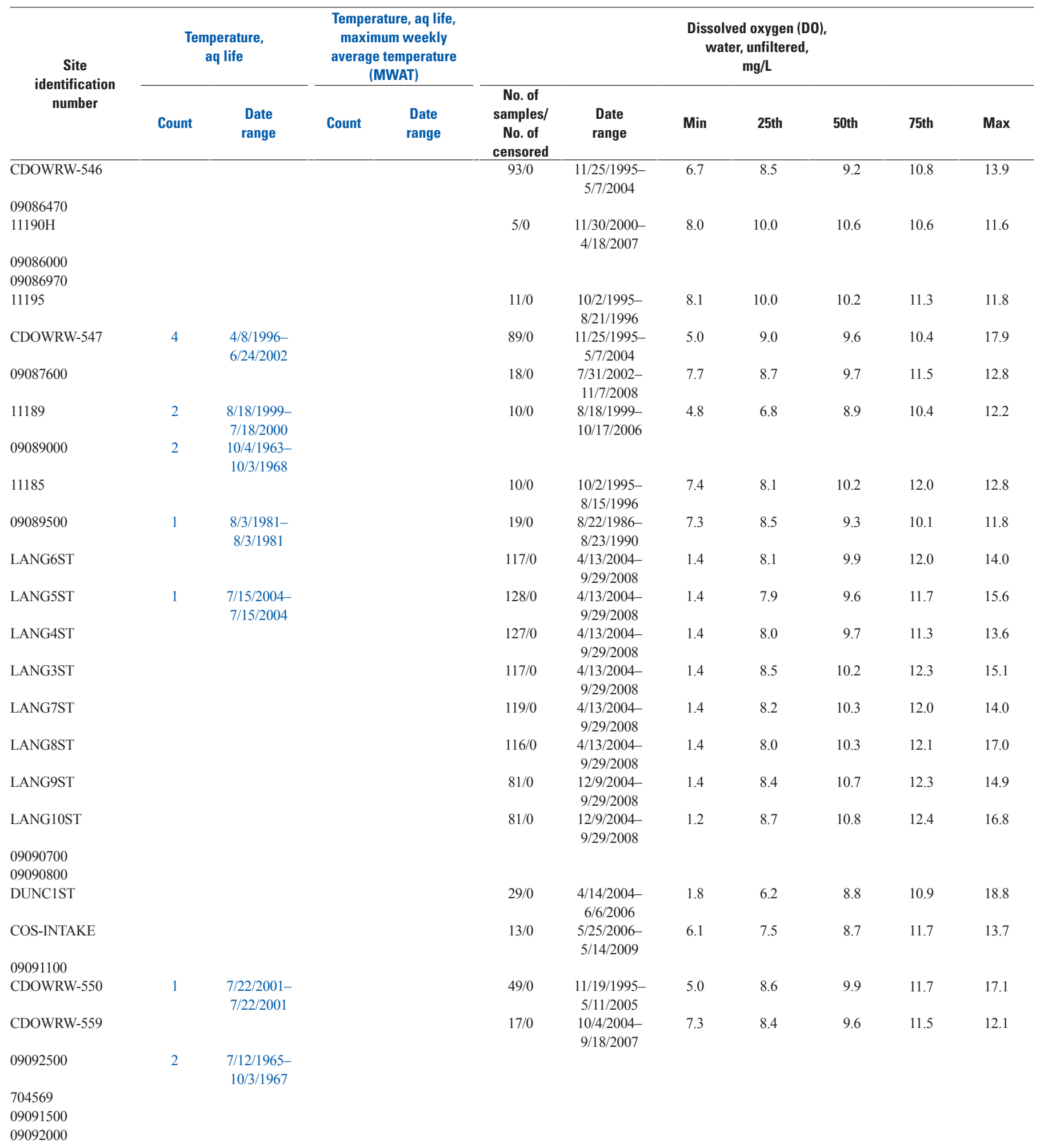


Appendix 1. Summary of surface-water-quality data and comparison to water-quality standards by site, by constituent, Piceance study area, western Colorado. Water-quality standards comparisons follow data summaries and are in blue text; standards are provided in table 3.-Continued

[CDPHE segment, Colorado Department of Health and the Environment stream segment as referred to in tables 2 and 3; latitude and longitude are in North American Datum of 1983; downstream order number assigned as part of analysis. $\mu \mathrm{g} / \mathrm{L}$, micrograms per liter; $\mu \mathrm{S} / \mathrm{cm}$, microsiemens per centimeter; $\mathrm{mg} / \mathrm{L}$, milligrams per liter; mL, milliliters; aq, aquatic; CO, Colorado; EPA, U.S. Environmental Protection Agency; Max, maximum; Min, minimum; NA, not applicable; No., number; NTU, nephelometric turbitidy units; WS, water supply; dates given in month/day/year format]

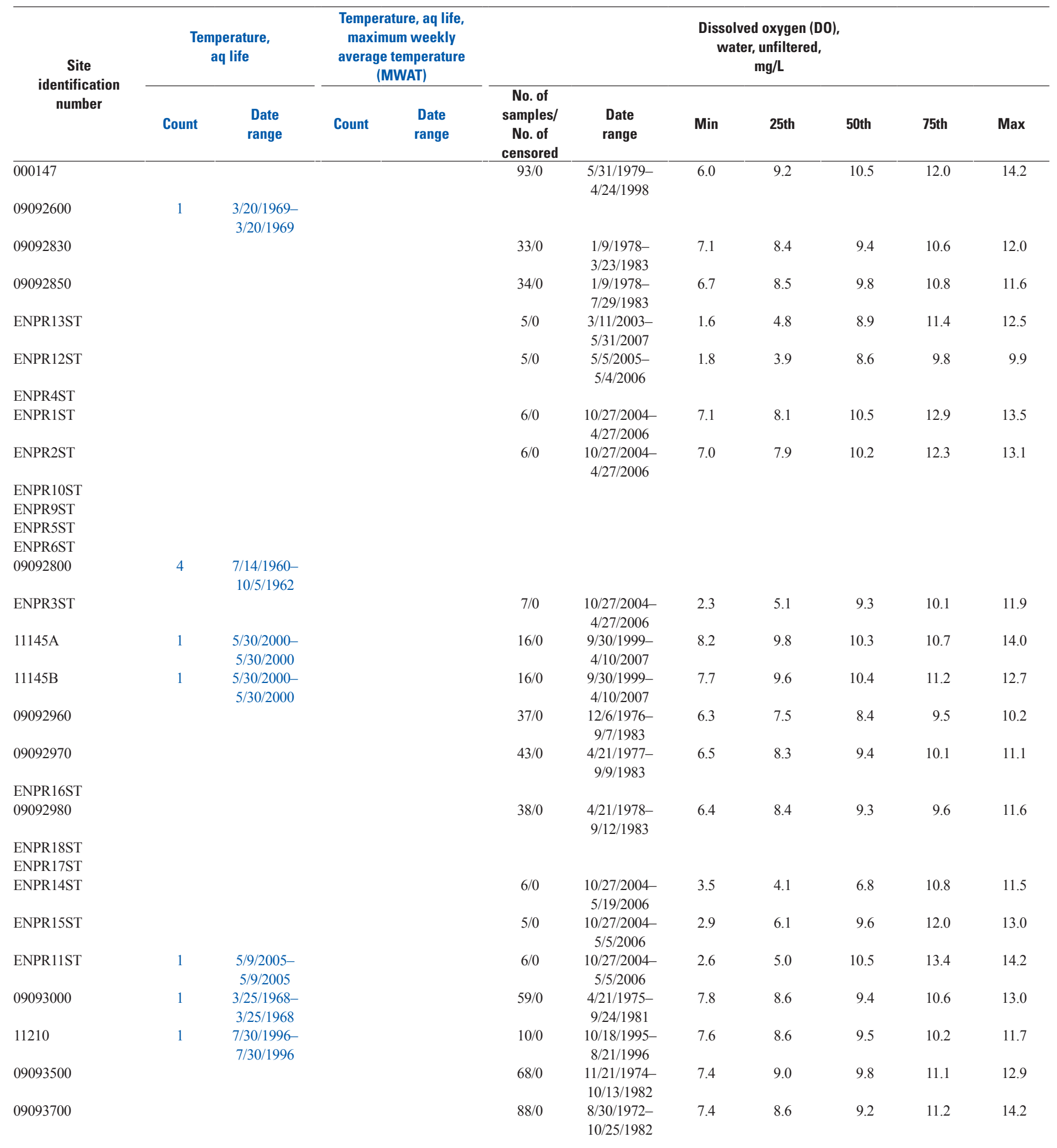


Appendix 1. Summary of surface-water-quality data and comparison to water-quality standards by site, by constituent, Piceance study area, western Colorado. Water-quality standards comparisons follow data summaries and are in blue text; standards are provided in table 3.-Continued

[CDPHE segment, Colorado Department of Health and the Environment stream segment as referred to in tables 2 and 3; latitude and longitude are in North American Datum of 1983; downstream order number assigned as part of analysis. $\mu \mathrm{g} / \mathrm{L}$, micrograms per liter; $\mu \mathrm{S} / \mathrm{cm}$, microsiemens per centimeter; $\mathrm{mg} / \mathrm{L}$, milligrams per liter; mL, milliliters; aq, aquatic; CO, Colorado; EPA, U.S. Environmental Protection Agency; Max, maximum; Min, minimum; NA, not applicable; No., number; NTU, nephelometric turbitidy units; WS, water supply; dates given in month/day/year format]

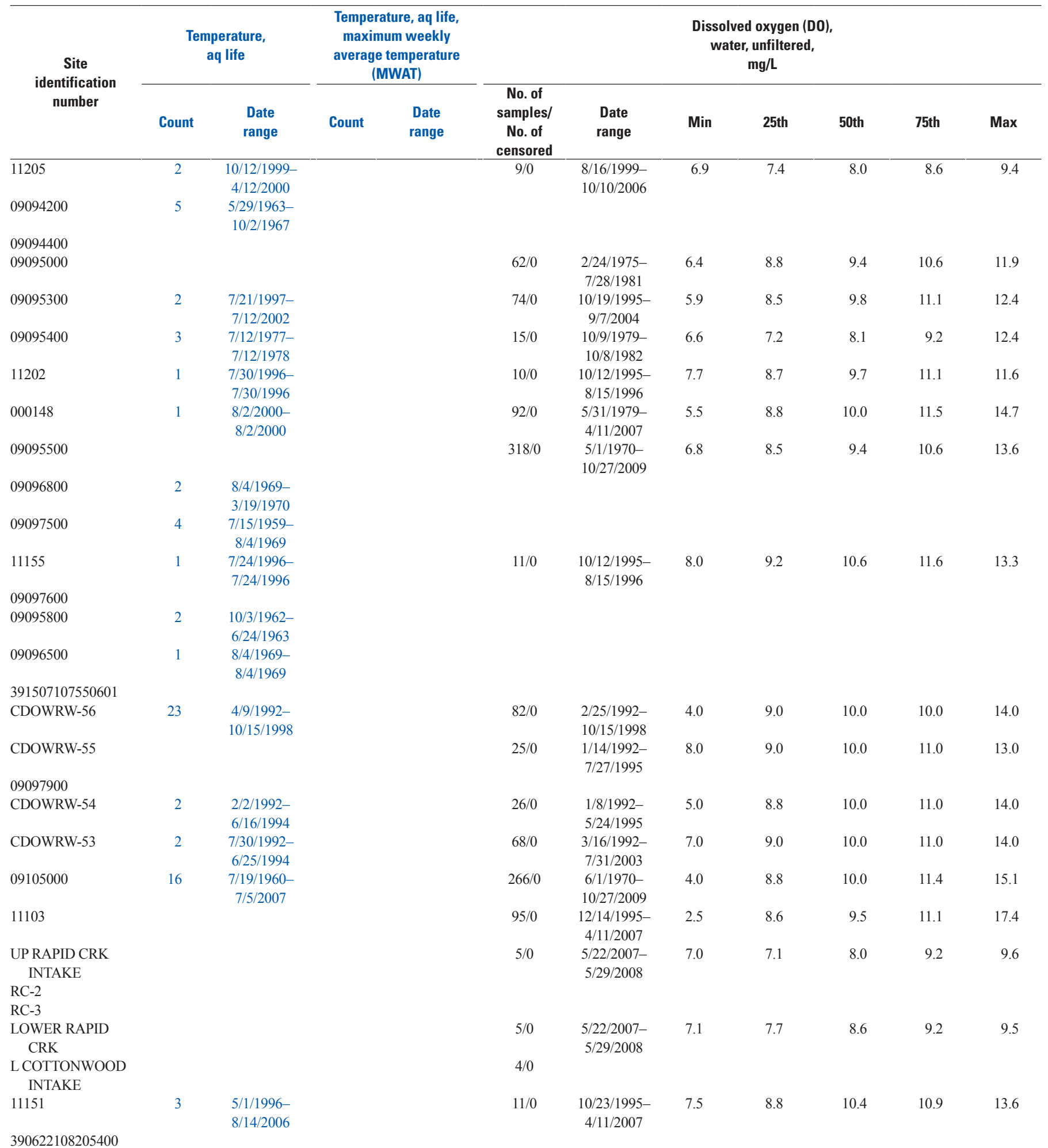


Appendix 1. Summary of surface-water-quality data and comparison to water-quality standards by site, by constituent, Piceance study area, western Colorado. Water-quality standards comparisons follow data summaries and are in blue text; standards are provided in table 3.-Continued

[CDPHE segment, Colorado Department of Health and the Environment stream segment as referred to in tables 2 and 3; latitude and longitude are in North American Datum of 1983; downstream order number assigned as part of analysis. $\mu \mathrm{g} / \mathrm{L}$, micrograms per liter; $\mu \mathrm{S} / \mathrm{cm}$, microsiemens per centimeter; $\mathrm{mg} / \mathrm{L}$, milligrams per liter; mL, milliliters; aq, aquatic; CO, Colorado; EPA, U.S. Environmental Protection Agency; Max, maximum; Min, minimum; NA, not applicable; No., number; NTU, nephelometric turbitidy units; WS, water supply; dates given in month/day/year format]

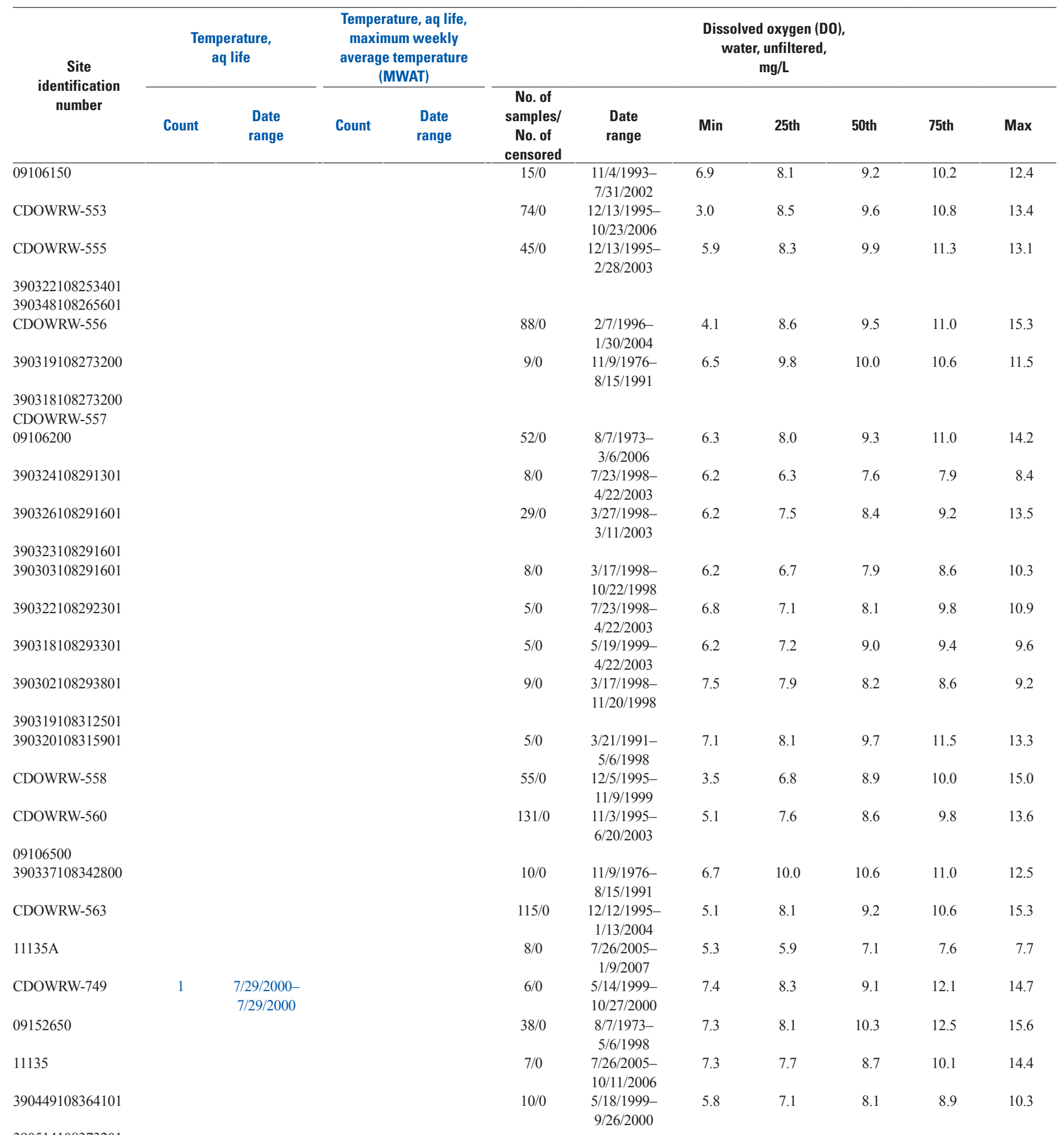


Appendix 1. Summary of surface-water-quality data and comparison to water-quality standards by site, by constituent, Piceance study area, western Colorado. Water-quality standards comparisons follow data summaries and are in blue text; standards are provided in table 3.-Continued

[CDPHE segment, Colorado Department of Health and the Environment stream segment as referred to in tables 2 and 3; latitude and longitude are in North American Datum of 1983; downstream order number assigned as part of analysis. $\mu \mathrm{g} / \mathrm{L}$, micrograms per liter; $\mu \mathrm{S} / \mathrm{cm}$, microsiemens per centimeter; mg/L, milligrams per liter; mL, milliliters; aq, aquatic; CO, Colorado; EPA, U.S. Environmental Protection Agency; Max, maximum; Min, minimum; NA, not applicable; No., number; NTU, nephelometric turbitidy units; WS, water supply; dates given in month/day/year format]

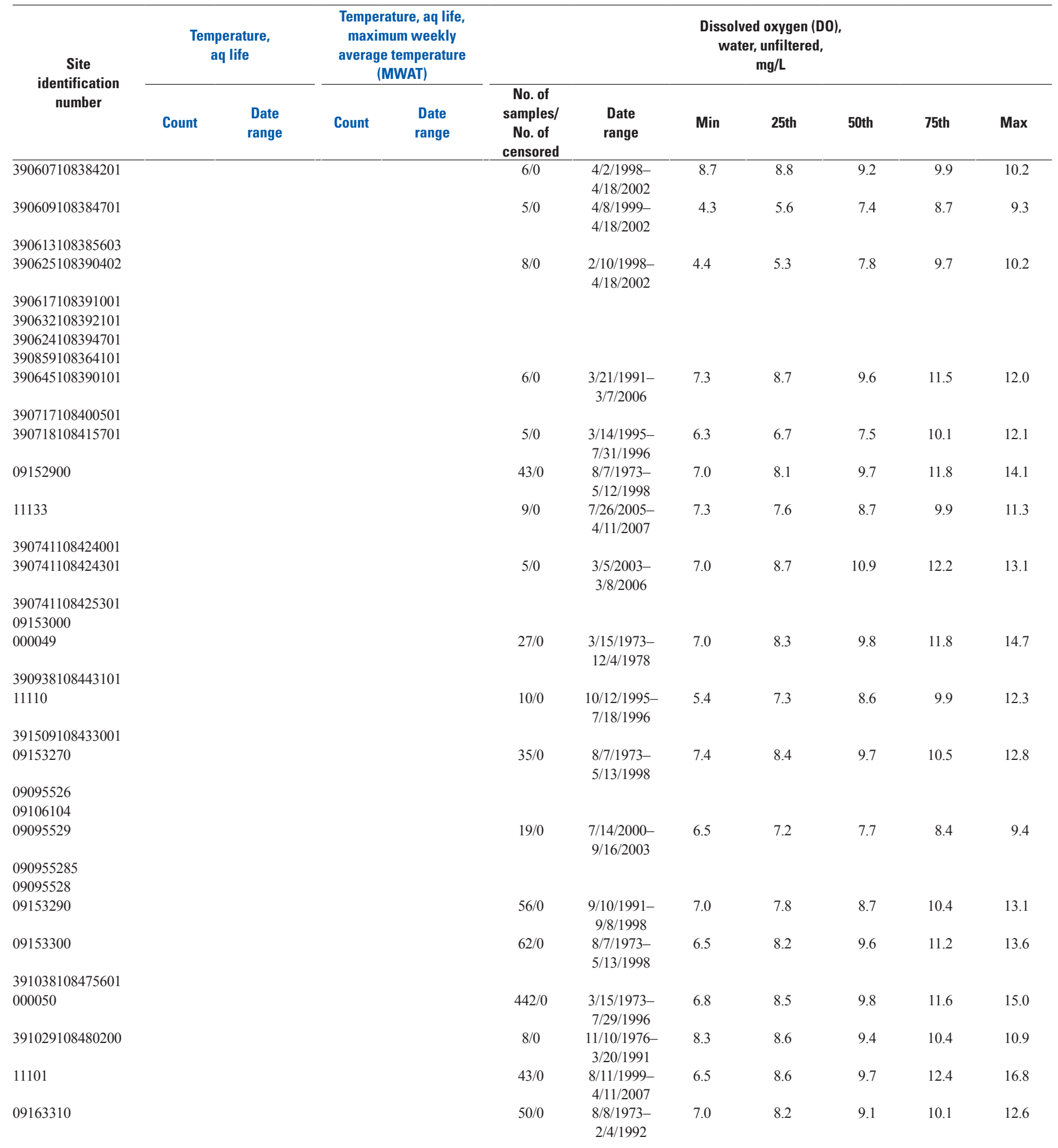


Appendix 1. Summary of surface-water-quality data and comparison to water-quality standards by site, by constituent, Piceance study area, western Colorado. Water-quality standards comparisons follow data summaries and are in blue text; standards are provided in table 3.-Continued

[CDPHE segment, Colorado Department of Health and the Environment stream segment as referred to in tables 2 and 3; latitude and longitude are in North American Datum of 1983; downstream order number assigned as part of analysis. $\mu \mathrm{g} / \mathrm{L}$, micrograms per liter; $\mu \mathrm{S} / \mathrm{cm}$, microsiemens per centimeter; $\mathrm{mg} / \mathrm{L}$, milligrams per liter; mL, milliliters; aq, aquatic; CO, Colorado; EPA, U.S. Environmental Protection Agency; Max, maximum; Min, minimum; NA, not applicable; No., number; NTU, nephelometric turbitidy units; WS, water supply; dates given in month/day/year format]

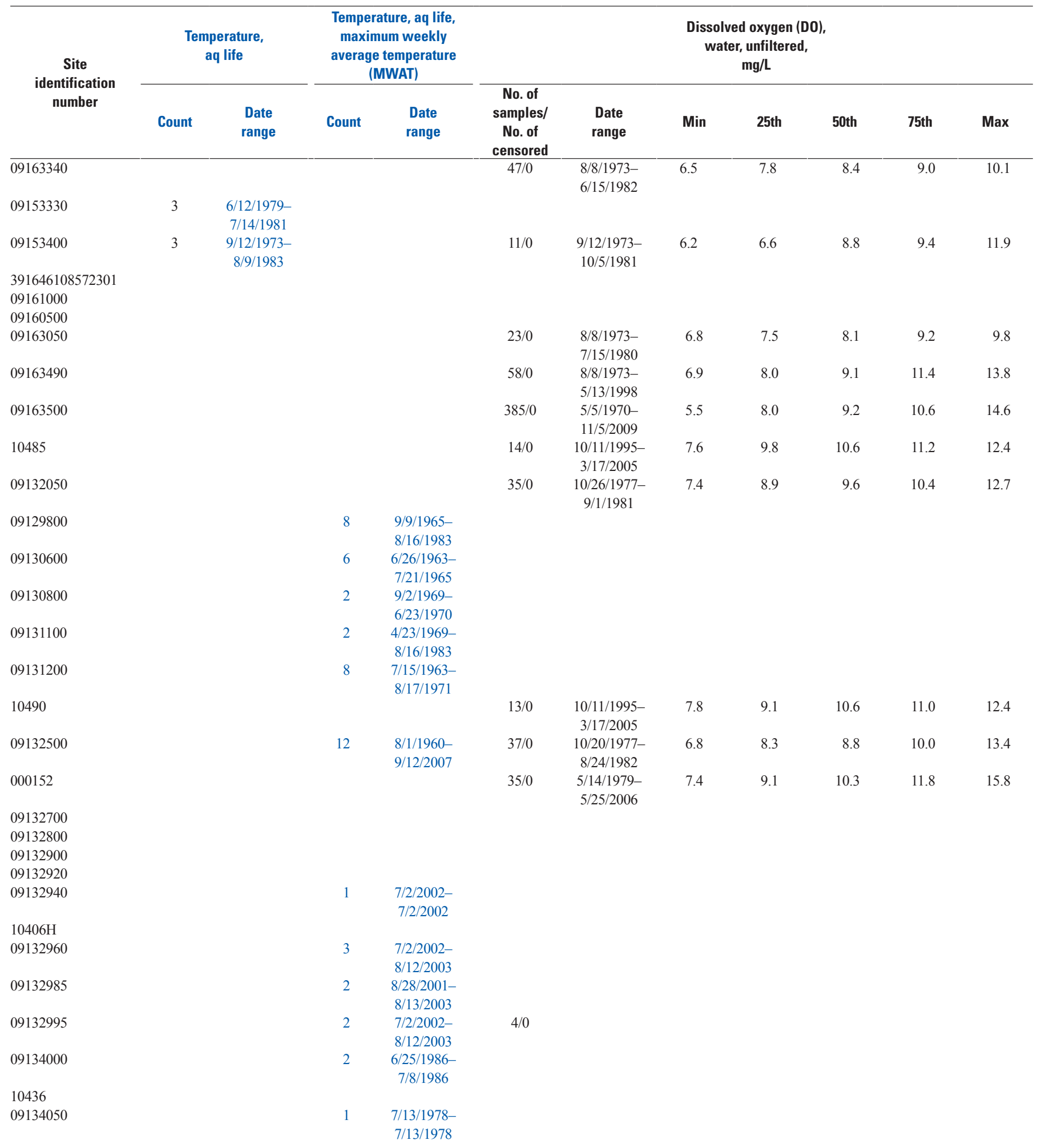


Appendix 1. Summary of surface-water-quality data and comparison to water-quality standards by site, by constituent, Piceance study area, western Colorado. Water-quality standards comparisons follow data summaries and are in blue text; standards are provided in table 3.-Continued

[CDPHE segment, Colorado Department of Health and the Environment stream segment as referred to in tables 2 and 3; latitude and longitude are in North American Datum of 1983; downstream order number assigned as part of analysis. $\mu \mathrm{g} / \mathrm{L}$, micrograms per liter; $\mu \mathrm{S} / \mathrm{cm}$, microsiemens per centimeter; mg/L, milligrams per liter; mL, milliliters; aq, aquatic; CO, Colorado; EPA, U.S. Environmental Protection Agency; Max, maximum; Min, minimum; NA, not applicable; No., number; NTU, nephelometric turbitidy units; WS, water supply; dates given in month/day/year format]

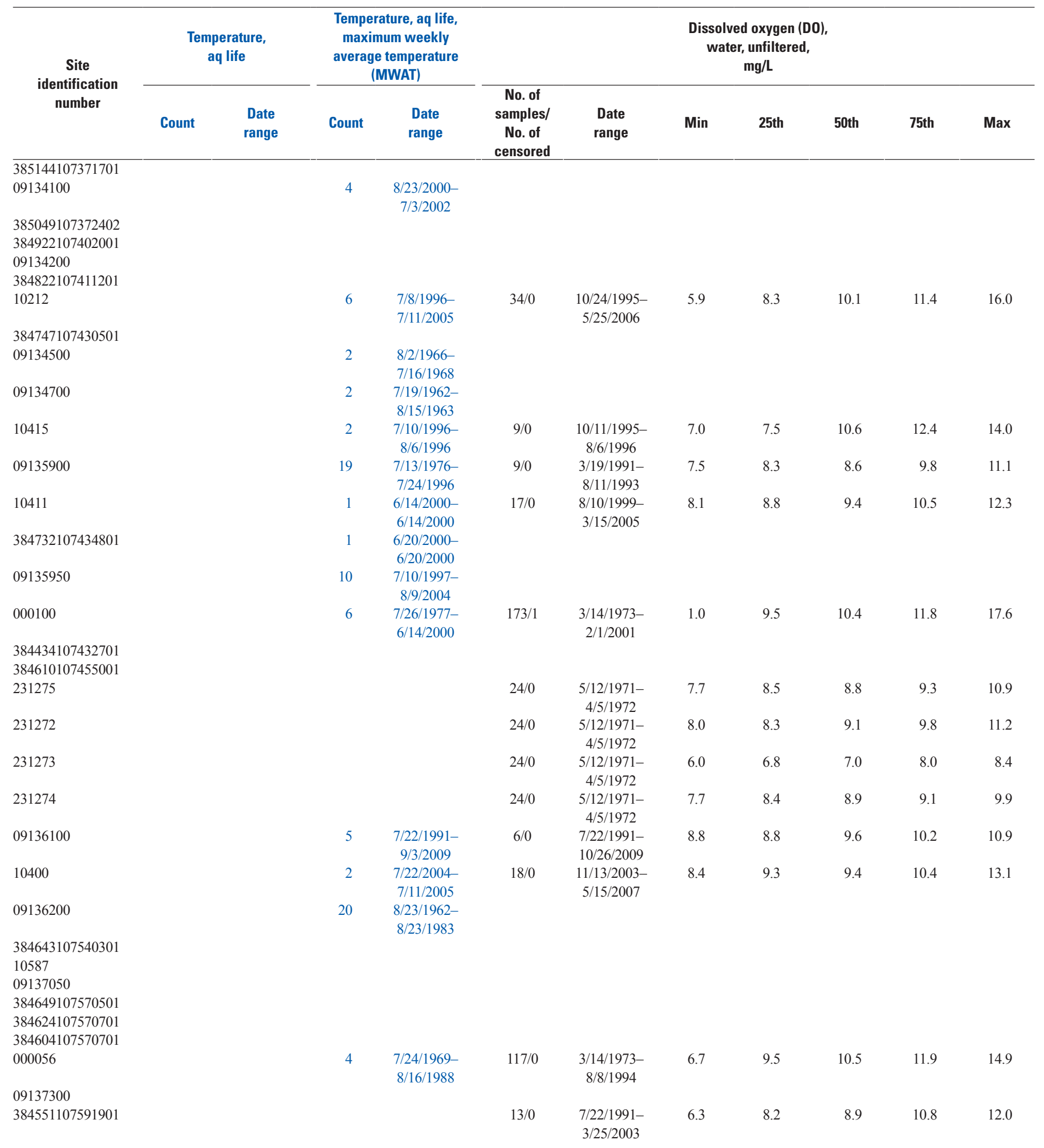


Appendix 1. Summary of surface-water-quality data and comparison to water-quality standards by site, by constituent, Piceance study area, western Colorado. Water-quality standards comparisons follow data summaries and are in blue text; standards are provided in table 3.-Continued

[CDPHE segment, Colorado Department of Health and the Environment stream segment as referred to in tables 2 and 3; latitude and longitude are in North American Datum of 1983; downstream order number assigned as part of analysis. $\mu \mathrm{g} / \mathrm{L}$, micrograms per liter; $\mu \mathrm{S} / \mathrm{cm}$, microsiemens per centimeter; $\mathrm{mg} / \mathrm{L}$, milligrams per liter; mL, milliliters; aq, aquatic; CO, Colorado; EPA, U.S. Environmental Protection Agency; Max, maximum; Min, minimum; NA, not applicable; No., number; NTU, nephelometric turbitidy units; WS, water supply; dates given in month/day/year format]

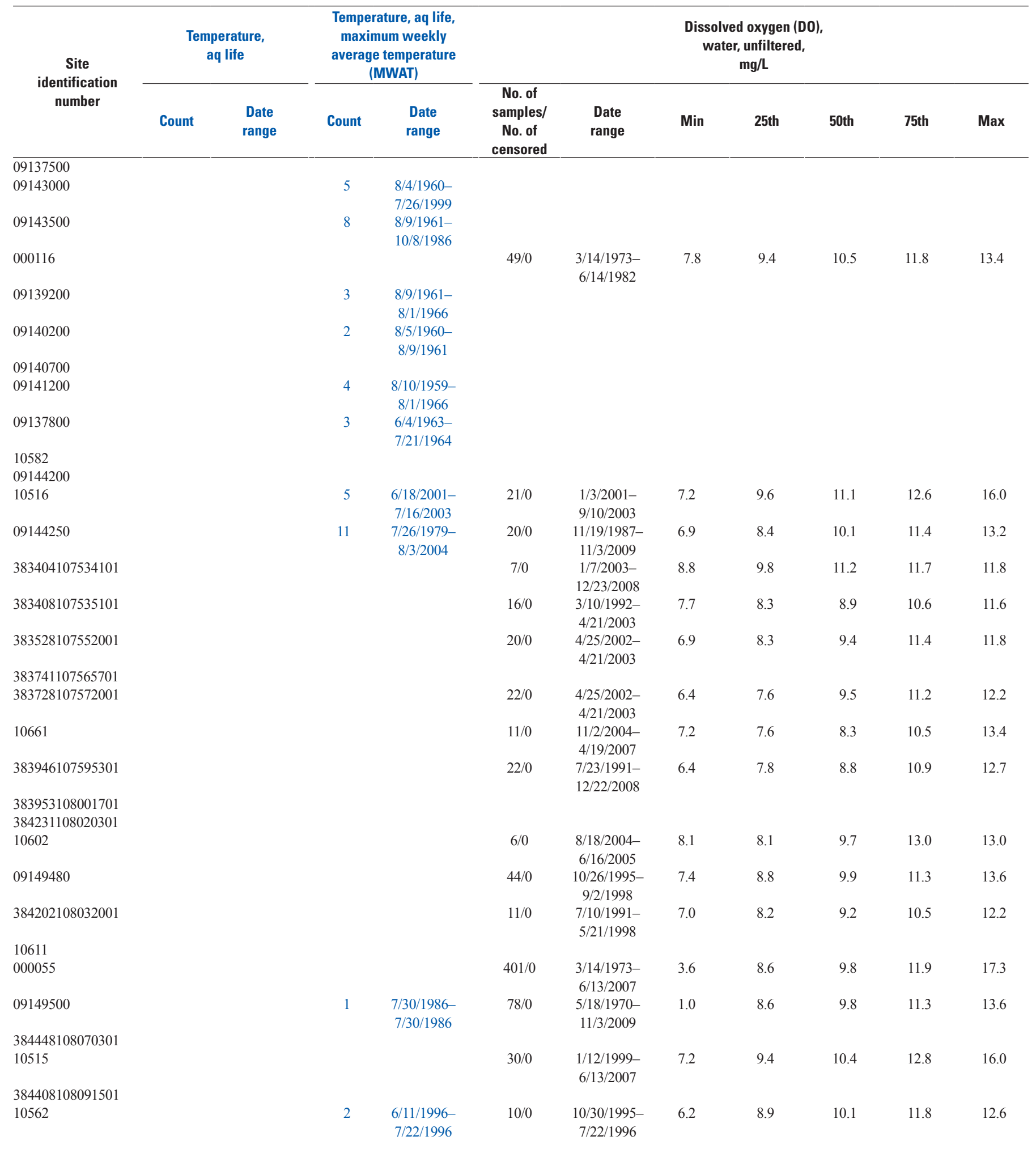


Appendix 1. Summary of surface-water-quality data and comparison to water-quality standards by site, by constituent, Piceance study area, western Colorado. Water-quality standards comparisons follow data summaries and are in blue text; standards are provided in table 3.-Continued

[CDPHE segment, Colorado Department of Health and the Environment stream segment as referred to in tables 2 and 3; latitude and longitude are in North American Datum of 1983; downstream order number assigned as part of analysis. $\mu \mathrm{g} / \mathrm{L}$, micrograms per liter; $\mu \mathrm{S} / \mathrm{cm}$, microsiemens per centimeter; $\mathrm{mg} / \mathrm{L}$, milligrams per liter; mL, milliliters; aq, aquatic; CO, Colorado; EPA, U.S. Environmental Protection Agency; Max, maximum; Min, minimum; NA, not applicable; No., number; NTU, nephelometric turbitidy units; WS, water supply; dates given in month/day/year format]

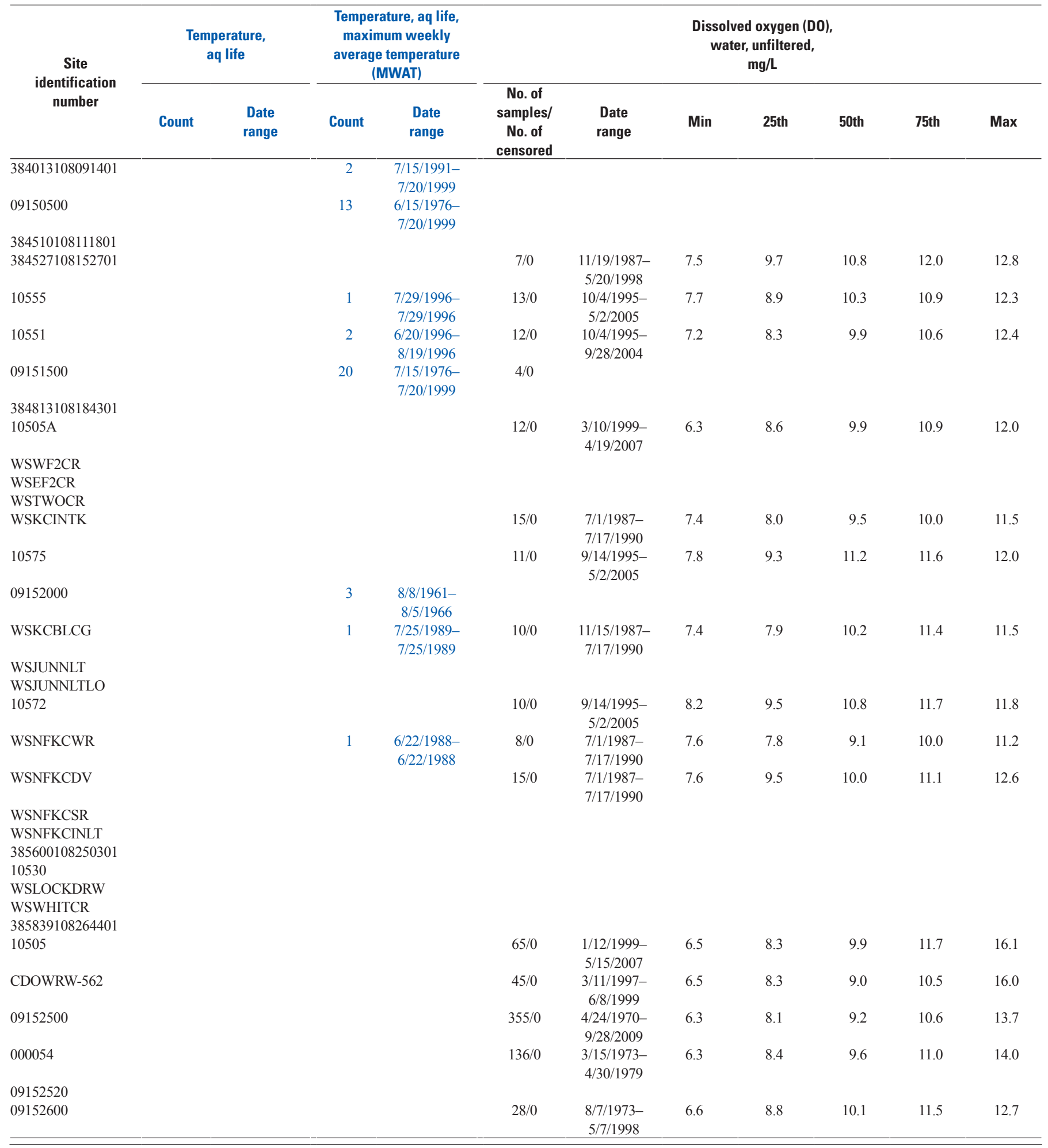


Appendix 1. Summary of surface-water-quality data and comparison to water-quality standards by site, by constituent, Piceance study area, western Colorado. Water-quality standards comparisons follow data summaries and are in blue text; standards are provided in table 3.-Continued

[CDPHE segment, Colorado Department of Health and the Environment stream segment as referred to in tables 2 and 3; latitude and longitude are in North American Datum of 1983; downstream order number assigned as part of analysis. $\mu \mathrm{g} / \mathrm{L}$, micrograms per liter; $\mu \mathrm{S} / \mathrm{cm}$, microsiemens per centimeter; $\mathrm{mg} / \mathrm{L}$, milligrams per liter; mL, milliliters; aq, aquatic; CO, Colorado; EPA, U.S. Environmental Protection Agency; Max, maximum; Min, minimum; NA, not applicable; No., number; NTU, nephelometric turbitidy units; WS, water supply; dates given in month/day/year format]

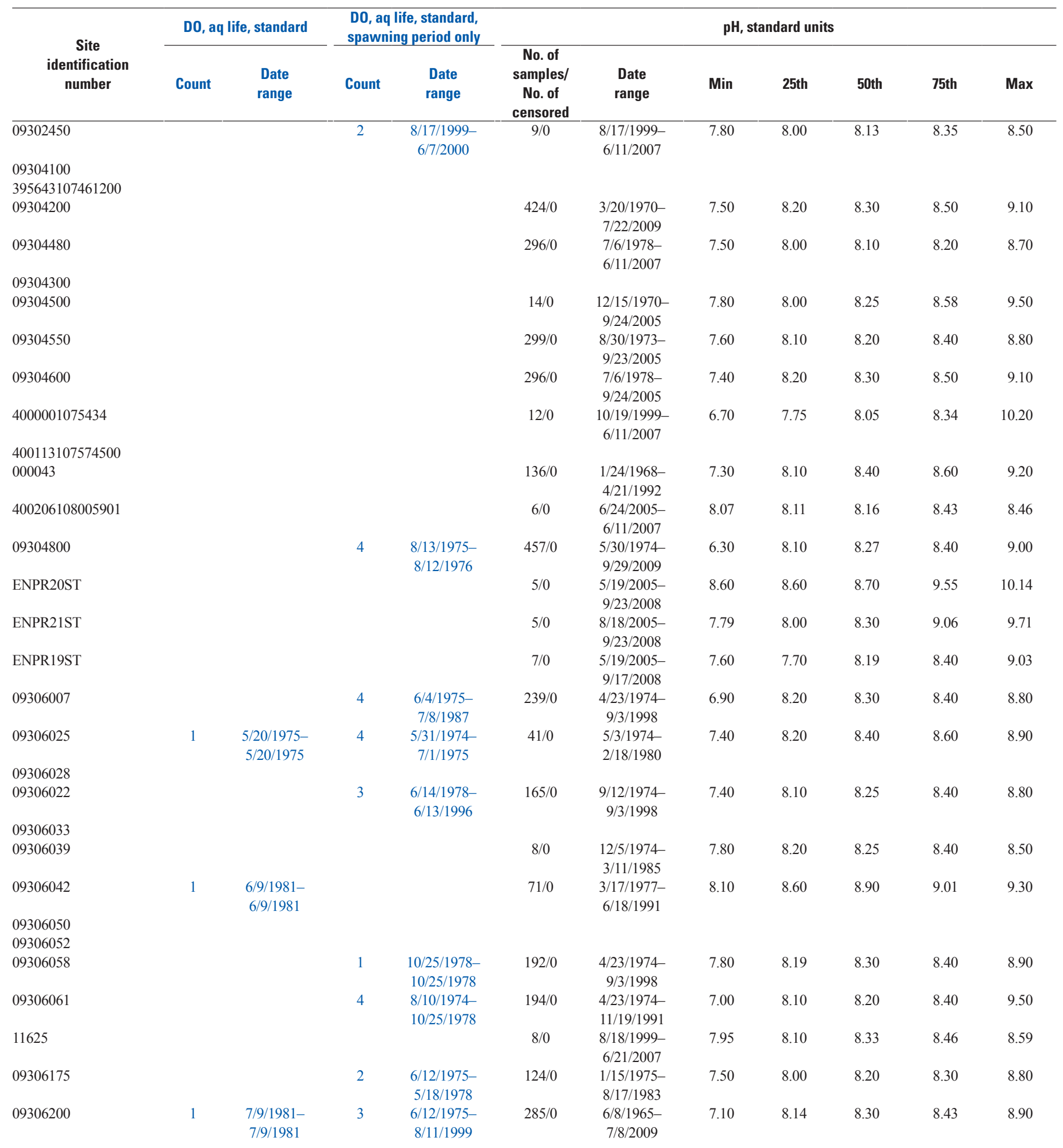


Appendix 1. Summary of surface-water-quality data and comparison to water-quality standards by site, by constituent, Piceance study area, western Colorado. Water-quality standards comparisons follow data summaries and are in blue text; standards are provided in table 3.-Continued

[CDPHE segment, Colorado Department of Health and the Environment stream segment as referred to in tables 2 and 3; latitude and longitude are in North American Datum of 1983; downstream order number assigned as part of analysis. $\mu \mathrm{g} / \mathrm{L}$, micrograms per liter; $\mu \mathrm{S} / \mathrm{cm}$, microsiemens per centimeter; $\mathrm{mg} / \mathrm{L}$, milligrams per liter; mL, milliliters; aq, aquatic; CO, Colorado; EPA, U.S. Environmental Protection Agency; Max, maximum; Min, minimum; NA, not applicable; No., number; NTU, nephelometric turbitidy units; WS, water supply; dates given in month/day/year format]

\begin{tabular}{|c|c|c|c|c|c|c|c|c|c|c|c|}
\hline \multirow{2}{*}{$\begin{array}{c}\text { Site } \\
\text { identification } \\
\text { number }\end{array}$} & \multicolumn{2}{|c|}{ D0, aq life, standard } & \multicolumn{2}{|c|}{$\begin{array}{l}\text { D0, aq life, standard, } \\
\text { spawning period only }\end{array}$} & \multicolumn{7}{|c|}{$\mathrm{pH}$, standard units } \\
\hline & Count & $\begin{array}{c}\text { Date } \\
\text { range }\end{array}$ & Count & $\begin{array}{l}\text { Date } \\
\text { range }\end{array}$ & $\begin{array}{c}\text { samples/ } \\
\text { No. of } \\
\text { censored }\end{array}$ & $\begin{array}{l}\text { Date } \\
\text { range }\end{array}$ & Min & 25th & 50th & 75th & Max \\
\hline 09306210 & & & & & $56 / 0$ & $\begin{array}{c}\text { 12/15/1970- } \\
8 / 18 / 1976\end{array}$ & 7.40 & 7.90 & 8.10 & 8.25 & 8.70 \\
\hline 09306222 & 3 & $\begin{array}{c}7 / 21 / 1976- \\
8 / 28 / 1991\end{array}$ & & & $278 / 0$ & $\begin{array}{c}6 / 8 / 1965- \\
7 / 7 / 2009\end{array}$ & 7.40 & 8.27 & 8.50 & 8.60 & 8.90 \\
\hline 09306224 & & & & & $48 / 0$ & $\begin{array}{l}\text { 11/9/1982- } \\
\text { 9/29/2009 }\end{array}$ & 8.00 & 8.20 & 8.40 & 8.50 & 8.70 \\
\hline 09306240 & & & & & $27 / 0$ & $\begin{array}{c}4 / 27 / 1974 \\
3 / 11 / 1985\end{array}$ & 6.90 & 8.00 & 8.10 & 8.30 & 9.00 \\
\hline \multicolumn{12}{|l|}{09306241} \\
\hline 09306235 & 1 & $\begin{array}{l}5 / 7 / 1985 \\
5 / 7 / 1985\end{array}$ & & & $87 / 0$ & $\begin{array}{c}3 / 14 / 1974 \\
11 / 8 / 1988\end{array}$ & 7.30 & 7.90 & 8.10 & 8.30 & 8.70 \\
\hline 11702 & & & & & $31 / 0$ & $\begin{array}{c}9 / 14 / 1999- \\
6 / 12 / 2007\end{array}$ & 7.20 & 8.20 & 8.40 & 8.63 & 9.03 \\
\hline 09306255 & 1 & $\begin{array}{c}7 / 10 / 1981- \\
7 / 10 / 1981\end{array}$ & & & $167 / 0$ & $\begin{array}{c}4 / 8 / 1965- \\
7 / 7 / 2009\end{array}$ & 7.60 & 8.50 & 8.60 & 8.70 & 9.10 \\
\hline 09306290 & & & & & $181 / 0$ & $\begin{array}{l}\text { 11/9/1982- } \\
9 / 30 / 2009\end{array}$ & 7.50 & 8.30 & 8.40 & 8.50 & 8.80 \\
\hline 09306300 & & & & & $77 / 0$ & $\begin{array}{l}8 / 6 / 1975- \\
9 / 22 / 1982\end{array}$ & 7.40 & 8.10 & 8.30 & 8.40 & 8.70 \\
\hline 09306305 & 2 & $\begin{array}{l}7 / 30 / 1998- \\
8 / 30 / 2000\end{array}$ & & & $81 / 0$ & $\begin{array}{c}4 / 21 / 1995- \\
7 / 28 / 2009\end{array}$ & 7.63 & 8.20 & 8.40 & 8.50 & 8.70 \\
\hline 09306380 & & & & & $23 / 0$ & $\begin{array}{l}2 / 8 / 1977- \\
11 / 8 / 1995\end{array}$ & 7.85 & 8.30 & 8.44 & 8.50 & 8.59 \\
\hline 400535108485700 & & & & & $9 / 0$ & $\begin{array}{c}8 / 25 / 1981- \\
7 / 28 / 2009\end{array}$ & 8.10 & 8.40 & 8.50 & 8.60 & 8.65 \\
\hline CDOWRW-47 & 3 & $\begin{array}{l}2 / 21 / 1996- \\
12 / 15 / 2004\end{array}$ & 9 & $\begin{array}{l}5 / 20 / 1993- \\
2 / 23 / 2007\end{array}$ & $238 / 0$ & $\begin{array}{l}11 / 26 / 1990- \\
5 / 7 / 2007\end{array}$ & 7.32 & 8.00 & 8.20 & 8.39 & 8.76 \\
\hline 09085100 & & & & & $262 / 0$ & $\begin{array}{c}12 / 6 / 1977- \\
6 / 19 / 1995\end{array}$ & 6.80 & 7.90 & 8.00 & 8.20 & 8.90 \\
\hline $11109 \mathrm{~A}$ & 1 & $\begin{array}{l}4 / 18 / 2007- \\
4 / 18 / 2007\end{array}$ & 1 & $\begin{array}{c}4 / 18 / 2007- \\
4 / 18 / 2007\end{array}$ & $5 / 0$ & $\begin{array}{c}10 / 23 / 2000- \\
4 / 18 / 2007\end{array}$ & 8.09 & 8.21 & 8.26 & 8.39 & 8.46 \\
\hline CDOWRW-197 & & & & & $6 / 0$ & $\begin{array}{l}1 / 8 / 2000 \\
5 / 11 / 2001\end{array}$ & 8.45 & 8.46 & 8.50 & 8.92 & 9.42 \\
\hline 09085150 & & & & & $22 / 0$ & $\begin{array}{l}4 / 13 / 2006- \\
10 / 13 / 2009\end{array}$ & 7.90 & 8.09 & 8.35 & 8.52 & 8.72 \\
\hline \multicolumn{12}{|l|}{$\begin{array}{l}09085200 \\
09085400\end{array}$} \\
\hline 000047 & 1 & $\begin{array}{c}10 / 27 / 1992- \\
10 / 27 / 1992\end{array}$ & 1 & $\begin{array}{c}10 / 27 / 1992- \\
10 / 27 / 1992\end{array}$ & $470 / 0$ & $\begin{array}{l}1 / 4 / 1968- \\
4 / 18 / 2007\end{array}$ & 6.45 & 8.10 & 8.30 & 8.50 & 9.50 \\
\hline
\end{tabular}


Appendix 1. Summary of surface-water-quality data and comparison to water-quality standards by site, by constituent, Piceance study area, western Colorado. Water-quality standards comparisons follow data summaries and are in blue text; standards are provided in table 3.-Continued

[CDPHE segment, Colorado Department of Health and the Environment stream segment as referred to in tables 2 and 3; latitude and longitude are in North American Datum of 1983; downstream order number assigned as part of analysis. $\mu \mathrm{g} / \mathrm{L}$, micrograms per liter; $\mu \mathrm{S} / \mathrm{cm}$, microsiemens per centimeter; $\mathrm{mg} / \mathrm{L}$, milligrams per liter; mL, milliliters; aq, aquatic; CO, Colorado; EPA, U.S. Environmental Protection Agency; Max, maximum; Min, minimum; NA, not applicable; No., number; NTU, nephelometric turbitidy units; WS, water supply; dates given in month/day/year format]

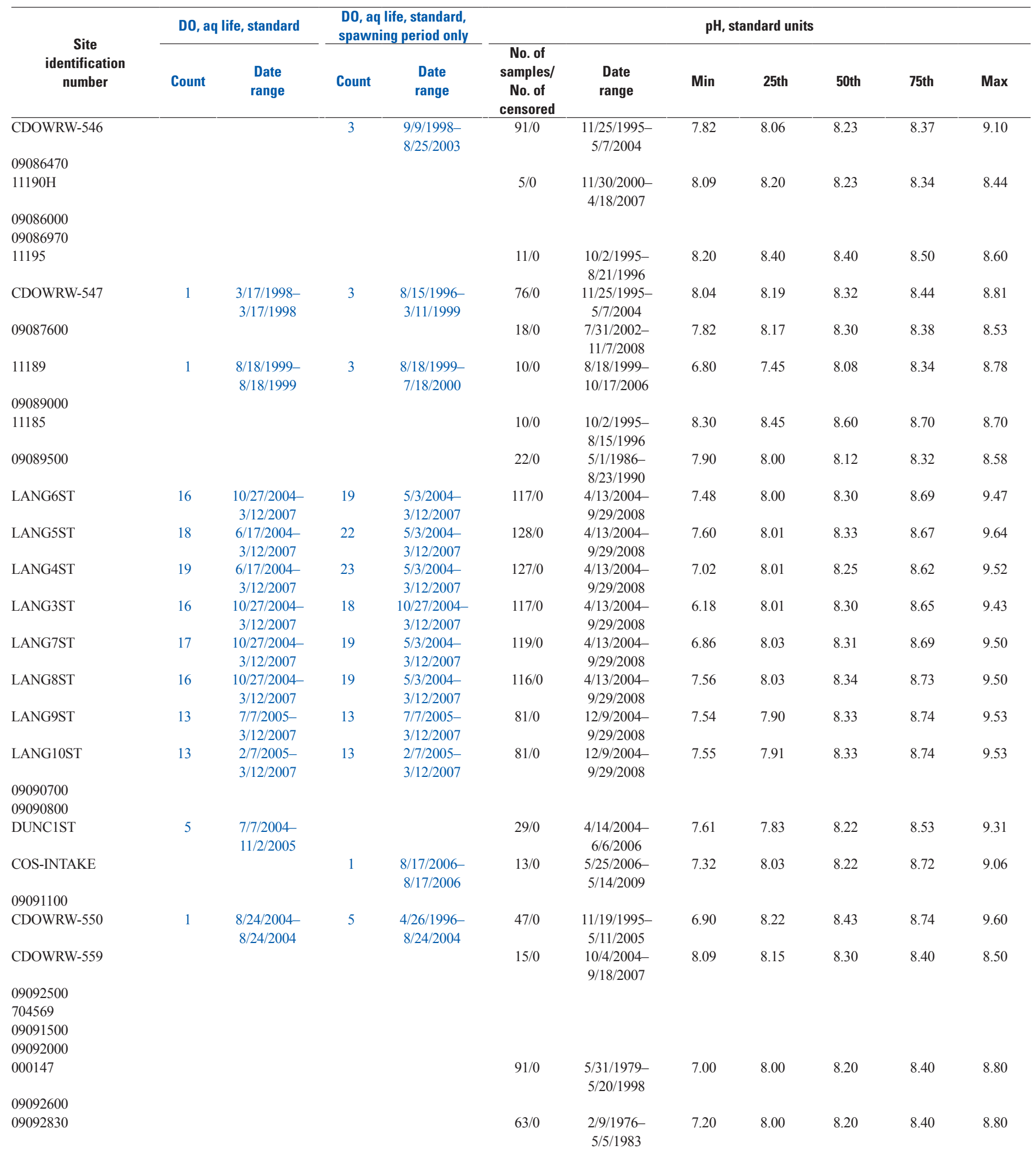


Appendix 1. Summary of surface-water-quality data and comparison to water-quality standards by site, by constituent, Piceance study area, western Colorado. Water-quality standards comparisons follow data summaries and are in blue text; standards are provided in table 3.-Continued

[CDPHE segment, Colorado Department of Health and the Environment stream segment as referred to in tables 2 and 3; latitude and longitude are in North American Datum of 1983; downstream order number assigned as part of analysis. $\mu \mathrm{g} / \mathrm{L}$, micrograms per liter; $\mu \mathrm{S} / \mathrm{cm}$, microsiemens per centimeter; $\mathrm{mg} / \mathrm{L}$, milligrams per liter; mL, milliliters; aq, aquatic; CO, Colorado; EPA, U.S. Environmental Protection Agency; Max, maximum; Min, minimum; NA, not applicable; No., number; NTU, nephelometric turbitidy units; WS, water supply; dates given in month/day/year format]

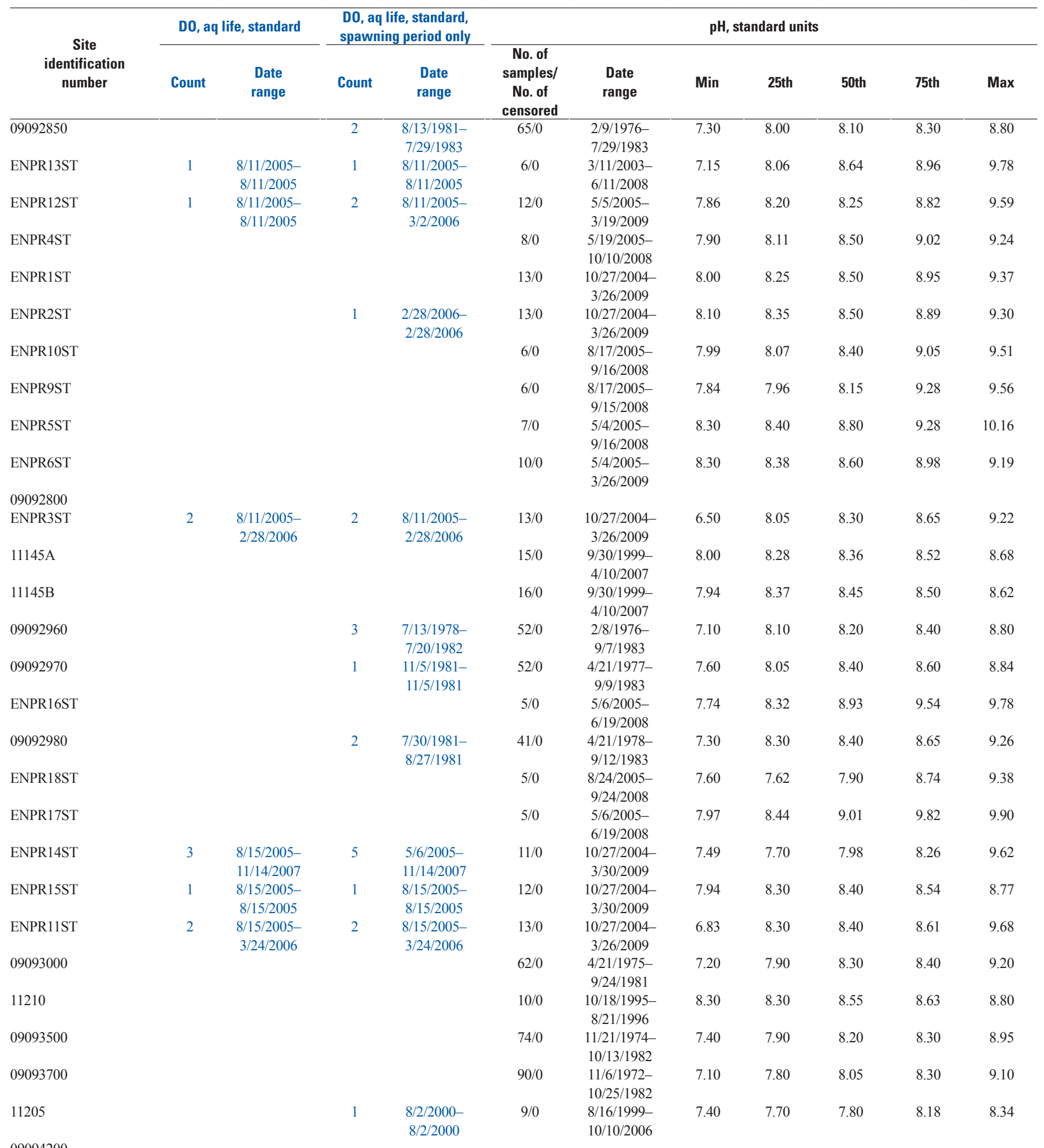


Appendix 1. Summary of surface-water-quality data and comparison to water-quality standards by site, by constituent, Piceance study area, western Colorado. Water-quality standards comparisons follow data summaries and are in blue text; standards are provided in table 3.-Continued

[CDPHE segment, Colorado Department of Health and the Environment stream segment as referred to in tables 2 and 3; latitude and longitude are in North American Datum of 1983; downstream order number assigned as part of analysis. $\mu \mathrm{g} / \mathrm{L}$, micrograms per liter; $\mu \mathrm{S} / \mathrm{cm}$, microsiemens per centimeter; $\mathrm{mg} / \mathrm{L}$, milligrams per liter; mL, milliliters; aq, aquatic; CO, Colorado; EPA, U.S. Environmental Protection Agency; Max, maximum; Min, minimum; NA, not applicable; No., number; NTU, nephelometric turbitidy units; WS, water supply; dates given in month/day/year format]

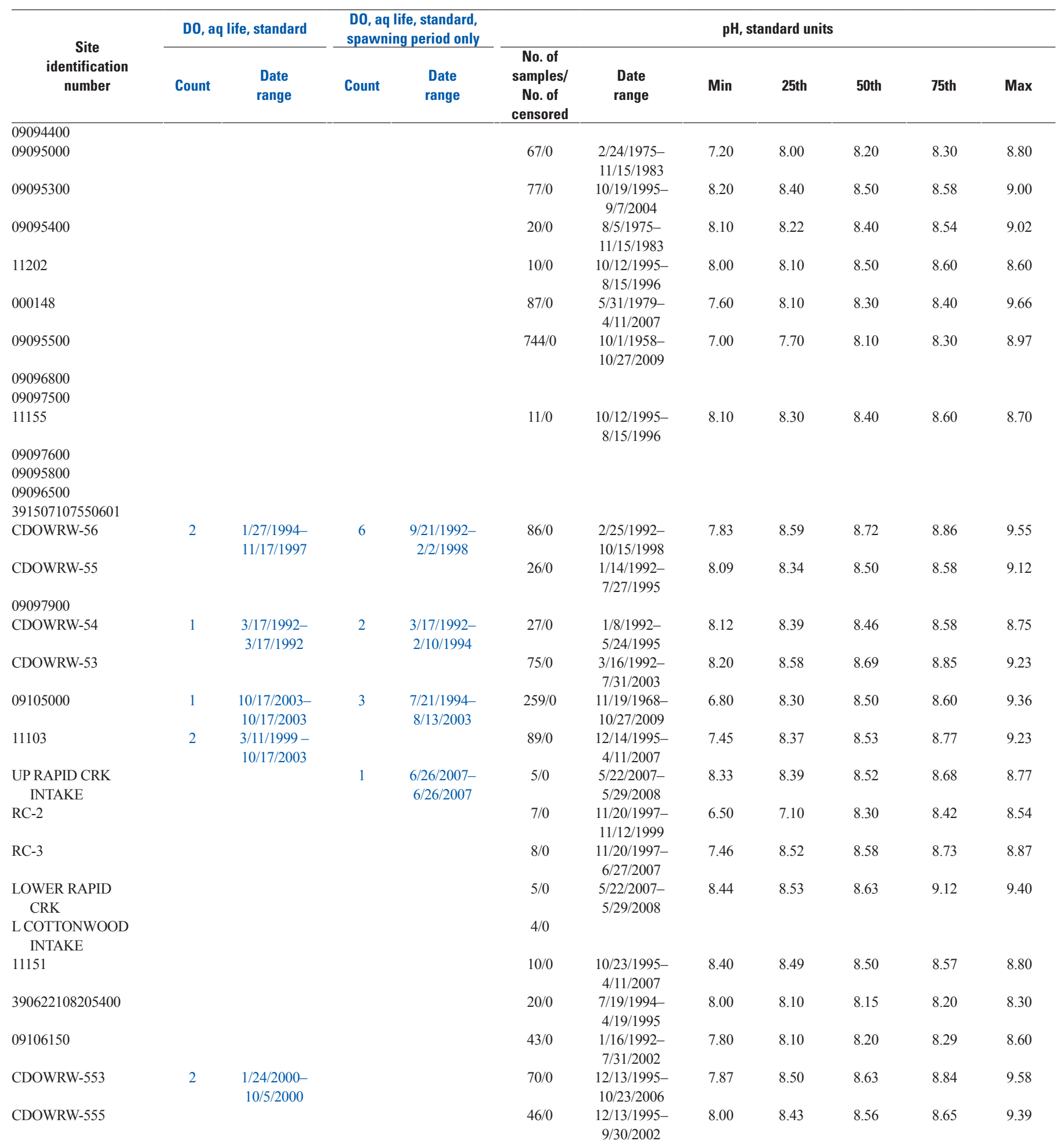


Appendix 1. Summary of surface-water-quality data and comparison to water-quality standards by site, by constituent, Piceance study area, western Colorado. Water-quality standards comparisons follow data summaries and are in blue text; standards are provided in table 3.-Continued

[CDPHE segment, Colorado Department of Health and the Environment stream segment as referred to in tables 2 and 3; latitude and longitude are in North American Datum of 1983; downstream order number assigned as part of analysis. $\mu \mathrm{g} / \mathrm{L}$, micrograms per liter; $\mu \mathrm{S} / \mathrm{cm}$, microsiemens per centimeter; $\mathrm{mg} / \mathrm{L}$, milligrams per liter; mL, milliliters; aq, aquatic; CO, Colorado; EPA, U.S. Environmental Protection Agency; Max, maximum; Min, minimum; NA, not applicable; No., number; NTU, nephelometric turbitidy units; WS, water supply; dates given in month/day/year format]

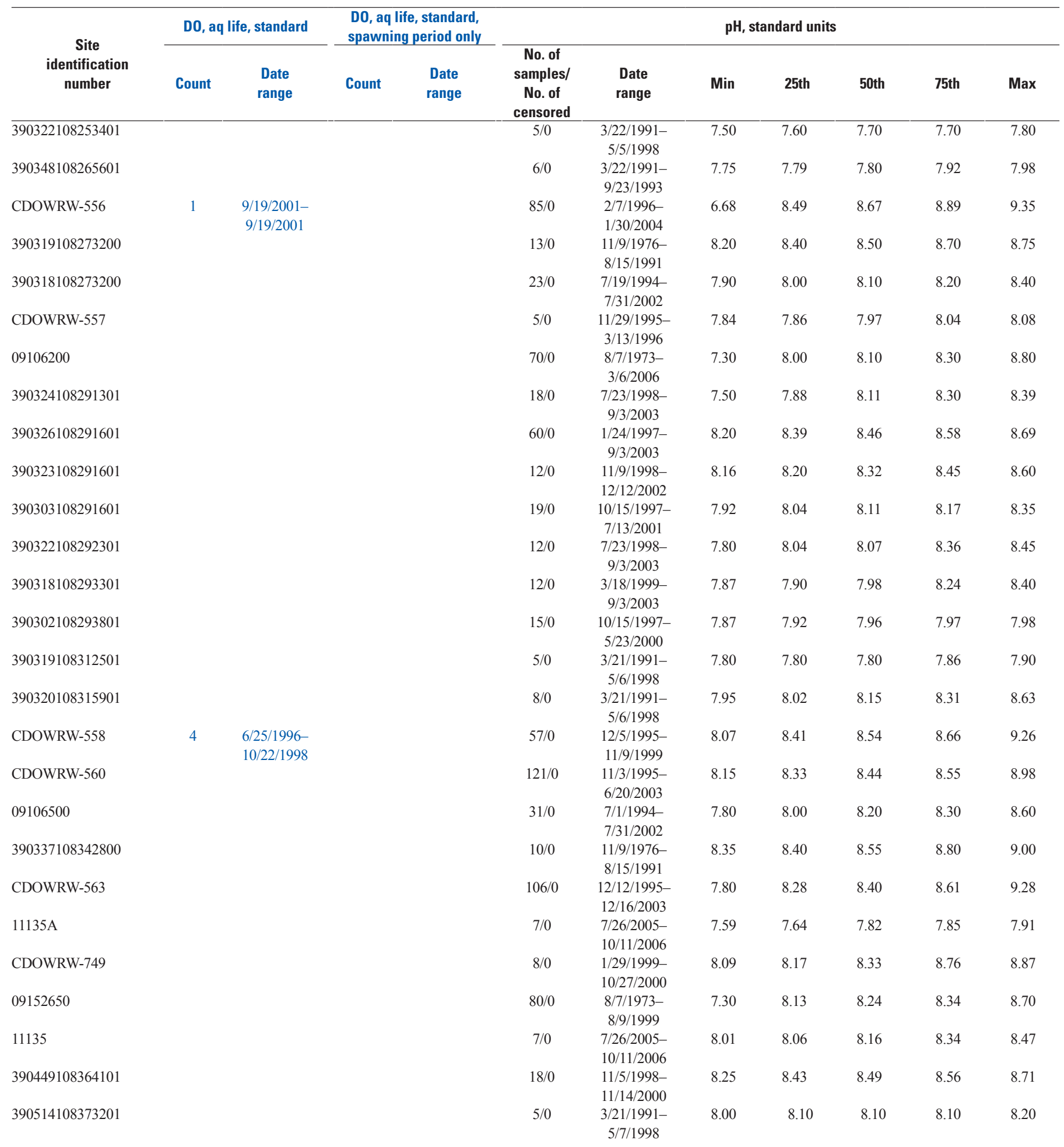


Appendix 1. Summary of surface-water-quality data and comparison to water-quality standards by site, by constituent, Piceance study area, western Colorado. Water-quality standards comparisons follow data summaries and are in blue text; standards are provided in table 3.-Continued

[CDPHE segment, Colorado Department of Health and the Environment stream segment as referred to in tables 2 and 3; latitude and longitude are in North American Datum of 1983; downstream order number assigned as part of analysis. $\mu \mathrm{g} / \mathrm{L}$, micrograms per liter; $\mu \mathrm{S} / \mathrm{cm}$, microsiemens per centimeter; $\mathrm{mg} / \mathrm{L}$, milligrams per liter; mL, milliliters; aq, aquatic; CO, Colorado; EPA, U.S. Environmental Protection Agency; Max, maximum; Min, minimum; NA, not applicable; No., number; NTU, nephelometric turbitidy units; WS, water supply; dates given in month/day/year format]

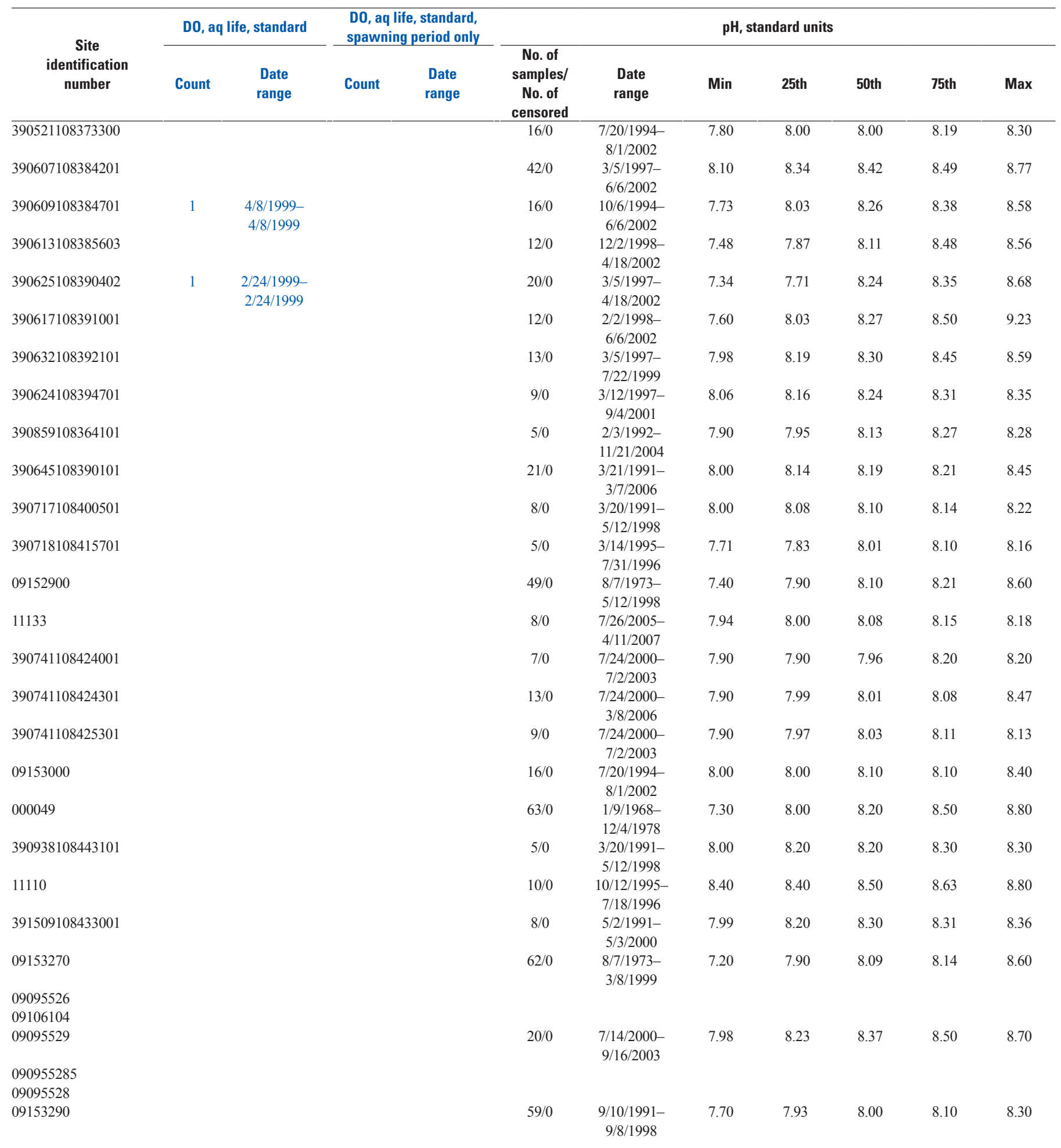


Appendix 1. Summary of surface-water-quality data and comparison to water-quality standards by site, by constituent, Piceance study area, western Colorado. Water-quality standards comparisons follow data summaries and are in blue text; standards are provided in table 3.-Continued

[CDPHE segment, Colorado Department of Health and the Environment stream segment as referred to in tables 2 and 3; latitude and longitude are in North American Datum of 1983; downstream order number assigned as part of analysis. $\mu \mathrm{g} / \mathrm{L}$, micrograms per liter; $\mu \mathrm{S} / \mathrm{cm}$, microsiemens per centimeter; $\mathrm{mg} / \mathrm{L}$, milligrams per liter; mL, milliliters; aq, aquatic; CO, Colorado; EPA, U.S. Environmental Protection Agency; Max, maximum; Min, minimum; NA, not applicable; No., number; NTU, nephelometric turbitidy units; WS, water supply; dates given in month/day/year format]

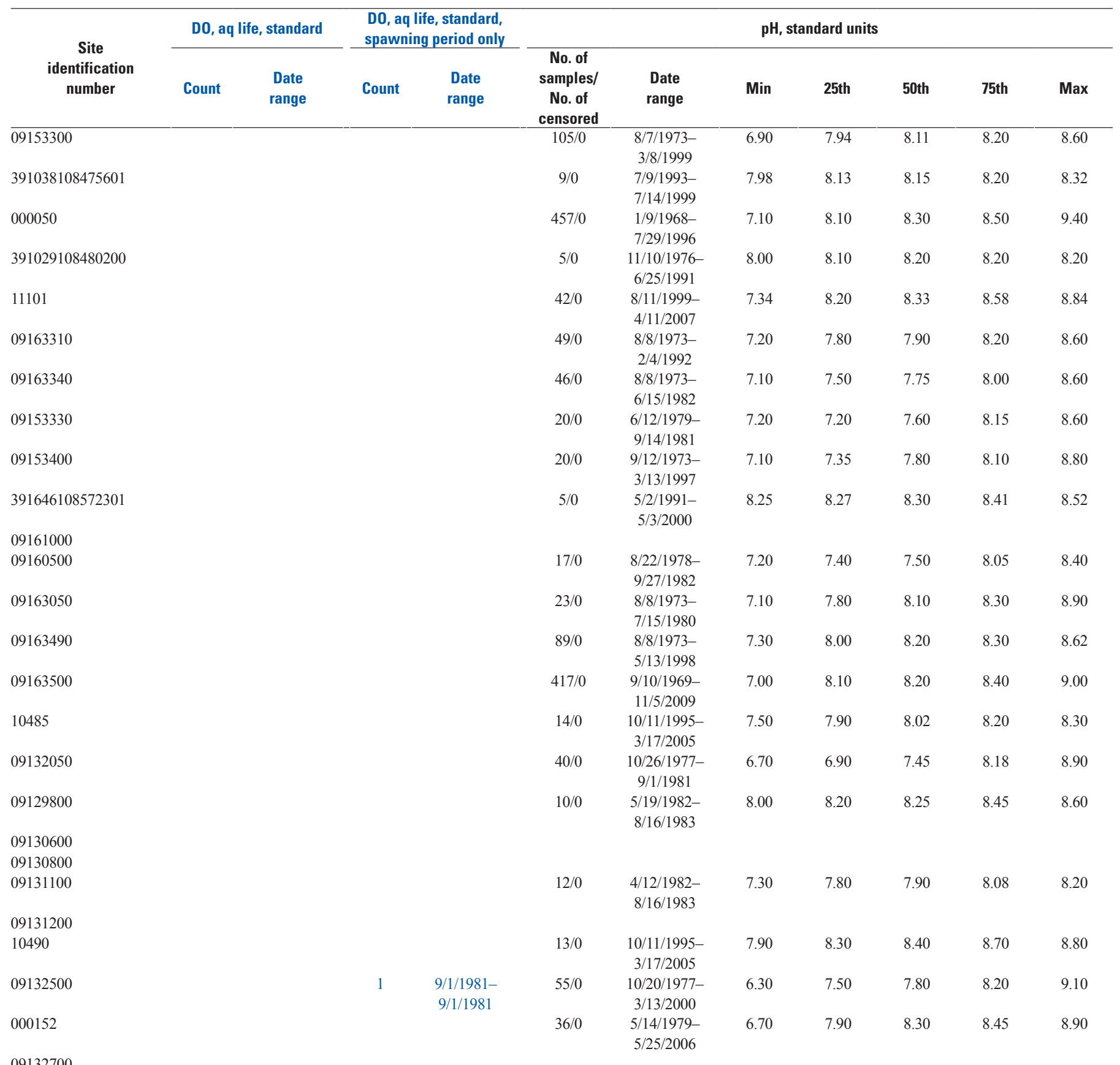

09132700

09132800

09132900

09132920

09132940

$10406 \mathrm{H}$

09132960 
Appendix 1. Summary of surface-water-quality data and comparison to water-quality standards by site, by constituent, Piceance study area, western Colorado. Water-quality standards comparisons follow data summaries and are in blue text; standards are provided in table 3.-Continued

[CDPHE segment, Colorado Department of Health and the Environment stream segment as referred to in tables 2 and 3; latitude and longitude are in North American Datum of 1983; downstream order number assigned as part of analysis. $\mu \mathrm{g} / \mathrm{L}$, micrograms per liter; $\mu \mathrm{S} / \mathrm{cm}$, microsiemens per centimeter; $\mathrm{mg} / \mathrm{L}$, milligrams per liter; mL, milliliters; aq, aquatic; CO, Colorado; EPA, U.S. Environmental Protection Agency; Max, maximum; Min, minimum; NA, not applicable; No., number; NTU, nephelometric turbitidy units; WS, water supply; dates given in month/day/year format]

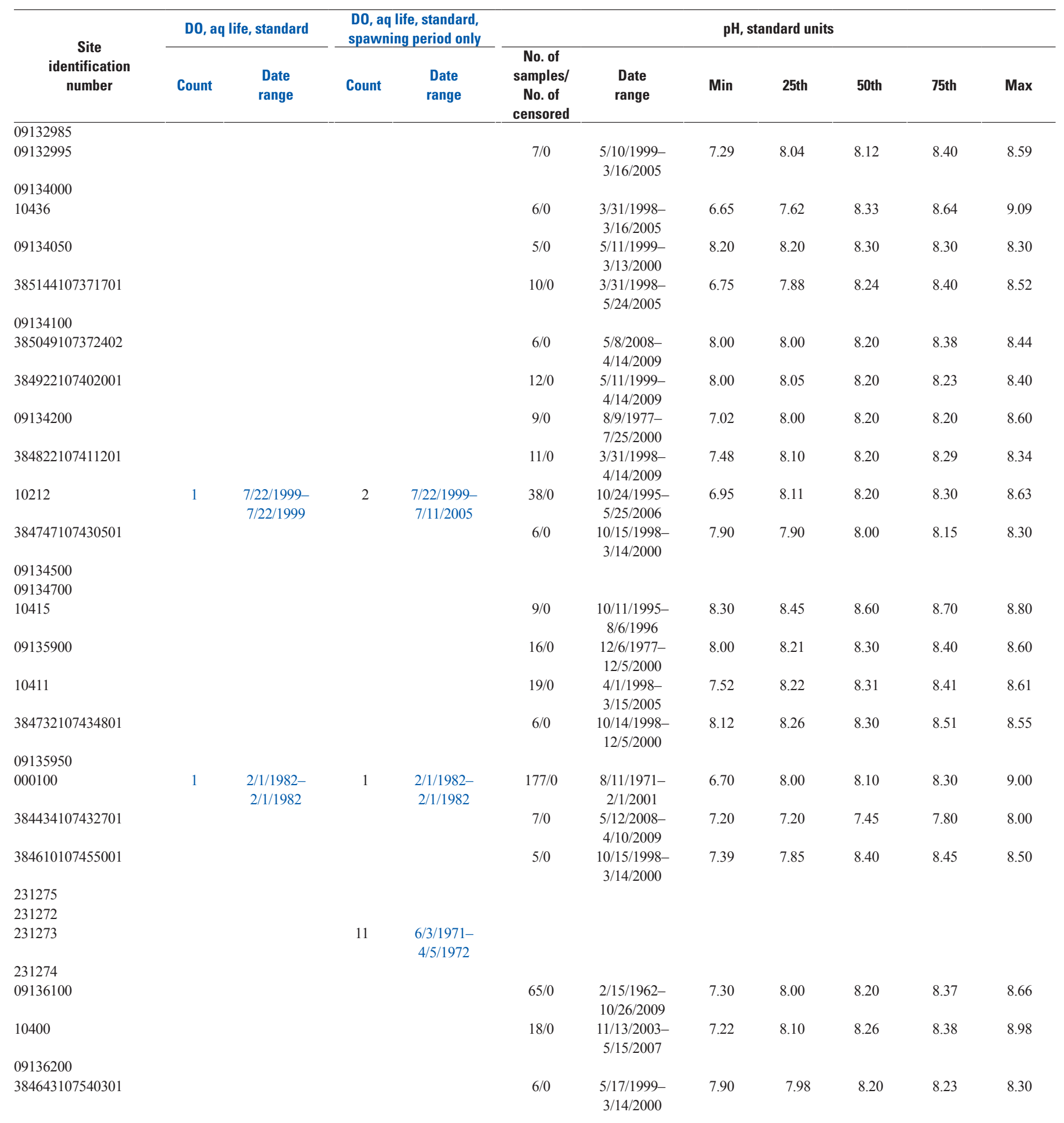


Appendix 1. Summary of surface-water-quality data and comparison to water-quality standards by site, by constituent, Piceance study area, western Colorado. Water-quality standards comparisons follow data summaries and are in blue text; standards are provided in table 3.-Continued

[CDPHE segment, Colorado Department of Health and the Environment stream segment as referred to in tables 2 and 3; latitude and longitude are in North American Datum of 1983; downstream order number assigned as part of analysis. $\mu \mathrm{g} / \mathrm{L}$, micrograms per liter; $\mu \mathrm{S} / \mathrm{cm}$, microsiemens per centimeter; $\mathrm{mg} / \mathrm{L}$, milligrams per liter; mL, milliliters; aq, aquatic; CO, Colorado; EPA, U.S. Environmental Protection Agency; Max, maximum; Min, minimum; NA, not applicable; No., number; NTU, nephelometric turbitidy units; WS, water supply; dates given in month/day/year format]

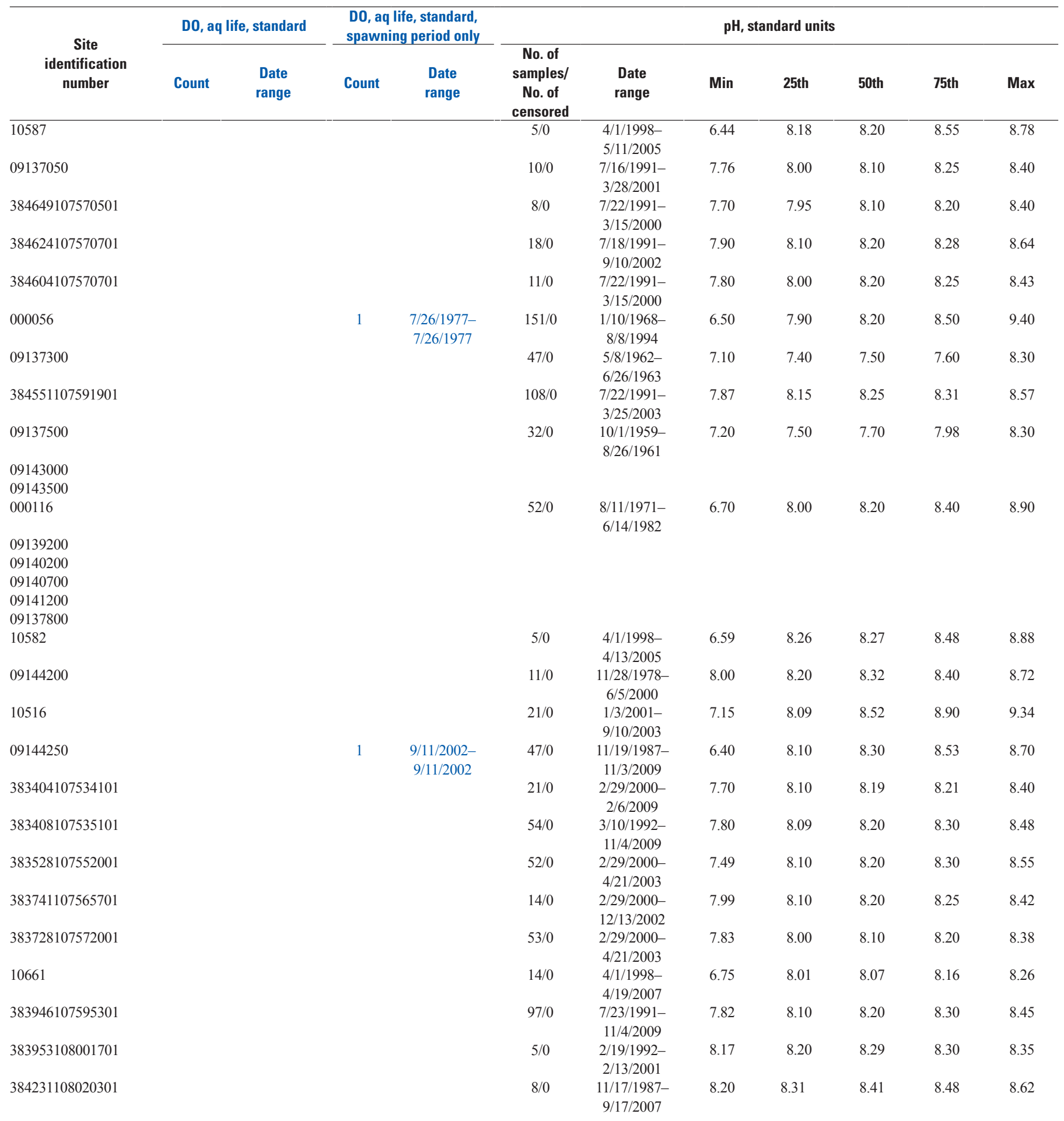


Appendix 1. Summary of surface-water-quality data and comparison to water-quality standards by site, by constituent, Piceance study area, western Colorado. Water-quality standards comparisons follow data summaries and are in blue text; standards are provided in table 3.-Continued

[CDPHE segment, Colorado Department of Health and the Environment stream segment as referred to in tables 2 and 3; latitude and longitude are in North American Datum of 1983; downstream order number assigned as part of analysis. $\mu \mathrm{g} / \mathrm{L}$, micrograms per liter; $\mu \mathrm{S} / \mathrm{cm}$, microsiemens per centimeter; $\mathrm{mg} / \mathrm{L}$, milligrams per liter; mL, milliliters; aq, aquatic; CO, Colorado; EPA, U.S. Environmental Protection Agency; Max, maximum; Min, minimum; NA, not applicable; No., number; NTU, nephelometric turbitidy units; WS, water supply; dates given in month/day/year format]

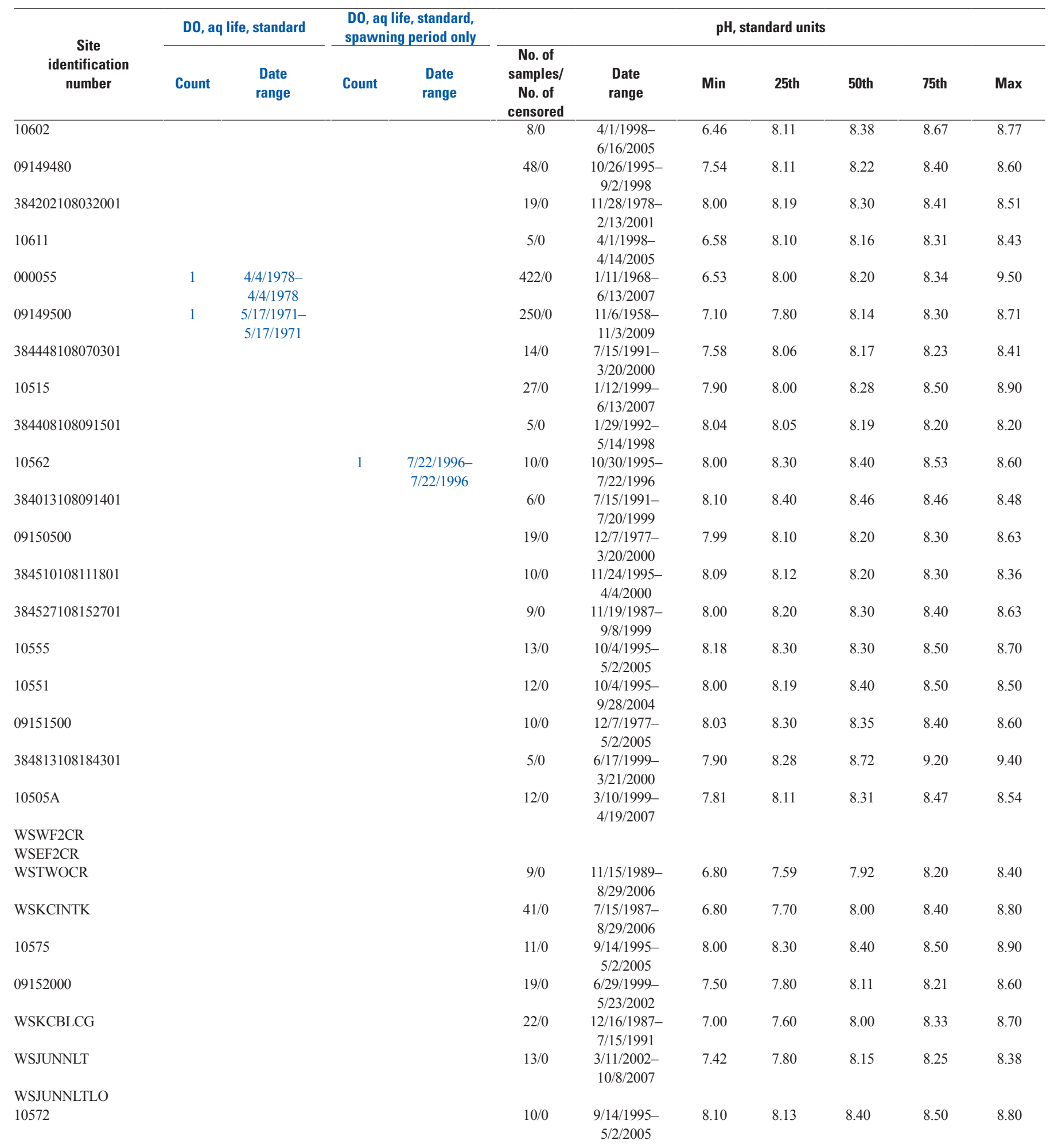


Appendix 1. Summary of surface-water-quality data and comparison to water-quality standards by site, by constituent, Piceance study area, western Colorado. Water-quality standards comparisons follow data summaries and are in blue text; standards are provided in table 3.-Continued

[CDPHE segment, Colorado Department of Health and the Environment stream segment as referred to in tables 2 and 3; latitude and longitude are in North American Datum of 1983; downstream order number assigned as part of analysis. $\mu \mathrm{g} / \mathrm{L}$, micrograms per liter; $\mu \mathrm{S} / \mathrm{cm}$, microsiemens per centimeter; $\mathrm{mg} / \mathrm{L}$, milligrams per liter; mL, milliliters; aq, aquatic; CO, Colorado; EPA, U.S. Environmental Protection Agency; Max, maximum; Min, minimum; NA, not applicable; No., number; NTU, nephelometric turbitidy units; WS, water supply; dates given in month/day/year format]

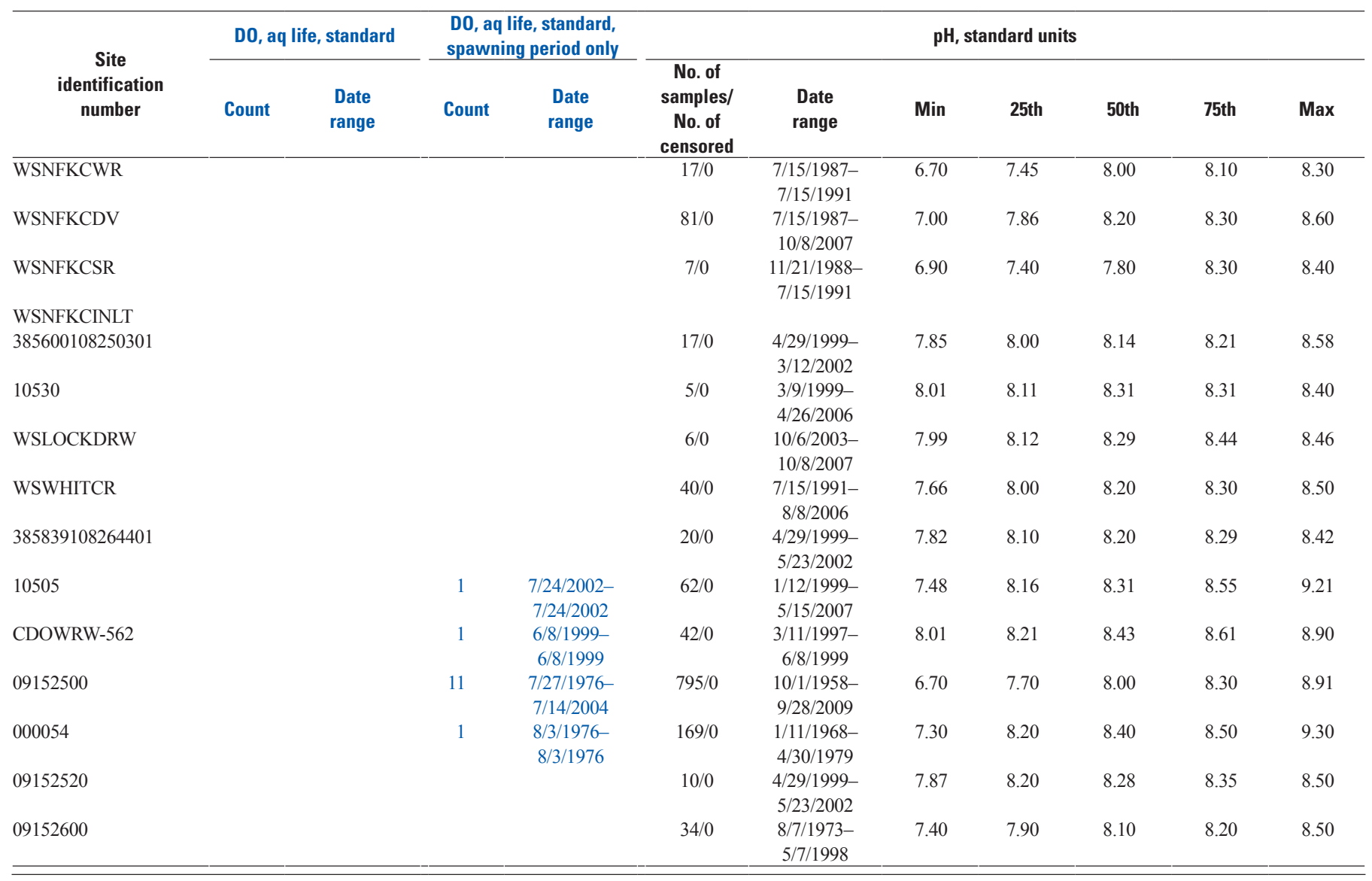


Appendix 1. Summary of surface-water-quality data and comparison to water-quality standards by site, by constituent, Piceance study area, western Colorado. Water-quality standards comparisons follow data summaries and are in blue text; standards are provided in table 3.-Continued

[CDPHE segment, Colorado Department of Health and the Environment stream segment as referred to in tables 2 and 3; latitude and longitude are in North American Datum of 1983; downstream order number assigned as part of analysis. $\mu \mathrm{g} / \mathrm{L}$, micrograms per liter; $\mu \mathrm{S} / \mathrm{cm}$, microsiemens per centimeter; $\mathrm{mg} / \mathrm{L}$, milligrams per liter; mL, milliliters; aq, aquatic; CO, Colorado; EPA, U.S. Environmental Protection Agency; Max, maximum; Min, minimum; NA, not applicable; No., number; NTU, nephelometric turbitidy units; WS, water supply; dates given in month/day/year format]

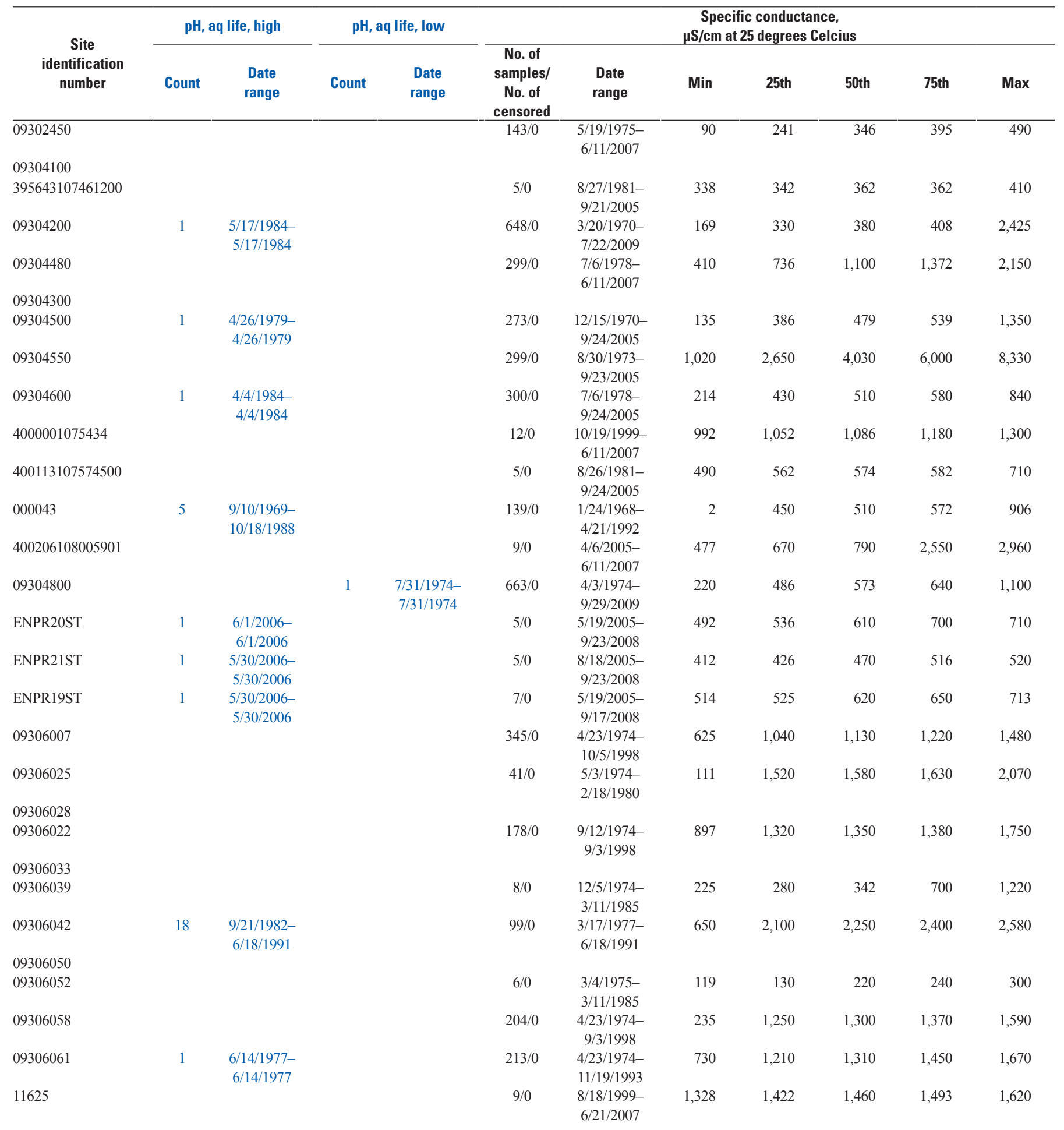


Appendix 1. Summary of surface-water-quality data and comparison to water-quality standards by site, by constituent, Piceance study area, western Colorado. Water-quality standards comparisons follow data summaries and are in blue text; standards are provided in table 3.-Continued

[CDPHE segment, Colorado Department of Health and the Environment stream segment as referred to in tables 2 and 3; latitude and longitude are in North American Datum of 1983; downstream order number assigned as part of analysis. $\mu \mathrm{g} / \mathrm{L}$, micrograms per liter; $\mu \mathrm{S} / \mathrm{cm}$, microsiemens per centimeter; $\mathrm{mg} / \mathrm{L}$, milligrams per liter; mL, milliliters; aq, aquatic; CO, Colorado; EPA, U.S. Environmental Protection Agency; Max, maximum; Min, minimum; NA, not applicable; No., number; NTU, nephelometric turbitidy units; WS, water supply; dates given in month/day/year format]

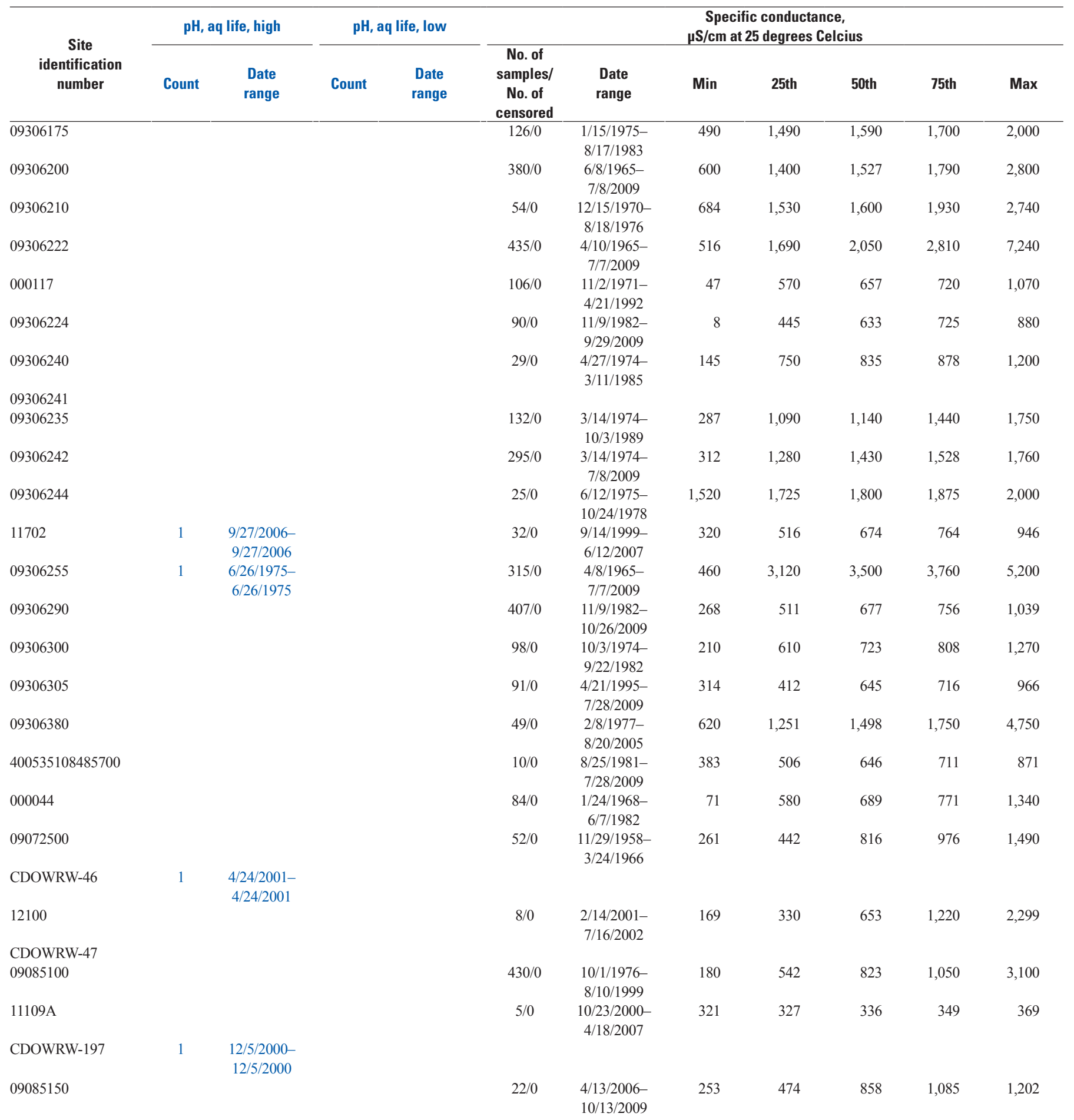


Appendix 1. Summary of surface-water-quality data and comparison to water-quality standards by site, by constituent, Piceance study area, western Colorado. Water-quality standards comparisons follow data summaries and are in blue text; standards are provided in table 3.-Continued

[CDPHE segment, Colorado Department of Health and the Environment stream segment as referred to in tables 2 and 3; latitude and longitude are in North American Datum of 1983; downstream order number assigned as part of analysis. $\mu \mathrm{g} / \mathrm{L}$, micrograms per liter; $\mu \mathrm{S} / \mathrm{cm}$, microsiemens per centimeter; $\mathrm{mg} / \mathrm{L}$, milligrams per liter; mL, milliliters; aq, aquatic; CO, Colorado; EPA, U.S. Environmental Protection Agency; Max, maximum; Min, minimum; NA, not applicable; No., number; NTU, nephelometric turbitidy units; WS, water supply; dates given in month/day/year format]

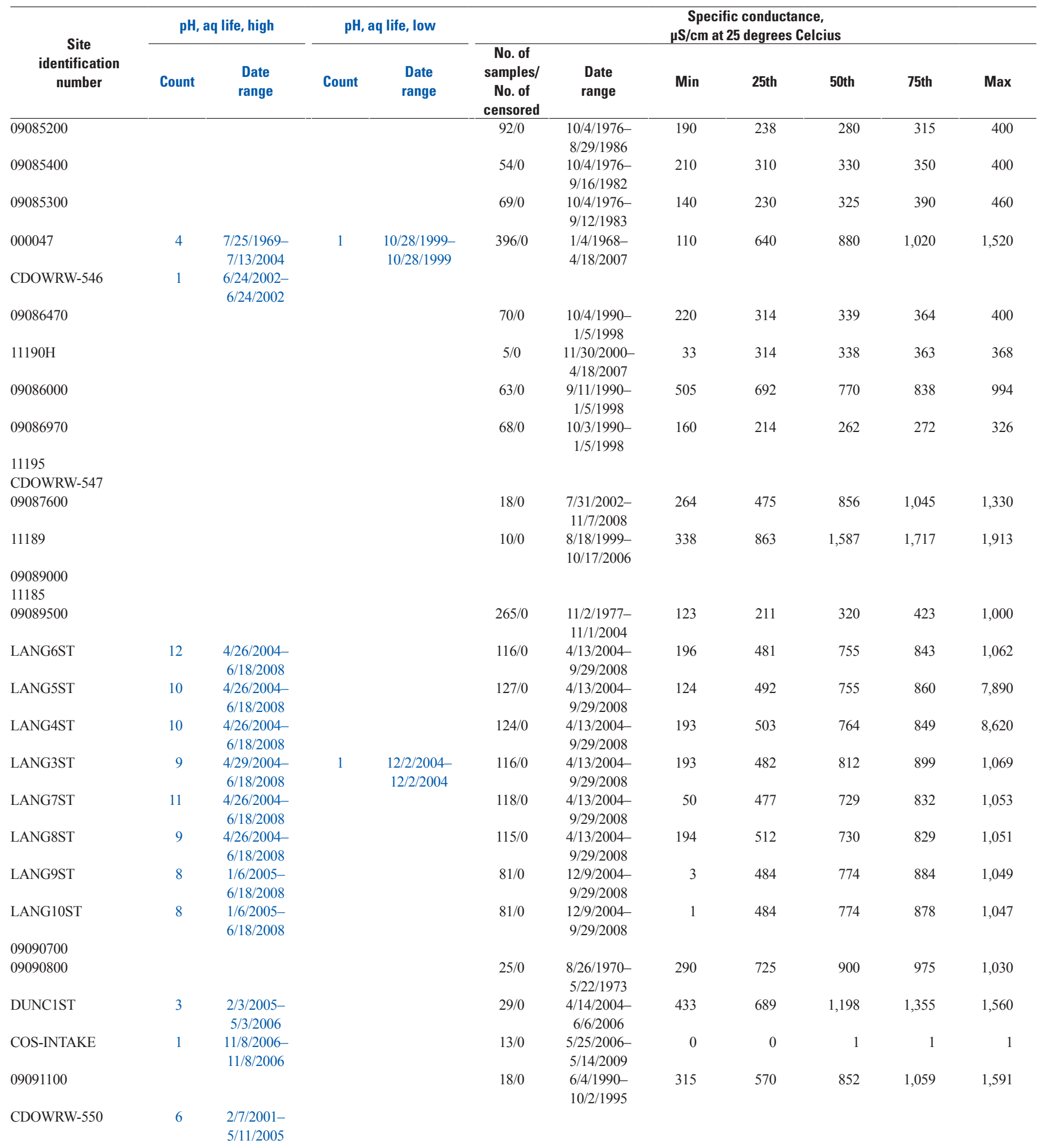


Appendix 1. Summary of surface-water-quality data and comparison to water-quality standards by site, by constituent, Piceance study area, western Colorado. Water-quality standards comparisons follow data summaries and are in blue text; standards are provided in table 3.-Continued

[CDPHE segment, Colorado Department of Health and the Environment stream segment as referred to in tables 2 and 3; latitude and longitude are in North American Datum of 1983; downstream order number assigned as part of analysis. $\mu \mathrm{g} / \mathrm{L}$, micrograms per liter; $\mu \mathrm{S} / \mathrm{cm}$, microsiemens per centimeter; $\mathrm{mg} / \mathrm{L}$, milligrams per liter; mL, milliliters; aq, aquatic; CO, Colorado; EPA, U.S. Environmental Protection Agency; Max, maximum; Min, minimum; NA, not applicable; No., number; NTU, nephelometric turbitidy units; WS, water supply; dates given in month/day/year format]

\begin{tabular}{|c|c|c|c|c|c|c|c|c|c|c|c|}
\hline $\begin{array}{c}\text { Site } \\
\text { identification } \\
\text { number }\end{array}$ & \multicolumn{2}{|c|}{ pH, aq life, high } & \multicolumn{2}{|c|}{ pH, aq life, low } & \multicolumn{7}{|c|}{$\begin{array}{c}\text { Specific conductance, } \\
\mu \mathrm{S} / \mathrm{cm} \text { at } 25 \text { degrees Celcius }\end{array}$} \\
\hline CDOWRW-559 & & & & & & & & & & & \\
\hline 09092500 & & & & & $65 / 0$ & $\begin{array}{c}10 / 5 / 1976- \\
9 / 7 / 1982\end{array}$ & 125 & 250 & 310 & 390 & 1,500 \\
\hline 09092000 & & & & & & & & & & & \\
\hline 000147 & & & & & $71 / 0$ & $\begin{array}{c}5 / 31 / 1979- \\
4 / 15 / 1992\end{array}$ & 2 & 550 & 860 & 980 & 1,310 \\
\hline 09092600 & & & & & & & & & & & \\
\hline 09092830 & & & & & $64 / 0$ & $\begin{array}{c}2 / 9 / 1976- \\
5 / 5 / 1983\end{array}$ & 370 & 480 & 510 & 529 & 697 \\
\hline 09092850 & & & & & $73 / 0$ & $\begin{array}{l}2 / 9 / 1976- \\
7 / 29 / 1983\end{array}$ & 380 & 481 & 523 & 540 & 1,250 \\
\hline ENPR4ST & 2 & $\begin{array}{c}11 / 9 / 2005- \\
5 / 4 / 2006\end{array}$ & & & $8 / 0$ & $\begin{array}{l}5 / 19 / 2005- \\
10 / 10 / 2008\end{array}$ & 493 & 526 & 616 & 693 & 820 \\
\hline ENPR1ST & 2 & $\begin{array}{l}11 / 14 / 2005 \\
2 / 28 / 2006\end{array}$ & & & $13 / 0$ & $\begin{array}{c}10 / 27 / 2004 \\
3 / 26 / 2009\end{array}$ & 476 & 604 & 647 & 760 & 880 \\
\hline ENPR2ST & 2 & $\begin{array}{l}11 / 14 / 2005 \\
2 / 28 / 2006\end{array}$ & & & $13 / 0$ & $\begin{array}{c}10 / 27 / 2004 \\
3 / 26 / 2009\end{array}$ & 440 & 557 & 663 & 720 & 860 \\
\hline ENPR10ST & 1 & $\begin{array}{c}5 / 4 / 2006- \\
5 / 4 / 2006\end{array}$ & & & $6 / 0$ & $\begin{array}{c}8 / 17 / 2005- \\
9 / 16 / 2008\end{array}$ & 448 & 583 & 640 & 696 & 800 \\
\hline ENPR9ST & 2 & $\begin{array}{l}11 / 10 / 2005- \\
5 / 2 / 2006\end{array}$ & & & $6 / 0$ & $\begin{array}{c}\text { 8/17/2005- } \\
9 / 15 / 2008\end{array}$ & 393 & 545 & 656 & 693 & 730 \\
\hline ENPR5ST & 2 & $\begin{array}{l}11 / 14 / 2005- \\
6 / 1 / 2006\end{array}$ & & & $7 / 0$ & $\begin{array}{l}5 / 4 / 2005- \\
9 / 16 / 2008\end{array}$ & 510 & 528 & 590 & 700 & 710 \\
\hline ENPR6ST & 2 & $\begin{array}{l}5 / 4 / 2005- \\
2 / 28 / 2006\end{array}$ & & & $10 / 0$ & $\begin{array}{l}5 / 4 / 2005- \\
3 / 26 / 2009\end{array}$ & 205 & 502 & 635 & 720 & 840 \\
\hline 09092970 & & & & & $53 / 0$ & $\begin{array}{c}4 / 21 / 1977- \\
9 / 9 / 1983\end{array}$ & 350 & 420 & 450 & 485 & 675 \\
\hline ENPR16ST & 2 & $\begin{array}{l}3 / 2 / 2006- \\
5 / 19 / 2006\end{array}$ & & & $5 / 0$ & $\begin{array}{l}5 / 6 / 2005- \\
6 / 19 / 2008\end{array}$ & 405 & 421 & 460 & 473 & 485 \\
\hline 09092980 & 2 & $\begin{array}{c}\text { 7/30/1981- } \\
9 / 23 / 1982\end{array}$ & & & $43 / 0$ & $\begin{array}{l}11 / 19 / 1976- \\
9 / 12 / 1983\end{array}$ & 415 & 532 & 572 & 600 & 800 \\
\hline ENPR18ST & 1 & $\begin{array}{l}5 / 24 / 2006 \\
5 / 24 / 2006\end{array}$ & & & $5 / 0$ & $\begin{array}{l}8 / 24 / 2005- \\
9 / 24 / 2008\end{array}$ & 518 & 536 & 590 & 7,340 & 14,000 \\
\hline ENPR17ST & 3 & $\begin{array}{l}5 / 6 / 2005- \\
5 / 19 / 2006\end{array}$ & & & $5 / 0$ & $\begin{array}{l}5 / 6 / 2005 \\
6 / 19 / 2008\end{array}$ & 409 & 423 & 460 & 590 & 603 \\
\hline ENPR14ST & 1 & $\begin{array}{c}5 / 19 / 2006 \\
5 / 19 / 2006\end{array}$ & & & $11 / 0$ & $\begin{array}{c}10 / 27 / 2004 \\
3 / 30 / 2009\end{array}$ & 473 & 628 & 750 & 17,860 & 90,300 \\
\hline ENPR15ST & & & & & $12 / 0$ & $\begin{array}{c}10 / 27 / 2004 \\
3 / 30 / 2009\end{array}$ & 413 & 575 & 765 & 855 & 870 \\
\hline
\end{tabular}


Appendix 1. Summary of surface-water-quality data and comparison to water-quality standards by site, by constituent, Piceance study area, western Colorado. Water-quality standards comparisons follow data summaries and are in blue text; standards are provided in table 3.-Continued

[CDPHE segment, Colorado Department of Health and the Environment stream segment as referred to in tables 2 and 3; latitude and longitude are in North American Datum of 1983; downstream order number assigned as part of analysis. $\mu \mathrm{g} / \mathrm{L}$, micrograms per liter; $\mu \mathrm{S} / \mathrm{cm}$, microsiemens per centimeter; $\mathrm{mg} / \mathrm{L}$, milligrams per liter; mL, milliliters; aq, aquatic; CO, Colorado; EPA, U.S. Environmental Protection Agency; Max, maximum; Min, minimum; NA, not applicable; No., number; NTU, nephelometric turbitidy units; WS, water supply; dates given in month/day/year format]

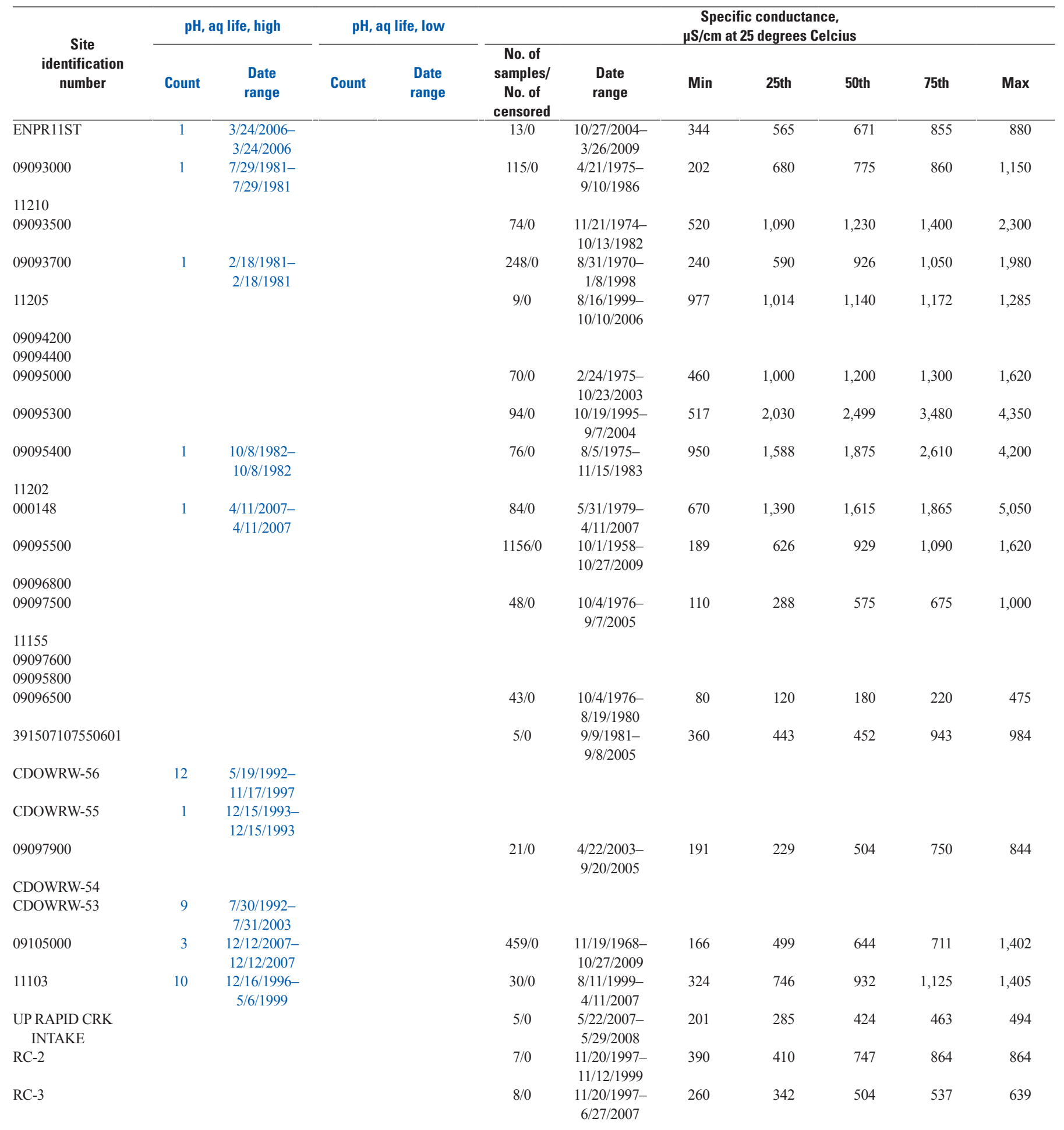


Appendix 1. Summary of surface-water-quality data and comparison to water-quality standards by site, by constituent, Piceance study area, western Colorado. Water-quality standards comparisons follow data summaries and are in blue text; standards are provided in table 3.-Continued

[CDPHE segment, Colorado Department of Health and the Environment stream segment as referred to in tables 2 and 3; latitude and longitude are in North American Datum of 1983; downstream order number assigned as part of analysis. $\mu \mathrm{g} / \mathrm{L}$, micrograms per liter; $\mu \mathrm{S} / \mathrm{cm}$, microsiemens per centimeter; mg $/ \mathrm{L}$, milligrams per liter; mL, milliliters; aq, aquatic; CO, Colorado; EPA, U.S. Environmental Protection Agency; Max, maximum; Min, minimum; NA, not applicable; No., number; NTU, nephelometric turbitidy units; WS, water supply; dates given in month/day/year format]

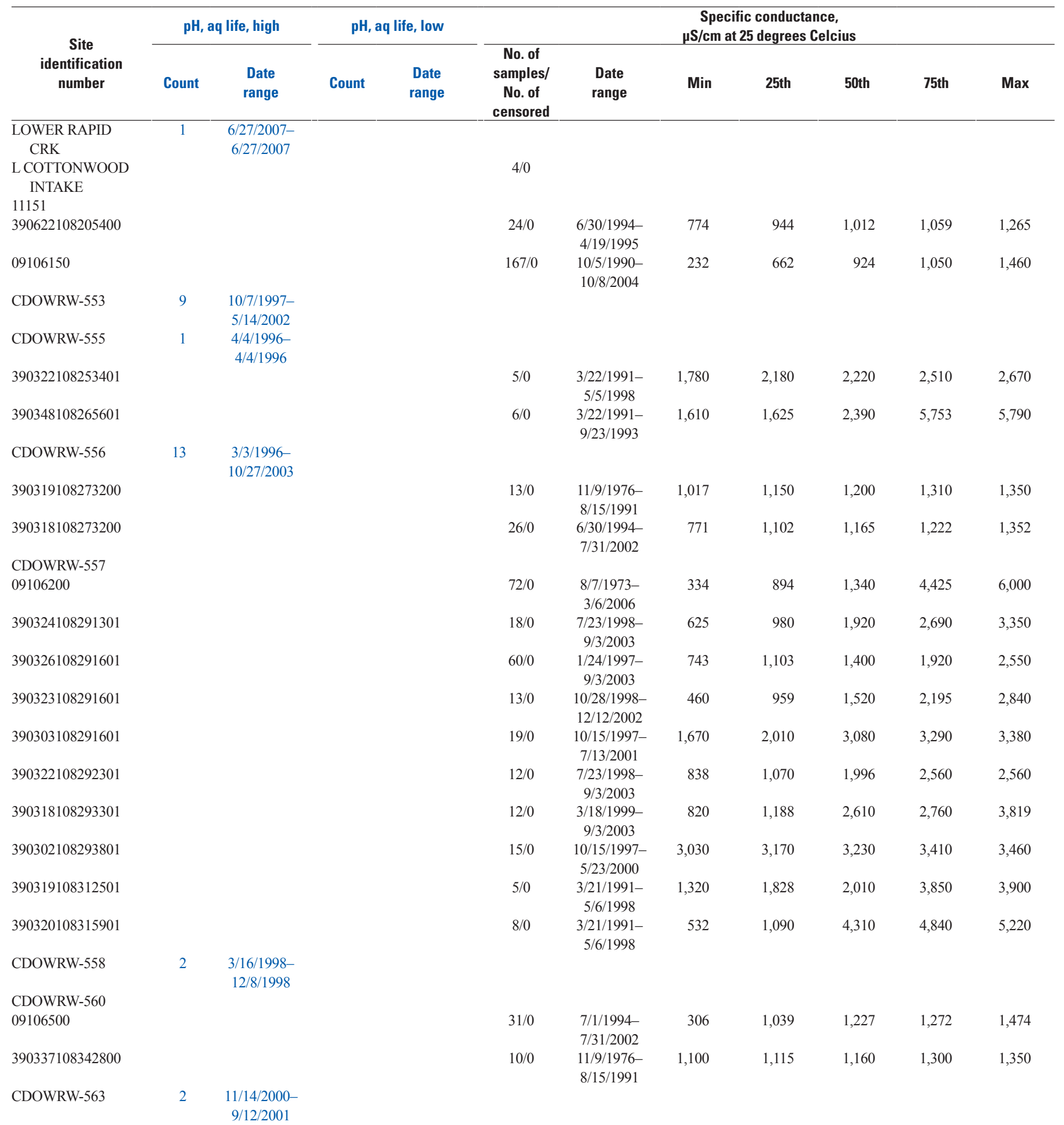


Appendix 1. Summary of surface-water-quality data and comparison to water-quality standards by site, by constituent, Piceance study area, western Colorado. Water-quality standards comparisons follow data summaries and are in blue text; standards are provided in table 3.-Continued

[CDPHE segment, Colorado Department of Health and the Environment stream segment as referred to in tables 2 and 3; latitude and longitude are in North American Datum of 1983; downstream order number assigned as part of analysis. $\mu \mathrm{g} / \mathrm{L}$, micrograms per liter; $\mu \mathrm{S} / \mathrm{cm}$, microsiemens per centimeter; $\mathrm{mg} / \mathrm{L}$, milligrams per liter; mL, milliliters; aq, aquatic; CO, Colorado; EPA, U.S. Environmental Protection Agency; Max, maximum; Min, minimum; NA, not applicable; No., number; NTU, nephelometric turbitidy units; WS, water supply; dates given in month/day/year format]

\begin{tabular}{|c|c|c|c|c|c|c|c|c|c|c|c|}
\hline $\begin{array}{c}\text { Site } \\
\text { identification } \\
\text { number }\end{array}$ & \multicolumn{2}{|c|}{ pH, aq life, high } & \multicolumn{2}{|c|}{ pH, aq life, low } & \multicolumn{7}{|c|}{$\begin{array}{c}\text { Specific conductance, } \\
\mu \mathrm{S} / \mathrm{cm} \text { at } 25 \text { degrees Celcius }\end{array}$} \\
\hline $11135 \mathrm{~A}$ & & & & & $8 / 0$ & $\begin{array}{l}7 / 26 / 2005- \\
1 / 9 / 2007\end{array}$ & 2,780 & 2,880 & 3,915 & 7,935 & 9,250 \\
\hline \multicolumn{12}{|l|}{ CDOWRW-749 } \\
\hline 11135 & & & & & $7 / 0$ & $\begin{array}{l}7 / 26 / 2005- \\
10 / 11 / 2006\end{array}$ & 1,023 & 1,260 & 1,333 & 2,060 & 4,410 \\
\hline 390449108364101 & & & & & $18 / 0$ & $\begin{array}{l}11 / 5 / 1998- \\
11 / 14 / 2000\end{array}$ & 550 & 689 & 775 & 926 & 996 \\
\hline 390514108373201 & & & & & $5 / 0$ & $\begin{array}{c}3 / 21 / 1991- \\
5 / 7 / 1998\end{array}$ & 962 & 1,260 & 1,470 & 2,630 & 2,680 \\
\hline 390521108373300 & & & & & $16 / 0$ & $\begin{array}{c}7 / 20 / 1994 \\
8 / 1 / 2002\end{array}$ & 319 & 624 & 1,154 & 1,191 & 1,445 \\
\hline 390613108385603 & & & & & $12 / 0$ & $\begin{array}{c}12 / 2 / 1998- \\
4 / 18 / 2002\end{array}$ & 391 & 800 & 1,265 & 3,538 & 7,760 \\
\hline 390625108390402 & & & & & $20 / 0$ & $\begin{array}{l}3 / 5 / 1997- \\
4 / 18 / 2002\end{array}$ & 410 & 889 & 1,001 & 3,955 & 6,990 \\
\hline 390617108391001 & 1 & $\begin{array}{c}2 / 24 / 1999 \\
2 / 24 / 1999\end{array}$ & & & $12 / 0$ & $\begin{array}{c}2 / 2 / 1998- \\
6 / 6 / 2002\end{array}$ & 462 & 800 & 1,450 & 3,395 & 6,830 \\
\hline 390632108392101 & & & & & $13 / 0$ & $\begin{array}{l}3 / 5 / 1997- \\
7 / 22 / 1999\end{array}$ & 640 & 920 & 959 & 1,915 & 5,260 \\
\hline 390624108394701 & & & & & $9 / 0$ & $\begin{array}{c}3 / 12 / 1997- \\
9 / 4 / 2001\end{array}$ & 918 & 1,250 & 1,560 & 2,240 & 2,720 \\
\hline 390859108364101 & & & & & $5 / 0$ & $\begin{array}{c}2 / 3 / 1992- \\
11 / 21 / 2004\end{array}$ & 831 & 1,350 & 1,420 & 3,810 & 4,260 \\
\hline 390645108390101 & & & & & $21 / 0$ & $\begin{array}{c}3 / 21 / 1991- \\
3 / 7 / 2006\end{array}$ & 1,010 & 1,350 & 1,750 & 4,500 & 4,670 \\
\hline 390741108424001 & & & & & $7 / 0$ & $\begin{array}{l}7 / 24 / 2000- \\
7 / 2 / 2003\end{array}$ & 935 & 1,340 & 2,450 & 3,390 & 3,460 \\
\hline 390741108424301 & & & & & $13 / 0$ & $\begin{array}{l}7 / 24 / 2000- \\
3 / 8 / 2006\end{array}$ & 1,270 & 1,600 & 3,920 & 4,110 & 4,220 \\
\hline 390741108425301 & & & & & $9 / 0$ & $\begin{array}{l}7 / 24 / 2000- \\
7 / 2 / 2003\end{array}$ & 604 & 1,480 & 1,660 & 4,035 & 4,175 \\
\hline 09153000 & & & & & $16 / 0$ & $\begin{array}{c}7 / 20 / 1994 \\
8 / 1 / 2002\end{array}$ & 313 & 640 & 1,160 & 1,227 & 1,335 \\
\hline 000049 & & & & & $74 / 0$ & $\begin{array}{l}1 / 9 / 1968- \\
12 / 4 / 1978\end{array}$ & 10 & 858 & 1,075 & 1,242 & 2,300 \\
\hline 390938108443101 & & & & & $5 / 0$ & $\begin{array}{l}3 / 20 / 1991- \\
5 / 12 / 1998\end{array}$ & 724 & 960 & 1,350 & 3,450 & 3,620 \\
\hline 11110 & & & & & & & & & & & \\
\hline 391509108433001 & & & & & $8 / 0$ & $\begin{array}{l}5 / 2 / 1991- \\
5 / 3 / 2000\end{array}$ & 3,580 & 18,150 & 20,600 & 22,050 & 24,000 \\
\hline
\end{tabular}


Appendix 1. Summary of surface-water-quality data and comparison to water-quality standards by site, by constituent, Piceance study area, western Colorado. Water-quality standards comparisons follow data summaries and are in blue text; standards are provided in table 3.-Continued

[CDPHE segment, Colorado Department of Health and the Environment stream segment as referred to in tables 2 and 3; latitude and longitude are in North American Datum of 1983; downstream order number assigned as part of analysis. $\mu \mathrm{g} / \mathrm{L}$, micrograms per liter; $\mu \mathrm{S} / \mathrm{cm}$, microsiemens per centimeter; $\mathrm{mg} / \mathrm{L}$, milligrams per liter; mL, milliliters; aq, aquatic; CO, Colorado; EPA, U.S. Environmental Protection Agency; Max, maximum; Min, minimum; NA, not applicable; No., number; NTU, nephelometric turbitidy units; WS, water supply; dates given in month/day/year format]

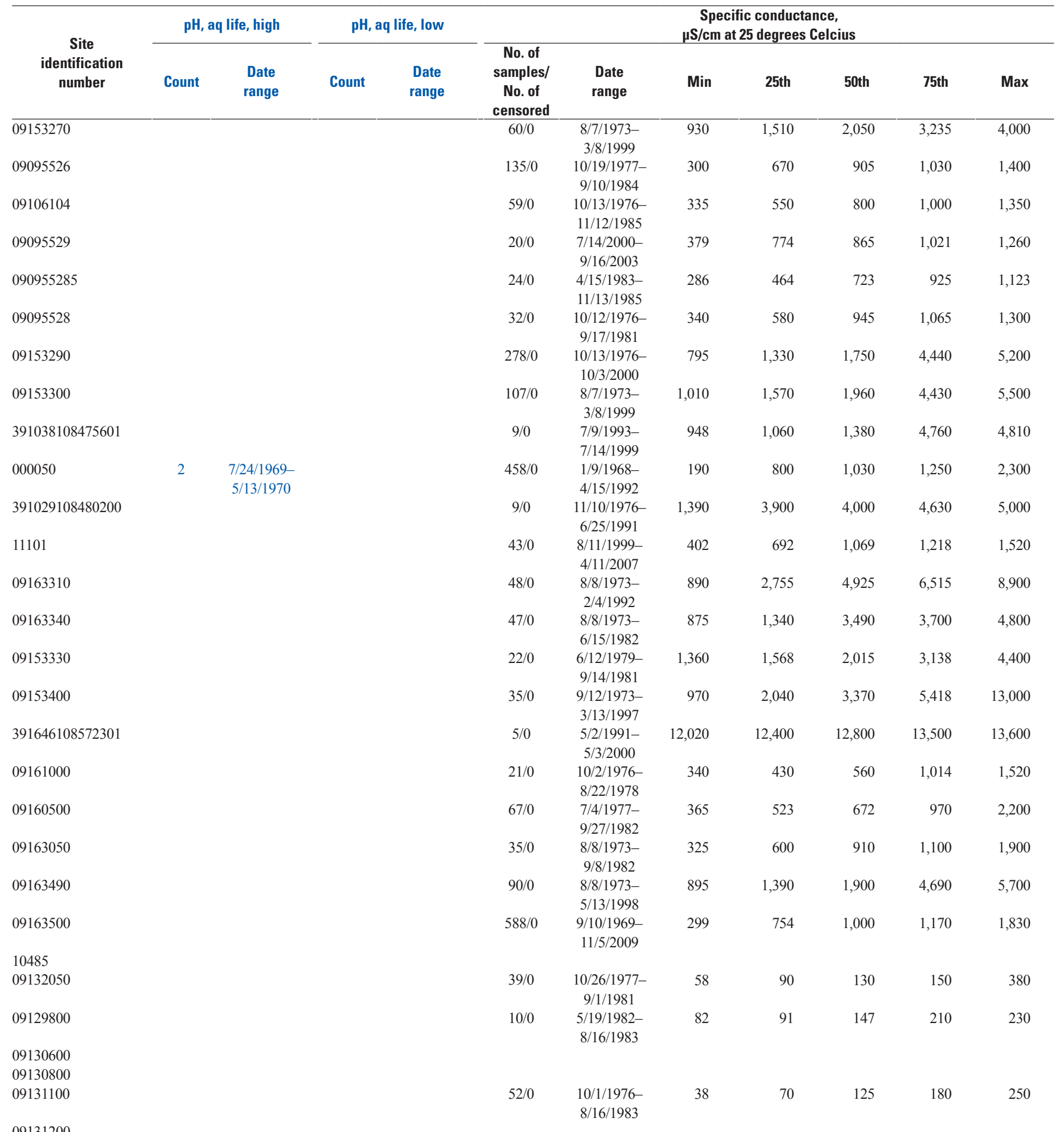

09131200 
Appendix 1. Summary of surface-water-quality data and comparison to water-quality standards by site, by constituent, Piceance study area, western Colorado. Water-quality standards comparisons follow data summaries and are in blue text; standards are provided in table 3.-Continued

[CDPHE segment, Colorado Department of Health and the Environment stream segment as referred to in tables 2 and 3; latitude and longitude are in North American Datum of 1983; downstream order number assigned as part of analysis. $\mu \mathrm{g} / \mathrm{L}$, micrograms per liter; $\mu \mathrm{S} / \mathrm{cm}$, microsiemens per centimeter; $\mathrm{mg} / \mathrm{L}$, milligrams per liter; mL, milliliters; aq, aquatic; CO, Colorado; EPA, U.S. Environmental Protection Agency; Max, maximum; Min, minimum; NA, not applicable; No., number; NTU, nephelometric turbitidy units; WS, water supply; dates given in month/day/year format]

\begin{tabular}{|c|c|c|c|c|c|c|c|c|c|c|c|}
\hline $\begin{array}{c}\text { Site } \\
\text { identification } \\
\text { number }\end{array}$ & \multicolumn{2}{|c|}{ pH, aq life, high } & \multicolumn{2}{|c|}{ pH, aq life, low } & \multicolumn{7}{|c|}{$\begin{array}{c}\text { Specific conductance, } \\
\mu \mathrm{S} / \mathrm{cm} \text { at } 25 \text { degrees Celcius }\end{array}$} \\
\hline \multicolumn{12}{|l|}{10490} \\
\hline 09132500 & 1 & $\begin{array}{l}7 / 15 / 1982- \\
7 / 15 / 1982\end{array}$ & 1 & $\begin{array}{c}12 / 8 / 1981- \\
12 / 8 / 1981\end{array}$ & $305 / 0$ & $\begin{array}{l}10 / 6 / 1976- \\
7 / 21 / 2009\end{array}$ & 20 & 115 & 152 & 182 & 585 \\
\hline \multicolumn{12}{|l|}{09132700} \\
\hline \multicolumn{12}{|l|}{09132800} \\
\hline \multicolumn{12}{|l|}{09132900} \\
\hline \multicolumn{12}{|l|}{09132920} \\
\hline 09132940 & & & & & $14 / 0$ & $\begin{array}{c}8 / 28 / 2001- \\
11 / 2 / 2004\end{array}$ & 126 & 173 & 204 & 222 & 274 \\
\hline \multicolumn{12}{|l|}{$10406 \mathrm{H}$} \\
\hline 09132995 & & & & & $33 / 0$ & $\begin{array}{c}5 / 10 / 1999 \\
3 / 16 / 2005\end{array}$ & 1 & 154 & 328 & 480 & 1,084 \\
\hline 09134000 & & & & & $174 / 0$ & $\begin{array}{l}1 / 2 / 1986- \\
10 / 14 / 2004\end{array}$ & 125 & 240 & 390 & 579 & 1,250 \\
\hline 10436 & 1 & $\begin{array}{c}12 / 1 / 1998 \\
12 / 1 / 1998\end{array}$ & & & & & & & & & \\
\hline 09134050 & & & & & $46 / 0$ & $\begin{array}{c}5 / 21 / 1976- \\
3 / 13 / 2000\end{array}$ & 240 & 700 & 1,010 & 1,300 & 2,200 \\
\hline \multicolumn{12}{|l|}{385144107371701} \\
\hline 09134100 & & & & & $29 / 0$ & $\begin{array}{c}3 / 2 / 2000- \\
10 / 13 / 2004\end{array}$ & 118 & 245 & 372 & 738 & 973 \\
\hline 385049107372402 & & & & & $6 / 0$ & $\begin{array}{l}5 / 8 / 2008 \\
4 / 14 / 2009\end{array}$ & 1,294 & 1,366 & 1,640 & 2,054 & 2,650 \\
\hline 384922107402001 & & & & & $12 / 0$ & $\begin{array}{c}5 / 11 / 1999- \\
4 / 14 / 2009\end{array}$ & 982 & 1,470 & 1,605 & 2,760 & 3,380 \\
\hline \multicolumn{12}{|l|}{09134500} \\
\hline \multicolumn{12}{|l|}{09134700} \\
\hline \multicolumn{12}{|l|}{10415} \\
\hline 09135900 & & & & & $222 / 0$ & $\begin{array}{c}5 / 19 / 1976- \\
12 / 5 / 2000\end{array}$ & 38 & 935 & 1,295 & 1,420 & 2,360 \\
\hline 10411 & & & & & $18 / 0$ & $\begin{array}{c}8 / 10 / 1999- \\
3 / 15 / 2005\end{array}$ & 550 & 1,107 & 1,171 & 1,273 & 1,349 \\
\hline 384732107434801 & & & & & $7 / 0$ & $\begin{array}{c}10 / 14 / 1998- \\
12 / 5 / 2000\end{array}$ & 1,140 & 1,190 & 1,230 & 1,430 & 1,470 \\
\hline 09135950 & & & & & $42 / 0$ & $\begin{array}{l}3 / 24 / 1997- \\
10 / 13 / 2004\end{array}$ & 218 & 546 & 1,192 & 1,436 & 1,660 \\
\hline 000100 & & & & & $125 / 0$ & $\begin{array}{c}8 / 11 / 1971- \\
2 / 1 / 2001\end{array}$ & 14 & 510 & 930 & 1,120 & 1,750 \\
\hline 384434107432701 & & & & & $7 / 0$ & $\begin{array}{c}5 / 12 / 2008- \\
4 / 10 / 2009\end{array}$ & 1,300 & 1,835 & 2,180 & 2,400 & 2,415 \\
\hline
\end{tabular}


Appendix 1. Summary of surface-water-quality data and comparison to water-quality standards by site, by constituent, Piceance study area, western Colorado. Water-quality standards comparisons follow data summaries and are in blue text; standards are provided in table 3.-Continued

[CDPHE segment, Colorado Department of Health and the Environment stream segment as referred to in tables 2 and 3; latitude and longitude are in North American Datum of 1983; downstream order number assigned as part of analysis. $\mu \mathrm{g} / \mathrm{L}$, micrograms per liter; $\mu \mathrm{S} / \mathrm{cm}$, microsiemens per centimeter; $\mathrm{mg} / \mathrm{L}$, milligrams per liter; mL, milliliters; aq, aquatic; CO, Colorado; EPA, U.S. Environmental Protection Agency; Max, maximum; Min, minimum; NA, not applicable; No., number; NTU, nephelometric turbitidy units; WS, water supply; dates given in month/day/year format]

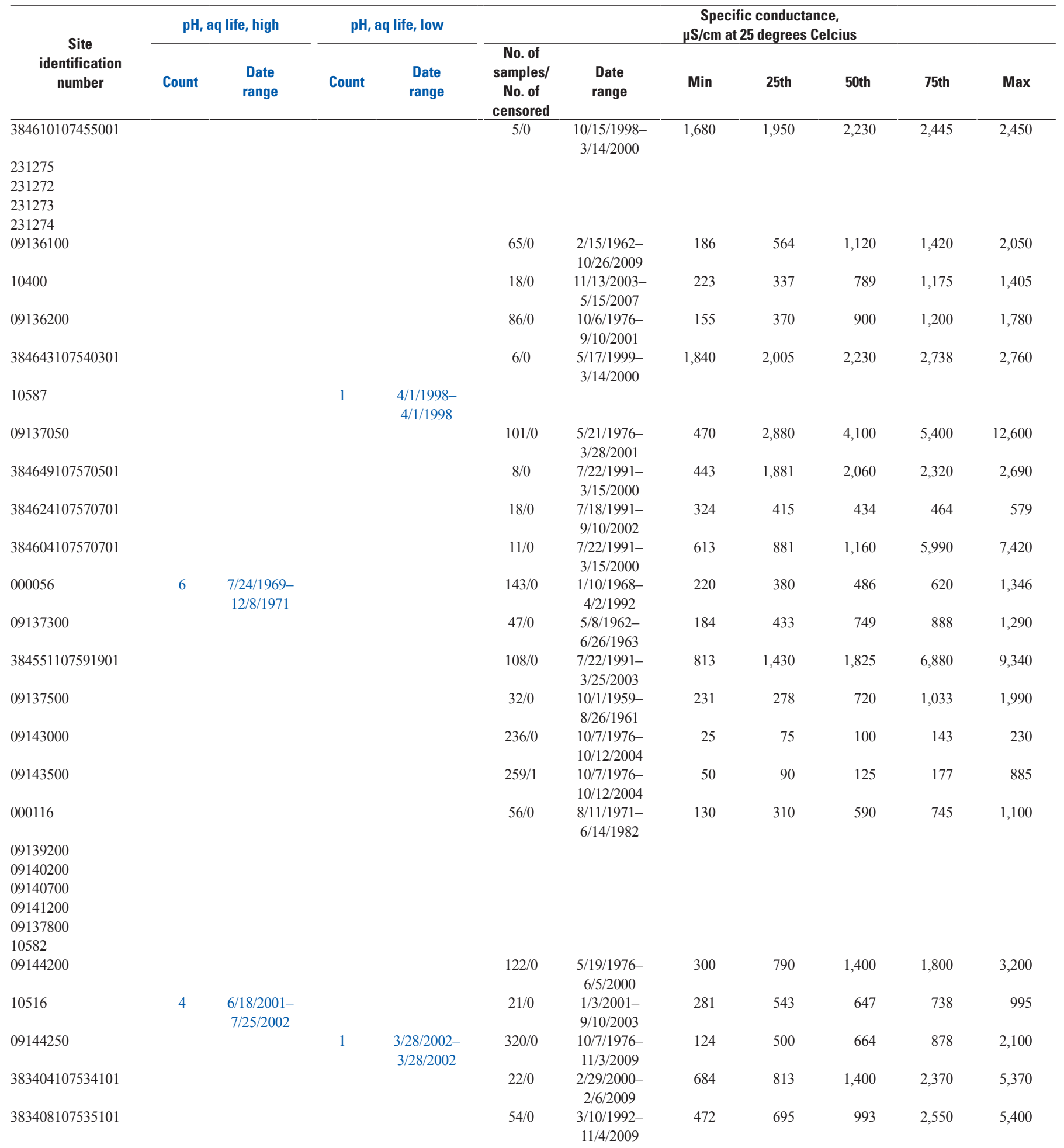


Appendix 1. Summary of surface-water-quality data and comparison to water-quality standards by site, by constituent, Piceance study area, western Colorado. Water-quality standards comparisons follow data summaries and are in blue text; standards are provided in table 3.-Continued

[CDPHE segment, Colorado Department of Health and the Environment stream segment as referred to in tables 2 and 3; latitude and longitude are in North American Datum of 1983; downstream order number assigned as part of analysis. $\mu \mathrm{g} / \mathrm{L}$, micrograms per liter; $\mu \mathrm{S} / \mathrm{cm}$, microsiemens per centimeter; $\mathrm{mg} / \mathrm{L}$, milligrams per liter; mL, milliliters; aq, aquatic; CO, Colorado; EPA, U.S. Environmental Protection Agency; Max, maximum; Min, minimum; NA, not applicable; No., number; NTU, nephelometric turbitidy units; WS, water supply; dates given in month/day/year format]

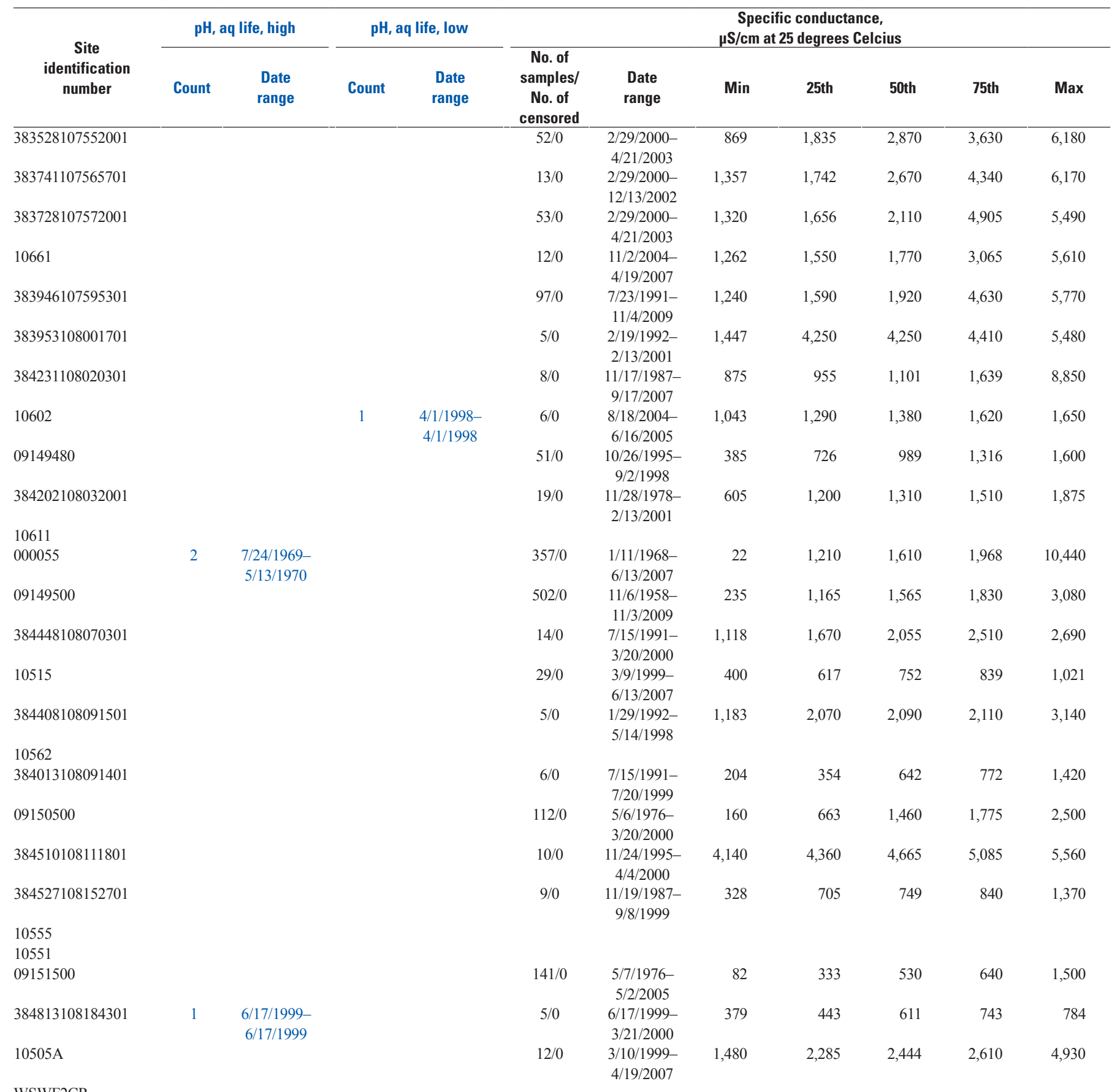

WSEF2CR

WSTWOCR

WSKCINTK

10575 
Appendix 1. Summary of surface-water-quality data and comparison to water-quality standards by site, by constituent, Piceance study area, western Colorado. Water-quality standards comparisons follow data summaries and are in blue text; standards are provided in table 3.-Continued

[CDPHE segment, Colorado Department of Health and the Environment stream segment as referred to in tables 2 and 3; latitude and longitude are in North American Datum of 1983; downstream order number assigned as part of analysis. $\mu \mathrm{g} / \mathrm{L}$, micrograms per liter; $\mu \mathrm{S} / \mathrm{cm}$, microsiemens per centimeter; $\mathrm{mg} / \mathrm{L}$, milligrams per liter; mL, milliliters; aq, aquatic; CO, Colorado; EPA, U.S. Environmental Protection Agency; Max, maximum; Min, minimum; NA, not applicable; No., number; NTU, nephelometric turbitidy units; WS, water supply; dates given in month/day/year format]

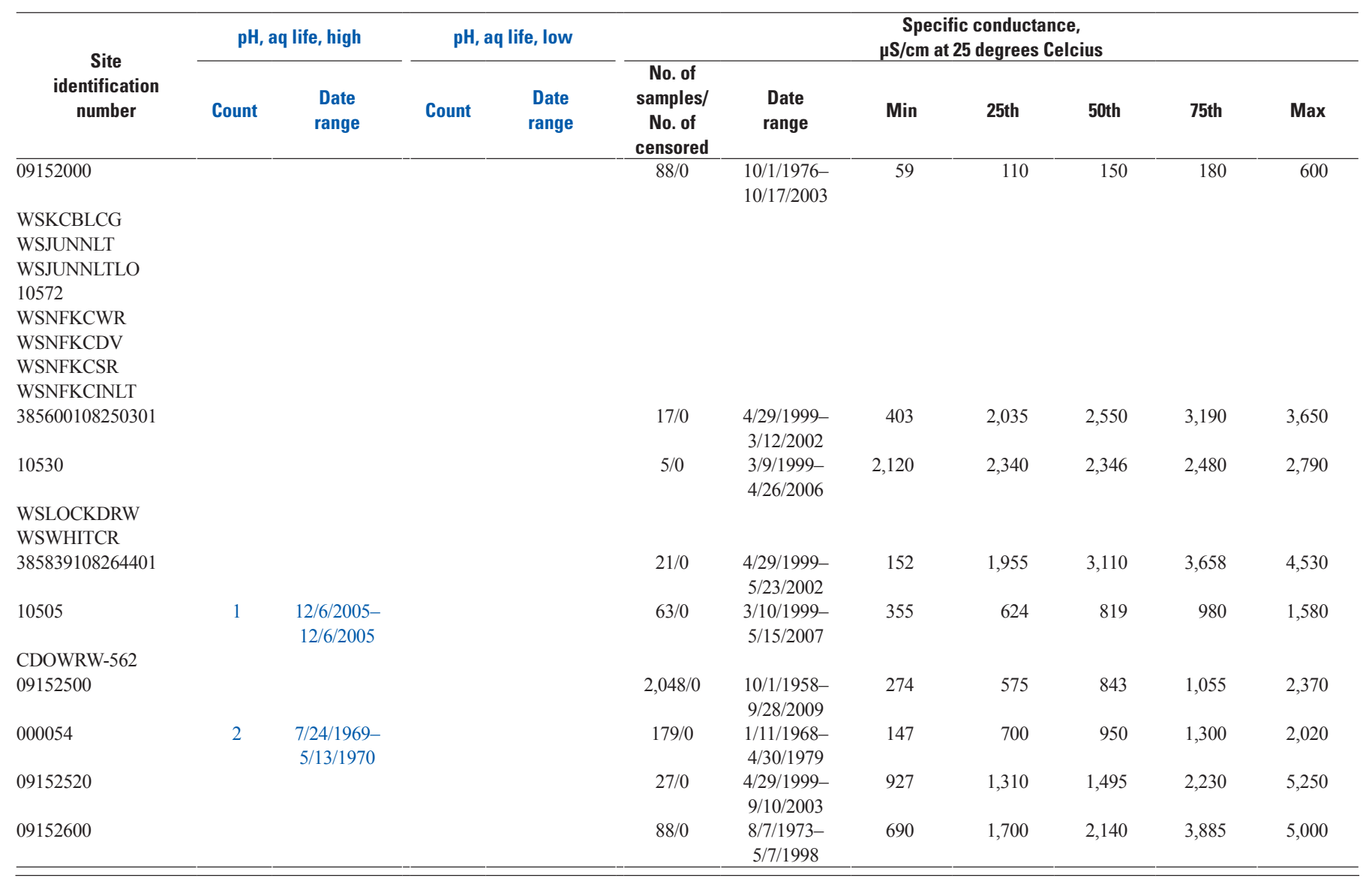


Appendix 1. Summary of surface-water-quality data and comparison to water-quality standards by site, by constituent, Piceance study area, western Colorado. Water-quality standards comparisons follow data summaries and are in blue text; standards are provided in table 3.-Continued

[CDPHE segment, Colorado Department of Health and the Environment stream segment as referred to in tables 2 and 3; latitude and longitude are in North American Datum of 1983; downstream order number assigned as part of analysis. $\mu \mathrm{g} / \mathrm{L}$, micrograms per liter; $\mu \mathrm{S} / \mathrm{cm}$, microsiemens per centimeter; $\mathrm{mg} / \mathrm{L}$, milligrams per liter; mL, milliliters; aq, aquatic; CO, Colorado; EPA, U.S. Environmental Protection Agency; Max, maximum; Min, minimum; NA, not applicable; No., number; NTU, nephelometric turbitidy units; WS, water supply; dates given in month/day/year format]

\begin{tabular}{|c|c|c|c|c|c|c|c|c|c|c|c|c|c|c|}
\hline \multirow{2}{*}{$\begin{array}{c}\text { Site } \\
\text { identification } \\
\text { number }\end{array}$} & \multicolumn{7}{|c|}{$\begin{array}{l}\text { Turbidity, } \\
\text { NTU }\end{array}$} & \multicolumn{7}{|c|}{$\begin{array}{c}\text { Alkalinity, } \\
\mathrm{mg} / \mathrm{L} \text { as } \mathrm{CaCO}_{3}\end{array}$} \\
\hline & $\begin{array}{c}\text { No. of } \\
\text { samples/ } \\
\text { No. of } \\
\text { censored }\end{array}$ & $\begin{array}{l}\text { Date } \\
\text { range }\end{array}$ & Min & 25th & 50th & 75th & Max & $\begin{array}{c}\text { No. of } \\
\text { samples/ } \\
\text { No. of } \\
\text { censored }\end{array}$ & $\begin{array}{l}\text { Date } \\
\text { range }\end{array}$ & Min & 25th & 50th & 75th & Max \\
\hline \multicolumn{15}{|l|}{09302450} \\
\hline \multicolumn{15}{|l|}{09304100} \\
\hline \multicolumn{15}{|l|}{395643107461200} \\
\hline 09304200 & $11 / 0$ & $\begin{array}{c}11 / 20 / 1987- \\
7 / 30 / 2002\end{array}$ & 0.9 & 1.5 & 2.5 & 7.0 & 12.0 & $245 / 0$ & $\begin{array}{c}3 / 20 / 1970- \\
7 / 30 / 2002\end{array}$ & 0 & 200 & 210 & 220 & 262 \\
\hline 09304480 & & & & & & & & $191 / 0$ & $\begin{array}{l}\text { 7/6/1978- } \\
\text { 9/30/1982 }\end{array}$ & 4 & 347 & 393 & 530 & 688 \\
\hline \multicolumn{15}{|l|}{09304300} \\
\hline 09304500 & & & & & & & & $5 / 0$ & $\begin{array}{c}12 / 15 / 1970- \\
5 / 30 / 1974\end{array}$ & 133 & 146 & 228 & 272 & 290 \\
\hline 09304550 & & & & & & & & $198 / 0$ & $\begin{array}{c}8 / 30 / 1973- \\
9 / 23 / 2005\end{array}$ & 254 & 1,026 & 1,165 & 1,269 & 1,680 \\
\hline 09304600 & & & & & & & & $237 / 0$ & $\begin{array}{l}\text { 7/6/1978- } \\
\text { 9/24/2005 }\end{array}$ & 147 & 220 & 236 & 254 & 394 \\
\hline \multicolumn{15}{|l|}{4000001075434} \\
\hline \multicolumn{15}{|l|}{400113107574500} \\
\hline 000043 & $70 / 0$ & $\begin{array}{c}3 / 27 / 1968- \\
6 / 10 / 1980\end{array}$ & 2.4 & 5.0 & 9.4 & 16.0 & 305.0 & & & & & & & \\
\hline \multicolumn{15}{|l|}{400206108005901} \\
\hline 09304800 & $48 / 0$ & $\begin{array}{l}4 / 3 / 1974 \\
9 / 10 / 2002\end{array}$ & 1.6 & 4.8 & 9.0 & 19.0 & 110.0 & $215 / 0$ & $\begin{array}{c}5 / 30 / 1974 \\
9 / 29 / 2009\end{array}$ & 0 & 238 & 266 & 310 & 524 \\
\hline \multicolumn{15}{|l|}{ ENPR20ST } \\
\hline \multicolumn{15}{|l|}{ ENPR21ST } \\
\hline \multicolumn{15}{|l|}{ ENPR19ST } \\
\hline 09306007 & $57 / 0$ & $\begin{array}{c}12 / 4 / 1974- \\
9 / 25 / 1981\end{array}$ & 0.0 & 3.0 & 11.0 & 34.0 & 480.0 & $88 / 0$ & $\begin{array}{c}4 / 23 / 1974 \\
9 / 27 / 1979\end{array}$ & 475 & 787 & 859 & 906 & 1,049 \\
\hline 09306025 & $11 / 0$ & $\begin{array}{l}\text { 5/9/1975- } \\
10 / 7 / 1975\end{array}$ & 1.0 & 1.0 & 4.0 & 14.0 & 16.0 & $38 / 0$ & $\begin{array}{l}5 / 3 / 1974 \\
10 / 5 / 1976\end{array}$ & 247 & 751 & 834 & 888 & 1,241 \\
\hline \multicolumn{15}{|l|}{09306028} \\
\hline 09306022 & $22 / 0$ & $\begin{array}{l}12 / 4 / 1974 \\
10 / 31 / 1975\end{array}$ & 0.0 & 2.0 & 8.0 & 16.3 & 30.0 & $67 / 0$ & $\begin{array}{c}10 / 4 / 1974 \\
8 / 22 / 1979\end{array}$ & 490 & 777 & 803 & 836 & 1,282 \\
\hline \multicolumn{15}{|l|}{09306033} \\
\hline \multicolumn{15}{|l|}{09306039} \\
\hline \multicolumn{15}{|l|}{09306042} \\
\hline \multicolumn{15}{|l|}{09306050} \\
\hline \multicolumn{15}{|l|}{09306052} \\
\hline 09306058 & $47 / 0$ & $\begin{array}{c}4 / 15 / 1975- \\
9 / 25 / 1981\end{array}$ & 1.0 & 4.0 & 15.0 & 30.0 & 350.0 & $66 / 0$ & $\begin{array}{c}4 / 23 / 1974- \\
8 / 22 / 1979\end{array}$ & 533 & 783 & 809 & 838 & 934 \\
\hline 09306061 & $57 / 0$ & $\begin{array}{c}12 / 6 / 1974- \\
9 / 25 / 1981\end{array}$ & 1.0 & 5.0 & 20.0 & 50.0 & 670.0 & $86 / 0$ & $\begin{array}{c}4 / 23 / 1974 \\
8 / 22 / 1979\end{array}$ & 492 & 859 & 918 & 1,016 & 1,131 \\
\hline \multicolumn{15}{|l|}{11625} \\
\hline 09306175 & $35 / 0$ & $\begin{array}{c}10 / 28 / 1976- \\
9 / 25 / 1981\end{array}$ & 1.0 & 2.0 & 8.0 & 24.0 & 430.0 & $57 / 0$ & $\begin{array}{c}\text { 1/15/1975- } \\
9 / 27 / 1979\end{array}$ & 246 & 901 & 934 & 985 & 1,065 \\
\hline 09306200 & $36 / 0$ & $\begin{array}{c}10 / 28 / 1976- \\
9 / 11 / 2002\end{array}$ & 2.0 & 4.0 & 9.0 & 30.0 & 280.0 & $142 / 0$ & $\begin{array}{c}\text { 6/8/1965- } \\
7 / 8 / 2009\end{array}$ & 304 & 512 & 946 & 1,100 & 1,529 \\
\hline 09306210 & & & & & & & & $54 / 0$ & $\begin{array}{c}12 / 15 / 1970- \\
8 / 18 / 1976\end{array}$ & 459 & 970 & 1,092 & 1,216 & 1,770 \\
\hline 09306222 & $35 / 0$ & $\begin{array}{c}10 / 28 / 1976- \\
7 / 31 / 2002\end{array}$ & 1.0 & 4.0 & 11.0 & 110.0 & 380.0 & $148 / 0$ & $\begin{array}{c}\text { 6/8/1965- } \\
7 / 7 / 2009\end{array}$ & 412 & 1,050 & 1,468 & 1,948 & 7,687 \\
\hline 000117 & $44 / 0$ & $\begin{array}{c}11 / 2 / 1971- \\
6 / 10 / 1980\end{array}$ & 2.7 & 12.0 & 30.8 & 72.5 & 500.0 & & & & & & & \\
\hline 09306224 & $13 / 0$ & $\begin{array}{c}11 / 20 / 1987- \\
8 / 26 / 1988\end{array}$ & 8.0 & 11.4 & 19.0 & 56.5 & 310.0 & $10 / 0$ & $\begin{array}{c}10 / 19 / 2007- \\
9 / 29 / 2009\end{array}$ & 122 & 130 & 159 & 174 & 182 \\
\hline 09306240 & $10 / 0$ & $\begin{array}{c}5 / 14 / 1975- \\
4 / 15 / 1982\end{array}$ & 2.0 & 13.0 & 105.0 & 300.0 & 590.0 & $15 / 0$ & $\begin{array}{c}4 / 27 / 1974 \\
6 / 16 / 1978\end{array}$ & 148 & 506 & 547 & 610 & 742 \\
\hline
\end{tabular}


Appendix 1. Summary of surface-water-quality data and comparison to water-quality standards by site, by constituent, Piceance study area, western Colorado. Water-quality standards comparisons follow data summaries and are in blue text; standards are provided in table 3.-Continued

[CDPHE segment, Colorado Department of Health and the Environment stream segment as referred to in tables 2 and 3; latitude and longitude are in North American Datum of 1983; downstream order number assigned as part of analysis. $\mu \mathrm{g} / \mathrm{L}$, micrograms per liter; $\mu \mathrm{S} / \mathrm{cm}$, microsiemens per centimeter; $\mathrm{mg} / \mathrm{L}$, milligrams per liter; mL, milliliters; aq, aquatic; CO, Colorado; EPA, U.S. Environmental Protection Agency; Max, maximum; Min, minimum; NA, not applicable; No., number; NTU, nephelometric turbitidy units; WS, water supply; dates given in month/day/year format]

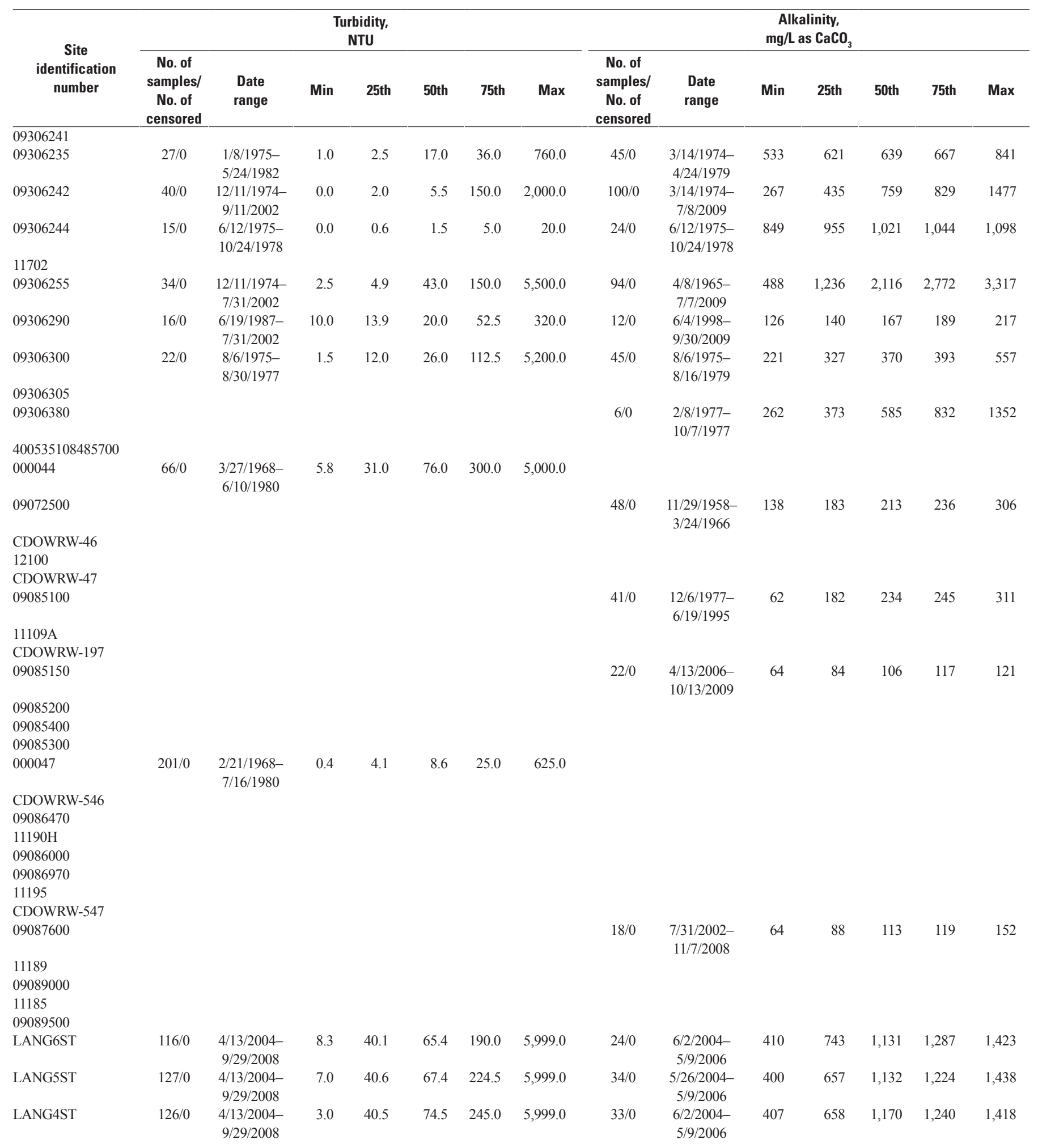


Appendix 1. Summary of surface-water-quality data and comparison to water-quality standards by site, by constituent, Piceance study area, western Colorado. Water-quality standards comparisons follow data summaries and are in blue text; standards are provided in table 3.-Continued

[CDPHE segment, Colorado Department of Health and the Environment stream segment as referred to in tables 2 and 3; latitude and longitude are in North American Datum of 1983; downstream order number assigned as part of analysis. $\mu \mathrm{g} / \mathrm{L}$, micrograms per liter; $\mu \mathrm{S} / \mathrm{cm}$, microsiemens per centimeter; $\mathrm{mg} / \mathrm{L}$, milligrams per liter; mL, milliliters; aq, aquatic; CO, Colorado; EPA, U.S. Environmental Protection Agency; Max, maximum; Min, minimum; NA, not applicable; No., number; NTU, nephelometric turbitidy units; WS, water supply; dates given in month/day/year format]

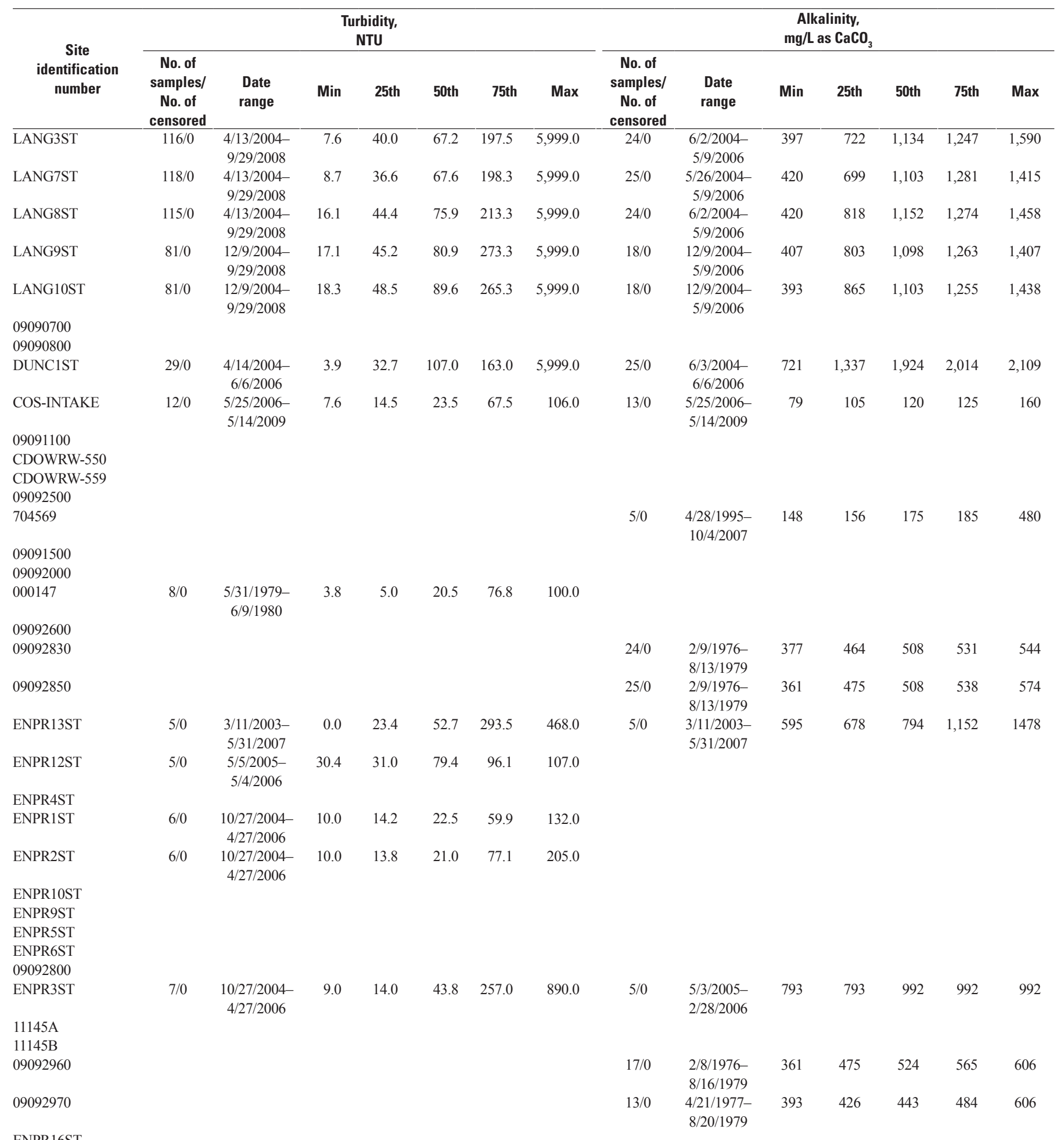

ENPR16ST 
Appendix 1. Summary of surface-water-quality data and comparison to water-quality standards by site, by constituent, Piceance study area, western Colorado. Water-quality standards comparisons follow data summaries and are in blue text; standards are provided in table 3.-Continued

[CDPHE segment, Colorado Department of Health and the Environment stream segment as referred to in tables 2 and 3; latitude and longitude are in North American Datum of 1983; downstream order number assigned as part of analysis. $\mu \mathrm{g} / \mathrm{L}$, micrograms per liter; $\mu \mathrm{S} / \mathrm{cm}$, microsiemens per centimeter; $\mathrm{mg} / \mathrm{L}$, milligrams per liter; mL, milliliters; aq, aquatic; CO, Colorado; EPA, U.S. Environmental Protection Agency; Max, maximum; Min, minimum; NA, not applicable; No., number; NTU, nephelometric turbitidy units; WS, water supply; dates given in month/day/year format]

\begin{tabular}{|c|c|c|c|c|c|c|c|c|c|c|c|c|c|c|}
\hline \multirow{2}{*}{$\begin{array}{c}\text { Site } \\
\text { identification } \\
\text { number }\end{array}$} & \multicolumn{7}{|c|}{$\begin{array}{c}\text { Turbidity, } \\
\text { NTU }\end{array}$} & \multicolumn{7}{|c|}{$\begin{array}{c}\text { Alkalinity, } \\
\mathrm{mg} / \mathrm{L} \text { as } \mathrm{CaCO}_{3}\end{array}$} \\
\hline & $\begin{array}{c}\text { No. of } \\
\text { samples/ } \\
\text { No. of } \\
\text { censored }\end{array}$ & $\begin{array}{l}\text { Date } \\
\text { range }\end{array}$ & Min & 25th & 50th & 75th & Max & $\begin{array}{c}\text { No. of } \\
\text { samples/ } \\
\text { No. of } \\
\text { censored }\end{array}$ & $\begin{array}{l}\text { Date } \\
\text { range }\end{array}$ & Min & 25th & 50th & 75th & Max \\
\hline 09092980 & & & & & & & & $7 / 0$ & $\begin{array}{c}4 / 21 / 1978- \\
8 / 20 / 1979\end{array}$ & 459 & 459 & 508 & 541 & 557 \\
\hline \multicolumn{15}{|l|}{ ENPR18ST } \\
\hline ENPR15ST & $5 / 0$ & $\begin{array}{c}10 / 27 / 2004 \\
5 / 5 / 2006\end{array}$ & 3.0 & 7.1 & 33.1 & 53.6 & 62.3 & & & & & & & \\
\hline ENPR11ST & $6 / 0$ & $\begin{array}{c}10 / 27 / 2004 \\
5 / 5 / 2006\end{array}$ & 10.0 & 12.5 & 42.4 & 143.8 & 336.0 & $5 / 0$ & $\begin{array}{c}5 / 9 / 2005- \\
5 / 5 / 2006\end{array}$ & 810 & 818 & 860 & 942 & 992 \\
\hline 09093000 & $23 / 0$ & $\begin{array}{c}\text { 6/11/1975- } \\
\text { 9/15/1977 }\end{array}$ & 0.1 & 1.3 & 3.0 & 20.0 & 110.0 & $41 / 0$ & $\begin{array}{c}4 / 21 / 1975- \\
8 / 17 / 1979\end{array}$ & 393 & 547 & 592 & 623 & 688 \\
\hline \multicolumn{15}{|l|}{11205} \\
\hline \multicolumn{15}{|l|}{09094200} \\
\hline \multicolumn{15}{|l|}{09094400} \\
\hline 09095000 & & & & & & & & $51 / 0$ & $\begin{array}{c}2 / 24 / 1975- \\
8 / 16 / 1979\end{array}$ & 233 & 754 & 836 & 885 & 942 \\
\hline 09095300 & & & & & & & & $75 / 0$ & $\begin{array}{l}\text { 10/19/1995- } \\
\text { 9/7/2004 }\end{array}$ & 108 & 346 & 400 & 454 & 572 \\
\hline \multicolumn{15}{|l|}{09095400} \\
\hline \multicolumn{15}{|l|}{11202} \\
\hline 000148 & $7 / 0$ & $\begin{array}{c}5 / 31 / 1979 \\
6 / 9 / 1980\end{array}$ & 44.0 & 66.0 & 370.0 & 960.0 & $2,300.0$ & & & & & & & \\
\hline 09095500 & & & & & & & & $424 / 0$ & $\begin{array}{l}10 / 1 / 1959 \\
10 / 27 / 2009\end{array}$ & 64 & 148 & 239 & 279 & 361 \\
\hline \multicolumn{15}{|l|}{ CDOWRW-55 } \\
\hline \multicolumn{15}{|l|}{09097900} \\
\hline \multicolumn{15}{|l|}{ CDOWRW-54 } \\
\hline \multicolumn{15}{|l|}{ CDOWRW-53 } \\
\hline 09105000 & & & & & & & & $149 / 0$ & $\begin{array}{c}11 / 19 / 1968- \\
10 / 27 / 2009\end{array}$ & 71 & 267 & 311 & 593 & 738 \\
\hline 11103 & & & & & & & & & & & & & & \\
\hline $\begin{array}{l}\text { UP RAPID CRK } \\
\text { INTAKE }\end{array}$ & & & & & & & & & & & & & & \\
\hline $\mathrm{RC}-2$ & $7 / 0$ & $\begin{array}{c}11 / 20 / 1997- \\
11 / 12 / 1999\end{array}$ & 0.0 & 0.0 & 0.5 & 3.0 & 245.0 & & & & & & & \\
\hline $\mathrm{RC}-3$ & $6 / 0$ & $\begin{array}{c}11 / 20 / 1997- \\
11 / 12 / 1999\end{array}$ & 1.0 & 1.5 & 4.0 & 13.5 & 30.0 & & & & & & & \\
\hline $\begin{array}{l}\text { LOWER RAPID } \\
\text { CRK }\end{array}$ & & & & & & & & & & & & & & \\
\hline $\begin{array}{l}\text { L COTTONWOOD } \\
\text { INTAKE }\end{array}$ & & & & & & & & $4 / 0$ & & & & & & \\
\hline
\end{tabular}


Appendix 1. Summary of surface-water-quality data and comparison to water-quality standards by site, by constituent, Piceance study area, western Colorado. Water-quality standards comparisons follow data summaries and are in blue text; standards are provided in table 3.-Continued

[CDPHE segment, Colorado Department of Health and the Environment stream segment as referred to in tables 2 and 3; latitude and longitude are in North American Datum of 1983; downstream order number assigned as part of analysis. $\mu \mathrm{g} / \mathrm{L}$, micrograms per liter; $\mu \mathrm{S} / \mathrm{cm}$, microsiemens per centimeter; $\mathrm{mg} / \mathrm{L}$, milligrams per liter; mL, milliliters; aq, aquatic; CO, Colorado; EPA, U.S. Environmental Protection Agency; Max, maximum; Min, minimum; NA, not applicable; No., number; NTU, nephelometric turbitidy units; WS, water supply; dates given in month/day/year format]

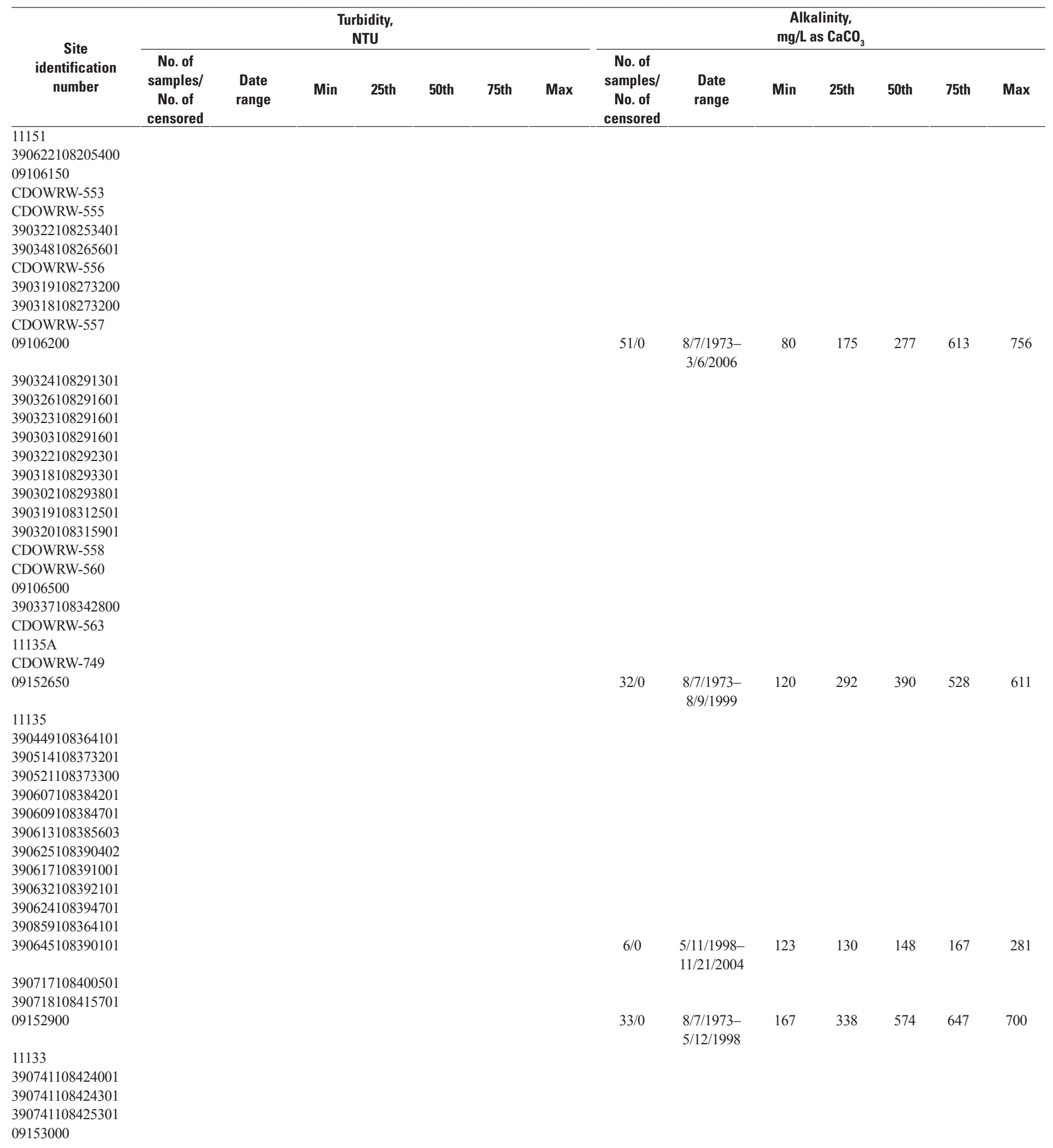


Appendix 1. Summary of surface-water-quality data and comparison to water-quality standards by site, by constituent, Piceance study area, western Colorado. Water-quality standards comparisons follow data summaries and are in blue text; standards are provided in table 3.-Continued

[CDPHE segment, Colorado Department of Health and the Environment stream segment as referred to in tables 2 and 3; latitude and longitude are in North American Datum of 1983; downstream order number assigned as part of analysis. $\mu \mathrm{g} / \mathrm{L}$, micrograms per liter; $\mu \mathrm{S} / \mathrm{cm}$, microsiemens per centimeter; $\mathrm{mg} / \mathrm{L}$, milligrams per liter; mL, milliliters; aq, aquatic; CO, Colorado; EPA, U.S. Environmental Protection Agency; Max, maximum; Min, minimum; NA, not applicable; No., number; NTU, nephelometric turbitidy units; WS, water supply; dates given in month/day/year format]

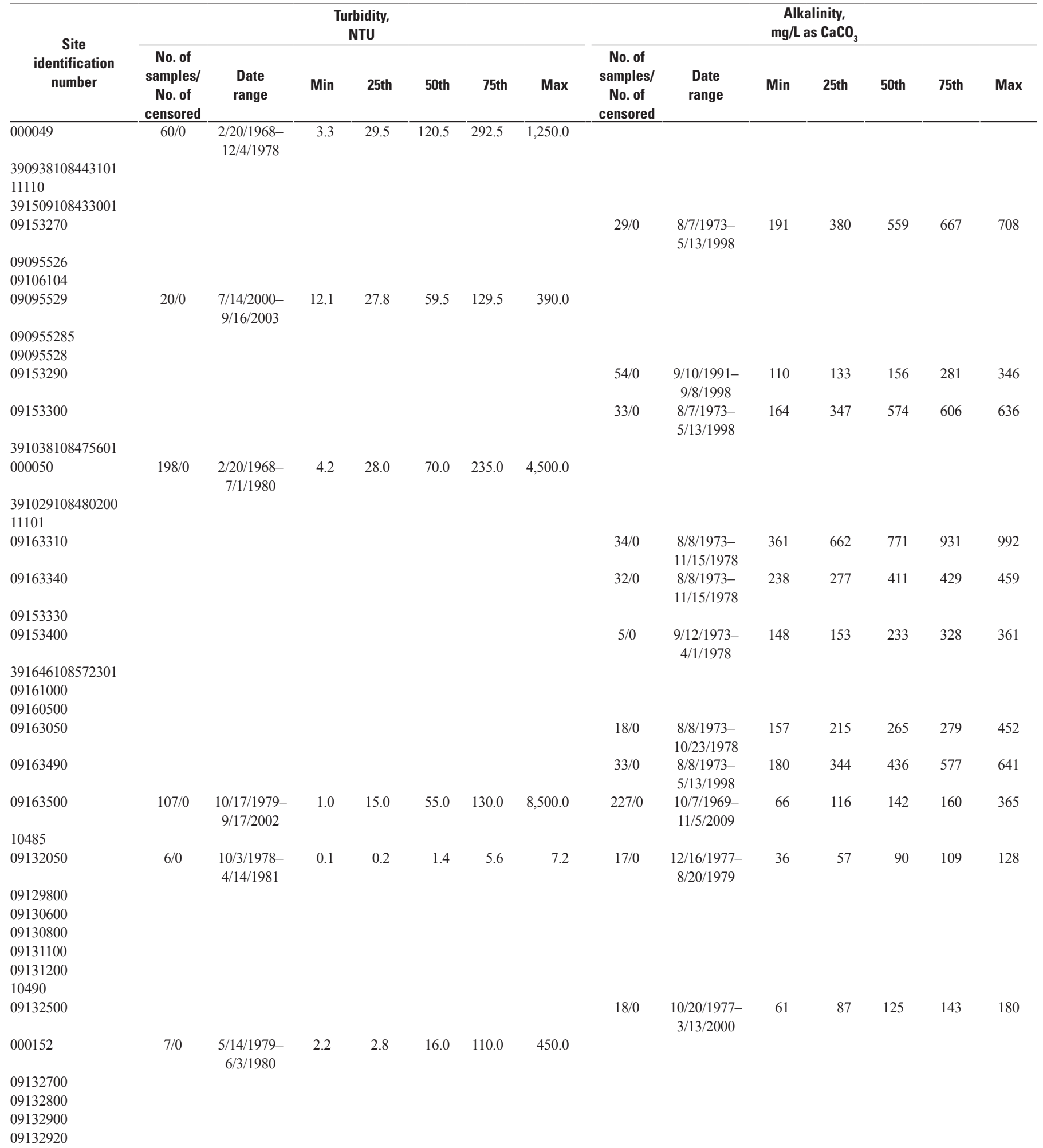


Appendix 1. Summary of surface-water-quality data and comparison to water-quality standards by site, by constituent, Piceance study area, western Colorado. Water-quality standards comparisons follow data summaries and are in blue text; standards are provided in table 3.-Continued

[CDPHE segment, Colorado Department of Health and the Environment stream segment as referred to in tables 2 and 3; latitude and longitude are in North American Datum of 1983; downstream order number assigned as part of analysis. $\mu \mathrm{g} / \mathrm{L}$, micrograms per liter; $\mu \mathrm{S} / \mathrm{cm}$, microsiemens per centimeter; $\mathrm{mg} / \mathrm{L}$, milligrams per liter; mL, milliliters; aq, aquatic; CO, Colorado; EPA, U.S. Environmental Protection Agency; Max, maximum; Min, minimum; NA, not applicable; No., number; NTU, nephelometric turbitidy units; WS, water supply; dates given in month/day/year format]

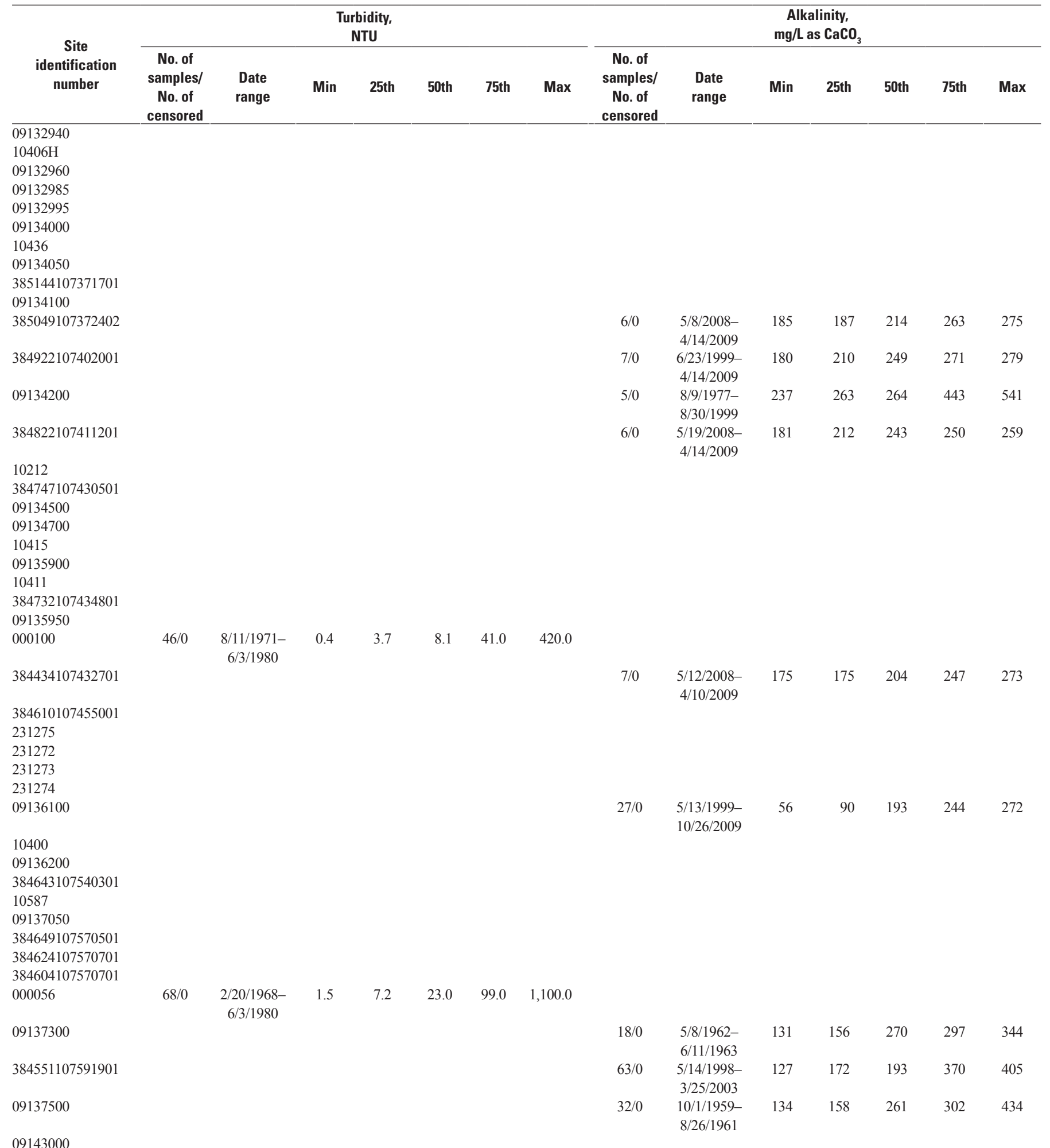


Appendix 1. Summary of surface-water-quality data and comparison to water-quality standards by site, by constituent, Piceance study area, western Colorado. Water-quality standards comparisons follow data summaries and are in blue text; standards are provided in table 3.-Continued

[CDPHE segment, Colorado Department of Health and the Environment stream segment as referred to in tables 2 and 3; latitude and longitude are in North American Datum of 1983; downstream order number assigned as part of analysis. $\mu \mathrm{g} / \mathrm{L}$, micrograms per liter; $\mu \mathrm{S} / \mathrm{cm}$, microsiemens per centimeter; $\mathrm{mg} / \mathrm{L}$, milligrams per liter; mL, milliliters; aq, aquatic; CO, Colorado; EPA, U.S. Environmental Protection Agency; Max, maximum; Min, minimum; NA, not applicable; No., number; NTU, nephelometric turbitidy units; WS, water supply; dates given in month/day/year format]

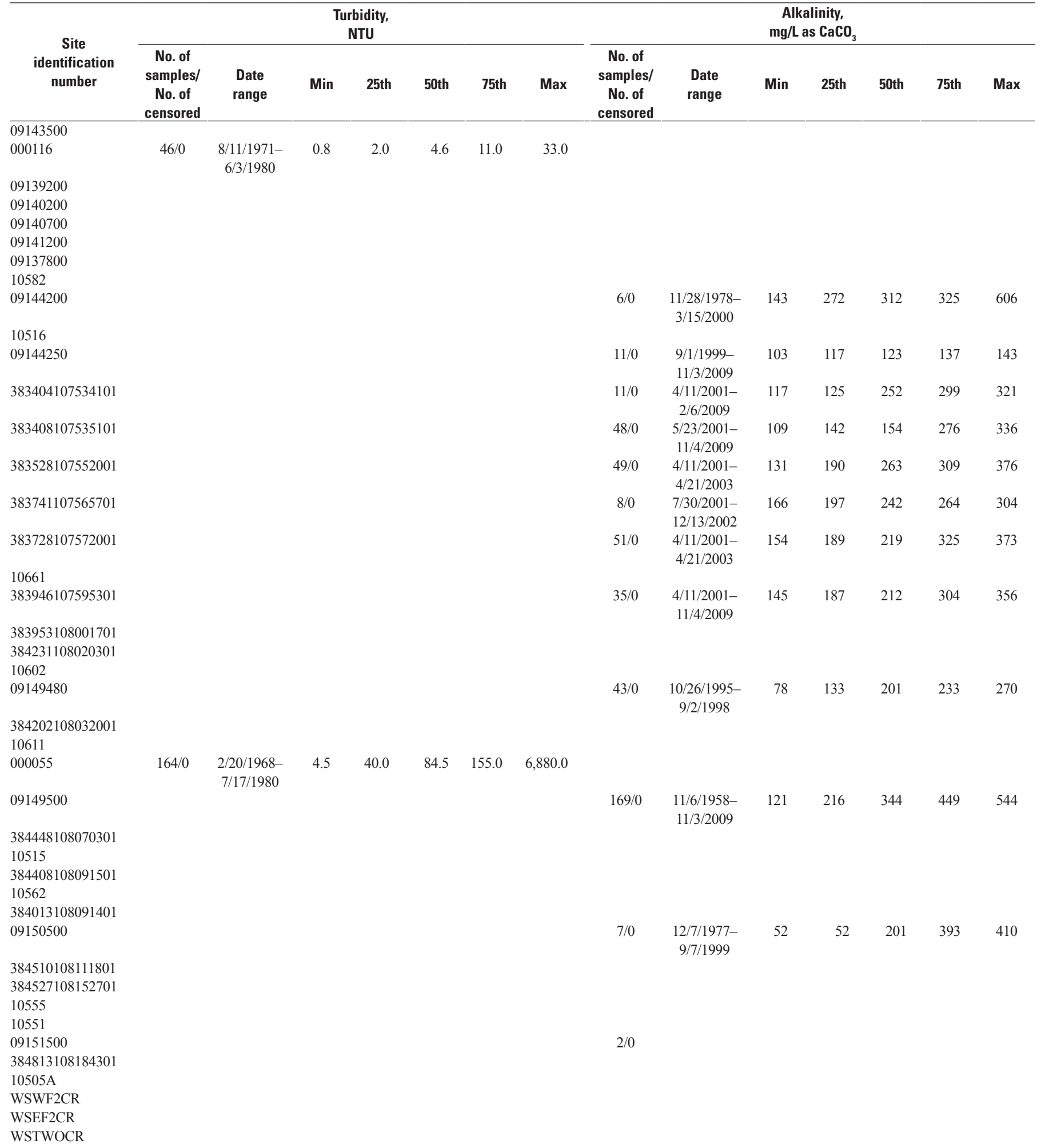


Appendix 1. Summary of surface-water-quality data and comparison to water-quality standards by site, by constituent, Piceance study area, western Colorado. Water-quality standards comparisons follow data summaries and are in blue text; standards are provided in table 3.-Continued

[CDPHE segment, Colorado Department of Health and the Environment stream segment as referred to in tables 2 and 3; latitude and longitude are in North American Datum of 1983; downstream order number assigned as part of analysis. $\mu \mathrm{g} / \mathrm{L}$, micrograms per liter; $\mu \mathrm{S} / \mathrm{cm}$, microsiemens per centimeter; $\mathrm{mg} / \mathrm{L}$, milligrams per liter; mL, milliliters; aq, aquatic; CO, Colorado; EPA, U.S. Environmental Protection Agency; Max, maximum; Min, minimum; NA, not applicable; No., number; NTU, nephelometric turbitidy units; WS, water supply; dates given in month/day/year format]

\begin{tabular}{|c|c|c|c|c|c|c|c|c|c|c|c|c|c|c|}
\hline \multirow{2}{*}{$\begin{array}{c}\text { Site } \\
\text { identification } \\
\text { number }\end{array}$} & \multicolumn{7}{|c|}{$\begin{array}{c}\text { Turbidity, } \\
\text { NTU }\end{array}$} & \multicolumn{7}{|c|}{$\begin{array}{c}\text { Alkalinity, } \\
\mathrm{mg} / \mathrm{L} \text { as } \mathrm{CaCO}_{3}\end{array}$} \\
\hline & $\begin{array}{c}\text { No. of } \\
\text { samples/ } \\
\text { No. of } \\
\text { censored }\end{array}$ & $\begin{array}{l}\text { Date } \\
\text { range }\end{array}$ & Min & 25th & 50th & 75th & Max & $\begin{array}{c}\text { No. of } \\
\text { samples/ } \\
\text { No. of } \\
\text { censored }\end{array}$ & $\begin{array}{l}\text { Date } \\
\text { range }\end{array}$ & Min & 25th & 50th & 75th & Max \\
\hline WSKCINTK & $34 / 0$ & $\begin{array}{c}\text { 7/15/1987- } \\
8 / 11 / 2008\end{array}$ & 0.2 & 2.0 & 3.1 & 5.6 & 46.0 & & & & & & & \\
\hline \multicolumn{15}{|l|}{10575} \\
\hline WSKCBLCG & $18 / 0$ & $\begin{array}{c}\text { 10/22/1987- } \\
7 / 15 / 1991\end{array}$ & 0.3 & 5.1 & 6.2 & 15.3 & 87.0 & & & & & & & \\
\hline WSJUNNLT & $31 / 0$ & $\begin{array}{c}11 / 29 / 2005- \\
11 / 27 / 2006\end{array}$ & 2.0 & 3.1 & 5.0 & 7.5 & 14.2 & & & & & & & \\
\hline WSJUNNLTLO & $29 / 0$ & $\begin{array}{c}11 / 29 / 2005- \\
11 / 27 / 2006\end{array}$ & 4.3 & 6.8 & 9.4 & 13.1 & 36.6 & & & & & & & \\
\hline \multicolumn{15}{|l|}{ WSNFKCSR } \\
\hline \multicolumn{15}{|l|}{ WSNFKCINLT } \\
\hline 385600108250301 & & & & & & & & $10 / 0$ & $\begin{array}{c}8 / 21 / 2000 \\
3 / 12 / 2002\end{array}$ & 62 & 225 & 264 & 292 & 308 \\
\hline \multicolumn{15}{|l|}{10530} \\
\hline \multicolumn{15}{|l|}{ WSLOCKDRW } \\
\hline WSWHITCR & $34 / 0$ & $\begin{array}{c}\text { 7/15/1991- } \\
8 / 8 / 2006\end{array}$ & 0.7 & 10.0 & 26.0 & 51.0 & 280.0 & & & & & & & \\
\hline 385839108264401 & & & & & & & & $16 / 0$ & $\begin{array}{c}6 / 29 / 1999 \\
5 / 23 / 2002\end{array}$ & 145 & 180 & 231 & 317 & 374 \\
\hline \multicolumn{15}{|l|}{$\begin{array}{l}10505 \\
\text { CDOWRW-562 }\end{array}$} \\
\hline 09152500 & $135 / 0$ & $\begin{array}{c}12 / 3 / 1975- \\
4 / 8 / 2005\end{array}$ & 1.0 & 7.6 & 27.0 & 74.0 & $1,800.0$ & $544 / 0$ & $\begin{array}{c}\text { 10/1/1959- } \\
9 / 28 / 2009\end{array}$ & 61 & 161 & 252 & 337 & 446 \\
\hline
\end{tabular}


Appendix 1. Summary of surface-water-quality data and comparison to water-quality standards by site, by constituent, Piceance study area, western Colorado. Water-quality standards comparisons follow data summaries and are in blue text; standards are provided in table 3.-Continued

[CDPHE segment, Colorado Department of Health and the Environment stream segment as referred to in tables 2 and 3; latitude and longitude are in North American Datum of 1983; downstream order number assigned as part of analysis. $\mu \mathrm{g} / \mathrm{L}$, micrograms per liter; $\mu \mathrm{S} / \mathrm{cm}$, microsiemens per centimeter; $\mathrm{mg} / \mathrm{L}$, milligrams per liter; mL, milliliters; aq, aquatic; CO, Colorado; EPA, U.S. Environmental Protection Agency; Max, maximum; Min, minimum; NA, not applicable; No., number; NTU, nephelometric turbitidy units; WS, water supply; dates given in month/day/year format]

\begin{tabular}{|c|c|c|c|c|c|c|c|c|c|c|c|c|c|c|c|}
\hline \multirow[b]{2}{*}{$\begin{array}{c}\text { Site } \\
\text { identification } \\
\text { number }\end{array}$} & \multicolumn{7}{|c|}{ Dissolved solids, water, filtered, mg/L } & \multicolumn{8}{|c|}{ Ammonia, water, filtered, $\mathrm{mg} / \mathrm{L}$ as nitrogen } \\
\hline & $\begin{array}{c}\text { No. of } \\
\text { samples/ } \\
\text { No. of } \\
\text { censored }\end{array}$ & $\begin{array}{l}\text { Date } \\
\text { range }\end{array}$ & Min & 25th & 50th & 75th & Max & $\begin{array}{c}\text { No. of } \\
\text { samples/ } \\
\text { No. of } \\
\text { censored }\end{array}$ & $\begin{array}{l}\text { Date } \\
\text { range }\end{array}$ & $\begin{array}{c}\text { Censoring } \\
\text { levels }\end{array}$ & Min & 25th & 50th & 75th & Max \\
\hline 09302450 & $6 / 0$ & $\begin{array}{c}8 / 17 / 1999 \\
8 / 24 / 2000\end{array}$ & 130 & 138 & 245 & 265 & 280 & & & & & & & & \\
\hline \multicolumn{16}{|l|}{09304100} \\
\hline 09304200 & $327 / 0$ & $\begin{array}{c}3 / 20 / 1970- \\
7 / 30 / 2002\end{array}$ & 0 & 193 & 226 & 240 & 365 & $88 / 49$ & $\begin{array}{c}8 / 27 / 1981- \\
7 / 22 / 2009\end{array}$ & $\begin{array}{c}0.010 .015 \\
0.020 .05\end{array}$ & 0.003 & 0.004 & 0.006 & 0.013 & 0.18 \\
\hline 09304480 & $288 / 0$ & $\begin{array}{l}7 / 6 / 1978- \\
9 / 26 / 1984\end{array}$ & 311 & 490 & 748 & 997 & 1,560 & & & & & & & & \\
\hline \multicolumn{16}{|l|}{09304300} \\
\hline 09304500 & $11 / 0$ & $\begin{array}{c}12 / 15 / 1970- \\
3 / 7 / 1995\end{array}$ & 91 & 124 & 321 & 353 & 455 & & & & & & & & \\
\hline 09304550 & $297 / 0$ & $\begin{array}{c}8 / 30 / 1973- \\
9 / 23 / 2005\end{array}$ & 662 & 2,180 & 3,230 & 5,370 & 8,080 & & & & & & & & \\
\hline 09304600 & $292 / 0$ & $\begin{array}{l}7 / 6 / 1978- \\
9 / 24 / 2005\end{array}$ & 119 & 253 & 307 & 352 & 438 & & & & & & & & \\
\hline 4000001075434 & $8 / 0$ & $\begin{array}{c}\text { 10/19/1999- } \\
\text { 9/27/2000 }\end{array}$ & 780 & 783 & 830 & 865 & 940 & & & & & & & & \\
\hline \multicolumn{16}{|l|}{400113107574500} \\
\hline 000043 & $137 / 0$ & $\begin{array}{c}1 / 24 / 1968- \\
4 / 21 / 1992\end{array}$ & 119 & 317 & 360 & 400 & 700 & & & & & & & & \\
\hline \multicolumn{16}{|l|}{400206108005901} \\
\hline 09304800 & $374 / 0$ & $\begin{array}{l}4 / 3 / 1974- \\
9 / 29 / 2009\end{array}$ & 130 & 300 & 364 & 407 & 734 & $99 / 60$ & $\begin{array}{c}8 / 26 / 1981- \\
9 / 29 / 2009\end{array}$ & $\begin{array}{c}0.010 .015 \\
0.020 .04 \\
0.0410 .06\end{array}$ & 0.005 & 0.007 & 0.009 & 0.02 & 0.14 \\
\hline ENPR20ST & $5 / 0$ & $\begin{array}{c}5 / 19 / 2005- \\
9 / 23 / 2008\end{array}$ & 330 & 350 & 390 & 435 & 450 & & & & & & & & \\
\hline ENPR21ST & $5 / 0$ & $\begin{array}{c}8 / 18 / 2005- \\
9 / 23 / 2008\end{array}$ & 230 & 240 & 270 & 310 & 330 & & & & & & & & \\
\hline ENPR19ST & $8 / 0$ & $\begin{array}{c}\text { 5/19/2005- } \\
9 / 17 / 2008\end{array}$ & 310 & 310 & 360 & 378 & 390 & & & & & & & & \\
\hline 09306007 & $191 / 0$ & $\begin{array}{c}4 / 23 / 1974 \\
9 / 3 / 1998\end{array}$ & 427 & 664 & 706 & 769 & 908 & $164 / 23$ & $\begin{array}{c}12 / 4 / 1974- \\
9 / 3 / 1998\end{array}$ & $\begin{array}{c}0.010 .015 \\
0.06\end{array}$ & 0 & 0.01 & 0.04 & 0.07 & 0.44 \\
\hline 09306025 & $41 / 0$ & $\begin{array}{l}5 / 3 / 1974 \\
2 / 18 / 1980\end{array}$ & 85 & 1,060 & 1,110 & 1,150 & 1,450 & $19 / 10$ & $\begin{array}{l}\text { 5/9/1975- } \\
2 / 18 / 1980\end{array}$ & 0.01 & 0.02 & 0.01 & 0.01 & 0.03 & 0.33 \\
\hline \multicolumn{16}{|l|}{09306028} \\
\hline 09306022 & $154 / 0$ & $\begin{array}{c}9 / 12 / 1974 \\
9 / 3 / 1998\end{array}$ & 703 & 900 & 923 & 946 & 1,160 & $138 / 26$ & $\begin{array}{c}12 / 4 / 1974 \\
9 / 3 / 1998\end{array}$ & $\begin{array}{c}0.010 .015 \\
0.06\end{array}$ & 0 & 0.01 & 0.03 & 0.05 & 0.17 \\
\hline \multicolumn{16}{|l|}{09306033} \\
\hline 09306039 & $8 / 0$ & $\begin{array}{c}12 / 5 / 1974 \\
3 / 11 / 1985\end{array}$ & 127 & 172 & 218 & 436 & 814 & $6 / 0$ & $\begin{array}{c}12 / 5 / 1974 \\
3 / 11 / 1985\end{array}$ & & 0 & 0.15 & 0.165 & 0.22 & 0.28 \\
\hline 09306042 & $70 / 0$ & $\begin{array}{c}3 / 17 / 1977- \\
6 / 18 / 1991\end{array}$ & 491 & 1,240 & 1,395 & 1,490 & 1,620 & $68 / 8$ & $\begin{array}{l}\text { 8/7/1979- } \\
6 / 18 / 1991\end{array}$ & 0.010 .06 & 0.01 & 0.02 & 0.065 & 0.15 & 2.3 \\
\hline \multicolumn{16}{|l|}{09306050} \\
\hline 09306058 & $149 / 0$ & $\begin{array}{c}4 / 23 / 1974 \\
9 / 3 / 1998\end{array}$ & 699 & 845 & 882 & 935 & 1,150 & $132 / 28$ & $\begin{array}{c}4 / 15 / 1975- \\
9 / 3 / 1998\end{array}$ & $\begin{array}{c}0.010 .015 \\
0.06\end{array}$ & 0 & 0.01 & 0.02 & 0.04 & 0.24 \\
\hline 09306061 & $157 / 0$ & $\begin{array}{l}4 / 23 / 1974 \\
11 / 19 / 1991\end{array}$ & 465 & 817 & 887 & 965 & 1,120 & $136 / 19$ & $\begin{array}{l}12 / 6 / 1974- \\
11 / 19 / 1991\end{array}$ & 0.010 .06 & 0 & 0.01 & 0.04 & 0.065 & 0.66 \\
\hline 11625 & $5 / 0$ & $\begin{array}{c}8 / 18 / 1999 \\
7 / 13 / 2000\end{array}$ & 960 & 985 & 1,100 & 1,305 & 1,310 & & & & & & & & \\
\hline 09306175 & $85 / 0$ & $\begin{array}{c}1 / 15 / 1975- \\
8 / 17 / 1983\end{array}$ & 298 & 1,030 & 1,130 & 1,190 & 1,380 & $26 / 3$ & $\begin{array}{c}1 / 25 / 1977- \\
8 / 17 / 1983\end{array}$ & 0.010 .06 & 0.01 & 0.01 & 0.03 & 0.07 & 0.24 \\
\hline 09306200 & $245 / 0$ & $\begin{array}{c}\text { 6/8/1965- } \\
7 / 8 / 2009\end{array}$ & 392 & 956 & 1,030 & 1,210 & 1,870 & $134 / 28$ & $\begin{array}{c}\text { 1/27/1977- } \\
7 / 8 / 2009\end{array}$ & $\begin{array}{c}0.010 .02 \\
0.0210 .015 \\
0.06\end{array}$ & 0.009 & 0.010 & 0.03 & 0.06 & 0.694 \\
\hline 09306210 & $58 / 0$ & $\begin{array}{c}12 / 15 / 1970- \\
8 / 18 / 1976\end{array}$ & 420 & 1,040 & 1,100 & 1,310 & 1,930 & & & & & & & & \\
\hline
\end{tabular}


Appendix 1. Summary of surface-water-quality data and comparison to water-quality standards by site, by constituent, Piceance study area, western Colorado. Water-quality standards comparisons follow data summaries and are in blue text; standards are provided in table 3.-Continued

[CDPHE segment, Colorado Department of Health and the Environment stream segment as referred to in tables 2 and 3; latitude and longitude are in North American Datum of 1983; downstream order number assigned as part of analysis. $\mu \mathrm{g} / \mathrm{L}$, micrograms per liter; $\mu \mathrm{S} / \mathrm{cm}$, microsiemens per centimeter; $\mathrm{mg} / \mathrm{L}$, milligrams per liter; mL, milliliters; aq, aquatic; CO, Colorado; EPA, U.S. Environmental Protection Agency; Max, maximum; Min, minimum; NA, not applicable; No., number; NTU, nephelometric turbitidy units; WS, water supply; dates given in month/day/year format]

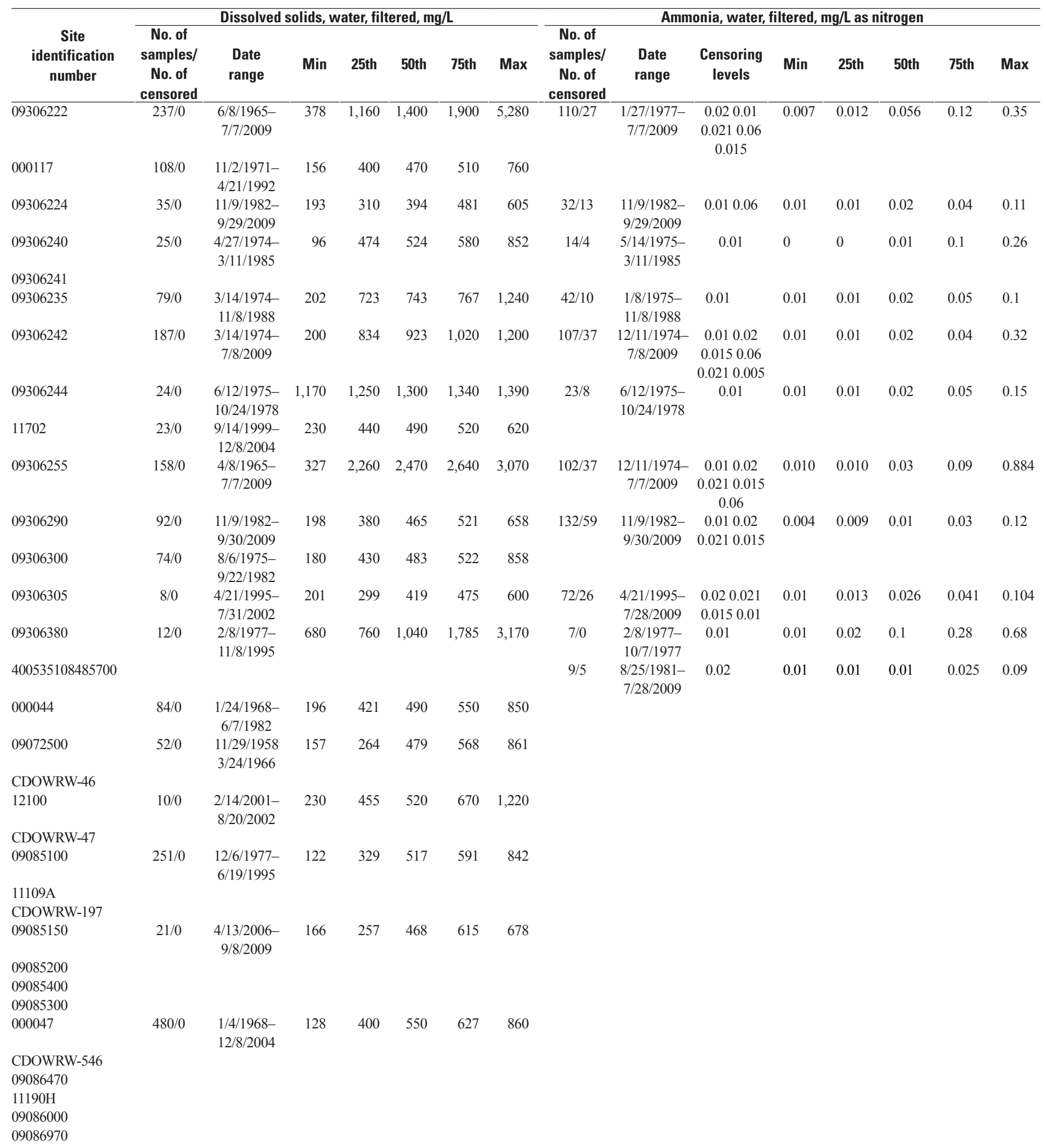


Appendix 1. Summary of surface-water-quality data and comparison to water-quality standards by site, by constituent, Piceance study area, western Colorado. Water-quality standards comparisons follow data summaries and are in blue text; standards are provided in table 3.-Continued

[CDPHE segment, Colorado Department of Health and the Environment stream segment as referred to in tables 2 and 3; latitude and longitude are in North American Datum of 1983; downstream order number assigned as part of analysis. $\mu \mathrm{g} / \mathrm{L}$, micrograms per liter; $\mu \mathrm{S} / \mathrm{cm}$, microsiemens per centimeter; $\mathrm{mg} / \mathrm{L}$, milligrams per liter; mL, milliliters; aq, aquatic; CO, Colorado; EPA, U.S. Environmental Protection Agency; Max, maximum; Min, minimum; NA, not applicable; No., number; NTU, nephelometric turbitidy units; WS, water supply; dates given in month/day/year format]

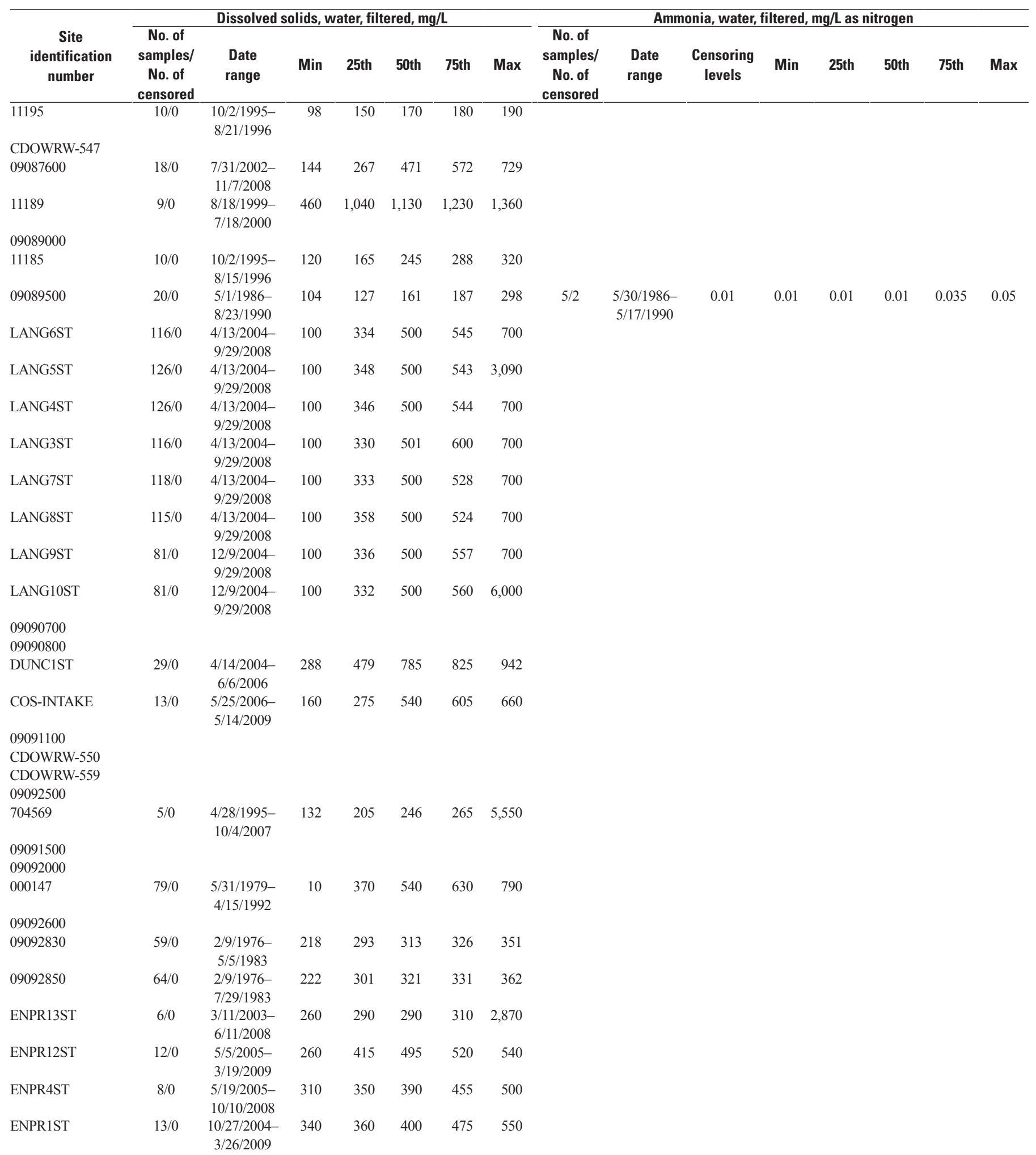


Appendix 1. Summary of surface-water-quality data and comparison to water-quality standards by site, by constituent, Piceance study area, western Colorado. Water-quality standards comparisons follow data summaries and are in blue text; standards are provided in table 3.-Continued

[CDPHE segment, Colorado Department of Health and the Environment stream segment as referred to in tables 2 and 3; latitude and longitude are in North American Datum of 1983; downstream order number assigned as part of analysis. $\mu \mathrm{g} / \mathrm{L}$, micrograms per liter; $\mu \mathrm{S} / \mathrm{cm}$, microsiemens per centimeter; mg/L, milligrams per liter; mL, milliliters; aq, aquatic; CO, Colorado; EPA, U.S. Environmental Protection Agency; Max, maximum; Min, minimum; NA, not applicable; No., number; NTU, nephelometric turbitidy units; WS, water supply; dates given in month/day/year format]

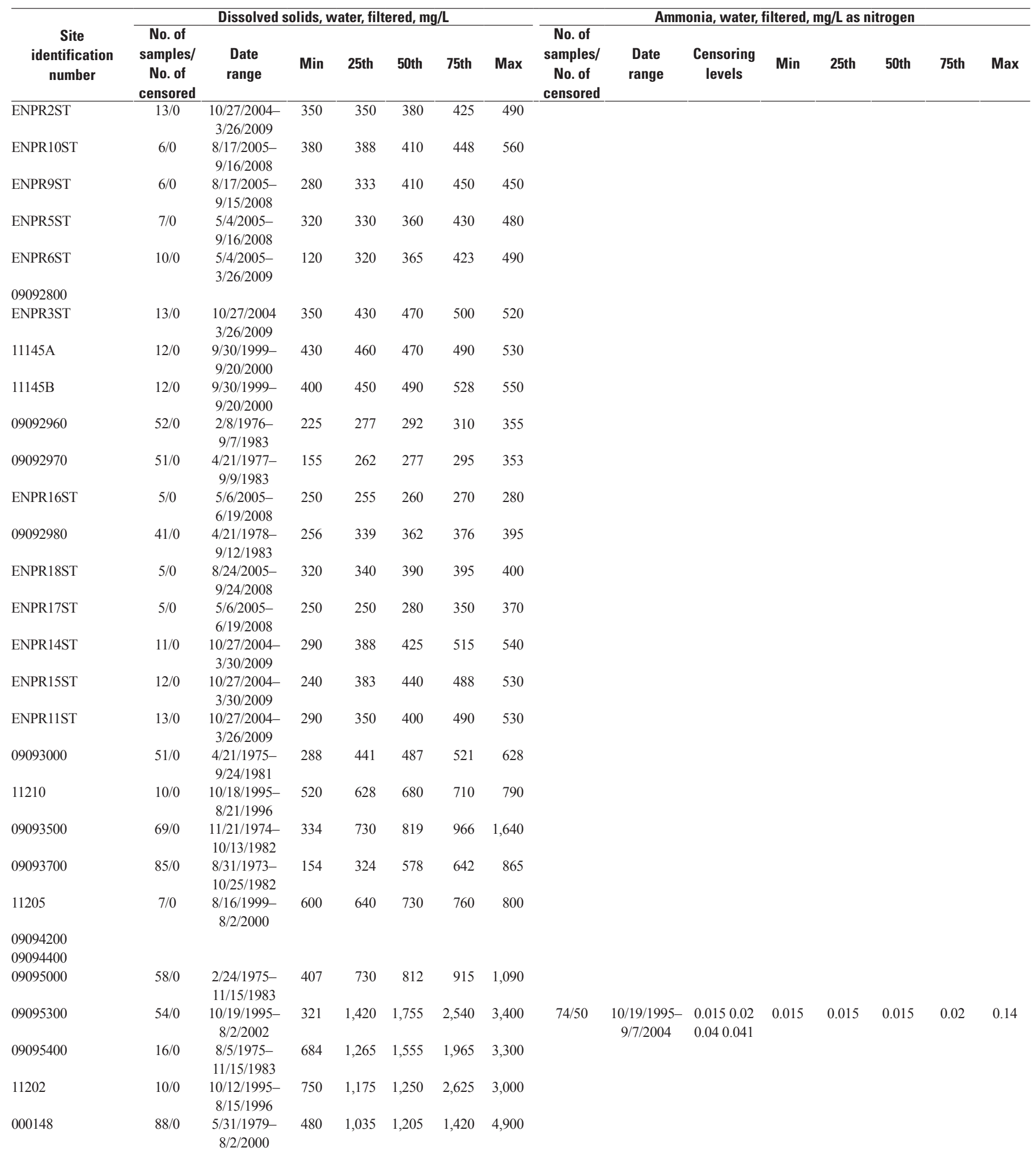


Appendix 1. Summary of surface-water-quality data and comparison to water-quality standards by site, by constituent, Piceance study area, western Colorado. Water-quality standards comparisons follow data summaries and are in blue text; standards are provided in table 3.-Continued

[CDPHE segment, Colorado Department of Health and the Environment stream segment as referred to in tables 2 and 3; latitude and longitude are in North American Datum of 1983; downstream order number assigned as part of analysis. $\mu \mathrm{g} / \mathrm{L}$, micrograms per liter; $\mu \mathrm{S} / \mathrm{cm}$, microsiemens per centimeter; $\mathrm{mg} / \mathrm{L}$, milligrams per liter; mL, milliliters; aq, aquatic; CO, Colorado; EPA, U.S. Environmental Protection Agency; Max, maximum; Min, minimum; NA, not applicable; No., number; NTU, nephelometric turbitidy units; WS, water supply; dates given in month/day/year format]

\begin{tabular}{|c|c|c|c|c|c|c|c|c|c|c|c|c|c|c|c|}
\hline \multirow[b]{2}{*}{$\begin{array}{c}\text { Site } \\
\text { identification } \\
\text { number }\end{array}$} & \multicolumn{7}{|c|}{ Dissolved solids, water, filtered, mg/L } & \multicolumn{8}{|c|}{ Ammonia, water, filtered, $\mathrm{mg} / \mathrm{L}$ as nitrogen } \\
\hline & $\begin{array}{c}\text { No. of } \\
\text { samples/ } \\
\text { No. of } \\
\text { censored }\end{array}$ & $\begin{array}{c}\text { Date } \\
\text { range }\end{array}$ & Min & 25th & 50th & 75th & Max & $\begin{array}{c}\text { No. of } \\
\text { samples/ } \\
\text { No. of } \\
\text { censored }\end{array}$ & $\begin{array}{l}\text { Date } \\
\text { range }\end{array}$ & $\begin{array}{l}\text { Censoring } \\
\text { levels }\end{array}$ & Min & 25th & 50th & 75th & Max \\
\hline 09095500 & $682 / 0$ & $\begin{array}{c}10 / 1 / 1958- \\
9 / 24 / 2009\end{array}$ & 103 & 371 & 552 & 646 & 970 & $50 / 21$ & $\begin{array}{c}3 / 27 / 1991- \\
9 / 3 / 2002\end{array}$ & $\begin{array}{ll}0.01 & 0.015 \\
0.02 & 0.021\end{array}$ & 0.01 & 0.01 & 0.02 & 0.04 & 0.14 \\
\hline $\begin{array}{l}09096800 \\
09097500\end{array}$ & & & & & & & & & & & & & & & \\
\hline 11155 & $11 / 0$ & $\begin{array}{c}10 / 12 / 1995- \\
8 / 15 / 1996\end{array}$ & 170 & 270 & 360 & 450 & 460 & & & & & & & & \\
\hline 09097600 & & & & & & & & & & & & & & & \\
\hline 09095800 & & & & & & & & & & & & & & & \\
\hline 09096500 & & & & & & & & & & & & & & & \\
\hline 391507107550601 & & & & & & & & & & & & & & & \\
\hline CDOWRW-56 & & & & & & & & & & & & & & & \\
\hline CDOWRW-55 & & & & & & & & & & & & & & & \\
\hline 09097900 & & & & & & & & & & & & & & & \\
\hline CDOWRW-54 & & & & & & & & & & & & & & & \\
\hline CDOWRW-53 & & & & & & & & & & & & & & & \\
\hline 09105000 & $216 / 0$ & $\begin{array}{c}11 / 19 / 1968- \\
9 / 24 / 2009\end{array}$ & 98 & 329 & 417 & 466 & 896 & $5 / 4$ & $\begin{array}{c}3 / 27 / 1991- \\
9 / 5 / 2002\end{array}$ & 0.010 .04 & & & & & \\
\hline 11103 & $26 / 0$ & $\begin{array}{c}\text { 8/11/1999- } \\
9 / 11 / 2003\end{array}$ & 220 & 395 & 545 & 675 & 760 & & & & & & & & \\
\hline $\begin{array}{l}\text { UP RAPID CRK } \\
\text { INTAKE }\end{array}$ & & & & & & & & & & & & & & & \\
\hline $\mathrm{RC}-2$ & & & & & & & & & & & & & & & \\
\hline $\mathrm{RC}-3$ & & & & & & & & & & & & & & & \\
\hline $\begin{array}{l}\text { LOWER RAPID } \\
\text { CRK }\end{array}$ & & & & & & & & & & & & & & & \\
\hline $\begin{array}{l}\text { L COTTONWOOD } \\
\text { INTAKE }\end{array}$ & & & & & & & & $4 / 4$ & & & & & & & \\
\hline 11151 & $7 / 0$ & $\begin{array}{c}10 / 23 / 1995- \\
7 / 1 / 1996\end{array}$ & 210 & 240 & 260 & 450 & 460 & & & & & & & & \\
\hline 390622108205400 & $24 / 0$ & $\begin{array}{c}6 / 30 / 1994 \\
4 / 19 / 1995\end{array}$ & 455 & 534 & 579 & 633 & 710 & & & & & & & & \\
\hline 09106150 & $43 / 0$ & $\begin{array}{l}1 / 16 / 1992- \\
7 / 31 / 2002\end{array}$ & 150 & 431 & 554 & 618 & 728 & & & & & & & & \\
\hline CDOWRW-553 & & & & & & & & & & & & & & & \\
\hline CDOWRW-555 & & & & & & & & & & & & & & & \\
\hline 390322108253401 & & & & & & & & & & & & & & & \\
\hline 390348108265601 & $5 / 0$ & $\begin{array}{c}3 / 22 / 1991- \\
9 / 23 / 1993\end{array}$ & 1,070 & 1,240 & 1,840 & 4,690 & 5,030 & & & & & & & & \\
\hline CDOWRW-556 & & & & & & & & & & & & & & & \\
\hline 390319108273200 & & & & & & & & & & & & & & & \\
\hline 390318108273200 & $26 / 0$ & $\begin{array}{c}6 / 30 / 1994 \\
7 / 31 / 2002\end{array}$ & 431 & 638 & 675 & 706 & 819 & & & & & & & & \\
\hline CDOWRW-557 & & & & & & & & & & & & & & & \\
\hline 09106200 & $62 / 0$ & $\begin{array}{c}8 / 7 / 1973- \\
3 / 6 / 2006\end{array}$ & 188 & 563 & 872 & 3,970 & 4,730 & & & & & & & & \\
\hline 390324108291301 & & & & & & & & & & & & & & & \\
\hline 390326108291601 & $18 / 0$ & $\begin{array}{c}\text { 2/25/1997- } \\
4 / 9 / 1999\end{array}$ & 479 & 643 & 910 & 1,445 & 1,910 & & & & & & & & \\
\hline 390323108291601 & & & & & & & & & & & & & & & \\
\hline 390303108291601 & & & & & & & & & & & & & & & \\
\hline 390322108292301 & & & & & & & & & & & & & & & \\
\hline 390318108293301 & & & & & & & & & & & & & & & \\
\hline 390302108293801 & & & & & & & & & & & & & & & \\
\hline 390319108312501 & & & & & & & & & & & & & & & \\
\hline 390320108315901 & $6 / 0$ & $\begin{array}{c}3 / 21 / 1991- \\
5 / 6 / 1998\end{array}$ & 309 & 788 & 3,660 & 4,280 & 4,720 & & & & & & & & \\
\hline
\end{tabular}


Appendix 1. Summary of surface-water-quality data and comparison to water-quality standards by site, by constituent, Piceance study area, western Colorado. Water-quality standards comparisons follow data summaries and are in blue text; standards are provided in table 3.-Continued

[CDPHE segment, Colorado Department of Health and the Environment stream segment as referred to in tables 2 and 3; latitude and longitude are in North American Datum of 1983; downstream order number assigned as part of analysis. $\mu \mathrm{g} / \mathrm{L}$, micrograms per liter; $\mu \mathrm{S} / \mathrm{cm}$, microsiemens per centimeter; $\mathrm{mg} / \mathrm{L}$, milligrams per liter; mL, milliliters; aq, aquatic; CO, Colorado; EPA, U.S. Environmental Protection Agency; Max, maximum; Min, minimum; NA, not applicable; No., number; NTU, nephelometric turbitidy units; WS, water supply; dates given in month/day/year format]

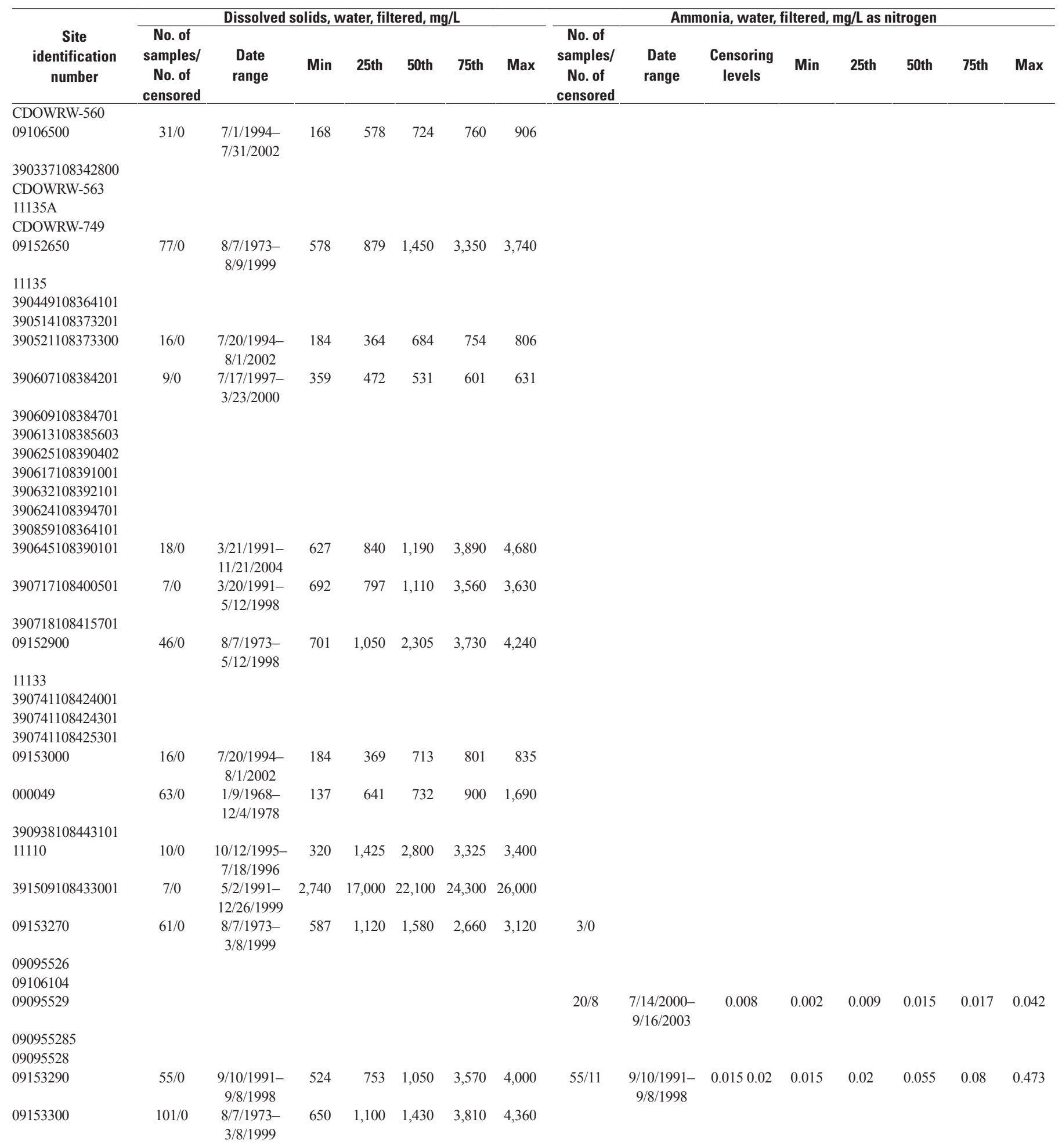


Appendix 1. Summary of surface-water-quality data and comparison to water-quality standards by site, by constituent, Piceance study area, western Colorado. Water-quality standards comparisons follow data summaries and are in blue text; standards are provided in table 3.-Continued

[CDPHE segment, Colorado Department of Health and the Environment stream segment as referred to in tables 2 and 3; latitude and longitude are in North American Datum of 1983; downstream order number assigned as part of analysis. $\mu \mathrm{g} / \mathrm{L}$, micrograms per liter; $\mu \mathrm{S} / \mathrm{cm}$, microsiemens per centimeter; $\mathrm{mg} / \mathrm{L}$, milligrams per liter; mL, milliliters; aq, aquatic; CO, Colorado; EPA, U.S. Environmental Protection Agency; Max, maximum; Min, minimum; NA, not applicable; No., number; NTU, nephelometric turbitidy units; WS, water supply; dates given in month/day/year format]

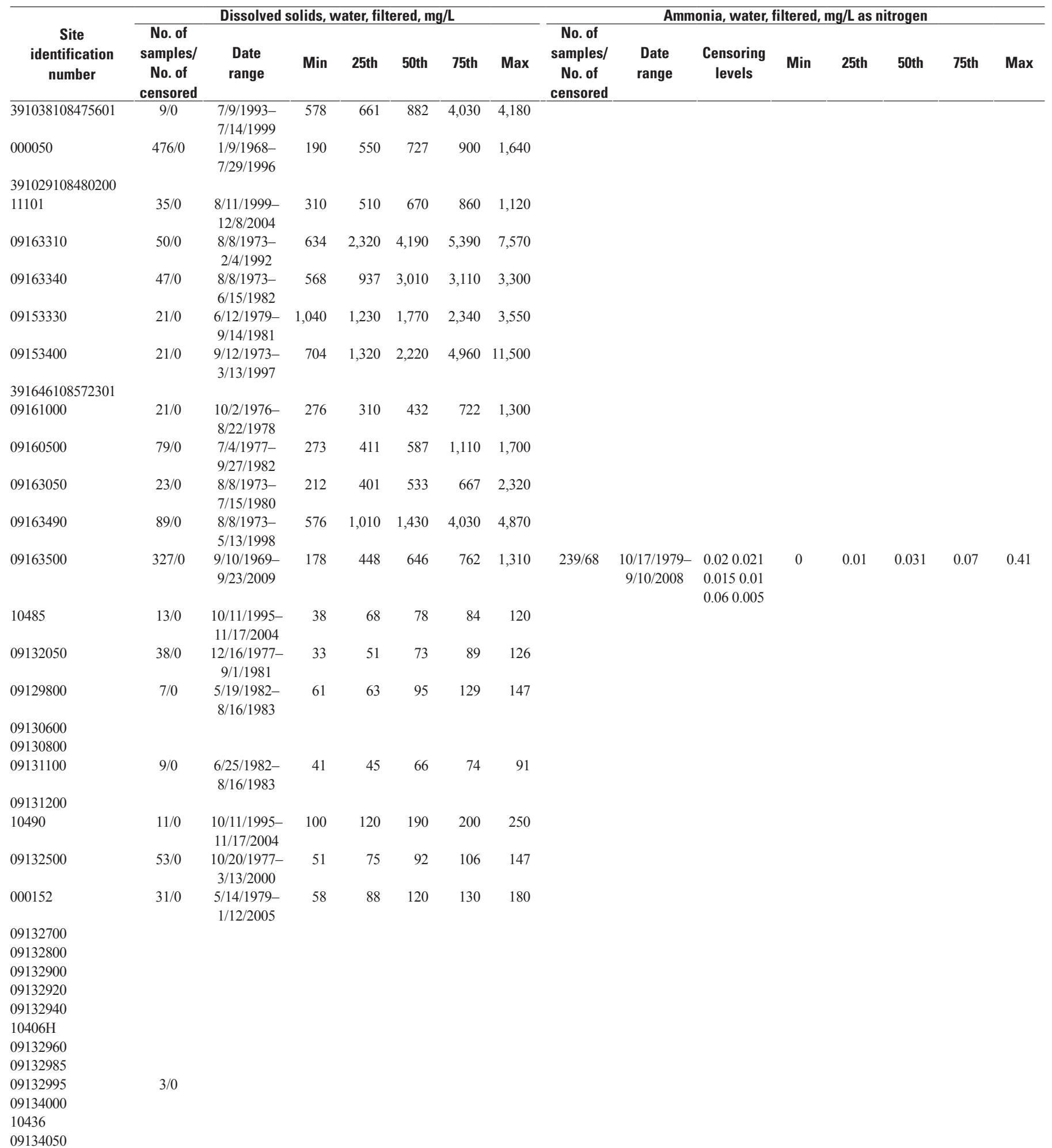


Appendix 1. Summary of surface-water-quality data and comparison to water-quality standards by site, by constituent, Piceance study area, western Colorado. Water-quality standards comparisons follow data summaries and are in blue text; standards are provided in table 3.-Continued

[CDPHE segment, Colorado Department of Health and the Environment stream segment as referred to in tables 2 and 3; latitude and longitude are in North American Datum of 1983; downstream order number assigned as part of analysis. $\mu \mathrm{g} / \mathrm{L}$, micrograms per liter; $\mu \mathrm{S} / \mathrm{cm}$, microsiemens per centimeter; mg/L, milligrams per liter; mL, milliliters; aq, aquatic; CO, Colorado; EPA, U.S. Environmental Protection Agency; Max, maximum; Min, minimum; NA, not applicable; No., number; NTU, nephelometric turbitidy units; WS, water supply; dates given in month/day/year format]

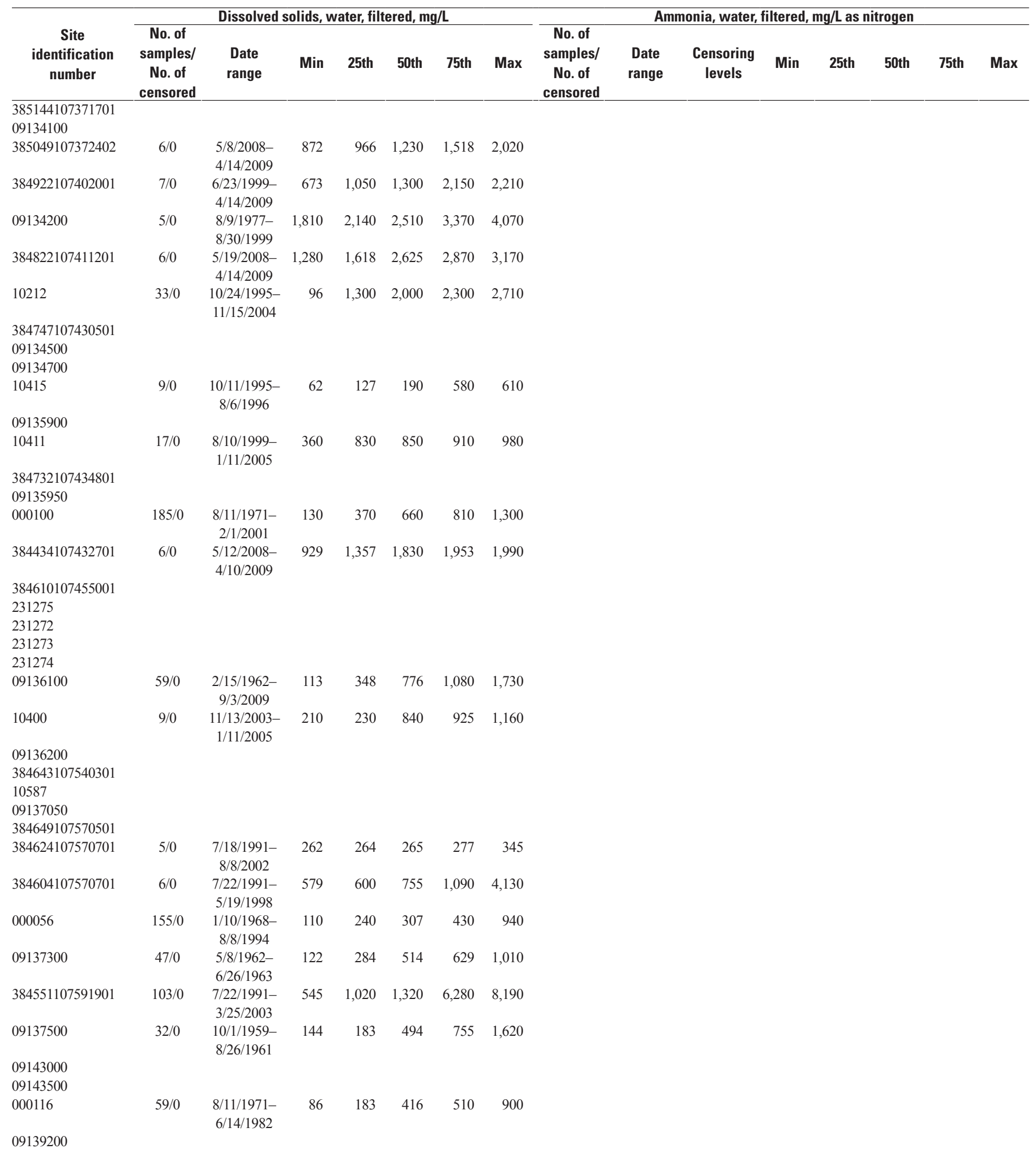


Appendix 1. Summary of surface-water-quality data and comparison to water-quality standards by site, by constituent, Piceance study area, western Colorado. Water-quality standards comparisons follow data summaries and are in blue text; standards are provided in table 3.-Continued

[CDPHE segment, Colorado Department of Health and the Environment stream segment as referred to in tables 2 and 3; latitude and longitude are in North American Datum of 1983; downstream order number assigned as part of analysis. $\mu \mathrm{g} / \mathrm{L}$, micrograms per liter; $\mu \mathrm{S} / \mathrm{cm}$, microsiemens per centimeter; $\mathrm{mg} / \mathrm{L}$, milligrams per liter; mL, milliliters; aq, aquatic; CO, Colorado; EPA, U.S. Environmental Protection Agency; Max, maximum; Min, minimum; NA, not applicable; No., number; NTU, nephelometric turbitidy units; WS, water supply; dates given in month/day/year format]

\begin{tabular}{|c|c|c|c|c|c|c|c|c|c|c|c|c|c|c|c|}
\hline \multirow[b]{2}{*}{$\begin{array}{c}\text { Site } \\
\text { identification } \\
\text { number }\end{array}$} & \multicolumn{7}{|c|}{ Dissolved solids, water, filtered, mg/L } & \multicolumn{8}{|c|}{ Ammonia, water, filtered, mg/L as nitrogen } \\
\hline & $\begin{array}{c}\text { No. of } \\
\text { samples/ } \\
\text { No. of } \\
\text { censored }\end{array}$ & $\begin{array}{c}\text { Date } \\
\text { range }\end{array}$ & Min & 25th & 50th & 75th & Max & $\begin{array}{c}\text { No. of } \\
\text { samples/ } \\
\text { No. of } \\
\text { censored }\end{array}$ & $\begin{array}{l}\text { Date } \\
\text { range }\end{array}$ & $\begin{array}{c}\text { Censoring } \\
\text { levels }\end{array}$ & Min & 25th & 50th & 75th & Max \\
\hline \multicolumn{16}{|l|}{09140200} \\
\hline \multicolumn{16}{|l|}{09140700} \\
\hline \multicolumn{16}{|l|}{09141200} \\
\hline \multicolumn{16}{|l|}{09137800} \\
\hline \multicolumn{16}{|l|}{10582} \\
\hline 09144200 & $8 / 0$ & $\begin{array}{c}11 / 28 / 1978- \\
3 / 15 / 2000\end{array}$ & 454 & 665 & 1,070 & 1,175 & 1,750 & $5 / 0$ & $\begin{array}{c}\text { 7/19/1991- } \\
5 / 19 / 1998\end{array}$ & & 0.01 & 0.02 & 0.023 & 0.029 & 0.072 \\
\hline 10516 & $22 / 0$ & $\begin{array}{l}1 / 3 / 2001- \\
9 / 10 / 2003\end{array}$ & 210 & 368 & 420 & 530 & 650 & & & & & & & & \\
\hline 09144250 & $30 / 0$ & $\begin{array}{c}11 / 19 / 1987- \\
8 / 6 / 2009\end{array}$ & 165 & 353 & 404 & 530 & 732 & & & & & & & & \\
\hline 383404107534101 & $11 / 0$ & $\begin{array}{c}4 / 11 / 2001- \\
2 / 6 / 2009\end{array}$ & 459 & 464 & 1,770 & 2,050 & 2,800 & & & & & & & & \\
\hline 383408107535101 & $49 / 0$ & $\begin{array}{c}3 / 10 / 1992- \\
10 / 8 / 2009\end{array}$ & 338 & 460 & 641 & 1,760 & 2,740 & & & & & & & & \\
\hline 383528107552001 & $49 / 0$ & $\begin{array}{l}4 / 11 / 2001- \\
4 / 21 / 2003\end{array}$ & 589 & 1,300 & 2,170 & 2,955 & 3,350 & & & & & & & & \\
\hline 383741107565701 & $8 / 0$ & $\begin{array}{l}7 / 30 / 2001- \\
12 / 13 / 2002\end{array}$ & 1,150 & 1,220 & 1,855 & 2,208 & 2,250 & & & & & & & & \\
\hline 383728107572001 & $51 / 0$ & $\begin{array}{c}4 / 11 / 2001- \\
4 / 21 / 2003\end{array}$ & 949 & 1,210 & 1,620 & 4,370 & 4,930 & & & & & & & & \\
\hline \multicolumn{16}{|l|}{10661} \\
\hline 383946107595301 & $84 / 0$ & $\begin{array}{l}\text { 7/23/1991- } \\
8 / 28 / 2009\end{array}$ & 887 & 1,170 & 1,480 & 4,070 & 5,090 & & & & & & & & \\
\hline \multicolumn{16}{|l|}{383953108001701} \\
\hline \multicolumn{16}{|l|}{384231108020301} \\
\hline \multicolumn{16}{|l|}{10602} \\
\hline 09149480 & $44 / 0$ & $\begin{array}{c}10 / 26 / 1995- \\
9 / 2 / 1998\end{array}$ & 241 & 501 & 847 & 1,028 & 1,170 & $44 / 6$ & $\begin{array}{c}10 / 26 / 1995- \\
9 / 2 / 1998\end{array}$ & 0.0150 .02 & 0.02 & 0.021 & 0.043 & 0.091 & 0.19 \\
\hline 384202108032001 & $17 / 0$ & $\begin{array}{c}11 / 28 / 1978- \\
5 / 21 / 1998\end{array}$ & 401 & 841 & 946 & 1,040 & 1,600 & & & & & & & & \\
\hline \multicolumn{16}{|l|}{10611} \\
\hline 000055 & $430 / 0$ & $\begin{array}{l}1 / 11 / 1968- \\
12 / 27 / 2004\end{array}$ & 180 & 970 & 1,300 & 1,670 & 6,500 & & & & & & & & \\
\hline 09149500 & $243 / 0$ & $\begin{array}{c}11 / 6 / 1958- \\
8 / 6 / 2009\end{array}$ & 140 & 967 & 1,240 & 1,590 & 2,550 & $7 / 2$ & $\begin{array}{c}5 / 30 / 1991- \\
8 / 13 / 2002\end{array}$ & 0.0210 .01 & 0.01 & 0.03 & 0.04 & 0.05 & 0.07 \\
\hline 384448108070301 & $10 / 0$ & $\begin{array}{c}7 / 15 / 1991- \\
5 / 14 / 1998\end{array}$ & 813 & 1,280 & 1,760 & 2,140 & 2,270 & & & & & & & & \\
\hline 10515 & $20 / 0$ & $\begin{array}{c}1 / 12 / 1999 \\
12 / 9 / 2004\end{array}$ & 250 & 445 & 490 & 555 & 830 & & & & & & & & \\
\hline 384408108091501 & $5 / 0$ & $\begin{array}{c}1 / 29 / 1992- \\
5 / 14 / 1998\end{array}$ & 873 & 1,650 & 1,660 & 1,680 & 2,760 & & & & & & & & \\
\hline 10562 & $10 / 0$ & $\begin{array}{c}10 / 30 / 1995- \\
7 / 22 / 1996\end{array}$ & 120 & 233 & 535 & 798 & 970 & & & & & & & & \\
\hline 384013108091401 & $6 / 0$ & $\begin{array}{c}7 / 15 / 1991- \\
7 / 20 / 1999\end{array}$ & 113 & 199 & 387 & 479 & 971 & & & & & & & & \\
\hline 09150500 & $15 / 0$ & $\begin{array}{c}12 / 7 / 1977- \\
9 / 7 / 1999\end{array}$ & 150 & 889 & 1,160 & 1,360 & 1,600 & & & & & & & & \\
\hline \multicolumn{16}{|l|}{384510108111801} \\
\hline 384527108152701 & $6 / 0$ & $\begin{array}{c}11 / 19 / 1987- \\
5 / 20 / 1998\end{array}$ & 199 & 367 & 498 & 646 & 1,030 & & & & & & & & \\
\hline 10555 & $11 / 0$ & $\begin{array}{l}10 / 4 / 1995- \\
10 / 26 / 2004\end{array}$ & 98 & 190 & 310 & 330 & 340 & & & & & & & & \\
\hline 10551 & $11 / 0$ & $\begin{array}{c}10 / 4 / 1995- \\
9 / 28 / 2004\end{array}$ & 180 & 310 & 320 & 410 & 430 & & & & & & & & \\
\hline $\begin{array}{l}09151500 \\
384813108184301\end{array}$ & $3 / 0$ & & & & & & & & & & & & & & \\
\hline
\end{tabular}


Appendix 1. Summary of surface-water-quality data and comparison to water-quality standards by site, by constituent, Piceance study area, western Colorado. Water-quality standards comparisons follow data summaries and are in blue text; standards are provided in table 3.-Continued

[CDPHE segment, Colorado Department of Health and the Environment stream segment as referred to in tables 2 and 3; latitude and longitude are in North American Datum of 1983; downstream order number assigned as part of analysis. $\mu \mathrm{g} / \mathrm{L}$, micrograms per liter; $\mu \mathrm{S} / \mathrm{cm}$, microsiemens per centimeter; mg/L, milligrams per liter; mL, milliliters; aq, aquatic; CO, Colorado; EPA, U.S. Environmental Protection Agency; Max, maximum; Min, minimum; NA, not applicable; No., number; NTU, nephelometric turbitidy units; WS, water supply; dates given in month/day/year format]

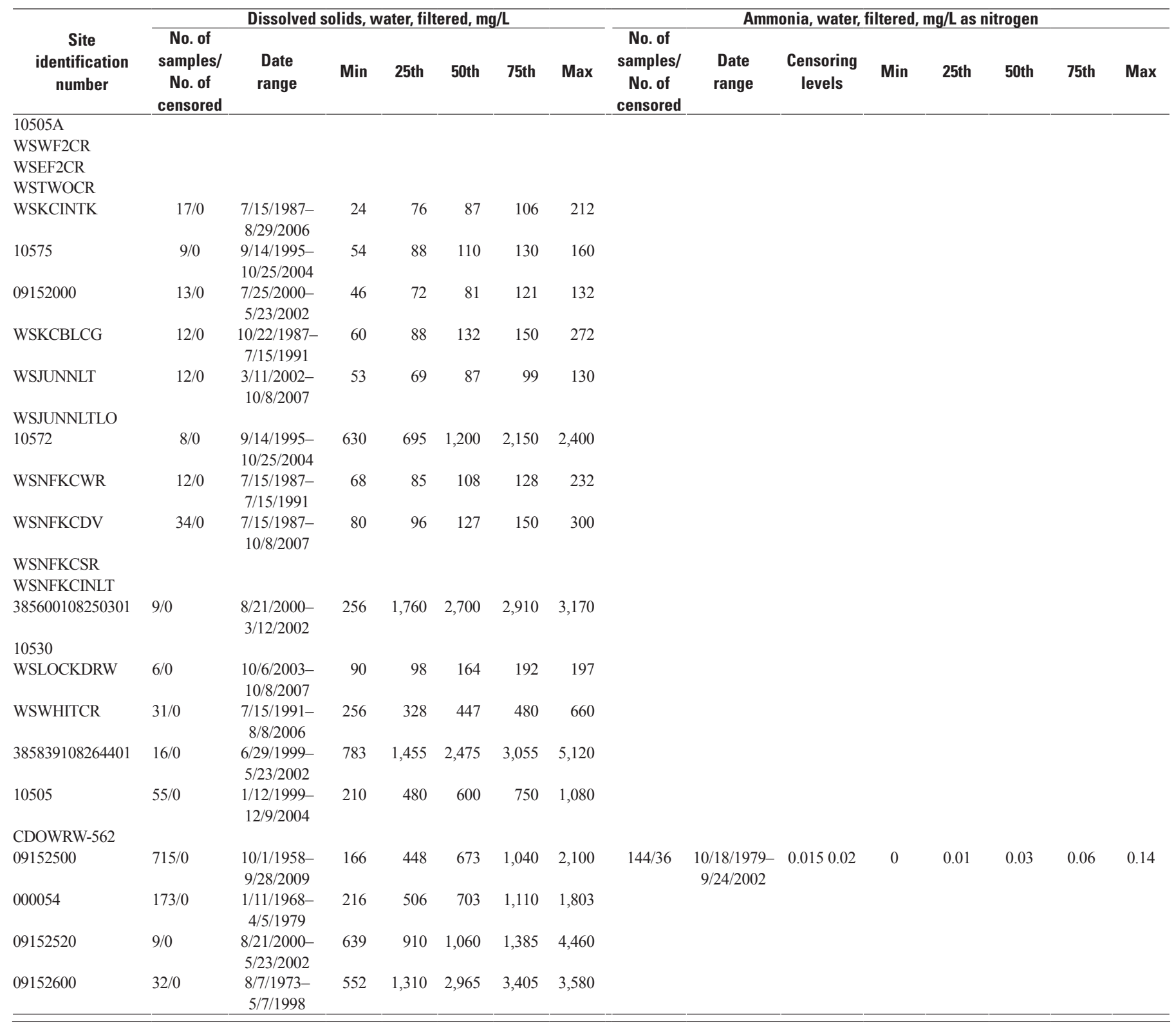


Appendix 1. Summary of surface-water-quality data and comparison to water-quality standards by site, by constituent, Piceance study area, western Colorado. Water-quality standards comparisons follow data summaries and are in blue text; standards are provided in table 3.-Continued

[CDPHE segment, Colorado Department of Health and the Environment stream segment as referred to in tables 2 and 3; latitude and longitude are in North American Datum of 1983; downstream order number assigned as part of analysis. $\mu \mathrm{g} / \mathrm{L}$, micrograms per liter; $\mu \mathrm{S} / \mathrm{cm}$, microsiemens per centimeter; $\mathrm{mg} / \mathrm{L}$, milligrams per liter; mL, milliliters; aq, aquatic; CO, Colorado; EPA, U.S. Environmental Protection Agency; Max, maximum; Min, minimum; NA, not applicable; No., number; NTU, nephelometric turbitidy units; WS, water supply; dates given in month/day/year format]

\begin{tabular}{|c|c|c|c|c|c|c|c|c|c|c|c|c|c|c|c|}
\hline \multirow[b]{2}{*}{$\begin{array}{c}\text { Site } \\
\text { identification } \\
\text { number }\end{array}$} & \multicolumn{8}{|c|}{ Nitrite + Nitrate, dissolved, $\mathrm{mg} / \mathrm{L}$ as nitrogen } & \multicolumn{7}{|c|}{ Orthophosphate, water, filtered, mg/L } \\
\hline & $\begin{array}{c}\text { No. of } \\
\text { samples/ } \\
\text { No. of } \\
\text { censored }\end{array}$ & $\begin{array}{l}\text { Date } \\
\text { range }\end{array}$ & $\begin{array}{l}\text { Censoring } \\
\text { levels }\end{array}$ & Min & 25th & 50th & 75th & Max & $\begin{array}{c}\text { No. of } \\
\text { samples/ } \\
\text { No. of } \\
\text { censored }\end{array}$ & $\begin{array}{l}\text { Date } \\
\text { range }\end{array}$ & Min & 25th & 50th & 75th & Max \\
\hline \multicolumn{16}{|l|}{09302450} \\
\hline \multicolumn{16}{|l|}{09304100} \\
\hline \multicolumn{16}{|l|}{395643107461200} \\
\hline 09304200 & $91 / 45$ & 8/27/1981- & 0.040 .09 & 0.006 & 0.008 & 0.014 & 0.047 & 0.447 & $59 / 0$ & 8/30/1973- & 0 & 0.028 & 0.031 & 0.06 & 0.126 \\
\hline & & $7 / 22 / 2009$ & 0.0140 .0107 & & & & & & & $7 / 22 / 2009$ & & & & & \\
\hline & & & 0.01970 .058 & & & & & & & & & & & & \\
\hline & & & 0.01491 & & & & & & & & & & & & \\
\hline & & & 0.01432 & & & & & & & & & & & & \\
\hline \multicolumn{16}{|l|}{09304480} \\
\hline \multicolumn{16}{|l|}{09304300} \\
\hline 09304500 & & & & & & & & & $8 / 0$ & $\begin{array}{c}12 / 15 / 1970- \\
8 / 27 / 1981\end{array}$ & 0.03 & 0.03 & 0.05 & 0.09 & 0.09 \\
\hline 09304550 & & & & & & & & & $5 / 0$ & $\begin{array}{c}8 / 30 / 1973- \\
8 / 26 / 1981\end{array}$ & 0.03 & 0.03 & 0.06 & 0.09 & 0.25 \\
\hline \multicolumn{16}{|l|}{09304600} \\
\hline \multicolumn{16}{|l|}{4000001075434} \\
\hline \multicolumn{16}{|l|}{400113107574500} \\
\hline 000043 & $56 / 0$ & $\begin{array}{c}10 / 15 / 1968- \\
5 / 9 / 1979\end{array}$ & & 0 & 0 & 0.16 & 0.235 & 11.5 & $29 / 0$ & $\begin{array}{c}10 / 15 / 1968- \\
9 / 26 / 1973\end{array}$ & 0 & 0.05 & 0.1 & 0.15 & 0.9 \\
\hline \multicolumn{16}{|l|}{400206108005901} \\
\hline 09304800 & $103 / 55$ & $\begin{array}{c}\text { 8/26/1981- } \\
\text { 9/29/2009 }\end{array}$ & $\begin{array}{c}0.040 .09 \\
0.0520 .038\end{array}$ & 0.004 & 0.028 & 0.034 & 0.08 & 0.23 & $62 / 0$ & 8/26/1981- & 0.012 & 0.031 & 0.055 & 0.067 & 0.153 \\
\hline & & & $\begin{array}{c}0.0520 .038 \\
0.080 .058\end{array}$ & & & & & & & 9/29/2009 & & & & & \\
\hline & & & 0.0420 .05859 & & & & & & & & & & & & \\
\hline & & & 0.0389 & & & & & & & & & & & & \\
\hline & & & 0.038850 .004 & & & & & & & & & & & & \\
\hline \multicolumn{16}{|l|}{ ENPR20ST } \\
\hline \multicolumn{16}{|l|}{ ENPR21ST } \\
\hline ENPR19ST & $6 / 0$ & $\begin{array}{c}11 / 22 / 2005- \\
9 / 17 / 2008\end{array}$ & & 0.113 & 0.127 & 0.189 & 0.232 & 0.248 & & & & & & & \\
\hline 09306007 & $90 / 5$ & $\begin{array}{c}12 / 4 / 1974 \\
9 / 3 / 1998\end{array}$ & 0.090 .04 & 0.01 & 0.22 & 0.47 & 0.85 & 2.79 & $128 / 0$ & $\begin{array}{c}4 / 23 / 1974 \\
4 / 29 / 1998\end{array}$ & 0 & 0.03 & 0.06 & 0.09 & 1.1 \\
\hline 09306025 & $11 / 1$ & $\begin{array}{l}5 / 9 / 1975- \\
10 / 7 / 1975\end{array}$ & 0.09 & 0 & 0.01 & 0.01 & 0.1 & 1.29 & $40 / 0$ & $\begin{array}{l}5 / 3 / 1974 \\
10 / 5 / 1976\end{array}$ & 0 & 0 & 0.03 & 0.06 & 0.8 \\
\hline \multicolumn{16}{|l|}{09306028} \\
\hline 09306022 & $57 / 0$ & $\begin{array}{c}12 / 4 / 1974 \\
9 / 3 / 1998\end{array}$ & & 0.31 & 1.19 & 1.49 & 1.79 & 3.69 & $90 / 0$ & $\begin{array}{c}9 / 12 / 1974 \\
9 / 3 / 1998\end{array}$ & 0 & 0.03 & 0.03 & 0.06 & 0.215 \\
\hline \multicolumn{16}{|l|}{09306033} \\
\hline \multicolumn{16}{|l|}{09306039} \\
\hline 09306042 & $24 / 3$ & $\begin{array}{l}7 / 1 / 1981- \\
6 / 18 / 1991\end{array}$ & 0.09 & 0.09 & 0.25 & 0.47 & 0.73 & 1.23 & $12 / 0$ & $\begin{array}{c}3 / 17 / 1977- \\
6 / 21 / 1990\end{array}$ & 0 & 0.031 & 0.061 & 0.091 & 0.153 \\
\hline \multicolumn{16}{|l|}{09306050} \\
\hline \multicolumn{16}{|l|}{09306052} \\
\hline 09306058 & $62 / 2$ & $\begin{array}{c}\text { 4/15/1975- } \\
9 / 3 / 1998\end{array}$ & 0.090 .04 & 0.02 & 0.14 & 0.225 & 0.38 & 1.49 & $82 / 0$ & $\begin{array}{c}4 / 23 / 1974 \\
9 / 3 / 1998\end{array}$ & 0 & 0.03 & 0.03 & 0.061 & 0.52 \\
\hline 09306061 & $53 / 2$ & $\begin{array}{l}12 / 6 / 1974 \\
11 / 19 / 1991\end{array}$ & 0.090 .04 & 0.04 & 0.34 & 0.58 & 0.79 & 2.69 & $107 / 0$ & $\begin{array}{l}4 / 23 / 1974 \\
11 / 19 / 1991\end{array}$ & 0 & 0.03 & 0.061 & 0.09 & 0.25 \\
\hline \multicolumn{16}{|l|}{11625} \\
\hline 09306175 & $59 / 0$ & $\begin{array}{c}1 / 25 / 1977- \\
8 / 17 / 1983\end{array}$ & & 0 & 0.15 & 0.22 & 0.38 & 3.67 & $85 / 0$ & $\begin{array}{c}1 / 15 / 1975- \\
8 / 17 / 1983\end{array}$ & 0 & 0 & 0.03 & 0.09 & 1.1 \\
\hline 09306200 & $166 / 25$ & $\begin{array}{c}1 / 27 / 1977- \\
7 / 8 / 2009\end{array}$ & $\begin{array}{c}0.090 .052 \\
0.080 .04 \\
0.0580 .042 \\
0.058610 .047 \\
0.0440 .038\end{array}$ & -0.02 & 0.069 & 0.419 & 0.7 & 2.98 & $230 / 0$ & $\begin{array}{c}12 / 15 / 1970- \\
7 / 8 / 2009\end{array}$ & 0 & 0.06 & 0.09 & 0.123 & 0.95 \\
\hline
\end{tabular}


Appendix 1. Summary of surface-water-quality data and comparison to water-quality standards by site, by constituent, Piceance study area, western Colorado. Water-quality standards comparisons follow data summaries and are in blue text; standards are provided in table 3.-Continued

[CDPHE segment, Colorado Department of Health and the Environment stream segment as referred to in tables 2 and 3; latitude and longitude are in North American Datum of 1983; downstream order number assigned as part of analysis. $\mu \mathrm{g} / \mathrm{L}$, micrograms per liter; $\mu \mathrm{S} / \mathrm{cm}$, microsiemens per centimeter; $\mathrm{mg} / \mathrm{L}$, milligrams per liter; mL, milliliters; aq, aquatic; CO, Colorado; EPA, U.S. Environmental Protection Agency; Max, maximum; Min, minimum; NA, not applicable; No., number; NTU, nephelometric turbitidy units; WS, water supply; dates given in month/day/year format]

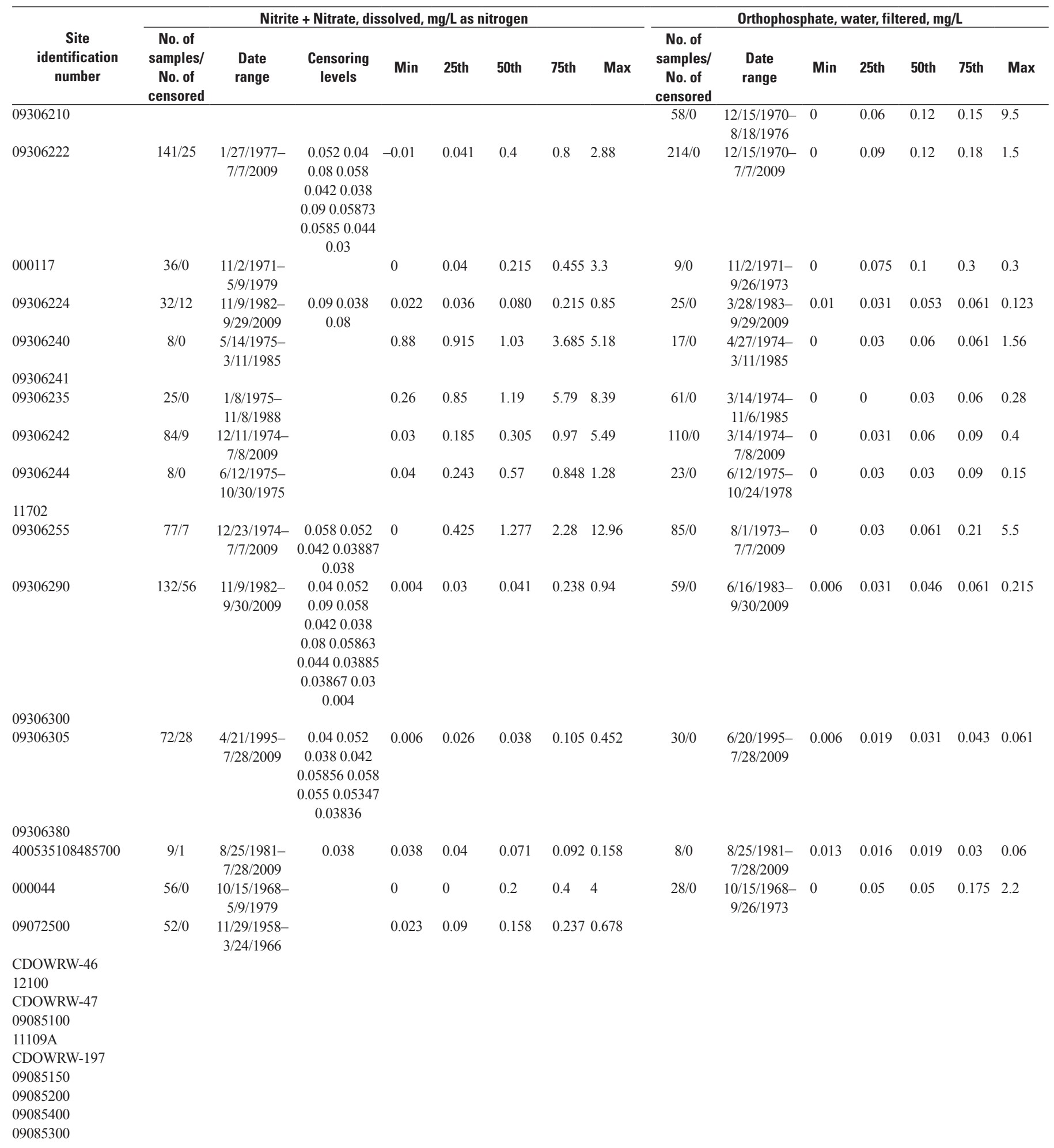


Appendix 1. Summary of surface-water-quality data and comparison to water-quality standards by site, by constituent, Piceance study area, western Colorado. Water-quality standards comparisons follow data summaries and are in blue text; standards are provided in table 3.-Continued

[CDPHE segment, Colorado Department of Health and the Environment stream segment as referred to in tables 2 and 3; latitude and longitude are in North American Datum of 1983; downstream order number assigned as part of analysis. $\mu \mathrm{g} / \mathrm{L}$, micrograms per liter; $\mu \mathrm{S} / \mathrm{cm}$, microsiemens per centimeter; $\mathrm{mg} / \mathrm{L}$, milligrams per liter; mL, milliliters; aq, aquatic; CO, Colorado; EPA, U.S. Environmental Protection Agency; Max, maximum; Min, minimum; NA, not applicable; No., number; NTU, nephelometric turbitidy units; WS, water supply; dates given in month/day/year format]

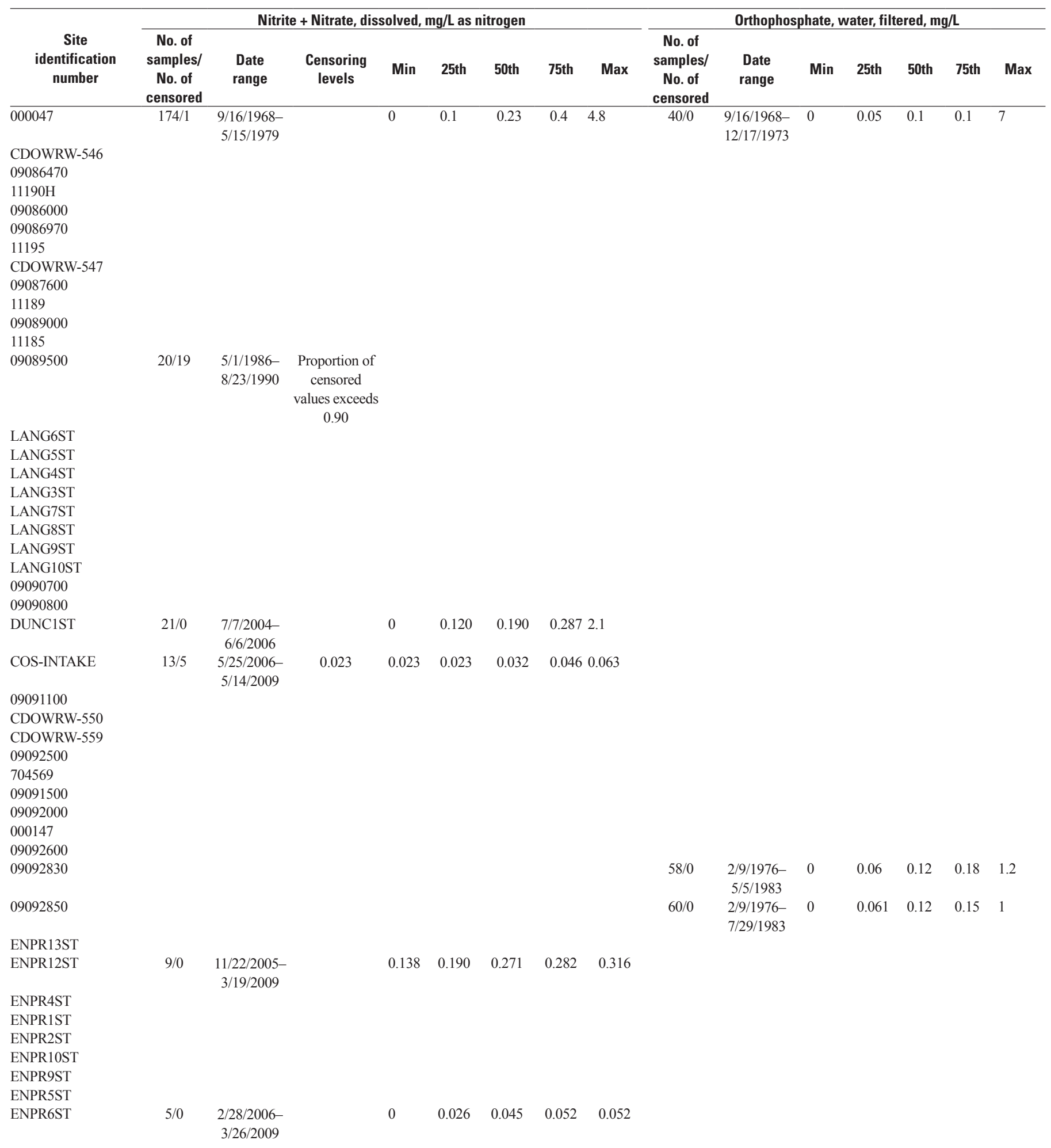


Appendix 1. Summary of surface-water-quality data and comparison to water-quality standards by site, by constituent, Piceance study area, western Colorado. Water-quality standards comparisons follow data summaries and are in blue text; standards are provided in table 3.-Continued

[CDPHE segment, Colorado Department of Health and the Environment stream segment as referred to in tables 2 and 3; latitude and longitude are in North American Datum of 1983; downstream order number assigned as part of analysis. $\mu \mathrm{g} / \mathrm{L}$, micrograms per liter; $\mu \mathrm{S} / \mathrm{cm}$, microsiemens per centimeter; $\mathrm{mg} / \mathrm{L}$, milligrams per liter; mL, milliliters; aq, aquatic; CO, Colorado; EPA, U.S. Environmental Protection Agency; Max, maximum; Min, minimum; NA, not applicable; No., number; NTU, nephelometric turbitidy units; WS, water supply; dates given in month/day/year format]

\begin{tabular}{|c|c|c|c|c|c|c|c|c|c|c|c|c|c|c|c|}
\hline \multirow[b]{2}{*}{$\begin{array}{c}\text { Site } \\
\text { identification } \\
\text { number }\end{array}$} & \multicolumn{8}{|c|}{ Nitrite + Nitrate, dissolved, $\mathrm{mg} / \mathrm{L}$ as nitrogen } & \multicolumn{7}{|c|}{ Orthophosphate, water, filtered, mg/L } \\
\hline & $\begin{array}{c}\text { No. of } \\
\text { samples/ } \\
\text { No. of } \\
\text { censored }\end{array}$ & $\begin{array}{l}\text { Date } \\
\text { range }\end{array}$ & $\begin{array}{l}\text { Censoring } \\
\text { levels }\end{array}$ & Min & 25th & 50th & 75th & Max & $\begin{array}{c}\text { No. of } \\
\text { samples/ } \\
\text { No. of } \\
\text { censored }\end{array}$ & $\begin{array}{l}\text { Date } \\
\text { range }\end{array}$ & Min & 25th & 50th & 75th & Max \\
\hline \multicolumn{16}{|l|}{09092800} \\
\hline ENPR3ST & $9 / 0$ & $\begin{array}{c}11 / 14 / 2005- \\
3 / 26 / 2009\end{array}$ & & 0.115 & 0.139 & 0.156 & 0.172 & 0.190 & & & & & & & \\
\hline \multicolumn{16}{|l|}{$11145 \mathrm{~A}$} \\
\hline 09092970 & & & & & & & & & $48 / 0$ & $\begin{array}{c}\text { 4/21/1977- } \\
\text { 9/9/1983 }\end{array}$ & 0 & 0.06 & 0.09 & 0.12 & 0.95 \\
\hline \multicolumn{16}{|l|}{ ENPR16ST } \\
\hline 09092980 & & & & & & & & & $34 / 0$ & $\begin{array}{c}4 / 21 / 1978- \\
9 / 12 / 1983\end{array}$ & 0 & 0.03 & 0.076 & 0.092 & 3.99 \\
\hline ENPR11ST & $9 / 0$ & $\begin{array}{c}11 / 28 / 2005- \\
3 / 26 / 2009\end{array}$ & & 0.183 & 0.200 & 0.294 & 0.429 & 0.723 & & & & & & & \\
\hline \multicolumn{16}{|l|}{09093000} \\
\hline \multicolumn{16}{|l|}{11210} \\
\hline 09093500 & & & & & & & & & $53 / 0$ & $\begin{array}{c}11 / 21 / 1974 \\
8 / 21 / 1979\end{array}$ & 0 & 0.03 & 0.06 & 0.12 & 0.86 \\
\hline 09093700 & & & & & & & & & $57 / 0$ & $\begin{array}{c}8 / 31 / 1973- \\
4 / 26 / 1979\end{array}$ & 0 & 0 & 0.03 & 0.03 & 0.15 \\
\hline \multicolumn{16}{|l|}{11205} \\
\hline \multirow{2}{*}{\multicolumn{16}{|c|}{$\begin{array}{l}09094200 \\
09094400\end{array}$}} \\
\hline & & & & & & & & & & & & & & & \\
\hline 09095000 & & & & & & & & & $53 / 0$ & $\begin{array}{c}2 / 24 / 1975- \\
8 / 16 / 1979\end{array}$ & 0 & 0.03 & 0.03 & 0.105 & 1.5 \\
\hline \multicolumn{16}{|l|}{09095400} \\
\hline \multicolumn{16}{|l|}{09097500} \\
\hline \multicolumn{16}{|l|}{11155} \\
\hline \multicolumn{16}{|l|}{09097600} \\
\hline 09095800 & & & & & & & & & & & & & & & \\
\hline 09096500 & & & & & & & & & & & & & & & \\
\hline 391507107550601 & & & & & & & & & & & & & & & \\
\hline CDOWRW-56 & & & & & & & & & & & & & & & \\
\hline CDOWRW-55 & & & & & & & & & & & & & & & \\
\hline 09097900 & & & & & & & & & & & & & & & \\
\hline CDOWRW-54 & & & & & & & & & & & & & & & \\
\hline CDOWRW-53 & & & & & & & & & & & & & & & \\
\hline 09105000 & $14 / 3$ & $\begin{array}{c}11 / 19 / 1968- \\
9 / 5 / 2002\end{array}$ & 0.0420 .03 & 0.03 & 0.068 & 0.171 & 0.52 & 0.904 & $65 / 0$ & $\begin{array}{c}11 / 19 / 1968- \\
5 / 22 / 1991\end{array}$ & 0 & 0.050 & 0.09 & 0.15 & 5 \\
\hline
\end{tabular}


Appendix 1. Summary of surface-water-quality data and comparison to water-quality standards by site, by constituent, Piceance study area, western Colorado. Water-quality standards comparisons follow data summaries and are in blue text; standards are provided in table 3.-Continued

[CDPHE segment, Colorado Department of Health and the Environment stream segment as referred to in tables 2 and 3; latitude and longitude are in North American Datum of 1983; downstream order number assigned as part of analysis. $\mu \mathrm{g} / \mathrm{L}$, micrograms per liter; $\mu \mathrm{S} / \mathrm{cm}$, microsiemens per centimeter; $\mathrm{mg} / \mathrm{L}$, milligrams per liter; mL, milliliters; aq, aquatic; CO, Colorado; EPA, U.S. Environmental Protection Agency; Max, maximum; Min, minimum; NA, not applicable; No., number; NTU, nephelometric turbitidy units; WS, water supply; dates given in month/day/year format]

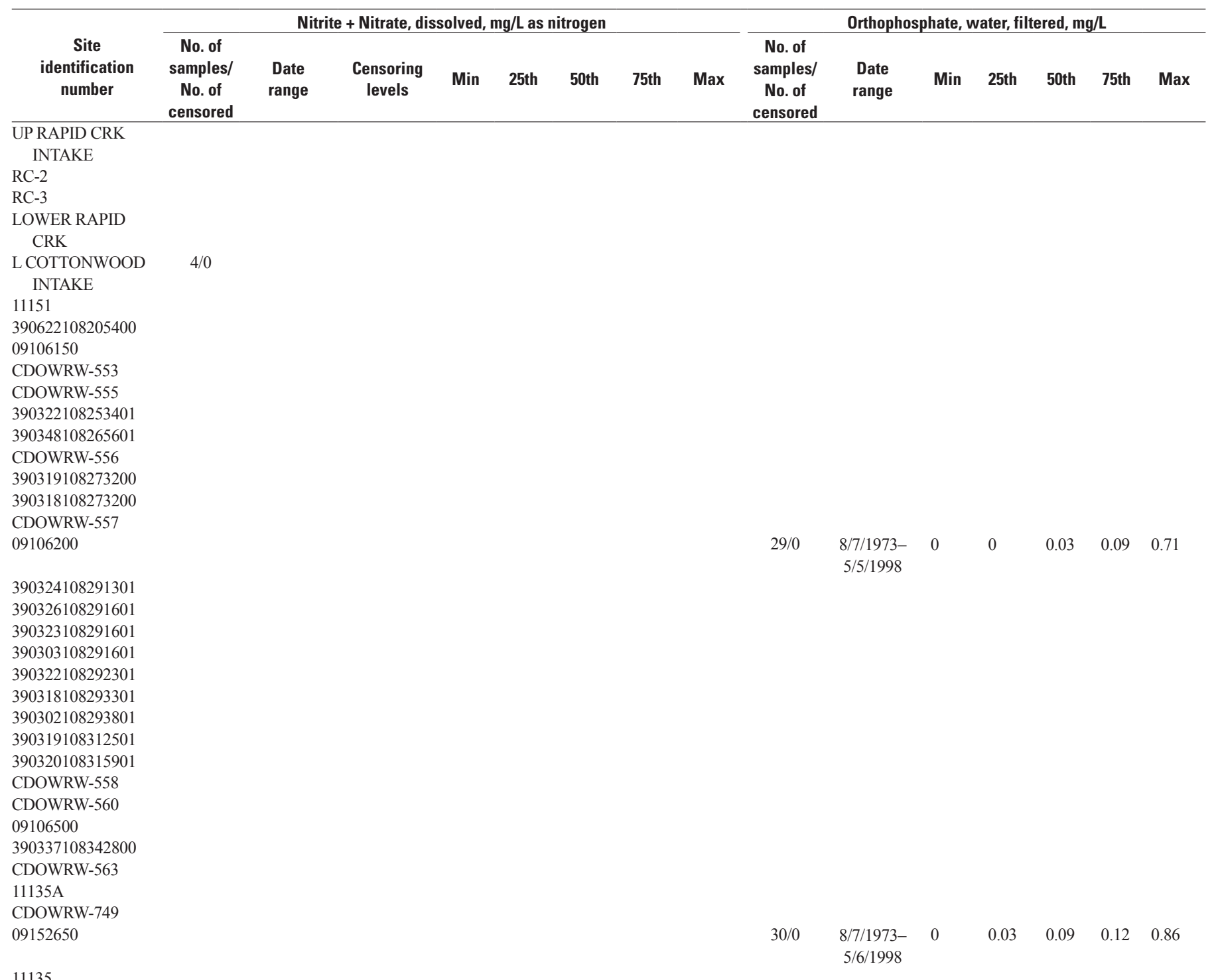

390449108364101

39051410837320

390521108373300

390607108384201

390609108384701

390613108385603

390625108390402

390617108391001

39063210839210

390624108394701

390859108364101

390645108390101

390717108400501

390718108415701 
Appendix 1. Summary of surface-water-quality data and comparison to water-quality standards by site, by constituent, Piceance study area, western Colorado. Water-quality standards comparisons follow data summaries and are in blue text; standards are provided in table 3.-Continued

[CDPHE segment, Colorado Department of Health and the Environment stream segment as referred to in tables 2 and 3; latitude and longitude are in North American Datum of 1983; downstream order number assigned as part of analysis. $\mu \mathrm{g} / \mathrm{L}$, micrograms per liter; $\mu \mathrm{S} / \mathrm{cm}$, microsiemens per centimeter; $\mathrm{mg} / \mathrm{L}$, milligrams per liter; mL, milliliters; aq, aquatic; CO, Colorado; EPA, U.S. Environmental Protection Agency; Max, maximum; Min, minimum; NA, not applicable; No., number; NTU, nephelometric turbitidy units; WS, water supply; dates given in month/day/year format]

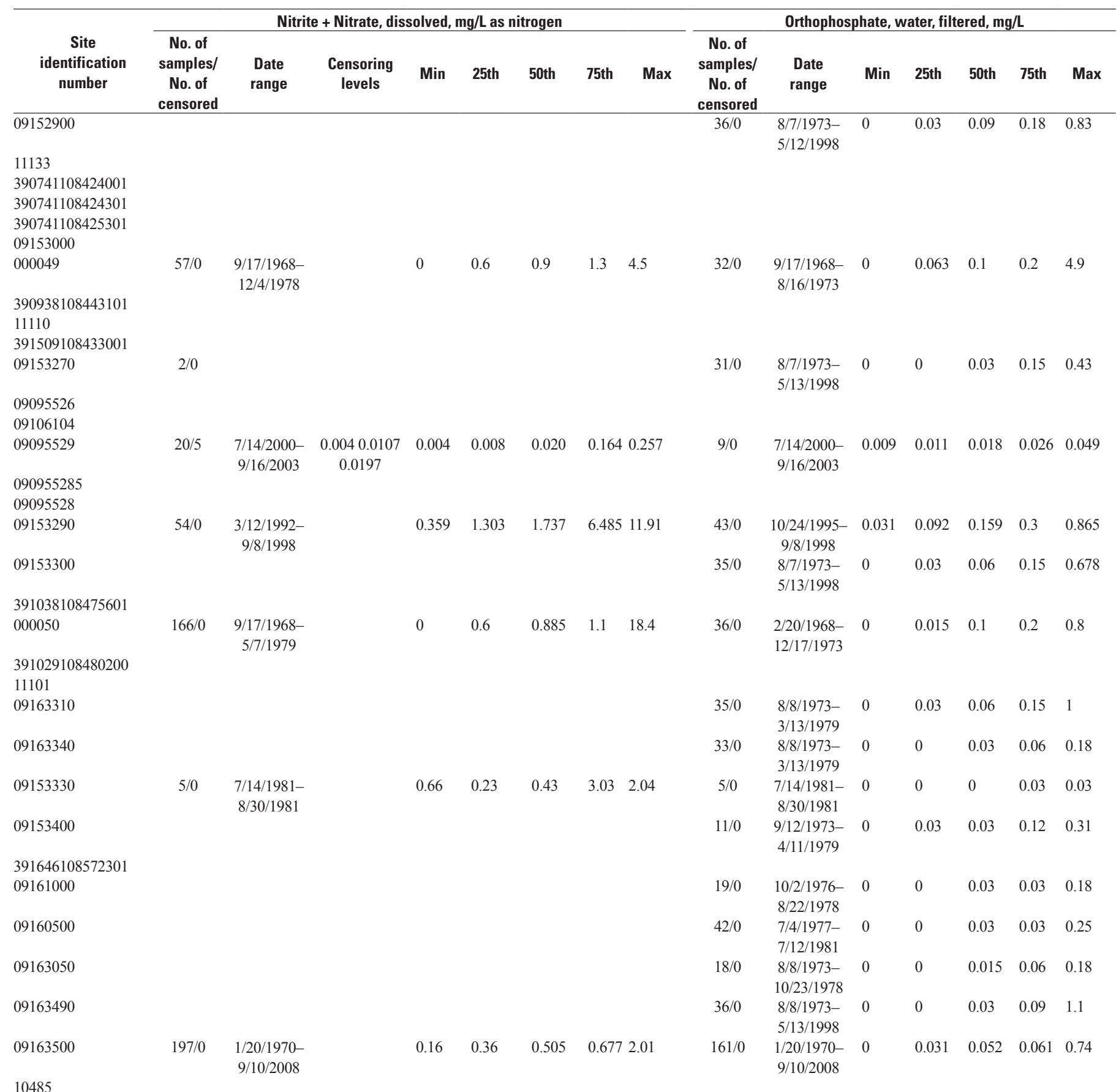

09132050

09129800

09130600

09130800 
Appendix 1. Summary of surface-water-quality data and comparison to water-quality standards by site, by constituent, Piceance study area, western Colorado. Water-quality standards comparisons follow data summaries and are in blue text; standards are provided in table 3.-Continued

[CDPHE segment, Colorado Department of Health and the Environment stream segment as referred to in tables 2 and 3; latitude and longitude are in North American Datum of 1983; downstream order number assigned as part of analysis. $\mu \mathrm{g} / \mathrm{L}$, micrograms per liter; $\mu \mathrm{S} / \mathrm{cm}$, microsiemens per centimeter; $\mathrm{mg} / \mathrm{L}$, milligrams per liter; mL, milliliters; aq, aquatic; CO, Colorado; EPA, U.S. Environmental Protection Agency; Max, maximum; Min, minimum; NA, not applicable; No., number; NTU, nephelometric turbitidy units; WS, water supply; dates given in month/day/year format]

\begin{tabular}{|c|c|c|c|c|c|c|c|c|c|c|c|c|c|c|c|}
\hline $\begin{array}{c}\text { Site } \\
\text { identification } \\
\text { number }\end{array}$ & \multicolumn{8}{|c|}{ Nitrite + Nitrate, dissolved, $\mathrm{mg} / \mathrm{L}$ as nitrogen } & \multicolumn{7}{|c|}{ Orthophosphate, water, filtered, mg/L } \\
\hline \multicolumn{16}{|l|}{09131100} \\
\hline \multicolumn{16}{|l|}{09131200} \\
\hline \multicolumn{16}{|l|}{10490} \\
\hline \multicolumn{16}{|l|}{09132500} \\
\hline \multicolumn{16}{|l|}{09132800} \\
\hline \multicolumn{16}{|l|}{09132900} \\
\hline \multicolumn{16}{|l|}{09132920} \\
\hline \multicolumn{16}{|l|}{09132940} \\
\hline \multicolumn{16}{|l|}{$10406 \mathrm{H}$} \\
\hline \multicolumn{16}{|l|}{09132960} \\
\hline \multicolumn{16}{|l|}{09132985} \\
\hline 385144107371701 & & & & & & & & & & & & & & & \\
\hline 09134100 & & & & & & & & & & & & & & & \\
\hline 385049107372402 & & & & & & & & & & & & & & & \\
\hline 384922107402001 & & & & & & & & & & & & & & & \\
\hline 09134200 & & & & & & & & & & & & & & & \\
\hline 384822107411201 & & & & & & & & & & & & & & & \\
\hline 10212 & & & & & & & & & & & & & & & \\
\hline 384747107430501 & & & & & & & & & & & & & & & \\
\hline 09134500 & & & & & & & & & & & & & & & \\
\hline 09134700 & & & & & & & & & & & & & & & \\
\hline 10415 & & & & & & & & & & & & & & & \\
\hline 09135900 & & & & & & & & & & & & & & & \\
\hline 10411 & & & & & & & & & & & & & & & \\
\hline 231273 & $24 / 0$ & $\begin{array}{c}5 / 12 / 1971- \\
4 / 5 / 1972\end{array}$ & & 0.34 & 0.493 & 0.685 & 0.838 & 1.78 & $24 / 0$ & $\begin{array}{c}5 / 12 / 1971- \\
4 / 5 / 1972\end{array}$ & 0.05 & 0.173 & 0.215 & 0.513 & 5.8 \\
\hline 231274 & $24 / 0$ & $\begin{array}{c}5 / 12 / 1971- \\
4 / 5 / 1972\end{array}$ & & 0.2 & 0.253 & 0.305 & 0.43 & 0.99 & $24 / 0$ & $\begin{array}{c}5 / 12 / 1971- \\
4 / 5 / 1972\end{array}$ & 0.01 & 0.085 & 0.11 & 0.238 & 0.55 \\
\hline 09136100 & & & & & & & & & & & & & & & \\
\hline 10400 & & & & & & & & & & & & & & & \\
\hline 09136200 & & & & & & & & & & & & & & & \\
\hline 384643107540301 & & & & & & & & & & & & & & & \\
\hline 10587 & & & & & & & & & & & & & & & \\
\hline 09137050 & & & & & & & & & & & & & & & \\
\hline 384649107570501 & & & & & & & & & & & & & & & \\
\hline $\begin{array}{l}384624107570701 \\
384604107570701\end{array}$ & & & & & & & & & & & & & & & \\
\hline
\end{tabular}


Appendix 1. Summary of surface-water-quality data and comparison to water-quality standards by site, by constituent, Piceance study area, western Colorado. Water-quality standards comparisons follow data summaries and are in blue text; standards are provided in table 3.-Continued

[CDPHE segment, Colorado Department of Health and the Environment stream segment as referred to in tables 2 and 3; latitude and longitude are in North American Datum of 1983; downstream order number assigned as part of analysis. $\mu \mathrm{g} / \mathrm{L}$, micrograms per liter; $\mu \mathrm{S} / \mathrm{cm}$, microsiemens per centimeter; $\mathrm{mg} / \mathrm{L}$, milligrams per liter; mL, milliliters; aq, aquatic; CO, Colorado; EPA, U.S. Environmental Protection Agency; Max, maximum; Min, minimum; NA, not applicable; No., number; NTU, nephelometric turbitidy units; WS, water supply; dates given in month/day/year format]

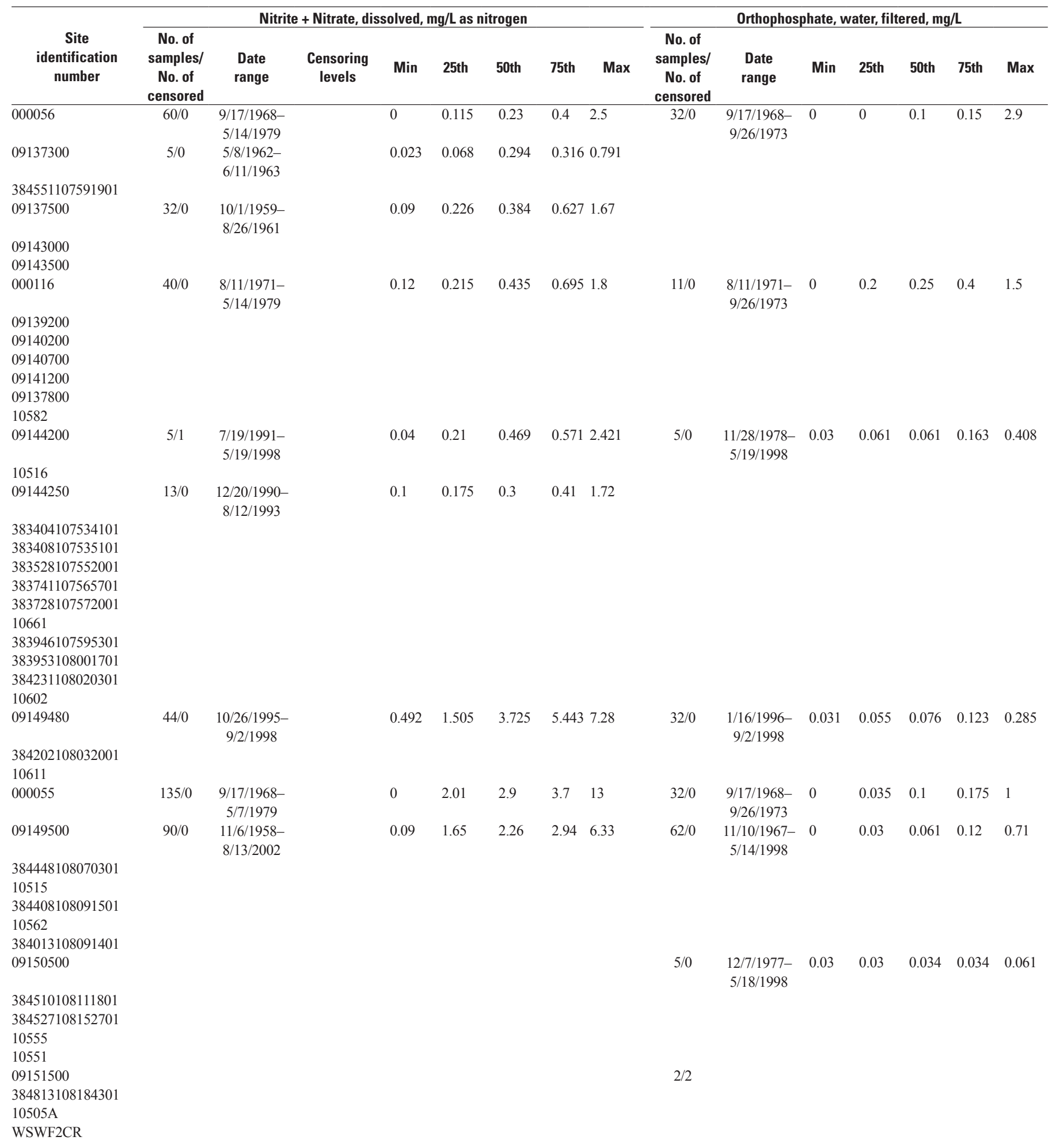


Appendix 1. Summary of surface-water-quality data and comparison to water-quality standards by site, by constituent, Piceance study area, western Colorado. Water-quality standards comparisons follow data summaries and are in blue text; standards are provided in table 3.-Continued

[CDPHE segment, Colorado Department of Health and the Environment stream segment as referred to in tables 2 and 3; latitude and longitude are in North American Datum of 1983; downstream order number assigned as part of analysis. $\mu \mathrm{g} / \mathrm{L}$, micrograms per liter; $\mu \mathrm{S} / \mathrm{cm}$, microsiemens per centimeter; $\mathrm{mg} / \mathrm{L}$, milligrams per liter; mL, milliliters; aq, aquatic; CO, Colorado; EPA, U.S. Environmental Protection Agency; Max, maximum; Min, minimum; NA, not applicable; No., number; NTU, nephelometric turbitidy units; WS, water supply; dates given in month/day/year format]

\begin{tabular}{|c|c|c|c|c|c|c|c|c|c|c|c|c|c|c|c|}
\hline \multirow[b]{2}{*}{$\begin{array}{c}\text { Site } \\
\text { identification } \\
\text { number }\end{array}$} & \multicolumn{8}{|c|}{ Nitrite + Nitrate, dissolved, $\mathrm{mg} / \mathrm{L}$ as nitrogen } & \multicolumn{7}{|c|}{ Orthophosphate, water, filtered, mg/L } \\
\hline & $\begin{array}{c}\text { No. of } \\
\text { samples/ } \\
\text { No. of } \\
\text { censored }\end{array}$ & $\begin{array}{l}\text { Date } \\
\text { range }\end{array}$ & $\begin{array}{l}\text { Censoring } \\
\text { levels }\end{array}$ & Min & 25th & 50th & 75th & Max & $\begin{array}{c}\text { No. of } \\
\text { samples/ } \\
\text { No. of } \\
\text { censored }\end{array}$ & $\begin{array}{l}\text { Date } \\
\text { range }\end{array}$ & Min & 25th & 50th & 75th & Max \\
\hline \\
\hline \multicolumn{16}{|l|}{ WSTWOCR } \\
\hline \multicolumn{16}{|l|}{ WSKCINTK } \\
\hline \multicolumn{16}{|l|}{10575} \\
\hline \multicolumn{16}{|l|}{ WSJUNNLT } \\
\hline \multicolumn{16}{|l|}{ WSJUNNLTLO } \\
\hline \multicolumn{16}{|l|}{10572} \\
\hline \multicolumn{16}{|l|}{ WSNFKCWR } \\
\hline \multicolumn{16}{|l|}{ WSNFKCDV } \\
\hline \multicolumn{16}{|l|}{ WSNFKCSR } \\
\hline \multicolumn{16}{|l|}{385839108264401} \\
\hline \multicolumn{16}{|l|}{10505} \\
\hline \multicolumn{16}{|l|}{ CDOWRW-562 } \\
\hline 09152500 & $313 / 0$ & $\begin{array}{c}10 / 1 / 1958- \\
9 / 24 / 2002\end{array}$ & & 0.045 & 0.497 & 0.84 & 1.24 & 2.26 & $210 / 0$ & $\begin{array}{c}10 / 1 / 1967- \\
9 / 11 / 1998\end{array}$ & 0 & 0.010 & 0.031 & 0.06 & 0.34 \\
\hline 000054 & $162 / 1$ & $\begin{array}{c}\text { 9/17/1968- } \\
4 / 30 / 1979\end{array}$ & & 0 & 0.64 & 1 & 1.5 & 4.9 & $32 / 0$ & $\begin{array}{l}9 / 17 / 1968- \\
11 / 12 / 1973\end{array}$ & 0 & 0 & 0.1 & 0.175 & 0.8 \\
\hline \multicolumn{16}{|l|}{09152520} \\
\hline 09152600 & & & & & & & & & $30 / 0$ & $\begin{array}{c}8 / 7 / 1973- \\
5 / 7 / 1998\end{array}$ & 0 & 0.06 & 0.105 & 0.21 & 0.83 \\
\hline
\end{tabular}


Appendix 1. Summary of surface-water-quality data and comparison to water-quality standards by site, by constituent, Piceance study area, western Colorado. Water-quality standards comparisons follow data summaries and are in blue text; standards are provided in table 3.-Continued

[CDPHE segment, Colorado Department of Health and the Environment stream segment as referred to in tables 2 and 3; latitude and longitude are in North American Datum of 1983; downstream order number assigned as part of analysis. $\mu \mathrm{g} / \mathrm{L}$, micrograms per liter; $\mu \mathrm{S} / \mathrm{cm}$, microsiemens per centimeter; $\mathrm{mg} / \mathrm{L}$, milligrams per liter; mL, milliliters; aq, aquatic; CO, Colorado; EPA, U.S. Environmental Protection Agency; Max, maximum; Min, minimum; NA, not applicable; No., number; NTU, nephelometric turbitidy units; WS, water supply; dates given in month/day/year format]

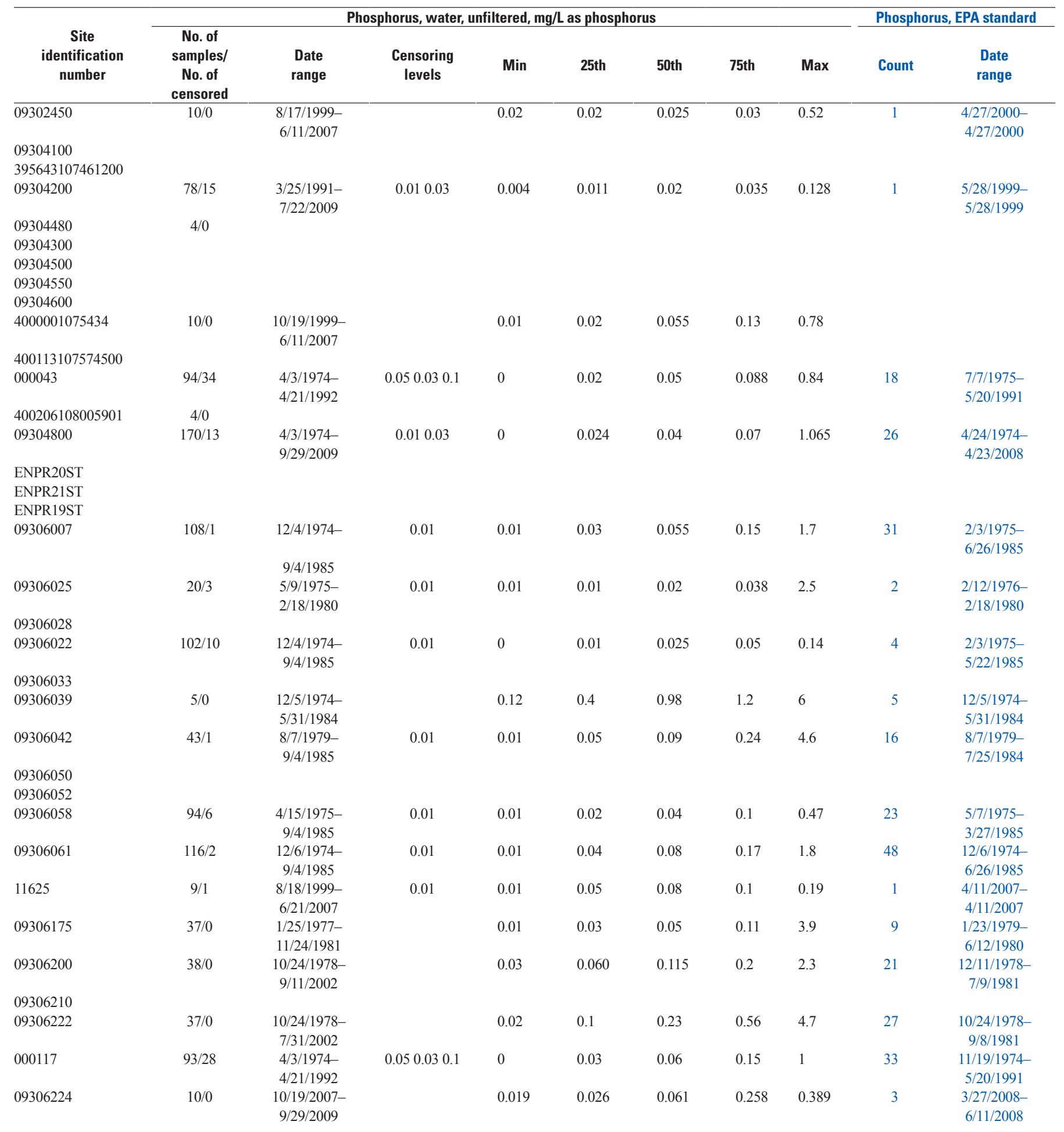


Appendix 1. Summary of surface-water-quality data and comparison to water-quality standards by site, by constituent, Piceance study area, western Colorado. Water-quality standards comparisons follow data summaries and are in blue text; standards are provided in table 3.-Continued

[CDPHE segment, Colorado Department of Health and the Environment stream segment as referred to in tables 2 and 3; latitude and longitude are in North American Datum of 1983; downstream order number assigned as part of analysis. $\mu \mathrm{g} / \mathrm{L}$, micrograms per liter; $\mu \mathrm{S} / \mathrm{cm}$, microsiemens per centimeter; $\mathrm{mg} / \mathrm{L}$, milligrams per liter; mL, milliliters; aq, aquatic; CO, Colorado; EPA, U.S. Environmental Protection Agency; Max, maximum; Min, minimum; NA, not applicable; No., number; NTU, nephelometric turbitidy units; WS, water supply; dates given in month/day/year format]

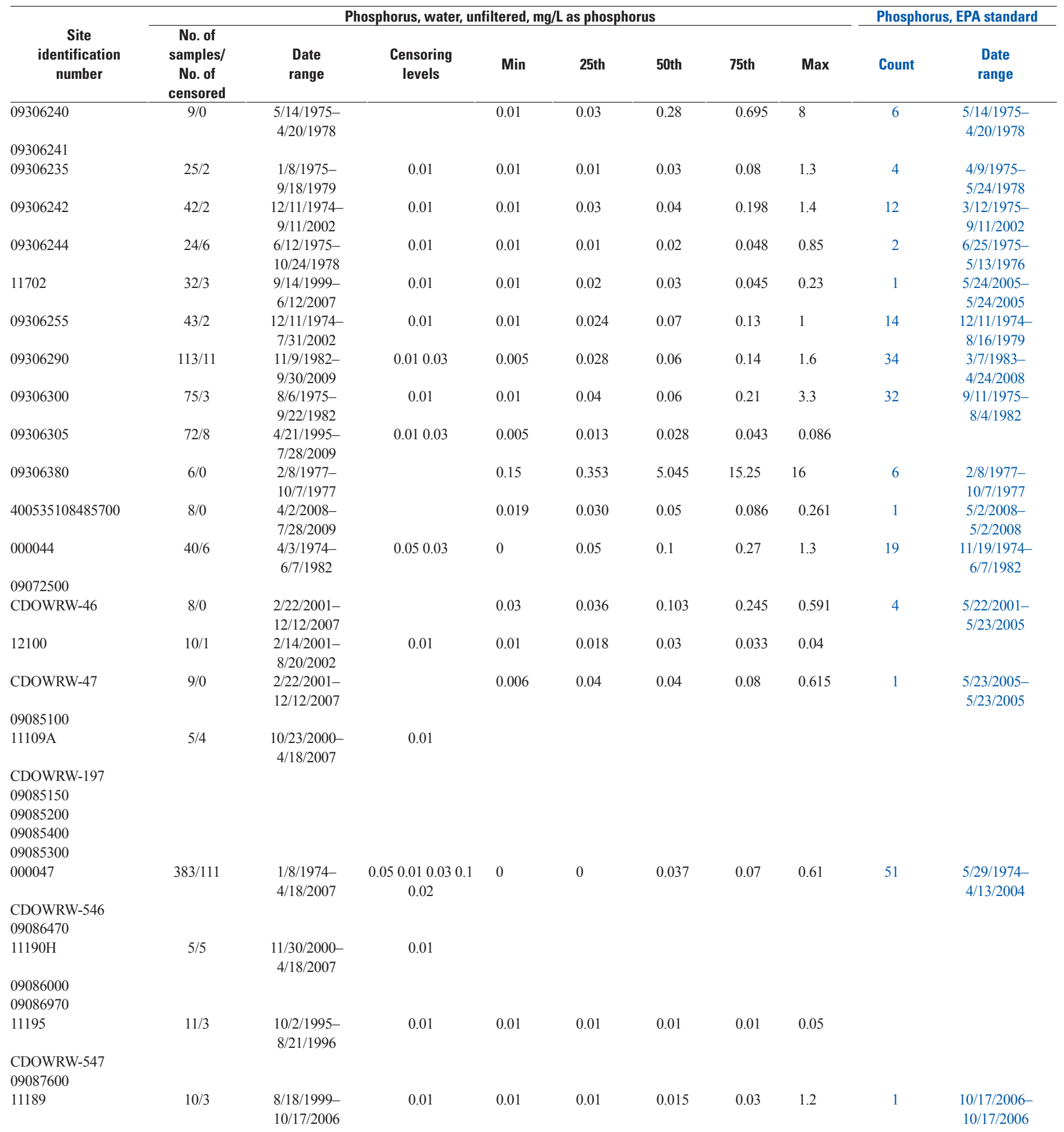


Appendix 1. Summary of surface-water-quality data and comparison to water-quality standards by site, by constituent, Piceance study area, western Colorado. Water-quality standards comparisons follow data summaries and are in blue text; standards are provided in table 3.-Continued

[CDPHE segment, Colorado Department of Health and the Environment stream segment as referred to in tables 2 and 3; latitude and longitude are in North American Datum of 1983; downstream order number assigned as part of analysis. $\mu \mathrm{g} / \mathrm{L}$, micrograms per liter; $\mu \mathrm{S} / \mathrm{cm}$, microsiemens per centimeter; mg/L, milligrams per liter; mL, milliliters; aq, aquatic; CO, Colorado; EPA, U.S. Environmental Protection Agency; Max, maximum; Min, minimum; NA, not applicable; No., number; NTU, nephelometric turbitidy units; WS, water supply; dates given in month/day/year format]

\begin{tabular}{|c|c|c|c|c|c|c|c|c|c|c|}
\hline \multirow[b]{2}{*}{$\begin{array}{c}\text { Site } \\
\text { identification } \\
\text { number }\end{array}$} & \multicolumn{8}{|c|}{ Phosphorus, water, unfiltered, $\mathrm{mg} / \mathrm{L}$ as phosphorus } & \multicolumn{2}{|c|}{ Phosphorus, EPA standard } \\
\hline & $\begin{array}{c}\text { No. of } \\
\text { samples/ } \\
\text { No. of } \\
\text { censored }\end{array}$ & $\begin{array}{l}\text { Date } \\
\text { range }\end{array}$ & $\begin{array}{l}\text { Censoring } \\
\text { levels }\end{array}$ & Min & 25th & 50th & 75th & Max & Count & $\begin{array}{l}\text { Date } \\
\text { range }\end{array}$ \\
\hline \multicolumn{11}{|l|}{09089000} \\
\hline 11185 & $10 / 1$ & $\begin{array}{c}\text { 10/2/1995- } \\
8 / 15 / 1996\end{array}$ & 0.01 & 0.01 & 0.025 & 0.05 & 0.233 & 0.74 & 4 & $\begin{array}{l}4 / 2 / 1996- \\
6 / 18 / 1996\end{array}$ \\
\hline 09089500 & $20 / 1$ & $\begin{array}{l}5 / 1 / 1986- \\
8 / 23 / 1990\end{array}$ & 0.01 & 0.01 & 0.02 & 0.05 & 0.128 & 0.32 & 7 & $\begin{array}{l}5 / 1 / 1986- \\
5 / 17 / 1990\end{array}$ \\
\hline \multicolumn{11}{|l|}{ LANG6ST } \\
\hline \multicolumn{11}{|l|}{ LANG5ST } \\
\hline \multicolumn{11}{|l|}{ LANG4ST } \\
\hline \multicolumn{11}{|l|}{ LANG3ST } \\
\hline \multicolumn{11}{|l|}{ LANG7ST } \\
\hline \multicolumn{11}{|l|}{ LANG8ST } \\
\hline \multicolumn{11}{|l|}{ LANG9ST } \\
\hline \multicolumn{11}{|l|}{ LANG10ST } \\
\hline \multicolumn{11}{|l|}{ DUNC1ST } \\
\hline \multicolumn{11}{|l|}{09091100} \\
\hline \multicolumn{11}{|l|}{ CDOWRW-550 } \\
\hline \multicolumn{11}{|l|}{ CDOWRW-559 } \\
\hline \multicolumn{11}{|l|}{09092500} \\
\hline \multicolumn{11}{|l|}{704569} \\
\hline \multicolumn{11}{|l|}{09091500} \\
\hline \multicolumn{11}{|l|}{09092000} \\
\hline 000147 & $77 / 31$ & $\begin{array}{c}5 / 31 / 1979 \\
4 / 15 / 1992\end{array}$ & 0.050 .01 & 0.01 & 0.04 & 0.052 & 0.12 & 5 & 23 & $\begin{array}{c}2 / 21 / 1980- \\
4 / 15 / 1992\end{array}$ \\
\hline 09092600 & & & & & & & & & & \\
\hline 09092830 & & & & & & & & & & \\
\hline 09092850 & & & & & & & & & & \\
\hline ENPR13ST & & & & & & & & & & \\
\hline ENPR3ST & & & & & & & & & & \\
\hline $11145 \mathrm{~A}$ & $16 / 2$ & $\begin{array}{c}9 / 30 / 1999 \\
4 / 10 / 2007\end{array}$ & 0.01 & 0.01 & 0.015 & 0.02 & 0.035 & 0.19 & 1 & $\begin{array}{c}4 / 10 / 2007- \\
4 / 10 / 2007\end{array}$ \\
\hline 11145B & $16 / 3$ & $\begin{array}{c}9 / 30 / 1999 \\
4 / 10 / 2007\end{array}$ & 0.01 & 0.01 & 0.01 & 0.02 & 0.02 & 0.65 & 1 & $\begin{array}{c}4 / 27 / 2000 \\
4 / 27 / 2000\end{array}$ \\
\hline
\end{tabular}

09092960

09092970

ENPR16ST

09092980

ENPR18ST

ENPR17ST

ENPR14ST

ENPR15ST

ENPR11ST 
Appendix 1. Summary of surface-water-quality data and comparison to water-quality standards by site, by constituent, Piceance study area, western Colorado. Water-quality standards comparisons follow data summaries and are in blue text; standards are provided in table 3.-Continued

[CDPHE segment, Colorado Department of Health and the Environment stream segment as referred to in tables 2 and 3; latitude and longitude are in North American Datum of 1983; downstream order number assigned as part of analysis. $\mu \mathrm{g} / \mathrm{L}$, micrograms per liter; $\mu \mathrm{S} / \mathrm{cm}$, microsiemens per centimeter; $\mathrm{mg} / \mathrm{L}$, milligrams per liter; mL, milliliters; aq, aquatic; CO, Colorado; EPA, U.S. Environmental Protection Agency; Max, maximum; Min, minimum; NA, not applicable; No., number; NTU, nephelometric turbitidy units; WS, water supply; dates given in month/day/year format]

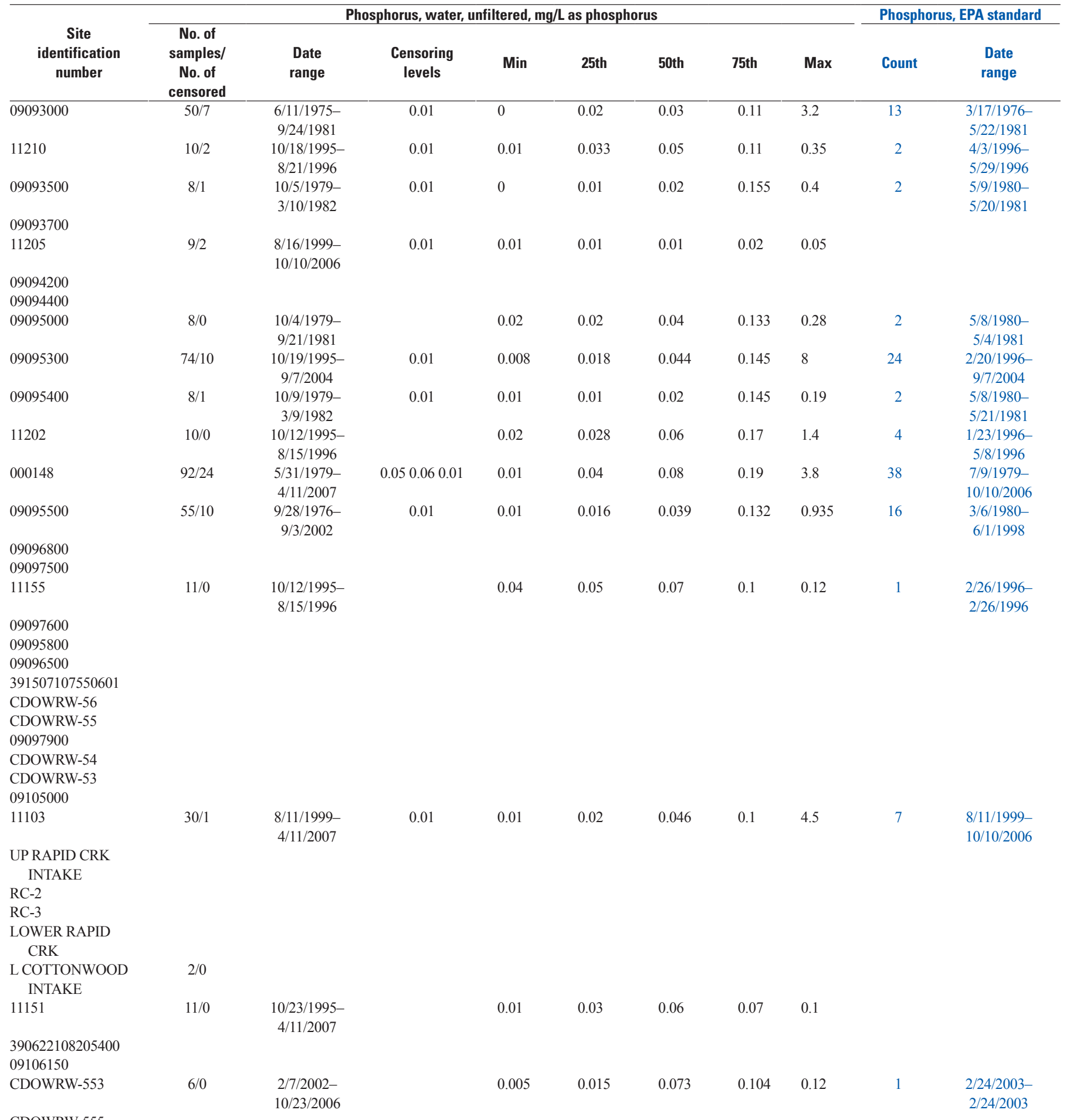

CDOWRW-555 
Appendix 1. Summary of surface-water-quality data and comparison to water-quality standards by site, by constituent, Piceance study area, western Colorado. Water-quality standards comparisons follow data summaries and are in blue text; standards are provided in table 3.-Continued

[CDPHE segment, Colorado Department of Health and the Environment stream segment as referred to in tables 2 and 3; latitude and longitude are in North American Datum of 1983; downstream order number assigned as part of analysis. $\mu \mathrm{g} / \mathrm{L}$, micrograms per liter; $\mu \mathrm{S} / \mathrm{cm}$, microsiemens per centimeter; mg/L, milligrams per liter; mL, milliliters; aq, aquatic; CO, Colorado; EPA, U.S. Environmental Protection Agency; Max, maximum; Min, minimum; NA, not applicable; No., number; NTU, nephelometric turbitidy units; WS, water supply; dates given in month/day/year format]

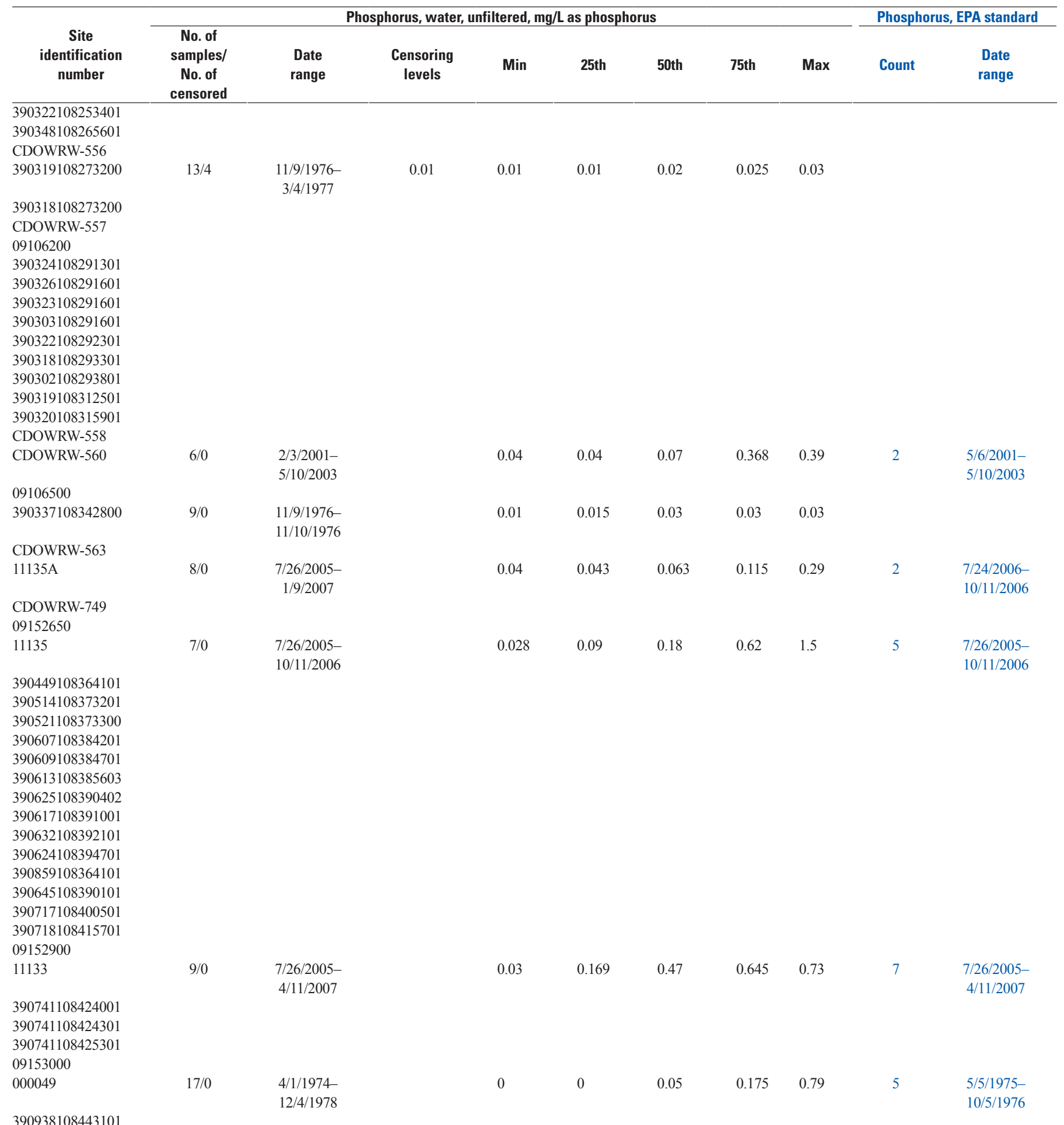


Appendix 1. Summary of surface-water-quality data and comparison to water-quality standards by site, by constituent, Piceance study area, western Colorado. Water-quality standards comparisons follow data summaries and are in blue text; standards are provided in table 3.-Continued

[CDPHE segment, Colorado Department of Health and the Environment stream segment as referred to in tables 2 and 3; latitude and longitude are in North American Datum of 1983; downstream order number assigned as part of analysis. $\mu \mathrm{g} / \mathrm{L}$, micrograms per liter; $\mu \mathrm{S} / \mathrm{cm}$, microsiemens per centimeter; $\mathrm{mg} / \mathrm{L}$, milligrams per liter; mL, milliliters; aq, aquatic; CO, Colorado; EPA, U.S. Environmental Protection Agency; Max, maximum; Min, minimum; NA, not applicable; No., number; NTU, nephelometric turbitidy units; WS, water supply; dates given in month/day/year format]

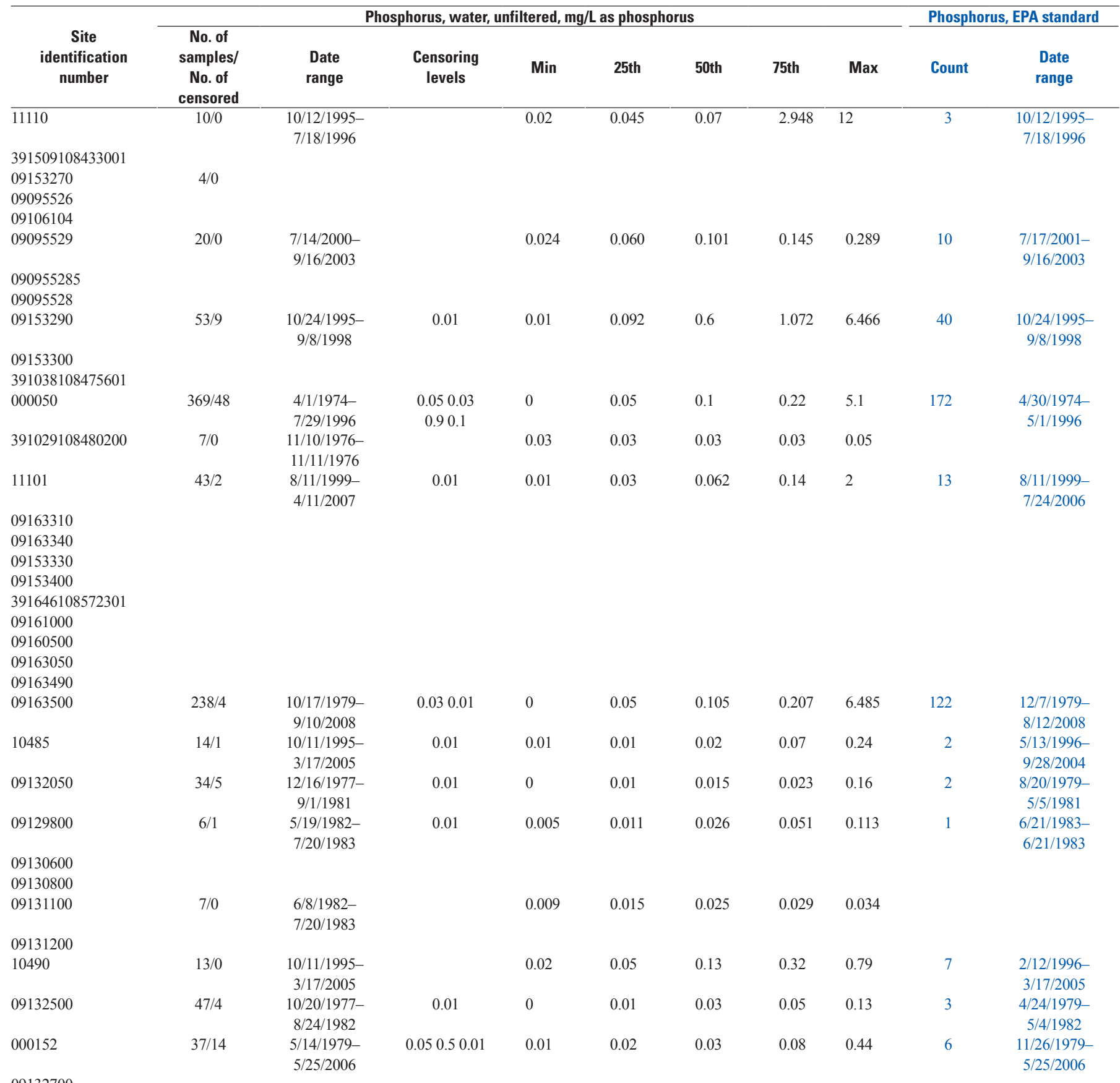

09132700

09132800

09132900

09132920

09132940

$10406 \mathrm{H}$ 
Appendix 1. Summary of surface-water-quality data and comparison to water-quality standards by site, by constituent, Piceance study area, western Colorado. Water-quality standards comparisons follow data summaries and are in blue text; standards are provided in table 3.-Continued

[CDPHE segment, Colorado Department of Health and the Environment stream segment as referred to in tables 2 and 3; latitude and longitude are in North American Datum of 1983; downstream order number assigned as part of analysis. $\mu \mathrm{g} / \mathrm{L}$, micrograms per liter; $\mu \mathrm{S} / \mathrm{cm}$, microsiemens per centimeter; $\mathrm{mg} / \mathrm{L}$, milligrams per liter; mL, milliliters; aq, aquatic; CO, Colorado; EPA, U.S. Environmental Protection Agency; Max, maximum; Min, minimum; NA, not applicable; No., number; NTU, nephelometric turbitidy units; WS, water supply; dates given in month/day/year format]

\begin{tabular}{|c|c|c|c|c|c|c|c|c|c|c|}
\hline \multirow[b]{2}{*}{$\begin{array}{c}\text { Site } \\
\text { identification } \\
\text { number }\end{array}$} & \multicolumn{8}{|c|}{ Phosphorus, water, unfiltered, $\mathrm{mg} / \mathrm{L}$ as phosphorus } & \multicolumn{2}{|c|}{ Phosphorus, EPA standard } \\
\hline & $\begin{array}{c}\text { No. of } \\
\text { samples/ } \\
\text { No. of } \\
\text { censored }\end{array}$ & $\begin{array}{l}\text { Date } \\
\text { range }\end{array}$ & $\begin{array}{l}\text { Censoring } \\
\text { levels }\end{array}$ & Min & 25th & 50th & 75th & Max & Count & $\begin{array}{l}\text { Date } \\
\text { range }\end{array}$ \\
\hline 09132995 & $3 / 0$ & & & & & & & & & \\
\hline \multicolumn{11}{|l|}{09134000} \\
\hline \multicolumn{11}{|l|}{09134050} \\
\hline 385144107371701 & $6 / 0$ & $\begin{array}{c}3 / 31 / 1998- \\
5 / 24 / 2005\end{array}$ & & 0.02 & 0.03 & 0.058 & 0.14 & 0.28 & 2 & $\begin{array}{c}3 / 31 / 1998- \\
5 / 24 / 2005\end{array}$ \\
\hline \multicolumn{11}{|l|}{09134100} \\
\hline \multicolumn{11}{|l|}{385049107372402} \\
\hline \multicolumn{11}{|l|}{384922107402001} \\
\hline \multicolumn{11}{|l|}{09134200} \\
\hline \multicolumn{11}{|l|}{384747107430501} \\
\hline \multirow{2}{*}{\multicolumn{11}{|c|}{$\begin{array}{l}09134500 \\
09134700\end{array}$}} \\
\hline & & & & & & & & & & \\
\hline 10415 & $9 / 0$ & $\begin{array}{c}\text { 10/11/1995- } \\
8 / 6 / 1996\end{array}$ & & 0.03 & 0.05 & 0.07 & 0.08 & 0.11 & 1 & $\begin{array}{c}6 / 10 / 1996- \\
6 / 10 / 1996\end{array}$ \\
\hline \multicolumn{11}{|l|}{09135900} \\
\hline 10411 & $20 / 2$ & $\begin{array}{l}4 / 1 / 1998- \\
3 / 15 / 2005\end{array}$ & 0.01 & 0.01 & 0.015 & 0.02 & 0.050 & 0.09 & & \\
\hline \multicolumn{11}{|l|}{384732107434801} \\
\hline 000100 & $158 / 36$ & $\begin{array}{c}4 / 1 / 1974 \\
2 / 1 / 2001\end{array}$ & 0.050 .010 .03 & 0 & 0.04 & 0.06 & 0.11 & 21 & 48 & $\begin{array}{c}5 / 8 / 1975- \\
2 / 8 / 2000\end{array}$ \\
\hline \multicolumn{11}{|l|}{384434107432701} \\
\hline 10587 & $5 / 1$ & $\begin{array}{l}4 / 1 / 1998- \\
5 / 11 / 2005\end{array}$ & 0.01 & 0.01 & 0.031 & 0.033 & 0.18 & 0.32 & 2 & $\begin{array}{l}4 / 1 / 1998- \\
5 / 11 / 2005\end{array}$ \\
\hline 09137050 & & & & & & & & & & \\
\hline 384649107570501 & & & & & & & & & & \\
\hline 384624107570701 & & & & & & & & & & \\
\hline 384604107570701 & & & & & & & & & & \\
\hline 000056 & $100 / 39$ & $\begin{array}{c}1 / 13 / 1974 \\
8 / 8 / 1994\end{array}$ & 0.050 .03 & 0 & 0 & 0.05 & 0.1 & 0.54 & 23 & $\begin{array}{c}1 / 13 / 1974 \\
4 / 2 / 1992\end{array}$ \\
\hline 09137300 & & & & & & & & & & \\
\hline 384551107591901 & & & & & & & & & & \\
\hline 09137500 & & & & & & & & & & \\
\hline 09143000 & & & & & & & & & & \\
\hline 09143500 & & & & & & & & & & \\
\hline
\end{tabular}


Appendix 1. Summary of surface-water-quality data and comparison to water-quality standards by site, by constituent, Piceance study area, western Colorado. Water-quality standards comparisons follow data summaries and are in blue text; standards are provided in table 3.-Continued

[CDPHE segment, Colorado Department of Health and the Environment stream segment as referred to in tables 2 and 3; latitude and longitude are in North American Datum of 1983; downstream order number assigned as part of analysis. $\mu \mathrm{g} / \mathrm{L}$, micrograms per liter; $\mu \mathrm{S} / \mathrm{cm}$, microsiemens per centimeter; $\mathrm{mg} / \mathrm{L}$, milligrams per liter; mL, milliliters; aq, aquatic; CO, Colorado; EPA, U.S. Environmental Protection Agency; Max, maximum; Min, minimum; NA, not applicable; No., number; NTU, nephelometric turbitidy units; WS, water supply; dates given in month/day/year format]

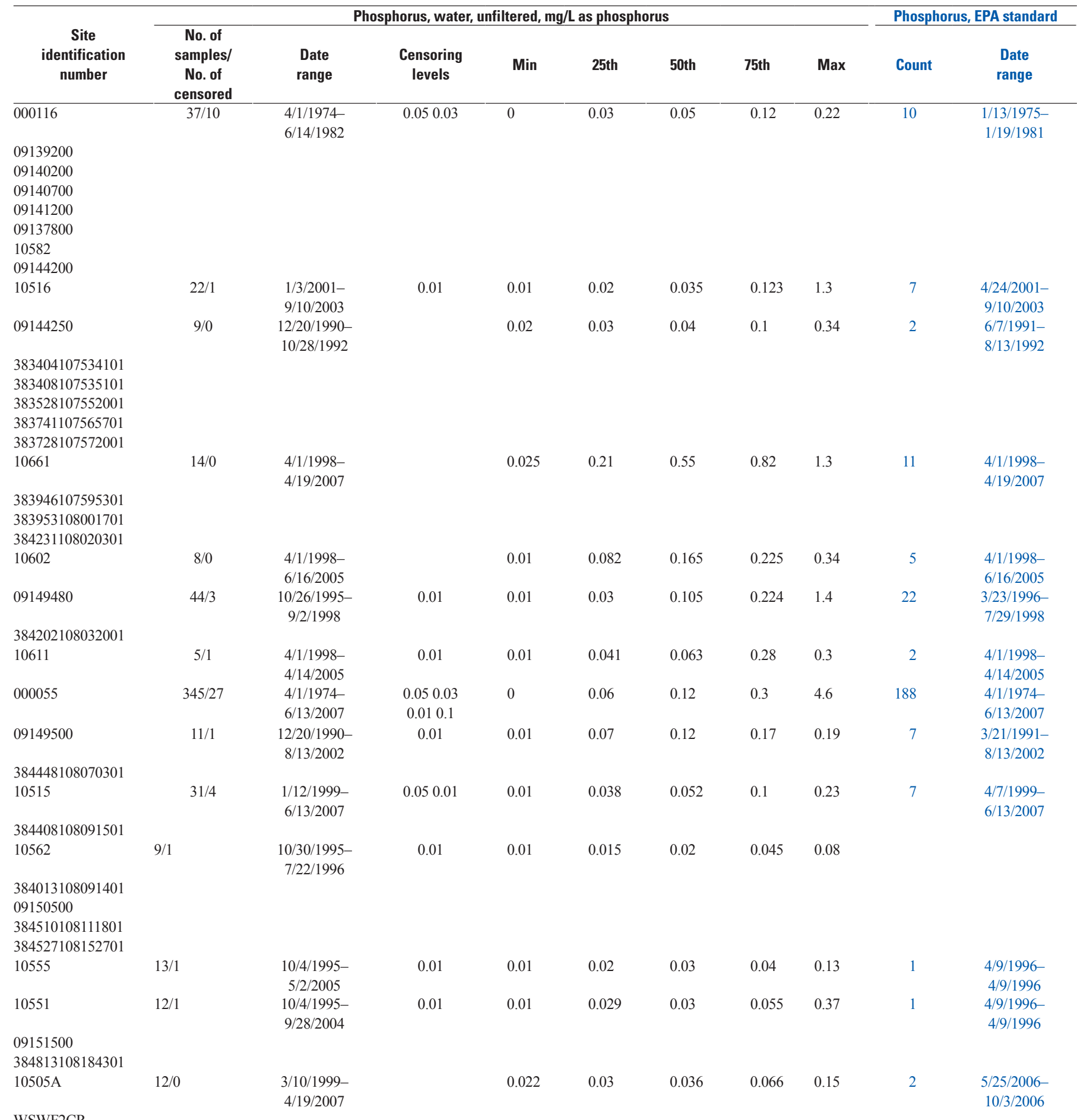

WSWF2CR

WSEF2CR 
Appendix 1. Summary of surface-water-quality data and comparison to water-quality standards by site, by constituent, Piceance study area, western Colorado. Water-quality standards comparisons follow data summaries and are in blue text; standards are provided in table 3.-Continued

[CDPHE segment, Colorado Department of Health and the Environment stream segment as referred to in tables 2 and 3; latitude and longitude are in North American Datum of 1983; downstream order number assigned as part of analysis. $\mu \mathrm{g} / \mathrm{L}$, micrograms per liter; $\mu \mathrm{S} / \mathrm{cm}$, microsiemens per centimeter; mg/L, milligrams per liter; mL, milliliters; aq, aquatic; CO, Colorado; EPA, U.S. Environmental Protection Agency; Max, maximum; Min, minimum; NA, not applicable; No., number; NTU, nephelometric turbitidy units; WS, water supply; dates given in month/day/year format]

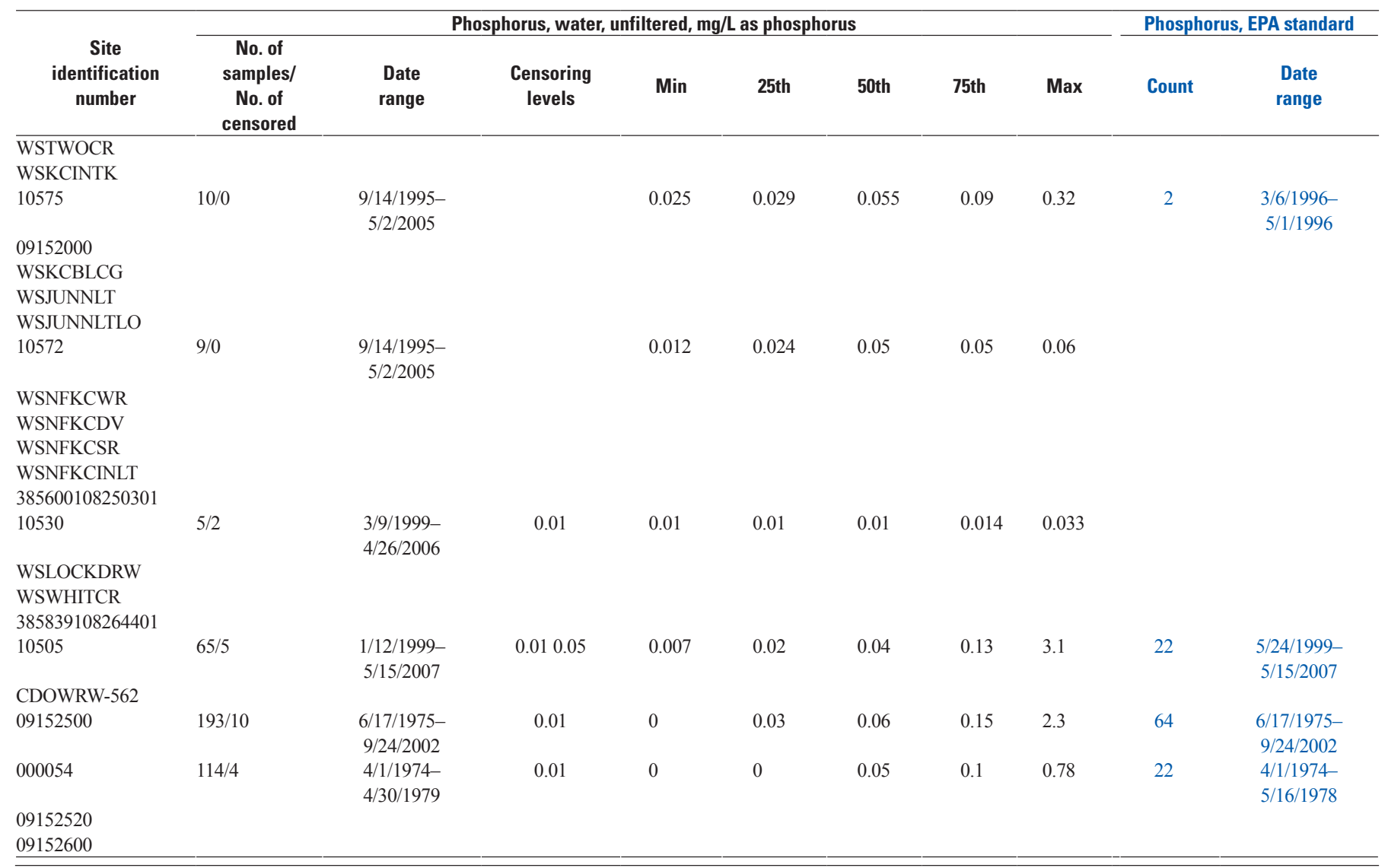


Appendix 1. Summary of surface-water-quality data and comparison to water-quality standards by site, by constituent, Piceance study area, western Colorado. Water-quality standards comparisons follow data summaries and are in blue text; standards are provided in table 3.-Continued

[CDPHE segment, Colorado Department of Health and the Environment stream segment as referred to in tables 2 and 3; latitude and longitude are in North American Datum of 1983; downstream order number assigned as part of analysis. $\mu \mathrm{g} / \mathrm{L}$, micrograms per liter; $\mu \mathrm{S} / \mathrm{cm}$, microsiemens per centimeter; $\mathrm{mg} / \mathrm{L}$, milligrams per liter; mL, milliliters; aq, aquatic; CO, Colorado; EPA, U.S. Environmental Protection Agency; Max, maximum; Min, minimum; NA, not applicable; No., number; NTU, nephelometric turbitidy units; WS, water supply; dates given in month/day/year format]

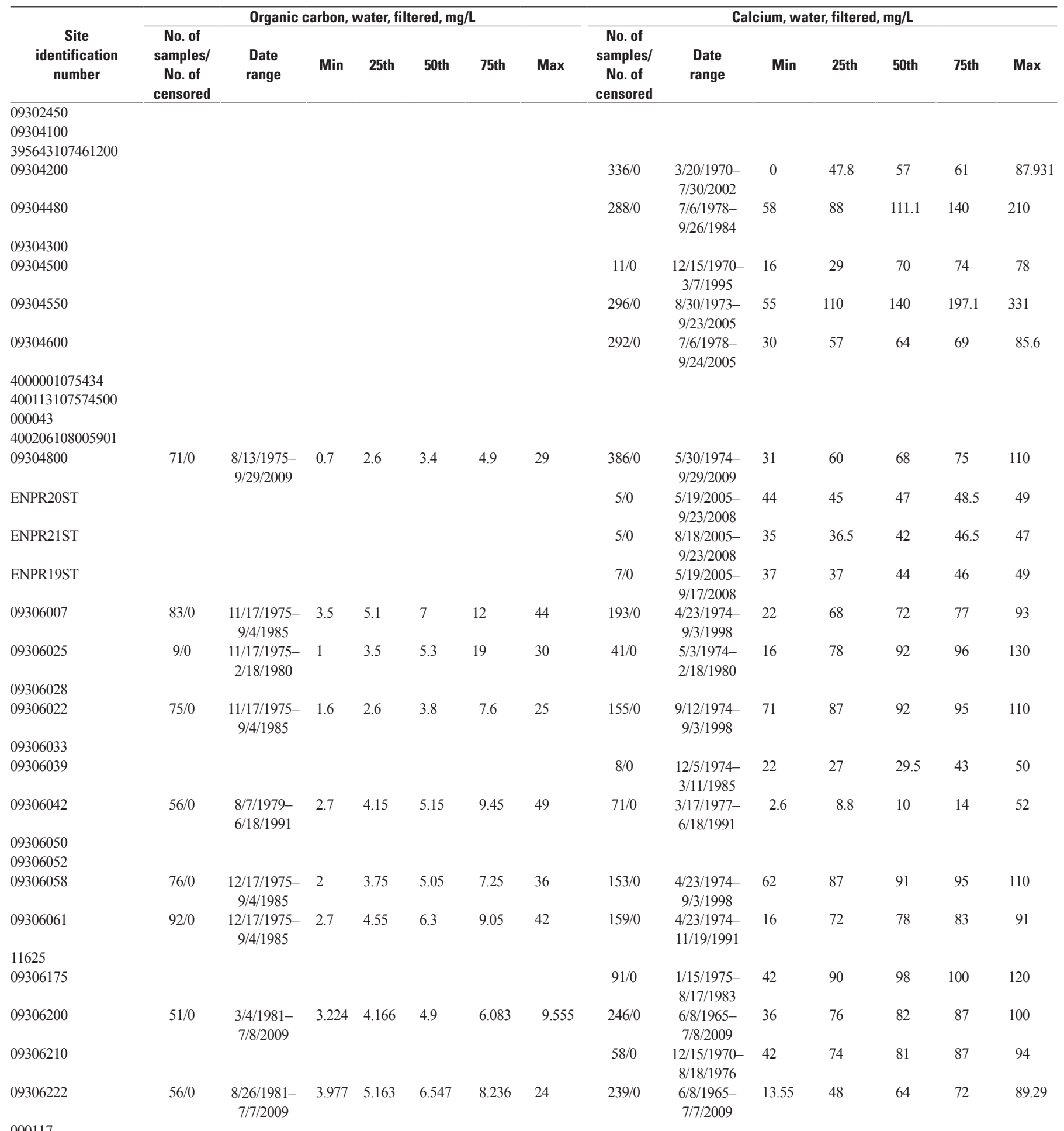

000117 
Appendix 1. Summary of surface-water-quality data and comparison to water-quality standards by site, by constituent, Piceance study area, western Colorado. Water-quality standards comparisons follow data summaries and are in blue text; standards are provided in table 3.-Continued

[CDPHE segment, Colorado Department of Health and the Environment stream segment as referred to in tables 2 and 3; latitude and longitude are in North American Datum of 1983; downstream order number assigned as part of analysis. $\mu \mathrm{g} / \mathrm{L}$, micrograms per liter; $\mu \mathrm{S} / \mathrm{cm}$, microsiemens per centimeter; $\mathrm{mg} / \mathrm{L}$, milligrams per liter; mL, milliliters; aq, aquatic; CO, Colorado; EPA, U.S. Environmental Protection Agency; Max, maximum; Min, minimum; NA, not applicable; No., number; NTU, nephelometric turbitidy units; WS, water supply; dates given in month/day/year format]

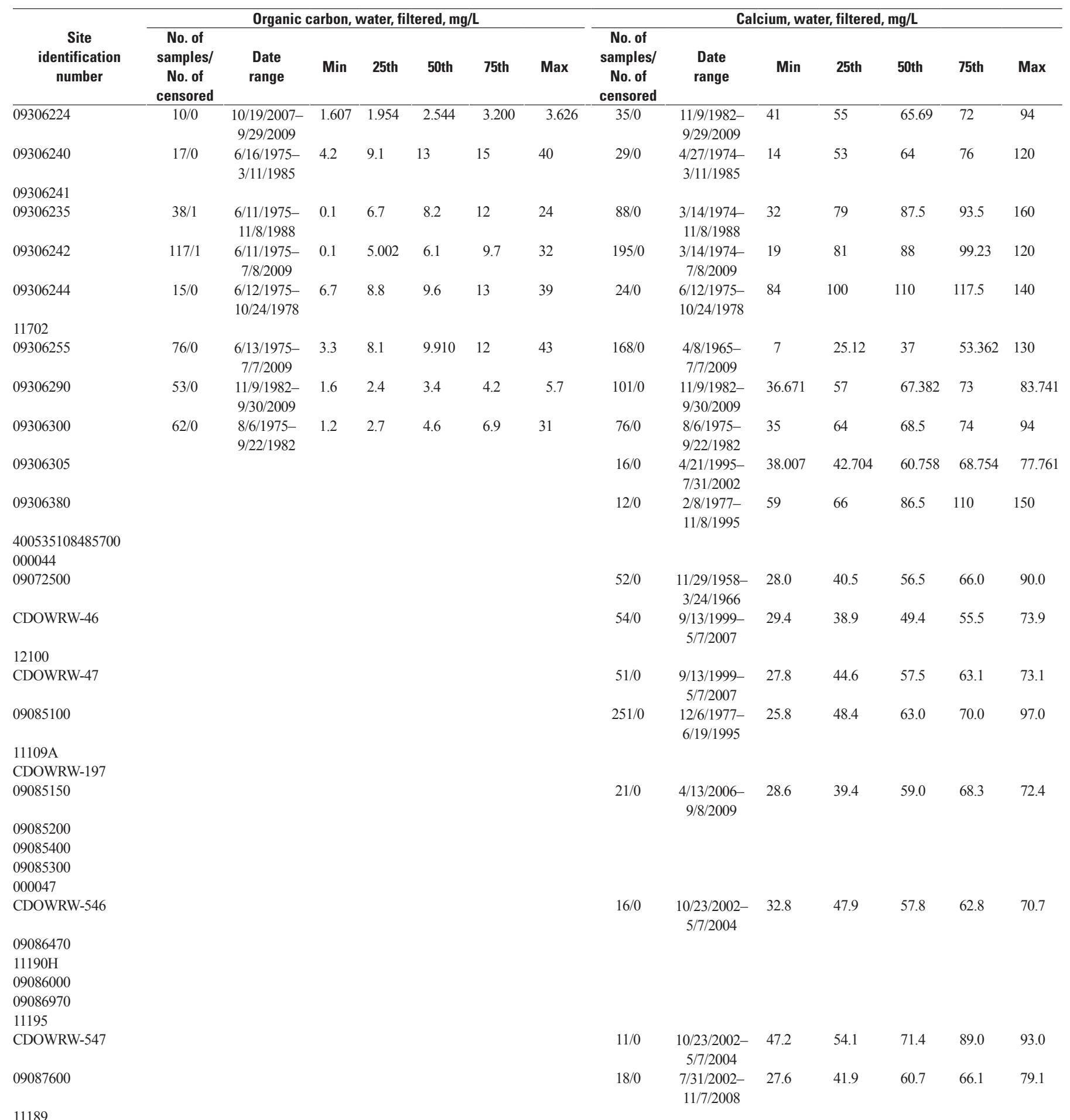

09089000

11185 
Appendix 1. Summary of surface-water-quality data and comparison to water-quality standards by site, by constituent, Piceance study area, western Colorado. Water-quality standards comparisons follow data summaries and are in blue text; standards are provided in table 3.-Continued

[CDPHE segment, Colorado Department of Health and the Environment stream segment as referred to in tables 2 and 3; latitude and longitude are in North American Datum of 1983; downstream order number assigned as part of analysis. $\mu \mathrm{g} / \mathrm{L}$, micrograms per liter; $\mu \mathrm{S} / \mathrm{cm}$, microsiemens per centimeter; mg/L, milligrams per liter; mL, milliliters; aq, aquatic; CO, Colorado; EPA, U.S. Environmental Protection Agency; Max, maximum; Min, minimum; NA, not applicable; No., number; NTU, nephelometric turbitidy units; WS, water supply; dates given in month/day/year format]

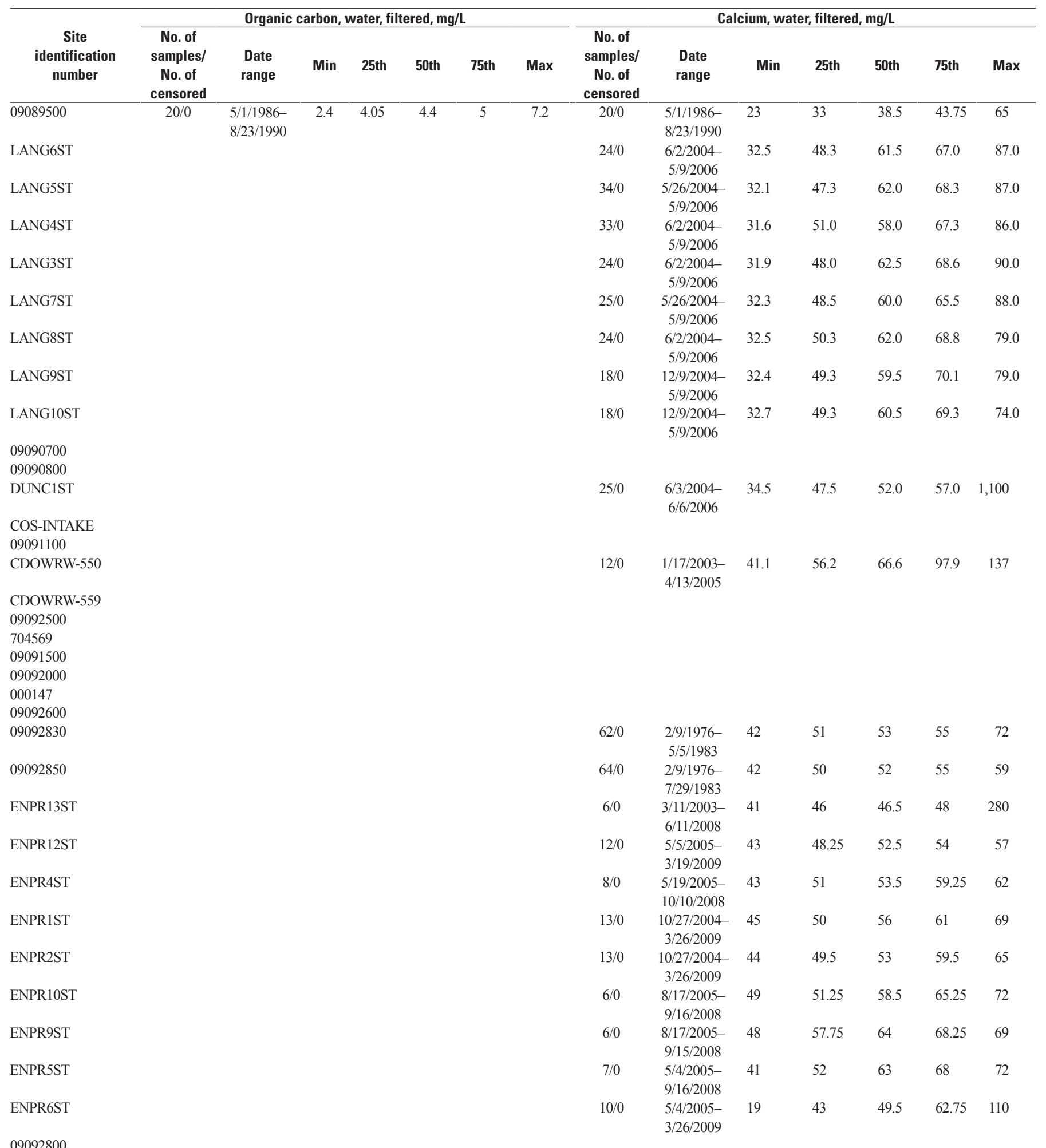


Appendix 1. Summary of surface-water-quality data and comparison to water-quality standards by site, by constituent, Piceance study area, western Colorado. Water-quality standards comparisons follow data summaries and are in blue text; standards are provided in table 3.-Continued

[CDPHE segment, Colorado Department of Health and the Environment stream segment as referred to in tables 2 and 3; latitude and longitude are in North American Datum of 1983; downstream order number assigned as part of analysis. $\mu \mathrm{g} / \mathrm{L}$, micrograms per liter; $\mu \mathrm{S} / \mathrm{cm}$, microsiemens per centimeter; $\mathrm{mg} / \mathrm{L}$, milligrams per liter; mL, milliliters; aq, aquatic; CO, Colorado; EPA, U.S. Environmental Protection Agency; Max, maximum; Min, minimum; NA, not applicable; No., number; NTU, nephelometric turbitidy units; WS, water supply; dates given in month/day/year format]

\begin{tabular}{|c|c|c|c|c|c|c|c|c|c|c|c|c|c|c|}
\hline $\begin{array}{c}\text { Site } \\
\text { identification } \\
\text { number }\end{array}$ & \multicolumn{7}{|c|}{ Organic carbon, water, filtered, mg/L } & \multicolumn{7}{|c|}{ Calcium, water, filtered, $\mathrm{mg} / \mathrm{L}$} \\
\hline \multicolumn{15}{|l|}{$11145 \mathrm{~A}$} \\
\hline \multicolumn{15}{|l|}{ 11145B } \\
\hline 09092970 & & & & & & & & $52 / 0$ & $\begin{array}{c}4 / 21 / 1977- \\
9 / 9 / 1983\end{array}$ & 43 & 50 & 52 & 55 & 69 \\
\hline ENPR16ST & & & & & & & & $5 / 0$ & $\begin{array}{l}5 / 6 / 2005- \\
6 / 19 / 2008\end{array}$ & 44 & 47 & 52 & 57.5 & 61 \\
\hline 09092980 & & & & & & & & $41 / 0$ & $\begin{array}{c}4 / 21 / 1978- \\
9 / 12 / 1983\end{array}$ & 37 & 44 & 46 & 50 & 68 \\
\hline \multicolumn{15}{|l|}{ ENPR18ST } \\
\hline ENPR15ST & & & & & & & & $12 / 0$ & $\begin{array}{c}10 / 27 / 2004 \\
3 / 30 / 2009\end{array}$ & 47 & 53.25 & 59 & 63.5 & 64 \\
\hline ENPR11ST & & & & & & & & $13 / 0$ & $\begin{array}{c}10 / 27 / 2004 \\
3 / 26 / 2009\end{array}$ & 47 & 52.5 & 60 & 63 & 68 \\
\hline 09093000 & $45 / 0$ & $\begin{array}{c}6 / 11 / 1975- \\
9 / 24 / 1981\end{array}$ & 1.8 & 2.8 & 3.6 & 6.8 & 18 & $53 / 0$ & $\begin{array}{c}4 / 21 / 1975- \\
9 / 24 / 1981\end{array}$ & 45 & 55 & 57 & 60 & 74 \\
\hline \multicolumn{15}{|l|}{11210} \\
\hline 09093500 & $7 / 0$ & $\begin{array}{c}10 / 5 / 1979- \\
3 / 10 / 1982\end{array}$ & 3.3 & 4.3 & 4.7 & 9.5 & 22 & $69 / 0$ & $\begin{array}{c}11 / 21 / 1974 \\
10 / 13 / 1982\end{array}$ & 49 & 78 & 87 & 99 & 160 \\
\hline 09093700 & & & & & & & & $86 / 0$ & $\begin{array}{l}8 / 31 / 1973- \\
10 / 25 / 1982\end{array}$ & 29.0 & 49.0 & 68.0 & 75.0 & 100 \\
\hline \multicolumn{15}{|l|}{11205} \\
\hline \multicolumn{15}{|l|}{$\begin{array}{l}09094200 \\
09094400\end{array}$} \\
\hline 09095500 & $46 / 0$ & $\begin{array}{c}9 / 2 / 1994 \\
9 / 9 / 1998\end{array}$ & 1.1 & 2 & 2.45 & 3.025 & 5.5 & $586 / 0$ & $\begin{array}{c}10 / 1 / 1958- \\
9 / 24 / 2009\end{array}$ & 10.4 & 51.7 & 65.5 & 73.0 & 100 \\
\hline \multicolumn{15}{|l|}{09096800} \\
\hline \multicolumn{15}{|l|}{09097500} \\
\hline \multicolumn{15}{|l|}{11155} \\
\hline \multicolumn{15}{|l|}{09097600} \\
\hline \multicolumn{15}{|l|}{09095800} \\
\hline \multicolumn{15}{|l|}{09096500} \\
\hline \multicolumn{15}{|l|}{391507107550601} \\
\hline \multicolumn{15}{|l|}{ CDOWRW-56 } \\
\hline \multicolumn{15}{|l|}{ CDOWRW-55 } \\
\hline \multicolumn{15}{|l|}{09097900} \\
\hline \multicolumn{15}{|l|}{ CDOWRW-54 } \\
\hline CDOWRW-53 & & & & & & & & & & & & & & \\
\hline 09105000 & & & & & & & & $226 / 0$ & $\begin{array}{c}11 / 19 / 1968- \\
9 / 24 / 2009\end{array}$ & 18.8 & 43.3 & 51.8 & 57.2 & 72.0 \\
\hline
\end{tabular}


Appendix 1. Summary of surface-water-quality data and comparison to water-quality standards by site, by constituent, Piceance study area, western Colorado. Water-quality standards comparisons follow data summaries and are in blue text; standards are provided in table 3.-Continued

[CDPHE segment, Colorado Department of Health and the Environment stream segment as referred to in tables 2 and 3; latitude and longitude are in North American Datum of 1983; downstream order number assigned as part of analysis. $\mu \mathrm{g} / \mathrm{L}$, micrograms per liter; $\mu \mathrm{S} / \mathrm{cm}$, microsiemens per centimeter; $\mathrm{mg} / \mathrm{L}$, milligrams per liter; mL, milliliters; aq, aquatic; CO, Colorado; EPA, U.S. Environmental Protection Agency; Max, maximum; Min, minimum; NA, not applicable; No., number; NTU, nephelometric turbitidy units; WS, water supply; dates given in month/day/year format]

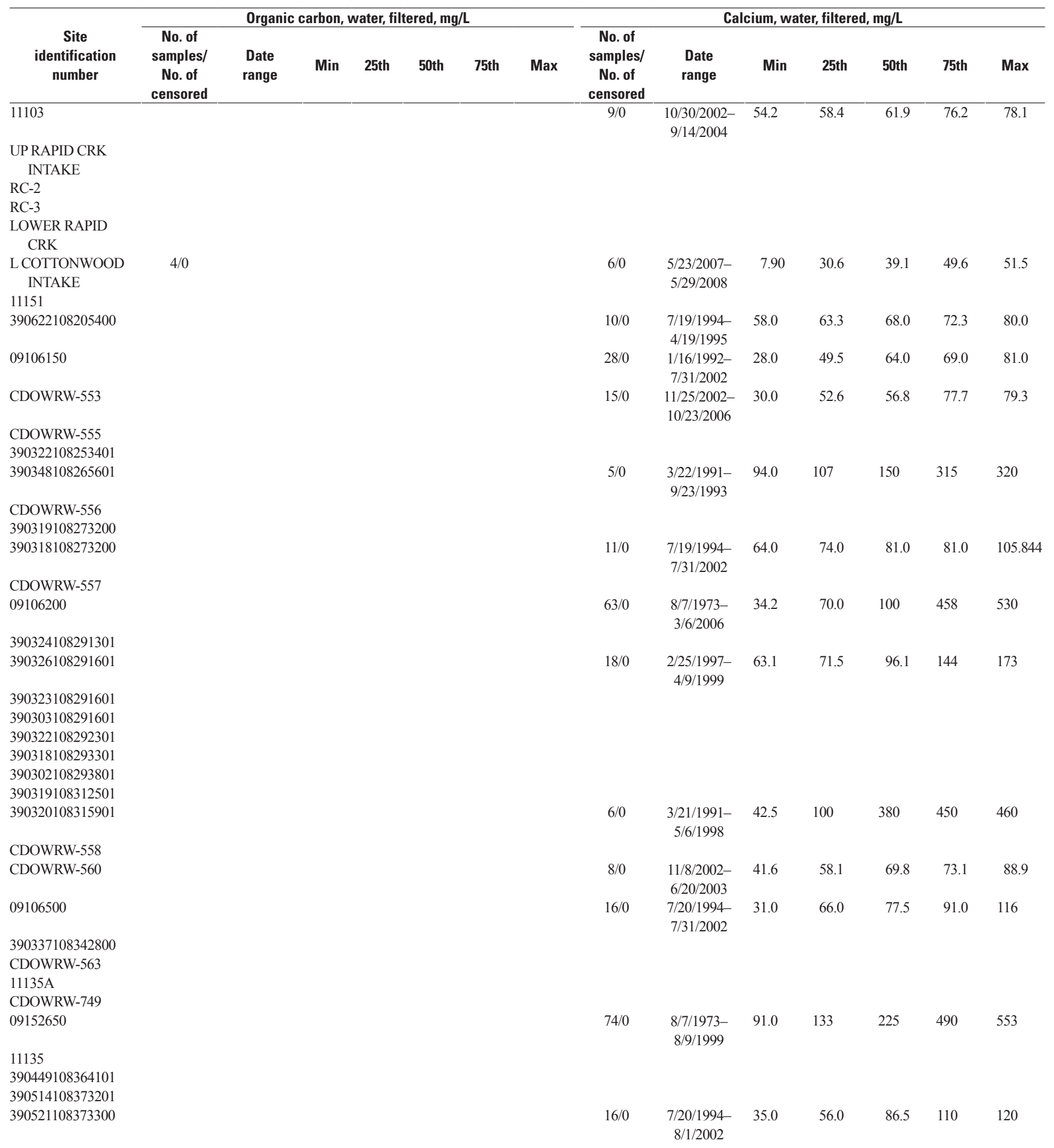


Appendix 1. Summary of surface-water-quality data and comparison to water-quality standards by site, by constituent, Piceance study area, western Colorado. Water-quality standards comparisons follow data summaries and are in blue text; standards are provided in table 3.-Continued

[CDPHE segment, Colorado Department of Health and the Environment stream segment as referred to in tables 2 and 3; latitude and longitude are in North American Datum of 1983; downstream order number assigned as part of analysis. $\mu \mathrm{g} / \mathrm{L}$, micrograms per liter; $\mu \mathrm{S} / \mathrm{cm}$, microsiemens per centimeter; mg/L, milligrams per liter; mL, milliliters; aq, aquatic; CO, Colorado; EPA, U.S. Environmental Protection Agency; Max, maximum; Min, minimum; NA, not applicable; No., number; NTU, nephelometric turbitidy units; WS, water supply; dates given in month/day/year format]

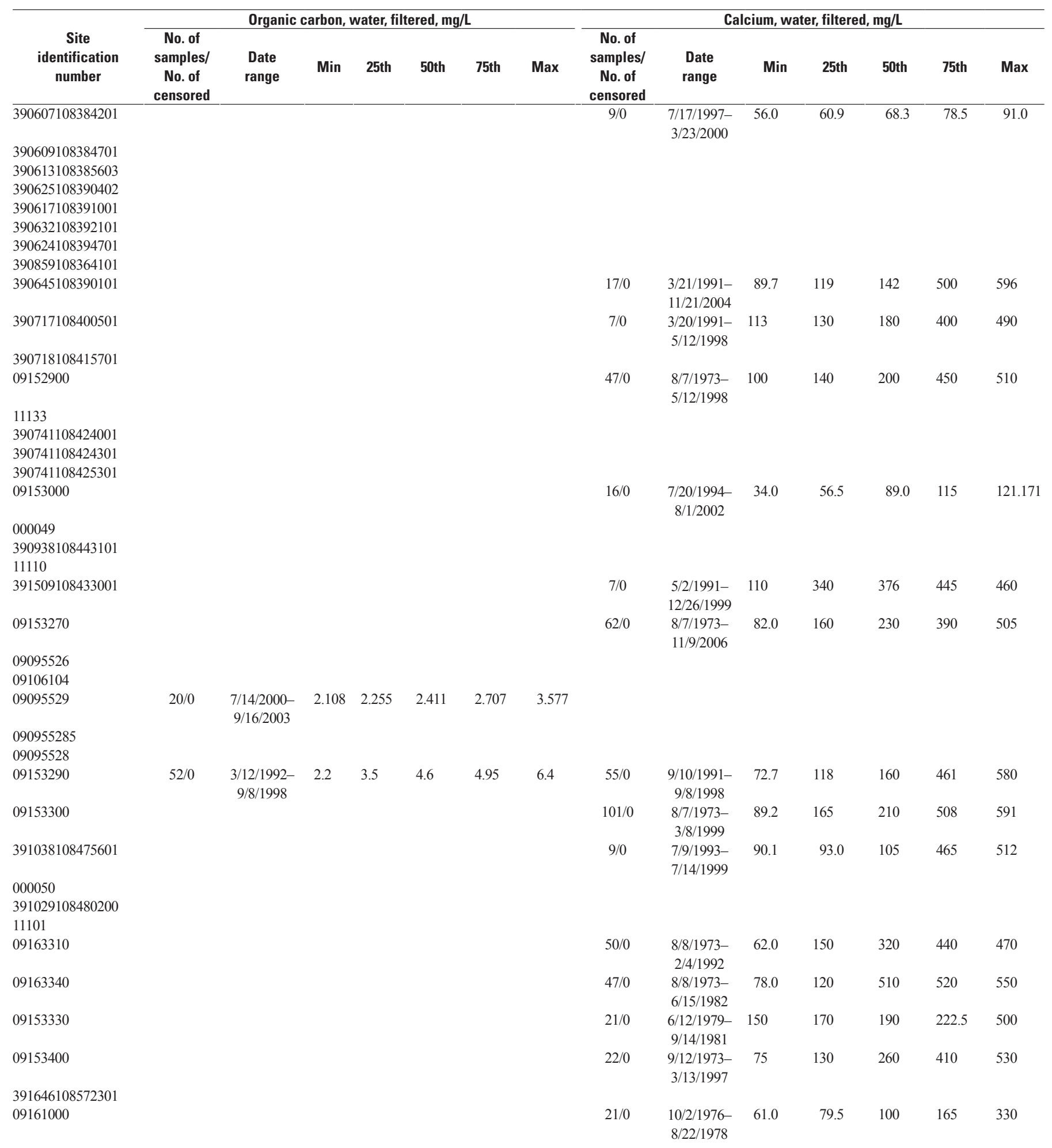


Appendix 1. Summary of surface-water-quality data and comparison to water-quality standards by site, by constituent, Piceance study area, western Colorado. Water-quality standards comparisons follow data summaries and are in blue text; standards are provided in table 3.-Continued

[CDPHE segment, Colorado Department of Health and the Environment stream segment as referred to in tables 2 and 3; latitude and longitude are in North American Datum of 1983; downstream order number assigned as part of analysis. $\mu \mathrm{g} / \mathrm{L}$, micrograms per liter; $\mu \mathrm{S} / \mathrm{cm}$, microsiemens per centimeter; $\mathrm{mg} / \mathrm{L}$, milligrams per liter; mL, milliliters; aq, aquatic; CO, Colorado; EPA, U.S. Environmental Protection Agency; Max, maximum; Min, minimum; NA, not applicable; No., number; NTU, nephelometric turbitidy units; WS, water supply; dates given in month/day/year format]

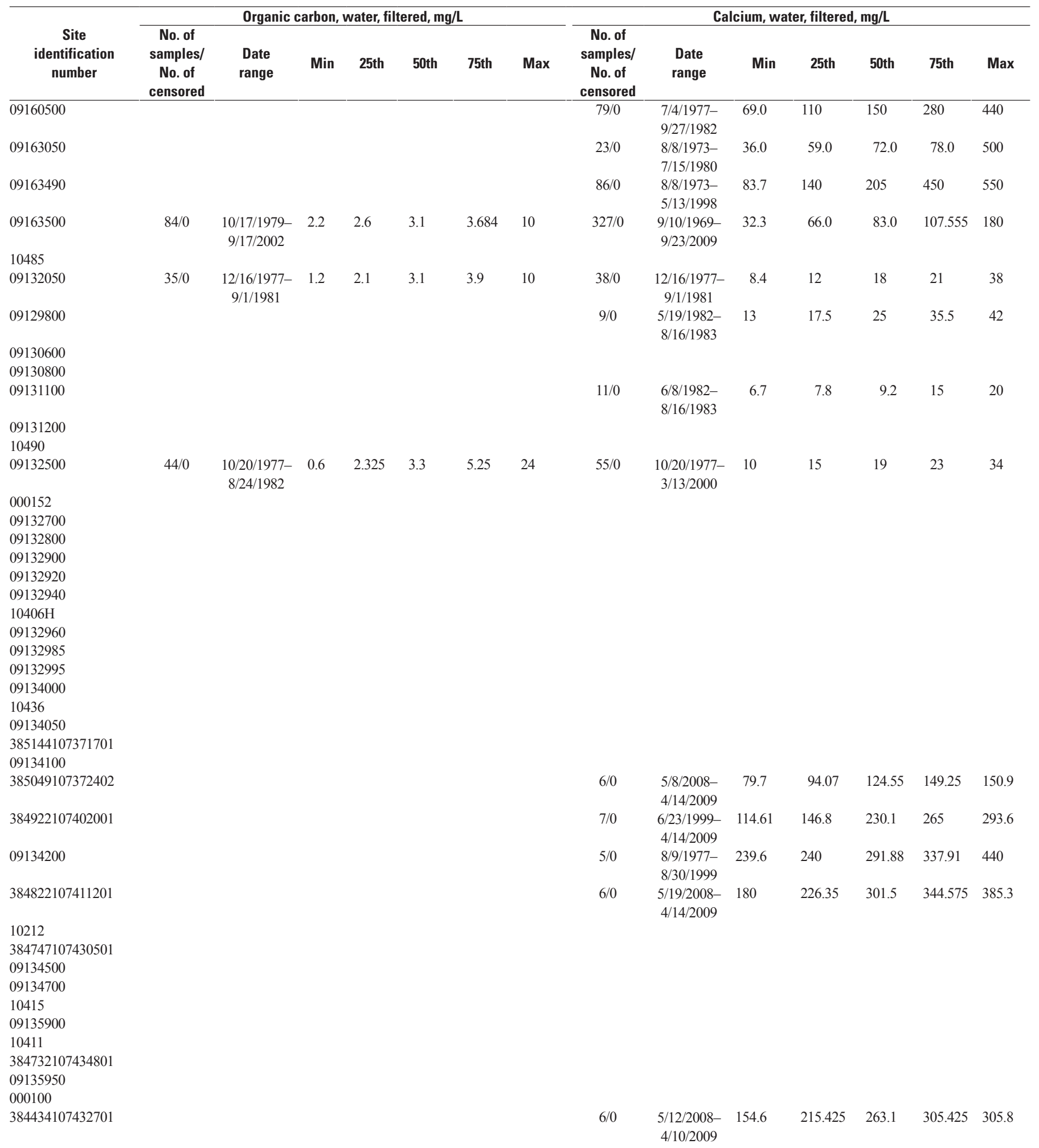


Appendix 1. Summary of surface-water-quality data and comparison to water-quality standards by site, by constituent, Piceance study area, western Colorado. Water-quality standards comparisons follow data summaries and are in blue text; standards are provided in table 3.-Continued

[CDPHE segment, Colorado Department of Health and the Environment stream segment as referred to in tables 2 and 3; latitude and longitude are in North American Datum of 1983; downstream order number assigned as part of analysis. $\mu \mathrm{g} / \mathrm{L}$, micrograms per liter; $\mu \mathrm{S} / \mathrm{cm}$, microsiemens per centimeter; mg/L, milligrams per liter; mL, milliliters; aq, aquatic; CO, Colorado; EPA, U.S. Environmental Protection Agency; Max, maximum; Min, minimum; NA, not applicable; No., number; NTU, nephelometric turbitidy units; WS, water supply; dates given in month/day/year format]

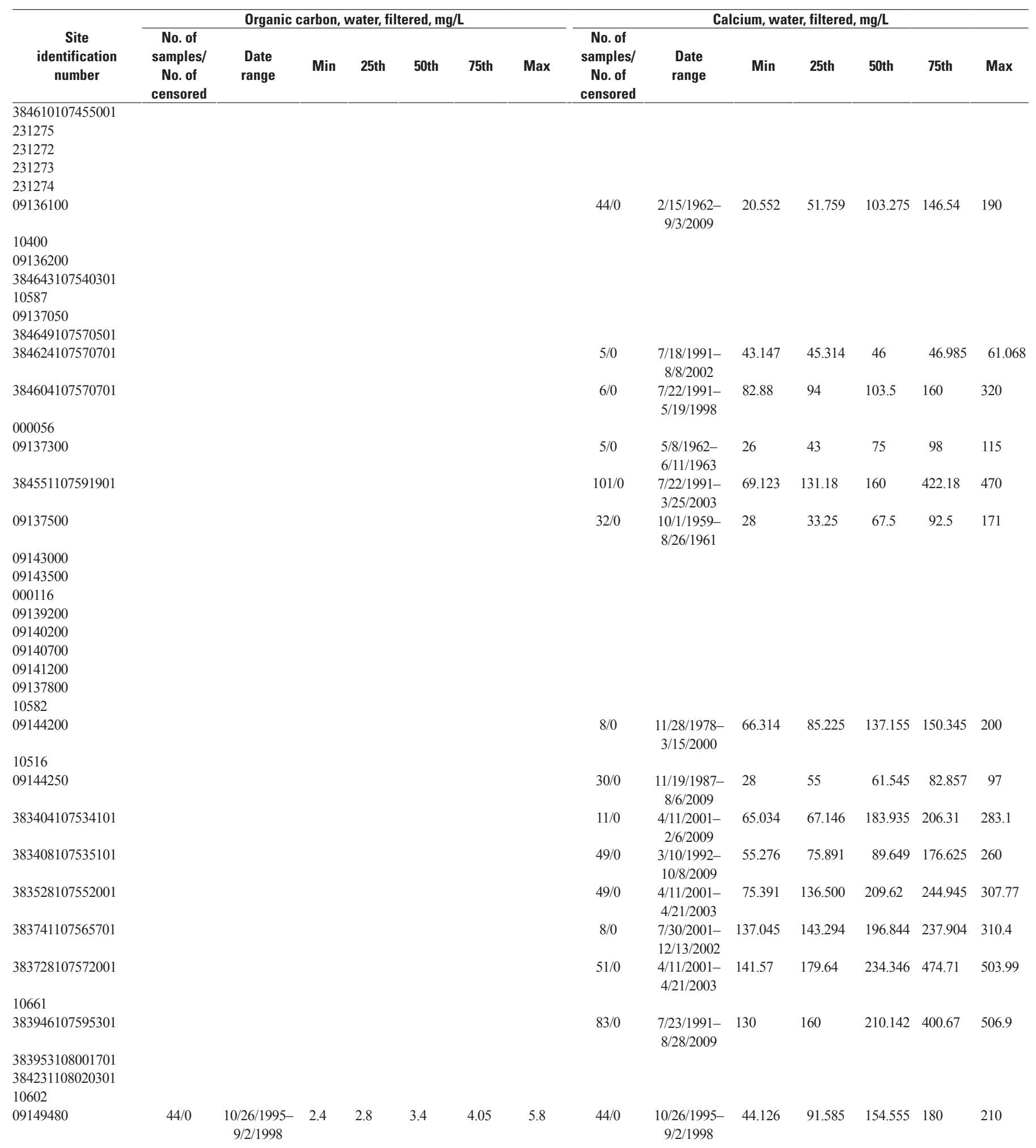


Appendix 1. Summary of surface-water-quality data and comparison to water-quality standards by site, by constituent, Piceance study area, western Colorado. Water-quality standards comparisons follow data summaries and are in blue text; standards are provided in table 3.-Continued

[CDPHE segment, Colorado Department of Health and the Environment stream segment as referred to in tables 2 and 3; latitude and longitude are in North American Datum of 1983; downstream order number assigned as part of analysis. $\mu \mathrm{g} / \mathrm{L}$, micrograms per liter; $\mu \mathrm{S} / \mathrm{cm}$, microsiemens per centimeter; $\mathrm{mg} / \mathrm{L}$, milligrams per liter; mL, milliliters; aq, aquatic; CO, Colorado; EPA, U.S. Environmental Protection Agency; Max, maximum; Min, minimum; NA, not applicable; No., number; NTU, nephelometric turbitidy units; WS, water supply; dates given in month/day/year format]

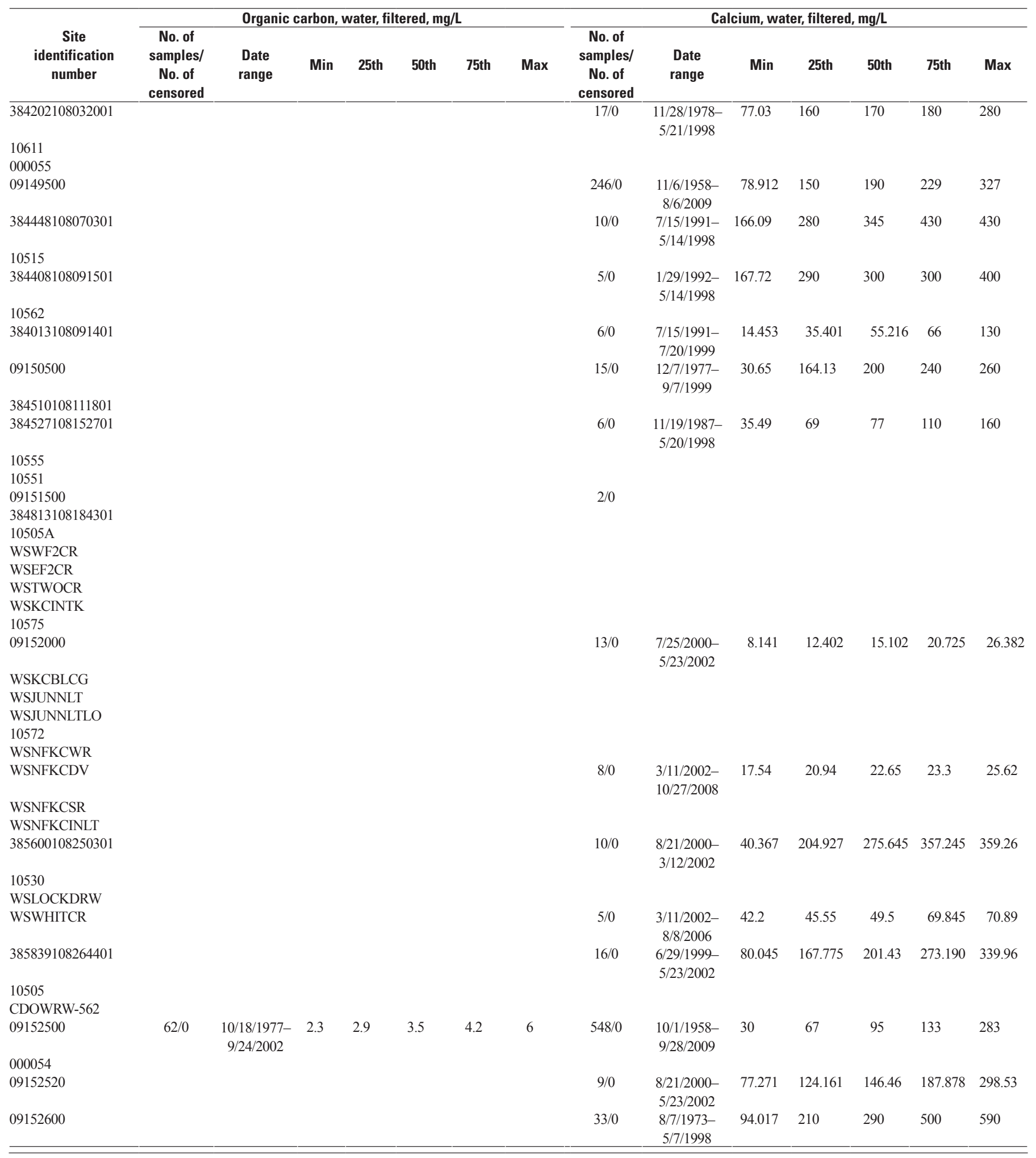


Appendix 1. Summary of surface-water-quality data and comparison to water-quality standards by site, by constituent, Piceance study area, western Colorado. Water-quality standards comparisons follow data summaries and are in blue text; standards are provided in table 3.-Continued

[CDPHE segment, Colorado Department of Health and the Environment stream segment as referred to in tables 2 and 3; latitude and longitude are in North American Datum of 1983; downstream order number assigned as part of analysis. $\mu \mathrm{g} / \mathrm{L}$, micrograms per liter; $\mu \mathrm{S} / \mathrm{cm}$, microsiemens per centimeter; $\mathrm{mg} / \mathrm{L}$, milligrams per liter; mL, milliliters; aq, aquatic; CO, Colorado; EPA, U.S. Environmental Protection Agency; Max, maximum; Min, minimum; NA, not applicable; No., number; NTU, nephelometric turbitidy units; WS, water supply; dates given in month/day/year format]

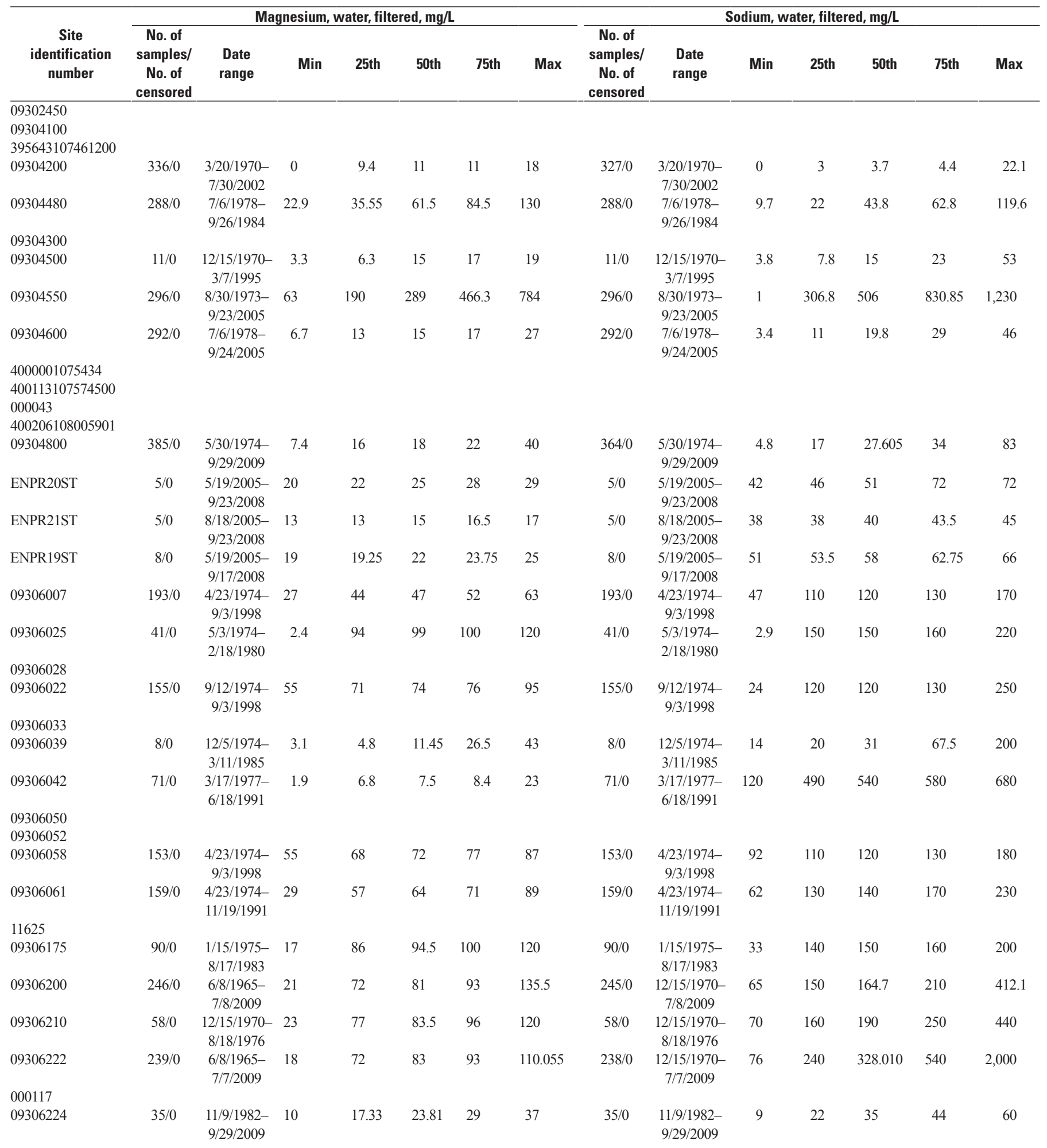


Appendix 1. Summary of surface-water-quality data and comparison to water-quality standards by site, by constituent, Piceance study area, western Colorado. Water-quality standards comparisons follow data summaries and are in blue text; standards are provided in table 3.-Continued

[CDPHE segment, Colorado Department of Health and the Environment stream segment as referred to in tables 2 and 3; latitude and longitude are in North American Datum of 1983; downstream order number assigned as part of analysis. $\mu \mathrm{g} / \mathrm{L}$, micrograms per liter; $\mu \mathrm{S} / \mathrm{cm}$, microsiemens per centimeter; $\mathrm{mg} / \mathrm{L}$, milligrams per liter; mL, milliliters; aq, aquatic; CO, Colorado; EPA, U.S. Environmental Protection Agency; Max, maximum; Min, minimum; NA, not applicable; No., number; NTU, nephelometric turbitidy units; WS, water supply; dates given in month/day/year format]

\begin{tabular}{|c|c|c|c|c|c|c|c|c|c|c|c|c|c|c|}
\hline \multirow[b]{2}{*}{$\begin{array}{c}\text { Site } \\
\text { identification } \\
\text { number }\end{array}$} & \multicolumn{7}{|c|}{ Magnesium, water, filtered, mg/L } & \multicolumn{7}{|c|}{ Sodium, water, filtered, mg/L } \\
\hline & $\begin{array}{c}\text { No. of } \\
\text { samples/ } \\
\text { No. of } \\
\text { censored }\end{array}$ & $\begin{array}{l}\text { Date } \\
\text { range }\end{array}$ & Min & 25th & 50th & 75th & Max & $\begin{array}{c}\text { No. of } \\
\text { samples/ } \\
\text { No. of } \\
\text { censored }\end{array}$ & $\begin{array}{l}\text { Date } \\
\text { range }\end{array}$ & Min & 25th & 50th & 75th & Max \\
\hline 09306240 & $29 / 0$ & $\begin{array}{c}4 / 27 / 1974 \\
3 / 11 / 1985\end{array}$ & 3.8 & 42 & 47 & 49 & 66 & $29 / 0$ & $\begin{array}{c}4 / 27 / 1974 \\
3 / 11 / 1985\end{array}$ & 2.7 & 49 & 54 & 59 & 93 \\
\hline \multicolumn{15}{|l|}{09306241} \\
\hline 09306235 & $88 / 0$ & $\begin{array}{c}3 / 14 / 1974 \\
11 / 8 / 1988\end{array}$ & 15 & 57 & 60 & 62 & 94 & $88 / 0$ & $\begin{array}{c}3 / 14 / 1974 \\
11 / 8 / 1988\end{array}$ & 22 & 83 & 86 & 89 & 150 \\
\hline 09306242 & $195 / 0$ & $\begin{array}{c}3 / 14 / 1974 \\
7 / 8 / 2009\end{array}$ & 14 & 64 & 70 & 78 & 88.28 & $195 / 0$ & $\begin{array}{c}3 / 14 / 1974 \\
7 / 8 / 2009\end{array}$ & 30 & 110 & 120 & 160 & 300 \\
\hline 09306244 & $24 / 0$ & $\begin{array}{l}6 / 12 / 1975- \\
10 / 24 / 1978\end{array}$ & 90 & 100 & 110 & 110 & 120 & $24 / 0$ & $\begin{array}{l}6 / 12 / 1975- \\
10 / 24 / 1978\end{array}$ & 170 & 180 & 185 & 190 & 200 \\
\hline \multicolumn{15}{|l|}{11702} \\
\hline 09306255 & $169 / 0$ & $\begin{array}{c}4 / 8 / 1965- \\
7 / 7 / 2009\end{array}$ & 11 & 110 & 130 & 163.659 & 210 & $167 / 0$ & $\begin{array}{c}8 / 1 / 1973- \\
7 / 7 / 2009\end{array}$ & 72.75 & 567.55 & 700 & 800 & 1,200 \\
\hline 09306290 & $101 / 0$ & $\begin{array}{c}\text { 11/9/1982- } \\
9 / 30 / 2009\end{array}$ & 10.621 & 20.51 & 27.897 & 32 & 41 & $92 / 0$ & $\begin{array}{c}\text { 11/9/1982- } \\
9 / 30 / 2009\end{array}$ & 12 & 32.855 & 46 & 57 & 82 \\
\hline 09306300 & $76 / 0$ & $\begin{array}{l}8 / 6 / 1975- \\
9 / 22 / 1982\end{array}$ & 9.7 & 21 & 24 & 27 & 48 & $75 / 0$ & $\begin{array}{l}8 / 6 / 1975- \\
9 / 22 / 1982\end{array}$ & 12 & 47 & 60 & 69 & 140 \\
\hline 09306305 & $17 / 0$ & $\begin{array}{c}4 / 21 / 1995- \\
7 / 31 / 2002\end{array}$ & 10.999 & 12 & 21 & 27.997 & 36.900 & $7 / 0$ & $\begin{array}{c}4 / 21 / 1995- \\
7 / 31 / 2002\end{array}$ & 13 & 16 & 40 & 53 & 74.163 \\
\hline 09306380 & $12 / 0$ & $\begin{array}{l}2 / 8 / 1977- \\
11 / 8 / 1995\end{array}$ & 26 & 45.5 & 76 & 130 & 220 & $12 / 0$ & $\begin{array}{l}2 / 8 / 1977- \\
11 / 8 / 1995\end{array}$ & 72 & 104.5 & 170 & 290 & 580 \\
\hline \multicolumn{15}{|l|}{$\begin{array}{l}400535108485700 \\
000044\end{array}$} \\
\hline 09072500 & $52 / 0$ & $\begin{array}{c}11 / 29 / 1958- \\
3 / 24 / 1966\end{array}$ & 4.6 & 8.05 & 11 & 13.5 & 23 & $36 / 0$ & $\begin{array}{c}11 / 29 / 1958- \\
3 / 24 / 1966\end{array}$ & 16 & 41 & 95 & 121.5 & 198 \\
\hline CDOWRW-46 & $54 / 0$ & $\begin{array}{c}9 / 13 / 1999 \\
5 / 7 / 2007\end{array}$ & 2.114 & 8.828 & 11.768 & 13.349 & 14.954 & $5 / 0$ & $\begin{array}{c}11 / 15 / 2006- \\
4 / 17 / 2007\end{array}$ & 106.7 & 116.25 & 130.3 & 169.5 & 196.9 \\
\hline \multicolumn{15}{|l|}{12100} \\
\hline CDOWRW-47 & $51 / 0$ & $\begin{array}{c}9 / 13 / 1999- \\
5 / 7 / 2007\end{array}$ & 5.899 & 8.992 & 11.861 & 13.59 & 15.484 & & & & & & & \\
\hline 09085100 & $251 / 0$ & $\begin{array}{c}12 / 6 / 1977- \\
6 / 19 / 1995\end{array}$ & 4.3 & 9.7 & 12 & 13 & 19 & $251 / 0$ & $\begin{array}{l}12 / 6 / 1977- \\
6 / 19 / 1995\end{array}$ & 5 & 53.7 & 104 & 129.9 & 200.1 \\
\hline \multicolumn{15}{|l|}{$11109 \mathrm{~A}$} \\
\hline 09085150 & $21 / 0$ & $\begin{array}{c}4 / 13 / 2006- \\
9 / 8 / 2009\end{array}$ & 5.711 & 7.336 & 10.78 & 12.995 & 14.21 & $21 / 0$ & $\begin{array}{c}4 / 13 / 2006- \\
9 / 8 / 2009\end{array}$ & 13.25 & 41.675 & 91.88 & 133.4 & 156.8 \\
\hline \multicolumn{15}{|l|}{09085200} \\
\hline \multicolumn{15}{|l|}{09085400} \\
\hline \multicolumn{15}{|l|}{09085300} \\
\hline CDOWRW-546 & $16 / 0$ & $\begin{array}{c}10 / 23 / 2002- \\
5 / 7 / 2004\end{array}$ & 6.952 & 10.578 & 13.229 & 14.654 & 16.255 & & & & & & & \\
\hline \multicolumn{15}{|l|}{09086470} \\
\hline \multicolumn{15}{|l|}{$11190 \mathrm{H}$} \\
\hline \multicolumn{15}{|l|}{09086000} \\
\hline \multicolumn{15}{|l|}{09086970} \\
\hline CDOWRW-547 & $12 / 0$ & $\begin{array}{c}10 / 23 / 2002- \\
5 / 7 / 2004\end{array}$ & 10.664 & 14.607 & 21.603 & 32.797 & 36.279 & & & & & & & \\
\hline 09087600 & $18 / 0$ & $\begin{array}{c}\text { 7/31/2002- } \\
11 / 7 / 2008\end{array}$ & 5.024 & 7.844 & 10.92 & 13.07 & 19.23 & $18 / 0$ & $\begin{array}{c}\text { 7/31/2002- } \\
11 / 7 / 2008\end{array}$ & 16.07 & 40.63 & 92.46 & 124.1 & 160.152 \\
\hline $\begin{array}{l}11189 \\
09089000 \\
11185\end{array}$ & & & & & & & & & & & & & & \\
\hline 09089500 & $20 / 0$ & $\begin{array}{l}5 / 1 / 1986- \\
8 / 23 / 1990\end{array}$ & 3.8 & 4.4 & 5.85 & 8.175 & 16 & $20 / 0$ & $\begin{array}{l}5 / 1 / 1986- \\
8 / 23 / 1990\end{array}$ & 5.8 & 7.325 & 10.25 & 16.5 & 30 \\
\hline LANG6ST & $24 / 0$ & $\begin{array}{c}6 / 2 / 2004 \\
5 / 9 / 2006\end{array}$ & 6.72 & 17.25 & 29.5 & 34.75 & 40 & $32 / 0$ & $\begin{array}{l}6 / 2 / 2004 \\
9 / 29 / 2008\end{array}$ & 14 & 46.5 & 79 & 89 & 110 \\
\hline
\end{tabular}


Appendix 1. Summary of surface-water-quality data and comparison to water-quality standards by site, by constituent, Piceance study area, western Colorado. Water-quality standards comparisons follow data summaries and are in blue text; standards are provided in table 3.-Continued

[CDPHE segment, Colorado Department of Health and the Environment stream segment as referred to in tables 2 and 3; latitude and longitude are in North American Datum of 1983; downstream order number assigned as part of analysis. $\mu \mathrm{g} / \mathrm{L}$, micrograms per liter; $\mu \mathrm{S} / \mathrm{cm}$, microsiemens per centimeter; mg/L, milligrams per liter; mL, milliliters; aq, aquatic; CO, Colorado; EPA, U.S. Environmental Protection Agency; Max, maximum; Min, minimum; NA, not applicable; No., number; NTU, nephelometric turbitidy units; WS, water supply; dates given in month/day/year format]

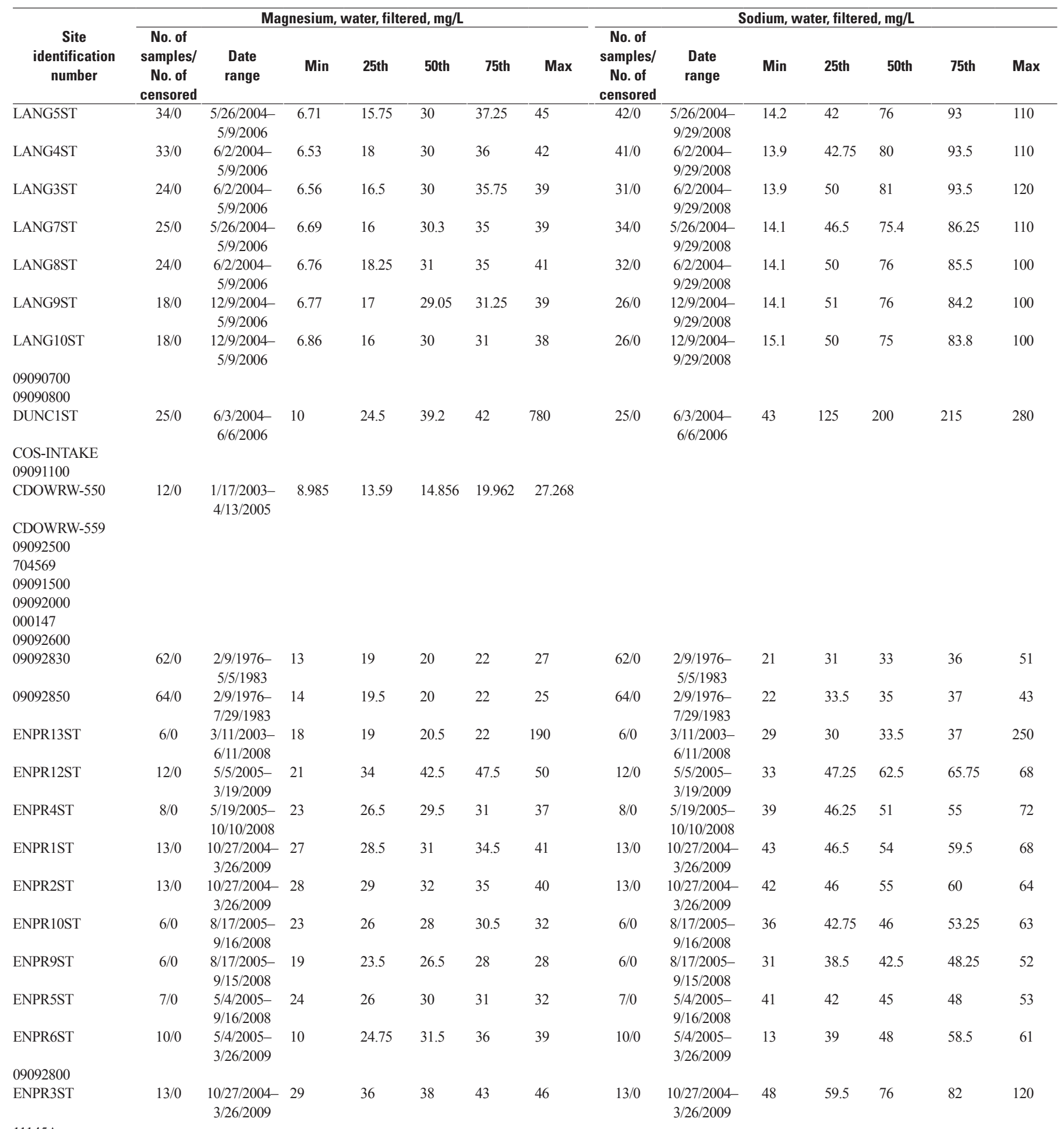


Appendix 1. Summary of surface-water-quality data and comparison to water-quality standards by site, by constituent, Piceance study area, western Colorado. Water-quality standards comparisons follow data summaries and are in blue text; standards are provided in table 3.-Continued

[CDPHE segment, Colorado Department of Health and the Environment stream segment as referred to in tables 2 and 3; latitude and longitude are in North American Datum of 1983; downstream order number assigned as part of analysis. $\mu \mathrm{g} / \mathrm{L}$, micrograms per liter; $\mu \mathrm{S} / \mathrm{cm}$, microsiemens per centimeter; $\mathrm{mg} / \mathrm{L}$, milligrams per liter; mL, milliliters; aq, aquatic; CO, Colorado; EPA, U.S. Environmental Protection Agency; Max, maximum; Min, minimum; NA, not applicable; No., number; NTU, nephelometric turbitidy units; WS, water supply; dates given in month/day/year format]

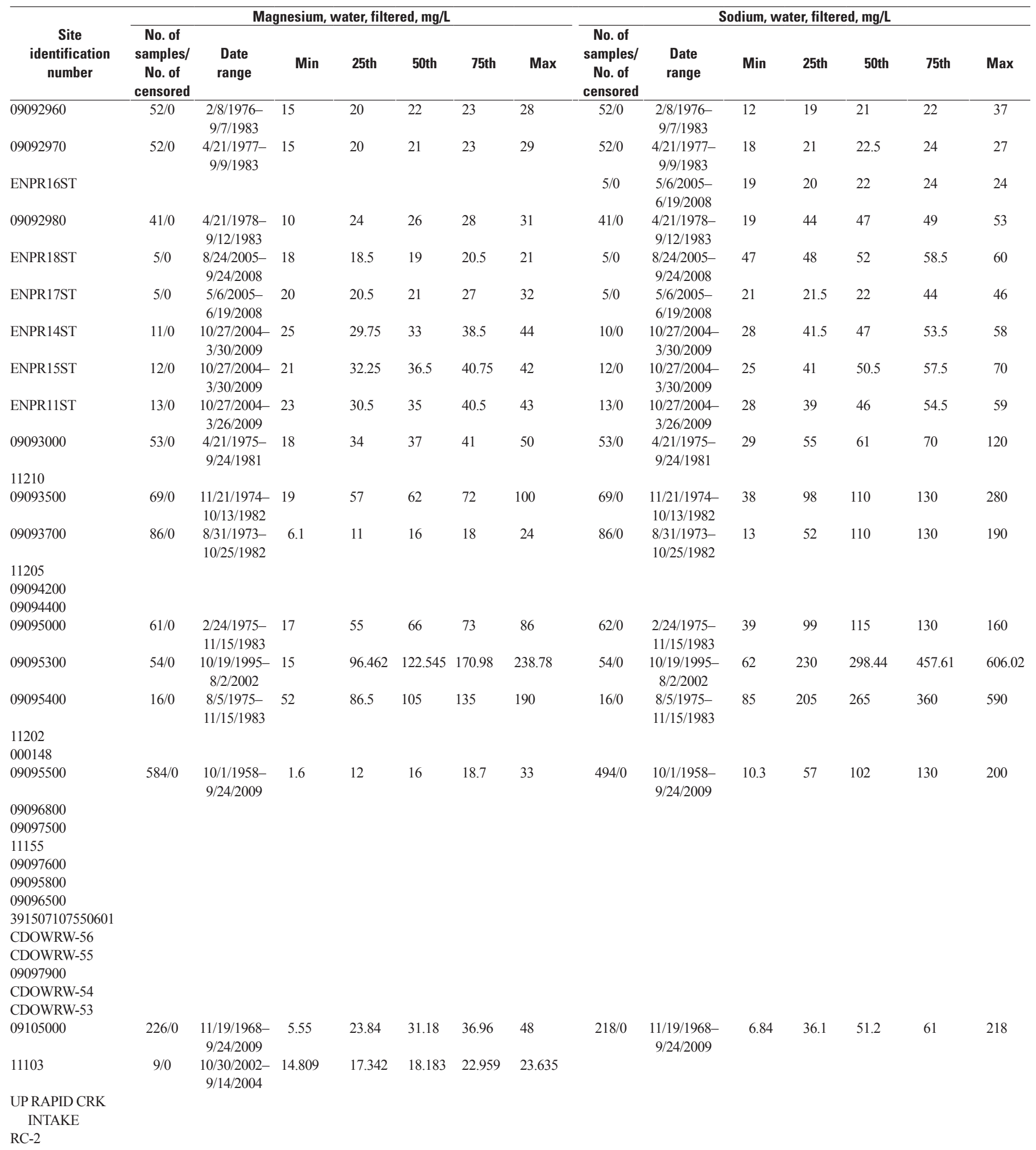


Appendix 1. Summary of surface-water-quality data and comparison to water-quality standards by site, by constituent, Piceance study area, western Colorado. Water-quality standards comparisons follow data summaries and are in blue text; standards are provided in table 3.-Continued

[CDPHE segment, Colorado Department of Health and the Environment stream segment as referred to in tables 2 and 3; latitude and longitude are in North American Datum of 1983; downstream order number assigned as part of analysis. $\mu \mathrm{g} / \mathrm{L}$, micrograms per liter; $\mu \mathrm{S} / \mathrm{cm}$, microsiemens per centimeter; $\mathrm{mg} / \mathrm{L}$, milligrams per liter; mL, milliliters; aq, aquatic; CO, Colorado; EPA, U.S. Environmental Protection Agency; Max, maximum; Min, minimum; NA, not applicable; No., number; NTU, nephelometric turbitidy units; WS, water supply; dates given in month/day/year format]

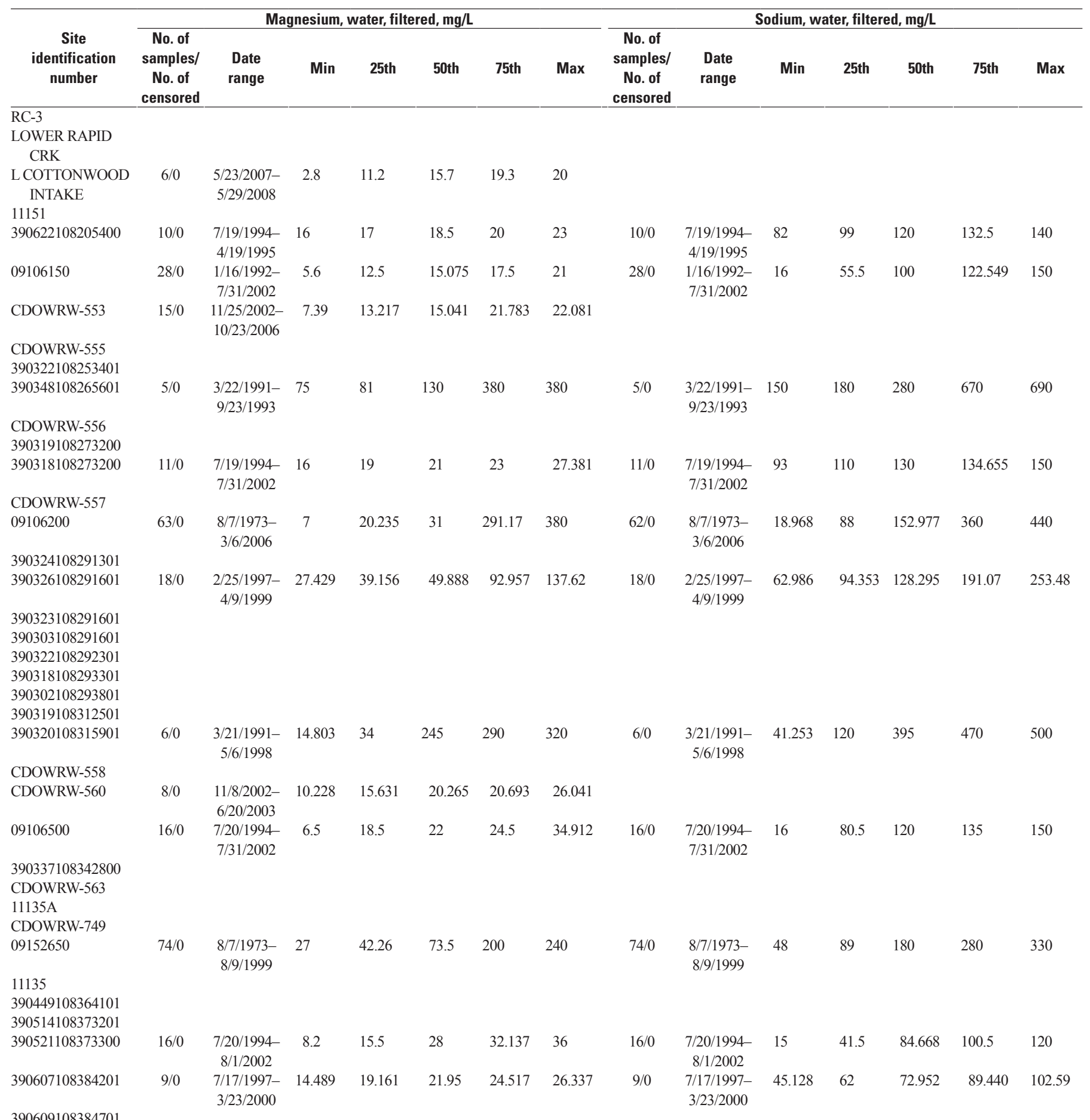
390613108385603 390625108390402 390617108391001 
Appendix 1. Summary of surface-water-quality data and comparison to water-quality standards by site, by constituent, Piceance study area, western Colorado. Water-quality standards comparisons follow data summaries and are in blue text; standards are provided in table 3.-Continued

[CDPHE segment, Colorado Department of Health and the Environment stream segment as referred to in tables 2 and 3; latitude and longitude are in North American Datum of 1983; downstream order number assigned as part of analysis. $\mu \mathrm{g} / \mathrm{L}$, micrograms per liter; $\mu \mathrm{S} / \mathrm{cm}$, microsiemens per centimeter; $\mathrm{mg} / \mathrm{L}$, milligrams per liter; mL, milliliters; aq, aquatic; CO, Colorado; EPA, U.S. Environmental Protection Agency; Max, maximum; Min, minimum; NA, not applicable; No., number; NTU, nephelometric turbitidy units; WS, water supply; dates given in month/day/year format]

\begin{tabular}{|c|c|c|c|c|c|c|c|c|c|c|c|c|c|c|}
\hline \multirow[b]{2}{*}{$\begin{array}{c}\text { Site } \\
\text { identification } \\
\text { number }\end{array}$} & \multicolumn{7}{|c|}{ Magnesium, water, filtered, mg/L } & \multicolumn{7}{|c|}{ Sodium, water, filtered, mg/L } \\
\hline & $\begin{array}{c}\text { No. of } \\
\text { samples/ } \\
\text { No. of } \\
\text { censored }\end{array}$ & $\begin{array}{l}\text { Date } \\
\text { range }\end{array}$ & Min & 25th & 50th & 75th & Max & $\begin{array}{c}\text { No. of } \\
\text { samples/ } \\
\text { No. of } \\
\text { censored }\end{array}$ & $\begin{array}{l}\text { Date } \\
\text { range }\end{array}$ & Min & 25th & 50th & 75th & Max \\
\hline \multicolumn{15}{|l|}{390632108392101} \\
\hline 390624108394701 & & & & & & & & & & & & & & \\
\hline \multicolumn{15}{|l|}{390859108364101} \\
\hline 390645108390101 & $17 / 0$ & $\begin{array}{l}3 / 21 / 1991- \\
11 / 21 / 2004\end{array}$ & 27.518 & 39 & 50.251 & 231.08 & 250 & $17 / 0$ & $\begin{array}{l}3 / 21 / 1991- \\
11 / 21 / 2004\end{array}$ & 68 & 94.638 & 142.93 & 385.84 & 420 \\
\hline 390717108400501 & $7 / 0$ & $\begin{array}{c}3 / 20 / 1991- \\
5 / 12 / 1998\end{array}$ & 35.703 & 38 & 50 & 210 & 230 & $7 / 0$ & $\begin{array}{c}3 / 20 / 1991- \\
5 / 12 / 1998\end{array}$ & 61.126 & 67 & 130 & 300 & 330 \\
\hline \multicolumn{15}{|l|}{390718108415701} \\
\hline 09152900 & $47 / 0$ & $\begin{array}{l}8 / 7 / 1973- \\
5 / 12 / 1998\end{array}$ & 29 & 44 & 57 & 200 & 280 & $46 / 0$ & $\begin{array}{l}8 / 7 / 1973- \\
5 / 12 / 1998\end{array}$ & 72 & 130 & 260 & 420 & 500 \\
\hline \multicolumn{15}{|l|}{11133} \\
\hline \multicolumn{15}{|l|}{390741108424001} \\
\hline \multicolumn{15}{|l|}{390741108424301} \\
\hline \multicolumn{15}{|l|}{390741108425301} \\
\hline 09153000 & $16 / 0$ & $\begin{array}{c}7 / 20 / 1994 \\
8 / 1 / 2002\end{array}$ & 8 & 16.5 & 29.5 & 33.927 & 38 & $16 / 0$ & $\begin{array}{c}7 / 20 / 1994 \\
8 / 1 / 2002\end{array}$ & 15 & 43.5 & 87 & 100 & 110 \\
\hline \multicolumn{15}{|l|}{000049} \\
\hline \multicolumn{15}{|l|}{390938108443101} \\
\hline \multicolumn{15}{|l|}{11110} \\
\hline 391509108433001 & $7 / 0$ & $\begin{array}{c}\text { 5/2/1991- } \\
12 / 26 / 1999\end{array}$ & 120 & $1,020.6$ & 1,300 & 1,400 & 1,600 & $7 / 0$ & $\begin{array}{c}5 / 2 / 1991- \\
12 / 26 / 1999\end{array}$ & 590 & 4,000.6 & 4,900 & $5,308.5$ & 6,100 \\
\hline 09153270 & $62 / 0$ & $\begin{array}{l}8 / 7 / 1973- \\
11 / 9 / 2006\end{array}$ & 26 & 55 & 86 & 160 & 252 & $62 / 0$ & $\begin{array}{l}8 / 7 / 1973- \\
11 / 9 / 2006\end{array}$ & 59.4 & 126.1 & 190 & 250 & 290 \\
\hline \multicolumn{15}{|l|}{09095526} \\
\hline \multicolumn{15}{|l|}{09106104} \\
\hline \multicolumn{15}{|l|}{09095529} \\
\hline \multicolumn{15}{|l|}{090955285} \\
\hline \multicolumn{15}{|l|}{09095528} \\
\hline 09153290 & $55 / 0$ & $\begin{array}{c}\text { 9/10/1991- } \\
\text { 9/8/1998 }\end{array}$ & 22 & 39.688 & 53 & 210 & 250 & $55 / 0$ & $\begin{array}{c}9 / 10 / 1991- \\
9 / 8 / 1998\end{array}$ & 54.028 & 73.359 & 103.89 & 290 & 370 \\
\hline 09153300 & $101 / 0$ & $\begin{array}{c}8 / 7 / 1973- \\
3 / 8 / 1999\end{array}$ & 31 & 55 & 74 & 240 & 290 & $101 / 0$ & $\begin{array}{c}\text { 8/7/1973- } \\
3 / 8 / 1999\end{array}$ & 55.191 & 110 & 180 & 340 & 450 \\
\hline 391038108475601 & $9 / 0$ & $\begin{array}{l}7 / 9 / 1993- \\
7 / 14 / 1999\end{array}$ & 27 & 28.689 & 37 & 225.36 & 239.55 & $9 / 0$ & $\begin{array}{l}7 / 9 / 1993- \\
7 / 14 / 1999\end{array}$ & 68 & 79.742 & 137.01 & 462.22 & 505.16 \\
\hline \multicolumn{15}{|l|}{000050} \\
\hline \multicolumn{15}{|l|}{391029108480200} \\
\hline 09163310 & $50 / 0$ & $\begin{array}{c}8 / 8 / 1973- \\
2 / 4 / 1992\end{array}$ & 8.6 & 130 & 220 & 300 & 430 & $50 / 0$ & $\begin{array}{c}8 / 8 / 1973- \\
2 / 4 / 1992\end{array}$ & 94 & 360 & 635 & 850 & 1,600 \\
\hline 09163340 & $47 / 0$ & $\begin{array}{l}\text { 8/8/1973- } \\
6 / 15 / 1982\end{array}$ & 23 & 35 & 130 & 150 & 160 & $47 / 0$ & $\begin{array}{l}8 / 8 / 1973- \\
6 / 15 / 1982\end{array}$ & 53 & 120 & 220 & 230 & 300 \\
\hline 09153330 & $21 / 0$ & $\begin{array}{c}6 / 12 / 1979 \\
9 / 14 / 1981\end{array}$ & 43 & 52 & 98 & 140 & 240 & $21 / 0$ & $\begin{array}{c}6 / 12 / 1979 \\
9 / 14 / 1981\end{array}$ & 82 & 103 & 140 & 285 & 630 \\
\hline 09153400 & $22 / 0$ & $\begin{array}{c}\text { 9/12/1973- } \\
3 / 13 / 1997\end{array}$ & 15 & 57 & 85 & 370 & 970 & $22 / 0$ & $\begin{array}{c}\text { 9/12/1973- } \\
3 / 13 / 1997\end{array}$ & 27 & 120 & 295 & 530 & 2,000 \\
\hline \multicolumn{15}{|l|}{391646108572301} \\
\hline 09161000 & $21 / 0$ & $\begin{array}{c}10 / 2 / 1976- \\
8 / 22 / 1978\end{array}$ & 3.7 & 4.75 & 6.6 & 12.9 & 35 & $21 / 0$ & $\begin{array}{c}10 / 2 / 1976- \\
8 / 22 / 1978\end{array}$ & 3.1 & 9.3 & 15 & 31.5 & 70 \\
\hline 09160500 & $79 / 0$ & $\begin{array}{l}7 / 4 / 1977- \\
9 / 27 / 1982\end{array}$ & 1.8 & 2.8 & 5.5 & 9 & 22 & $79 / 0$ & $\begin{array}{l}\text { 7/4/1977- } \\
\text { 9/27/1982 }\end{array}$ & 1.6 & 3.4 & 7.3 & 12 & 56 \\
\hline 09163050 & $23 / 0$ & $\begin{array}{l}8 / 8 / 1973- \\
7 / 15 / 1980\end{array}$ & 7.6 & 13 & 17 & 19 & 69 & $23 / 0$ & $\begin{array}{l}8 / 8 / 1973- \\
7 / 15 / 1980\end{array}$ & 23 & 51 & 85 & 130 & 170 \\
\hline 09163490 & $86 / 0$ & $\begin{array}{l}8 / 8 / 1973- \\
5 / 13 / 1998\end{array}$ & 28 & 48 & 77.5 & 250 & 300 & $86 / 0$ & $\begin{array}{l}8 / 8 / 1973- \\
5 / 13 / 1998\end{array}$ & 59 & 120 & 175 & 440 & 630 \\
\hline 09163500 & $327 / 0$ & $\begin{array}{c}\text { 9/10/1969- } \\
9 / 23 / 2009\end{array}$ & 7.9 & 20 & 28 & 33.32 & 57 & $327 / 0$ & $\begin{array}{c}\text { 9/10/1969- } \\
\text { 9/23/2009 }\end{array}$ & 14.412 & 53.478 & 86.003 & 102 & 170 \\
\hline
\end{tabular}

10485 
Appendix 1. Summary of surface-water-quality data and comparison to water-quality standards by site, by constituent, Piceance study area, western Colorado. Water-quality standards comparisons follow data summaries and are in blue text; standards are provided in table 3.-Continued

[CDPHE segment, Colorado Department of Health and the Environment stream segment as referred to in tables 2 and 3; latitude and longitude are in North American Datum of 1983; downstream order number assigned as part of analysis. $\mu \mathrm{g} / \mathrm{L}$, micrograms per liter; $\mu \mathrm{S} / \mathrm{cm}$, microsiemens per centimeter; $\mathrm{mg} / \mathrm{L}$, milligrams per liter; mL, milliliters; aq, aquatic; CO, Colorado; EPA, U.S. Environmental Protection Agency; Max, maximum; Min, minimum; NA, not applicable; No., number; NTU, nephelometric turbitidy units; WS, water supply; dates given in month/day/year format]

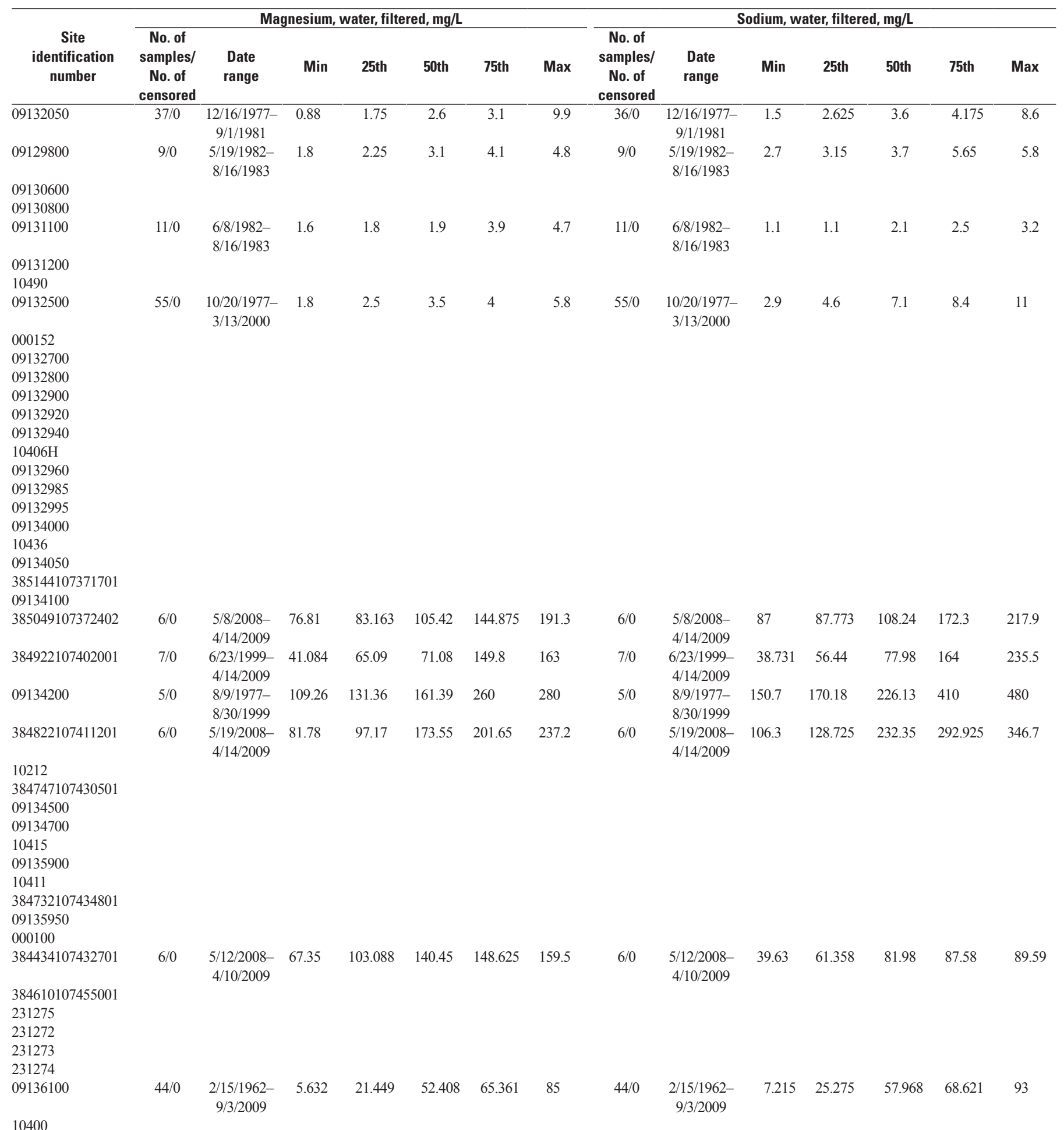


Appendix 1. Summary of surface-water-quality data and comparison to water-quality standards by site, by constituent, Piceance study area, western Colorado. Water-quality standards comparisons follow data summaries and are in blue text; standards are provided in table 3.-Continued

[CDPHE segment, Colorado Department of Health and the Environment stream segment as referred to in tables 2 and 3; latitude and longitude are in North American Datum of 1983; downstream order number assigned as part of analysis. $\mu \mathrm{g} / \mathrm{L}$, micrograms per liter; $\mu \mathrm{S} / \mathrm{cm}$, microsiemens per centimeter; $\mathrm{mg} / \mathrm{L}$, milligrams per liter; mL, milliliters; aq, aquatic; CO, Colorado; EPA, U.S. Environmental Protection Agency; Max, maximum; Min, minimum; NA, not applicable; No., number; NTU, nephelometric turbitidy units; WS, water supply; dates given in month/day/year format]

\begin{tabular}{|c|c|c|c|c|c|c|c|c|c|c|c|c|c|c|}
\hline \multirow[b]{2}{*}{$\begin{array}{c}\text { Site } \\
\text { identification } \\
\text { number }\end{array}$} & \multicolumn{7}{|c|}{ Magnesium, water, filtered, mg/L } & \multicolumn{7}{|c|}{ Sodium, water, filtered, mg/L } \\
\hline & $\begin{array}{c}\text { No. of } \\
\text { samples/ } \\
\text { No. of } \\
\text { censored }\end{array}$ & $\begin{array}{l}\text { Date } \\
\text { range }\end{array}$ & Min & 25th & 50th & 75th & Max & $\begin{array}{c}\text { No. of } \\
\text { samples/ } \\
\text { No. of } \\
\text { censored }\end{array}$ & $\begin{array}{l}\text { Date } \\
\text { range }\end{array}$ & Min & 25th & 50th & 75th & Max \\
\hline \multicolumn{15}{|l|}{09136200} \\
\hline \multicolumn{15}{|l|}{384643107540301} \\
\hline \multicolumn{15}{|l|}{10587} \\
\hline \multicolumn{15}{|l|}{09137050} \\
\hline \multicolumn{15}{|l|}{384649107570501} \\
\hline 384624107570701 & $5 / 0$ & $\begin{array}{c}\text { 7/18/1991- } \\
\text { 8/8/2002 }\end{array}$ & 14.673 & 15 & 15.793 & 16.884 & 19.622 & $5 / 0$ & $\begin{array}{c}\text { 7/18/1991- } \\
8 / 8 / 2002\end{array}$ & 17.428 & 18 & 19.168 & 20.01 & 21.601 \\
\hline 384604107570701 & $6 / 0$ & $\begin{array}{c}\text { 7/22/1991- } \\
5 / 19 / 1998\end{array}$ & 22 & 25.23 & 29.5 & 44 & 160 & $6 / 0$ & $\begin{array}{c}\text { 7/22/1991- } \\
5 / 19 / 1998\end{array}$ & 53 & 68.7 & 80.5 & 140 & 720 \\
\hline \multicolumn{15}{|l|}{000056} \\
\hline 09137300 & $5 / 0$ & $\begin{array}{l}5 / 8 / 1962- \\
6 / 11 / 1963\end{array}$ & 4.1 & 9.55 & 26 & 38 & 41 & $5 / 0$ & $\begin{array}{l}5 / 8 / 1962- \\
6 / 11 / 1963\end{array}$ & 6 & 14 & 36 & 58.5 & 72 \\
\hline 384551107591901 & $101 / 0$ & $\begin{array}{c}7 / 22 / 1991- \\
3 / 25 / 2003\end{array}$ & 24.073 & 44 & 60.232 & 262.12 & 330 & $101 / 0$ & $\begin{array}{c}7 / 22 / 1991- \\
3 / 25 / 2003\end{array}$ & 63 & 122.57 & 167.201 & $1,138.154$ & $1,685.6$ \\
\hline 09137500 & $32 / 0$ & $\begin{array}{c}10 / 1 / 1959 \\
8 / 26 / 1961\end{array}$ & 6.6 & 8.3 & 23.5 & 39.75 & 85 & $32 / 0$ & $\begin{array}{c}10 / 1 / 1959- \\
8 / 26 / 1961\end{array}$ & 8.8 & 14 & 52.5 & 81.75 & 198 \\
\hline \multicolumn{15}{|l|}{09143000} \\
\hline \multicolumn{15}{|l|}{09143500} \\
\hline \multicolumn{15}{|l|}{000116} \\
\hline \multicolumn{15}{|l|}{09139200} \\
\hline \multicolumn{15}{|l|}{09140200} \\
\hline \multicolumn{15}{|l|}{09140700} \\
\hline \multicolumn{15}{|l|}{09141200} \\
\hline \multirow{2}{*}{\multicolumn{15}{|c|}{$\begin{array}{l}09137800 \\
10582\end{array}$}} \\
\hline & & & & & & & & & & & & & & 10582 \\
\hline 09144200 & $8 / 0$ & $\begin{array}{c}11 / 28 / 1978- \\
3 / 15 / 2000\end{array}$ & 33.932 & 47.436 & 75.520 & 80.953 & 120 & $8 / 0$ & $\begin{array}{c}11 / 28 / 1978- \\
3 / 15 / 2000\end{array}$ & 40.734 & 58.498 & 86.702 & 101.532 & 190 \\
\hline \multicolumn{15}{|l|}{10516} \\
\hline 09144250 & $30 / 0$ & $\begin{array}{c}11 / 19 / 1987- \\
8 / 6 / 2009\end{array}$ & 8.4 & 19 & 22 & 26 & 41 & $30 / 0$ & $\begin{array}{c}11 / 19 / 1987- \\
8 / 6 / 2009\end{array}$ & 11 & 28 & 32.008 & 44 & 66 \\
\hline 383404107534101 & $11 / 0$ & $\begin{array}{c}\text { 4/11/2001- } \\
\text { 2/6/2009 }\end{array}$ & 19.561 & 22.4 & 103.47 & 108.4 & 131.4 & $11 / 0$ & $\begin{array}{c}\text { 4/11/2001- } \\
\text { 2/6/2009 }\end{array}$ & 52.108 & 54.875 & 253.152 & 304.35 & 410 \\
\hline 383408107535101 & $49 / 0$ & $\begin{array}{c}3 / 10 / 1992- \\
10 / 8 / 2009\end{array}$ & 16.304 & 20.36 & 28.622 & 96.92 & 123.29 & $49 / 0$ & $\begin{array}{c}3 / 10 / 1992- \\
10 / 8 / 2009\end{array}$ & 26.399 & 46.32 & 69.18 & 251.8 & 490 \\
\hline 383528107552001 & $49 / 0$ & $\begin{array}{c}4 / 11 / 2001- \\
4 / 21 / 2003\end{array}$ & 28.407 & 63.441 & 109.62 & 150.35 & 174.82 & $49 / 0$ & $\begin{array}{c}4 / 11 / 2001- \\
4 / 21 / 2003\end{array}$ & 73.107 & 182.512 & 320.33 & 470.42 & 564.3 \\
\hline 383741107565701 & $8 / 0$ & $\begin{array}{l}\text { 7/30/2001- } \\
12 / 13 / 2002\end{array}$ & 56.006 & 58.570 & 93.651 & 108.884 & 186.26 & $8 / 0$ & $\begin{array}{l}\text { 7/30/2001- } \\
12 / 13 / 2002\end{array}$ & 141.832 & 166.975 & 256.406 & 321.880 & 567.19 \\
\hline 383728107572001 & $51 / 0$ & $\begin{array}{c}4 / 11 / 2001- \\
4 / 21 / 2003\end{array}$ & 43.295 & 57.070 & 77.088 & 236.98 & 295.46 & $51 / 0$ & $\begin{array}{c}4 / 11 / 2001- \\
4 / 21 / 2003\end{array}$ & 77.37 & 114.048 & 150.889 & 527.25 & 690.4 \\
\hline \multicolumn{15}{|l|}{10661} \\
\hline 383946107595301 & $83 / 0$ & $\begin{array}{c}\text { 7/23/1991- } \\
\text { 8/28/2009 }\end{array}$ & 39 & 53 & 68.481 & 218.74 & 310 & $83 / 0$ & $\begin{array}{c}\text { 7/23/1991- } \\
8 / 28 / 2009\end{array}$ & 89 & 114.15 & 163.097 & 548.33 & 824.5 \\
\hline \multicolumn{15}{|l|}{$\begin{array}{l}383953108001701 \\
384231108020301 \\
10602\end{array}$} \\
\hline 09149480 & $44 / 0$ & $\begin{array}{c}10 / 26 / 1995- \\
9 / 2 / 1998\end{array}$ & 11.926 & 24 & 35 & 52.257 & 62 & $44 / 0$ & $\begin{array}{c}10 / 26 / 1995- \\
9 / 2 / 1998\end{array}$ & 13.543 & 29.187 & 44.407 & 60.669 & 73 \\
\hline 384202108032001 & $17 / 0$ & $\begin{array}{c}11 / 28 / 1978- \\
5 / 21 / 1998\end{array}$ & 18.5 & 39 & 43 & 48 & 78 & $17 / 0$ & $\begin{array}{c}11 / 28 / 1978- \\
5 / 21 / 1998\end{array}$ & 24.751 & 52 & 64 & 70 & 110 \\
\hline $\begin{array}{l}10611 \\
000055\end{array}$ & & & & & & & & & & & & & & \\
\hline 09149500 & $246 / 0$ & $\begin{array}{c}11 / 6 / 1958- \\
8 / 6 / 2009\end{array}$ & 13 & 43.423 & 56.612 & 75 & 170 & $229 / 0$ & $\begin{array}{c}11 / 6 / 1958- \\
8 / 6 / 2009\end{array}$ & 39 & 82.960 & 110 & 160 & 328 \\
\hline
\end{tabular}


Appendix 1. Summary of surface-water-quality data and comparison to water-quality standards by site, by constituent, Piceance study area, western Colorado. Water-quality standards comparisons follow data summaries and are in blue text; standards are provided in table 3.-Continued

[CDPHE segment, Colorado Department of Health and the Environment stream segment as referred to in tables 2 and 3; latitude and longitude are in North American Datum of 1983; downstream order number assigned as part of analysis. $\mu \mathrm{g} / \mathrm{L}$, micrograms per liter; $\mu \mathrm{S} / \mathrm{cm}$, microsiemens per centimeter; mg/L, milligrams per liter; mL, milliliters; aq, aquatic; CO, Colorado; EPA, U.S. Environmental Protection Agency; Max, maximum; Min, minimum; NA, not applicable; No., number; NTU, nephelometric turbitidy units; WS, water supply; dates given in month/day/year format]

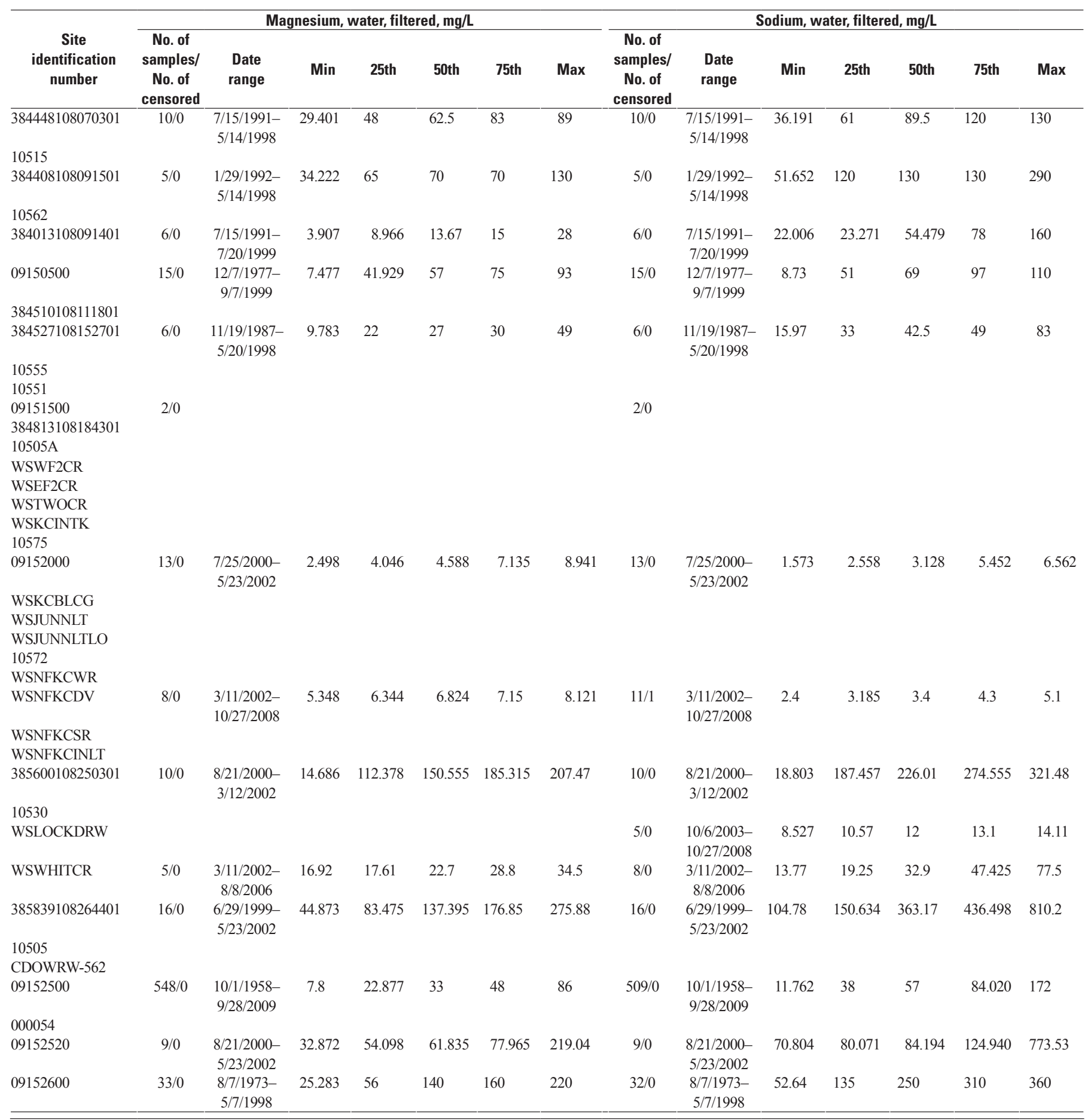


Appendix 1. Summary of surface-water-quality data and comparison to water-quality standards by site, by constituent, Piceance study area, western Colorado. Water-quality standards comparisons follow data summaries and are in blue text; standards are provided in table 3.-Continued

[CDPHE segment, Colorado Department of Health and the Environment stream segment as referred to in tables 2 and 3; latitude and longitude are in North American Datum of 1983; downstream order number assigned as part of analysis. $\mu \mathrm{g} / \mathrm{L}$, micrograms per liter; $\mu \mathrm{S} / \mathrm{cm}$, microsiemens per centimeter; $\mathrm{mg} / \mathrm{L}$, milligrams per liter; mL, milliliters; aq, aquatic; CO, Colorado; EPA, U.S. Environmental Protection Agency; Max, maximum; Min, minimum; NA, not applicable; No., number; NTU, nephelometric turbitidy units; WS, water supply; dates given in month/day/year format]

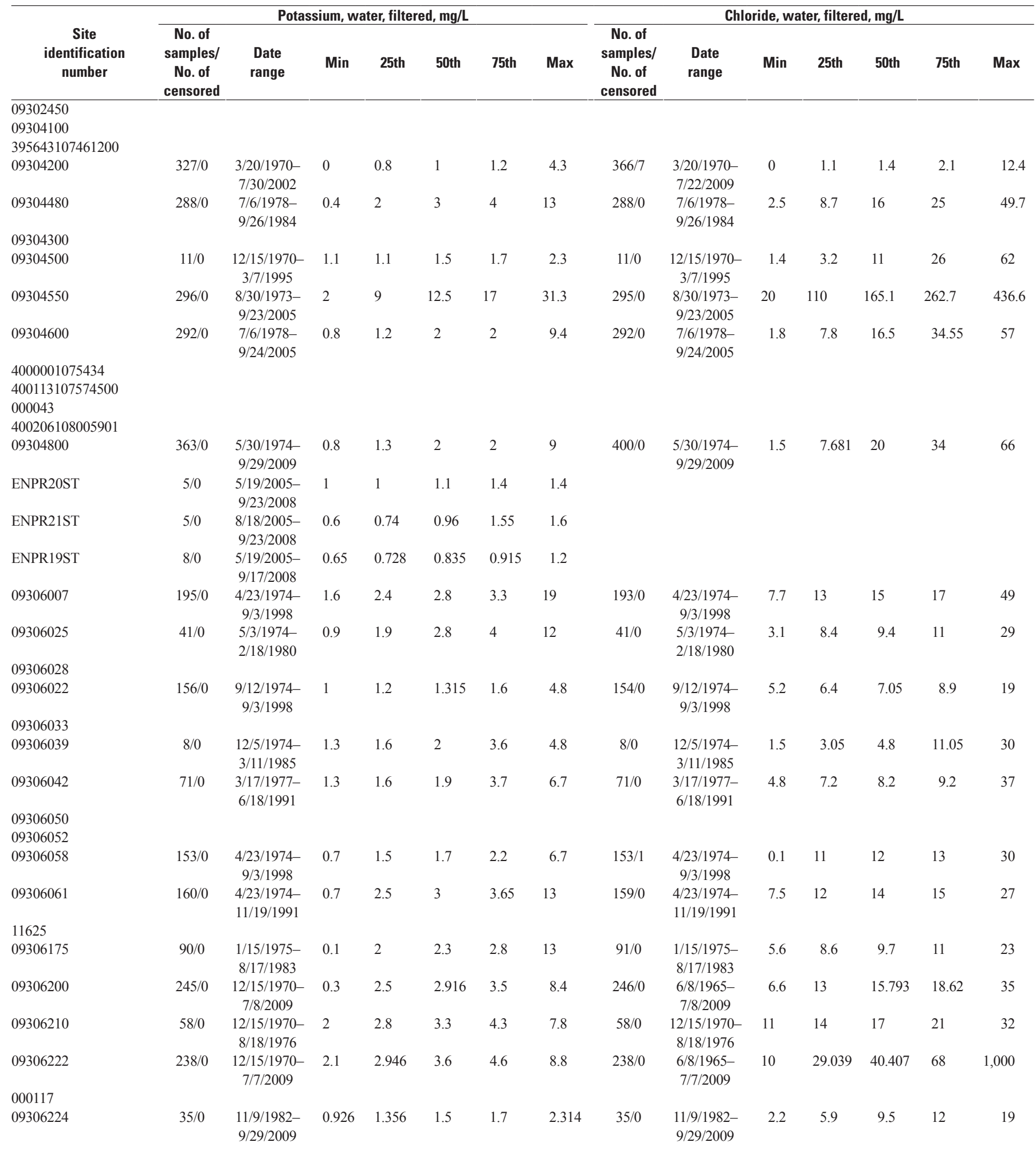


Appendix 1. Summary of surface-water-quality data and comparison to water-quality standards by site, by constituent, Piceance study area, western Colorado. Water-quality standards comparisons follow data summaries and are in blue text; standards are provided in table 3.-Continued

[CDPHE segment, Colorado Department of Health and the Environment stream segment as referred to in tables 2 and 3; latitude and longitude are in North American Datum of 1983; downstream order number assigned as part of analysis. $\mu \mathrm{g} / \mathrm{L}$, micrograms per liter; $\mu \mathrm{S} / \mathrm{cm}$, microsiemens per centimeter; $\mathrm{mg} / \mathrm{L}$, milligrams per liter; mL, milliliters; aq, aquatic; CO, Colorado; EPA, U.S. Environmental Protection Agency; Max, maximum; Min, minimum; NA, not applicable; No., number; NTU, nephelometric turbitidy units; WS, water supply; dates given in month/day/year format]

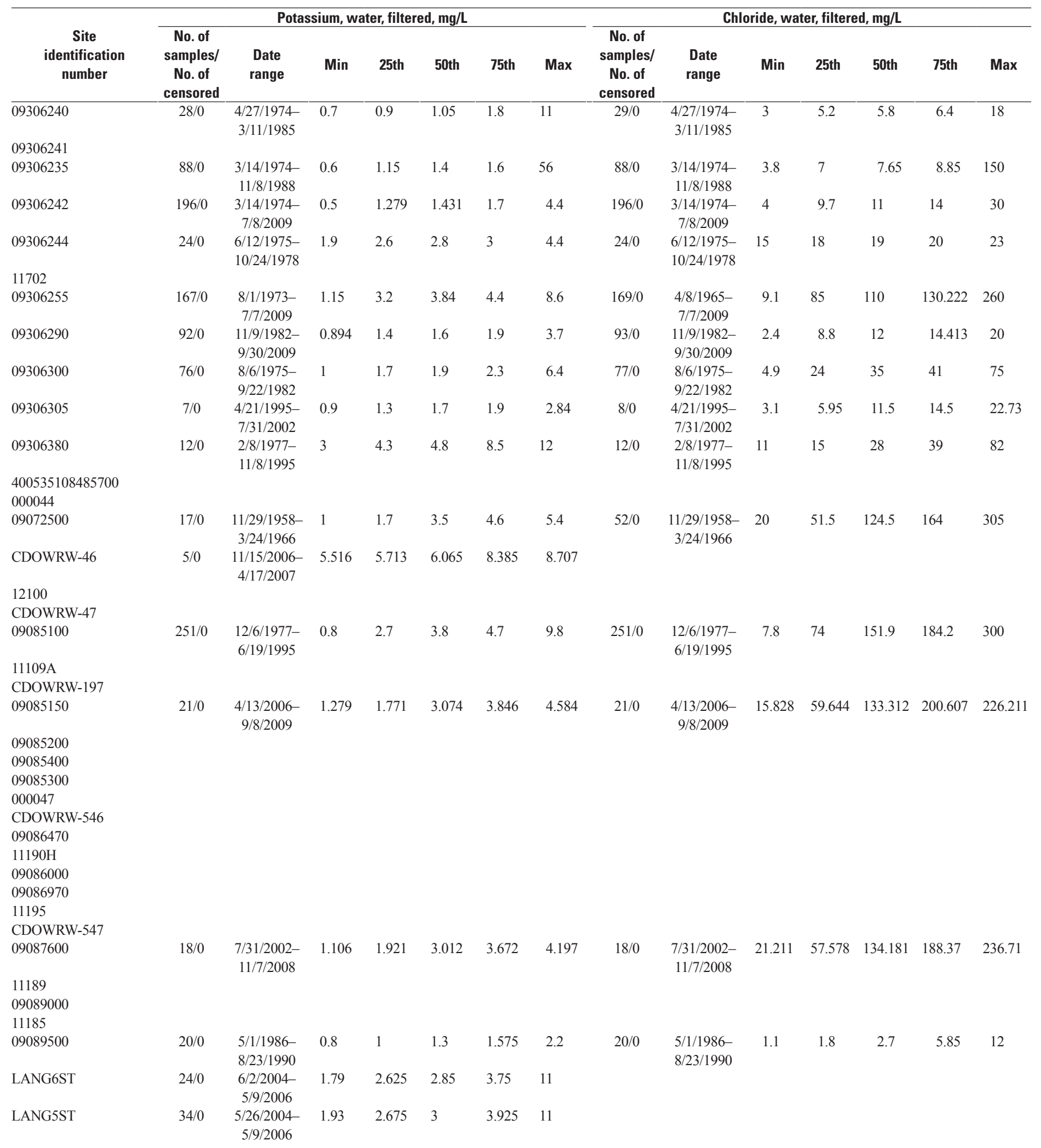


Appendix 1. Summary of surface-water-quality data and comparison to water-quality standards by site, by constituent, Piceance study area, western Colorado. Water-quality standards comparisons follow data summaries and are in blue text; standards are provided in table 3.-Continued

[CDPHE segment, Colorado Department of Health and the Environment stream segment as referred to in tables 2 and 3; latitude and longitude are in North American Datum of 1983; downstream order number assigned as part of analysis. $\mu \mathrm{g} / \mathrm{L}$, micrograms per liter; $\mu \mathrm{S} / \mathrm{cm}$, microsiemens per centimeter; mg/L, milligrams per liter; mL, milliliters; aq, aquatic; CO, Colorado; EPA, U.S. Environmental Protection Agency; Max, maximum; Min, minimum; NA, not applicable; No., number; NTU, nephelometric turbitidy units; WS, water supply; dates given in month/day/year format]

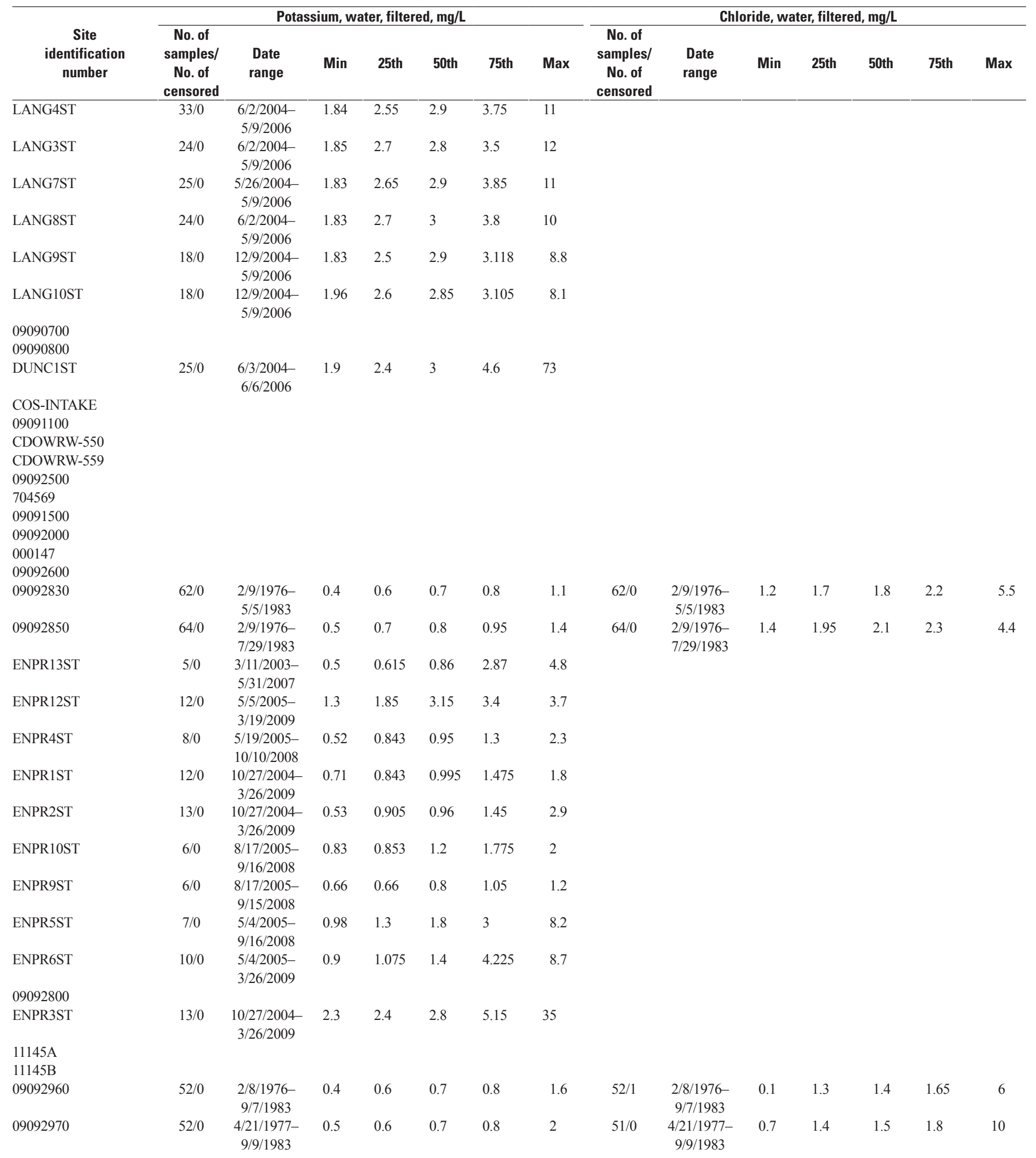


Appendix 1. Summary of surface-water-quality data and comparison to water-quality standards by site, by constituent, Piceance study area, western Colorado. Water-quality standards comparisons follow data summaries and are in blue text; standards are provided in table 3.-Continued

[CDPHE segment, Colorado Department of Health and the Environment stream segment as referred to in tables 2 and 3; latitude and longitude are in North American Datum of 1983; downstream order number assigned as part of analysis. $\mu \mathrm{g} / \mathrm{L}$, micrograms per liter; $\mu \mathrm{S} / \mathrm{cm}$, microsiemens per centimeter; $\mathrm{mg} / \mathrm{L}$, milligrams per liter; mL, milliliters; aq, aquatic; CO, Colorado; EPA, U.S. Environmental Protection Agency; Max, maximum; Min, minimum; NA, not applicable; No., number; NTU, nephelometric turbitidy units; WS, water supply; dates given in month/day/year format]

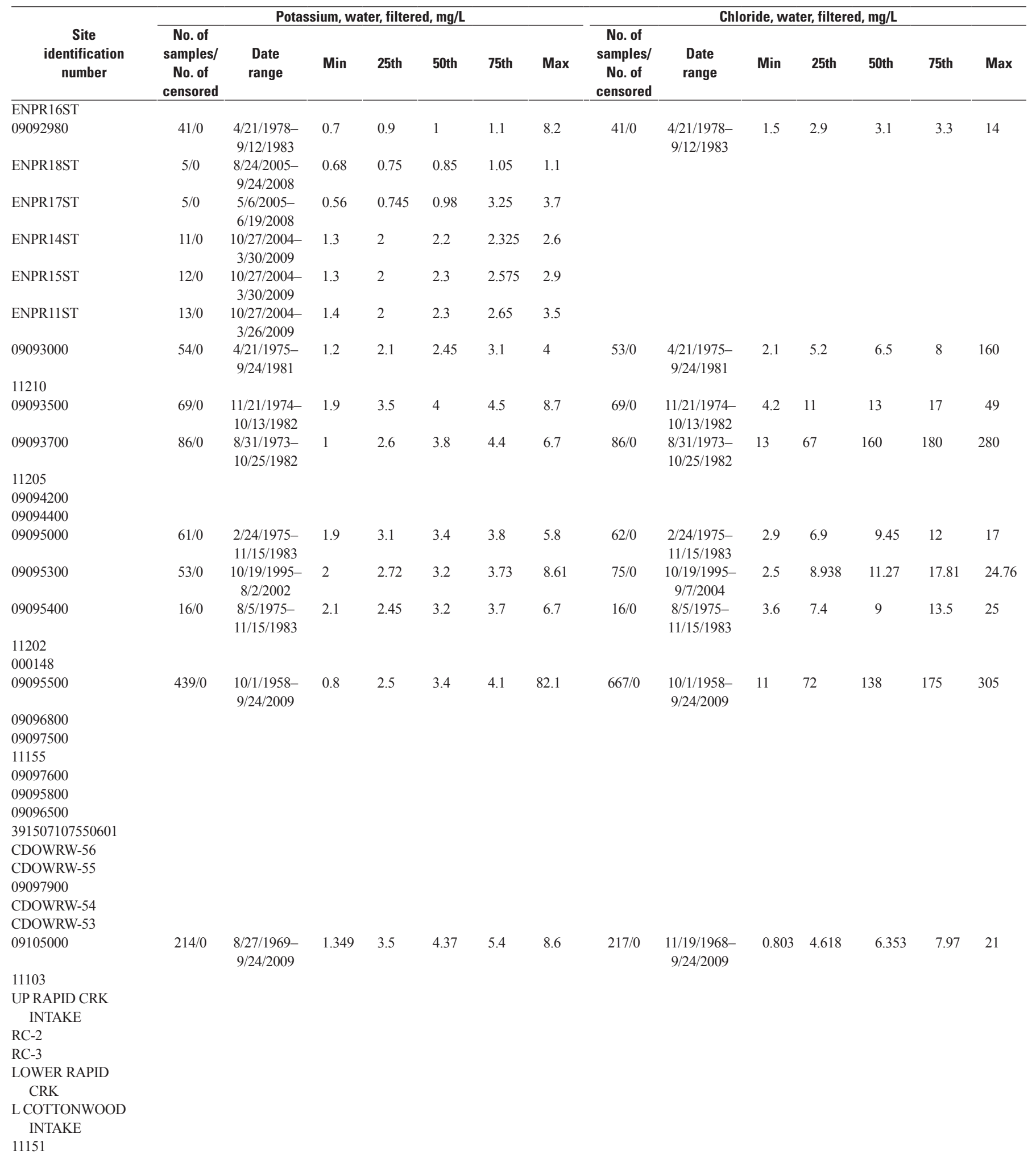


Appendix 1. Summary of surface-water-quality data and comparison to water-quality standards by site, by constituent, Piceance study area, western Colorado. Water-quality standards comparisons follow data summaries and are in blue text; standards are provided in table 3.-Continued

[CDPHE segment, Colorado Department of Health and the Environment stream segment as referred to in tables 2 and 3; latitude and longitude are in North American Datum of 1983; downstream order number assigned as part of analysis. $\mu \mathrm{g} / \mathrm{L}$, micrograms per liter; $\mu \mathrm{S} / \mathrm{cm}$, microsiemens per centimeter; $\mathrm{mg} / \mathrm{L}$, milligrams per liter; mL, milliliters; aq, aquatic; CO, Colorado; EPA, U.S. Environmental Protection Agency; Max, maximum; Min, minimum; NA, not applicable; No., number; NTU, nephelometric turbitidy units; WS, water supply; dates given in month/day/year format]

\begin{tabular}{|c|c|c|c|c|c|c|c|c|c|c|c|c|c|c|}
\hline \multirow[b]{2}{*}{$\begin{array}{c}\text { Site } \\
\text { identification } \\
\text { number }\end{array}$} & \multicolumn{7}{|c|}{ Potassium, water, filtered, mg/L } & \multicolumn{7}{|c|}{ Chloride, water, filtered, mg/L } \\
\hline & $\begin{array}{l}\text { No. of } \\
\text { samples/ } \\
\text { No. of } \\
\text { censored }\end{array}$ & $\begin{array}{l}\text { Date } \\
\text { range }\end{array}$ & Min & 25th & 50th & 75th & Max & $\begin{array}{l}\text { No. of } \\
\text { samples/ } \\
\text { No. of } \\
\text { censored }\end{array}$ & $\begin{array}{l}\text { Date } \\
\text { range }\end{array}$ & Min & 25th & 50th & 75th & Max \\
\hline 390622108205400 & $10 / 0$ & $\begin{array}{l}7 / 19 / 1994- \\
4 / 19 / 1995\end{array}$ & 3.4 & 3.65 & 3.85 & 4.425 & 4.6 & $10 / 0$ & $\begin{array}{c}/ 19 / 1994- \\
4 / 19 / 1995\end{array}$ & 94 & 130 & 155 & 180 & 180 \\
\hline 09106150 & $28 / 0$ & $\begin{array}{l}1 / 16 / 1992- \\
7 / 31 / 2002\end{array}$ & 1.2 & 2.75 & 3.35 & 3.85 & 4.5 & $28 / 0$ & $\begin{array}{c}1 / 16 / 1992- \\
7 / 31 / 2002\end{array}$ & 16 & 67 & 140 & 170 & 200 \\
\hline $\begin{array}{l}\text { CDOWRW-553 } \\
\text { CDOWRW-555 } \\
390322108253401\end{array}$ & & & & & & & & & & & & & & \\
\hline 390348108265601 & $5 / 0$ & $\begin{array}{l}3 / 22 / 1991- \\
9 / 23 / 1993\end{array}$ & 3.8 & 4.85 & 6.7 & 11 & 11 & $5 / 0$ & $\begin{array}{c}3 / 22 / 1991- \\
9 / 23 / 1993\end{array}$ & 75 & 107.5 & 160 & 225 & 230 \\
\hline $\begin{array}{l}\text { CDOWRW-556 } \\
390319108273200\end{array}$ & & & & & & & & & & & & & & \\
\hline 390318108273200 & $11 / 0$ & $\begin{array}{l}7 / 19 / 1994 \\
7 / 31 / 2002\end{array}$ & 2.8 & 3.6 & 3.8 & 4.2 & 4.6 & $11 / 0$ & $\begin{array}{c}7 / 19 / 1994- \\
7 / 31 / 2002\end{array}$ & 120 & 140 & 160 & 182.07 & 200 \\
\hline CDOWRW-557 & & & & & & & & & & & & & & \\
\hline 09106200 & $63 / 0$ & $\begin{array}{c}\text { 8/7/1973- } \\
3 / 6 / 2006\end{array}$ & 1.368 & 3.510 & 4.89 & 8.9 & 18 & $63 / 0$ & $\begin{array}{c}8 / 7 / 1973- \\
3 / 6 / 2006\end{array}$ & 22.38 & 117.68 & 190 & 230 & 270 \\
\hline 390324108291301 & & & & & & & & $7 / 0$ & $\begin{array}{c}12 / 14 / 1998- \\
8 / 17 / 1999\end{array}$ & 65.155 & 95.89 & 160.07 & 179.5 & 192.6 \\
\hline 390326108291601 & $18 / 0$ & $\begin{array}{c}2 / 25 / 1997- \\
4 / 9 / 1999\end{array}$ & 2.47 & 3.365 & 4.13 & 4.98 & 6.37 & $25 / 0$ & $\begin{array}{c}2 / 25 / 1997- \\
8 / 17 / 1999\end{array}$ & 49.619 & 75.796 & 122.12 & 150.635 & 180.45 \\
\hline 390323108291601 & & & & & & & & $8 / 0$ & $\begin{array}{c}12 / 14 / 1998- \\
8 / 17 / 1999\end{array}$ & 34.467 & 68.271 & 120.85 & 157.115 & 171.71 \\
\hline $\begin{array}{l}390303108291601 \\
390322108292301 \\
390318108293301 \\
390302108293801 \\
390319108312501\end{array}$ & & & & & & & & & & & & & & \\
\hline 390320108315901 & $6 / 0$ & $\begin{array}{c}3 / 21 / 1991- \\
5 / 6 / 1998\end{array}$ & 3.77 & 4.5 & 9.65 & 11 & 47 & $6 / 0$ & $\begin{array}{c}3 / 21 / 1991- \\
5 / 6 / 1998\end{array}$ & 37.512 & 130 & 225 & 240 & 330 \\
\hline $\begin{array}{l}\text { CDOWRW-558 } \\
\text { CDOWRW-560 }\end{array}$ & & & & & & & & & & & & & & \\
\hline 09106500 & $16 / 0$ & $\begin{array}{l}7 / 20 / 1994 \\
7 / 31 / 2002\end{array}$ & 1.2 & 3 & 3.75 & 4.15 & 4.89 & $16 / 0$ & $\begin{array}{c}7 / 20 / 1994 \\
7 / 31 / 2002\end{array}$ & 14 & 94.5 & 155 & 180 & 200 \\
\hline $\begin{array}{l}390337108342800 \\
\text { CDOWRW-563 } \\
\text { 11135A } \\
\text { CDOWRW-749 }\end{array}$ & & & & & & & & & & & & & & \\
\hline 09152650 & $74 / 0$ & $\begin{array}{c}\text { 8/7/1973- } \\
8 / 9 / 1999\end{array}$ & 2.55 & 4.2 & 6.35 & 8.6 & 38 & $74 / 0$ & $\begin{array}{c}8 / 7 / 1973- \\
8 / 9 / 1999\end{array}$ & 38 & 91 & 160 & 180 & 210 \\
\hline $\begin{array}{l}11135 \\
390449108364101 \\
390514108373201\end{array}$ & & & & & & & & & & & & & & \\
\hline 390521108373300 & $16 / 0$ & $\begin{array}{c}7 / 20 / 1994 \\
8 / 1 / 2002\end{array}$ & 1.4 & 2.45 & 3.4 & 3.95 & 4.1 & $16 / 0$ & $\begin{array}{c}7 / 20 / 1994- \\
8 / 1 / 2002\end{array}$ & 10 & 37 & 62.44 & 91.5 & 140 \\
\hline 390607108384201 & $9 / 0$ & $\begin{array}{c}7 / 17 / 1997- \\
3 / 23 / 2000\end{array}$ & 2.02 & 2.855 & 3.17 & 3.49 & 3.61 & $9 / 0$ & $\begin{array}{c}\text { 7/17/1997- } \\
3 / 23 / 2000\end{array}$ & 44.226 & 56.424 & 66.864 & 102.022 & 107.35 \\
\hline $\begin{array}{l}390609108384701 \\
390613108385603 \\
390625108390402 \\
390617108391001 \\
390632108392101 \\
390624108394701 \\
390859108364101\end{array}$ & & & & & & & & & & & & & & \\
\hline 390645108390101 & $17 / 0$ & $\begin{array}{l}3 / 21 / 1991- \\
11 / 21 / 2004\end{array}$ & 3 & 3.93 & 4.89 & 8.59 & 9.3 & $17 / 0$ & $\begin{array}{l}3 / 21 / 1991- \\
11 / 21 / 2004\end{array}$ & 57.343 & 90.977 & 150 & 222.31 & 290 \\
\hline 390717108400501 & $7 / 0$ & $\begin{array}{c}3 / 20 / 1991- \\
5 / 12 / 1998\end{array}$ & 3.6 & 3.88 & 5 & 7.9 & 8.6 & $7 / 0$ & $\begin{array}{c}3 / 20 / 1991- \\
5 / 12 / 1998\end{array}$ & 52.955 & 64 & 140 & 200 & 230 \\
\hline
\end{tabular}


Appendix 1. Summary of surface-water-quality data and comparison to water-quality standards by site, by constituent, Piceance study area, western Colorado. Water-quality standards comparisons follow data summaries and are in blue text; standards are provided in table 3.-Continued

[CDPHE segment, Colorado Department of Health and the Environment stream segment as referred to in tables 2 and 3; latitude and longitude are in North American Datum of 1983; downstream order number assigned as part of analysis. $\mu \mathrm{g} / \mathrm{L}$, micrograms per liter; $\mu \mathrm{S} / \mathrm{cm}$, microsiemens per centimeter; $\mathrm{mg} / \mathrm{L}$, milligrams per liter; mL, milliliters; aq, aquatic; CO, Colorado; EPA, U.S. Environmental Protection Agency; Max, maximum; Min, minimum; NA, not applicable; No., number; NTU, nephelometric turbitidy units; WS, water supply; dates given in month/day/year format]

\begin{tabular}{|c|c|c|c|c|c|c|c|c|c|c|c|c|c|c|}
\hline \multirow[b]{2}{*}{$\begin{array}{c}\text { Site } \\
\text { identification } \\
\text { number }\end{array}$} & \multicolumn{7}{|c|}{ Potassium, water, filtered, mg/L } & \multicolumn{7}{|c|}{ Chloride, water, filtered, $\mathrm{mg} / \mathrm{L}$} \\
\hline & $\begin{array}{c}\text { No. of } \\
\text { samples/ } \\
\text { No. of } \\
\text { censored }\end{array}$ & $\begin{array}{l}\text { Date } \\
\text { range }\end{array}$ & Min & 25th & 50th & 75th & Max & $\begin{array}{c}\text { No. of } \\
\text { samples/ } \\
\text { No. of } \\
\text { censored }\end{array}$ & $\begin{array}{l}\text { Date } \\
\text { range }\end{array}$ & Min & 25th & 50th & 75th & Max \\
\hline 390718108415701 & & & & & & & & & & & & & & \\
\hline 09152900 & $47 / 0$ & $\begin{array}{l}8 / 7 / 1973- \\
5 / 12 / 1998\end{array}$ & 2.9 & 4.6 & 6.3 & 8.7 & 12 & $47 / 0$ & $\begin{array}{l}8 / 7 / 1973- \\
5 / 12 / 1998\end{array}$ & 56 & 110 & 200 & 220 & 260 \\
\hline \multicolumn{15}{|l|}{11133} \\
\hline \multicolumn{15}{|l|}{390741108424001} \\
\hline \multicolumn{15}{|l|}{390741108424301} \\
\hline \multicolumn{15}{|l|}{390741108425301} \\
\hline 09153000 & $16 / 0$ & $\begin{array}{c}7 / 20 / 1994 \\
8 / 1 / 2002\end{array}$ & 1.4 & 2.5 & 3.55 & 4.1 & 5 & $16 / 0$ & $\begin{array}{c}7 / 20 / 1994 \\
8 / 1 / 2002\end{array}$ & 9.6 & 38 & 71.5 & 89 & 120 \\
\hline \multicolumn{15}{|l|}{000049} \\
\hline \multicolumn{15}{|l|}{$\begin{array}{l}390938108443101 \\
11110\end{array}$} \\
\hline 391509108433001 & $7 / 0$ & $\begin{array}{c}5 / 2 / 1991- \\
12 / 26 / 1999\end{array}$ & 0.47 & 2.5 & 3.2 & 3.5 & 4.09 & $7 / 0$ & $\begin{array}{c}5 / 2 / 1991- \\
12 / 26 / 1999\end{array}$ & 36 & 211.58 & 280 & 330 & 357.94 \\
\hline 09153270 & $62 / 0$ & $\begin{array}{l}8 / 7 / 1973- \\
11 / 9 / 2006\end{array}$ & 3.27 & 4.65 & 5.99 & 6.65 & 10.88 & $59 / 0$ & $\begin{array}{c}8 / 7 / 1973- \\
3 / 8 / 1999\end{array}$ & 42.097 & 93 & 150 & 170 & 220 \\
\hline \multicolumn{15}{|l|}{09095526} \\
\hline \multicolumn{15}{|l|}{09106104} \\
\hline \multicolumn{15}{|l|}{09095529} \\
\hline \multicolumn{15}{|l|}{090955285} \\
\hline \multicolumn{15}{|l|}{09095528} \\
\hline 09153290 & $55 / 0$ & $\begin{array}{c}\text { 9/10/1991- } \\
\text { 9/8/1998 }\end{array}$ & 2.91 & 3.78 & 4.5 & 8.5 & 10.25 & $55 / 0$ & $\begin{array}{c}\text { 9/10/1991- } \\
\text { 9/8/1998 }\end{array}$ & 41.515 & 64.62 & 104.16 & 200 & 240 \\
\hline 09153300 & $101 / 0$ & $\begin{array}{l}8 / 7 / 1973- \\
3 / 8 / 1999\end{array}$ & 3.23 & 4.7 & 6.9 & 9.89 & 14 & $101 / 0$ & $\begin{array}{l}\text { 8/7/1973- } \\
3 / 8 / 1999\end{array}$ & 43.831 & 100 & 180 & 210 & 270 \\
\hline 391038108475601 & $9 / 0$ & $\begin{array}{l}7 / 9 / 1993- \\
7 / 14 / 1999\end{array}$ & 3.6 & 4.23 & 5.5 & 11.45 & 13.35 & $9 / 0$ & $\begin{array}{l}\text { 7/9/1993- } \\
7 / 14 / 1999\end{array}$ & 54 & 77.156 & 132.97 & 208.54 & 213.88 \\
\hline \multicolumn{15}{|l|}{000050} \\
\hline \multicolumn{15}{|l|}{391029108480200} \\
\hline 09163310 & $50 / 0$ & $\begin{array}{c}\text { 8/8/1973- } \\
2 / 4 / 1992\end{array}$ & 2.5 & 5.3 & 5.95 & 6.9 & 13 & $50 / 0$ & $\begin{array}{c}\text { 8/8/1973- } \\
2 / 4 / 1992\end{array}$ & 10 & 100 & 215 & 280 & 380 \\
\hline 09163340 & $47 / 0$ & $\begin{array}{l}8 / 8 / 1973- \\
6 / 15 / 1982\end{array}$ & 2.9 & 4.2 & 6.6 & 7.2 & 8.5 & $47 / 0$ & $\begin{array}{l}8 / 8 / 1973- \\
6 / 15 / 1982\end{array}$ & 70 & 140 & 160 & 170 & 220 \\
\hline 09153330 & $21 / 0$ & $\begin{array}{c}6 / 12 / 1979- \\
9 / 14 / 1981\end{array}$ & 6.1 & 10 & 12 & 14 & 76 & $21 / 0$ & $\begin{array}{c}\text { 6/12/1979- } \\
9 / 14 / 1981\end{array}$ & 7.5 & 13 & 20 & 26.5 & 36 \\
\hline 09153400 & $22 / 0$ & $\begin{array}{c}\text { 9/12/1973- } \\
3 / 13 / 1997\end{array}$ & 3.9 & 8.4 & 9.7 & 13 & 27 & $22 / 0$ & $\begin{array}{c}9 / 12 / 1973- \\
3 / 13 / 1997\end{array}$ & 3.3 & 12 & 22.5 & 47 & 150 \\
\hline \multicolumn{15}{|l|}{391646108572301} \\
\hline 09161000 & $21 / 0$ & $\begin{array}{c}10 / 2 / 1976- \\
8 / 22 / 1978\end{array}$ & 3.3 & 4.15 & 5 & 7.1 & 14 & $21 / 0$ & $\begin{array}{l}10 / 2 / 1976- \\
8 / 22 / 1978\end{array}$ & 0.8 & 2.1 & 3.6 & 5.45 & 37 \\
\hline 09160500 & $79 / 0$ & $\begin{array}{l}\text { 7/4/1977- } \\
9 / 27 / 1982\end{array}$ & 2.4 & 3.6 & 5.1 & 8.7 & 16 & $79 / 0$ & $\begin{array}{l}7 / 4 / 1977- \\
9 / 27 / 1982\end{array}$ & 0.2 & 1.3 & 2.6 & 4.6 & 52 \\
\hline 09163050 & $23 / 0$ & $\begin{array}{l}8 / 8 / 1973- \\
7 / 15 / 1980\end{array}$ & 1.5 & 2.5 & 3.7 & 4.5 & 9.1 & $23 / 0$ & $\begin{array}{l}8 / 8 / 1973- \\
7 / 15 / 1980\end{array}$ & 28 & 63 & 110 & 180 & 250 \\
\hline 09163490 & $86 / 0$ & $\begin{array}{l}8 / 8 / 1973- \\
5 / 13 / 1998\end{array}$ & 2.1 & 4.2 & 6.05 & 8.3 & 12 & $86 / 0$ & $\begin{array}{l}8 / 8 / 1973- \\
5 / 13 / 1998\end{array}$ & 38.132 & 98 & 155 & 200 & 540 \\
\hline 09163500 & $326 / 0$ & $\begin{array}{c}\text { 9/10/1969- } \\
9 / 23 / 2009\end{array}$ & 1.4 & 2.69 & 3.5 & 4.1 & 7.7 & $333 / 0$ & $\begin{array}{c}9 / 10 / 1969- \\
9 / 23 / 2009\end{array}$ & 9.7 & 47 & 78.786 & 95 & 182.39 \\
\hline \multicolumn{15}{|l|}{10485} \\
\hline 09132050 & $37 / 0$ & $\begin{array}{c}12 / 16 / 1977- \\
9 / 1 / 1981\end{array}$ & 0.3 & 0.4 & 0.5 & 0.6 & 1.9 & $37 / 0$ & $\begin{array}{c}\text { 12/16/1977- } \\
9 / 1 / 1981\end{array}$ & 0.3 & 0.6 & 1.1 & 1.3 & 2.8 \\
\hline 09129800 & $9 / 0$ & $\begin{array}{c}5 / 19 / 1982- \\
8 / 16 / 1983\end{array}$ & 0.6 & 0.7 & 0.8 & 1 & 1.1 & $9 / 0$ & $\begin{array}{c}5 / 19 / 1982- \\
8 / 16 / 1983\end{array}$ & 0.5 & 0.85 & 1 & 1.3 & 1.5 \\
\hline
\end{tabular}

09130800 
Appendix 1. Summary of surface-water-quality data and comparison to water-quality standards by site, by constituent, Piceance study area, western Colorado. Water-quality standards comparisons follow data summaries and are in blue text; standards are provided in table 3.-Continued

[CDPHE segment, Colorado Department of Health and the Environment stream segment as referred to in tables 2 and 3; latitude and longitude are in North American Datum of 1983; downstream order number assigned as part of analysis. $\mu \mathrm{g} / \mathrm{L}$, micrograms per liter; $\mu \mathrm{S} / \mathrm{cm}$, microsiemens per centimeter; $\mathrm{mg} / \mathrm{L}$, milligrams per liter; mL, milliliters; aq, aquatic; CO, Colorado; EPA, U.S. Environmental Protection Agency; Max, maximum; Min, minimum; NA, not applicable; No., number; NTU, nephelometric turbitidy units; WS, water supply; dates given in month/day/year format]

\begin{tabular}{|c|c|c|c|c|c|c|c|c|c|c|c|c|c|c|}
\hline $\begin{array}{c}\text { Site } \\
\text { identification } \\
\text { number }\end{array}$ & \multicolumn{7}{|c|}{ Potassium, water, filtered, mg/L } & \multicolumn{7}{|c|}{ Chloride, water, filtered, $\mathrm{mg} / \mathrm{L}$} \\
\hline \multicolumn{15}{|l|}{09131200} \\
\hline \multicolumn{15}{|l|}{09132700} \\
\hline \multicolumn{15}{|l|}{09132800} \\
\hline \multicolumn{15}{|l|}{09132900} \\
\hline \multicolumn{15}{|l|}{09132920} \\
\hline \multicolumn{15}{|l|}{09132940} \\
\hline \multicolumn{15}{|l|}{$10406 \mathrm{H}$} \\
\hline \multicolumn{15}{|l|}{09132960} \\
\hline \multirow{2}{*}{\multicolumn{15}{|c|}{$\begin{array}{l}10436 \\
09134050\end{array}$}} \\
\hline & & & & & & & & & & & & & & \\
\hline \multicolumn{15}{|l|}{385144107371701} \\
\hline 385049107372402 & $6 / 0$ & $\begin{array}{l}5 / 8 / 2008- \\
4 / 14 / 2009\end{array}$ & 3.063 & 3.444 & 4.103 & 8.520 & 9.53 & $6 / 0$ & $\begin{array}{l}5 / 8 / 2008- \\
4 / 14 / 2009\end{array}$ & 7.023 & 9.005 & 12.648 & 20.460 & 27.607 \\
\hline 384922107402001 & $7 / 0$ & $\begin{array}{c}6 / 23 / 1999 \\
4 / 14 / 2009\end{array}$ & 3.11 & 4.1 & 5.5 & 6.363 & 12.87 & $7 / 0$ & $\begin{array}{c}6 / 23 / 1999- \\
4 / 14 / 2009\end{array}$ & 6.769 & 8.166 & 15.372 & 32.104 & 57.287 \\
\hline 09134200 & $5 / 0$ & $\begin{array}{l}\text { 8/9/1977- } \\
8 / 30 / 1999\end{array}$ & 5.22 & 5.51 & 7.74 & 9.9 & 11 & $5 / 0$ & $\begin{array}{l}\text { 8/9/1977- } \\
8 / 30 / 1999\end{array}$ & 11.7 & 15.27 & 22.057 & 38 & 45 \\
\hline 384822107411201 & $6 / 0$ & $\begin{array}{c}5 / 19 / 2008- \\
4 / 14 / 2009\end{array}$ & 5.983 & 5.983 & 7.506 & 11.512 & 16.78 & $6 / 0$ & $\begin{array}{c}5 / 19 / 2008- \\
4 / 14 / 2009\end{array}$ & 10.385 & 10.860 & 19.022 & 28.927 & 36.401 \\
\hline 10212 & & & & & & & & & & & & & & \\
\hline 384434107432701 & $6 / 0$ & $\begin{array}{c}5 / 12 / 2008- \\
4 / 10 / 2009\end{array}$ & 4.157 & 4.986 & 6.053 & 7.280 & 7.65 & $6 / 0$ & $\begin{array}{c}5 / 12 / 2008- \\
4 / 10 / 2009\end{array}$ & 7.807 & 9.506 & 15.980 & 16.577 & 16.603 \\
\hline 384610107455001 & & & & & & & & & & & & & & \\
\hline 231275 & & & & & & & & & & & & & & \\
\hline 231272 & & & & & & & & & & & & & & \\
\hline 231273 & & & & & & & & & & & & & & \\
\hline 231274 & & & & & & & & & & & & & & \\
\hline 09136100 & $44 / 0$ & $\begin{array}{c}2 / 15 / 1962- \\
9 / 3 / 2009\end{array}$ & 1.07 & 2.07 & 4.725 & 5.67 & 8.1 & $60 / 1$ & $\begin{array}{c}2 / 15 / 1962- \\
9 / 3 / 2009\end{array}$ & 0.29 & 4.2 & 8.992 & 10.55 & 19 \\
\hline 10400 & & & & & & & & & & & & & & \\
\hline 09136200 & & & & & & & & & & & & & & \\
\hline 384643107540301 & & & & & & & & & & & & & & \\
\hline 10587 & & & & & & & & & & & & & & \\
\hline 09137050 & & & & & & & & & & & & & & \\
\hline 384649107570501 & & & & & & & & & & & & & & \\
\hline 384624107570701 & $5 / 0$ & $\begin{array}{c}7 / 18 / 1991- \\
8 / 8 / 2002\end{array}$ & 2.16 & 2.22 & 2.32 & 2.49 & 2.5 & $5 / 0$ & $\begin{array}{c}7 / 18 / 1991- \\
8 / 8 / 2002\end{array}$ & 3.99 & 4.82 & 5.15 & 6 & 6 \\
\hline
\end{tabular}


Appendix 1. Summary of surface-water-quality data and comparison to water-quality standards by site, by constituent, Piceance study area, western Colorado. Water-quality standards comparisons follow data summaries and are in blue text; standards are provided in table 3.-Continued

[CDPHE segment, Colorado Department of Health and the Environment stream segment as referred to in tables 2 and 3; latitude and longitude are in North American Datum of 1983; downstream order number assigned as part of analysis. $\mu \mathrm{g} / \mathrm{L}$, micrograms per liter; $\mu \mathrm{S} / \mathrm{cm}$, microsiemens per centimeter; $\mathrm{mg} / \mathrm{L}$, milligrams per liter; mL, milliliters; aq, aquatic; CO, Colorado; EPA, U.S. Environmental Protection Agency; Max, maximum; Min, minimum; NA, not applicable; No., number; NTU, nephelometric turbitidy units; WS, water supply; dates given in month/day/year format]

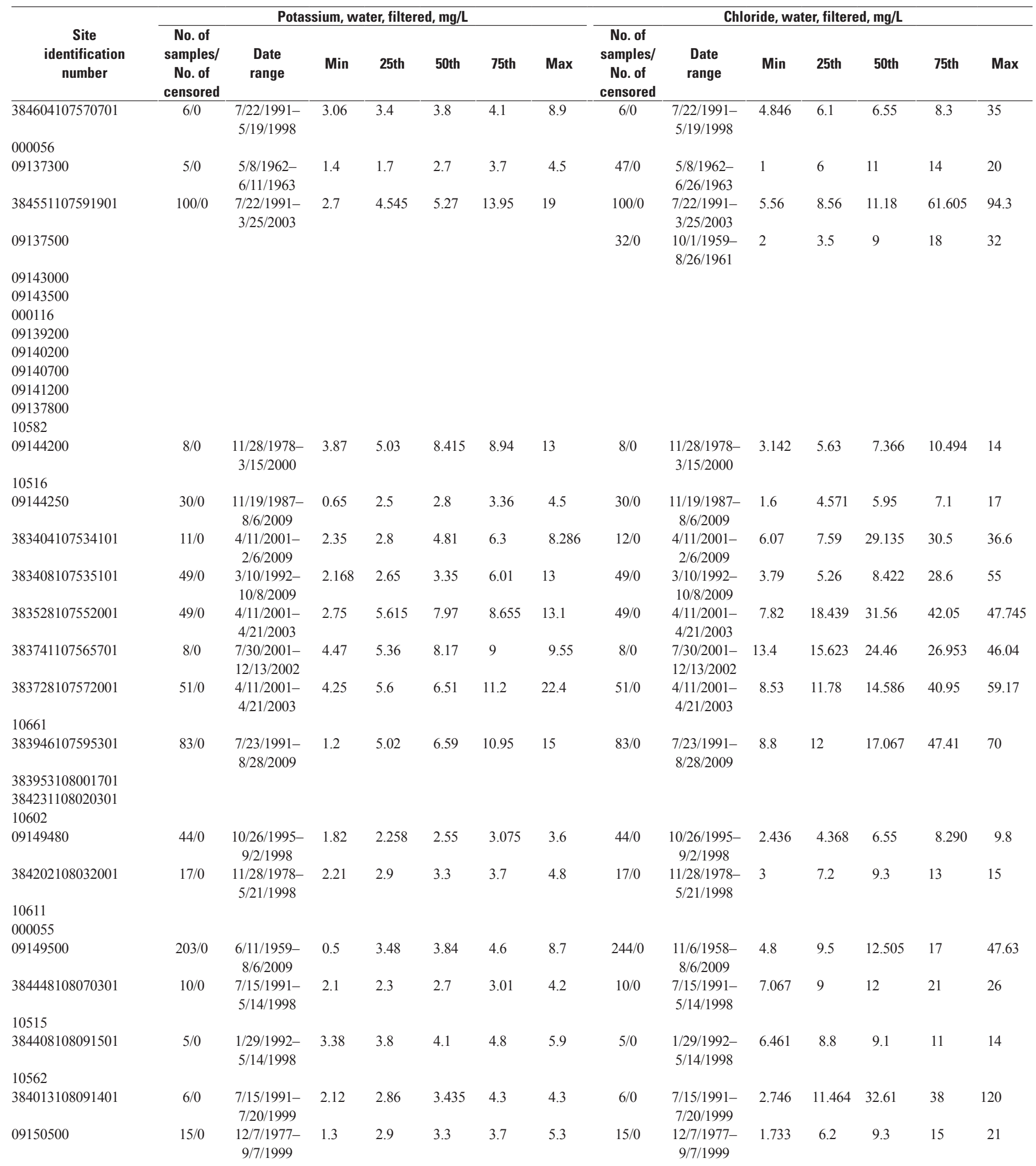


Appendix 1. Summary of surface-water-quality data and comparison to water-quality standards by site, by constituent, Piceance study area, western Colorado. Water-quality standards comparisons follow data summaries and are in blue text; standards are provided in table 3.-Continued

[CDPHE segment, Colorado Department of Health and the Environment stream segment as referred to in tables 2 and 3; latitude and longitude are in North American Datum of 1983; downstream order number assigned as part of analysis. $\mu \mathrm{g} / \mathrm{L}$, micrograms per liter; $\mu \mathrm{S} / \mathrm{cm}$, microsiemens per centimeter; $\mathrm{mg} / \mathrm{L}$, milligrams per liter; mL, milliliters; aq, aquatic; CO, Colorado; EPA, U.S. Environmental Protection Agency; Max, maximum; Min, minimum; NA, not applicable; No., number; NTU, nephelometric turbitidy units; WS, water supply; dates given in month/day/year format]

\begin{tabular}{|c|c|c|c|c|c|c|c|c|c|c|c|c|c|c|}
\hline \multirow[b]{2}{*}{$\begin{array}{c}\text { Site } \\
\text { identification } \\
\text { number }\end{array}$} & \multicolumn{7}{|c|}{ Potassium, water, filtered, mg/L } & \multicolumn{7}{|c|}{ Chloride, water, filtered, mg/L } \\
\hline & $\begin{array}{c}\text { No. of } \\
\text { samples/ } \\
\text { No. of } \\
\text { censored }\end{array}$ & $\begin{array}{l}\text { Date } \\
\text { range }\end{array}$ & Min & 25th & 50th & 75th & $\operatorname{Max}$ & $\begin{array}{c}\text { No. of } \\
\text { samples/ } \\
\text { No. of } \\
\text { censored }\end{array}$ & $\begin{array}{l}\text { Date } \\
\text { range }\end{array}$ & Min & 25th & 50th & 75th & Max \\
\hline \multicolumn{15}{|l|}{384510108111801} \\
\hline 384527108152701 & $6 / 0$ & $\begin{array}{c}11 / 19 / 1987- \\
5 / 20 / 1998\end{array}$ & 1.61 & 2.4 & 2.9 & 3.4 & 4.2 & $6 / 0$ & $\begin{array}{c}11 / 19 / 1987- \\
5 / 20 / 1998\end{array}$ & 0.3 & 2.083 & 6.8 & 8.6 & 11 \\
\hline \multicolumn{15}{|l|}{10555} \\
\hline \multicolumn{15}{|l|}{10551} \\
\hline 09151500 & $2 / 0$ & & & & & & & $2 / 0$ & & & & & & \\
\hline \multicolumn{15}{|l|}{384813108184301} \\
\hline \multicolumn{15}{|l|}{$10505 \mathrm{~A}$} \\
\hline \multicolumn{15}{|l|}{ WSWF2CR } \\
\hline \multicolumn{15}{|l|}{ WSEF2CR } \\
\hline \multicolumn{15}{|l|}{ WSTWOCR } \\
\hline \multicolumn{15}{|l|}{ WSKCINTK } \\
\hline \multicolumn{15}{|l|}{10575} \\
\hline 09152000 & $13 / 0$ & $\begin{array}{l}7 / 25 / 2000- \\
5 / 23 / 2002\end{array}$ & 0.66 & 0.905 & 1.05 & 1.295 & 1.44 & $13 / 0$ & $\begin{array}{c}7 / 25 / 2000 \\
5 / 23 / 2002\end{array}$ & 0.39 & 0.45 & 0.56 & 0.745 & 1.45 \\
\hline \multicolumn{15}{|l|}{ WSKCBLCG } \\
\hline WSJUNNLT & & & & & & & & $13 / 9$ & $\begin{array}{c}3 / 11 / 2002- \\
10 / 8 / 2007\end{array}$ & 0.641 & 0.016 & 0.085 & 0.641 & 10.6 \\
\hline \multicolumn{15}{|l|}{ WSJUNNLTLO } \\
\hline \multicolumn{15}{|l|}{10572} \\
\hline \multicolumn{15}{|l|}{ WSNFKCWR } \\
\hline WSNFKCDV & $8 / 2$ & $\begin{array}{l}3 / 11 / 2002- \\
10 / 27 / 2008\end{array}$ & 0.812 & 1.058 & 1.162 & 1.2 & 2.15 & $13 / 9$ & $\begin{array}{c}3 / 11 / 2002- \\
10 / 8 / 2007\end{array}$ & 0.5 & 0.197 & 0.368 & 0.5 & 1.148 \\
\hline \multicolumn{15}{|l|}{ WSNFKCSR } \\
\hline \multicolumn{15}{|l|}{ WSNFKCINLT } \\
\hline 385600108250301 & $10 / 1$ & $\begin{array}{c}8 / 21 / 2000- \\
3 / 12 / 2002\end{array}$ & 0.1 & 1.45 & 5.375 & 6.01 & 6.53 & $10 / 0$ & $\begin{array}{c}8 / 21 / 2000 \\
3 / 12 / 2002\end{array}$ & 2.92 & 22.218 & 26.919 & 32.533 & 40.54 \\
\hline \multicolumn{15}{|l|}{10530} \\
\hline WSLOCKDRW & & & & & & & & $6 / 4$ & $\begin{array}{c}10 / 6 / 2003- \\
10 / 8 / 2007\end{array}$ & & & & & \\
\hline WSWHITCR & $5 / 2$ & $\begin{array}{c}3 / 11 / 2002- \\
8 / 8 / 2006\end{array}$ & 1.46 & 1.499 & 1.9 & 3 & 3 & $8 / 0$ & $\begin{array}{c}3 / 11 / 2002- \\
5 / 2 / 2006\end{array}$ & 1.316 & 2.026 & 2.772 & 3.808 & 5.1 \\
\hline 385839108264401 & $16 / 0$ & $\begin{array}{c}6 / 29 / 1999- \\
5 / 23 / 2002\end{array}$ & 3.76 & 4.503 & 5.965 & 7.065 & 10.15 & $16 / 0$ & $\begin{array}{c}6 / 29 / 1999- \\
5 / 23 / 2002\end{array}$ & 11.78 & 19.066 & 40.61 & 52.7 & 95.120 \\
\hline \multicolumn{15}{|l|}{10505} \\
\hline \multicolumn{15}{|l|}{ CDOWRW-562 } \\
\hline 09152500 & $437 / 0$ & $\begin{array}{c}10 / 1 / 1958- \\
9 / 28 / 2009\end{array}$ & 1.5 & 2.6 & 3.3 & 4 & 8.7 & $715 / 0$ & $\begin{array}{c}10 / 1 / 1958- \\
9 / 28 / 2009\end{array}$ & 1 & 6.3 & 9.5 & 15 & 58 \\
\hline \multicolumn{15}{|l|}{000054} \\
\hline 09152520 & $9 / 0$ & $\begin{array}{c}8 / 21 / 2000- \\
5 / 23 / 2002\end{array}$ & 3.01 & 3.46 & 3.87 & 5.41 & 14.25 & $9 / 0$ & $\begin{array}{c}8 / 21 / 2000- \\
5 / 23 / 2002\end{array}$ & 6.87 & 8.11 & 10.55 & 15.57 & 129.41 \\
\hline 09152600 & $33 / 0$ & $\begin{array}{c}8 / 7 / 1973- \\
5 / 7 / 1998\end{array}$ & 2.28 & 4.6 & 5.5 & 6.9 & 11 & $33 / 0$ & $\begin{array}{c}8 / 7 / 1973- \\
5 / 7 / 1998\end{array}$ & 45.487 & 130 & 190 & 210 & 240 \\
\hline
\end{tabular}


Appendix 1. Summary of surface-water-quality data and comparison to water-quality standards by site, by constituent, Piceance study area, western Colorado. Water-quality standards comparisons follow data summaries and are in blue text; standards are provided in table 3.-Continued

[CDPHE segment, Colorado Department of Health and the Environment stream segment as referred to in tables 2 and 3; latitude and longitude are in North American Datum of 1983; downstream order number assigned as part of analysis. $\mu \mathrm{g} / \mathrm{L}$, micrograms per liter; $\mu \mathrm{S} / \mathrm{cm}$, microsiemens per centimeter; $\mathrm{mg} / \mathrm{L}$, milligrams per liter; mL, milliliters; aq, aquatic; CO, Colorado; EPA, U.S. Environmental Protection Agency; Max, maximum; Min, minimum; NA, not applicable; No., number; NTU, nephelometric turbitidy units; WS, water supply; dates given in month/day/year format]

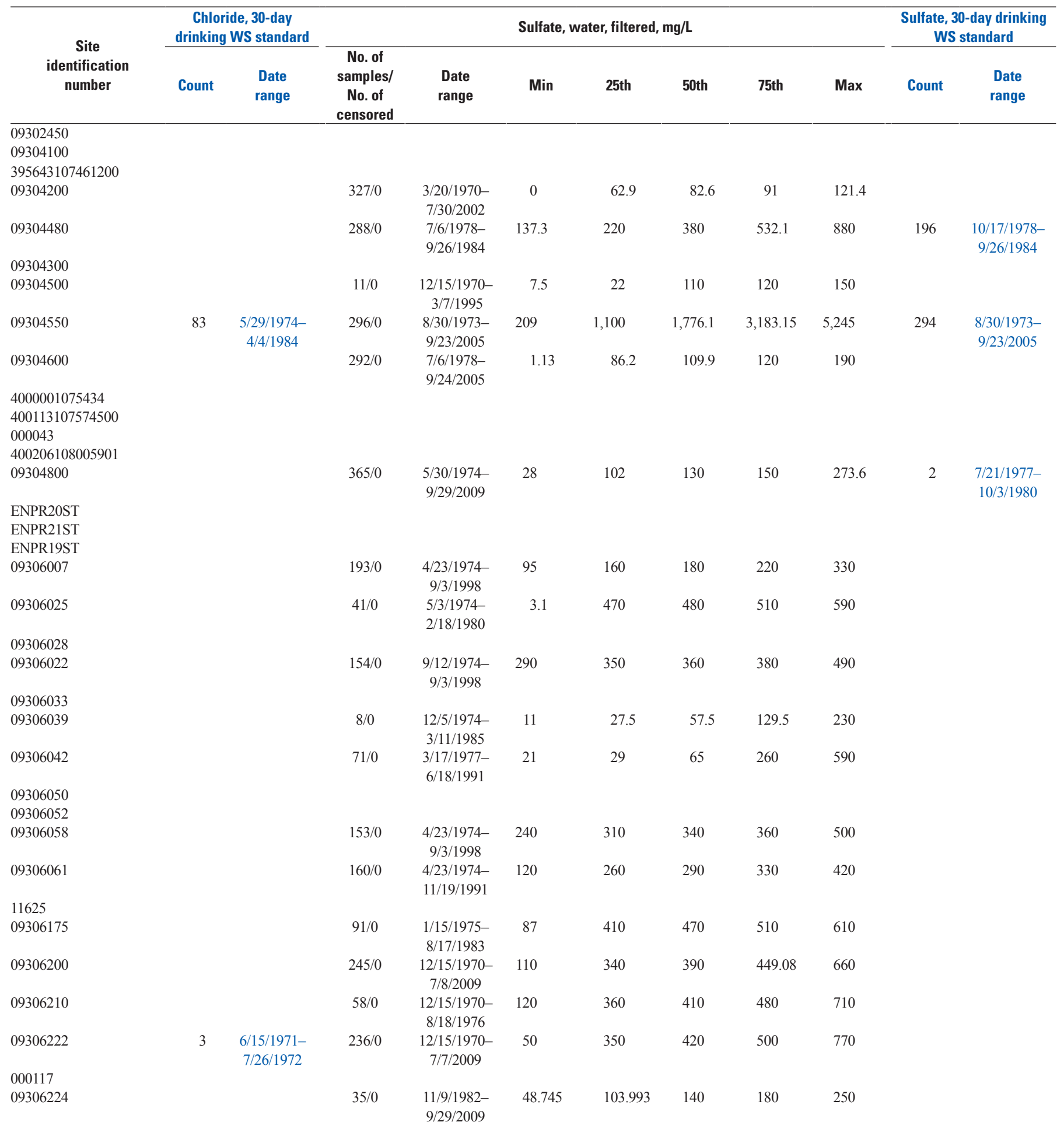


Appendix 1. Summary of surface-water-quality data and comparison to water-quality standards by site, by constituent, Piceance study area, western Colorado. Water-quality standards comparisons follow data summaries and are in blue text; standards are provided in table 3.-Continued

[CDPHE segment, Colorado Department of Health and the Environment stream segment as referred to in tables 2 and 3; latitude and longitude are in North American Datum of 1983; downstream order number assigned as part of analysis. $\mu \mathrm{g} / \mathrm{L}$, micrograms per liter; $\mu \mathrm{S} / \mathrm{cm}$, microsiemens per centimeter; $\mathrm{mg} / \mathrm{L}$, milligrams per liter; mL, milliliters; aq, aquatic; CO, Colorado; EPA, U.S. Environmental Protection Agency; Max, maximum; Min, minimum; NA, not applicable; No., number; NTU, nephelometric turbitidy units; WS, water supply; dates given in month/day/year format]

\begin{tabular}{|c|c|c|c|c|c|c|c|c|c|c|c|}
\hline \multirow[b]{2}{*}{$\begin{array}{c}\text { Site } \\
\text { identification } \\
\text { number }\end{array}$} & \multicolumn{2}{|c|}{$\begin{array}{c}\text { Chloride, 30-day } \\
\text { drinking WS standard }\end{array}$} & \multicolumn{7}{|c|}{ Sulfate, water, filtered, mg/L } & \multicolumn{2}{|c|}{$\begin{array}{c}\text { Sulfate, } 30 \text {-day drinking } \\
\text { WS standard }\end{array}$} \\
\hline & Count & $\begin{array}{l}\text { Date } \\
\text { range }\end{array}$ & $\begin{array}{c}\text { No. of } \\
\text { samples/ } \\
\text { No. of } \\
\text { censored }\end{array}$ & $\begin{array}{l}\text { Date } \\
\text { range }\end{array}$ & Min & 25th & 50th & 75th & Max & Count & $\begin{array}{l}\text { Date } \\
\text { range }\end{array}$ \\
\hline 09306240 & & & $29 / 0$ & $\begin{array}{c}4 / 27 / 1974 \\
3 / 11 / 1985\end{array}$ & 4.7 & 140 & 170 & 190 & 340 & & \\
\hline \multicolumn{12}{|l|}{09306241} \\
\hline 09306235 & & & $88 / 0$ & $\begin{array}{c}3 / 14 / 1974 \\
11 / 8 / 1988\end{array}$ & 52 & 270 & 280 & 300 & 610 & & \\
\hline 09306242 & & & $195 / 0$ & $\begin{array}{c}3 / 14 / 1974 \\
7 / 8 / 2009\end{array}$ & 52 & 290 & 350 & 393.821 & 540 & & \\
\hline 09306244 & & & $24 / 0$ & $\begin{array}{c}6 / 12 / 1975- \\
10 / 24 / 1978\end{array}$ & 480 & 520 & 560 & 580 & 610 & & \\
\hline \multicolumn{12}{|l|}{11702} \\
\hline 09306255 & & & $167 / 0$ & $\begin{array}{c}5 / 16 / 1972- \\
7 / 7 / 2009\end{array}$ & 75 & 560 & 640 & 864.17 & 1,300 & & \\
\hline 09306290 & & & $93 / 0$ & $\begin{array}{c}11 / 9 / 1982- \\
9 / 30 / 2009\end{array}$ & 48 & 130 & 180 & 210 & 290 & 6 & $\begin{array}{c}4 / 11 / 1984 \\
3 / 24 / 1993\end{array}$ \\
\hline 09306300 & & & $77 / 0$ & $\begin{array}{l}8 / 6 / 1975- \\
9 / 22 / 1982\end{array}$ & 42 & 140 & 170 & 190 & 310 & 5 & $\begin{array}{c}9 / 11 / 1975- \\
3 / 27 / 1979\end{array}$ \\
\hline 09306305 & & & $8 / 0$ & $\begin{array}{c}4 / 21 / 1995- \\
7 / 31 / 2002\end{array}$ & 50 & 88 & 150 & 185 & 234.03 & & \\
\hline 09306380 & & & $12 / 0$ & $\begin{array}{l}2 / 8 / 1977- \\
11 / 8 / 1995\end{array}$ & 330 & 345 & 510 & 985 & 1,700 & & \\
\hline \multicolumn{12}{|l|}{$\begin{array}{l}400535108485700 \\
000044\end{array}$} \\
\hline 09072500 & 3 & $\begin{array}{l}11 / 2 / 1960 \\
12 / 10 / 1963\end{array}$ & $52 / 0$ & $\begin{array}{c}11 / 29 / 1958- \\
3 / 24 / 1966\end{array}$ & 27 & 56 & 98 & 114.5 & 155 & & \\
\hline \multicolumn{11}{|l|}{ CDOWRW-46 } & 12100 \\
\hline \multicolumn{12}{|l|}{ CDOWRW-47 } \\
\hline 09085100 & 14 & $\begin{array}{l}1 / 16 / 1981- \\
12 / 24 / 1981\end{array}$ & $250 / 0$ & $\begin{array}{c}12 / 6 / 1977- \\
6 / 19 / 1995\end{array}$ & 0 & 76 & 103 & 121 & 190 & & \\
\hline \multicolumn{12}{|l|}{$11109 \mathrm{~A}$} \\
\hline 09085150 & & & $21 / 0$ & $\begin{array}{c}4 / 13 / 2006- \\
9 / 8 / 2009\end{array}$ & 29.307 & 48.981 & 89.309 & 109.479 & 122.563 & & \\
\hline \multicolumn{12}{|l|}{09085200} \\
\hline \multicolumn{12}{|l|}{09085400} \\
\hline \multicolumn{12}{|l|}{09085300} \\
\hline \multicolumn{12}{|l|}{000047} \\
\hline \multicolumn{12}{|l|}{ CDOWRW-546 } \\
\hline \multicolumn{7}{|l|}{09086470} & & & & & \\
\hline \multicolumn{12}{|l|}{09086000} \\
\hline \multicolumn{12}{|l|}{09086970} \\
\hline \multicolumn{12}{|l|}{11195} \\
\hline \multicolumn{12}{|l|}{ CDOWRW-547 } \\
\hline 09087600 & & & $18 / 0$ & $\begin{array}{c}\text { 7/31/2002- } \\
11 / 7 / 2008\end{array}$ & 27.967 & 54.577 & 91.490 & 107.518 & 142.86 & & \\
\hline \multicolumn{12}{|l|}{11189} \\
\hline \multicolumn{12}{|l|}{09089000} \\
\hline 09089500 & & & $20 / 0$ & $\begin{array}{l}5 / 1 / 1986- \\
8 / 23 / 1990\end{array}$ & 4 & 9.2 & 11 & 16.75 & 32 & & \\
\hline $\begin{array}{l}\text { LANG6ST } \\
\text { LANG5ST } \\
\text { LANG4ST }\end{array}$ & & & & & & & & & & & \\
\hline
\end{tabular}


Appendix 1. Summary of surface-water-quality data and comparison to water-quality standards by site, by constituent, Piceance study area, western Colorado. Water-quality standards comparisons follow data summaries and are in blue text; standards are provided in table 3.-Continued

[CDPHE segment, Colorado Department of Health and the Environment stream segment as referred to in tables 2 and 3; latitude and longitude are in North American Datum of 1983; downstream order number assigned as part of analysis. $\mu \mathrm{g} / \mathrm{L}$, micrograms per liter; $\mu \mathrm{S} / \mathrm{cm}$, microsiemens per centimeter; mg/L, milligrams per liter; mL, milliliters; aq, aquatic; CO, Colorado; EPA, U.S. Environmental Protection Agency; Max, maximum; Min, minimum; NA, not applicable; No., number; NTU, nephelometric turbitidy units; WS, water supply; dates given in month/day/year format]

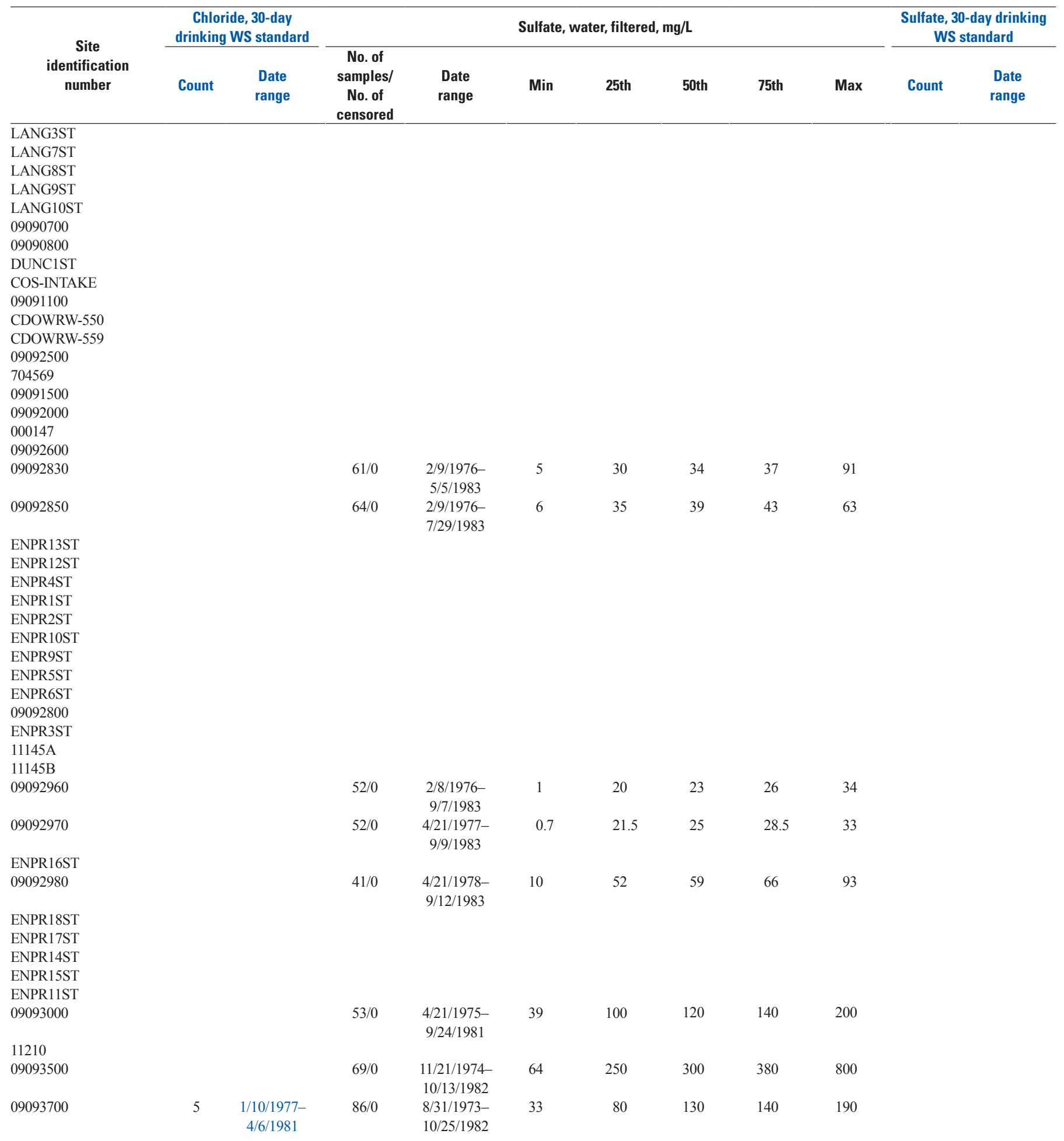


Appendix 1. Summary of surface-water-quality data and comparison to water-quality standards by site, by constituent, Piceance study area, western Colorado. Water-quality standards comparisons follow data summaries and are in blue text; standards are provided in table 3.-Continued

[CDPHE segment, Colorado Department of Health and the Environment stream segment as referred to in tables 2 and 3; latitude and longitude are in North American Datum of 1983; downstream order number assigned as part of analysis. $\mu \mathrm{g} / \mathrm{L}$, micrograms per liter; $\mu \mathrm{S} / \mathrm{cm}$, microsiemens per centimeter; $\mathrm{mg} / \mathrm{L}$, milligrams per liter; mL, milliliters; aq, aquatic; CO, Colorado; EPA, U.S. Environmental Protection Agency; Max, maximum; Min, minimum; NA, not applicable; No., number; NTU, nephelometric turbitidy units; WS, water supply; dates given in month/day/year format]

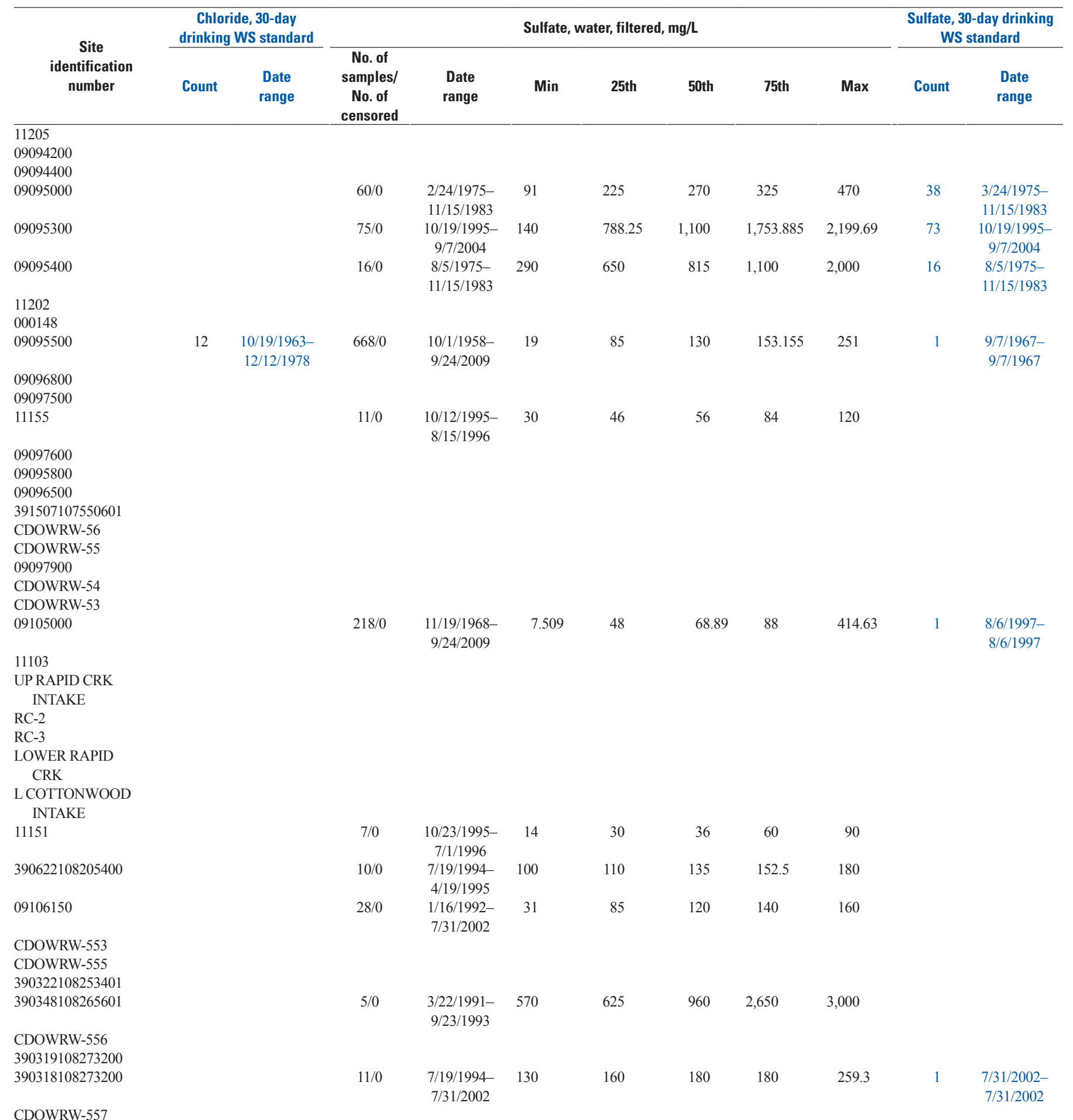


Appendix 1. Summary of surface-water-quality data and comparison to water-quality standards by site, by constituent, Piceance study area, western Colorado. Water-quality standards comparisons follow data summaries and are in blue text; standards are provided in table 3.-Continued

[CDPHE segment, Colorado Department of Health and the Environment stream segment as referred to in tables 2 and 3; latitude and longitude are in North American Datum of 1983; downstream order number assigned as part of analysis. $\mu \mathrm{g} / \mathrm{L}$, micrograms per liter; $\mu \mathrm{S} / \mathrm{cm}$, microsiemens per centimeter; mg/L, milligrams per liter; mL, milliliters; aq, aquatic; CO, Colorado; EPA, U.S. Environmental Protection Agency; Max, maximum; Min, minimum; NA, not applicable; No., number; NTU, nephelometric turbitidy units; WS, water supply; dates given in month/day/year format]

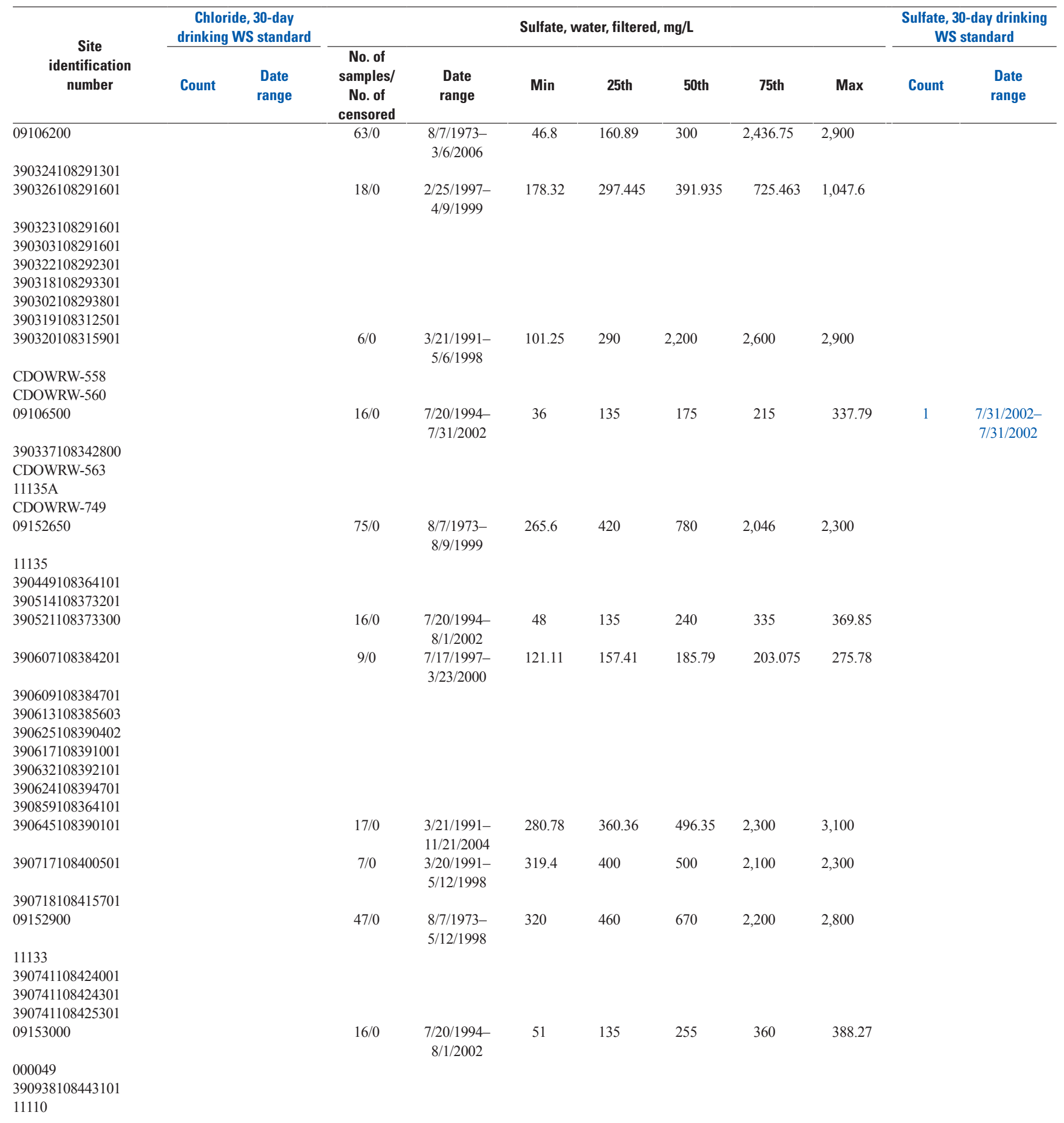


Appendix 1. Summary of surface-water-quality data and comparison to water-quality standards by site, by constituent, Piceance study area, western Colorado. Water-quality standards comparisons follow data summaries and are in blue text; standards are provided in table 3.-Continued

[CDPHE segment, Colorado Department of Health and the Environment stream segment as referred to in tables 2 and 3; latitude and longitude are in North American Datum of 1983; downstream order number assigned as part of analysis. $\mu \mathrm{g} / \mathrm{L}$, micrograms per liter; $\mu \mathrm{S} / \mathrm{cm}$, microsiemens per centimeter; mg/L, milligrams per liter; mL, milliliters; aq, aquatic; CO, Colorado; EPA, U.S. Environmental Protection Agency; Max, maximum; Min, minimum; NA, not applicable; No., number; NTU, nephelometric turbitidy units; WS, water supply; dates given in month/day/year format]

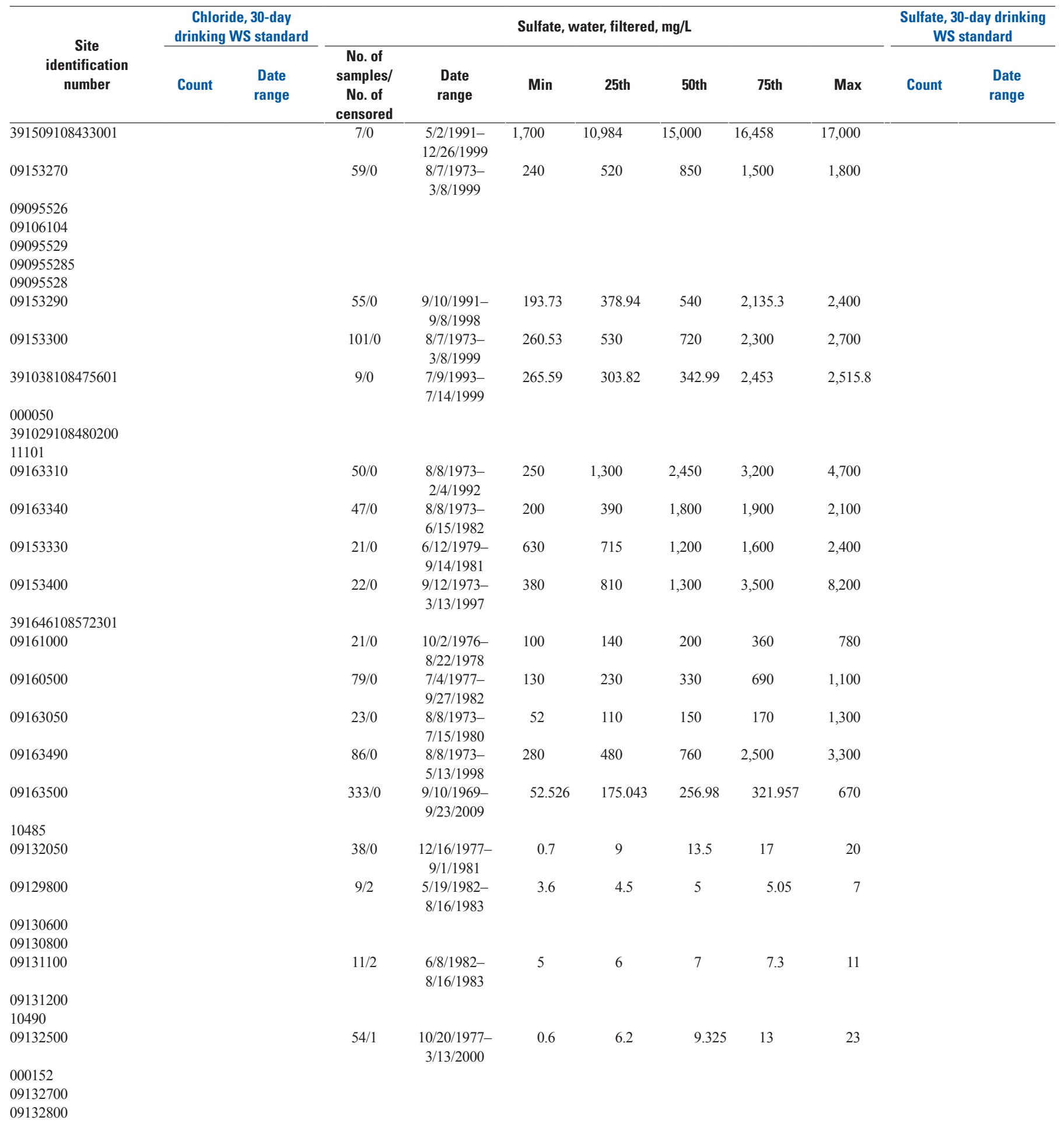


Appendix 1. Summary of surface-water-quality data and comparison to water-quality standards by site, by constituent, Piceance study area, western Colorado. Water-quality standards comparisons follow data summaries and are in blue text; standards are provided in table 3.-Continued

[CDPHE segment, Colorado Department of Health and the Environment stream segment as referred to in tables 2 and 3; latitude and longitude are in North American Datum of 1983; downstream order number assigned as part of analysis. $\mu \mathrm{g} / \mathrm{L}$, micrograms per liter; $\mu \mathrm{S} / \mathrm{cm}$, microsiemens per centimeter; mg/L, milligrams per liter; mL, milliliters; aq, aquatic; CO, Colorado; EPA, U.S. Environmental Protection Agency; Max, maximum; Min, minimum; NA, not applicable; No., number; NTU, nephelometric turbitidy units; WS, water supply; dates given in month/day/year format]

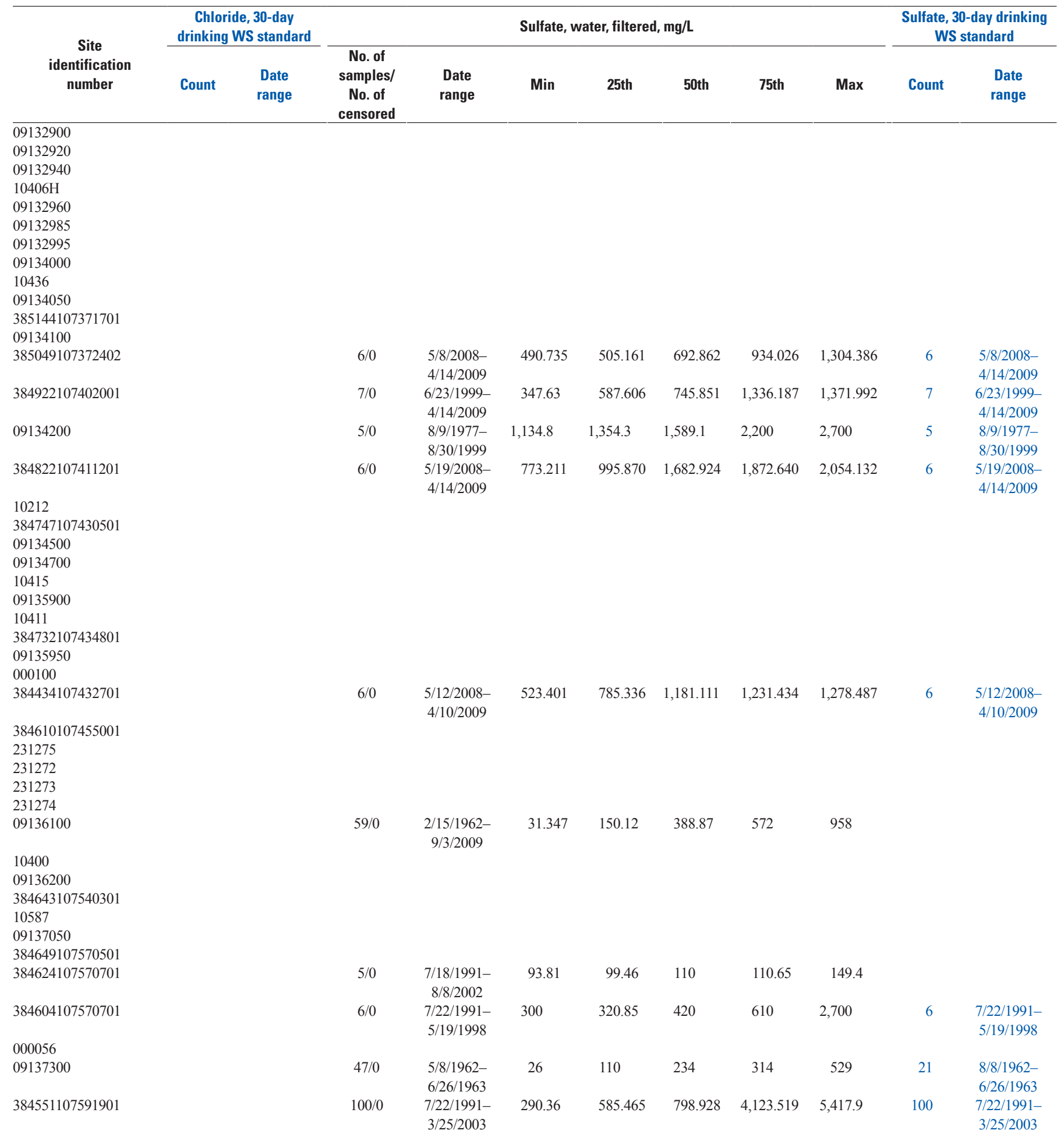


Appendix 1. Summary of surface-water-quality data and comparison to water-quality standards by site, by constituent, Piceance study area, western Colorado. Water-quality standards comparisons follow data summaries and are in blue text; standards are provided in table 3.-Continued

[CDPHE segment, Colorado Department of Health and the Environment stream segment as referred to in tables 2 and 3; latitude and longitude are in North American Datum of 1983; downstream order number assigned as part of analysis. $\mu \mathrm{g} / \mathrm{L}$, micrograms per liter; $\mu \mathrm{S} / \mathrm{cm}$, microsiemens per centimeter; $\mathrm{mg} / \mathrm{L}$, milligrams per liter; mL, milliliters; aq, aquatic; CO, Colorado; EPA, U.S. Environmental Protection Agency; Max, maximum; Min, minimum; NA, not applicable; No., number; NTU, nephelometric turbitidy units; WS, water supply; dates given in month/day/year format]

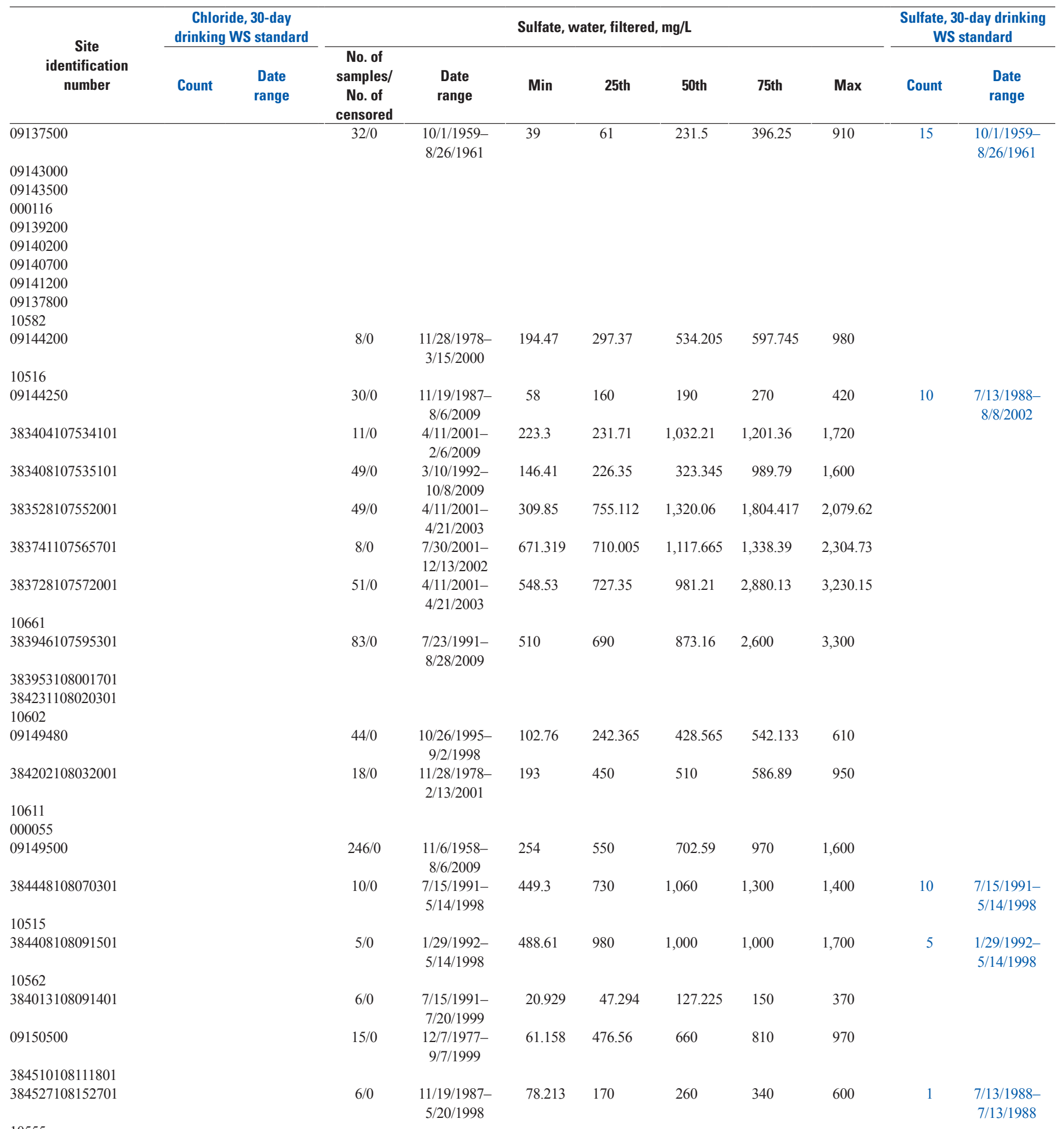

10555 
Appendix 1. Summary of surface-water-quality data and comparison to water-quality standards by site, by constituent, Piceance study area, western Colorado. Water-quality standards comparisons follow data summaries and are in blue text; standards are provided in table 3.-Continued

[CDPHE segment, Colorado Department of Health and the Environment stream segment as referred to in tables 2 and 3; latitude and longitude are in North American Datum of 1983; downstream order number assigned as part of analysis. $\mu \mathrm{g} / \mathrm{L}$, micrograms per liter; $\mu \mathrm{S} / \mathrm{cm}$, microsiemens per centimeter; mg/L, milligrams per liter; mL, milliliters; aq, aquatic; CO, Colorado; EPA, U.S. Environmental Protection Agency; Max, maximum; Min, minimum; NA, not applicable; No., number; NTU, nephelometric turbitidy units; WS, water supply; dates given in month/day/year format]

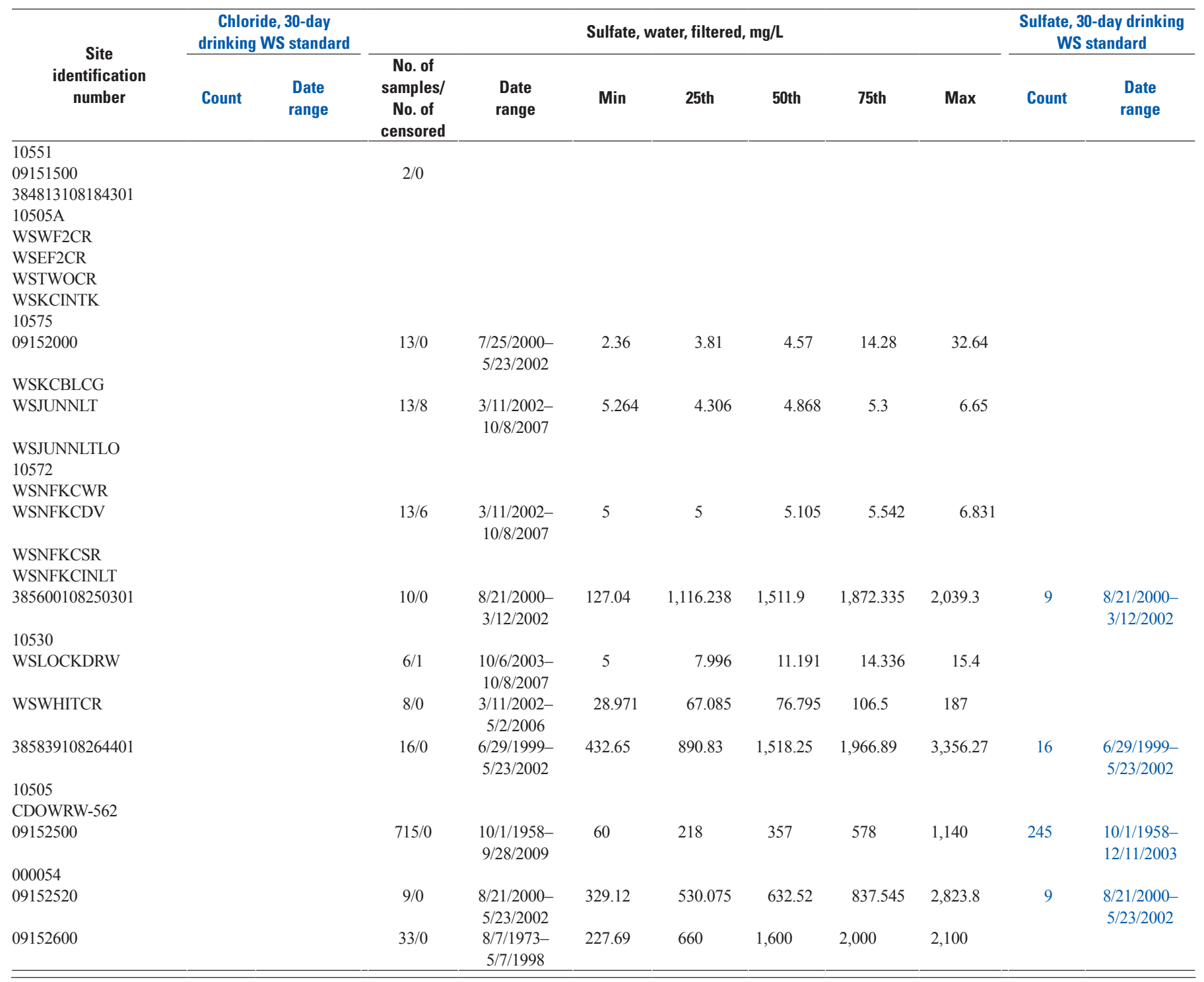


Appendix 1. Summary of surface-water-quality data and comparison to water-quality standards by site, by constituent, Piceance study area, western Colorado. Water-quality standards comparisons follow data summaries and are in blue text; standards are provided in table 3.-Continued

[CDPHE segment, Colorado Department of Health and the Environment stream segment as referred to in tables 2 and 3; latitude and longitude are in North American Datum of 1983; downstream order number assigned as part of analysis. $\mu \mathrm{g} / \mathrm{L}$, micrograms per liter; $\mu \mathrm{S} / \mathrm{cm}$, microsiemens per centimeter; $\mathrm{mg} / \mathrm{L}$, milligrams per liter; mL, milliliters; aq, aquatic; CO, Colorado; EPA, U.S. Environmental Protection Agency; Max, maximum; Min, minimum; NA, not applicable; No., number; NTU, nephelometric turbitidy units; WS, water supply; dates given in month/day/year format]

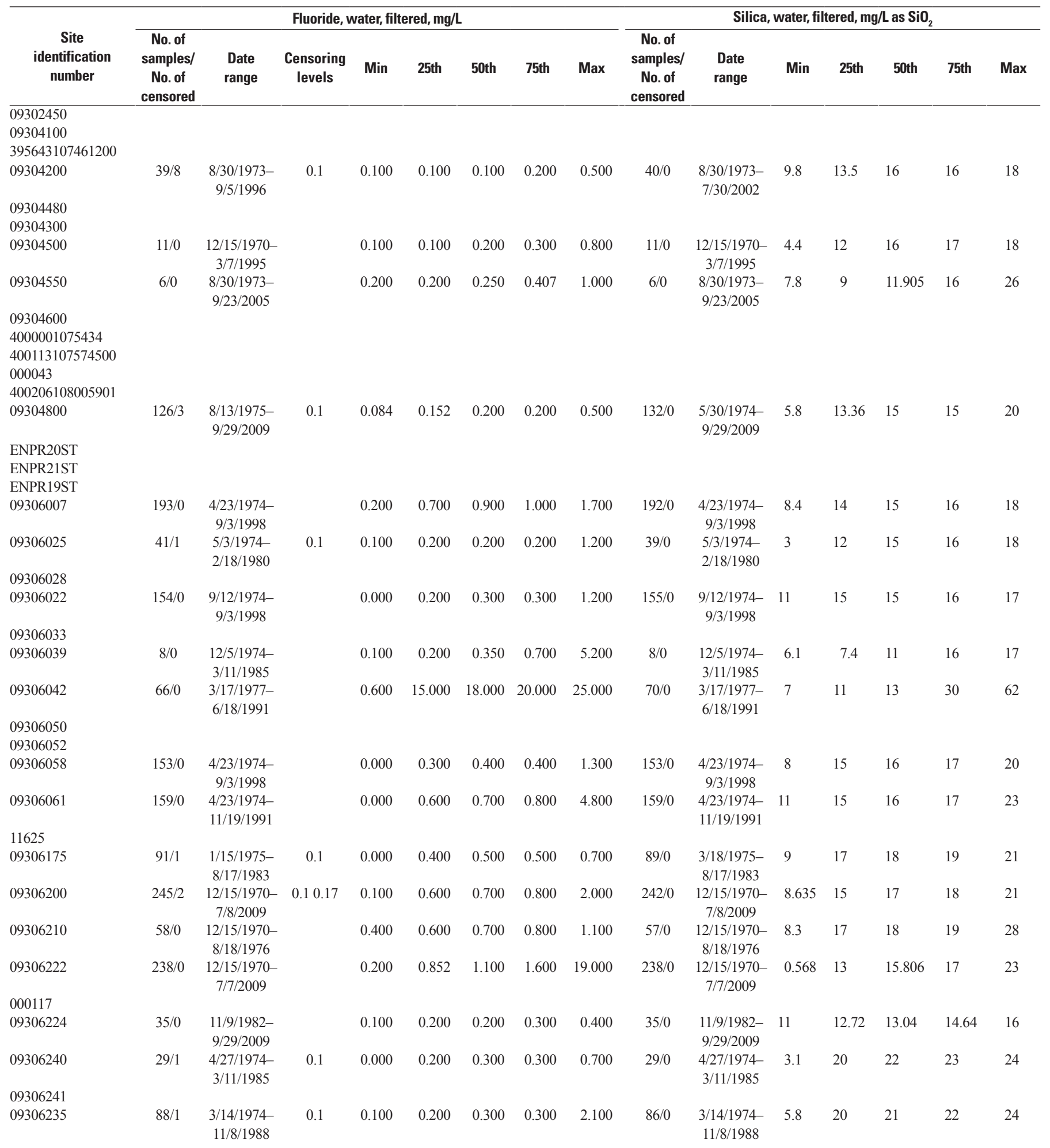


Appendix 1. Summary of surface-water-quality data and comparison to water-quality standards by site, by constituent, Piceance study area, western Colorado. Water-quality standards comparisons follow data summaries and are in blue text; standards are provided in table 3.-Continued

[CDPHE segment, Colorado Department of Health and the Environment stream segment as referred to in tables 2 and 3; latitude and longitude are in North American Datum of 1983; downstream order number assigned as part of analysis. $\mu \mathrm{g} / \mathrm{L}$, micrograms per liter; $\mu \mathrm{S} / \mathrm{cm}$, microsiemens per centimeter; $\mathrm{mg} / \mathrm{L}$, milligrams per liter; mL, milliliters; aq, aquatic; CO, Colorado; EPA, U.S. Environmental Protection Agency; Max, maximum; Min, minimum; NA, not applicable; No., number; NTU, nephelometric turbitidy units; WS, water supply; dates given in month/day/year format]

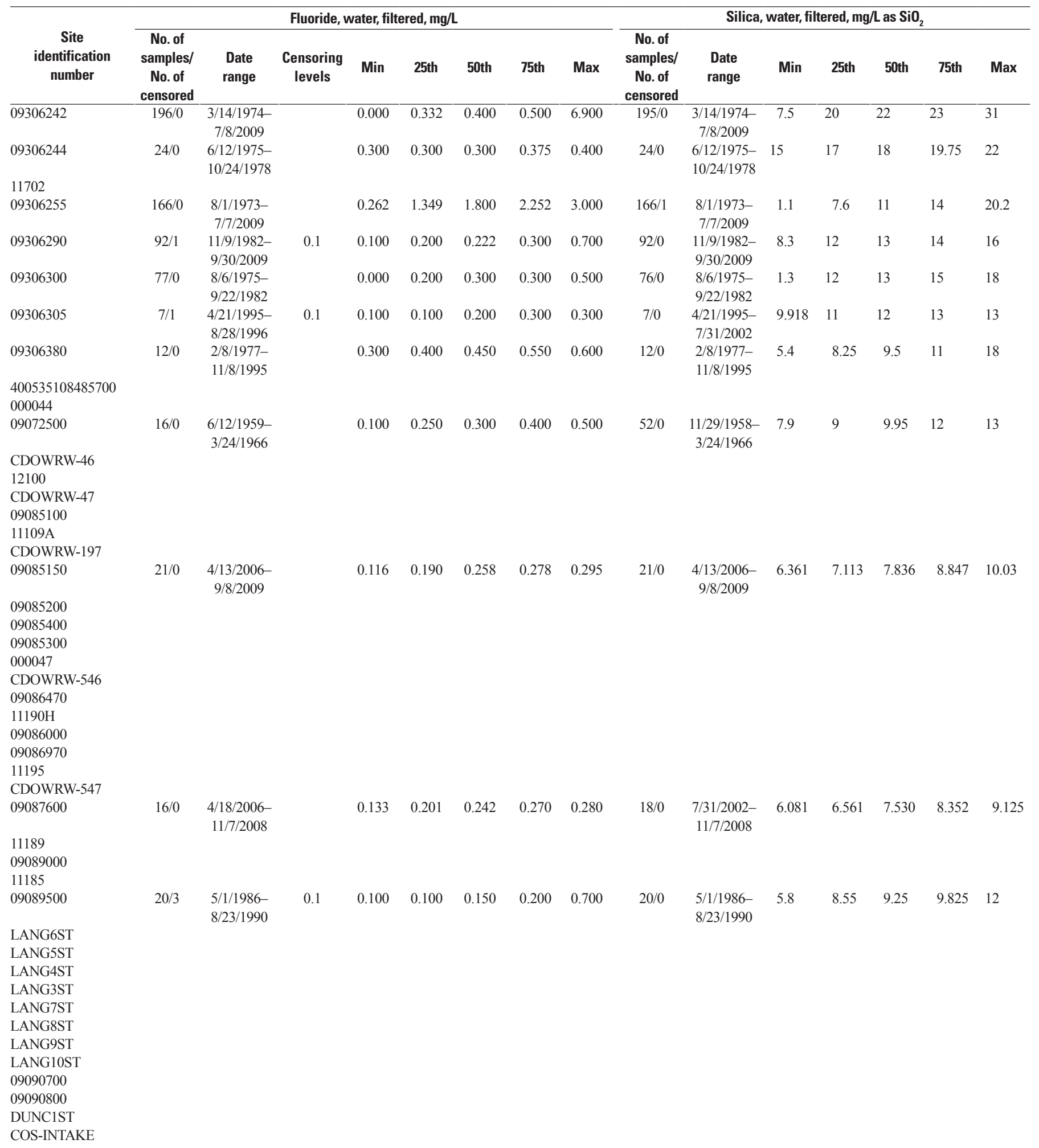


Appendix 1. Summary of surface-water-quality data and comparison to water-quality standards by site, by constituent, Piceance study area, western Colorado. Water-quality standards comparisons follow data summaries and are in blue text; standards are provided in table 3.-Continued

[CDPHE segment, Colorado Department of Health and the Environment stream segment as referred to in tables 2 and 3; latitude and longitude are in North American Datum of 1983; downstream order number assigned as part of analysis. $\mu \mathrm{g} / \mathrm{L}$, micrograms per liter; $\mu \mathrm{S} / \mathrm{cm}$, microsiemens per centimeter; mg/L, milligrams per liter; mL, milliliters; aq, aquatic; CO, Colorado; EPA, U.S. Environmental Protection Agency; Max, maximum; Min, minimum; NA, not applicable; No., number; NTU, nephelometric turbitidy units; WS, water supply; dates given in month/day/year format]

\begin{tabular}{|c|c|c|c|c|c|c|c|c|c|c|c|c|c|c|c|}
\hline \multirow[b]{2}{*}{$\begin{array}{c}\text { Site } \\
\text { identification } \\
\text { number }\end{array}$} & \multicolumn{8}{|c|}{ Fluoride, water, filtered, $\mathrm{mg} / \mathrm{L}$} & \multicolumn{7}{|c|}{ Silica, water, filtered, $\mathrm{mg} / \mathrm{L}$ as $\mathrm{SiO}_{2}$} \\
\hline & $\begin{array}{c}\text { No. of } \\
\text { samples/ } \\
\text { No. of } \\
\text { censored }\end{array}$ & $\begin{array}{l}\text { Date } \\
\text { range }\end{array}$ & $\begin{array}{l}\text { Censoring } \\
\text { levels }\end{array}$ & Min & 25th & 50th & 75th & Max & $\begin{array}{c}\text { No. of } \\
\text { samples/ } \\
\text { No. of } \\
\text { censored }\end{array}$ & $\begin{array}{l}\text { Date } \\
\text { range }\end{array}$ & Min & 25th & 50th & 75th & Max \\
\hline \multicolumn{16}{|l|}{09091100} \\
\hline \multicolumn{16}{|l|}{ CDOWRW-550 } \\
\hline \multicolumn{16}{|l|}{ CDOWRW-559 } \\
\hline \multicolumn{16}{|l|}{09092500} \\
\hline \multicolumn{16}{|l|}{09092000} \\
\hline \multirow{2}{*}{\multicolumn{16}{|c|}{$\begin{array}{l}000147 \\
09092600\end{array}$}} \\
\hline & & & & & & & & & & & & & & & \\
\hline \multicolumn{16}{|c|}{$\begin{array}{lllll}0.100 & 0.200 & 0.200 & 0.200 & 0.300\end{array}$} \\
\hline 09092850 & $64 / 0$ & $\begin{array}{l}\text { 2/9/1976- } \\
7 / 29 / 1983\end{array}$ & & 0.100 & 0.200 & 0.200 & 0.300 & 0.400 & $64 / 0$ & $\begin{array}{l}\text { 2/9/1976- } \\
7 / 29 / 1983\end{array}$ & 12 & 13.5 & 15 & 16 & 18 \\
\hline \multicolumn{16}{|l|}{ ENPR2ST } \\
\hline \multicolumn{16}{|l|}{ ENPR10ST } \\
\hline ENPR9ST & & & & & & & & & & & & & & & \\
\hline ENPR5ST & & & & & & & & & & & & & & & \\
\hline ENPR6ST & & & & & & & & & & & & & & & \\
\hline 09092800 & & & & & & & & & & & & & & & \\
\hline ENPR3ST & & & & & & & & & & & & & & & \\
\hline $11145 \mathrm{~A}$ & & & & & & & & & & & & & & & \\
\hline $11145 \mathrm{~B}$ & & & & & & & & & & & & & & & \\
\hline 09092960 & $52 / 0$ & $\begin{array}{c}2 / 8 / 1976- \\
9 / 7 / 1983\end{array}$ & & 0.100 & 0.200 & 0.200 & 0.200 & 0.500 & $52 / 0$ & $\begin{array}{c}2 / 8 / 1976- \\
9 / 7 / 1983\end{array}$ & 13 & 14 & 15 & 16 & 19 \\
\hline 09092970 & $52 / 1$ & $\begin{array}{c}\text { 4/21/1977- } \\
\text { 9/9/1983 }\end{array}$ & 0.1 & 0.100 & 0.200 & 0.200 & 0.200 & 0.300 & $52 / 0$ & $\begin{array}{c}\text { 4/21/1977- } \\
\text { 9/9/1983 }\end{array}$ & 11 & 14 & 15 & 16 & 19 \\
\hline ENPR16ST & & & & & & & & & & & & & & & \\
\hline 11210 & & & & & & & & & & & & & & & \\
\hline 09093500 & $69 / 0$ & $\begin{array}{c}11 / 21 / 1974 \\
10 / 13 / 1982\end{array}$ & & 0.300 & 0.700 & 0.800 & 0.900 & 3.700 & $67 / 0$ & $\begin{array}{c}11 / 21 / 1974 \\
10 / 13 / 1982\end{array}$ & 14 & 17 & 17 & 19 & 23 \\
\hline 09093700 & $86 / 0$ & $\begin{array}{l}8 / 31 / 1973- \\
10 / 25 / 1982\end{array}$ & & 0.000 & 0.200 & 0.300 & 0.300 & 0.800 & $86 / 0$ & $\begin{array}{l}8 / 31 / 1973- \\
10 / 25 / 1982\end{array}$ & 0.4 & 7.3 & 7.95 & 8.8 & 11 \\
\hline 11205 & & & & & & & & & & & & & & & \\
\hline $\begin{array}{l}09094200 \\
09094400\end{array}$ & & & & & & & & & & & & & & & \\
\hline 09095000 & $62 / 0$ & $\begin{array}{l}2 / 24 / 1975- \\
11 / 15 / 1983\end{array}$ & & 0.100 & 0.600 & 0.700 & 0.800 & 1.000 & $60 / 0$ & $\begin{array}{l}2 / 24 / 1975- \\
11 / 15 / 1983\end{array}$ & 11 & 15 & 16 & 17 & 18 \\
\hline 09095300 & $54 / 0$ & $\begin{array}{c}10 / 19 / 1995- \\
8 / 2 / 2002\end{array}$ & & 0.200 & 0.300 & 0.321 & 0.367 & 0.500 & $54 / 0$ & $\begin{array}{c}10 / 19 / 1995- \\
8 / 2 / 2002\end{array}$ & 0.17 & 10 & 14.047 & 16 & 17.786 \\
\hline 09095400 & $16 / 0$ & $\begin{array}{c}8 / 5 / 1975- \\
11 / 15 / 1983\end{array}$ & & 0.300 & 0.300 & 0.300 & 0.400 & 0.500 & $16 / 0$ & $\begin{array}{c}8 / 5 / 1975- \\
11 / 15 / 1983\end{array}$ & 7 & 13.5 & 16 & 17.5 & 20 \\
\hline $\begin{array}{l}11202 \\
000148\end{array}$ & & & & & & & & & & & & & & & \\
\hline
\end{tabular}


Appendix 1. Summary of surface-water-quality data and comparison to water-quality standards by site, by constituent, Piceance study area, western Colorado. Water-quality standards comparisons follow data summaries and are in blue text; standards are provided in table 3.-Continued

[CDPHE segment, Colorado Department of Health and the Environment stream segment as referred to in tables 2 and 3; latitude and longitude are in North American Datum of 1983; downstream order number assigned as part of analysis. $\mu \mathrm{g} / \mathrm{L}$, micrograms per liter; $\mu \mathrm{S} / \mathrm{cm}$, microsiemens per centimeter; $\mathrm{mg} / \mathrm{L}$, milligrams per liter; mL, milliliters; aq, aquatic; CO, Colorado; EPA, U.S. Environmental Protection Agency; Max, maximum; Min, minimum; NA, not applicable; No., number; NTU, nephelometric turbitidy units; WS, water supply; dates given in month/day/year format]

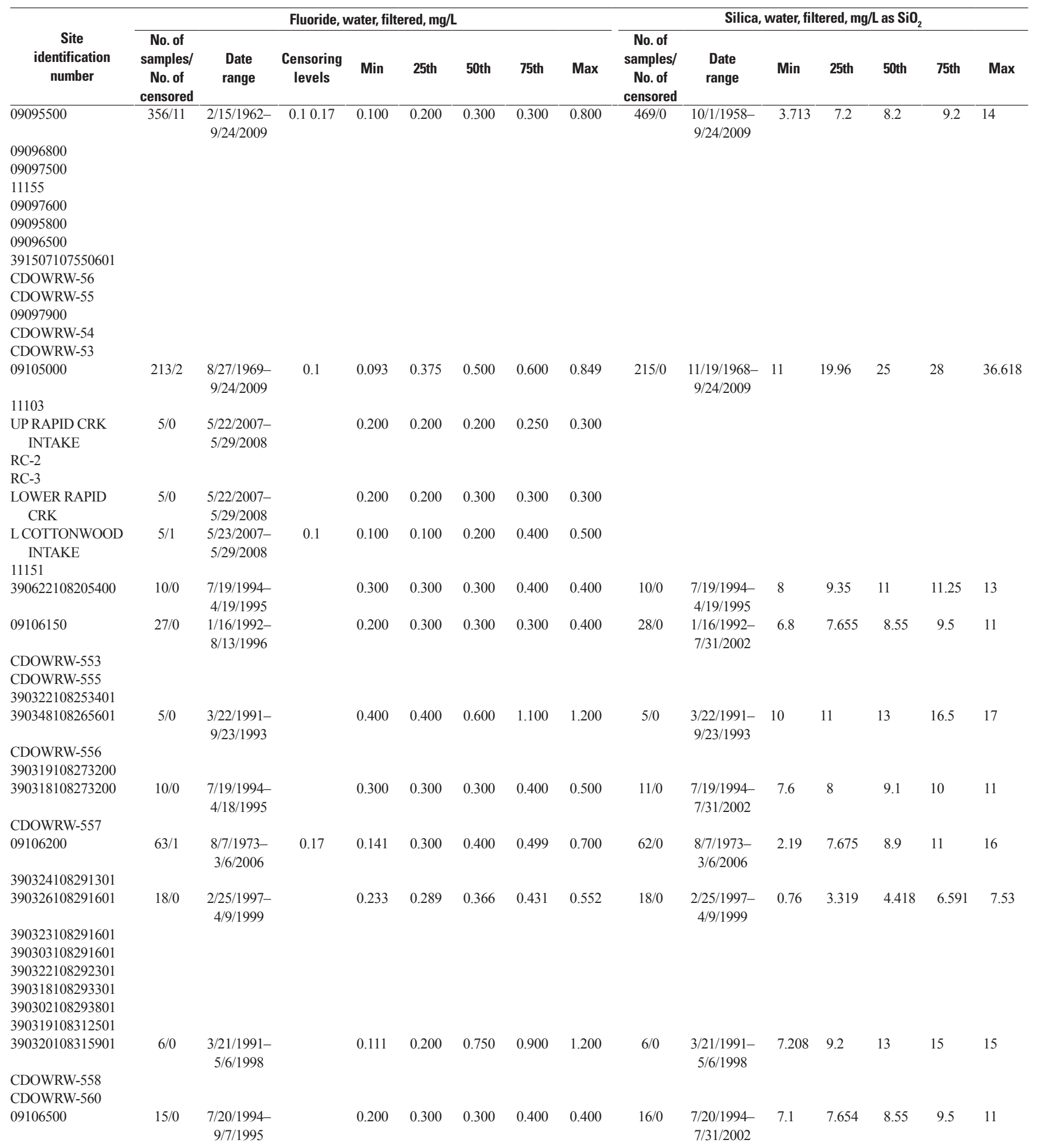


Appendix 1. Summary of surface-water-quality data and comparison to water-quality standards by site, by constituent, Piceance study area, western Colorado. Water-quality standards comparisons follow data summaries and are in blue text; standards are provided in table 3.-Continued

[CDPHE segment, Colorado Department of Health and the Environment stream segment as referred to in tables 2 and 3; latitude and longitude are in North American Datum of 1983; downstream order number assigned as part of analysis. $\mu \mathrm{g} / \mathrm{L}$, micrograms per liter; $\mu \mathrm{S} / \mathrm{cm}$, microsiemens per centimeter; mg/L, milligrams per liter; mL, milliliters; aq, aquatic; CO, Colorado; EPA, U.S. Environmental Protection Agency; Max, maximum; Min, minimum; NA, not applicable; No., number; NTU, nephelometric turbitidy units; WS, water supply; dates given in month/day/year format]

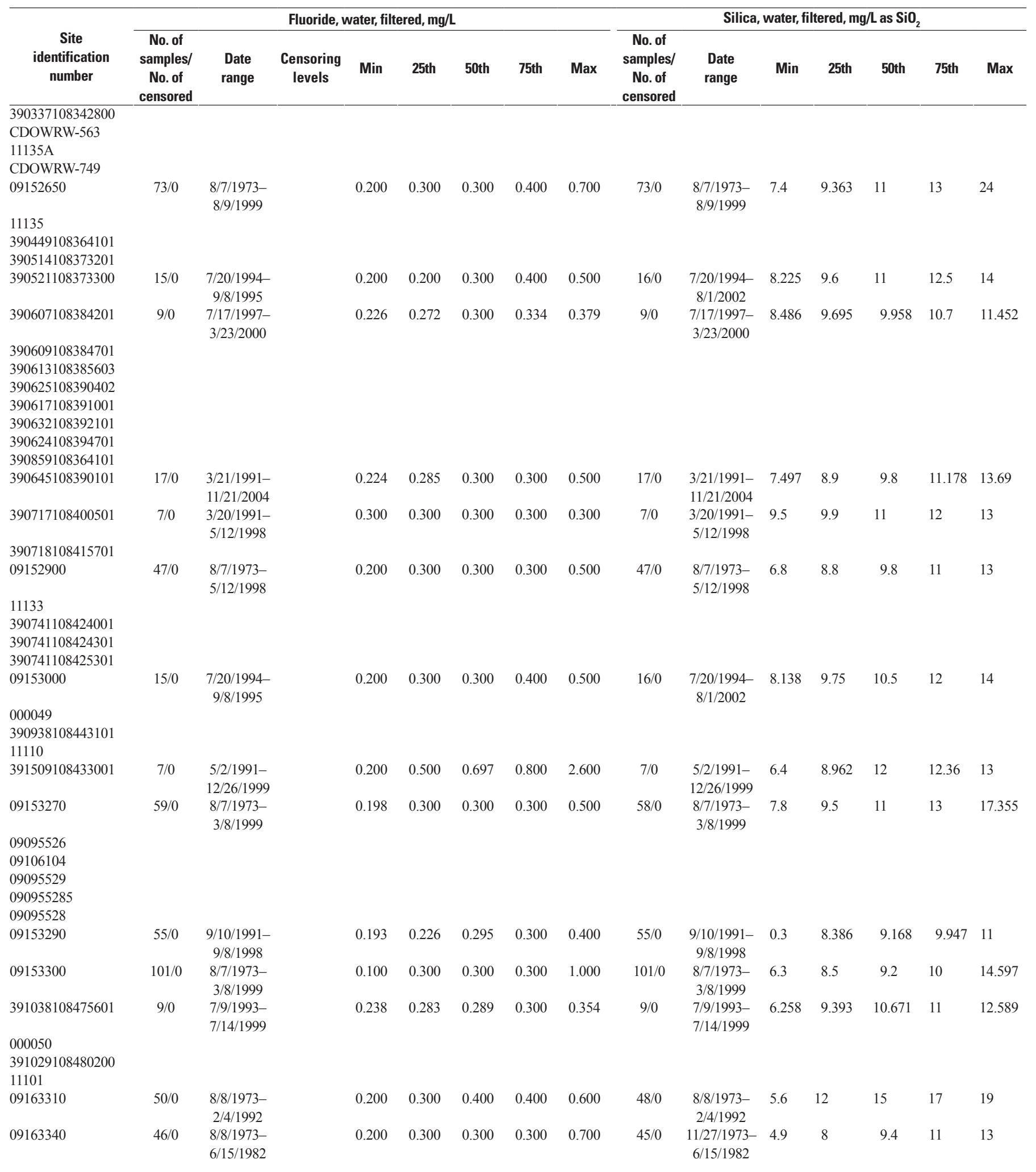


Appendix 1. Summary of surface-water-quality data and comparison to water-quality standards by site, by constituent, Piceance study area, western Colorado. Water-quality standards comparisons follow data summaries and are in blue text; standards are provided in table 3.-Continued

[CDPHE segment, Colorado Department of Health and the Environment stream segment as referred to in tables 2 and 3; latitude and longitude are in North American Datum of 1983; downstream order number assigned as part of analysis. $\mu \mathrm{g} / \mathrm{L}$, micrograms per liter; $\mu \mathrm{S} / \mathrm{cm}$, microsiemens per centimeter; mg/L, milligrams per liter; mL, milliliters; aq, aquatic; CO, Colorado; EPA, U.S. Environmental Protection Agency; Max, maximum; Min, minimum; NA, not applicable; No., number; NTU, nephelometric turbitidy units; WS, water supply; dates given in month/day/year format]

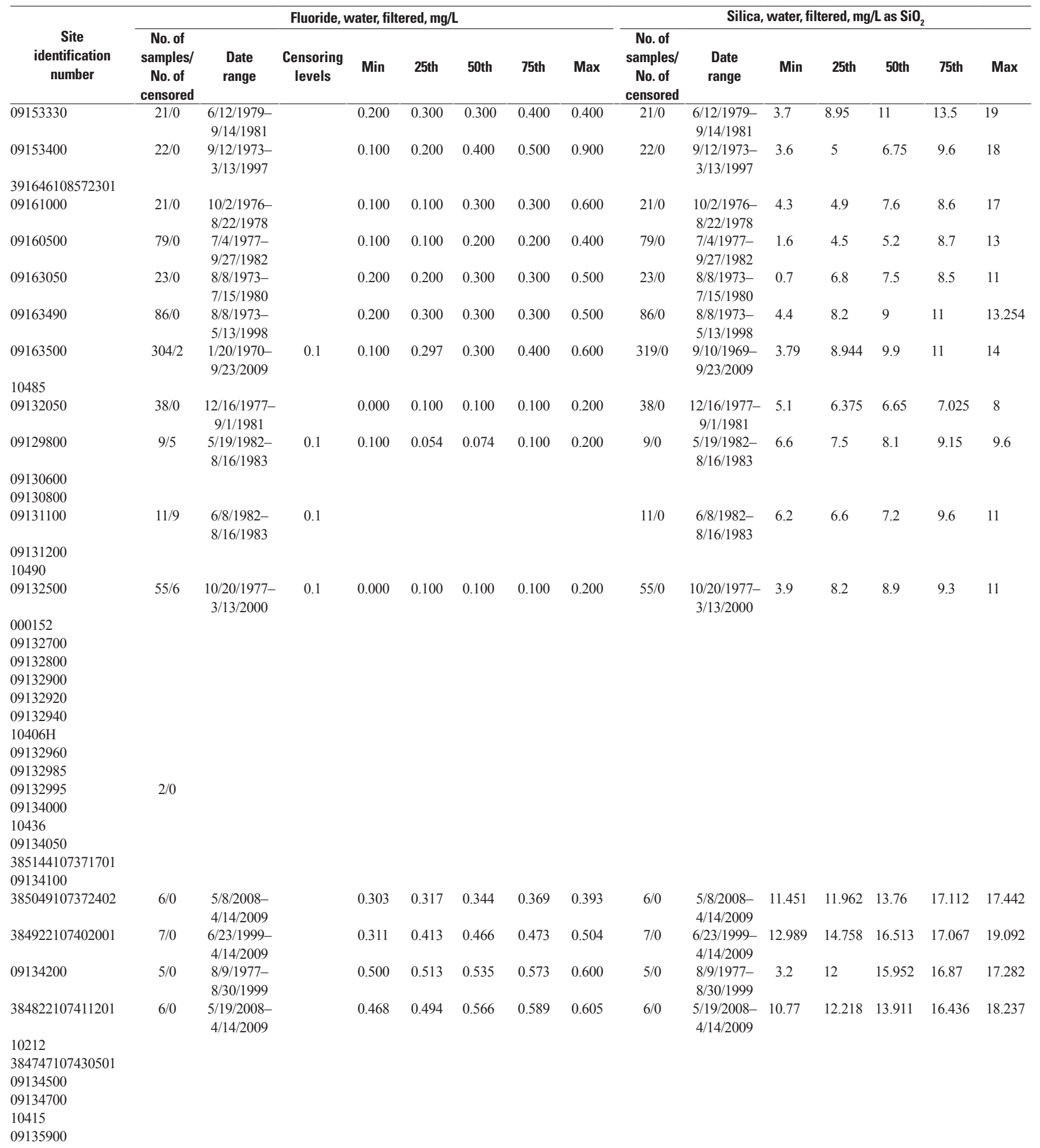


Appendix 1. Summary of surface-water-quality data and comparison to water-quality standards by site, by constituent, Piceance study area, western Colorado. Water-quality standards comparisons follow data summaries and are in blue text; standards are provided in table 3.-Continued

[CDPHE segment, Colorado Department of Health and the Environment stream segment as referred to in tables 2 and 3; latitude and longitude are in North American Datum of 1983; downstream order number assigned as part of analysis. $\mu \mathrm{g} / \mathrm{L}$, micrograms per liter; $\mu \mathrm{S} / \mathrm{cm}$, microsiemens per centimeter; mg/L, milligrams per liter; mL, milliliters; aq, aquatic; CO, Colorado; EPA, U.S. Environmental Protection Agency; Max, maximum; Min, minimum; NA, not applicable; No., number; NTU, nephelometric turbitidy units; WS, water supply; dates given in month/day/year format]

\begin{tabular}{|c|c|c|c|c|c|c|c|c|c|c|c|c|c|c|c|}
\hline \multirow[b]{2}{*}{$\begin{array}{c}\text { Site } \\
\text { identification } \\
\text { number }\end{array}$} & \multicolumn{8}{|c|}{ Fluoride, water, filtered, $\mathrm{mg} / \mathrm{L}$} & \multicolumn{7}{|c|}{ Silica, water, filtered, $\mathrm{mg} / \mathrm{L}$ as $\mathrm{SiO}_{2}$} \\
\hline & $\begin{array}{c}\text { No. of } \\
\text { samples/ } \\
\text { No. of } \\
\text { censored }\end{array}$ & $\begin{array}{l}\text { Date } \\
\text { range }\end{array}$ & $\begin{array}{l}\text { Censoring } \\
\text { levels }\end{array}$ & Min & 25th & 50th & 75th & Max & $\begin{array}{c}\text { No. of } \\
\text { samples/ } \\
\text { No. of } \\
\text { censored }\end{array}$ & $\begin{array}{l}\text { Date } \\
\text { range }\end{array}$ & Min & 25th & 50th & 75th & Max \\
\hline \multicolumn{16}{|l|}{$\overline{10411}$} \\
\hline \multicolumn{16}{|l|}{384732107434801} \\
\hline \multicolumn{16}{|l|}{09135950} \\
\hline \multicolumn{16}{|l|}{000100} \\
\hline \multicolumn{16}{|l|}{384610107455001} \\
\hline \multicolumn{16}{|l|}{231275} \\
\hline \multicolumn{16}{|l|}{231272} \\
\hline \multirow{2}{*}{\multicolumn{16}{|c|}{$\begin{array}{l}231273 \\
231274\end{array}$}} \\
\hline & & & & & & & & & & & & & & & \\
\hline \multirow[t]{2}{*}{09136100} & $44 / 0$ & $\begin{array}{c}2 / 15 / 1962- \\
9 / 3 / 2009\end{array}$ & & 0.068 & 0.200 & 0.394 & 0.500 & 0.616 & $44 / 0$ & $\begin{array}{c}2 / 15 / 1962- \\
9 / 3 / 2009\end{array}$ & 9.377 & 11.118 & 16.148 & 19.448 & 23.26 \\
\hline & \multicolumn{15}{|c|}{$\begin{array}{l}10400 \\
09136200\end{array}$} \\
\hline \multicolumn{10}{|l|}{$\begin{array}{l}10587 \\
09137050\end{array}$} & & & & & & \\
\hline \multicolumn{16}{|l|}{384649107570501} \\
\hline 384624107570701 & $5 / 0$ & $\begin{array}{c}7 / 18 / 1991- \\
8 / 8 / 2002\end{array}$ & & 0.193 & 0.249 & 0.268 & 0.272 & 0.300 & & & & & & & \\
\hline 384604107570701 & $6 / 0$ & $\begin{array}{c}7 / 22 / 1991- \\
5 / 19 / 1998\end{array}$ & & 0.288 & 0.400 & 0.400 & 0.400 & 0.500 & $6 / 0$ & $\begin{array}{c}7 / 22 / 1991- \\
5 / 19 / 1998\end{array}$ & 5.6 & 13 & 14 & 14 & 14.873 \\
\hline \multicolumn{16}{|l|}{000056} \\
\hline 09137300 & $5 / 0$ & $\begin{array}{l}5 / 8 / 1962- \\
6 / 11 / 1963\end{array}$ & & 0.200 & 0.200 & 0.300 & 0.350 & 0.400 & $5 / 0$ & $\begin{array}{l}5 / 8 / 1962- \\
6 / 11 / 1963\end{array}$ & 11 & 11 & 12 & 14 & 15 \\
\hline 384551107591901 & $100 / 0$ & $\begin{array}{c}7 / 22 / 1991- \\
3 / 25 / 2003\end{array}$ & & 0.200 & 0.304 & 0.370 & 0.400 & 0.506 & $100 / 0$ & $\begin{array}{c}7 / 22 / 1991- \\
3 / 25 / 2003\end{array}$ & 4.824 & 8.428 & 11.828 & 13.138 & 16.124 \\
\hline 09137500 & & & & & & & & & $32 / 0$ & $\begin{array}{c}10 / 1 / 1959 \\
8 / 26 / 1961\end{array}$ & 9.6 & 12 & 14 & 15.75 & 22 \\
\hline \multicolumn{16}{|l|}{09143000} \\
\hline 10516 & & & & & & & & & & & & & & & \\
\hline 09144250 & $26 / 0$ & $\begin{array}{c}12 / 20 / 1990- \\
8 / 6 / 2009\end{array}$ & & 0.200 & 0.235 & 0.299 & 0.300 & 0.400 & $26 / 0$ & $\begin{array}{c}12 / 20 / 1990- \\
8 / 6 / 2009\end{array}$ & 11 & 12 & 12.703 & 13 & 15 \\
\hline 383404107534101 & $11 / 0$ & $\begin{array}{c}4 / 11 / 2001- \\
2 / 6 / 2009\end{array}$ & & 0.260 & 0.277 & 0.534 & 0.549 & 0.569 & $11 / 0$ & $\begin{array}{c}4 / 11 / 2001- \\
2 / 6 / 2009\end{array}$ & 11.761 & 13.035 & 20.938 & 21.364 & 22.250 \\
\hline 383408107535101 & $49 / 0$ & $\begin{array}{c}3 / 10 / 1992- \\
10 / 8 / 2009\end{array}$ & & 0.239 & 0.300 & 0.329 & 0.495 & 0.671 & $49 / 0$ & $\begin{array}{c}3 / 10 / 1992- \\
10 / 8 / 2009\end{array}$ & 9.8 & 12.049 & 13.164 & 19.367 & 23.137 \\
\hline 383528107552001 & $51 / 0$ & $\begin{array}{c}4 / 11 / 2001- \\
4 / 21 / 2003\end{array}$ & & 0.273 & 0.351 & 0.433 & 0.510 & 0.634 & $49 / 0$ & $\begin{array}{c}4 / 11 / 2001- \\
4 / 21 / 2003\end{array}$ & 10.628 & 12.569 & 14.089 & 18.327 & 21.084 \\
\hline 383741107565701 & $8 / 0$ & $\begin{array}{l}7 / 30 / 2001- \\
12 / 13 / 2002\end{array}$ & & 0.301 & 0.354 & 0.399 & 0.457 & 0.479 & $8 / 0$ & $\begin{array}{l}7 / 30 / 2001- \\
12 / 13 / 2002\end{array}$ & 10.926 & 12.567 & 13.406 & 14.587 & 16.587 \\
\hline 383728107572001 & $51 / 0$ & $\begin{array}{c}4 / 11 / 2001- \\
4 / 21 / 2003\end{array}$ & & 0.351 & 0.421 & 0.491 & 0.536 & 0.620 & $51 / 0$ & $\begin{array}{c}4 / 11 / 2001- \\
4 / 21 / 2003\end{array}$ & 3.292 & 10.204 & 12.167 & 13.692 & 15.315 \\
\hline 10661 & & & & & & & & & & & & & & & \\
\hline 383946107595301 & $83 / 0$ & $\begin{array}{c}7 / 23 / 1991- \\
8 / 28 / 2009\end{array}$ & & 0.300 & 0.400 & 0.464 & 0.500 & 1.200 & $83 / 0$ & $\begin{array}{c}\text { 7/23/1991- } \\
8 / 28 / 2009\end{array}$ & 5.9 & 11 & 12.883 & 13.8 & 15.12 \\
\hline
\end{tabular}


Appendix 1. Summary of surface-water-quality data and comparison to water-quality standards by site, by constituent, Piceance study area, western Colorado. Water-quality standards comparisons follow data summaries and are in blue text; standards are provided in table 3.-Continued

[CDPHE segment, Colorado Department of Health and the Environment stream segment as referred to in tables 2 and 3; latitude and longitude are in North American Datum of 1983; downstream order number assigned as part of analysis. $\mu \mathrm{g} / \mathrm{L}$, micrograms per liter; $\mu \mathrm{S} / \mathrm{cm}$, microsiemens per centimeter; $\mathrm{mg} / \mathrm{L}$, milligrams per liter; mL, milliliters; aq, aquatic; CO, Colorado; EPA, U.S. Environmental Protection Agency; Max, maximum; Min, minimum; NA, not applicable; No., number; NTU, nephelometric turbitidy units; WS, water supply; dates given in month/day/year format]

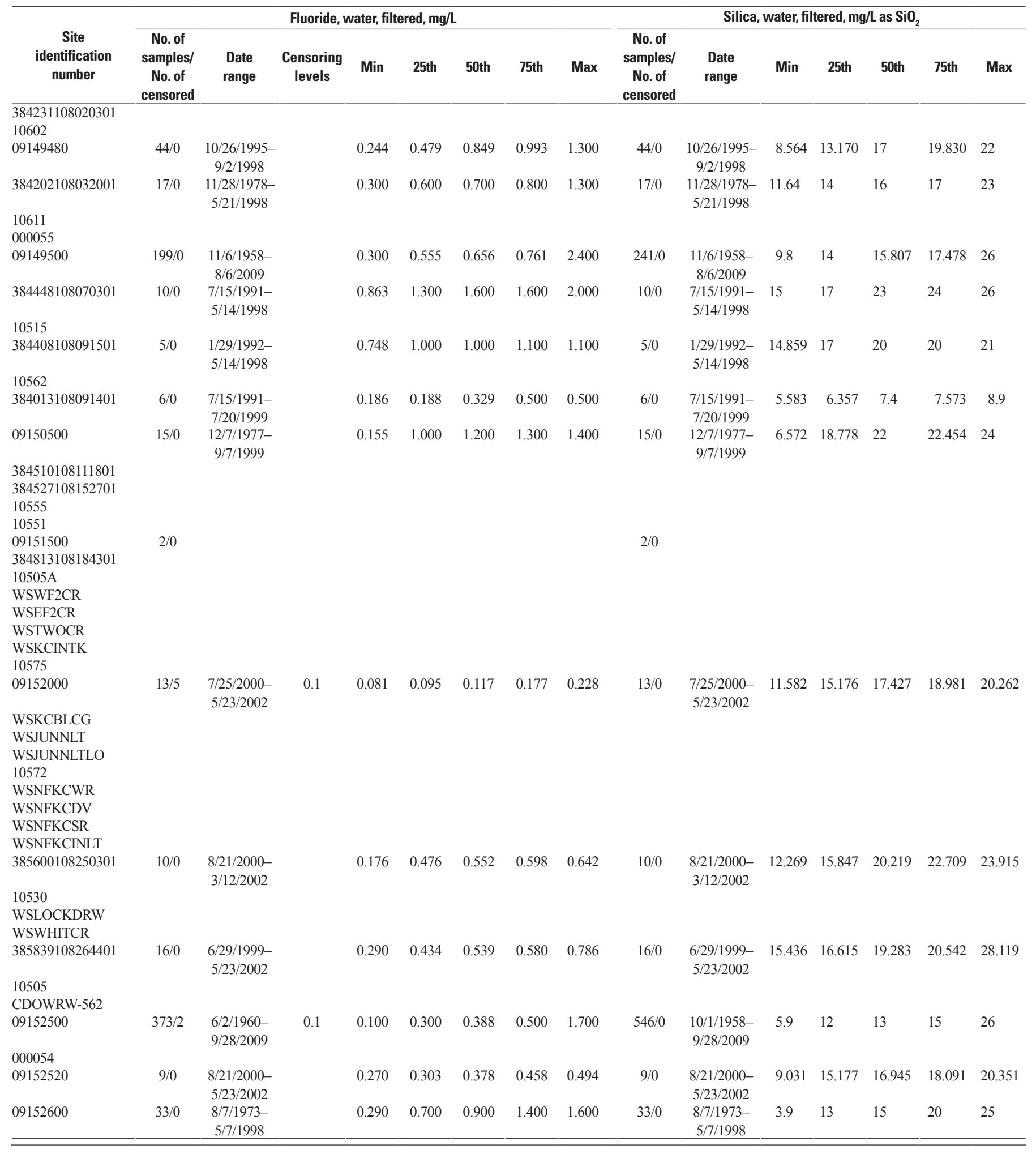


Appendix 1. Summary of surface-water-quality data and comparison to water-quality standards by site, by constituent, Piceance study area, western Colorado. Water-quality standards comparisons follow data summaries and are in blue text; standards are provided in table 3.-Continued

[CDPHE segment, Colorado Department of Health and the Environment stream segment as referred to in tables 2 and 3; latitude and longitude are in North American Datum of 1983; downstream order number assigned as part of analysis. $\mu \mathrm{g} / \mathrm{L}$, micrograms per liter; $\mu \mathrm{S} / \mathrm{cm}$, microsiemens per centimeter; $\mathrm{mg} / \mathrm{L}$, milligrams per liter; mL, milliliters; aq, aquatic; CO, Colorado; EPA, U.S. Environmental Protection Agency; Max, maximum; Min, minimum; NA, not applicable; No., number; NTU, nephelometric turbitidy units; WS, water supply; dates given in month/day/year format]

\begin{tabular}{|c|c|c|c|c|c|c|c|c|c|c|c|c|}
\hline $\begin{array}{c}\text { Site } \\
\text { identification } \\
\text { number }\end{array}$ & \multicolumn{8}{|c|}{ Copper, water, filtered, $\mu \mathrm{g} / \mathrm{L}$} & \multicolumn{2}{|c|}{$\begin{array}{c}\text { Copper, aq life, } \\
\text { 30-day chronic standard }\end{array}$} & \multicolumn{2}{|c|}{$\begin{array}{l}\text { Copper, aq life, } \\
\text { acute }\end{array}$} \\
\hline$\overline{09302450}$ & $10 / 10$ & $\begin{array}{c}8 / 17 / 1999- \\
6 / 11 / 2007\end{array}$ & 45840 & & & & & & 1 & $\begin{array}{c}10 / 19 / 1999- \\
10 / 19 / 1999\end{array}$ & 1 & $\begin{array}{c}10 / 19 / 1999 \\
10 / 19 / 1999\end{array}$ \\
\hline \multicolumn{13}{|l|}{09304100} \\
\hline 09304480 & $5 / 5$ & $\begin{array}{c}8 / 26 / 1981- \\
6 / 11 / 2007\end{array}$ & 5 & & & & & & & & & \\
\hline \multicolumn{13}{|l|}{09304300} \\
\hline \multicolumn{13}{|l|}{09304500} \\
\hline \multicolumn{13}{|l|}{$\begin{array}{l}09304550 \\
09304600\end{array}$} \\
\hline \multicolumn{13}{|l|}{400206108005901} \\
\hline 09304800 & $46 / 14$ & $\begin{array}{l}4 / 24 / 1974- \\
9 / 29 / 2009\end{array}$ & 0.512 & 0.22 & 0.569 & 0.896 & 1.834 & 78.142 & 2 & $\begin{array}{l}6 / 7 / 2005- \\
9 / 12 / 2005\end{array}$ & 2 & $\begin{array}{l}\text { 6/7/2005- } \\
9 / 12 / 2005\end{array}$ \\
\hline \multicolumn{13}{|l|}{ ENPR20ST } \\
\hline \multicolumn{13}{|l|}{ ENPR21ST } \\
\hline \multicolumn{13}{|l|}{ ENPR19ST } \\
\hline 09306007 & $67 / 19$ & $\begin{array}{c}5 / 22 / 1974 \\
5 / 22 / 1985\end{array}$ & 124 & 0 & 1 & 2 & 4 & 15 & & & & \\
\hline 09306025 & $29 / 10$ & $\begin{array}{c}5 / 22 / 1974 \\
2 / 18 / 1980\end{array}$ & 25 & 2 & 2 & 2 & 4 & 8 & & & & \\
\hline \multicolumn{13}{|l|}{09306028} \\
\hline 09306022 & $47 / 17$ & $\begin{array}{c}9 / 12 / 1974 \\
5 / 22 / 1985\end{array}$ & 125 & 0 & 0 & 1 & 3 & 8 & & & & \\
\hline 09306061 & $69 / 16$ & $\begin{array}{c}5 / 22 / 1974 \\
5 / 23 / 1985\end{array}$ & 124520 & 0 & 2 & 2 & 3 & 20 & & & & \\
\hline 11625 & 9/9 & $\begin{array}{c}8 / 18 / 1999 \\
6 / 21 / 2007\end{array}$ & 5420 & & & & & & & & & \\
\hline 09306175 & $66 / 14$ & $\begin{array}{l}1 / 15 / 1975- \\
11 / 24 / 1981\end{array}$ & 220 & 0 & 1 & 2 & 3 & 13.5 & & & & \\
\hline 09306200 & $93 / 6$ & $\begin{array}{c}6 / 10 / 1974 \\
7 / 8 / 2009\end{array}$ & 0.512 & 0 & 1 & 2 & 3 & 13 & & & & \\
\hline \multicolumn{13}{|l|}{09306210} \\
\hline 09306222 & $95 / 6$ & $\begin{array}{c}6 / 10 / 1974- \\
7 / 7 / 2009\end{array}$ & 2 & 0 & 1.601 & 2.101 & 3.132 & 24 & & & & \\
\hline 000117 & $17 / 17$ & $\begin{array}{c}6 / 29 / 1988- \\
4 / 21 / 1992\end{array}$ & 45 & & & & & & & & & \\
\hline 09306224 & $15 / 9$ & $\begin{array}{l}11 / 9 / 1982- \\
9 / 29 / 2009\end{array}$ & 0.5 & 0.5 & 0.5 & 0.5 & 2 & 5 & & & & \\
\hline 09306240 & $12 / 1$ & $\begin{array}{c}5 / 17 / 1974 \\
4 / 18 / 1979\end{array}$ & 2 & 2 & 2 & 4.5 & 14.5 & 22 & 2 & $\begin{array}{l}3 / 18 / 1976- \\
8 / 25 / 1977\end{array}$ & 1 & $\begin{array}{c}3 / 18 / 1976- \\
3 / 18 / 1976\end{array}$ \\
\hline
\end{tabular}


Appendix 1. Summary of surface-water-quality data and comparison to water-quality standards by site, by constituent, Piceance study area, western Colorado. Water-quality standards comparisons follow data summaries and are in blue text; standards are provided in table 3.-Continued

[CDPHE segment, Colorado Department of Health and the Environment stream segment as referred to in tables 2 and 3; latitude and longitude are in North American Datum of 1983; downstream order number assigned as part of analysis. $\mu \mathrm{g} / \mathrm{L}$, micrograms per liter; $\mu \mathrm{S} / \mathrm{cm}$, microsiemens per centimeter; mg/L, milligrams per liter; mL, milliliters; aq, aquatic; CO, Colorado; EPA, U.S. Environmental Protection Agency; Max, maximum; Min, minimum; NA, not applicable; No., number; NTU, nephelometric turbitidy units; WS, water supply; dates given in month/day/year format]

\begin{tabular}{|c|c|c|c|c|c|c|c|c|c|c|c|c|}
\hline $\begin{array}{c}\text { Site } \\
\text { identification } \\
\text { number }\end{array}$ & \multicolumn{8}{|c|}{ Copper, water, filtered, $\mu \mathrm{g} / \mathrm{L}$} & \multicolumn{2}{|c|}{$\begin{array}{c}\text { Copper, aq life, } \\
\text { 30-day chronic standard }\end{array}$} & \multicolumn{2}{|c|}{$\begin{array}{l}\text { Copper, aq life, } \\
\text { acute }\end{array}$} \\
\hline \multicolumn{13}{|l|}{09306241} \\
\hline 09306235 & $39 / 9$ & $\begin{array}{c}5 / 17 / 1974 \\
11 / 6 / 1985\end{array}$ & 2 & 2 & 2 & 3 & 5 & 17 & & & & \\
\hline 09306244 & $14 / 7$ & $\begin{array}{l}6 / 12 / 1975- \\
10 / 24 / 1978\end{array}$ & 2 & 2 & 0.628 & 2 & 3.5 & 7 & & & & \\
\hline 11702 & $32 / 29$ & $\begin{array}{l}9 / 14 / 1999- \\
6 / 12 / 2007\end{array}$ & 345820 & & & & & & 1 & $\begin{array}{c}\text { 9/14/1999- } \\
9 / 14 / 1999\end{array}$ & & \\
\hline 09306255 & $48 / 16$ & $\begin{array}{l}5 / 16 / 1972- \\
7 / 7 / 2009\end{array}$ & 0.52420 & 1.022 & 2 & 3 & 4 & 14.5 & & & & \\
\hline 09306290 & $30 / 7$ & $\begin{array}{l}11 / 9 / 1982- \\
9 / 30 / 2009\end{array}$ & 0.51 & 0.500 & 0.566 & 1.784 & 3 & 11 & & & & \\
\hline CDOWRW-46 & $81 / 0$ & $\begin{array}{l}3 / 6 / 1991- \\
1 / 22 / 2007\end{array}$ & & 1 & 1.2 & 1.5 & 2.4 & 6.8 & & & & \\
\hline 12100 & $9 / 7$ & $\begin{array}{l}2 / 14 / 2001- \\
8 / 20 / 2002\end{array}$ & 43 & & & & & & & & & \\
\hline CDOWRW-47 & $88 / 0$ & $\begin{array}{l}3 / 6 / 1991- \\
6 / 27 / 2006\end{array}$ & & 1 & 1.25 & 1.55 & 2.55 & 20.8 & 2 & $\begin{array}{c}4 / 22 / 1996- \\
5 / 21 / 1996\end{array}$ & & \\
\hline 09085100 & $12 / 4$ & $\begin{array}{l}12 / 18 / 1990- \\
8 / 11 / 1993\end{array}$ & 1 & 1 & 1 & 1 & 1.75 & 8 & & & & \\
\hline 11109A & $5 / 5$ & $\begin{array}{l}10 / 23 / 2000- \\
4 / 18 / 2007\end{array}$ & 54 & & & & & & & & & \\
\hline $11190 \mathrm{H}$ & $5 / 5$ & $\begin{array}{l}11 / 30 / 2000- \\
4 / 18 / 2007\end{array}$ & $\begin{array}{l}5 \\
4\end{array}$ & & & & & & & & & \\
\hline \multicolumn{13}{|l|}{09086000} \\
\hline 11195 & $11 / 10$ & $\begin{array}{c}10 / 2 / 1995- \\
8 / 21 / 1996\end{array}$ & 4 & & & & & & & & & \\
\hline \multicolumn{13}{|l|}{ CDOWRW-547 } \\
\hline 11189 & $10 / 9$ & $\begin{array}{l}8 / 18 / 1999 \\
10 / 17 / 2006\end{array}$ & 420 & & & & & & & & & \\
\hline $\begin{array}{l}09089000 \\
11185\end{array}$ & $10 / 6$ & $\begin{array}{l}10 / 2 / 1995- \\
8 / 15 / 1996\end{array}$ & 4 & 4 & 3.073 & 3.746 & 5 & 6 & & & & \\
\hline
\end{tabular}


Appendix 1. Summary of surface-water-quality data and comparison to water-quality standards by site, by constituent, Piceance study area, western Colorado. Water-quality standards comparisons follow data summaries and are in blue text; standards are provided in table 3.-Continued

[CDPHE segment, Colorado Department of Health and the Environment stream segment as referred to in tables 2 and 3; latitude and longitude are in North American Datum of 1983; downstream order number assigned as part of analysis. $\mu \mathrm{g} / \mathrm{L}$, micrograms per liter; $\mu \mathrm{S} / \mathrm{cm}$, microsiemens per centimeter; mg $/ \mathrm{L}$, milligrams per liter; mL, milliliters; aq, aquatic; CO, Colorado; EPA, U.S. Environmental Protection Agency; Max, maximum; Min, minimum; NA, not applicable; No., number; NTU, nephelometric turbitidy units; WS, water supply; dates given in month/day/year format]

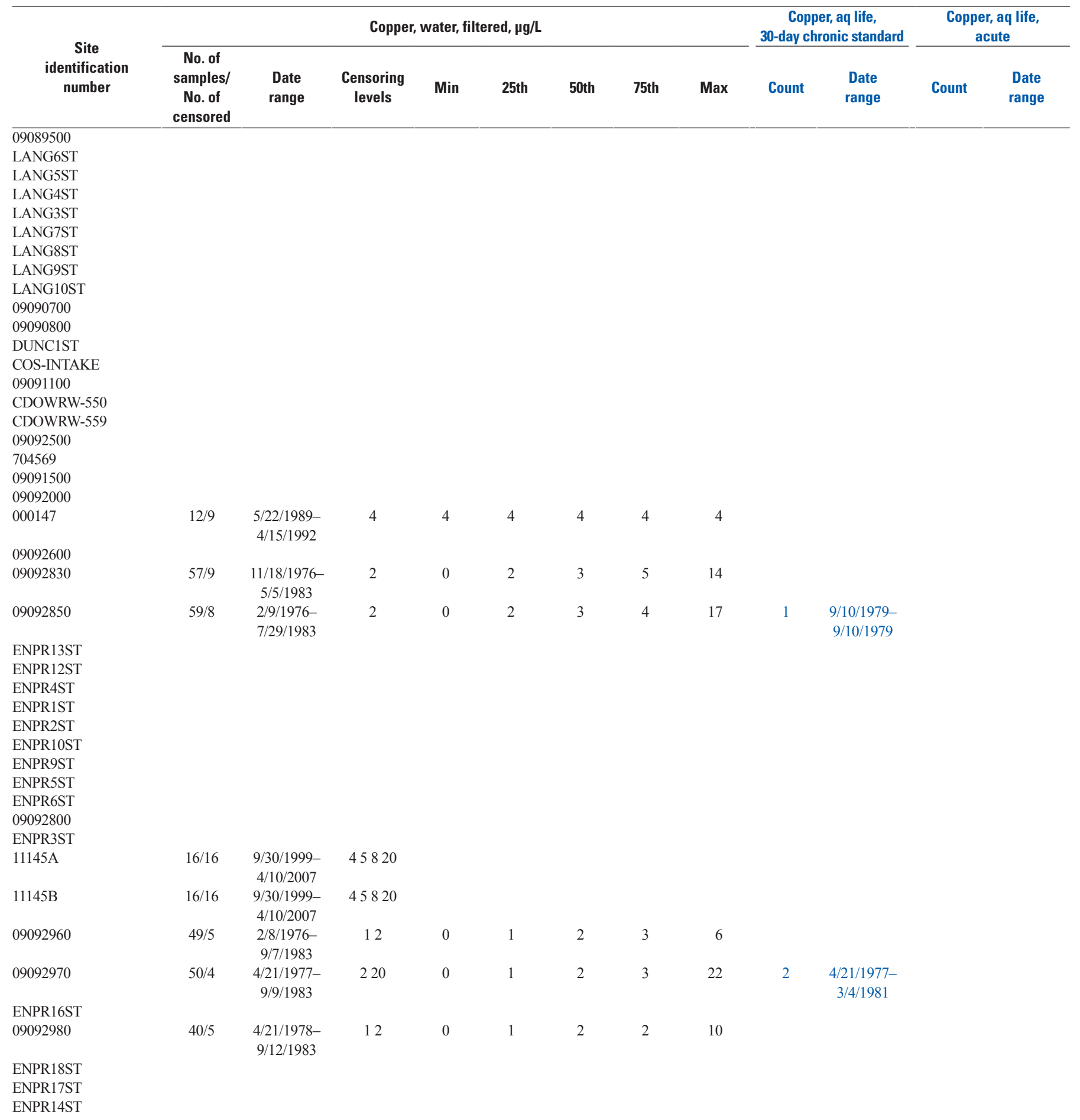


Appendix 1. Summary of surface-water-quality data and comparison to water-quality standards by site, by constituent, Piceance study area, western Colorado. Water-quality standards comparisons follow data summaries and are in blue text; standards are provided in table 3.-Continued

[CDPHE segment, Colorado Department of Health and the Environment stream segment as referred to in tables 2 and 3; latitude and longitude are in North American Datum of 1983; downstream order number assigned as part of analysis. $\mu \mathrm{g} / \mathrm{L}$, micrograms per liter; $\mu \mathrm{S} / \mathrm{cm}$, microsiemens per centimeter; mg/L, milligrams per liter; mL, milliliters; aq, aquatic; CO, Colorado; EPA, U.S. Environmental Protection Agency; Max, maximum; Min, minimum; NA, not applicable; No., number; NTU, nephelometric turbitidy units; WS, water supply; dates given in month/day/year format]

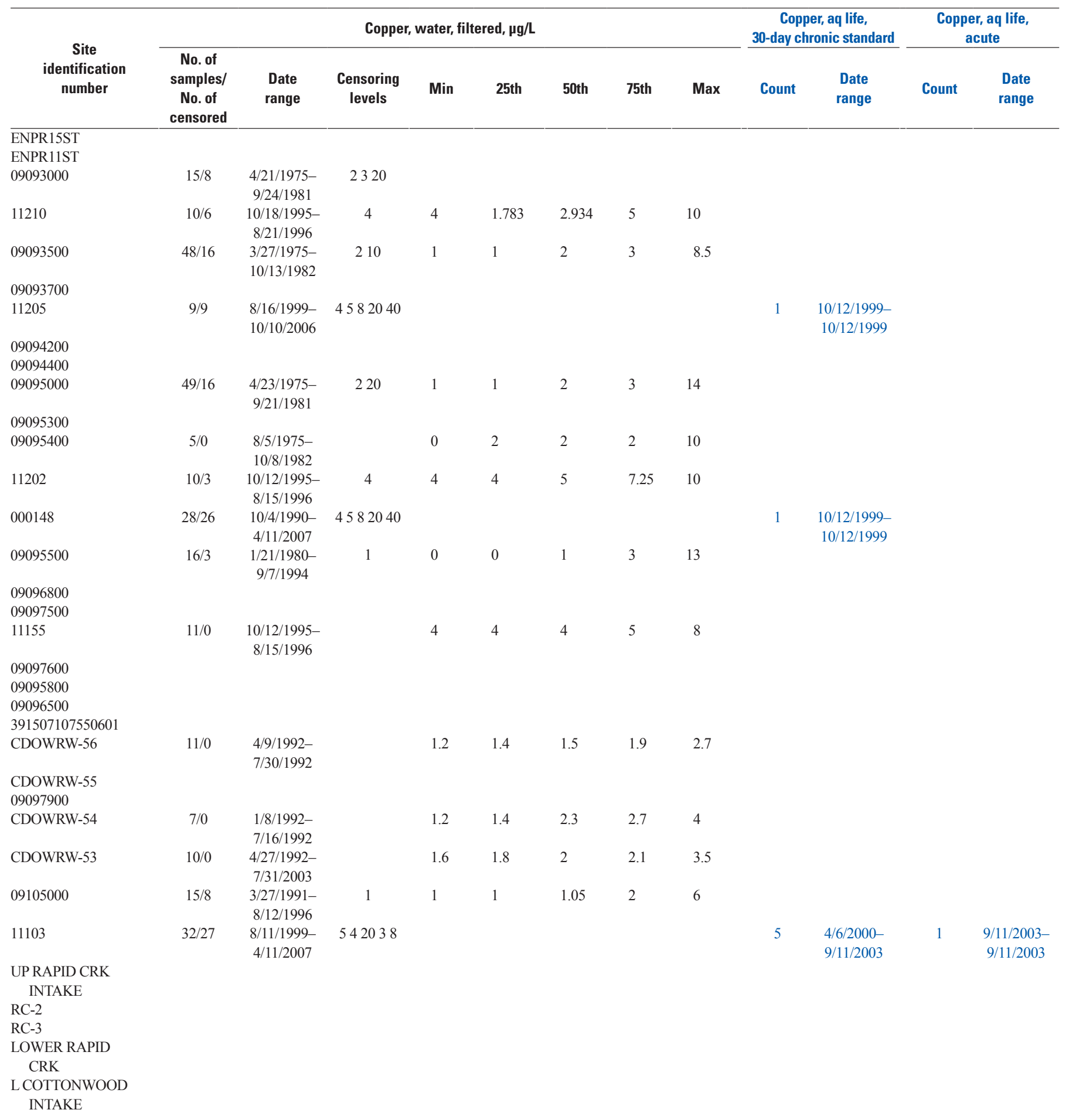


Appendix 1. Summary of surface-water-quality data and comparison to water-quality standards by site, by constituent, Piceance study area, western Colorado. Water-quality standards comparisons follow data summaries and are in blue text; standards are provided in table 3.-Continued

[CDPHE segment, Colorado Department of Health and the Environment stream segment as referred to in tables 2 and 3; latitude and longitude are in North American Datum of 1983; downstream order number assigned as part of analysis. $\mu \mathrm{g} / \mathrm{L}$, micrograms per liter; $\mu \mathrm{S} / \mathrm{cm}$, microsiemens per centimeter; mg/L, milligrams per liter; mL, milliliters; aq, aquatic; CO, Colorado; EPA, U.S. Environmental Protection Agency; Max, maximum; Min, minimum; NA, not applicable; No., number; NTU, nephelometric turbitidy units; WS, water supply; dates given in month/day/year format]

\begin{tabular}{|c|c|c|c|c|c|c|c|c|c|c|c|c|}
\hline \multirow{2}{*}{$\begin{array}{c}\text { Site } \\
\text { identification } \\
\text { number }\end{array}$} & \multicolumn{8}{|c|}{ Copper, water, filtered, $\mu \mathrm{g} / \mathrm{L}$} & \multicolumn{2}{|c|}{$\begin{array}{c}\text { Copper, aq life, } \\
\text { 30-day chronic standard }\end{array}$} & \multicolumn{2}{|c|}{$\begin{array}{c}\text { Copper, aq life, } \\
\text { acute }\end{array}$} \\
\hline & $\begin{array}{c}\text { samples/ } \\
\text { No. of } \\
\text { censored }\end{array}$ & $\begin{array}{l}\text { Date } \\
\text { range }\end{array}$ & $\begin{array}{l}\text { Censoring } \\
\text { levels }\end{array}$ & Min & 25th & 50th & 75th & Max & Count & $\begin{array}{c}\text { Date } \\
\text { range }\end{array}$ & Count & $\begin{array}{l}\text { Date } \\
\text { range }\end{array}$ \\
\hline 11151 & $11 / 4$ & $\begin{array}{c}10 / 23 / 1995- \\
4 / 11 / 2007\end{array}$ & 4 & 4 & 4 & 4 & 4 & 4.5 & & & & \\
\hline \multicolumn{13}{|l|}{390622108205400} \\
\hline 09106150 & $12 / 8$ & $\begin{array}{l}11 / 4 / 1993- \\
8 / 13 / 1996\end{array}$ & 1 & 1 & 0.410 & 0.619 & 1 & 2 & & & & \\
\hline
\end{tabular}

CDOWRW-553

CDOWRW-555

390322108253401

390348108265601

CDOWRW-556

390319108273200

390318108273200

CDOWRW-557

09106200

390324108291301

390326108291601

390323108291601

390303108291601

390322108292301

390318108293301

390302108293801

390319108312501

390320108315901

CDOWRW-558

CDOWRW-560

09106500

390337108342800

CDOWRW-563

$11135 \mathrm{~A}$

$8 / 8 \quad 7 / 26 / 2005-\quad 525$

CDOWRW-749

09152650

11135

$7 / 7 \quad 7 / 26 / 2005$

$10 / 11 / 2006$

$1 / 9 / 2007$

390449108364101

390514108373201

390521108373300

390607108384201

390609108384701

390613108385603

390625108390402

390617108391001

390632108392101

390624108394701

390859108364101

390645108390101

390717108400501

390718108415701

09152900

11133 
Appendix 1. Summary of surface-water-quality data and comparison to water-quality standards by site, by constituent, Piceance study area, western Colorado. Water-quality standards comparisons follow data summaries and are in blue text; standards are provided in table 3.-Continued

[CDPHE segment, Colorado Department of Health and the Environment stream segment as referred to in tables 2 and 3; latitude and longitude are in North American Datum of 1983; downstream order number assigned as part of analysis. $\mu \mathrm{g} / \mathrm{L}$, micrograms per liter; $\mu \mathrm{S} / \mathrm{cm}$, microsiemens per centimeter; mg/L, milligrams per liter; mL, milliliters; aq, aquatic; CO, Colorado; EPA, U.S. Environmental Protection Agency; Max, maximum; Min, minimum; NA, not applicable; No., number; NTU, nephelometric turbitidy units; WS, water supply; dates given in month/day/year format]

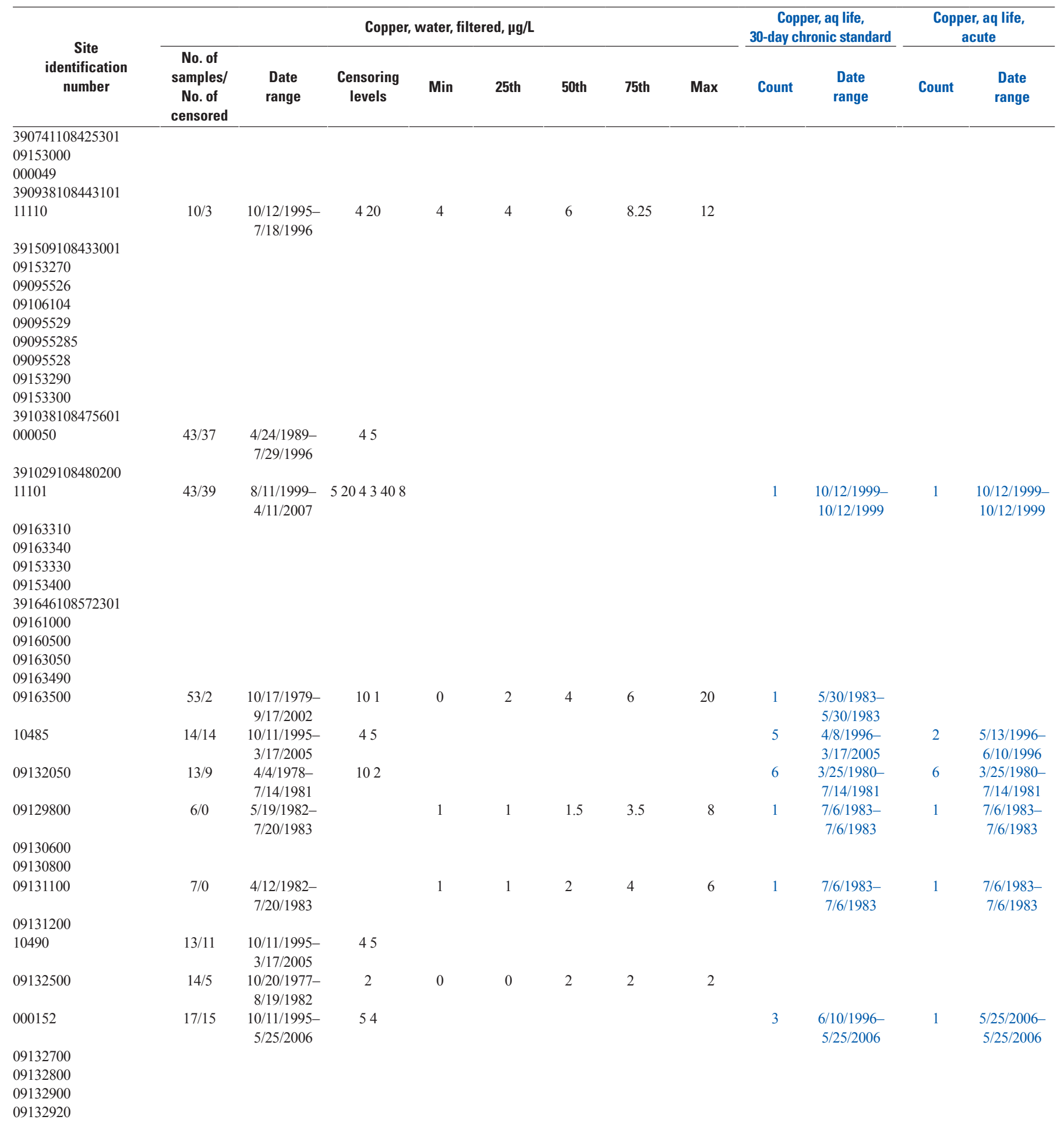


Appendix 1. Summary of surface-water-quality data and comparison to water-quality standards by site, by constituent, Piceance study area, western Colorado. Water-quality standards comparisons follow data summaries and are in blue text; standards are provided in table 3.-Continued

[CDPHE segment, Colorado Department of Health and the Environment stream segment as referred to in tables 2 and 3; latitude and longitude are in North American Datum of 1983; downstream order number assigned as part of analysis. $\mu \mathrm{g} / \mathrm{L}$, micrograms per liter; $\mu \mathrm{S} / \mathrm{cm}$, microsiemens per centimeter; mg/L, milligrams per liter; mL, milliliters; aq, aquatic; CO, Colorado; EPA, U.S. Environmental Protection Agency; Max, maximum; Min, minimum; NA, not applicable; No., number; NTU, nephelometric turbitidy units; WS, water supply; dates given in month/day/year format]

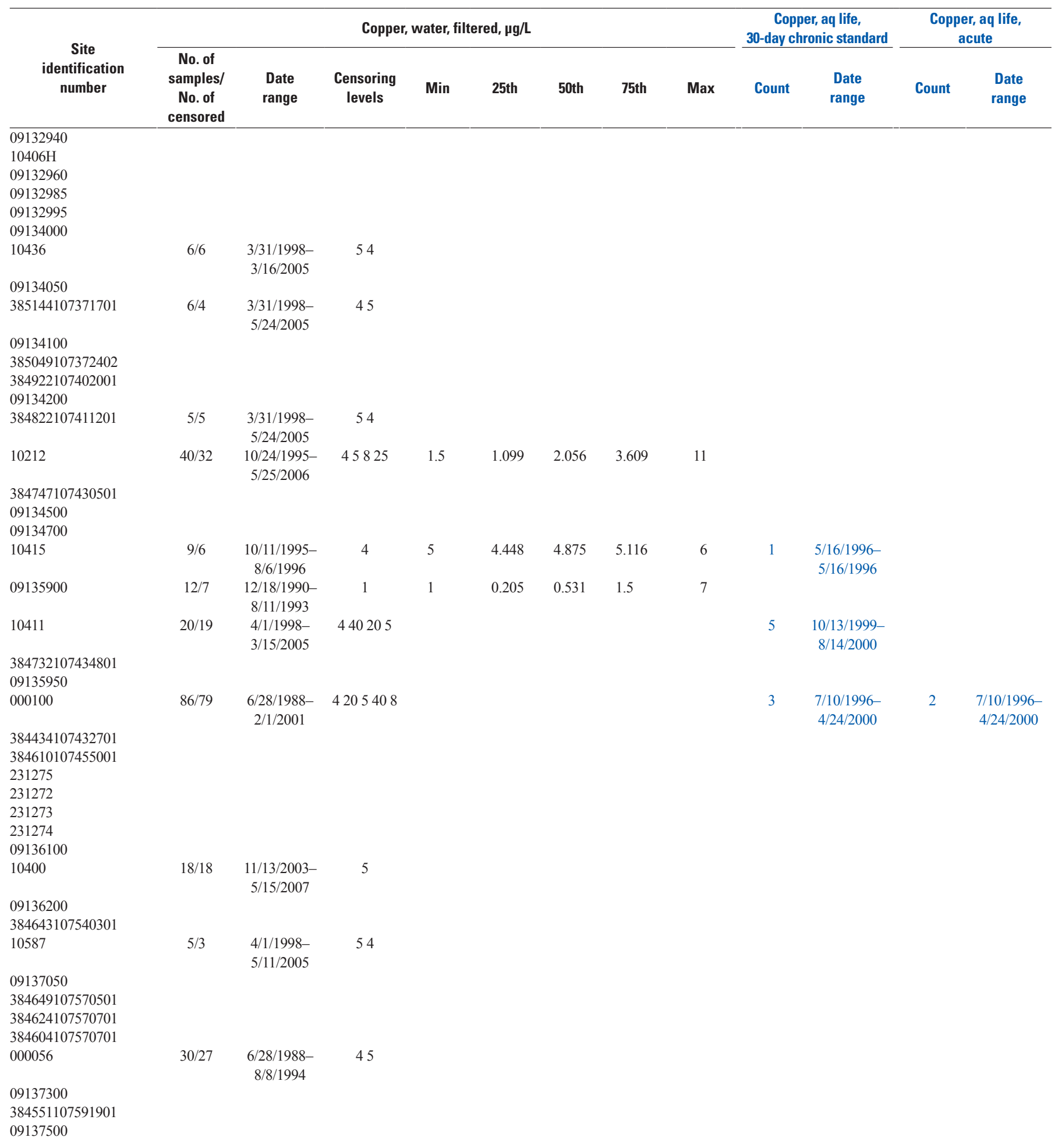


Appendix 1. Summary of surface-water-quality data and comparison to water-quality standards by site, by constituent, Piceance study area, western Colorado. Water-quality standards comparisons follow data summaries and are in blue text; standards are provided in table 3.-Continued

[CDPHE segment, Colorado Department of Health and the Environment stream segment as referred to in tables 2 and 3; latitude and longitude are in North American Datum of 1983; downstream order number assigned as part of analysis. $\mu \mathrm{g} / \mathrm{L}$, micrograms per liter; $\mu \mathrm{S} / \mathrm{cm}$, microsiemens per centimeter; mg/L, milligrams per liter; mL, milliliters; aq, aquatic; CO, Colorado; EPA, U.S. Environmental Protection Agency; Max, maximum; Min, minimum; NA, not applicable; No., number; NTU, nephelometric turbitidy units; WS, water supply; dates given in month/day/year format]

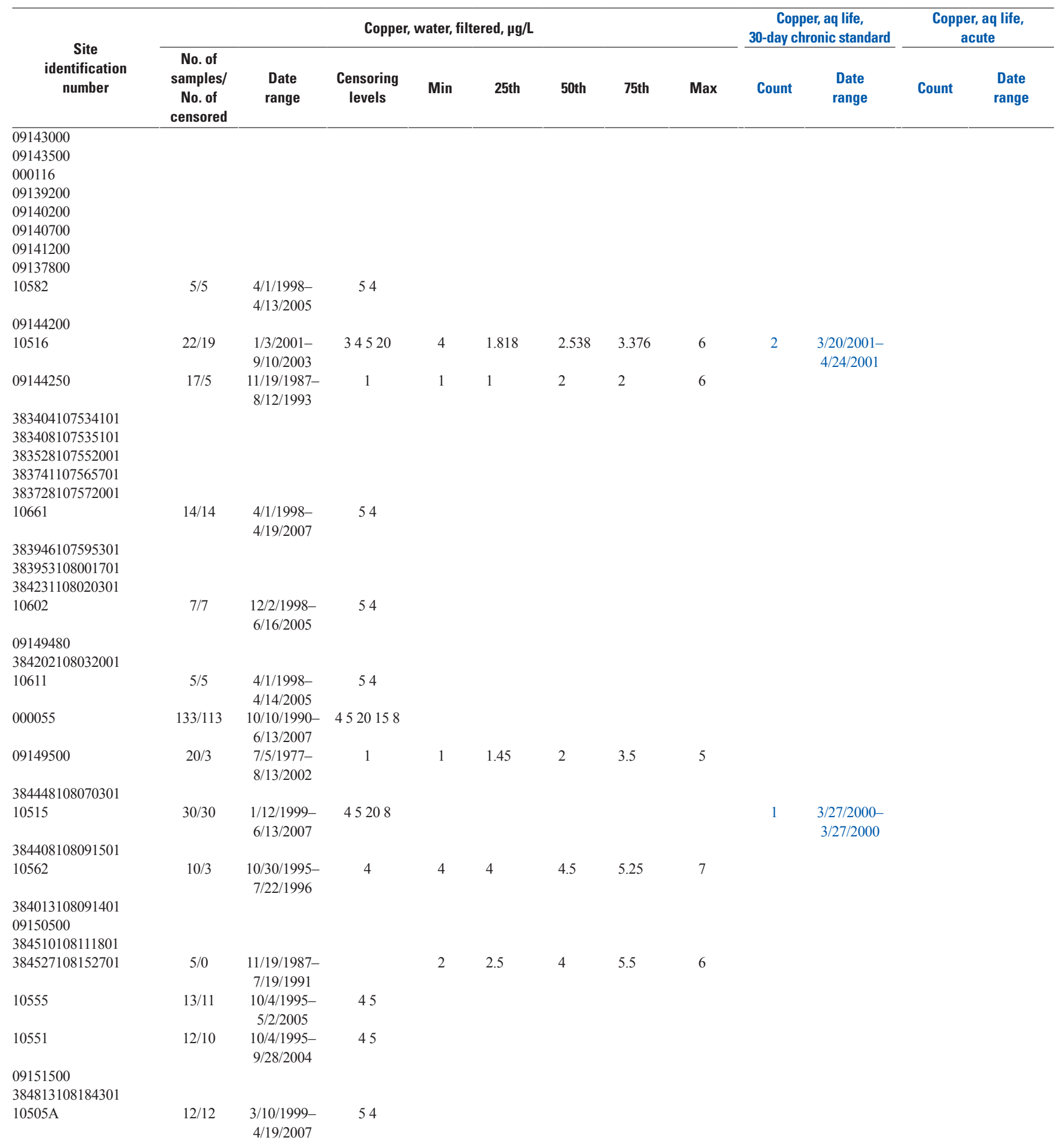


Appendix 1. Summary of surface-water-quality data and comparison to water-quality standards by site, by constituent, Piceance study area, western Colorado. Water-quality standards comparisons follow data summaries and are in blue text; standards are provided in table 3.-Continued

[CDPHE segment, Colorado Department of Health and the Environment stream segment as referred to in tables 2 and 3; latitude and longitude are in North American Datum of 1983; downstream order number assigned as part of analysis. $\mu \mathrm{g} / \mathrm{L}$, micrograms per liter; $\mu \mathrm{S} / \mathrm{cm}$, microsiemens per centimeter; mg/L, milligrams per liter; mL, milliliters; aq, aquatic; CO, Colorado; EPA, U.S. Environmental Protection Agency; Max, maximum; Min, minimum; NA, not applicable; No., number; NTU, nephelometric turbitidy units; WS, water supply; dates given in month/day/year format]

\begin{tabular}{|c|c|c|c|c|c|c|c|c|c|c|c|c|}
\hline $\begin{array}{c}\text { Site } \\
\text { identification } \\
\text { number }\end{array}$ & \multicolumn{8}{|c|}{ Copper, water, filtered, $\mu \mathrm{g} / \mathrm{L}$} & \multicolumn{2}{|c|}{$\begin{array}{c}\text { Copper, aq life, } \\
\text { 30-day chronic standard }\end{array}$} & \multicolumn{2}{|c|}{$\begin{array}{l}\text { Copper, aq life, } \\
\text { acute }\end{array}$} \\
\hline \multicolumn{13}{|l|}{ WSWF2CR } \\
\hline \multicolumn{13}{|l|}{ WSEF2CR } \\
\hline \multicolumn{13}{|l|}{ WSTWOCR } \\
\hline \multicolumn{13}{|l|}{09152000} \\
\hline \multicolumn{13}{|l|}{ WSKCBLCG } \\
\hline \multicolumn{13}{|l|}{ WSJUNNLT } \\
\hline \multicolumn{13}{|l|}{ WSJUNNLTLO } \\
\hline 10572 & $9 / 4$ & $\begin{array}{c}9 / 14 / 1995- \\
5 / 2 / 2005\end{array}$ & 58 & 5 & 5 & 5 & 11 & 19 & & & & \\
\hline \multicolumn{13}{|l|}{ WSNFKCINLT } \\
\hline \multicolumn{13}{|l|}{385600108250301} \\
\hline 10530 & $5 / 5$ & $\begin{array}{l}3 / 9 / 1999 \\
4 / 26 / 2006\end{array}$ & 54 & & & & & & & & & \\
\hline WSLOCKDRW & $5 / 1$ & $\begin{array}{l}10 / 6 / 2003- \\
10 / 27 / 2008\end{array}$ & 1 & 1 & 1.2 & 1.8 & 2.02 & 4 & & & & \\
\hline WSWHITCR & $8 / 3$ & $\begin{array}{c}3 / 11 / 2002- \\
8 / 8 / 2006\end{array}$ & 1030 & 0.5 & 1.125 & 4.5 & 10 & 5 & 1 & $\begin{array}{l}10 / 26 / 2004- \\
10 / 26 / 2004\end{array}$ & 1 & $\begin{array}{c}10 / 26 / 2004 \\
10 / 26 / 2004\end{array}$ \\
\hline \multicolumn{13}{|l|}{385839108264401} \\
\hline 10505 & $65 / 61$ & $\begin{array}{l}1 / 12 / 1999 \\
5 / 15 / 2007\end{array}$ & 54203408 & & & & & & 3 & $\begin{array}{c}10 / 13 / 1999 \\
4 / 24 / 2001\end{array}$ & 2 & $\begin{array}{c}10 / 13 / 1999 \\
4 / 24 / 2000\end{array}$ \\
\hline \multicolumn{13}{|l|}{ CDOWRW-562 } \\
\hline 09152500 & $65 / 4$ & $\begin{array}{c}8 / 20 / 1975- \\
9 / 24 / 2002\end{array}$ & 210 & 0 & 2 & 2.703 & 4 & 23 & 1 & $\begin{array}{c}5 / 30 / 1986- \\
5 / 30 / 1986\end{array}$ & 1 & $\begin{array}{c}5 / 30 / 1986- \\
5 / 30 / 1986\end{array}$ \\
\hline
\end{tabular}


Appendix 1. Summary of surface-water-quality data and comparison to water-quality standards by site, by constituent, Piceance study area, western Colorado. Water-quality standards comparisons follow data summaries and are in blue text; standards are provided in table 3.-Continued

[CDPHE segment, Colorado Department of Health and the Environment stream segment as referred to in tables 2 and 3; latitude and longitude are in North American Datum of 1983; downstream order number assigned as part of analysis. $\mu \mathrm{g} / \mathrm{L}$, micrograms per liter; $\mu \mathrm{S} / \mathrm{cm}$, microsiemens per centimeter; mg/L, milligrams per liter; mL, milliliters; aq, aquatic; CO, Colorado; EPA, U.S. Environmental Protection Agency; Max, maximum; Min, minimum; NA, not applicable; No., number; NTU, nephelometric turbitidy units; WS, water supply; dates given in month/day/year format]

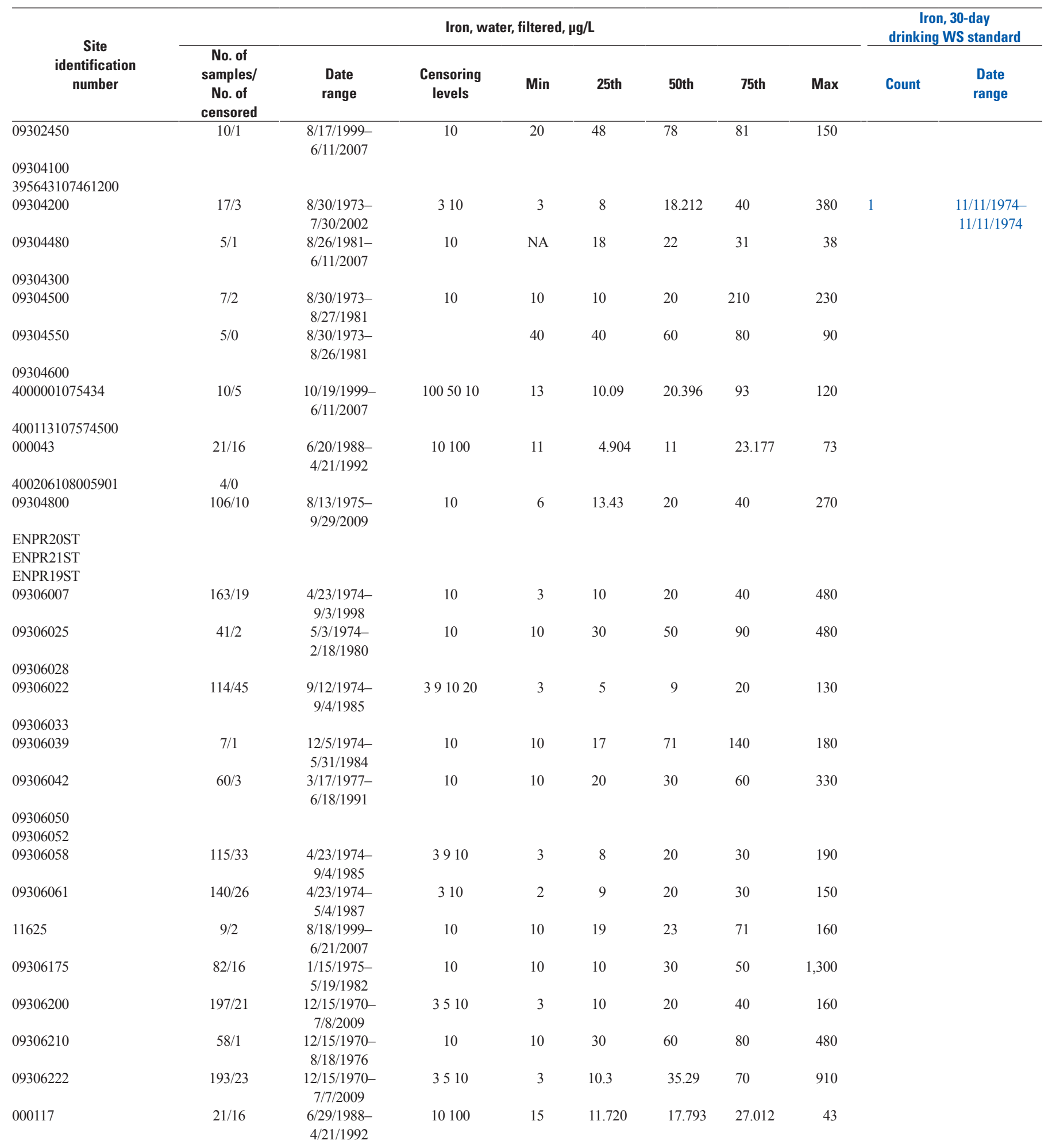


Appendix 1. Summary of surface-water-quality data and comparison to water-quality standards by site, by constituent, Piceance study area, western Colorado. Water-quality standards comparisons follow data summaries and are in blue text; standards are provided in table 3.-Continued

[CDPHE segment, Colorado Department of Health and the Environment stream segment as referred to in tables 2 and 3; latitude and longitude are in North American Datum of 1983; downstream order number assigned as part of analysis. $\mu \mathrm{g} / \mathrm{L}$, micrograms per liter; $\mu \mathrm{S} / \mathrm{cm}$, microsiemens per centimeter; mg/L, milligrams per liter; mL, milliliters; aq, aquatic; CO, Colorado; EPA, U.S. Environmental Protection Agency; Max, maximum; Min, minimum; NA, not applicable; No., number; NTU, nephelometric turbitidy units; WS, water supply; dates given in month/day/year format]

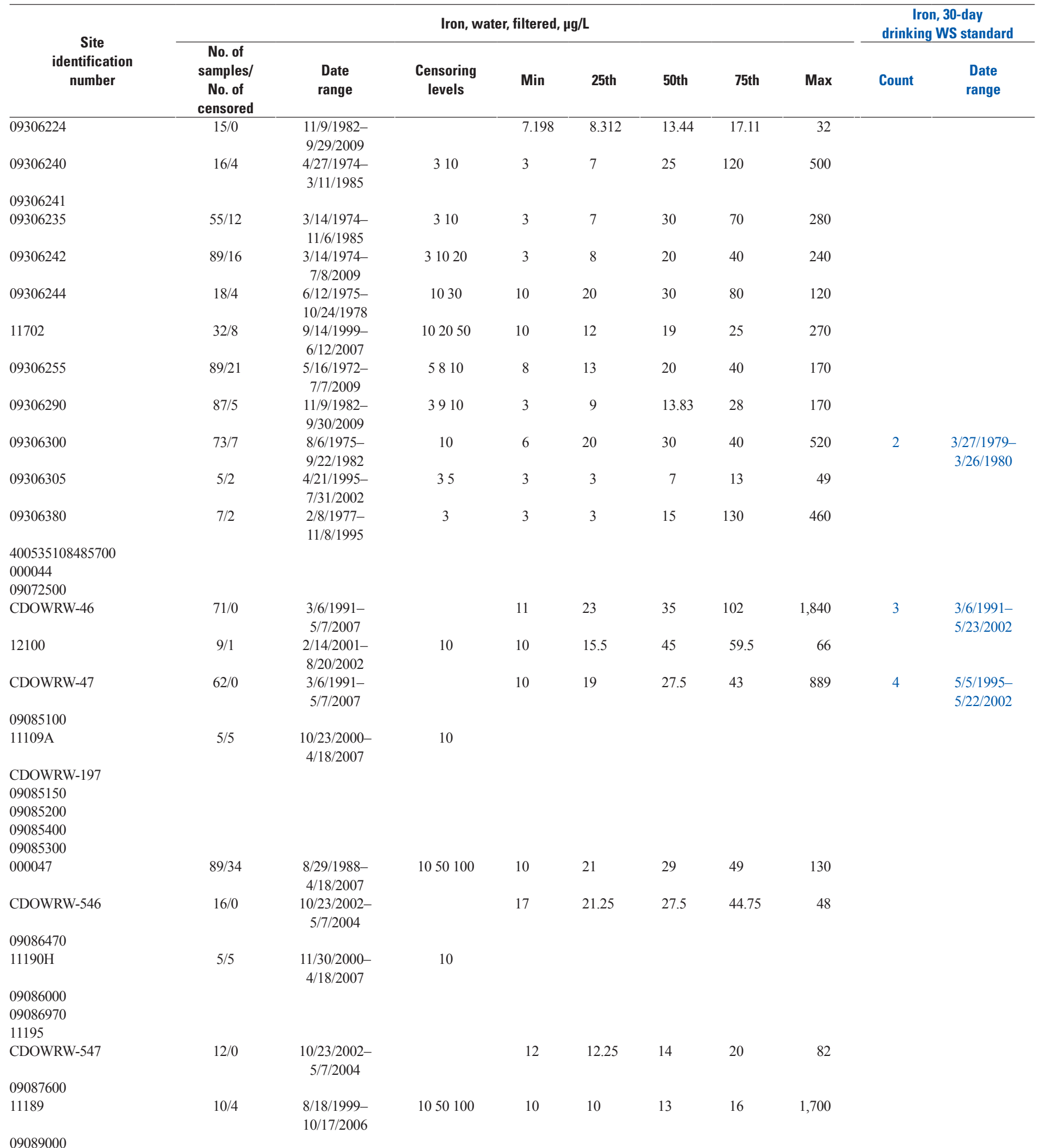


Appendix 1. Summary of surface-water-quality data and comparison to water-quality standards by site, by constituent, Piceance study area, western Colorado. Water-quality standards comparisons follow data summaries and are in blue text; standards are provided in table 3.-Continued

[CDPHE segment, Colorado Department of Health and the Environment stream segment as referred to in tables 2 and 3; latitude and longitude are in North American Datum of 1983; downstream order number assigned as part of analysis. $\mu \mathrm{g} / \mathrm{L}$, micrograms per liter; $\mu \mathrm{S} / \mathrm{cm}$, microsiemens per centimeter; mg/L, milligrams per liter; mL, milliliters; aq, aquatic; CO, Colorado; EPA, U.S. Environmental Protection Agency; Max, maximum; Min, minimum; NA, not applicable; No., number; NTU, nephelometric turbitidy units; WS, water supply; dates given in month/day/year format]

\begin{tabular}{|c|c|c|c|c|c|c|c|c|c|c|}
\hline \multirow{2}{*}{$\begin{array}{c}\text { Site } \\
\text { identification } \\
\text { number }\end{array}$} & \multicolumn{8}{|c|}{ Iron, water, filtered, $\mu \mathrm{g} / \mathrm{L}$} & \multicolumn{2}{|c|}{$\begin{array}{c}\text { Iron, 30-day } \\
\text { drinking WS standard }\end{array}$} \\
\hline & $\begin{array}{l}\text { samples/ } \\
\text { No. of } \\
\text { censored }\end{array}$ & $\begin{array}{c}\text { Date } \\
\text { range }\end{array}$ & $\begin{array}{l}\text { Censoring } \\
\text { levels }\end{array}$ & Min & 25th & 50th & 75th & Max & Count & $\begin{array}{l}\text { Date } \\
\text { range }\end{array}$ \\
\hline \multicolumn{11}{|l|}{$\overline{11185}$} \\
\hline 09089500 & $20 / 0$ & $\begin{array}{l}5 / 1 / 1986- \\
8 / 23 / 1990\end{array}$ & & 8 & 24.25 & 45 & 87.75 & 860 & 2 & $\begin{array}{l}5 / 30 / 1986 \\
5 / 10 / 1989\end{array}$ \\
\hline LANG5ST & $30 / 0$ & $\begin{array}{l}5 / 26 / 2004 \\
2 / 13 / 2006\end{array}$ & & 320 & 450 & 960 & 1,775 & 37,000 & 30 & $\begin{array}{l}5 / 26 / 2004 \\
2 / 13 / 2006\end{array}$ \\
\hline LANG4ST & $29 / 0$ & $\begin{array}{l}6 / 2 / 2004 \\
2 / 13 / 2006\end{array}$ & & 260 & 425 & 910 & 2,050 & 26,000 & 27 & $\begin{array}{l}6 / 9 / 2004 \\
2 / 13 / 2006\end{array}$ \\
\hline LANG3ST & $21 / 0$ & $\begin{array}{l}6 / 2 / 2004 \\
2 / 13 / 2006\end{array}$ & & 210 & 455 & 820 & 1,750 & 25,000 & 20 & $\begin{array}{l}6 / 2 / 2004 \\
2 / 13 / 2006\end{array}$ \\
\hline LANG7ST & $22 / 0$ & $\begin{array}{l}5 / 26 / 2004 \\
2 / 13 / 2006\end{array}$ & & 340 & 517.5 & 1,010 & 1,850 & 16,000 & 22 & $\begin{array}{l}5 / 26 / 2004 \\
2 / 13 / 2006\end{array}$ \\
\hline LANG10ST & $16 / 0$ & $\begin{array}{l}12 / 9 / 2004 \\
4 / 10 / 2006\end{array}$ & & 70.8 & 652.5 & 1,100 & 1,975 & 12,000 & 15 & $\begin{array}{l}12 / 9 / 2004 \\
2 / 13 / 2006\end{array}$ \\
\hline \multicolumn{11}{|l|}{09090700} \\
\hline DUNC1ST & $17 / 0$ & $\begin{array}{l}6 / 3 / 2004 \\
2 / 8 / 2006\end{array}$ & & 210 & 420 & 770 & 1,100 & 5,100 & 15 & $\begin{array}{r}\text { 7/7/2004- } \\
\text { 2/8/2006 }\end{array}$ \\
\hline \multicolumn{11}{|l|}{ COS-INTAKE } \\
\hline CDOWRW-550 & $11 / 0$ & $\begin{array}{l}1 / 17 / 2003- \\
4 / 13 / 2005\end{array}$ & & 13 & 17 & 23 & 63 & 2,922 & 1 & $\begin{array}{l}5 / 23 / 2003 \\
5 / 23 / 2003\end{array}$ \\
\hline \multicolumn{11}{|l|}{ CDOWRW-559 } \\
\hline $\begin{array}{l}09092500 \\
704569 \\
09091500\end{array}$ & & & & & & & & & & \\
\hline \multicolumn{11}{|l|}{ ENPR13ST } \\
\hline \multicolumn{11}{|l|}{ ENPR12ST } \\
\hline \multicolumn{11}{|l|}{ ENPR4ST } \\
\hline \multicolumn{11}{|l|}{ ENPR1ST } \\
\hline \multicolumn{11}{|l|}{ ENPR2ST } \\
\hline \multicolumn{11}{|l|}{ ENPR10ST } \\
\hline \multicolumn{11}{|l|}{ ENPR9ST } \\
\hline \multicolumn{11}{|l|}{ ENPR5ST } \\
\hline \multicolumn{11}{|l|}{ ENPR6ST } \\
\hline 09092800 & & & & & & & & & & \\
\hline ENPR3ST & $5 / 0$ & $\begin{array}{l}5 / 3 / 2005- \\
2 / 28 / 2006\end{array}$ & & 120 & 225 & 440 & 18,500 & 19,000 & & \\
\hline $11145 \mathrm{~A}$ & $16 / 15$ & $\begin{array}{c}9 / 30 / 1999 \\
4 / 10 / 2007\end{array}$ & 102050100 & & & & & & & \\
\hline 11145B & $16 / 16$ & $\begin{array}{c}9 / 30 / 1999 \\
4 / 10 / 2007\end{array}$ & 102050100 & & & & & & & \\
\hline
\end{tabular}


Appendix 1. Summary of surface-water-quality data and comparison to water-quality standards by site, by constituent, Piceance study area, western Colorado. Water-quality standards comparisons follow data summaries and are in blue text; standards are provided in table 3.-Continued

[CDPHE segment, Colorado Department of Health and the Environment stream segment as referred to in tables 2 and 3; latitude and longitude are in North American Datum of 1983; downstream order number assigned as part of analysis. $\mu \mathrm{g} / \mathrm{L}$, micrograms per liter; $\mu \mathrm{S} / \mathrm{cm}$, microsiemens per centimeter; mg/L, milligrams per liter; mL, milliliters; aq, aquatic; CO, Colorado; EPA, U.S. Environmental Protection Agency; Max, maximum; Min, minimum; NA, not applicable; No., number; NTU, nephelometric turbitidy units; WS, water supply; dates given in month/day/year format]

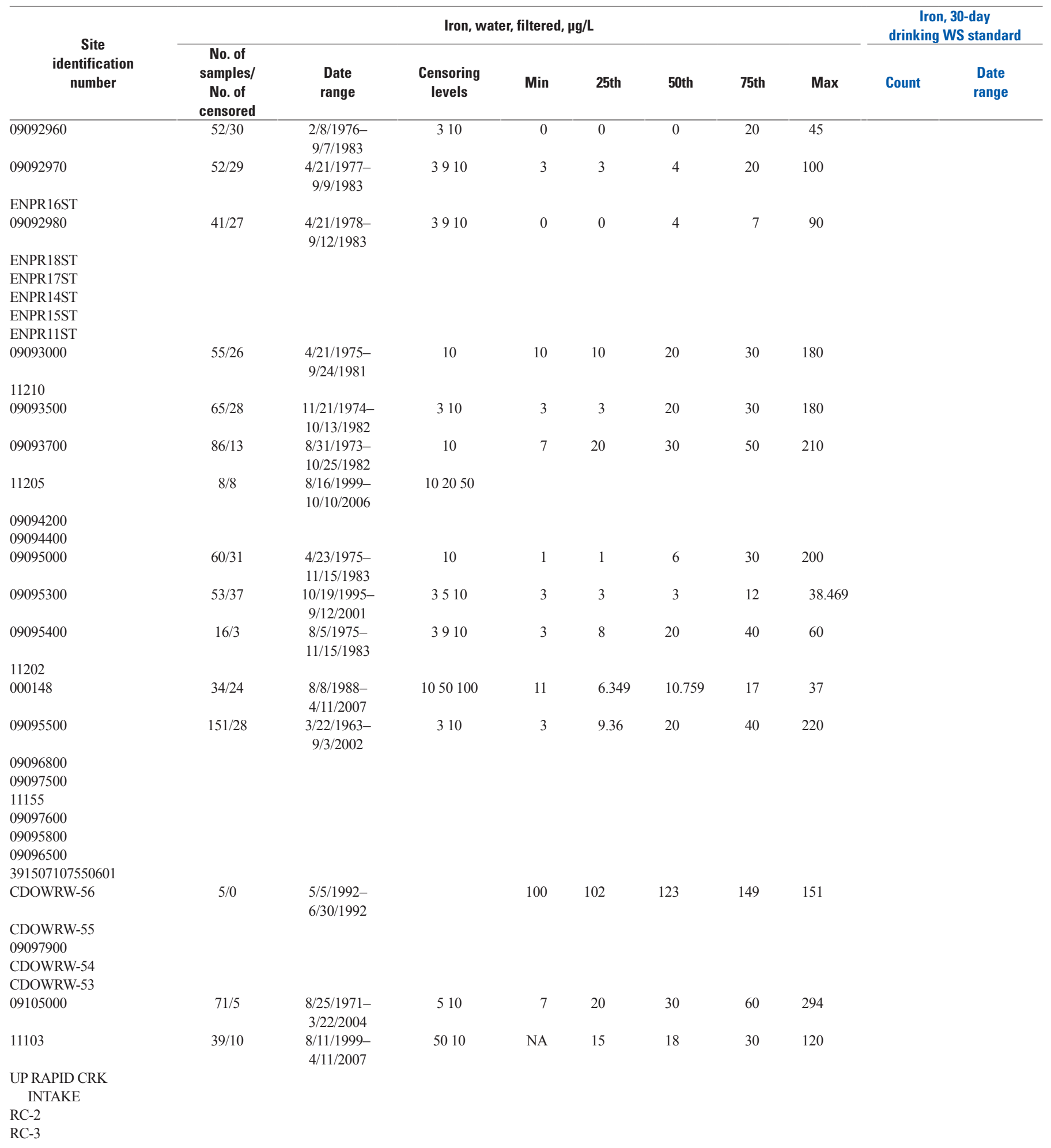


Appendix 1. Summary of surface-water-quality data and comparison to water-quality standards by site, by constituent, Piceance study area, western Colorado. Water-quality standards comparisons follow data summaries and are in blue text; standards are provided in table 3.-Continued

[CDPHE segment, Colorado Department of Health and the Environment stream segment as referred to in tables 2 and 3; latitude and longitude are in North American Datum of 1983; downstream order number assigned as part of analysis. $\mu \mathrm{g} / \mathrm{L}$, micrograms per liter; $\mu \mathrm{S} / \mathrm{cm}$, microsiemens per centimeter; mg/L, milligrams per liter; mL, milliliters; aq, aquatic; CO, Colorado; EPA, U.S. Environmental Protection Agency; Max, maximum; Min, minimum; NA, not applicable; No., number; NTU, nephelometric turbitidy units; WS, water supply; dates given in month/day/year format]

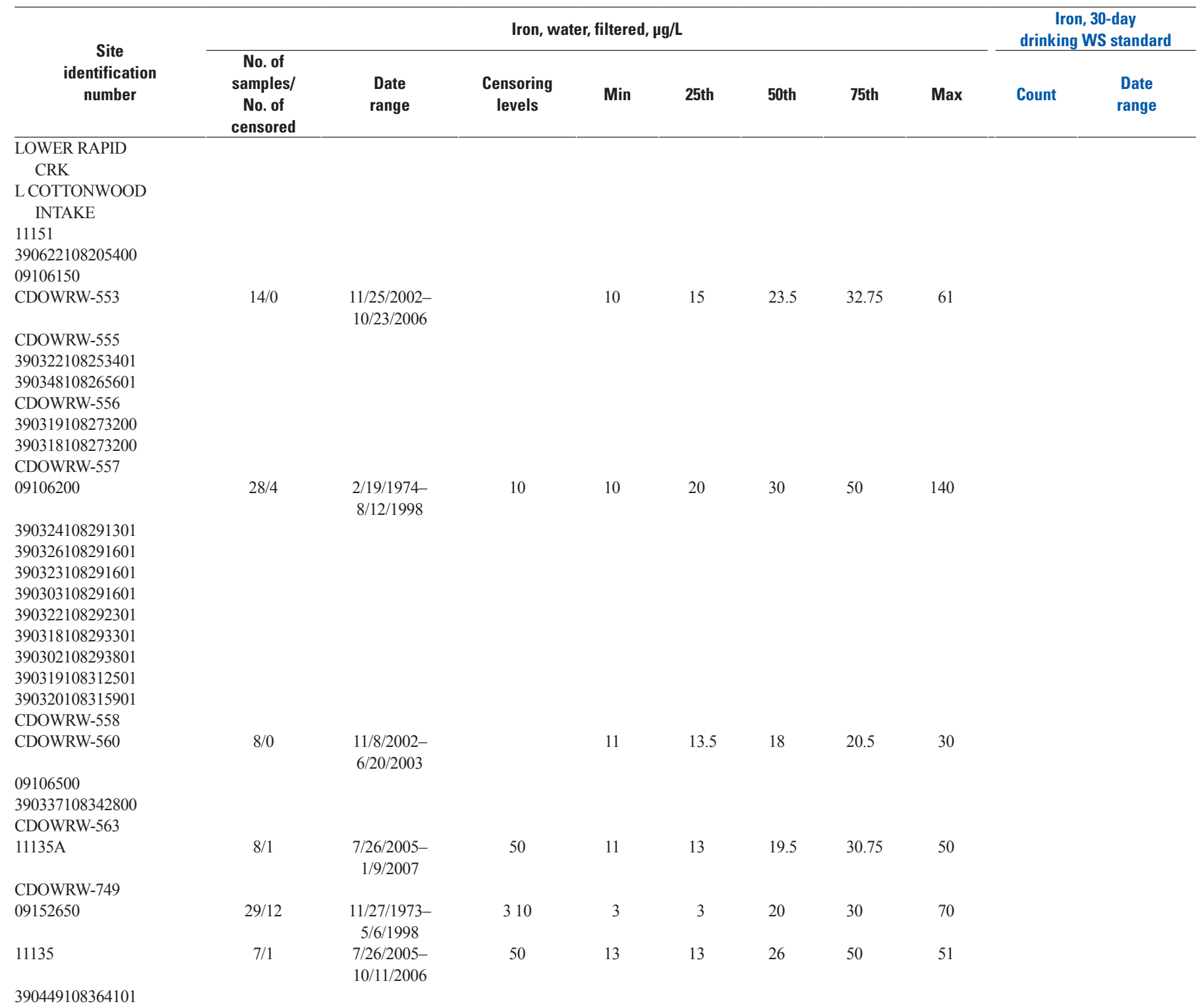

390514108373201

390521108373300

390607108384201

390609108384701

390613108385603

390625108390402

390617108391001

390632108392101

390624108394701

390859108364101

390645108390101

390717108400501

390718108415701 
Appendix 1. Summary of surface-water-quality data and comparison to water-quality standards by site, by constituent, Piceance study area, western Colorado. Water-quality standards comparisons follow data summaries and are in blue text; standards are provided in table 3.-Continued

[CDPHE segment, Colorado Department of Health and the Environment stream segment as referred to in tables 2 and 3; latitude and longitude are in North American Datum of 1983; downstream order number assigned as part of analysis. $\mu \mathrm{g} / \mathrm{L}$, micrograms per liter; $\mu \mathrm{S} / \mathrm{cm}$, microsiemens per centimeter; mg/L, milligrams per liter; mL, milliliters; aq, aquatic; CO, Colorado; EPA, U.S. Environmental Protection Agency; Max, maximum; Min, minimum; NA, not applicable; No., number; NTU, nephelometric turbitidy units; WS, water supply; dates given in month/day/year format]

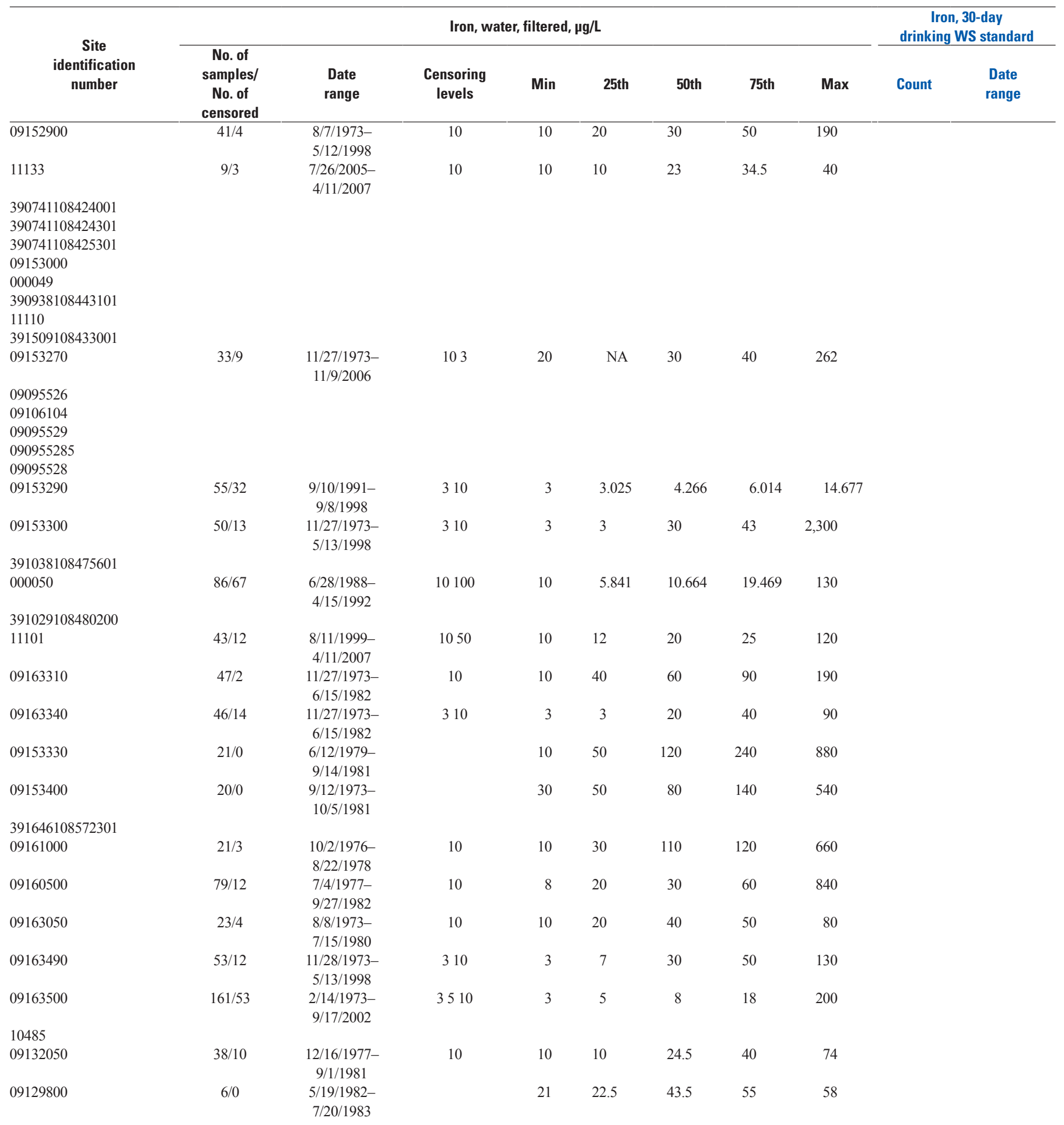


Appendix 1. Summary of surface-water-quality data and comparison to water-quality standards by site, by constituent, Piceance study area, western Colorado. Water-quality standards comparisons follow data summaries and are in blue text; standards are provided in table 3.-Continued

[CDPHE segment, Colorado Department of Health and the Environment stream segment as referred to in tables 2 and 3; latitude and longitude are in North American Datum of 1983; downstream order number assigned as part of analysis. $\mu \mathrm{g} / \mathrm{L}$, micrograms per liter; $\mu \mathrm{S} / \mathrm{cm}$, microsiemens per centimeter; mg/L, milligrams per liter; mL, milliliters; aq, aquatic; CO, Colorado; EPA, U.S. Environmental Protection Agency; Max, maximum; Min, minimum; NA, not applicable; No., number; NTU, nephelometric turbitidy units; WS, water supply; dates given in month/day/year format]

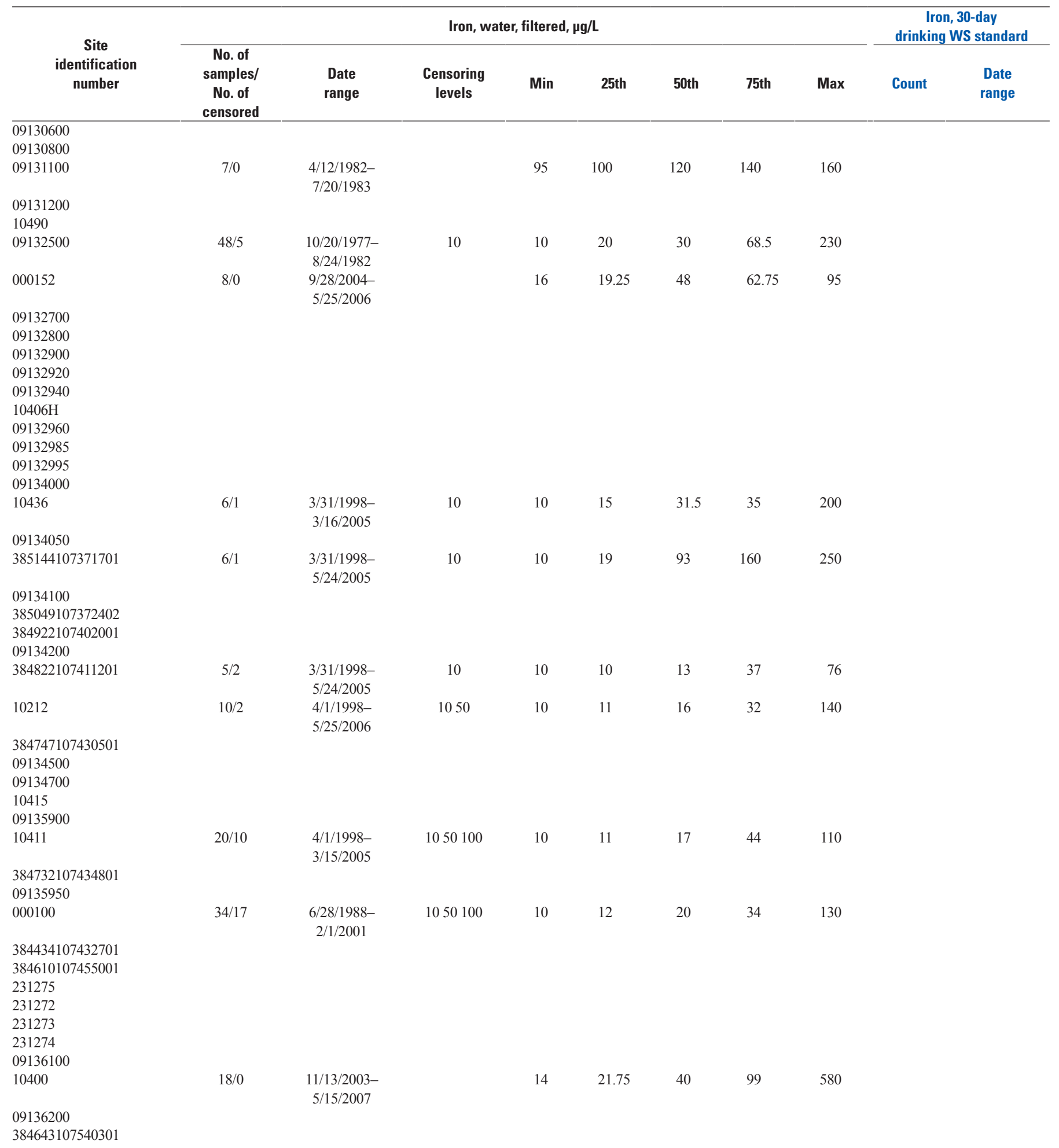


Appendix 1. Summary of surface-water-quality data and comparison to water-quality standards by site, by constituent, Piceance study area, western Colorado. Water-quality standards comparisons follow data summaries and are in blue text; standards are provided in table 3.-Continued

[CDPHE segment, Colorado Department of Health and the Environment stream segment as referred to in tables 2 and 3; latitude and longitude are in North American Datum of 1983; downstream order number assigned as part of analysis. $\mu \mathrm{g} / \mathrm{L}$, micrograms per liter; $\mu \mathrm{S} / \mathrm{cm}$, microsiemens per centimeter; mg/L, milligrams per liter; mL, milliliters; aq, aquatic; CO, Colorado; EPA, U.S. Environmental Protection Agency; Max, maximum; Min, minimum; NA, not applicable; No., number; NTU, nephelometric turbitidy units; WS, water supply; dates given in month/day/year format]

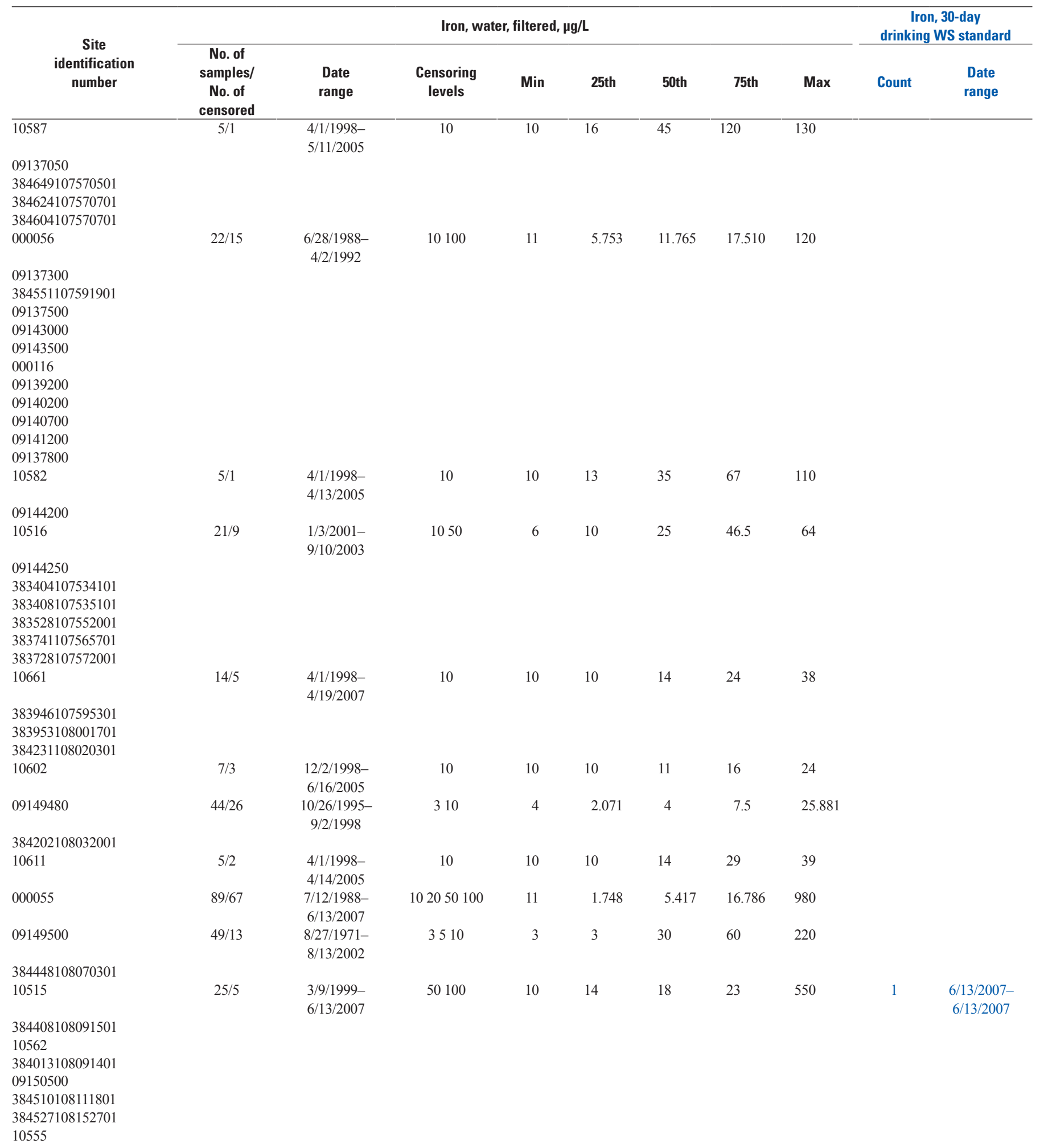


Appendix 1. Summary of surface-water-quality data and comparison to water-quality standards by site, by constituent, Piceance study area, western Colorado. Water-quality standards comparisons follow data summaries and are in blue text; standards are provided in table 3.-Continued

[CDPHE segment, Colorado Department of Health and the Environment stream segment as referred to in tables 2 and 3; latitude and longitude are in North American Datum of 1983; downstream order number assigned as part of analysis. $\mu \mathrm{g} / \mathrm{L}$, micrograms per liter; $\mu \mathrm{S} / \mathrm{cm}$, microsiemens per centimeter; mg/L, milligrams per liter; mL, milliliters; aq, aquatic; CO, Colorado; EPA, U.S. Environmental Protection Agency; Max, maximum; Min, minimum; NA, not applicable; No., number; NTU, nephelometric turbitidy units; WS, water supply; dates given in month/day/year format]

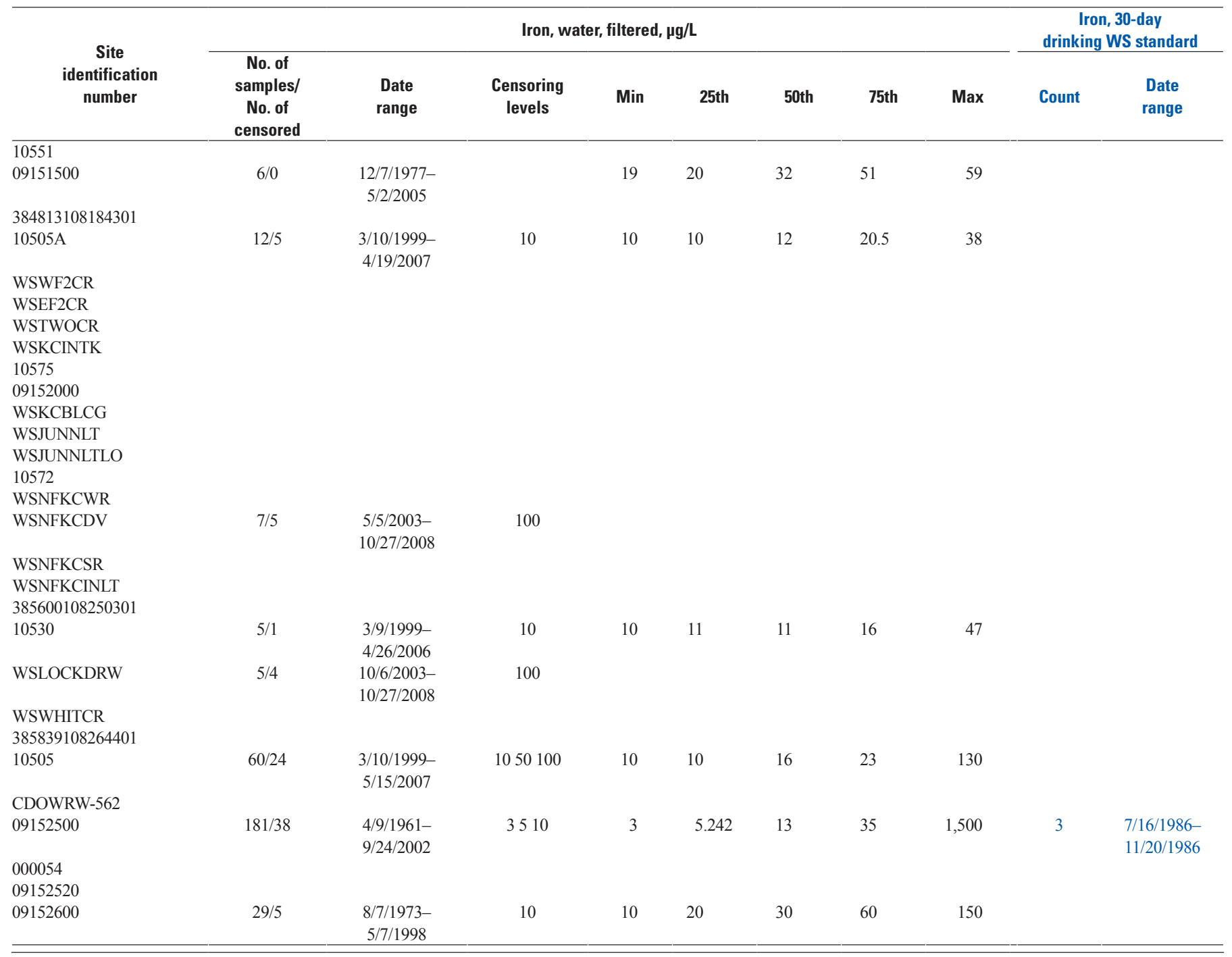


Appendix 1. Summary of surface-water-quality data and comparison to water-quality standards by site, by constituent, Piceance study area, western Colorado. Water-quality standards comparisons follow data summaries and are in blue text; standards are provided in table 3.-Continued

[CDPHE segment, Colorado Department of Health and the Environment stream segment as referred to in tables 2 and 3; latitude and longitude are in North American Datum of 1983; downstream order number assigned as part of analysis. $\mu \mathrm{g} / \mathrm{L}$, micrograms per liter; $\mu \mathrm{S} / \mathrm{cm}$, microsiemens per centimeter; mg/L, milligrams per liter; mL, milliliters; aq, aquatic; CO, Colorado; EPA, U.S. Environmental Protection Agency; Max, maximum; Min, minimum; NA, not applicable; No., number; NTU, nephelometric turbitidy units; WS, water supply; dates given in month/day/year format]

\begin{tabular}{|c|c|c|c|c|c|c|c|c|c|c|}
\hline \multirow{2}{*}{$\begin{array}{c}\text { Site } \\
\text { identification } \\
\text { number }\end{array}$} & \multicolumn{8}{|c|}{ Iron, total recoverable, $\mu \mathrm{g} / \mathrm{L}$} & \multicolumn{2}{|c|}{$\begin{array}{c}\text { Iron, aq life, } \\
\text { 30-day chronic standard }\end{array}$} \\
\hline & $\begin{array}{c}\text { samples/ } \\
\text { No. of } \\
\text { censored }\end{array}$ & $\begin{array}{l}\text { Date } \\
\text { range }\end{array}$ & $\begin{array}{l}\text { Censoring } \\
\text { levels }\end{array}$ & Min & 25th & 50th & 75th & Max & Count & $\begin{array}{l}\text { Date } \\
\text { range }\end{array}$ \\
\hline 09302450 & $10 / 0$ & $\begin{array}{c}8 / 17 / 1999- \\
6 / 11 / 2007\end{array}$ & & 65 & 100 & 295 & 380 & 9,100 & 1 & $\begin{array}{c}4 / 27 / 2000 \\
4 / 27 / 2000\end{array}$ \\
\hline \multicolumn{11}{|l|}{$\begin{array}{l}09304100 \\
395643107461200\end{array}$} \\
\hline 09304480 & $5 / 0$ & $\begin{array}{l}8 / 26 / 1981- \\
6 / 11 / 2007\end{array}$ & & 310 & 350 & 530 & 570 & 1,400 & & \\
\hline \multicolumn{11}{|l|}{09304300} \\
\hline \multicolumn{11}{|l|}{09304500} \\
\hline \multirow{2}{*}{\multicolumn{11}{|c|}{$\begin{array}{l}09304550 \\
09304600\end{array}$}} \\
\hline \multicolumn{10}{|l|}{09304600} & \\
\hline \multicolumn{11}{|l|}{400113107574500} \\
\hline 400206108005901 & $4 / 0$ & & & & & & & & & \\
\hline 09304800 & $38 / 0$ & $\begin{array}{c}9 / 10 / 1975- \\
6 / 25 / 2002\end{array}$ & & 60 & 140 & 350 & 580 & 5,300 & 6 & $\begin{array}{c}8 / 31 / 1977- \\
5 / 26 / 2000\end{array}$ \\
\hline \multicolumn{11}{|l|}{ ENPR20ST } \\
\hline \multicolumn{11}{|l|}{ ENPR21ST } \\
\hline \multicolumn{11}{|l|}{ ENPR19ST } \\
\hline \multicolumn{11}{|l|}{09306007} \\
\hline \multicolumn{11}{|l|}{09306025} \\
\hline \multicolumn{11}{|l|}{09306028} \\
\hline 09306022 & & & & & & & & & & \\
\hline 09306033 & & & & & & & & & & \\
\hline \multicolumn{11}{|l|}{09306039} \\
\hline \multicolumn{11}{|l|}{09306052} \\
\hline 09306200 & $7 / 0$ & $\begin{array}{c}4 / 18 / 1979- \\
12 / 2 / 1981\end{array}$ & & 390 & 420 & 1,400 & 27,000 & 81,000 & 4 & $\begin{array}{c}4 / 18 / 1979- \\
12 / 2 / 1981\end{array}$ \\
\hline \multicolumn{11}{|l|}{09306210} \\
\hline 09306222 & $9 / 0$ & $\begin{array}{c}7 / 17 / 1973- \\
12 / 2 / 1981\end{array}$ & & 360 & 990 & 2,300 & 27,000 & 65,000 & 6 & $\begin{array}{l}7 / 17 / 1973- \\
8 / 26 / 1981\end{array}$ \\
\hline 000117 & $89 / 2$ & $\begin{array}{c}11 / 2 / 1971- \\
6 / 29 / 1988\end{array}$ & 100 & 0 & 280 & 510 & 1,300 & 6,800 & 26 & $\begin{array}{l}3 / 4 / 1975- \\
4 / 19 / 1988\end{array}$ \\
\hline 09306224 & $5 / 0$ & $\begin{array}{c}11 / 17 / 1986- \\
5 / 17 / 1988\end{array}$ & & 190 & 345 & 820 & 7,750 & 8,100 & 2 & $\begin{array}{c}5 / 16 / 1987- \\
5 / 17 / 1988\end{array}$ \\
\hline 09306240 & & & & & & & & & & \\
\hline 09306241 & & & & & & & & & & \\
\hline 09306235 & & & & & & & & & & \\
\hline 09306242 & & & & & & & & & & \\
\hline 09306244 & & & & & & & & & & \\
\hline 11702 & $32 / 0$ & $\begin{array}{c}9 / 14 / 1999 \\
6 / 12 / 2007\end{array}$ & & 67 & 104.5 & 245 & 410 & 11,000 & 3 & $\begin{array}{l}5 / 23 / 2001- \\
4 / 24 / 2006\end{array}$ \\
\hline
\end{tabular}


Appendix 1. Summary of surface-water-quality data and comparison to water-quality standards by site, by constituent, Piceance study area, western Colorado. Water-quality standards comparisons follow data summaries and are in blue text; standards are provided in table 3.-Continued

[CDPHE segment, Colorado Department of Health and the Environment stream segment as referred to in tables 2 and 3; latitude and longitude are in North American Datum of 1983; downstream order number assigned as part of analysis. $\mu \mathrm{g} / \mathrm{L}$, micrograms per liter; $\mu \mathrm{S} / \mathrm{cm}$, microsiemens per centimeter; mg/L, milligrams per liter; mL, milliliters; aq, aquatic; CO, Colorado; EPA, U.S. Environmental Protection Agency; Max, maximum; Min, minimum; NA, not applicable; No., number; NTU, nephelometric turbitidy units; WS, water supply; dates given in month/day/year format]

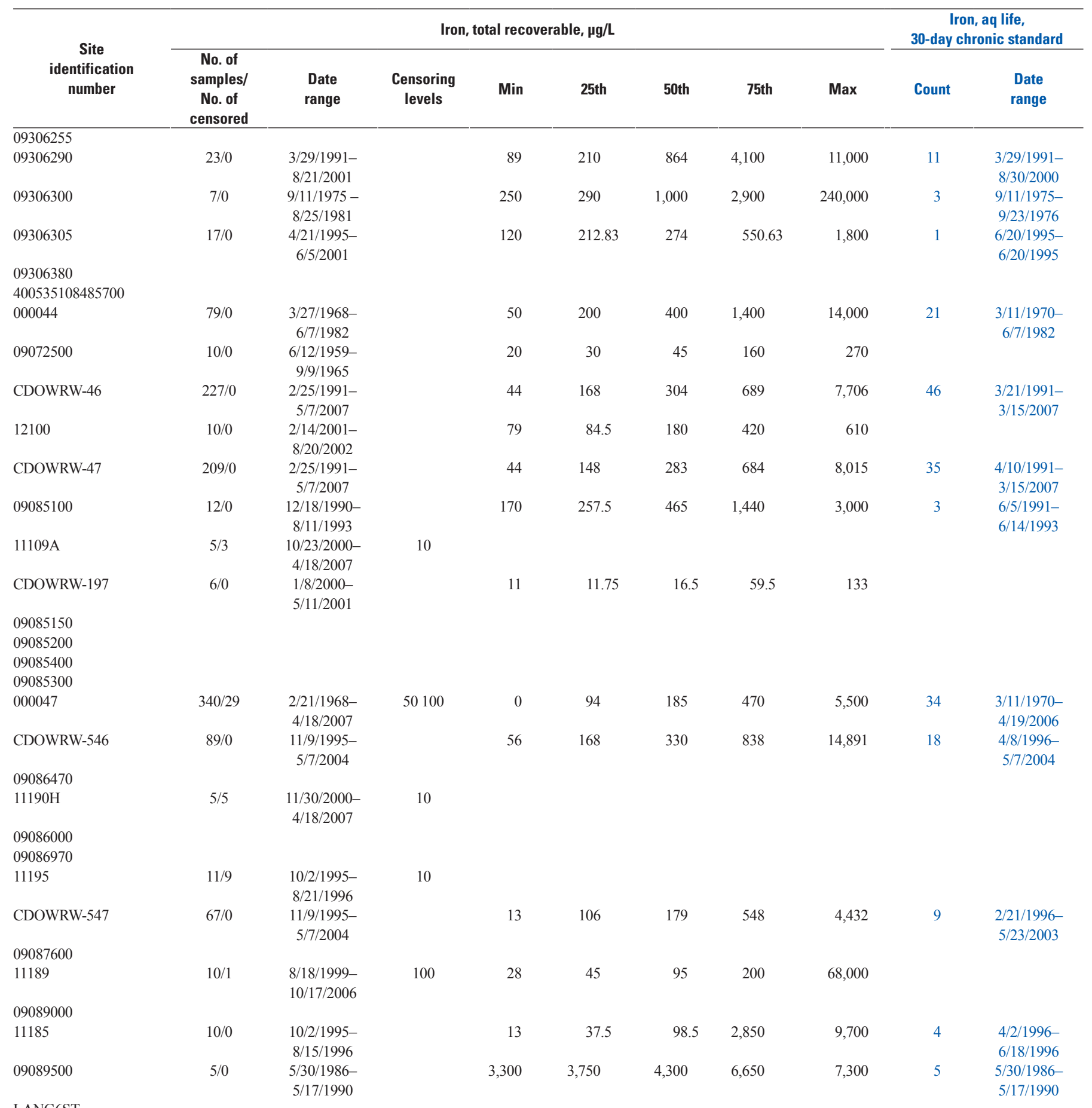

LANG5ST

LANG4ST

LANG3ST 
Appendix 1. Summary of surface-water-quality data and comparison to water-quality standards by site, by constituent, Piceance study area, western Colorado. Water-quality standards comparisons follow data summaries and are in blue text; standards are provided in table 3.-Continued

[CDPHE segment, Colorado Department of Health and the Environment stream segment as referred to in tables 2 and 3; latitude and longitude are in North American Datum of 1983; downstream order number assigned as part of analysis. $\mu \mathrm{g} / \mathrm{L}$, micrograms per liter; $\mu \mathrm{S} / \mathrm{cm}$, microsiemens per centimeter; mg/L, milligrams per liter; mL, milliliters; aq, aquatic; CO, Colorado; EPA, U.S. Environmental Protection Agency; Max, maximum; Min, minimum; NA, not applicable; No., number; NTU, nephelometric turbitidy units; WS, water supply; dates given in month/day/year format]

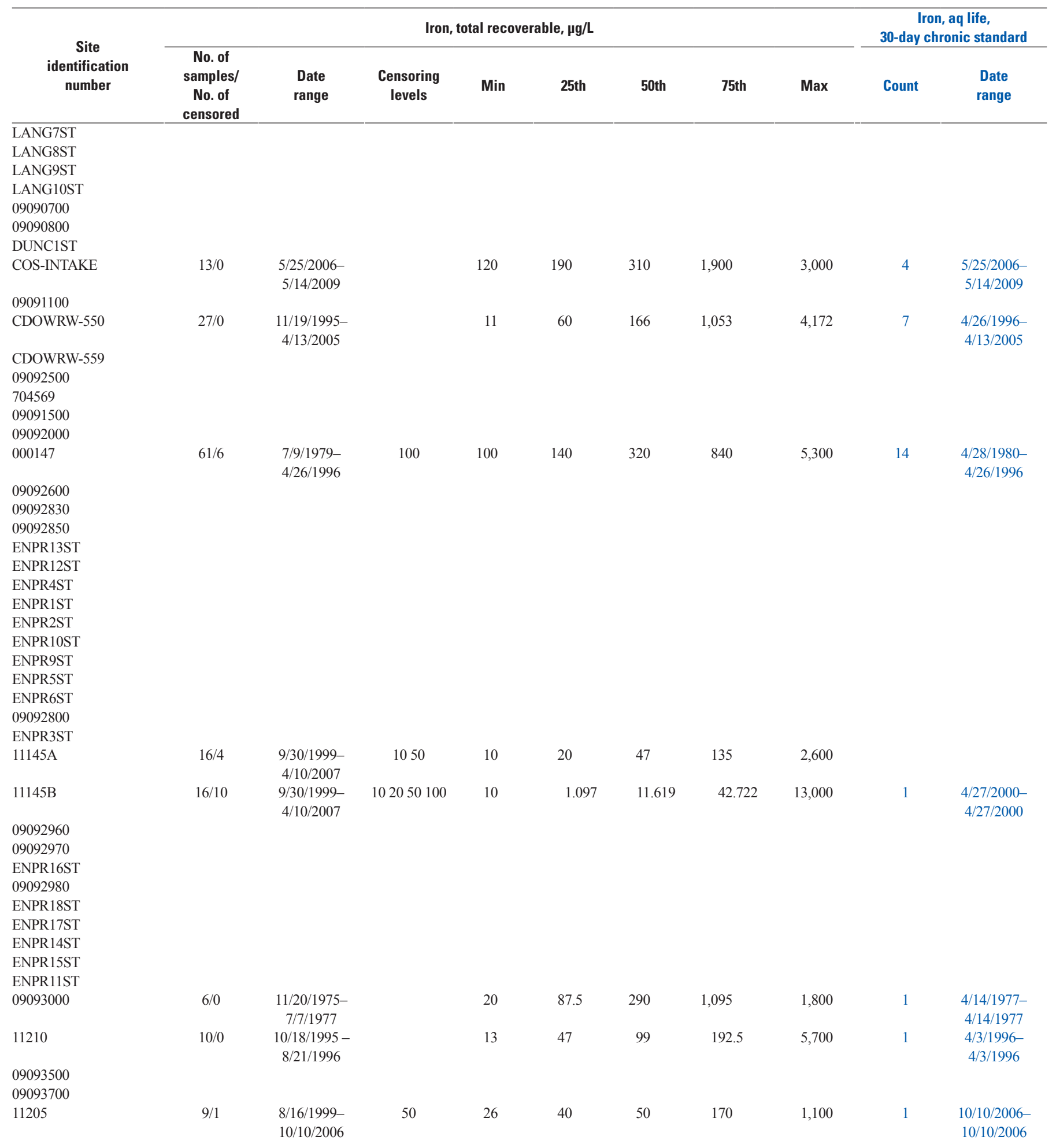


Appendix 1. Summary of surface-water-quality data and comparison to water-quality standards by site, by constituent, Piceance study area, western Colorado. Water-quality standards comparisons follow data summaries and are in blue text; standards are provided in table 3.-Continued

[CDPHE segment, Colorado Department of Health and the Environment stream segment as referred to in tables 2 and 3; latitude and longitude are in North American Datum of 1983; downstream order number assigned as part of analysis. $\mu \mathrm{g} / \mathrm{L}$, micrograms per liter; $\mu \mathrm{S} / \mathrm{cm}$, microsiemens per centimeter; mg/L, milligrams per liter; mL, milliliters; aq, aquatic; CO, Colorado; EPA, U.S. Environmental Protection Agency; Max, maximum; Min, minimum; NA, not applicable; No., number; NTU, nephelometric turbitidy units; WS, water supply; dates given in month/day/year format]

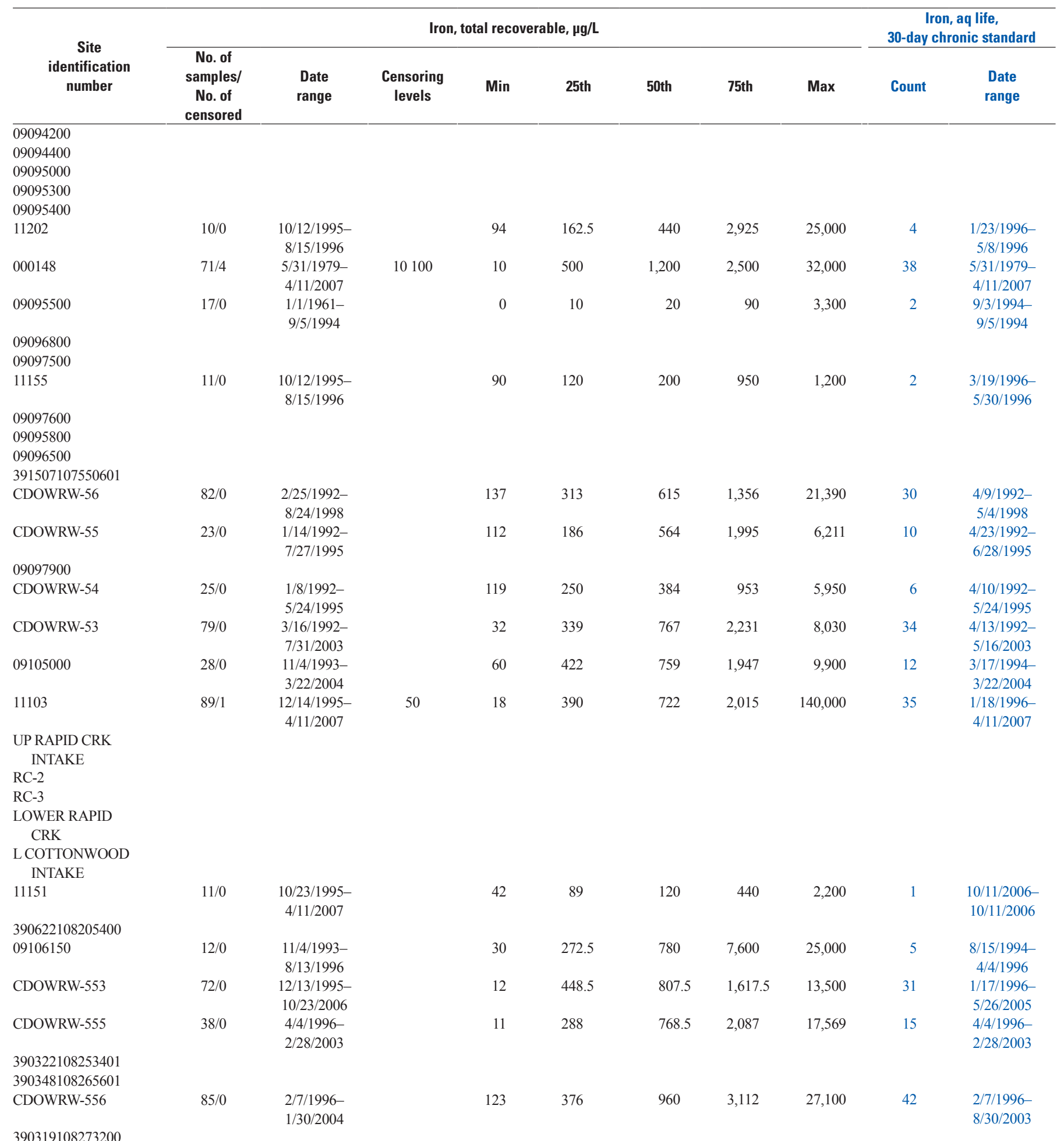


Appendix 1. Summary of surface-water-quality data and comparison to water-quality standards by site, by constituent, Piceance study area, western Colorado. Water-quality standards comparisons follow data summaries and are in blue text; standards are provided in table 3.-Continued

[CDPHE segment, Colorado Department of Health and the Environment stream segment as referred to in tables 2 and 3; latitude and longitude are in North American Datum of 1983; downstream order number assigned as part of analysis. $\mu \mathrm{g} / \mathrm{L}$, micrograms per liter; $\mu \mathrm{S} / \mathrm{cm}$, microsiemens per centimeter; mg/L, milligrams per liter; mL, milliliters; aq, aquatic; CO, Colorado; EPA, U.S. Environmental Protection Agency; Max, maximum; Min, minimum; NA, not applicable; No., number; NTU, nephelometric turbitidy units; WS, water supply; dates given in month/day/year format]

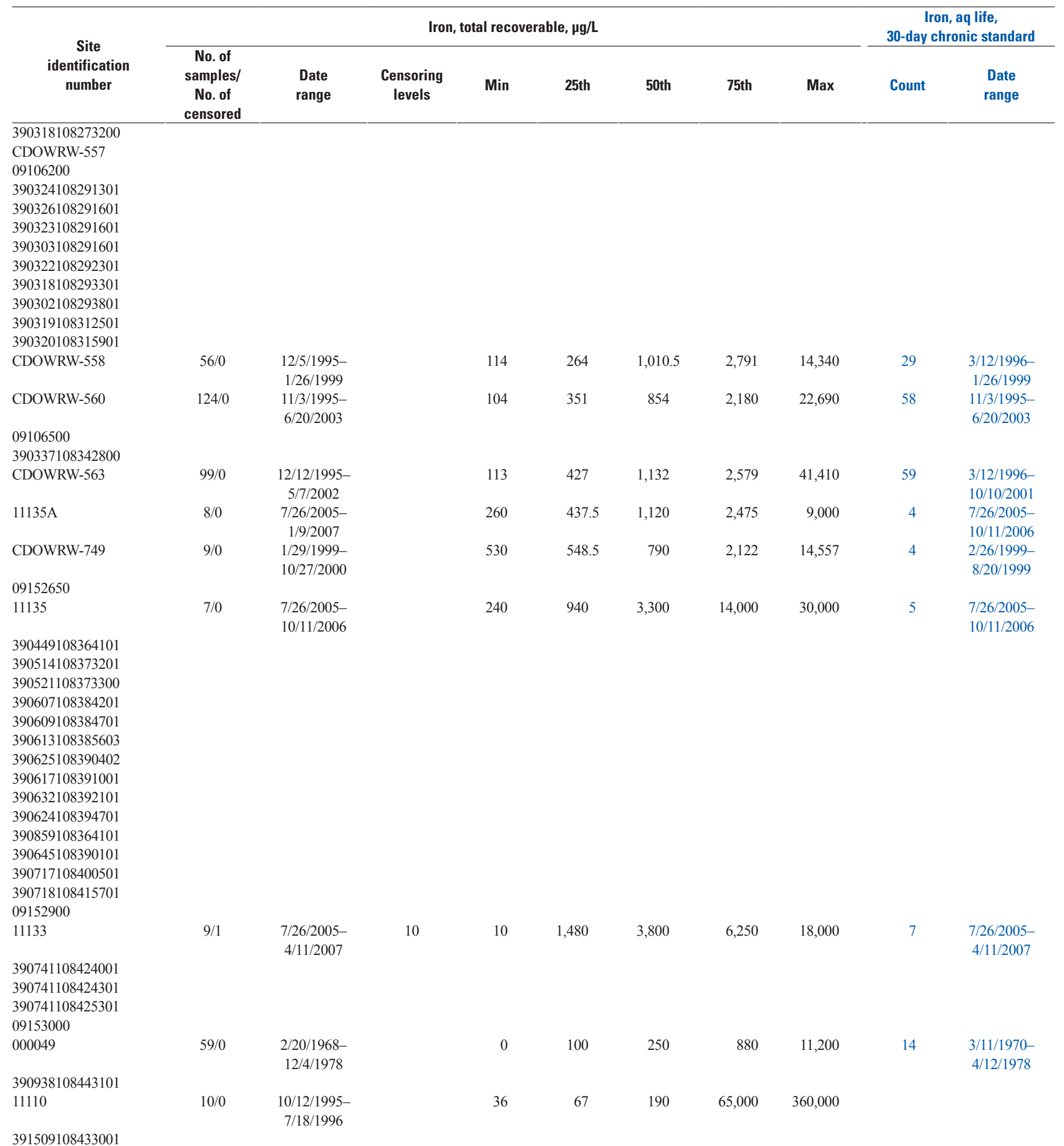


Appendix 1. Summary of surface-water-quality data and comparison to water-quality standards by site, by constituent, Piceance study area, western Colorado. Water-quality standards comparisons follow data summaries and are in blue text; standards are provided in table 3.-Continued

[CDPHE segment, Colorado Department of Health and the Environment stream segment as referred to in tables 2 and 3; latitude and longitude are in North American Datum of 1983; downstream order number assigned as part of analysis. $\mu \mathrm{g} / \mathrm{L}$, micrograms per liter; $\mu \mathrm{S} / \mathrm{cm}$, microsiemens per centimeter; mg/L, milligrams per liter; mL, milliliters; aq, aquatic; CO, Colorado; EPA, U.S. Environmental Protection Agency; Max, maximum; Min, minimum; NA, not applicable; No., number; NTU, nephelometric turbitidy units; WS, water supply; dates given in month/day/year format]

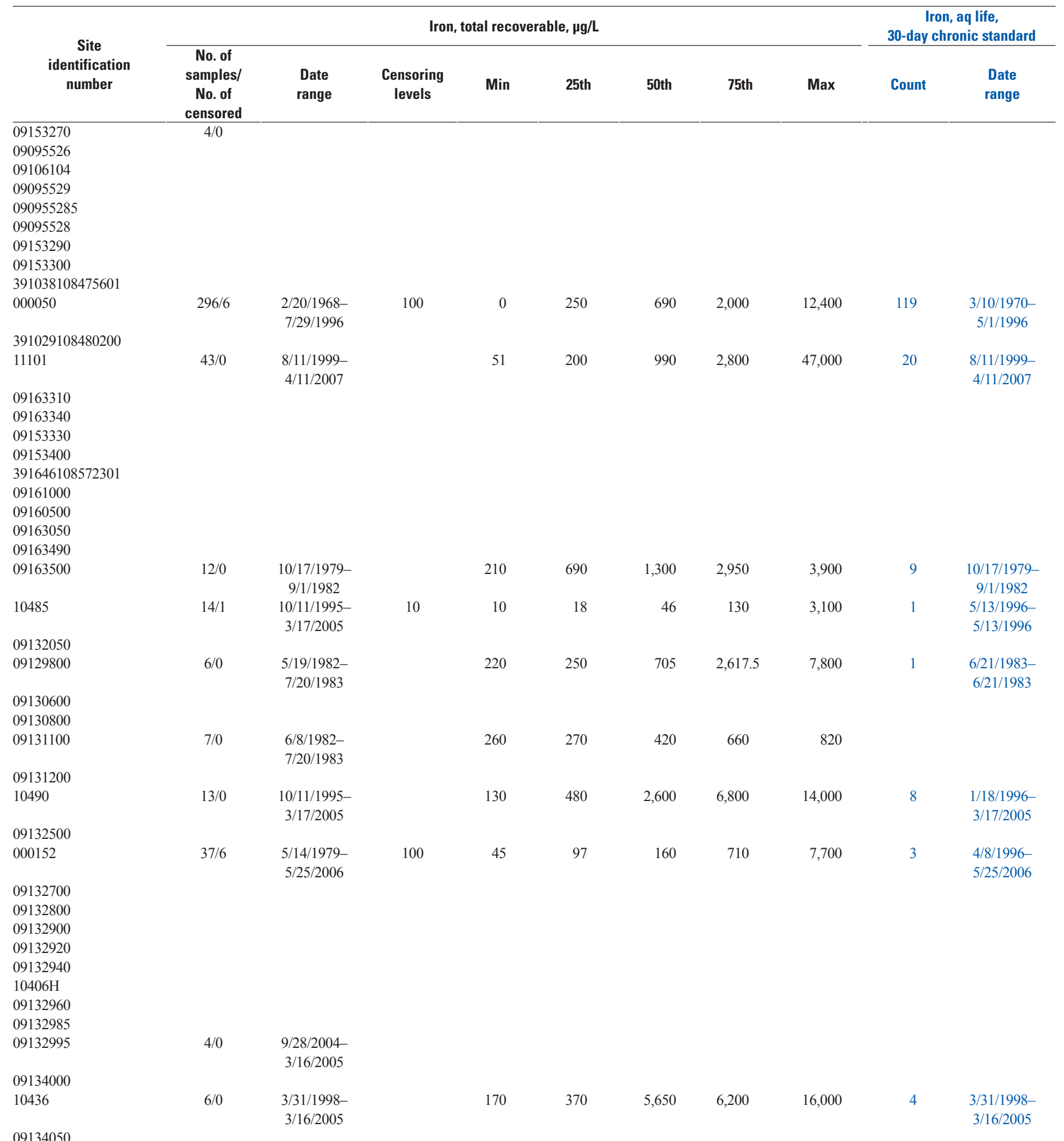


Appendix 1. Summary of surface-water-quality data and comparison to water-quality standards by site, by constituent, Piceance study area, western Colorado. Water-quality standards comparisons follow data summaries and are in blue text; standards are provided in table 3.-Continued

[CDPHE segment, Colorado Department of Health and the Environment stream segment as referred to in tables 2 and 3; latitude and longitude are in North American Datum of 1983; downstream order number assigned as part of analysis. $\mu \mathrm{g} / \mathrm{L}$, micrograms per liter; $\mu \mathrm{S} / \mathrm{cm}$, microsiemens per centimeter; mg/L, milligrams per liter; mL, milliliters; aq, aquatic; CO, Colorado; EPA, U.S. Environmental Protection Agency; Max, maximum; Min, minimum; NA, not applicable; No., number; NTU, nephelometric turbitidy units; WS, water supply; dates given in month/day/year format]

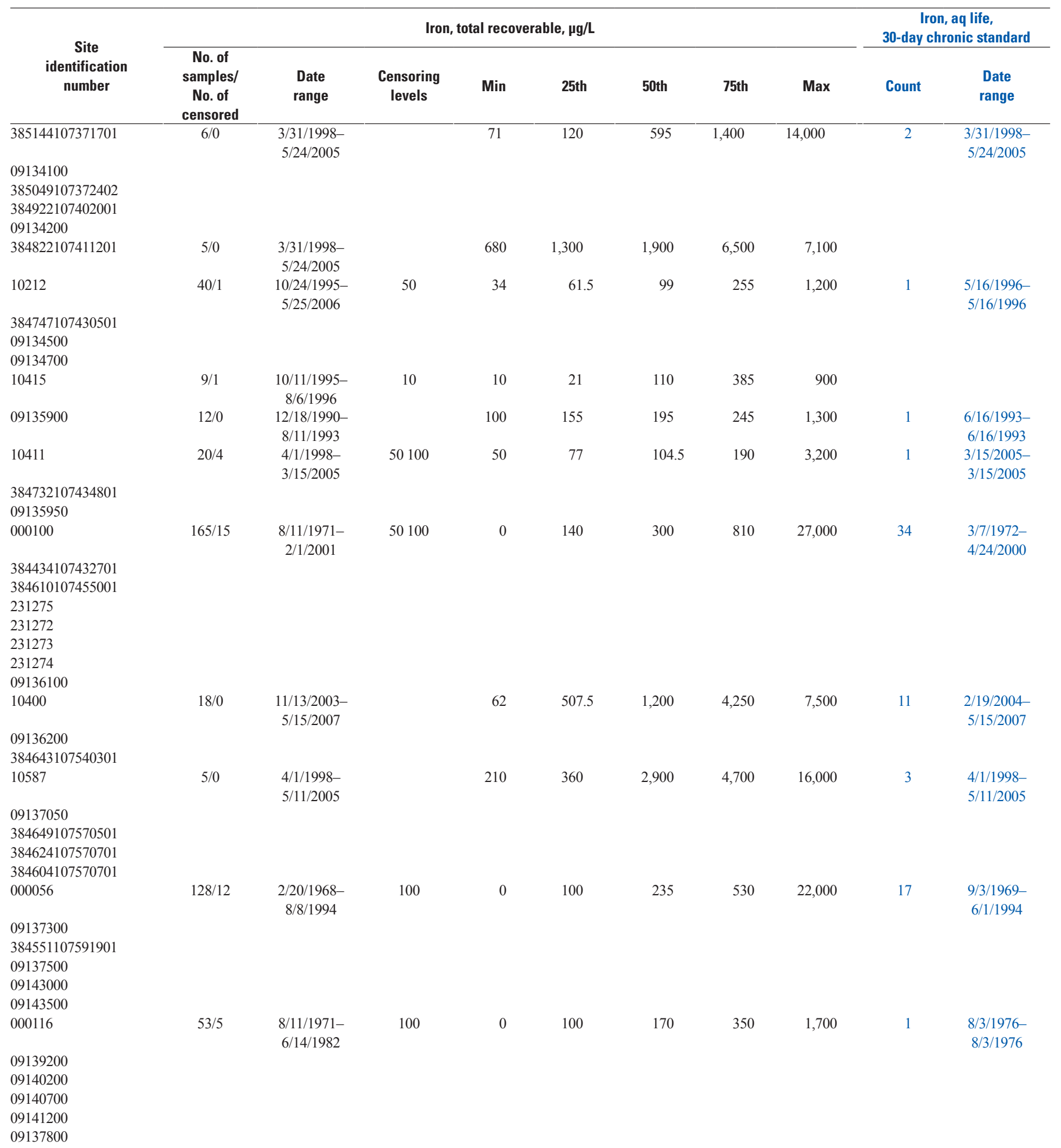


Appendix 1. Summary of surface-water-quality data and comparison to water-quality standards by site, by constituent, Piceance study area, western Colorado. Water-quality standards comparisons follow data summaries and are in blue text; standards are provided in table 3.-Continued

[CDPHE segment, Colorado Department of Health and the Environment stream segment as referred to in tables 2 and 3; latitude and longitude are in North American Datum of 1983; downstream order number assigned as part of analysis. $\mu \mathrm{g} / \mathrm{L}$, micrograms per liter; $\mu \mathrm{S} / \mathrm{cm}$, microsiemens per centimeter; $\mathrm{mg} / \mathrm{L}$, milligrams per liter; mL, milliliters; aq, aquatic; CO, Colorado; EPA, U.S. Environmental Protection Agency; Max, maximum; Min, minimum; NA, not applicable; No., number; NTU, nephelometric turbitidy units; WS, water supply; dates given in month/day/year format]

\begin{tabular}{|c|c|c|c|c|c|c|c|c|c|c|}
\hline \multirow[b]{2}{*}{$\begin{array}{c}\text { Site } \\
\text { identification } \\
\text { number }\end{array}$} & \multicolumn{8}{|c|}{ Iron, total recoverable, $\mu \mathrm{g} / \mathrm{L}$} & \multicolumn{2}{|c|}{$\begin{array}{c}\text { Iron, aq life, } \\
\text { 30-day chronic standard }\end{array}$} \\
\hline & $\begin{array}{c}\text { No. of } \\
\text { samples/ } \\
\text { No. of } \\
\text { censored }\end{array}$ & $\begin{array}{l}\text { Date } \\
\text { range }\end{array}$ & $\begin{array}{l}\text { Censoring } \\
\text { levels }\end{array}$ & Min & 25th & 50th & 75th & Max & Count & $\begin{array}{l}\text { Date } \\
\text { range }\end{array}$ \\
\hline 10582 & $5 / 0$ & $\begin{array}{l}4 / 1 / 1998- \\
4 / 13 / 2005\end{array}$ & & 370 & 2,200 & 2,800 & 3,100 & 12,000 & 4 & $\begin{array}{l}4 / 1 / 1998- \\
4 / 13 / 2005\end{array}$ \\
\hline \multicolumn{11}{|l|}{09144200} \\
\hline 09144250 & $11 / 0$ & $\begin{array}{c}12 / 20 / 1990- \\
8 / 12 / 1993\end{array}$ & & 320 & 590 & 740 & 2,700 & 4,800 & 5 & $\begin{array}{l}\text { 6/7/1991- } \\
8 / 12 / 1993\end{array}$ \\
\hline \multicolumn{11}{|l|}{383404107534101} \\
\hline \multicolumn{11}{|l|}{383408107535101} \\
\hline \multicolumn{11}{|l|}{383528107552001} \\
\hline \multicolumn{11}{|l|}{383741107565701} \\
\hline \multicolumn{11}{|l|}{383728107572001} \\
\hline \multicolumn{11}{|l|}{384231108020301} \\
\hline 10602 & $7 / 0$ & $\begin{array}{l}4 / 1 / 1998- \\
6 / 16 / 2005\end{array}$ & & 420 & 450 & 1,900 & 2,200 & 4,900 & 1 & $\begin{array}{l}4 / 1 / 1998- \\
4 / 1 / 1998\end{array}$ \\
\hline \multicolumn{11}{|l|}{09149480} \\
\hline \multicolumn{11}{|l|}{384202108032001} \\
\hline 10611 & $5 / 0$ & $\begin{array}{l}4 / 1 / 1998 \\
4 / 14 / 2005\end{array}$ & & 110 & 670 & 5,600 & 5,900 & 14,000 & 3 & $\begin{array}{l}4 / 1 / 1998- \\
4 / 14 / 2005\end{array}$ \\
\hline 000055 & $321 / 6$ & $\begin{array}{c}9 / 17 / 1968- \\
6 / 13 / 2007\end{array}$ & 1050100 & 0 & 290 & 920 & 2,600 & 21,000 & 90 & $\begin{array}{l}5 / 8 / 1975- \\
6 / 13 / 2007\end{array}$ \\
\hline 09149500 & $29 / 0$ & $\begin{array}{l}11 / 6 / 1958- \\
8 / 12 / 1997\end{array}$ & & 0 & 30 & 290 & 3,300 & 14,000 & 10 & $\begin{array}{l}\text { 3/21/1991- } \\
8 / 12 / 1997\end{array}$ \\
\hline \multicolumn{11}{|l|}{384448108070301} \\
\hline 10515 & $31 / 0$ & $\begin{array}{c}1 / 12 / 1999- \\
6 / 13 / 2007\end{array}$ & & 48 & 230 & 440 & 1,600 & 4,400 & 13 & $\begin{array}{l}\text { 4/7/1999- } \\
6 / 13 / 2007\end{array}$ \\
\hline \multicolumn{11}{|l|}{384013108091401} \\
\hline 10551 & $12 / 0$ & $\begin{array}{l}\text { 10/4/1995- } \\
9 / 28 / 2004\end{array}$ & & 71 & 85 & 120 & 565 & 5,200 & 1 & $\begin{array}{l}\text { 4/9/1996- } \\
\text { 4/9/1996 }\end{array}$ \\
\hline 09151500 & $4 / 0$ & & & & & & & & & \\
\hline \multicolumn{11}{|l|}{384813108184301} \\
\hline $10505 \mathrm{~A}$ & $12 / 0$ & $\begin{array}{c}3 / 10 / 1999 \\
4 / 19 / 2007\end{array}$ & & 140 & 355 & 730 & 1,850 & 3,200 & 5 & $\begin{array}{c}3 / 10 / 1999 \\
10 / 3 / 2006\end{array}$ \\
\hline \multicolumn{11}{|l|}{ WSWF2CR } \\
\hline \multicolumn{11}{|l|}{ WSEF2CR } \\
\hline \multicolumn{11}{|l|}{ WSTWOCR } \\
\hline WSKCINTK & & & & & & & & & & \\
\hline 10575 & $10 / 0$ & $\begin{array}{c}\text { 9/14/1995- } \\
5 / 2 / 2005\end{array}$ & & 58 & 85 & 140 & 480 & 3,700 & 2 & $\begin{array}{c}3 / 6 / 1996- \\
5 / 1 / 1996\end{array}$ \\
\hline
\end{tabular}

WSKCBLCG 
Appendix 1. Summary of surface-water-quality data and comparison to water-quality standards by site, by constituent, Piceance study area, western Colorado. Water-quality standards comparisons follow data summaries and are in blue text; standards are provided in table 3.-Continued

[CDPHE segment, Colorado Department of Health and the Environment stream segment as referred to in tables 2 and 3; latitude and longitude are in North American Datum of 1983; downstream order number assigned as part of analysis. $\mu \mathrm{g} / \mathrm{L}$, micrograms per liter; $\mu \mathrm{S} / \mathrm{cm}$, microsiemens per centimeter; $\mathrm{mg} / \mathrm{L}$, milligrams per liter; mL, milliliters; aq, aquatic; CO, Colorado; EPA, U.S. Environmental Protection Agency; Max, maximum; Min, minimum; NA, not applicable; No., number; NTU, nephelometric turbitidy units; WS, water supply; dates given in month/day/year format]

\begin{tabular}{|c|c|c|c|c|c|c|c|c|c|c|}
\hline \multirow{2}{*}{$\begin{array}{c}\text { Site } \\
\text { identification } \\
\text { number }\end{array}$} & \multicolumn{8}{|c|}{ Iron, total recoverable, $\mu \mathrm{g} / \mathrm{L}$} & \multicolumn{2}{|c|}{$\begin{array}{c}\text { Iron, aq life, } \\
\text { 30-day chronic standard }\end{array}$} \\
\hline & $\begin{array}{c}\text { No. of } \\
\text { samples/ } \\
\text { No. of } \\
\text { censored }\end{array}$ & $\begin{array}{l}\text { Date } \\
\text { range }\end{array}$ & $\begin{array}{l}\text { Censoring } \\
\text { levels }\end{array}$ & Min & 25th & 50th & 75th & Max & Count & $\begin{array}{l}\text { Date } \\
\text { range }\end{array}$ \\
\hline \multicolumn{11}{|l|}{ WSJUNNLT } \\
\hline \multicolumn{11}{|l|}{ WSJUNNLTLO } \\
\hline 10572 & $9 / 0$ & $\begin{array}{c}9 / 14 / 1995- \\
5 / 2 / 2005\end{array}$ & & 21 & 130 & 140 & 210 & 400 & & \\
\hline \multicolumn{11}{|l|}{ WSNFKCWR } \\
\hline \multicolumn{11}{|l|}{ WSNFKCDV } \\
\hline \multicolumn{11}{|l|}{ WSNFKCSR } \\
\hline \multicolumn{11}{|l|}{ WSNFKCINLT } \\
\hline \multicolumn{11}{|l|}{385600108250301} \\
\hline 10530 & $5 / 0$ & $\begin{array}{l}3 / 9 / 1999 \\
4 / 26 / 2006\end{array}$ & & 73 & 180 & 280 & 370 & 730 & & \\
\hline \multicolumn{11}{|l|}{ WSLOCKDRW } \\
\hline CDOWRW-562 & $42 / 0$ & $\begin{array}{c}\text { 3/11/1997- } \\
6 / 8 / 1999\end{array}$ & & 110 & 655.25 & 1,475 & $3,068.75$ & 8,394 & 28 & $\begin{array}{c}3 / 11 / 1997- \\
5 / 25 / 1999\end{array}$ \\
\hline 09152500 & $54 / 0$ & $\begin{array}{c}\text { 10/5/1959- } \\
9 / 7 / 1982\end{array}$ & & 0 & 10 & 220 & 990 & 8,800 & 11 & $\begin{array}{l}4 / 7 / 1976- \\
9 / 7 / 1982\end{array}$ \\
\hline 000054 & $79 / 0$ & $\begin{array}{c}2 / 20 / 1968- \\
4 / 30 / 1979\end{array}$ & & 0 & 100 & 300 & 800 & 10,100 & 17 & $\begin{array}{c}4 / 28 / 1975- \\
4 / 30 / 1979\end{array}$ \\
\hline $\begin{array}{l}09152520 \\
09152600\end{array}$ & & & & & & & & & & \\
\hline
\end{tabular}


Appendix 1. Summary of surface-water-quality data and comparison to water-quality standards by site, by constituent, Piceance study area, western Colorado. Water-quality standards comparisons follow data summaries and are in blue text; standards are provided in table 3.-Continued

[CDPHE segment, Colorado Department of Health and the Environment stream segment as referred to in tables 2 and 3; latitude and longitude are in North American Datum of 1983; downstream order number assigned as part of analysis. $\mu \mathrm{g} / \mathrm{L}$, micrograms per liter; $\mu \mathrm{S} / \mathrm{cm}$, microsiemens per centimeter; mg/L, milligrams per liter; mL, milliliters; aq, aquatic; CO, Colorado; EPA, U.S. Environmental Protection Agency; Max, maximum; Min, minimum; NA, not applicable; No., number; NTU, nephelometric turbitidy units; WS, water supply; dates given in month/day/year format]

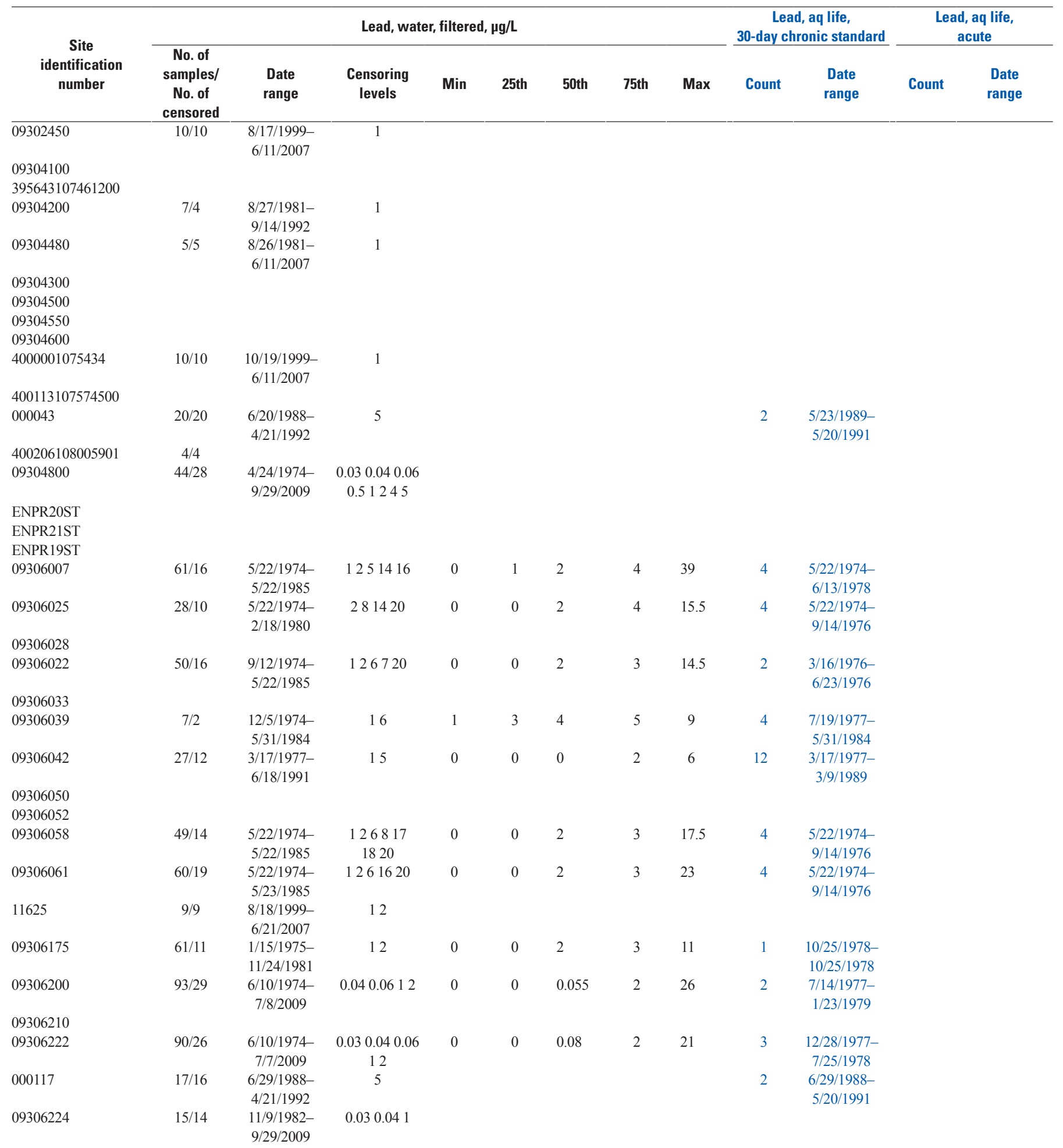


Appendix 1. Summary of surface-water-quality data and comparison to water-quality standards by site, by constituent, Piceance study area, western Colorado. Water-quality standards comparisons follow data summaries and are in blue text; standards are provided in table 3.-Continued

[CDPHE segment, Colorado Department of Health and the Environment stream segment as referred to in tables 2 and 3; latitude and longitude are in North American Datum of 1983; downstream order number assigned as part of analysis. $\mu \mathrm{g} / \mathrm{L}$, micrograms per liter; $\mu \mathrm{S} / \mathrm{cm}$, microsiemens per centimeter; mg/L, milligrams per liter; mL, milliliters; aq, aquatic; CO, Colorado; EPA, U.S. Environmental Protection Agency; Max, maximum; Min, minimum; NA, not applicable; No., number; NTU, nephelometric turbitidy units; WS, water supply; dates given in month/day/year format]

\begin{tabular}{|c|c|c|c|c|c|c|c|c|c|c|c|c|}
\hline $\begin{array}{c}\text { Site } \\
\text { identification } \\
\text { number }\end{array}$ & \multicolumn{8}{|c|}{ Lead, water, filtered, $\mu \mathrm{g} / \mathrm{L}$} & \multicolumn{2}{|c|}{$\begin{array}{c}\text { Lead, aq life, } \\
\text { 30-day chronic standard }\end{array}$} & \multicolumn{2}{|c|}{$\begin{array}{l}\text { Lead, aq life, } \\
\text { acute }\end{array}$} \\
\hline 09306240 & $11 / 5$ & $\begin{array}{c}5 / 17 / 1974 \\
4 / 20 / 1978\end{array}$ & 2410 & 2 & 2 & 5 & 10 & 11 & 4 & $\begin{array}{l}5 / 30 / 1974 \\
8 / 25 / 1977\end{array}$ & & \\
\hline 09306241 & & & & & & & & & & & & \\
\hline 09306242 & $53 / 19$ & $\begin{array}{c}5 / 17 / 1974 \\
7 / 8 / 2009\end{array}$ & $\begin{array}{c}0.0412610 \\
1315\end{array}$ & 0.033 & 0.076 & 2 & 3 & 36 & 5 & $\begin{array}{c}5 / 17 / 1974 \\
4 / 20 / 1978\end{array}$ & & \\
\hline 09306244 & $13 / 5$ & $\begin{array}{l}6 / 12 / 1975- \\
10 / 24 / 1978\end{array}$ & 29 & 2 & 2 & 3 & 7.5 & 9 & & & & \\
\hline 11702 & $32 / 31$ & $\begin{array}{l}9 / 14 / 1999- \\
6 / 12 / 2007\end{array}$ & 1 & & & & & & 1 & $\begin{array}{l}12 / 9 / 2003- \\
12 / 9 / 2003\end{array}$ & & \\
\hline 09306255 & $43 / 13$ & $\begin{array}{c}5 / 16 / 1972- \\
7 / 7 / 2009\end{array}$ & $\begin{array}{c}0.030 .04216 \\
17203150\end{array}$ & 0.094 & 0.151 & 2 & 4 & 31.5 & 6 & $\begin{array}{c}6 / 21 / 1974 \\
6 / 23 / 1976\end{array}$ & & \\
\hline 09306305 & & & & & & & & & & & & \\
\hline 09306380 & $5 / 3$ & $\begin{array}{l}2 / 8 / 1977- \\
11 / 8 / 1995\end{array}$ & 10 & & & & & & & & & \\
\hline 400535108485700 & & & & & & & & & & & & \\
\hline $\begin{array}{l}000044 \\
09072500\end{array}$ & & & & & & & & & & & & \\
\hline CDOWRW-46 & & & & & & & & & & & & \\
\hline 12100 & 9/9 & $\begin{array}{l}2 / 14 / 2001- \\
8 / 20 / 2002\end{array}$ & 1 & & & & & & & & & \\
\hline CDOWRW-47 & & & & & & & & & & & & \\
\hline 09085100 & $12 / 10$ & $\begin{array}{l}12 / 18 / 1990- \\
8 / 11 / 1993\end{array}$ & 1 & & & & & & & & & \\
\hline 11109A & $5 / 5$ & $\begin{array}{l}10 / 23 / 2000- \\
4 / 18 / 2007\end{array}$ & 1 & & & & & & & & & \\
\hline $\begin{array}{l}\text { CDOWRW-546 } \\
09086470\end{array}$ & & & & & & & & & & & & \\
\hline $11190 \mathrm{H}$ & $5 / 5$ & $\begin{array}{l}11 / 30 / 2000- \\
4 / 18 / 2007\end{array}$ & 1 & & & & & & & & & \\
\hline $\begin{array}{l}09086000 \\
09086970\end{array}$ & & & & & & & & & & & & \\
\hline 11195 & $11 / 11$ & $\begin{array}{l}10 / 2 / 1995- \\
8 / 21 / 1996\end{array}$ & 1 & & & & & & & & & \\
\hline $\begin{array}{l}\text { CDOWRW-547 } \\
09087600\end{array}$ & & & & & & & & & & & & \\
\hline 11189 & $10 / 9$ & $\begin{array}{l}8 / 18 / 1999 \\
10 / 17 / 2006\end{array}$ & 1 & & & & & & & & & \\
\hline 09089000 & & & & & & & & & & & & \\
\hline 11185 & $10 / 10$ & $\begin{array}{l}10 / 2 / 1995- \\
8 / 15 / 1996\end{array}$ & 1 & & & & & & & & & \\
\hline
\end{tabular}


Appendix 1. Summary of surface-water-quality data and comparison to water-quality standards by site, by constituent, Piceance study area, western Colorado. Water-quality standards comparisons follow data summaries and are in blue text; standards are provided in table 3.-Continued

[CDPHE segment, Colorado Department of Health and the Environment stream segment as referred to in tables 2 and 3; latitude and longitude are in North American Datum of 1983; downstream order number assigned as part of analysis. $\mu \mathrm{g} / \mathrm{L}$, micrograms per liter; $\mu \mathrm{S} / \mathrm{cm}$, microsiemens per centimeter; mg/L, milligrams per liter; mL, milliliters; aq, aquatic; CO, Colorado; EPA, U.S. Environmental Protection Agency; Max, maximum; Min, minimum; NA, not applicable; No., number; NTU, nephelometric turbitidy units; WS, water supply; dates given in month/day/year format]

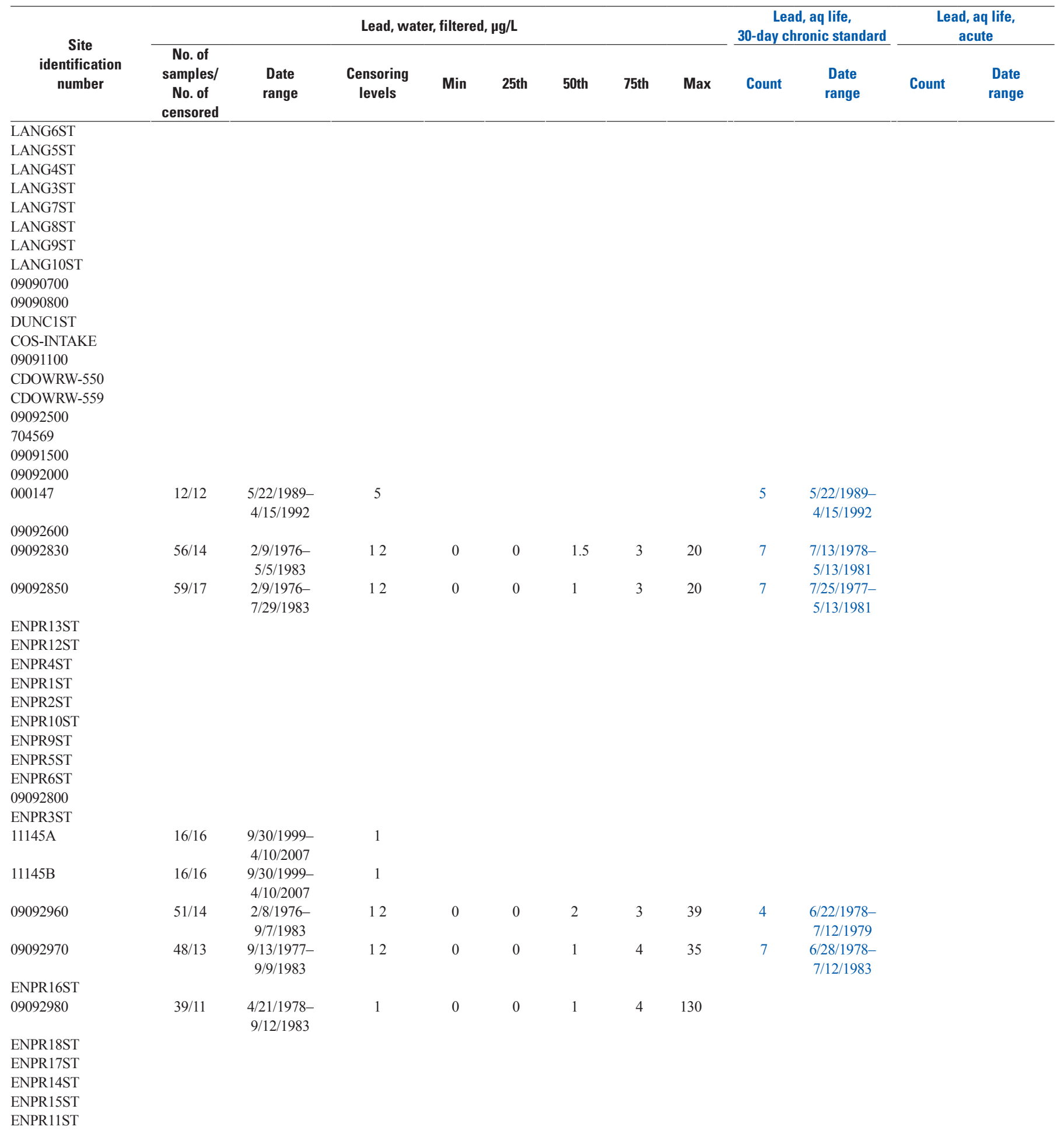


Appendix 1. Summary of surface-water-quality data and comparison to water-quality standards by site, by constituent, Piceance study area, western Colorado. Water-quality standards comparisons follow data summaries and are in blue text; standards are provided in table 3.-Continued

[CDPHE segment, Colorado Department of Health and the Environment stream segment as referred to in tables 2 and 3; latitude and longitude are in North American Datum of 1983; downstream order number assigned as part of analysis. $\mu \mathrm{g} / \mathrm{L}$, micrograms per liter; $\mu \mathrm{S} / \mathrm{cm}$, microsiemens per centimeter; mg/L, milligrams per liter; mL, milliliters; aq, aquatic; CO, Colorado; EPA, U.S. Environmental Protection Agency; Max, maximum; Min, minimum; NA, not applicable; No., number; NTU, nephelometric turbitidy units; WS, water supply; dates given in month/day/year format]

\begin{tabular}{|c|c|c|c|c|c|c|c|c|c|c|c|c|}
\hline $\begin{array}{c}\text { Site } \\
\text { identification } \\
\text { number }\end{array}$ & \multicolumn{8}{|c|}{ Lead, water, filtered, $\mu \mathrm{g} / \mathrm{L}$} & \multicolumn{2}{|c|}{$\begin{array}{c}\text { Lead, aq life, } \\
\text { 30-day chronic standard }\end{array}$} & \multicolumn{2}{|c|}{$\begin{array}{l}\text { Lead, aq life, } \\
\text { acute }\end{array}$} \\
\hline 09093000 & $15 / 3$ & $\begin{array}{c}4 / 21 / 1975- \\
9 / 24 / 1981\end{array}$ & 210 & 0 & 2 & 3 & 5 & 45 & 3 & $\begin{array}{l}4 / 1 / 1976- \\
10 / 3 / 1979\end{array}$ & & \\
\hline 11210 & $10 / 10$ & $\begin{array}{l}10 / 18 / 1995- \\
8 / 21 / 1996\end{array}$ & 1 & & & & & & & & & \\
\hline \multicolumn{13}{|l|}{09093700} \\
\hline 11205 & 9/9 & $\begin{array}{l}8 / 16 / 1999- \\
10 / 10 / 2006\end{array}$ & 1 & & & & & & & & & \\
\hline \multicolumn{13}{|l|}{09094200} \\
\hline \multicolumn{13}{|l|}{09094400} \\
\hline 09095000 & $43 / 8$ & $\begin{array}{c}4 / 23 / 1975- \\
9 / 21 / 1981\end{array}$ & 2 & 1 & 2 & 3 & 9 & 56 & 9 & $\begin{array}{l}4 / 3 / 1978- \\
10 / 4 / 1979\end{array}$ & & \\
\hline 000148 & $28 / 28$ & $\begin{array}{l}10 / 4 / 1990- \\
4 / 11 / 2007\end{array}$ & 135 & & & & & & & & & \\
\hline 09095500 & $16 / 6$ & $\begin{array}{c}1 / 21 / 1980- \\
9 / 7 / 1994\end{array}$ & 1 & 0 & 0 & 0 & 2 & 5 & & & & \\
\hline \multicolumn{13}{|l|}{09096800} \\
\hline \multicolumn{13}{|l|}{09097500} \\
\hline 11155 & $11 / 0$ & $\begin{array}{l}10 / 12 / 1995- \\
8 / 15 / 1996\end{array}$ & 1 & 1 & 1 & 1 & 1 & 1 & & & & \\
\hline \multicolumn{13}{|l|}{09097600} \\
\hline \multicolumn{13}{|l|}{09095800} \\
\hline \multicolumn{13}{|l|}{09096500} \\
\hline \multicolumn{13}{|l|}{391507107550601} \\
\hline \multicolumn{13}{|l|}{$\begin{array}{l}\text { UP RAPID CRK } \\
\text { INTAKE }\end{array}$} \\
\hline \multicolumn{13}{|l|}{ RC-2 } \\
\hline \multicolumn{13}{|l|}{$\mathrm{RC}-3$} \\
\hline \multicolumn{13}{|l|}{ LOWER RAPID } \\
\hline $\begin{array}{l}\text { L COTTONWOOD } \\
\text { INTAKE }\end{array}$ & & & & & & & & & & & & \\
\hline 11151 & $11 / 4$ & $\begin{array}{c}10 / 23 / 1995- \\
4 / 11 / 2007\end{array}$ & 1 & 1 & 1 & 1 & 1 & 1 & & & & \\
\hline 390622108205400 & & & & & & & & & & & & \\
\hline 09106150 & $12 / 11$ & $\begin{array}{l}11 / 4 / 1993- \\
8 / 13 / 1996\end{array}$ & 1 & & & & & & & & & \\
\hline $\begin{array}{l}\text { CDOWRW-553 } \\
\text { CDOWRW-555 }\end{array}$ & & & & & & & & & & & & \\
\hline
\end{tabular}


Appendix 1. Summary of surface-water-quality data and comparison to water-quality standards by site, by constituent, Piceance study area, western Colorado. Water-quality standards comparisons follow data summaries and are in blue text; standards are provided in table 3.-Continued

[CDPHE segment, Colorado Department of Health and the Environment stream segment as referred to in tables 2 and 3; latitude and longitude are in North American Datum of 1983; downstream order number assigned as part of analysis. $\mu \mathrm{g} / \mathrm{L}$, micrograms per liter; $\mu \mathrm{S} / \mathrm{cm}$, microsiemens per centimeter; mg/L, milligrams per liter; mL, milliliters; aq, aquatic; CO, Colorado; EPA, U.S. Environmental Protection Agency; Max, maximum; Min, minimum; NA, not applicable; No., number; NTU, nephelometric turbitidy units; WS, water supply; dates given in month/day/year format]

\begin{tabular}{|c|c|c|c|c|c|c|c|c|c|c|c|c|}
\hline \multirow{2}{*}{$\begin{array}{c}\text { Site } \\
\text { identification } \\
\text { number }\end{array}$} & \multicolumn{8}{|c|}{ Lead, water, filtered, $\mu \mathrm{g} / \mathrm{L}$} & \multicolumn{2}{|c|}{$\begin{array}{c}\text { Lead, aq life, } \\
\text { 30-day chronic standard }\end{array}$} & \multicolumn{2}{|c|}{$\begin{array}{l}\text { Lead, aq life, } \\
\text { acute }\end{array}$} \\
\hline & $\begin{array}{c}\text { samples/ } \\
\text { No. of } \\
\text { censored }\end{array}$ & $\begin{array}{l}\text { Date } \\
\text { range }\end{array}$ & $\begin{array}{l}\text { Censoring } \\
\text { levels }\end{array}$ & Min & 25th & 50th & 75th & Max & Count & $\begin{array}{l}\text { Date } \\
\text { range }\end{array}$ & Count & $\begin{array}{l}\text { Date } \\
\text { range }\end{array}$ \\
\hline
\end{tabular}

390322108253401 390348108265601 CDOWRW-556

390319108273200

390318108273200

CDOWRW-557

09106200

390324108291301

390326108291601

390323108291601

390303108291601

390322108292301

390318108293301

390302108293801

390319108312501

390320108315901

CDOWRW-558

CDOWRW-560

09106500

390337108342800

CDOWRW-563

$11135 \mathrm{~A}$

CDOWRW-749

09152650

11135

390449108364101

390514108373201

390521108373300

390607108384201

390609108384701

390613108385603

390625108390402

390617108391001

390632108392101

390624108394701

390859108364101

390645108390101

390717108400501

390718108415701

09152900

11133

390741108424001

390741108424301

390741108425301

09153000

000049

390938108443101

11110 $\begin{array}{lll}8 / 8 & 7 / 26 / 2005- & 1\end{array}$

$1 / 9 / 2007$

$7 / 26 / 2005-\quad 1$

$10 / 11 / 2006$

(n)

$\begin{array}{ccc}9 / 8 & 7 / 26 / 2005- & 1 \\ & 4 / 11 / 2007 & \end{array}$

(1)

$\begin{array}{ccc}10 / 10 & 10 / 12 / 1995- & 1 \\ 7 / 18 / 1996 & \end{array}$


Appendix 1. Summary of surface-water-quality data and comparison to water-quality standards by site, by constituent, Piceance study area, western Colorado. Water-quality standards comparisons follow data summaries and are in blue text; standards are provided in table 3.-Continued

[CDPHE segment, Colorado Department of Health and the Environment stream segment as referred to in tables 2 and 3; latitude and longitude are in North American Datum of 1983; downstream order number assigned as part of analysis. $\mu \mathrm{g} / \mathrm{L}$, micrograms per liter; $\mu \mathrm{S} / \mathrm{cm}$, microsiemens per centimeter; mg/L, milligrams per liter; mL, milliliters; aq, aquatic; CO, Colorado; EPA, U.S. Environmental Protection Agency; Max, maximum; Min, minimum; NA, not applicable; No., number; NTU, nephelometric turbitidy units; WS, water supply; dates given in month/day/year format]

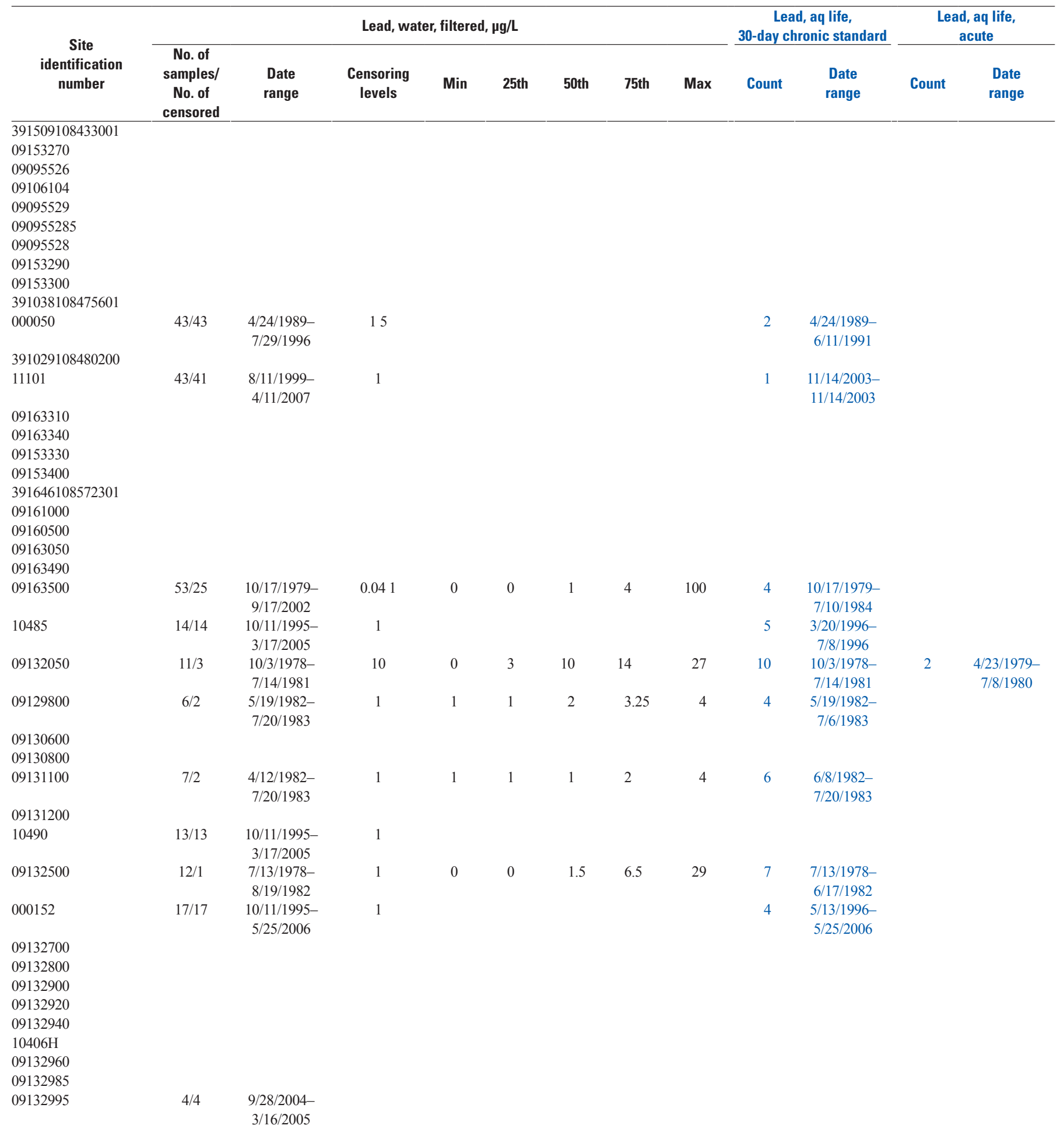


Appendix 1. Summary of surface-water-quality data and comparison to water-quality standards by site, by constituent, Piceance study area, western Colorado. Water-quality standards comparisons follow data summaries and are in blue text; standards are provided in table 3.-Continued

[CDPHE segment, Colorado Department of Health and the Environment stream segment as referred to in tables 2 and 3; latitude and longitude are in North American Datum of 1983; downstream order number assigned as part of analysis. $\mu \mathrm{g} / \mathrm{L}$, micrograms per liter; $\mu \mathrm{S} / \mathrm{cm}$, microsiemens per centimeter; mg/L, milligrams per liter; mL, milliliters; aq, aquatic; CO, Colorado; EPA, U.S. Environmental Protection Agency; Max, maximum; Min, minimum; NA, not applicable; No., number; NTU, nephelometric turbitidy units; WS, water supply; dates given in month/day/year format]

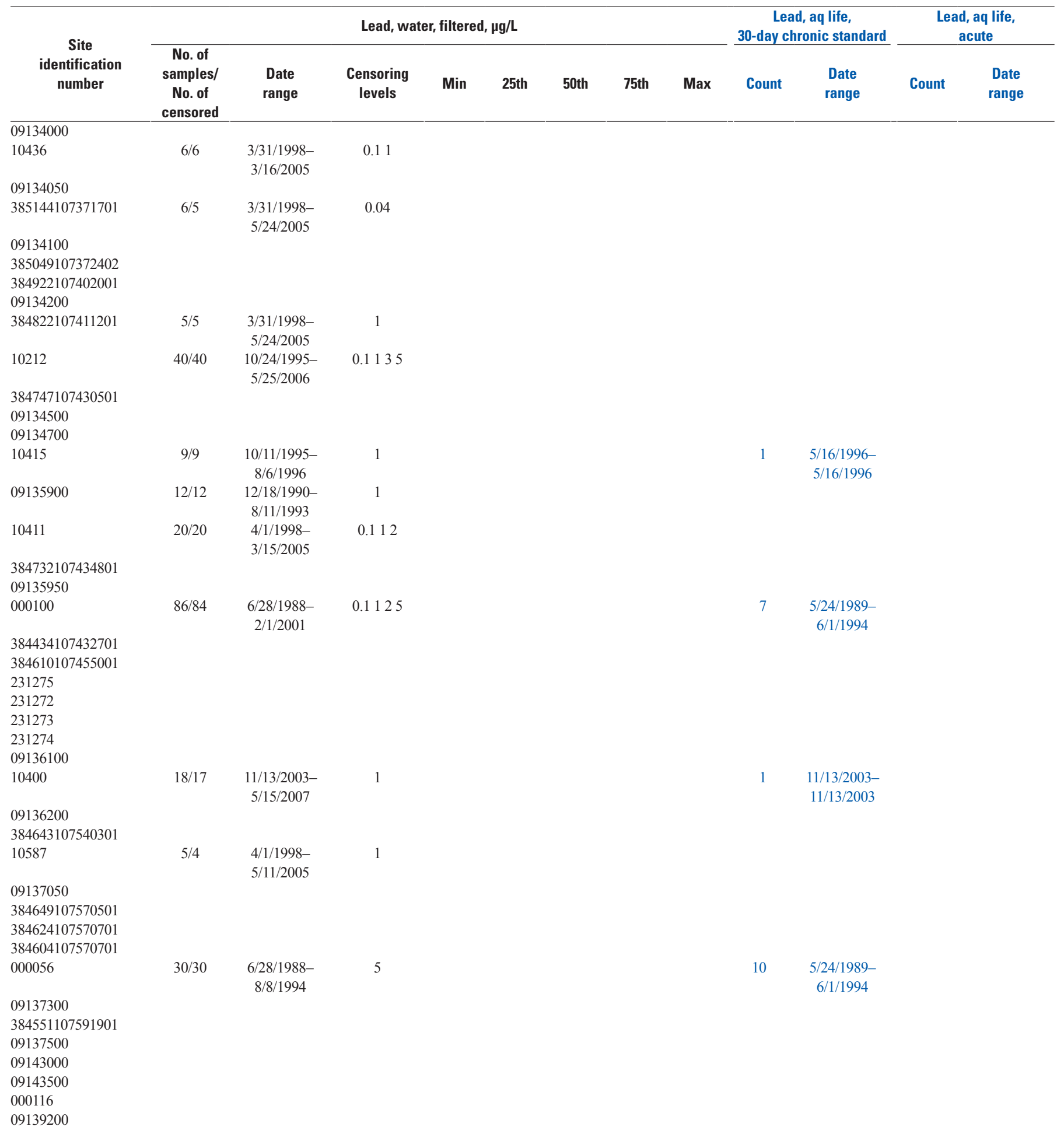


Appendix 1. Summary of surface-water-quality data and comparison to water-quality standards by site, by constituent, Piceance study area, western Colorado. Water-quality standards comparisons follow data summaries and are in blue text; standards are provided in table 3.-Continued

[CDPHE segment, Colorado Department of Health and the Environment stream segment as referred to in tables 2 and 3; latitude and longitude are in North American Datum of 1983; downstream order number assigned as part of analysis. $\mu \mathrm{g} / \mathrm{L}$, micrograms per liter; $\mu \mathrm{S} / \mathrm{cm}$, microsiemens per centimeter; mg/L, milligrams per liter; mL, milliliters; aq, aquatic; CO, Colorado; EPA, U.S. Environmental Protection Agency; Max, maximum; Min, minimum; NA, not applicable; No., number; NTU, nephelometric turbitidy units; WS, water supply; dates given in month/day/year format]

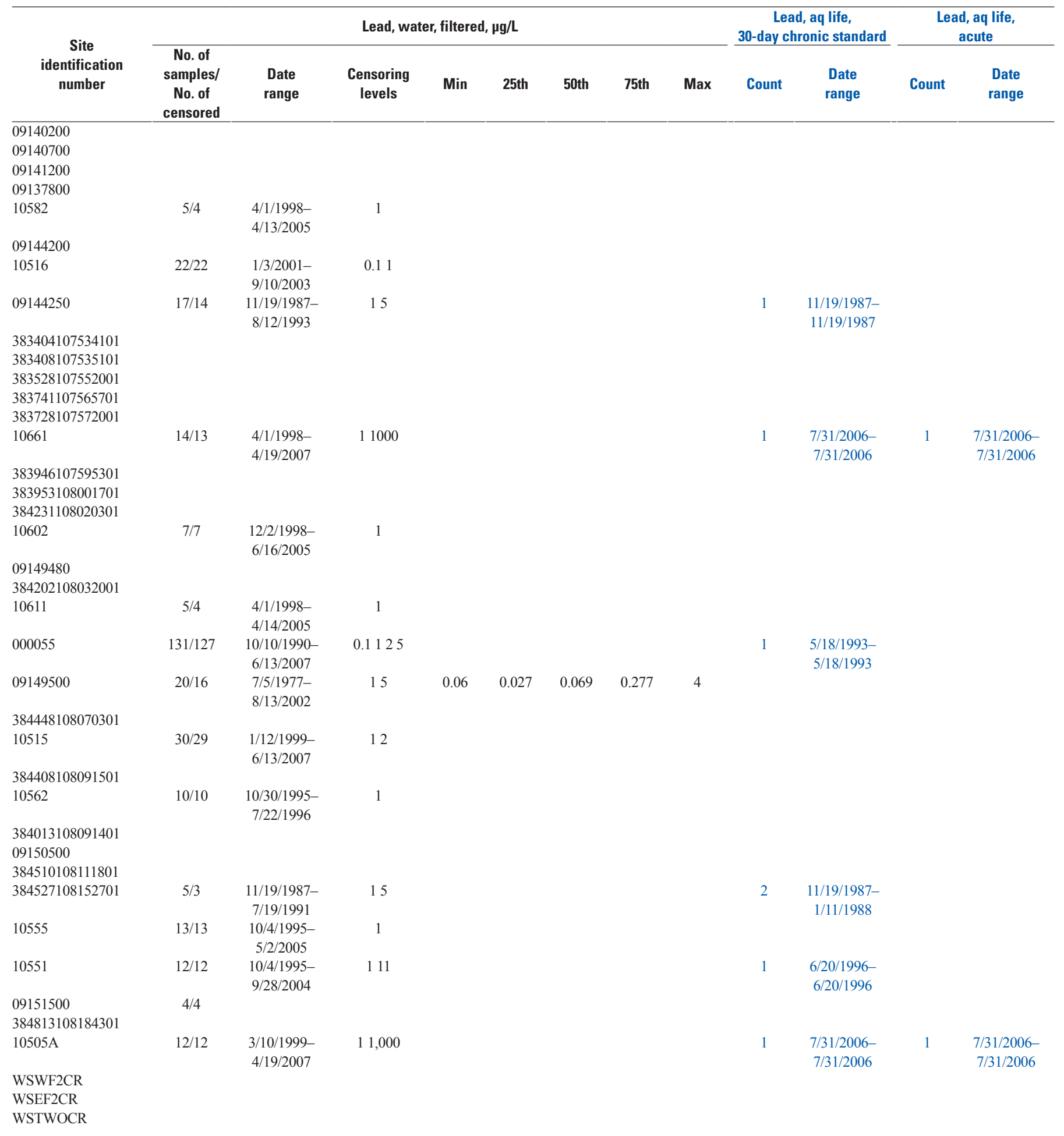


Appendix 1. Summary of surface-water-quality data and comparison to water-quality standards by site, by constituent, Piceance study area, western Colorado. Water-quality standards comparisons follow data summaries and are in blue text; standards are provided in table 3.-Continued

[CDPHE segment, Colorado Department of Health and the Environment stream segment as referred to in tables 2 and 3; latitude and longitude are in North American Datum of 1983; downstream order number assigned as part of analysis. $\mu \mathrm{g} / \mathrm{L}$, micrograms per liter; $\mu \mathrm{S} / \mathrm{cm}$, microsiemens per centimeter; mg/L, milligrams per liter; mL, milliliters; aq, aquatic; CO, Colorado; EPA, U.S. Environmental Protection Agency; Max, maximum; Min, minimum; NA, not applicable; No., number; NTU, nephelometric turbitidy units; WS, water supply; dates given in month/day/year format]

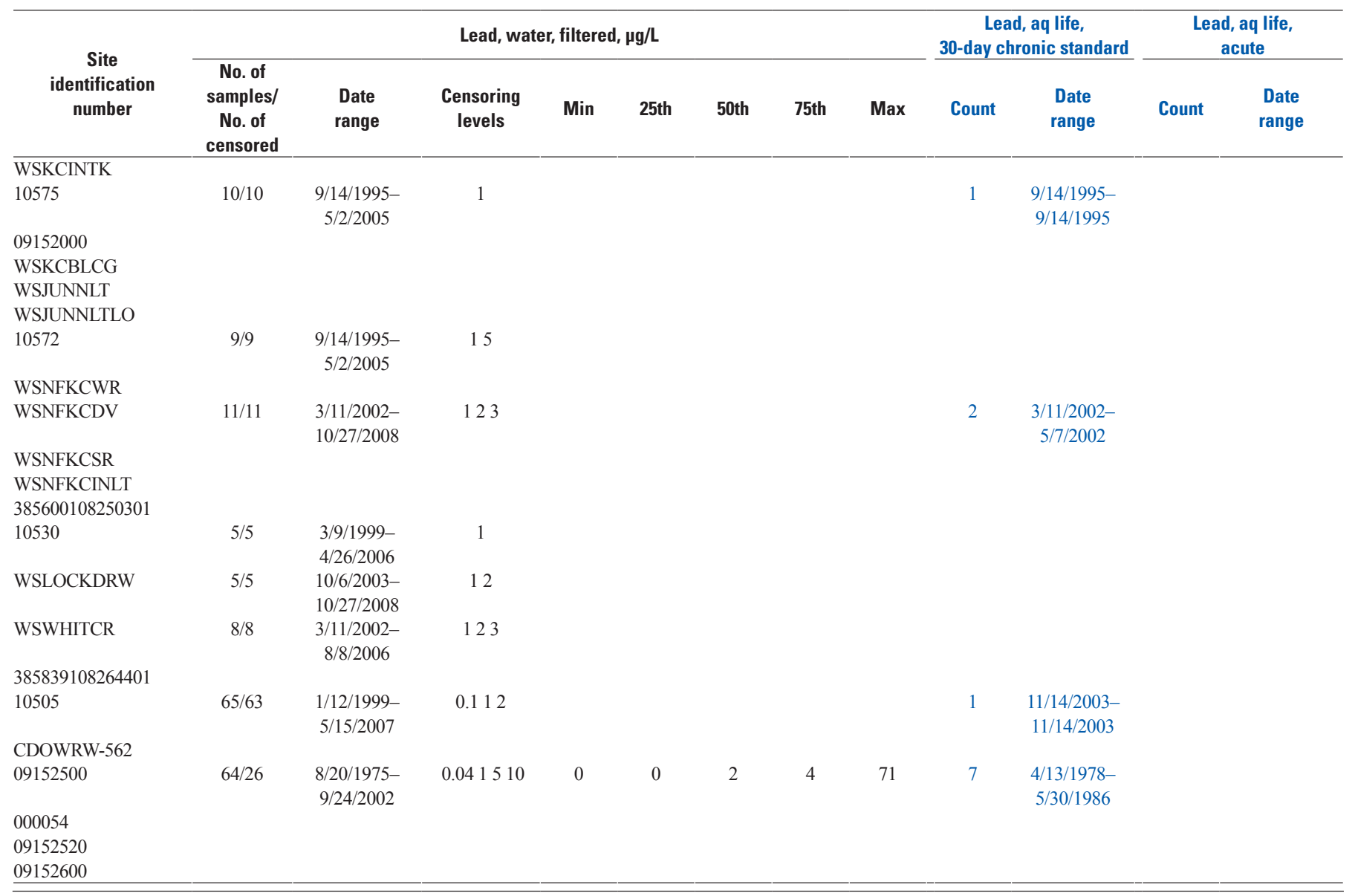


Appendix 1. Summary of surface-water-quality data and comparison to water-quality standards by site, by constituent, Piceance study area, western Colorado. Water-quality standards comparisons follow data summaries and are in blue text; standards are provided in table 3.-Continued

[CDPHE segment, Colorado Department of Health and the Environment stream segment as referred to in tables 2 and 3; latitude and longitude are in North American Datum of 1983; downstream order number assigned as part of analysis. $\mu \mathrm{g} / \mathrm{L}$, micrograms per liter; $\mu \mathrm{S} / \mathrm{cm}$, microsiemens per centimeter; mg/L, milligrams per liter; mL, milliliters; aq, aquatic; CO, Colorado; EPA, U.S. Environmental Protection Agency; Max, maximum; Min, minimum; NA, not applicable; No., number; NTU, nephelometric turbitidy units; WS, water supply; dates given in month/day/year format]

\begin{tabular}{|c|c|c|c|c|c|c|c|c|c|c|c|c|c|c|}
\hline \multirow{2}{*}{$\begin{array}{c}\text { Site } \\
\text { identification } \\
\text { number }\end{array}$} & \multicolumn{8}{|c|}{ Zinc, water, filtered, $\mu \mathrm{g} / \mathrm{L}$} & \multicolumn{2}{|c|}{$\begin{array}{c}\text { Zinc, aq life, } \\
\text { 30-day chronic, } \\
\text { sculpin standard }\end{array}$} & \multicolumn{2}{|c|}{$\begin{array}{l}\text { Zinc, aq life, } \\
\text { 30-day chronic } \\
\text { standard }\end{array}$} & \multicolumn{2}{|r|}{$\begin{array}{l}\text { Zinc, } \\
\text { aq life, } \\
\text { acute }\end{array}$} \\
\hline & $\begin{array}{c}\text { No. of } \\
\text { samples/ } \\
\text { No. of } \\
\text { censored }\end{array}$ & $\begin{array}{c}\text { Date } \\
\text { range }\end{array}$ & $\begin{array}{l}\text { Censoring } \\
\text { levels }\end{array}$ & Min & 25th & 50th & 75th & Max & Count & $\begin{array}{c}\text { Date } \\
\text { range }\end{array}$ & Count & $\begin{array}{l}\text { Date } \\
\text { range }\end{array}$ & Count & $\begin{array}{l}\text { Date } \\
\text { range }\end{array}$ \\
\hline 09302450 & $10 / 4$ & $\begin{array}{c}8 / 17 / 1999- \\
6 / 11 / 2007\end{array}$ & 10500 & 10 & 10 & 12 & 25 & 293 & 1 & $\begin{array}{c}10 / 19 / 1999 \\
10 / 19 / 1999\end{array}$ & 1 & $\begin{array}{c}10 / 19 / 1999- \\
10 / 19 / 1999\end{array}$ & 1 & $\begin{array}{c}10 / 19 / 1999 \\
10 / 19 / 1999\end{array}$ \\
\hline 09304200 & $7 / 3$ & $\begin{array}{c}8 / 27 / 1981- \\
9 / 14 / 1992\end{array}$ & 310 & 3 & 3 & 4 & 14 & 17 & & & & & & \\
\hline 09304480 & $5 / 3$ & $\begin{array}{c}8 / 26 / 1981- \\
6 / 11 / 2007\end{array}$ & 103 & 3 & 3 & 3 & 11 & 13 & & & & & & \\
\hline \multicolumn{15}{|l|}{09304300} \\
\hline \multicolumn{15}{|l|}{09304500} \\
\hline \multicolumn{15}{|l|}{$\begin{array}{l}09304550 \\
09304600\end{array}$} \\
\hline 400206108005901 & $4 / 2$ & & & & & & & & & & & & & \\
\hline 09304800 & $44 / 21$ & $\begin{array}{c}4 / 24 / 1974- \\
9 / 29 / 2009\end{array}$ & $\begin{array}{c}0.30 .913 \\
101220\end{array}$ & 0.3 & 0.604 & 1.36 & 5 & 60 & & & & & & \\
\hline \multicolumn{15}{|l|}{ ENPR20ST } \\
\hline \multicolumn{15}{|l|}{ ENPR21ST } \\
\hline \multicolumn{15}{|l|}{ ENPR19ST } \\
\hline 09306007 & $90 / 39$ & $\begin{array}{c}5 / 22 / 1974 \\
9 / 3 / 1998\end{array}$ & 3121520 & 3 & 3 & 7 & 20 & 60 & & & & & & \\
\hline 09306025 & $28 / 12$ & $\begin{array}{c}5 / 22 / 1974 \\
2 / 18 / 1980\end{array}$ & 20 & 4 & 4 & 20 & 20 & 260 & & & & & & \\
\hline \multicolumn{15}{|l|}{09306028} \\
\hline \multicolumn{15}{|l|}{09306050} \\
\hline 09306058 & $49 / 19$ & $\begin{array}{c}5 / 22 / 1974 \\
5 / 22 / 1985\end{array}$ & 31220 & 2 & 4 & 9 & 20 & 60 & & & & & & \\
\hline 09306061 & $66 / 26$ & $\begin{array}{c}5 / 22 / 1974 \\
5 / 4 / 1987\end{array}$ & 31020 & 0 & 5 & 8 & 20 & 50 & & & & & & \\
\hline 11625 & $9 / 4$ & $\begin{array}{c}8 / 18 / 1999 \\
6 / 21 / 2007\end{array}$ & 1050 & 10 & 10 & 17.5 & 22 & 37 & & & & & & \\
\hline 09306175 & $69 / 27$ & $\begin{array}{c}1 / 15 / 1975- \\
5 / 19 / 1982\end{array}$ & 31220 & 2 & 4 & 9 & 20 & 70 & & & & & & \\
\hline 09306200 & $127 / 38$ & $\begin{array}{r}6 / 10 / 1974 \\
7 / 8 / 2009\end{array}$ & $\begin{array}{c}0.30 .913 \\
101220\end{array}$ & 0.3 & 1.428 & 4 & 9 & 30 & & & & & & \\
\hline \multicolumn{15}{|l|}{09306210} \\
\hline 09306222 & $119 / 40$ & $\begin{array}{c}6 / 10 / 1974 \\
7 / 7 / 2009\end{array}$ & $\begin{array}{c}0.30 .9137 \\
1020\end{array}$ & 0 & 1.432 & 2.117 & 10 & 50 & & & & & & \\
\hline 000117 & $21 / 18$ & $\begin{array}{c}6 / 29 / 1988- \\
4 / 21 / 1992\end{array}$ & 810 & 10 & 8 & 10 & 10 & 20 & & & & & & \\
\hline 09306224 & $15 / 9$ & $\begin{array}{c}\text { 11/9/1982- } \\
\text { 9/29/2009 }\end{array}$ & 1.8256 & 0.9 & 0.9 & 0.9 & 6 & 8 & & & & & & \\
\hline
\end{tabular}


Appendix 1. Summary of surface-water-quality data and comparison to water-quality standards by site, by constituent, Piceance study area, western Colorado. Water-quality standards comparisons follow data summaries and are in blue text; standards are provided in table 3.-Continued

[CDPHE segment, Colorado Department of Health and the Environment stream segment as referred to in tables 2 and 3; latitude and longitude are in North American Datum of 1983; downstream order number assigned as part of analysis. $\mu \mathrm{g} / \mathrm{L}$, micrograms per liter; $\mu \mathrm{S} / \mathrm{cm}$, microsiemens per centimeter; $\mathrm{mg} / \mathrm{L}$, milligrams per liter; mL, milliliters; aq, aquatic; CO, Colorado; EPA, U.S. Environmental Protection Agency; Max, maximum; Min, minimum; NA, not applicable; No., number; NTU, nephelometric turbitidy units; WS, water supply; dates given in month/day/year format]

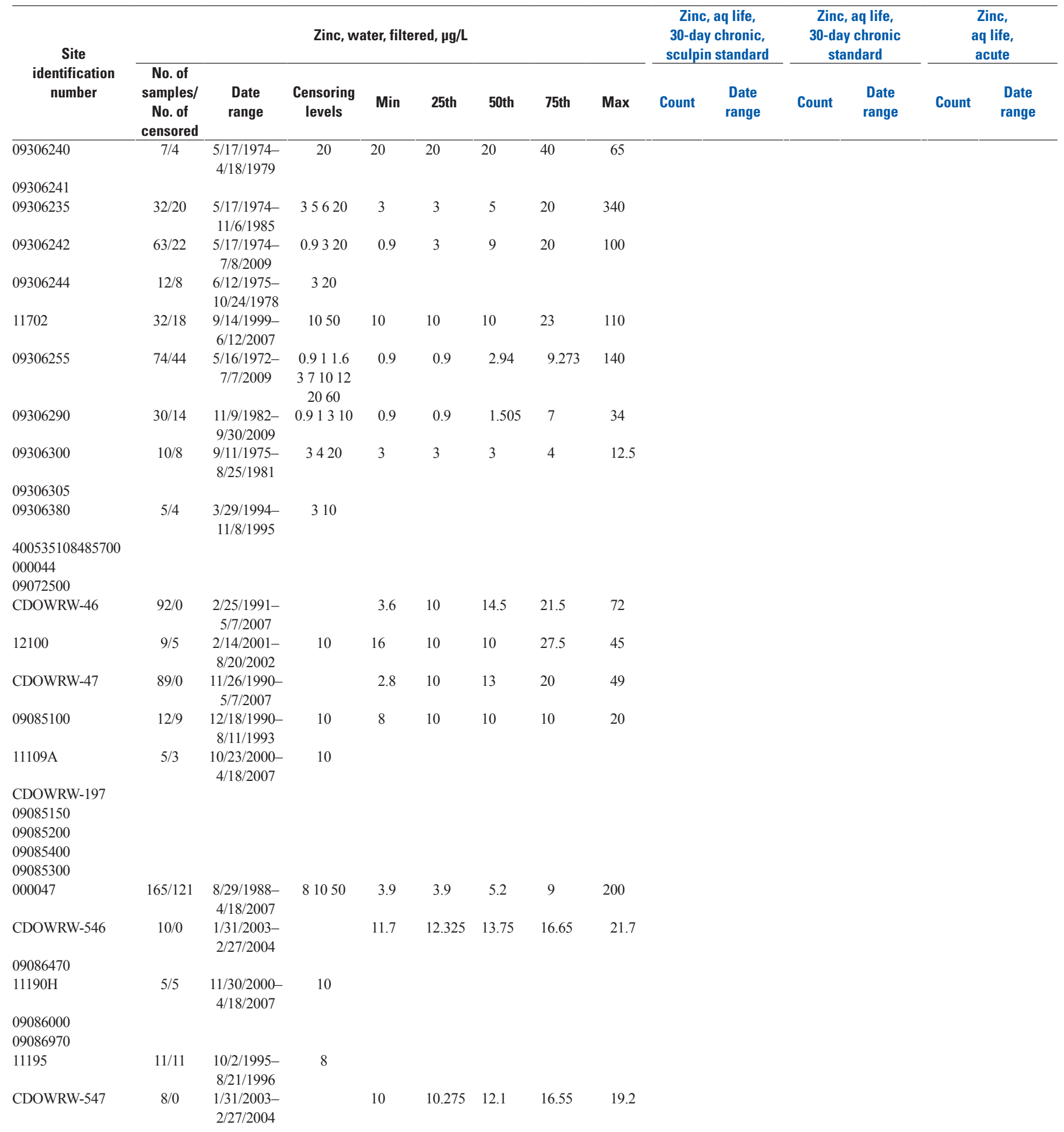


Appendix 1. Summary of surface-water-quality data and comparison to water-quality standards by site, by constituent, Piceance study area, western Colorado. Water-quality standards comparisons follow data summaries and are in blue text; standards are provided in table 3.-Continued

[CDPHE segment, Colorado Department of Health and the Environment stream segment as referred to in tables 2 and 3; latitude and longitude are in North American Datum of 1983; downstream order number assigned as part of analysis. $\mu \mathrm{g} / \mathrm{L}$, micrograms per liter; $\mu \mathrm{S} / \mathrm{cm}$, microsiemens per centimeter; mg/L, milligrams per liter; mL, milliliters; aq, aquatic; CO, Colorado; EPA, U.S. Environmental Protection Agency; Max, maximum; Min, minimum; NA, not applicable; No., number; NTU, nephelometric turbitidy units; WS, water supply; dates given in month/day/year format]

\begin{tabular}{|c|c|c|c|c|c|c|c|c|c|c|c|c|c|c|}
\hline \multirow{2}{*}{$\begin{array}{c}\text { Site } \\
\text { identification } \\
\text { number }\end{array}$} & \multicolumn{8}{|c|}{ Zinc, water, filtered, $\mu \mathrm{g} / \mathrm{L}$} & \multicolumn{2}{|c|}{$\begin{array}{c}\text { Zinc, aq life, } \\
30 \text {-day chronic, } \\
\text { sculpin standard }\end{array}$} & \multicolumn{2}{|c|}{$\begin{array}{l}\text { Zinc, aq life, } \\
\text { 30-day chronic } \\
\text { standard }\end{array}$} & \multicolumn{2}{|c|}{$\begin{array}{l}\text { Zinc, } \\
\text { aq life, } \\
\text { acute }\end{array}$} \\
\hline & $\begin{array}{c}\text { No. of } \\
\text { samples/ } \\
\text { No. of } \\
\text { censored }\end{array}$ & $\begin{array}{l}\text { Date } \\
\text { range }\end{array}$ & $\begin{array}{l}\text { Censoring } \\
\text { levels }\end{array}$ & Min & 25th & 50th & 75th & Max & Count & $\begin{array}{l}\text { Date } \\
\text { range }\end{array}$ & Count & $\begin{array}{l}\text { Date } \\
\text { range }\end{array}$ & Count & $\begin{array}{l}\text { Date } \\
\text { range }\end{array}$ \\
\hline \multicolumn{15}{|l|}{09087600} \\
\hline 11189 & $10 / 1$ & $\begin{array}{l}8 / 18 / 1999 \\
10 / 17 / 2006\end{array}$ & 100 & 16 & 23 & 26 & 55 & 14,000 & & & & & & \\
\hline 11185 & $10 / 10$ & $\begin{array}{c}10 / 2 / 1995- \\
8 / 15 / 1996\end{array}$ & 8 & & & & & & & & & & & \\
\hline \multicolumn{15}{|l|}{09089500} \\
\hline \multicolumn{15}{|l|}{ LANG6ST } \\
\hline \multicolumn{15}{|l|}{ LANG5ST } \\
\hline \multicolumn{15}{|l|}{ LANG4ST } \\
\hline \multicolumn{15}{|l|}{ LANG3ST } \\
\hline \multicolumn{15}{|l|}{09090700} \\
\hline \multicolumn{15}{|l|}{09090800} \\
\hline \multicolumn{15}{|l|}{ DUNC1ST } \\
\hline \multicolumn{15}{|l|}{ COS-INTAKE } \\
\hline 09091100 & & & & & & & & & & & & & & \\
\hline CDOWRW-550 & $6 / 0$ & $\begin{array}{c}1 / 17 / 2003- \\
4 / 13 / 2005\end{array}$ & & 2.6 & 4.025 & 8.2 & 43.625 & 79.4 & & & & & & \\
\hline CDOWRW-559 & & & & & & & & & & & & & & \\
\hline 09092500 & & & & & & & & & & & & & & \\
\hline 704569 & & & & & & & & & & & & & & \\
\hline 09091500 & & & & & & & & & & & & & & \\
\hline 09092000 & & & & & & & & & & & & & & \\
\hline 000147 & $22 / 20$ & $\begin{array}{l}8 / 8 / 1988- \\
4 / 15 / 1992\end{array}$ & 81050 & & & & & & & & & & & \\
\hline ENPR1ST & & & & & & & & & & & & & & \\
\hline ENPR2ST & & & & & & & & & & & & & & \\
\hline ENPR10ST & & & & & & & & & & & & & & \\
\hline ENPR9ST & & & & & & & & & & & & & & \\
\hline ENPR5ST & & & & & & & & & & & & & & \\
\hline ENPR6ST & & & & & & & & & & & & & & \\
\hline 09092800 & & & & & & & & & & & & & & \\
\hline ENPR3ST & & & & & & & & & & & & & & \\
\hline $11145 \mathrm{~A}$ & $16 / 7$ & $\begin{array}{c}9 / 30 / 1999 \\
4 / 10 / 2007\end{array}$ & 1050100 & 10 & 10 & 16 & 24 & 81 & & & & & & \\
\hline 11145B & $16 / 9$ & $\begin{array}{c}9 / 30 / 1999 \\
4 / 10 / 2007\end{array}$ & 1050100 & 10 & 10 & 11 & 20 & 80.5 & & & & & & \\
\hline 09092960 & $50 / 21$ & $\begin{array}{c}\text { 2/8/1976- } \\
\text { 9/7/1983 }\end{array}$ & 320 & 3 & 3 & 5 & 10 & 99 & & & & & & \\
\hline
\end{tabular}


Appendix 1. Summary of surface-water-quality data and comparison to water-quality standards by site, by constituent, Piceance study area, western Colorado. Water-quality standards comparisons follow data summaries and are in blue text; standards are provided in table 3.-Continued

[CDPHE segment, Colorado Department of Health and the Environment stream segment as referred to in tables 2 and 3; latitude and longitude are in North American Datum of 1983; downstream order number assigned as part of analysis. $\mu \mathrm{g} / \mathrm{L}$, micrograms per liter; $\mu \mathrm{S} / \mathrm{cm}$, microsiemens per centimeter; mg/L, milligrams per liter; mL, milliliters; aq, aquatic; CO, Colorado; EPA, U.S. Environmental Protection Agency; Max, maximum; Min, minimum; NA, not applicable; No., number; NTU, nephelometric turbitidy units; WS, water supply; dates given in month/day/year format]

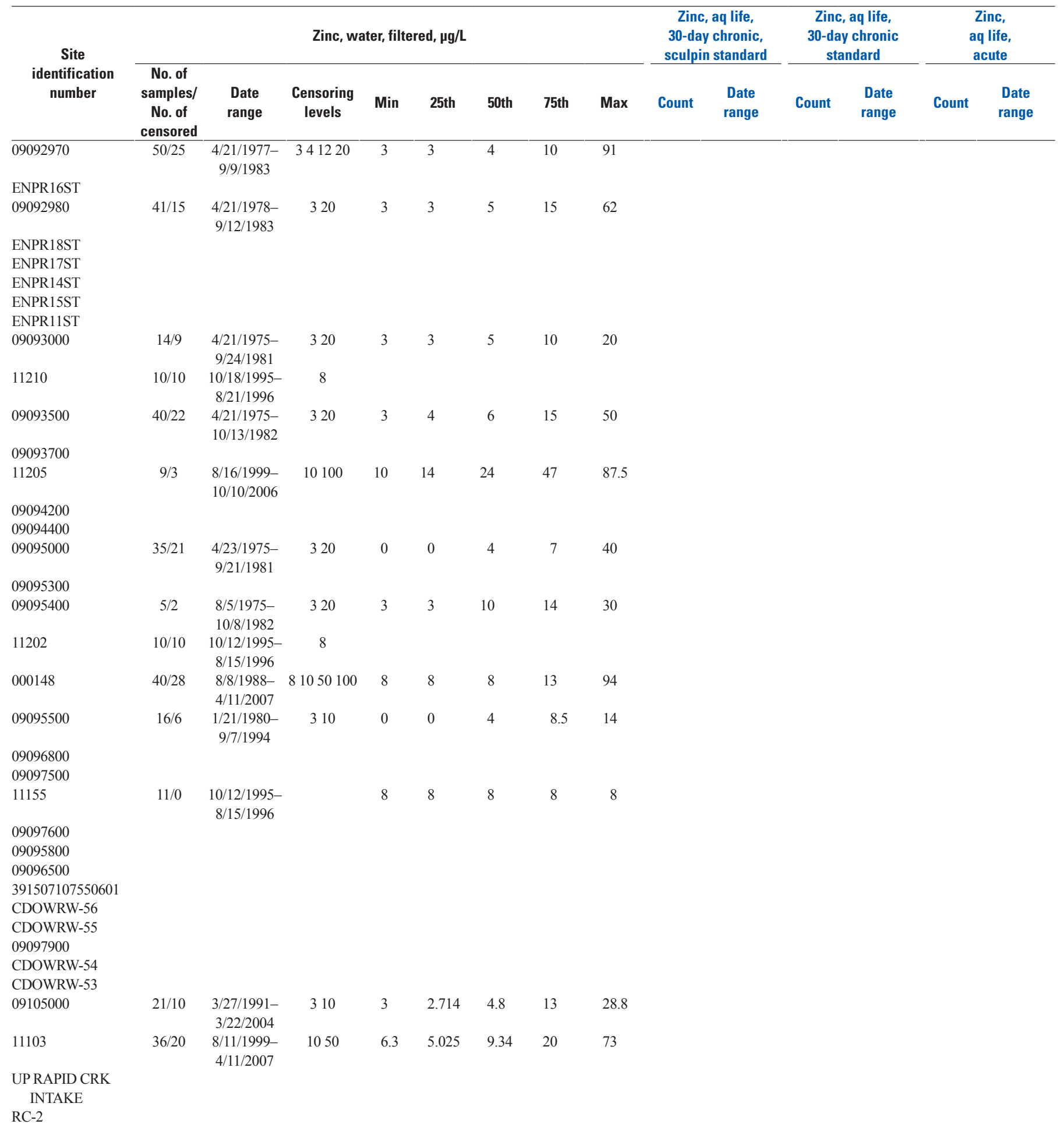


Appendix 1. Summary of surface-water-quality data and comparison to water-quality standards by site, by constituent, Piceance study area, western Colorado. Water-quality standards comparisons follow data summaries and are in blue text; standards are provided in table 3.-Continued

[CDPHE segment, Colorado Department of Health and the Environment stream segment as referred to in tables 2 and 3; latitude and longitude are in North American Datum of 1983; downstream order number assigned as part of analysis. $\mu \mathrm{g} / \mathrm{L}$, micrograms per liter; $\mu \mathrm{S} / \mathrm{cm}$, microsiemens per centimeter; mg/L, milligrams per liter; mL, milliliters; aq, aquatic; CO, Colorado; EPA, U.S. Environmental Protection Agency; Max, maximum; Min, minimum; NA, not applicable; No., number; NTU, nephelometric turbitidy units; WS, water supply; dates given in month/day/year format]

\begin{tabular}{|c|c|c|c|c|c|c|c|c|c|c|c|c|c|c|}
\hline \multirow{2}{*}{$\begin{array}{c}\text { Site } \\
\text { identification } \\
\text { number }\end{array}$} & \multicolumn{8}{|c|}{ Zinc, water, filtered, $\mu \mathrm{g} / \mathrm{L}$} & \multicolumn{2}{|c|}{$\begin{array}{c}\text { Zinc, aq life, } \\
\text { 30-day chronic, } \\
\text { sculpin standard }\end{array}$} & \multicolumn{2}{|c|}{$\begin{array}{c}\text { Zinc, aq life, } \\
\text { 30-day chronic } \\
\text { standard }\end{array}$} & \multicolumn{2}{|c|}{$\begin{array}{l}\text { Zinc, } \\
\text { aq life, } \\
\text { acute }\end{array}$} \\
\hline & $\begin{array}{c}\text { No. of } \\
\text { samples/ } \\
\text { No. of } \\
\text { censored }\end{array}$ & $\begin{array}{l}\text { Date } \\
\text { range }\end{array}$ & $\begin{array}{l}\text { Censoring } \\
\text { levels }\end{array}$ & Min & 25th & 50th & 75th & Max & Count & $\begin{array}{l}\text { Date } \\
\text { range }\end{array}$ & Count & $\begin{array}{l}\text { Date } \\
\text { range }\end{array}$ & Count & $\begin{array}{l}\text { Date } \\
\text { range }\end{array}$ \\
\hline \multicolumn{15}{|l|}{$\overline{\mathrm{RC}}-3$} \\
\hline \multicolumn{14}{|l|}{ LOWER RAPID } & CRK \\
\hline \multicolumn{15}{|l|}{$\begin{array}{l}\text { L COTTONWOOD } \\
\text { INTAKE }\end{array}$} \\
\hline 11151 & $11 / 4$ & $\begin{array}{c}10 / 23 / 1995- \\
4 / 11 / 2007\end{array}$ & 810 & 8 & 8 & 8 & 8 & 9 & & & & & & \\
\hline \multicolumn{15}{|l|}{390622108205400} \\
\hline 09106150 & $12 / 10$ & $\begin{array}{l}11 / 4 / 1993- \\
8 / 13 / 1996\end{array}$ & 310 & & & & & & & & & & & \\
\hline CDOWRW-553 & $11 / 0$ & $\begin{array}{c}11 / 25 / 2002- \\
10 / 23 / 2006\end{array}$ & & 3.5 & 3.9 & 6.7 & 10.8 & 19.9 & & & & & & \\
\hline
\end{tabular}

COWRW-555

390322108253401

390348108265601

CDOWRW-556

390319108273200

390318108273200

CDOWRW-557

09106200

390324108291301

390326108291601

390323108291601

390303108291601

390322108292301

390318108293301

390302108293801

390319108312501

390320108315901

CDOWRW-558

CDOWRW-560

09106500

390337108342800

CDOWRW-563

$11135 \mathrm{~A}$

$8 / 7 \quad 7 / 26 / 2005-$

1050

CDOWRW-749

$1 / 9 / 2007$

09152650

11135

7/7 7/26/2005-

$10 / 11 / 2006$

10

390449108364101

390514108373201

390521108373300

390607108384201

390609108384701

390613108385603

390625108390402

390617108391001

390632108392101

390624108394701

390859108364101

390645108390101

390717108400501 
Appendix 1. Summary of surface-water-quality data and comparison to water-quality standards by site, by constituent, Piceance study area, western Colorado. Water-quality standards comparisons follow data summaries and are in blue text; standards are provided in table 3.-Continued

[CDPHE segment, Colorado Department of Health and the Environment stream segment as referred to in tables 2 and 3; latitude and longitude are in North American Datum of 1983; downstream order number assigned as part of analysis. $\mu \mathrm{g} / \mathrm{L}$, micrograms per liter; $\mu \mathrm{S} / \mathrm{cm}$, microsiemens per centimeter; $\mathrm{mg} / \mathrm{L}$, milligrams per liter; mL, milliliters; aq, aquatic; CO, Colorado; EPA, U.S. Environmental Protection Agency; Max, maximum; Min, minimum; NA, not applicable; No., number; NTU, nephelometric turbitidy units; WS, water supply; dates given in month/day/year format]

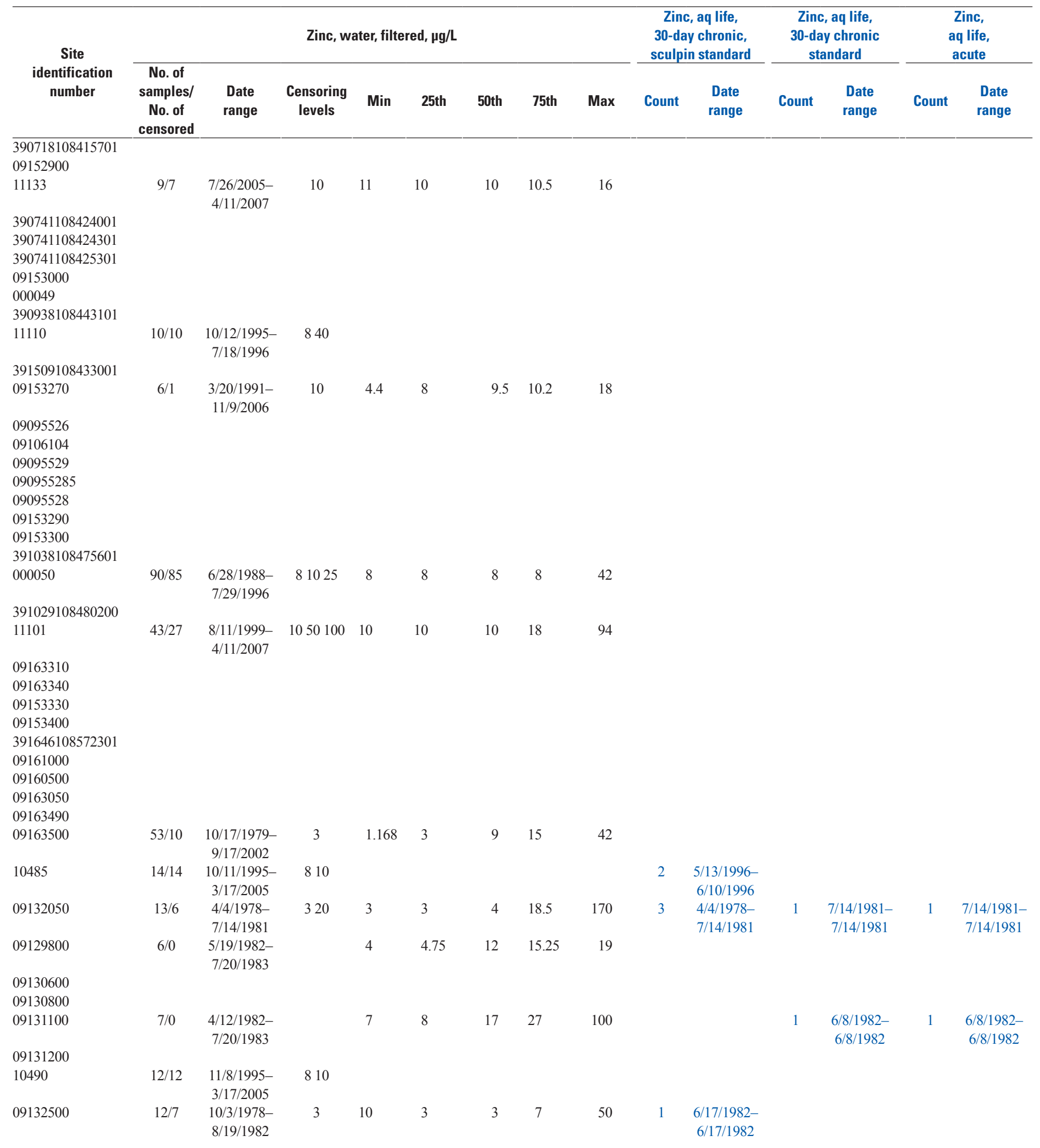


Appendix 1. Summary of surface-water-quality data and comparison to water-quality standards by site, by constituent, Piceance study area, western Colorado. Water-quality standards comparisons follow data summaries and are in blue text; standards are provided in table 3.-Continued

[CDPHE segment, Colorado Department of Health and the Environment stream segment as referred to in tables 2 and 3; latitude and longitude are in North American Datum of 1983; downstream order number assigned as part of analysis. $\mu \mathrm{g} / \mathrm{L}$, micrograms per liter; $\mu \mathrm{S} / \mathrm{cm}$, microsiemens per centimeter; $\mathrm{mg} / \mathrm{L}$, milligrams per liter; mL, milliliters; aq, aquatic; CO, Colorado; EPA, U.S. Environmental Protection Agency; Max, maximum; Min, minimum; NA, not applicable; No., number; NTU, nephelometric turbitidy units; WS, water supply; dates given in month/day/year format]

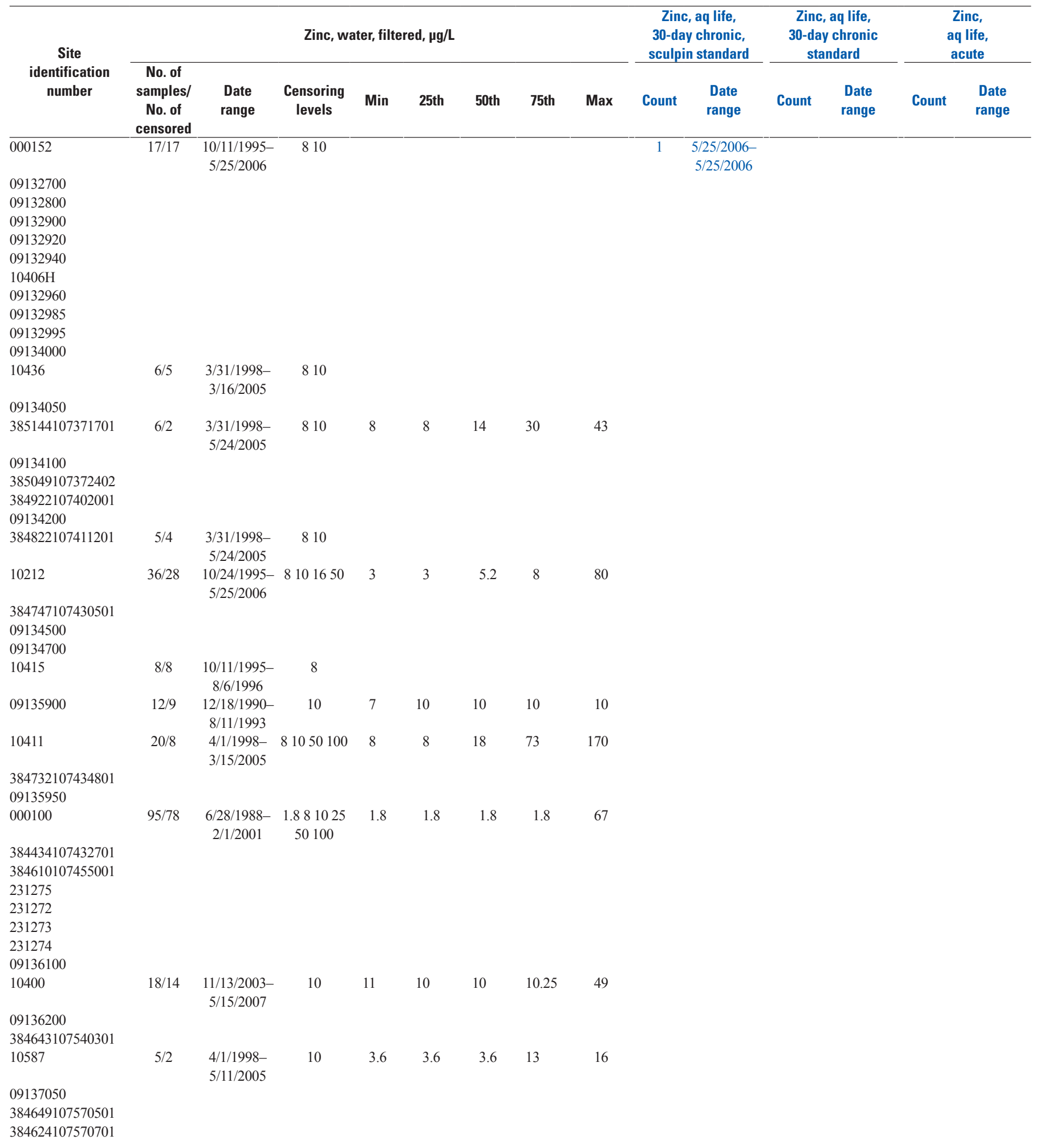


Appendix 1. Summary of surface-water-quality data and comparison to water-quality standards by site, by constituent, Piceance study area, western Colorado. Water-quality standards comparisons follow data summaries and are in blue text; standards are provided in table 3.-Continued

[CDPHE segment, Colorado Department of Health and the Environment stream segment as referred to in tables 2 and 3; latitude and longitude are in North American Datum of 1983; downstream order number assigned as part of analysis. $\mu \mathrm{g} / \mathrm{L}$, micrograms per liter; $\mu \mathrm{S} / \mathrm{cm}$, microsiemens per centimeter; mg/L, milligrams per liter; mL, milliliters; aq, aquatic; CO, Colorado; EPA, U.S. Environmental Protection Agency; Max, maximum; Min, minimum; NA, not applicable; No., number; NTU, nephelometric turbitidy units; WS, water supply; dates given in month/day/year format]

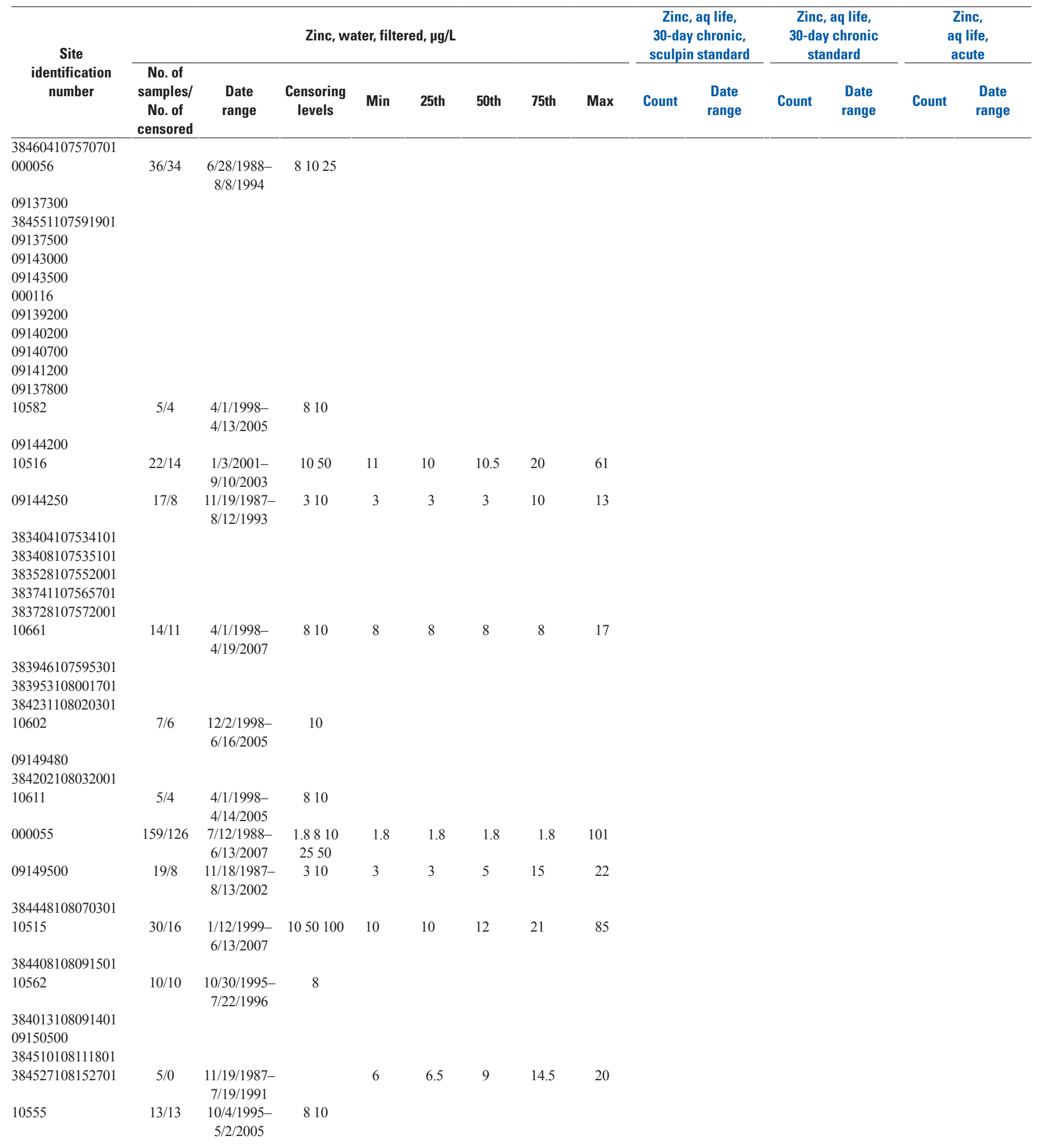


Appendix 1. Summary of surface-water-quality data and comparison to water-quality standards by site, by constituent, Piceance study area, western Colorado. Water-quality standards comparisons follow data summaries and are in blue text; standards are provided in table 3.-Continued

[CDPHE segment, Colorado Department of Health and the Environment stream segment as referred to in tables 2 and 3; latitude and longitude are in North American Datum of 1983; downstream order number assigned as part of analysis. $\mu \mathrm{g} / \mathrm{L}$, micrograms per liter; $\mu \mathrm{S} / \mathrm{cm}$, microsiemens per centimeter; mg/L, milligrams per liter; mL, milliliters; aq, aquatic; CO, Colorado; EPA, U.S. Environmental Protection Agency; Max, maximum; Min, minimum; NA, not applicable; No., number; NTU, nephelometric turbitidy units; WS, water supply; dates given in month/day/year format]

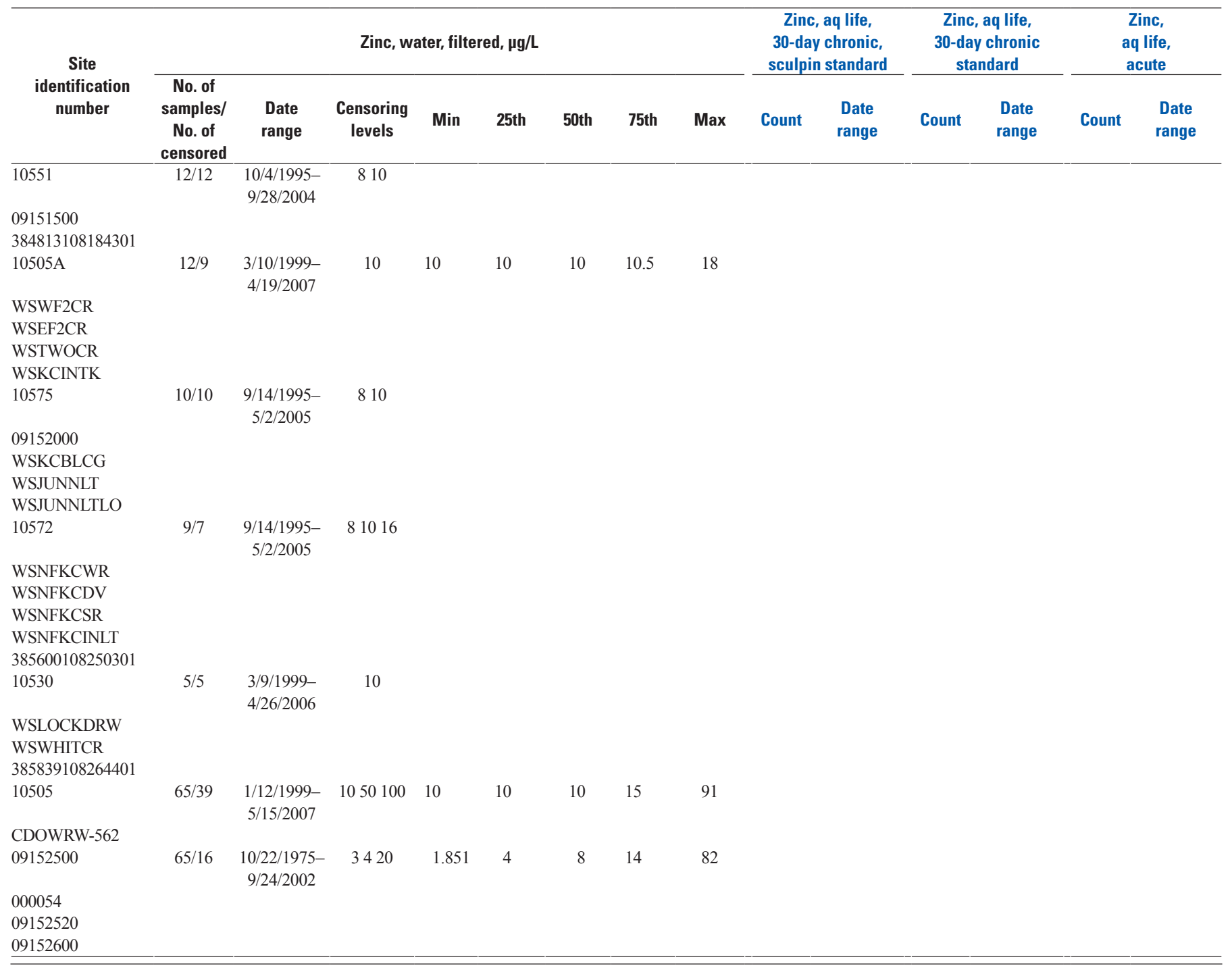


Appendix 1. Summary of surface-water-quality data and comparison to water-quality standards by site, by constituent, Piceance study area, western Colorado. Water-quality standards comparisons follow data summaries and are in blue text; standards are provided in table 3.-Continued

[CDPHE segment, Colorado Department of Health and the Environment stream segment as referred to in tables 2 and 3; latitude and longitude are in North American Datum of 1983; downstream order number assigned as part of analysis. $\mu \mathrm{g} / \mathrm{L}$, micrograms per liter; $\mu \mathrm{S} / \mathrm{cm}$, microsiemens per centimeter; $\mathrm{mg} / \mathrm{L}$, milligrams per liter; mL, milliliters; aq, aquatic; CO, Colorado; EPA, U.S. Environmental Protection Agency; Max, maximum; Min, minimum; NA, not applicable; No., number; NTU, nephelometric turbitidy units; WS, water supply; dates given in month/day/year format]

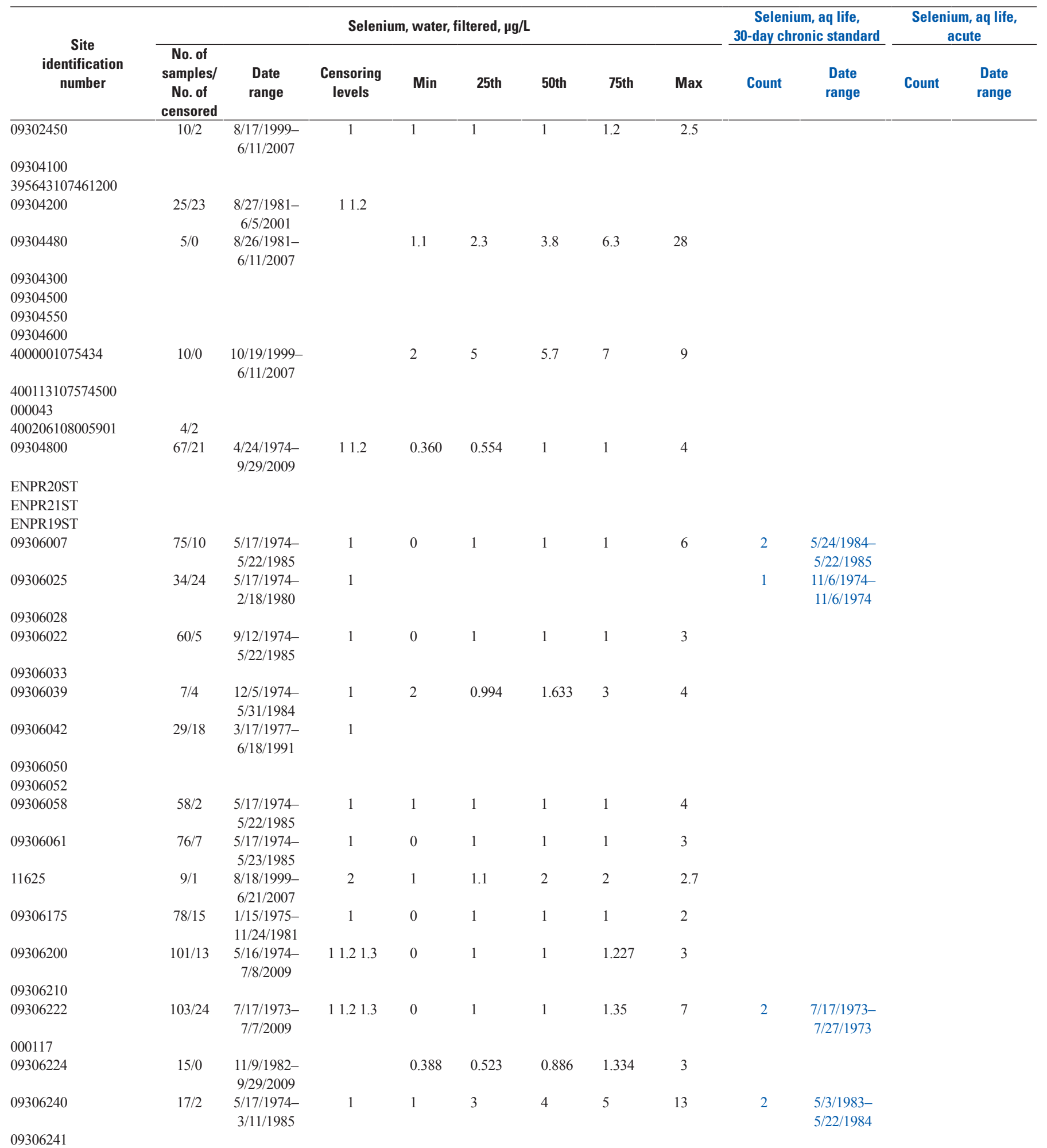


Appendix 1. Summary of surface-water-quality data and comparison to water-quality standards by site, by constituent, Piceance study area, western Colorado. Water-quality standards comparisons follow data summaries and are in blue text; standards are provided in table 3.-Continued

[CDPHE segment, Colorado Department of Health and the Environment stream segment as referred to in tables 2 and 3; latitude and longitude are in North American Datum of 1983; downstream order number assigned as part of analysis. $\mu \mathrm{g} / \mathrm{L}$, micrograms per liter; $\mu \mathrm{S} / \mathrm{cm}$, microsiemens per centimeter; mg/L, milligrams per liter; mL, milliliters; aq, aquatic; CO, Colorado; EPA, U.S. Environmental Protection Agency; Max, maximum; Min, minimum; NA, not applicable; No., number; NTU, nephelometric turbitidy units; WS, water supply; dates given in month/day/year format]

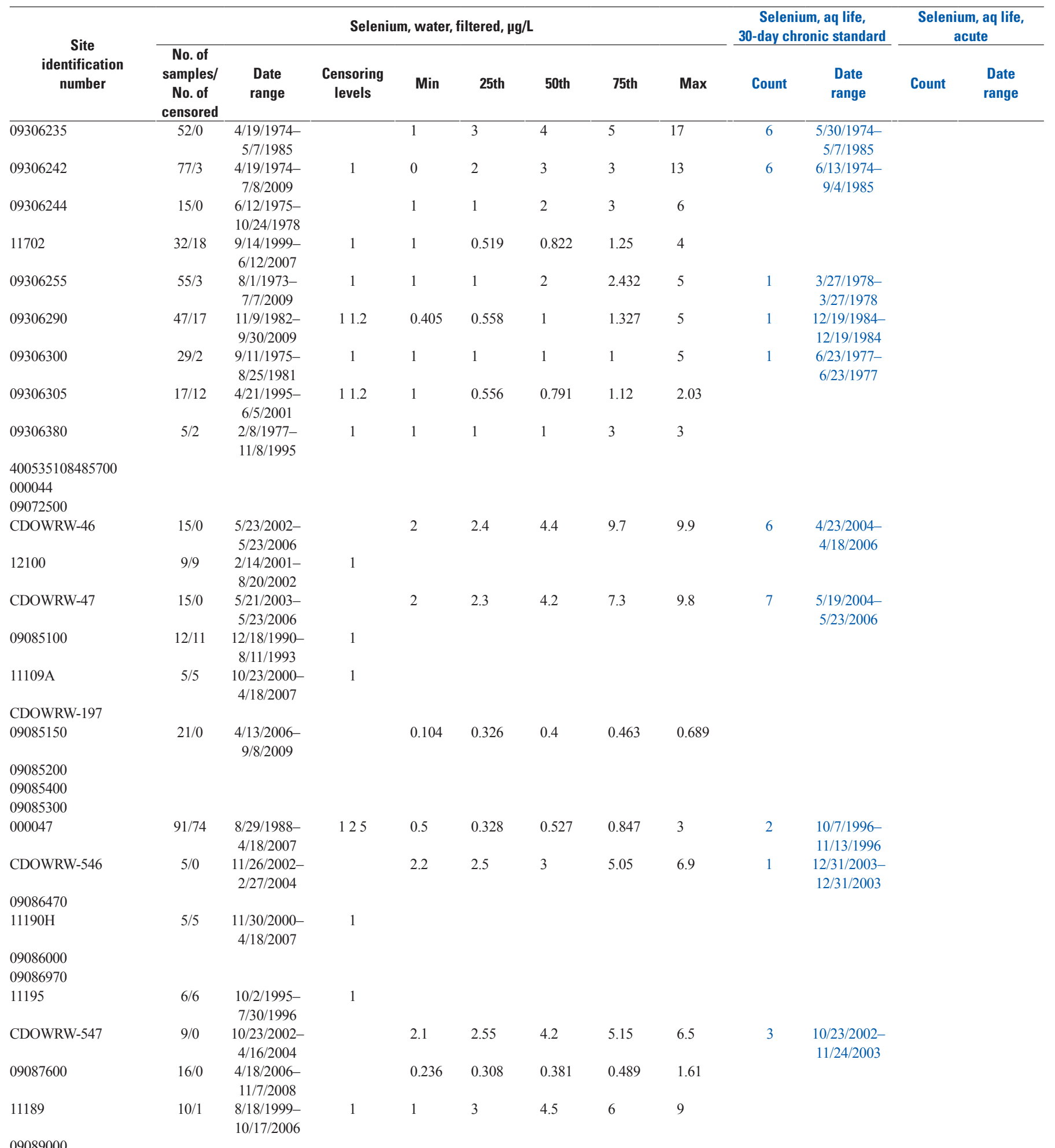


Appendix 1. Summary of surface-water-quality data and comparison to water-quality standards by site, by constituent, Piceance study area, western Colorado. Water-quality standards comparisons follow data summaries and are in blue text; standards are provided in table 3.-Continued

[CDPHE segment, Colorado Department of Health and the Environment stream segment as referred to in tables 2 and 3; latitude and longitude are in North American Datum of 1983; downstream order number assigned as part of analysis. $\mu \mathrm{g} / \mathrm{L}$, micrograms per liter; $\mu \mathrm{S} / \mathrm{cm}$, microsiemens per centimeter; $\mathrm{mg} / \mathrm{L}$, milligrams per liter; mL, milliliters; aq, aquatic; CO, Colorado; EPA, U.S. Environmental Protection Agency; Max, maximum; Min, minimum; NA, not applicable; No., number; NTU, nephelometric turbitidy units; WS, water supply; dates given in month/day/year format]

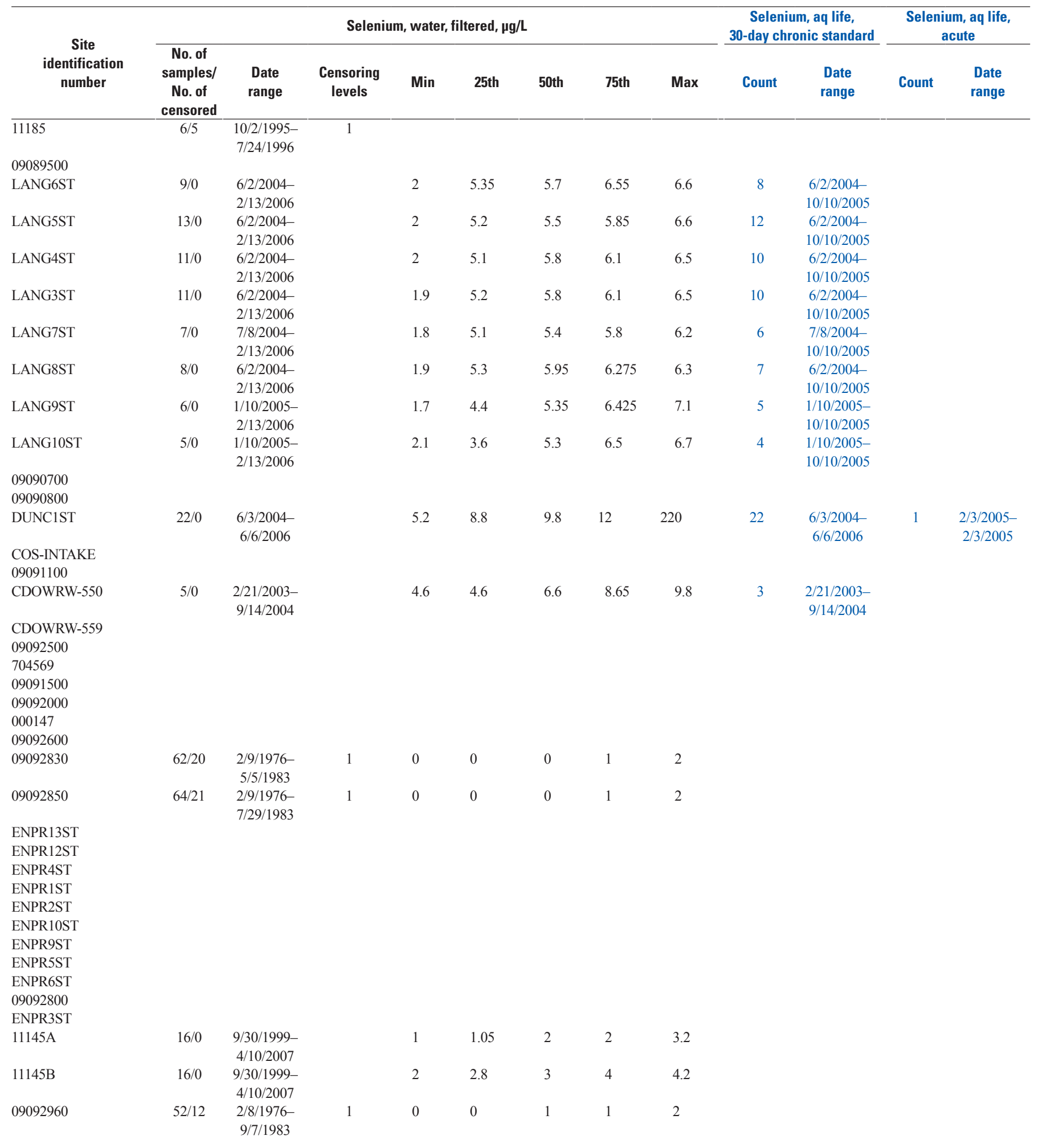


Appendix 1. Summary of surface-water-quality data and comparison to water-quality standards by site, by constituent, Piceance study area, western Colorado. Water-quality standards comparisons follow data summaries and are in blue text; standards are provided in table 3.-Continued

[CDPHE segment, Colorado Department of Health and the Environment stream segment as referred to in tables 2 and 3; latitude and longitude are in North American Datum of 1983; downstream order number assigned as part of analysis. $\mu \mathrm{g} / \mathrm{L}$, micrograms per liter; $\mu \mathrm{S} / \mathrm{cm}$, microsiemens per centimeter; mg/L, milligrams per liter; mL, milliliters; aq, aquatic; CO, Colorado; EPA, U.S. Environmental Protection Agency; Max, maximum; Min, minimum; NA, not applicable; No., number; NTU, nephelometric turbitidy units; WS, water supply; dates given in month/day/year format]

\begin{tabular}{|c|c|c|c|c|c|c|c|c|c|c|c|c|}
\hline $\begin{array}{c}\text { Site } \\
\text { identification } \\
\text { number }\end{array}$ & \multicolumn{8}{|c|}{ Selenium, water, filtered, $\mu \mathrm{g} / \mathrm{L}$} & \multicolumn{2}{|c|}{$\begin{array}{c}\text { Selenium, aq life, } \\
\text { 30-day chronic standard } \\
\end{array}$} & \multicolumn{2}{|c|}{$\begin{array}{c}\text { Selenium, aq life, } \\
\text { acute }\end{array}$} \\
\hline 09092970 & $52 / 12$ & $\begin{array}{c}4 / 21 / 1977- \\
9 / 9 / 1983\end{array}$ & 1 & 0 & 0 & 1 & 1 & 2 & & & & \\
\hline \multicolumn{13}{|l|}{ ENPR16ST } \\
\hline \multicolumn{13}{|l|}{ ENPR18ST } \\
\hline \multicolumn{13}{|l|}{ ENPR17ST } \\
\hline \multicolumn{13}{|l|}{ ENPR14ST } \\
\hline \multicolumn{13}{|l|}{ ENPR15ST } \\
\hline \multicolumn{13}{|l|}{ ENPR11ST } \\
\hline 09093000 & $33 / 3$ & $\begin{array}{c}4 / 21 / 1975- \\
9 / 24 / 1981\end{array}$ & 1 & 1 & 1 & 2 & 2 & 4 & & & & \\
\hline \multicolumn{13}{|l|}{09093700} \\
\hline 11205 & $9 / 0$ & $\begin{array}{l}8 / 16 / 1999 \\
10 / 10 / 2006\end{array}$ & & 1.5 & 3 & 4 & 5 & 5 & 4 & $\begin{array}{c}8 / 16 / 1999 \\
2 / 7 / 2000\end{array}$ & & \\
\hline \multicolumn{13}{|l|}{09094200} \\
\hline \multicolumn{13}{|l|}{09094400} \\
\hline 09095000 & $58 / 3$ & $\begin{array}{c}2 / 24 / 1975- \\
9 / 21 / 1981\end{array}$ & 1 & 0 & 3 & 3 & 4 & 7 & 7 & $\begin{array}{c}8 / 11 / 1975- \\
5 / 4 / 1981\end{array}$ & & \\
\hline 09095300 & $37 / 0$ & $\begin{array}{c}3 / 18 / 1996- \\
6 / 13 / 2001\end{array}$ & & 1 & 2.4 & 4 & 6 & 25 & 16 & $\begin{array}{c}6 / 11 / 1996- \\
6 / 13 / 2001\end{array}$ & 1 & $\begin{array}{l}\text { 9/8/1997- } \\
\text { 9/8/1997 }\end{array}$ \\
\hline 09095400 & $5 / 0$ & $\begin{array}{l}8 / 5 / 1975- \\
10 / 8 / 1982\end{array}$ & & 2 & 2 & 4 & 4 & 7 & 1 & $\begin{array}{l}8 / 5 / 1975- \\
8 / 5 / 1975\end{array}$ & & \\
\hline 11202 & $10 / 0$ & $\begin{array}{c}10 / 12 / 1995- \\
8 / 15 / 1996\end{array}$ & & 1 & 2 & 4 & 4 & 4 & & & & \\
\hline 000148 & $18 / 3$ & $\begin{array}{c}1 / 13 / 1999 \\
4 / 11 / 2007\end{array}$ & 3 & 2 & 2.8 & 3 & 4 & 4 & & & & \\
\hline \multirow{2}{*}{\multicolumn{13}{|c|}{$\begin{array}{l}09097600 \\
09095800\end{array}$}} \\
\hline \multirow{2}{*}{\multicolumn{13}{|c|}{$\begin{array}{l}09095800 \\
09096500\end{array}$}} \\
\hline & & & & & & & & & & & & \\
\hline \multicolumn{13}{|l|}{391507107550601} \\
\hline \multicolumn{13}{|l|}{ CDOWRW-56 } \\
\hline \multicolumn{13}{|l|}{ CDOWRW-55 } \\
\hline \multicolumn{13}{|l|}{09097900} \\
\hline \multicolumn{13}{|l|}{ CDOWRW-54 } \\
\hline \multicolumn{13}{|l|}{ CDOWRW-53 } \\
\hline 09105000 & $27 / 17$ & $\begin{array}{l}3 / 27 / 1991- \\
4 / 14 / 2003\end{array}$ & 1 & 0.599 & 0.262 & 0.647 & 1.14 & 9.4 & 3 & $\begin{array}{l}11 / 26 / 2002- \\
1 / 29 / 2003\end{array}$ & & \\
\hline 11103 & $30 / 21$ & $\begin{array}{c}8 / 11 / 1999 \\
4 / 11 / 2007\end{array}$ & 1 & 1 & 0.395 & 0.594 & 1 & 2.8 & & & & \\
\hline $\begin{array}{l}\text { UP RAPID CRK } \\
\text { INTAKE }\end{array}$ & & & & & & & & & & & & \\
\hline RC-2 & & & & & & & & & & & & \\
\hline RC-3 & & & & & & & & & & & & \\
\hline $\begin{array}{l}\text { LOWER RAPID } \\
\text { CRK }\end{array}$ & & & & & & & & & & & & \\
\hline
\end{tabular}


Appendix 1. Summary of surface-water-quality data and comparison to water-quality standards by site, by constituent, Piceance study area, western Colorado. Water-quality standards comparisons follow data summaries and are in blue text; standards are provided in table 3.-Continued

[CDPHE segment, Colorado Department of Health and the Environment stream segment as referred to in tables 2 and 3; latitude and longitude are in North American Datum of 1983; downstream order number assigned as part of analysis. $\mu \mathrm{g} / \mathrm{L}$, micrograms per liter; $\mu \mathrm{S} / \mathrm{cm}$, microsiemens per centimeter; mg/L, milligrams per liter; mL, milliliters; aq, aquatic; CO, Colorado; EPA, U.S. Environmental Protection Agency; Max, maximum; Min, minimum; NA, not applicable; No., number; NTU, nephelometric turbitidy units; WS, water supply; dates given in month/day/year format]

\begin{tabular}{|c|c|c|c|c|c|c|c|c|c|c|c|c|}
\hline \multirow[b]{2}{*}{$\begin{array}{c}\text { Site } \\
\text { identification } \\
\text { number }\end{array}$} & \multicolumn{8}{|c|}{ Selenium, water, filtered, $\mu \mathrm{g} / \mathrm{L}$} & \multicolumn{2}{|c|}{$\begin{array}{c}\text { Selenium, aq life, } \\
\text { 30-day chronic standard }\end{array}$} & \multicolumn{2}{|c|}{$\begin{array}{c}\text { Selenium, aq life, } \\
\text { acute }\end{array}$} \\
\hline & $\begin{array}{c}\text { No. of } \\
\text { samples/ } \\
\text { No. of } \\
\text { censored }\end{array}$ & $\begin{array}{l}\text { Date } \\
\text { range }\end{array}$ & $\begin{array}{l}\text { Censoring } \\
\text { levels }\end{array}$ & Min & 25th & 50th & 75th & Max & Count & $\begin{array}{l}\text { Date } \\
\text { range }\end{array}$ & Count & $\begin{array}{l}\text { Date } \\
\text { range }\end{array}$ \\
\hline \multicolumn{13}{|l|}{$\begin{array}{l}\text { L COTTONWOOD } \\
\text { INTAKE }\end{array}$} \\
\hline 11151 & $11 / 2$ & $\begin{array}{l}10 / 23 / 1995- \\
4 / 11 / 2007\end{array}$ & 1 & 1 & 1 & 1 & 1 & 2.3 & & & & \\
\hline 390622108205400 & $10 / 5$ & $\begin{array}{l}7 / 19 / 1994 \\
4 / 19 / 1995\end{array}$ & 1 & 1 & 1 & 1 & 1 & 1 & & & & \\
\hline 09106150 & $26 / 20$ & $\begin{array}{l}1 / 16 / 1992- \\
7 / 31 / 2002\end{array}$ & 12 & 0.564 & 0.564 & 0.676 & 0.802 & 1 & & & & \\
\hline CDOWRW-553 & $9 / 0$ & $\begin{array}{l}11 / 25 / 2002- \\
10 / 23 / 2006\end{array}$ & & 2.1 & 2.3 & 3.8 & 5.85 & 6.8 & 4 & $\begin{array}{l}11 / 25 / 2002- \\
10 / 23 / 2006\end{array}$ & & \\
\hline \multicolumn{13}{|l|}{ CDOWRW-555 } \\
\hline 390348108265601 & $5 / 0$ & $\begin{array}{l}3 / 22 / 1991- \\
9 / 23 / 1993\end{array}$ & & 18 & 18 & 34 & 93 & 100 & 5 & $\begin{array}{l}3 / 22 / 1991- \\
9 / 23 / 1993\end{array}$ & 3 & $\begin{array}{l}3 / 22 / 1991- \\
9 / 23 / 1993\end{array}$ \\
\hline \multicolumn{13}{|l|}{$\begin{array}{l}\text { CDOWRW-556 } \\
390319108273200\end{array}$} \\
\hline 390318108273200 & $11 / 0$ & $\begin{array}{c}7 / 19 / 1994 \\
7 / 31 / 2002\end{array}$ & & 1 & 1 & 1 & 2 & 2.603 & & & & \\
\hline \multicolumn{13}{|l|}{ CDOWRW-557 } \\
\hline 09106200 & $41 / 5$ & $\begin{array}{l}\text { 7/5/1977- } \\
3 / 6 / 2006\end{array}$ & 1 & 0.556 & 0.999 & 3.32 & 23 & 47 & 20 & $\begin{array}{l}7 / 5 / 1977- \\
3 / 6 / 2006\end{array}$ & 13 & $\begin{array}{c}3 / 21 / 1991- \\
3 / 6 / 2006\end{array}$ \\
\hline 390324108291301 & $15 / 6$ & $\begin{array}{l}\text { 7/23/1998- } \\
9 / 3 / 2003\end{array}$ & 1 & 0.606 & 0.697 & 0.899 & 1.47 & 11.76 & 3 & $\begin{array}{c}11 / 24 / 1998- \\
2 / 19 / 1999\end{array}$ & & \\
\hline 390326108291601 & $59 / 0$ & $\begin{array}{l}1 / 24 / 1997- \\
9 / 3 / 2003\end{array}$ & & 1.93 & 3.49 & 4.87 & 7.2 & 14.84 & 33 & $\begin{array}{l}1 / 24 / 1997- \\
4 / 22 / 2003\end{array}$ & & \\
\hline 390323108291601 & $11 / 0$ & $\begin{array}{l}11 / 9 / 1998- \\
12 / 12 / 2002\end{array}$ & & 1.15 & 1.75 & 3.57 & 6.43 & 9.4 & 5 & $\begin{array}{l}11 / 24 / 1998- \\
12 / 12 / 2002\end{array}$ & & \\
\hline 390303108291601 & $19 / 0$ & $\begin{array}{c}10 / 15 / 1997- \\
7 / 13 / 2001\end{array}$ & & 9.59 & 13.283 & 20 & 23 & 27.46 & 19 & $\begin{array}{c}10 / 15 / 1997- \\
7 / 13 / 2001\end{array}$ & 11 & $\begin{array}{c}10 / 15 / 1997- \\
3 / 2 / 2000\end{array}$ \\
\hline 390322108292301 & $7 / 0$ & $\begin{array}{l}\text { 7/23/1998- } \\
\text { 9/3/2003 }\end{array}$ & & 1.406 & 2.262 & 2.57 & 7.806 & 7.826 & 2 & $\begin{array}{l}2 / 19 / 2003- \\
3 / 11 / 2003\end{array}$ & & \\
\hline 390318108293301 & $9 / 0$ & $\begin{array}{c}3 / 18 / 1999 \\
9 / 3 / 2003\end{array}$ & & 1.47 & 1.888 & 4.526 & 10.445 & 13.25 & 4 & $\begin{array}{l}3 / 18 / 1999- \\
3 / 11 / 2003\end{array}$ & & \\
\hline 390302108293801 & $15 / 0$ & $\begin{array}{c}10 / 15 / 1997- \\
5 / 23 / 2000\end{array}$ & & 12.78 & 16.51 & 17.15 & 20 & 21.91 & 15 & $\begin{array}{l}10 / 15 / 1997- \\
5 / 23 / 2000\end{array}$ & 6 & $\begin{array}{l}10 / 15 / 1997- \\
3 / 2 / 2000\end{array}$ \\
\hline \multicolumn{13}{|l|}{390319108312501} \\
\hline 390320108315901 & $6 / 0$ & $\begin{array}{c}3 / 21 / 1991- \\
1 / 20 / 1995\end{array}$ & & 6 & 44.25 & 86 & 102.5 & 110 & 6 & $\begin{array}{l}3 / 21 / 1991- \\
1 / 20 / 1995\end{array}$ & 5 & $\begin{array}{l}3 / 21 / 1991- \\
1 / 20 / 1995\end{array}$ \\
\hline \multicolumn{13}{|l|}{ CDOWRW-558 } \\
\hline CDOWRW-560 & $5 / 0$ & $\begin{array}{l}12 / 7 / 2002- \\
5 / 10 / 2003\end{array}$ & & 2 & 2.65 & 4 & 5.85 & 7.5 & 1 & $\begin{array}{l}3 / 8 / 2003- \\
3 / 8 / 2003\end{array}$ & & \\
\hline 09106500 & $16 / 3$ & $\begin{array}{l}7 / 20 / 1994 \\
7 / 31 / 2002\end{array}$ & 1 & 1 & 1 & 1 & 2 & 3.811 & & & & \\
\hline \multicolumn{13}{|l|}{390337108342800} \\
\hline $11135 \mathrm{~A}$ & $8 / 0$ & $\begin{array}{l}\text { 7/26/2005- } \\
\text { 1/9/2007 }\end{array}$ & & 12 & 14.5 & 23 & 63 & 67 & 8 & $\begin{array}{l}7 / 26 / 2005- \\
1 / 9 / 2007\end{array}$ & 5 & $\begin{array}{l}\text { 7/26/2005- } \\
\text { 1/9/2007 }\end{array}$ \\
\hline \multicolumn{13}{|l|}{ CDOWRW-749 } \\
\hline 09152650 & $50 / 0$ & $\begin{array}{l}3 / 21 / 1991- \\
8 / 9 / 1999\end{array}$ & & 5 & 9 & 14 & 85 & 110 & 50 & $\begin{array}{l}3 / 21 / 1991- \\
8 / 9 / 1999\end{array}$ & 24 & $\begin{array}{c}3 / 21 / 1991- \\
4 / 13 / 1999\end{array}$ \\
\hline 11135 & $7 / 0$ & $\begin{array}{l}7 / 26 / 2005- \\
10 / 11 / 2006\end{array}$ & & 7.3 & 8.9 & 9.9 & 22 & 92 & 7 & $\begin{array}{l}7 / 26 / 2005- \\
10 / 11 / 2006\end{array}$ & 2 & $\begin{array}{l}7 / 26 / 2005- \\
12 / 6 / 2005\end{array}$ \\
\hline 390449108364101 & $18 / 0$ & $\begin{array}{l}11 / 5 / 1998- \\
11 / 14 / 2000\end{array}$ & & 2.773 & 3.423 & 3.995 & 5.209 & 6.3 & 5 & $\begin{array}{l}12 / 7 / 1998- \\
11 / 14 / 2000\end{array}$ & & \\
\hline
\end{tabular}


Appendix 1. Summary of surface-water-quality data and comparison to water-quality standards by site, by constituent, Piceance study area, western Colorado. Water-quality standards comparisons follow data summaries and are in blue text; standards are provided in table 3.-Continued

[CDPHE segment, Colorado Department of Health and the Environment stream segment as referred to in tables 2 and 3; latitude and longitude are in North American Datum of 1983; downstream order number assigned as part of analysis. $\mu \mathrm{g} / \mathrm{L}$, micrograms per liter; $\mu \mathrm{S} / \mathrm{cm}$, microsiemens per centimeter; $\mathrm{mg} / \mathrm{L}$, milligrams per liter; mL, milliliters; aq, aquatic; CO, Colorado; EPA, U.S. Environmental Protection Agency; Max, maximum; Min, minimum; NA, not applicable; No., number; NTU, nephelometric turbitidy units; WS, water supply; dates given in month/day/year format]

\begin{tabular}{|c|c|c|c|c|c|c|c|c|c|c|c|c|}
\hline \multirow[b]{2}{*}{$\begin{array}{c}\text { Site } \\
\text { identification } \\
\text { number }\end{array}$} & \multicolumn{8}{|c|}{ Selenium, water, filtered, $\mu \mathrm{g} / \mathrm{L}$} & \multicolumn{2}{|c|}{$\begin{array}{c}\text { Selenium, aq life, } \\
\text { 30-day chronic standard }\end{array}$} & \multicolumn{2}{|c|}{$\begin{array}{c}\text { Selenium, aq life, } \\
\text { acute }\end{array}$} \\
\hline & $\begin{array}{c}\text { No. of } \\
\text { samples/ } \\
\text { No. of } \\
\text { censored }\end{array}$ & $\begin{array}{l}\text { Date } \\
\text { range }\end{array}$ & $\begin{array}{l}\text { Censoring } \\
\text { levels }\end{array}$ & Min & 25th & 50th & 75th & Max & Count & $\begin{array}{l}\text { Date } \\
\text { range }\end{array}$ & Count & $\begin{array}{l}\text { Date } \\
\text { range }\end{array}$ \\
\hline 390521108373300 & $16 / 2$ & $\begin{array}{c}7 / 20 / 1994 \\
8 / 1 / 2002\end{array}$ & 1 & 1 & 2 & 3.5 & 4.5 & 6 & 4 & $\begin{array}{c}7 / 20 / 1994 \\
8 / 1 / 2002\end{array}$ & & \\
\hline 390607108384201 & $34 / 5$ & $\begin{array}{c}3 / 5 / 1997- \\
6 / 6 / 2002\end{array}$ & 1 & 1 & 1.316 & 2 & 2.91 & 7.66 & 1 & $\begin{array}{c}8 / 6 / 1997- \\
8 / 6 / 1997\end{array}$ & & \\
\hline 390609108384701 & $14 / 0$ & $\begin{array}{c}10 / 6 / 1994 \\
6 / 6 / 2002\end{array}$ & & 0.932 & 2 & 2.971 & 3.34 & 9.281 & 2 & $\begin{array}{c}7 / 27 / 2000- \\
6 / 6 / 2002\end{array}$ & & \\
\hline 390613108385603 & $10 / 2$ & $\begin{array}{c}12 / 2 / 1998- \\
4 / 18 / 2002\end{array}$ & 11.2 & 1 & 1.341 & 2.795 & 5.885 & 8.91 & 3 & $\begin{array}{l}4 / 8 / 1999 \\
4 / 18 / 2002\end{array}$ & & \\
\hline 390625108390402 & $14 / 0$ & $\begin{array}{l}3 / 5 / 1997- \\
4 / 18 / 2002\end{array}$ & & 1.386 & 2.6 & 4.15 & 44.56 & 92.71 & 7 & $\begin{array}{c}2 / 24 / 1999 \\
4 / 18 / 2002\end{array}$ & 4 & $\begin{array}{c}2 / 24 / 1999 \\
3 / 23 / 2000\end{array}$ \\
\hline 390617108391001 & $9 / 0$ & $\begin{array}{c}2 / 24 / 1999 \\
6 / 6 / 2002\end{array}$ & & 1.557 & 1.935 & 9.191 & 11.65 & 14.962 & 5 & $\begin{array}{c}10 / 21 / 1999 \\
6 / 6 / 2002\end{array}$ & & \\
\hline 390632108392101 & $8 / 0$ & $\begin{array}{l}3 / 5 / 1997- \\
7 / 22 / 1999\end{array}$ & & 1.35 & 3.25 & 4.185 & 12.478 & 37.77 & 3 & $\begin{array}{c}\text { 2/24/1999- } \\
7 / 22 / 1999\end{array}$ & 1 & $\begin{array}{c}2 / 24 / 1999 \\
2 / 24 / 1999\end{array}$ \\
\hline 390624108394701 & $9 / 0$ & $\begin{array}{c}3 / 12 / 1997- \\
9 / 4 / 2001\end{array}$ & & 3.6 & 5.796 & 6.333 & 8.489 & 13.096 & 8 & $\begin{array}{c}3 / 12 / 1997- \\
9 / 4 / 2001\end{array}$ & & \\
\hline 390859108364101 & $5 / 0$ & $\begin{array}{c}2 / 3 / 1992- \\
11 / 21 / 2004\end{array}$ & & 6 & 6 & 8 & 65.22 & 74 & 5 & $\begin{array}{c}2 / 3 / 1992- \\
11 / 21 / 2004\end{array}$ & 2 & $\begin{array}{c}2 / 3 / 1992- \\
11 / 21 / 2004\end{array}$ \\
\hline 390645108390101 & $19 / 0$ & $\begin{array}{c}3 / 21 / 1991- \\
3 / 7 / 2006\end{array}$ & & 7 & 10.51 & 33.6 & 65.75 & 94.06 & 19 & $\begin{array}{c}3 / 21 / 1991- \\
3 / 7 / 2006\end{array}$ & 11 & $\begin{array}{c}3 / 21 / 1991- \\
3 / 7 / 2006\end{array}$ \\
\hline 390717108400501 & $6 / 0$ & $\begin{array}{c}3 / 20 / 1991- \\
9 / 22 / 1993\end{array}$ & & 6 & 6.75 & 10.5 & 31.25 & 35 & 6 & $\begin{array}{c}3 / 20 / 1991- \\
9 / 22 / 1993\end{array}$ & 2 & $\begin{array}{c}3 / 20 / 1991- \\
2 / 3 / 1992\end{array}$ \\
\hline 390718108415701 & $5 / 1$ & $\begin{array}{c}3 / 14 / 1995- \\
7 / 31 / 1996\end{array}$ & 1 & 1 & 3.5 & 14 & 45 & 48 & 4 & $\begin{array}{c}3 / 14 / 1995- \\
7 / 31 / 1996\end{array}$ & 2 & $\begin{array}{c}3 / 14 / 1995- \\
3 / 12 / 1996\end{array}$ \\
\hline 09152900 & $6 / 0$ & $\begin{array}{c}3 / 20 / 1991- \\
9 / 22 / 1993\end{array}$ & & 9 & 9.75 & 46 & 83 & 92 & 6 & $\begin{array}{c}3 / 20 / 1991- \\
9 / 22 / 1993\end{array}$ & 3 & $\begin{array}{c}3 / 20 / 1991- \\
3 / 24 / 1992\end{array}$ \\
\hline 11133 & $9 / 0$ & $\begin{array}{c}\text { 7/26/2005- } \\
4 / 11 / 2007\end{array}$ & & 9.5 & 10.5 & 13 & 26 & 44 & 9 & $\begin{array}{c}\text { 7/26/2005- } \\
4 / 11 / 2007\end{array}$ & 2 & $\begin{array}{c}12 / 6 / 2005- \\
1 / 9 / 2007\end{array}$ \\
\hline 390741108424001 & $7 / 0$ & $\begin{array}{c}7 / 24 / 2000- \\
7 / 2 / 2003\end{array}$ & & 2.09 & 2.506 & 4.335 & 16.03 & 16.57 & 3 & $\begin{array}{c}7 / 24 / 2000 \\
3 / 15 / 2001\end{array}$ & & \\
\hline 390741108424301 & $13 / 0$ & $\begin{array}{c}7 / 24 / 2000- \\
3 / 8 / 2006\end{array}$ & & 10.341 & 11.088 & 32.54 & 40.34 & 59.95 & 13 & $\begin{array}{c}\text { 7/24/2000- } \\
3 / 8 / 2006\end{array}$ & 7 & $\begin{array}{c}12 / 1 / 2000- \\
3 / 8 / 2006\end{array}$ \\
\hline 390741108425301 & $9 / 0$ & $\begin{array}{c}7 / 24 / 2000- \\
7 / 2 / 2003\end{array}$ & & 2.801 & 10.215 & 14.89 & 39.46 & 58.11 & 8 & $\begin{array}{c}7 / 24 / 2000- \\
7 / 2 / 2003\end{array}$ & 4 & $\begin{array}{c}12 / 1 / 2000- \\
4 / 1 / 2003\end{array}$ \\
\hline 09153000 & $16 / 3$ & $\begin{array}{c}7 / 20 / 1994 \\
8 / 1 / 2002\end{array}$ & 1 & 1 & 2.5 & 3.5 & 5 & 6.343 & 7 & $\begin{array}{c}7 / 20 / 1994 \\
8 / 1 / 2002\end{array}$ & & \\
\hline \multicolumn{13}{|l|}{000049} \\
\hline $\begin{array}{l}390938108443101 \\
11110\end{array}$ & $6 / 4$ & $\begin{array}{c}10 / 12 / 1995- \\
7 / 18 / 1996\end{array}$ & 15 & & & & & & & & & \\
\hline 391509108433001 & $8 / 0$ & $\begin{array}{c}5 / 2 / 1991- \\
5 / 3 / 2000\end{array}$ & & 2 & 2 & 2.85 & 6.02 & 15.9 & & & & \\
\hline 09153270 & $33 / 0$ & $\begin{array}{c}3 / 20 / 1991- \\
11 / 9 / 2006\end{array}$ & & 3.97 & 12 & 19 & 32 & 84 & 29 & $\begin{array}{c}3 / 20 / 1991- \\
3 / 8 / 1999\end{array}$ & 16 & $\begin{array}{c}3 / 20 / 1991- \\
3 / 8 / 1999\end{array}$ \\
\hline \multicolumn{13}{|l|}{09095526} \\
\hline \multicolumn{13}{|l|}{09106104} \\
\hline \multicolumn{13}{|l|}{09095529} \\
\hline \multicolumn{13}{|l|}{090955285} \\
\hline 09095528 & & & & & & & & & & & & \\
\hline 09153290 & $54 / 0$ & $\begin{array}{c}9 / 10 / 1991- \\
9 / 8 / 1998\end{array}$ & & 4.3 & 13.1 & 18 & 52 & 170 & 53 & $\begin{array}{c}\text { 9/10/1991- } \\
\text { 9/8/1998 }\end{array}$ & 25 & $\begin{array}{c}9 / 10 / 1991- \\
9 / 8 / 1998\end{array}$ \\
\hline 09153300 & $54 / 0$ & $\begin{array}{c}8 / 27 / 1991- \\
3 / 8 / 1999\end{array}$ & & 6.7 & 17 & 24 & 80 & 150 & 54 & $\begin{array}{c}\text { 8/27/1991- } \\
3 / 8 / 1999\end{array}$ & 37 & $\begin{array}{c}\text { 8/27/1991- } \\
3 / 8 / 1999\end{array}$ \\
\hline 391038108475601 & $9 / 0$ & $\begin{array}{l}\text { 7/9/1993- } \\
7 / 14 / 1999\end{array}$ & & 1.63 & 2 & 2.02 & 11.5 & 13.83 & 3 & $\begin{array}{c}11 / 19 / 1998- \\
1 / 20 / 1999\end{array}$ & & \\
\hline
\end{tabular}


Appendix 1. Summary of surface-water-quality data and comparison to water-quality standards by site, by constituent, Piceance study area, western Colorado. Water-quality standards comparisons follow data summaries and are in blue text; standards are provided in table 3.-Continued

[CDPHE segment, Colorado Department of Health and the Environment stream segment as referred to in tables 2 and 3; latitude and longitude are in North American Datum of 1983; downstream order number assigned as part of analysis. $\mu \mathrm{g} / \mathrm{L}$, micrograms per liter; $\mu \mathrm{S} / \mathrm{cm}$, microsiemens per centimeter; $\mathrm{mg} / \mathrm{L}$, milligrams per liter; mL, milliliters; aq, aquatic; CO, Colorado; EPA, U.S. Environmental Protection Agency; Max, maximum; Min, minimum; NA, not applicable; No., number; NTU, nephelometric turbitidy units; WS, water supply; dates given in month/day/year format]

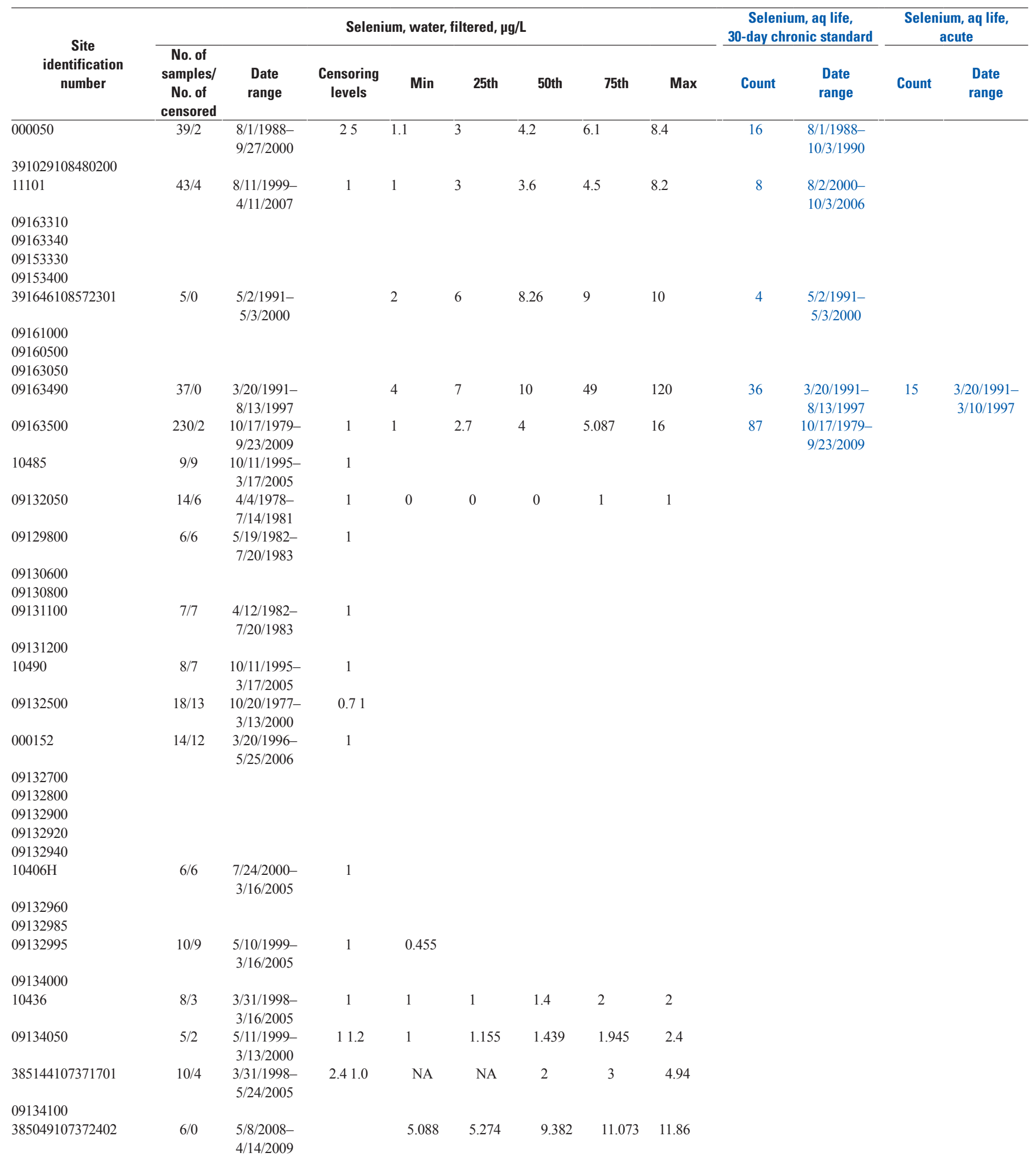


Appendix 1. Summary of surface-water-quality data and comparison to water-quality standards by site, by constituent, Piceance study area, western Colorado. Water-quality standards comparisons follow data summaries and are in blue text; standards are provided in table 3.-Continued

[CDPHE segment, Colorado Department of Health and the Environment stream segment as referred to in tables 2 and 3; latitude and longitude are in North American Datum of 1983; downstream order number assigned as part of analysis. $\mu \mathrm{g} / \mathrm{L}$, micrograms per liter; $\mu \mathrm{S} / \mathrm{cm}$, microsiemens per centimeter; $\mathrm{mg} / \mathrm{L}$, milligrams per liter; mL, milliliters; aq, aquatic; CO, Colorado; EPA, U.S. Environmental Protection Agency; Max, maximum; Min, minimum; NA, not applicable; No., number; NTU, nephelometric turbitidy units; WS, water supply; dates given in month/day/year format]

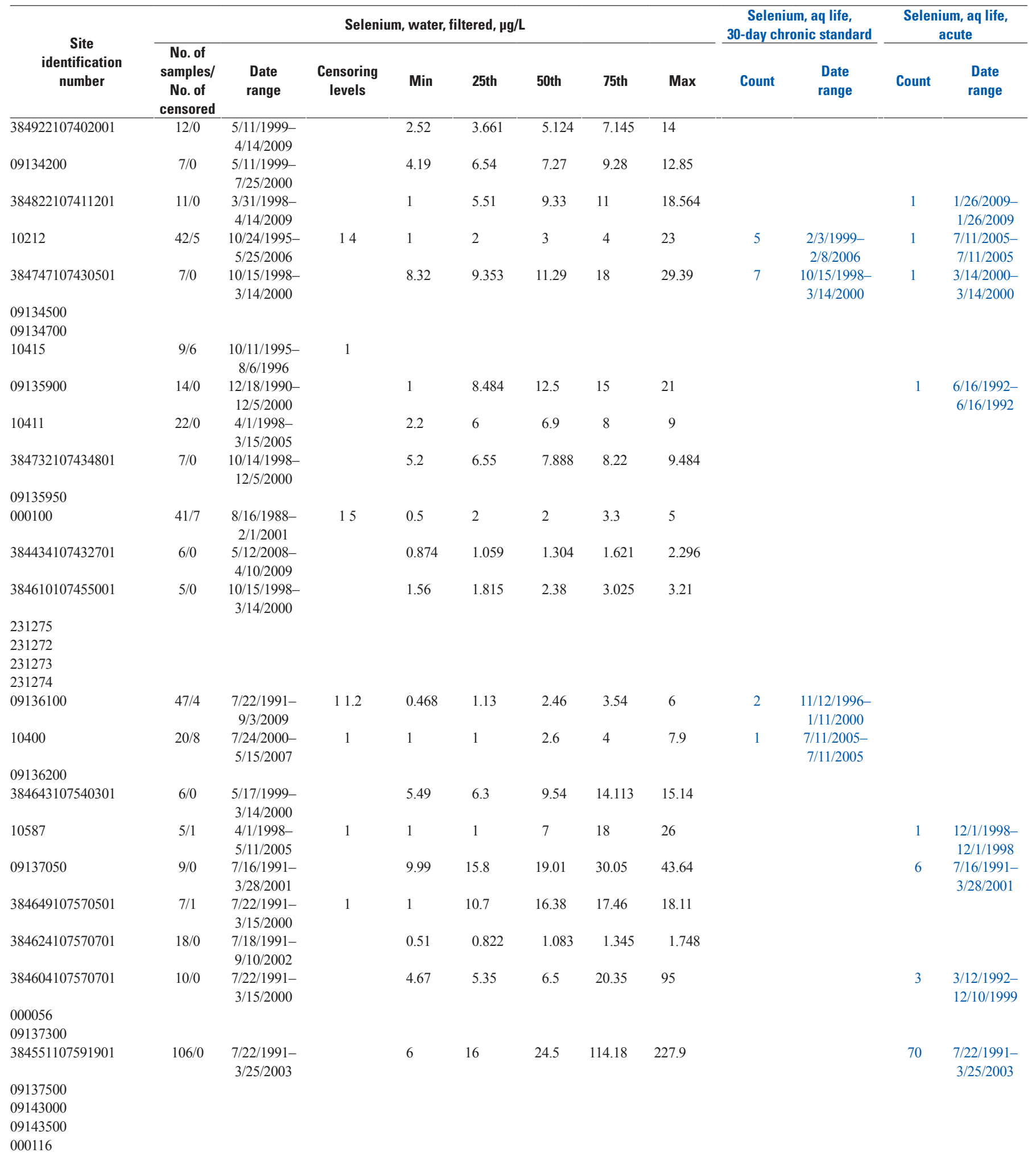


Appendix 1. Summary of surface-water-quality data and comparison to water-quality standards by site, by constituent, Piceance study area, western Colorado. Water-quality standards comparisons follow data summaries and are in blue text; standards are provided in table 3.-Continued

[CDPHE segment, Colorado Department of Health and the Environment stream segment as referred to in tables 2 and 3; latitude and longitude are in North American Datum of 1983; downstream order number assigned as part of analysis. $\mu \mathrm{g} / \mathrm{L}$, micrograms per liter; $\mu \mathrm{S} / \mathrm{cm}$, microsiemens per centimeter; $\mathrm{mg} / \mathrm{L}$, milligrams per liter; mL, milliliters; aq, aquatic; CO, Colorado; EPA, U.S. Environmental Protection Agency; Max, maximum; Min, minimum; NA, not applicable; No., number; NTU, nephelometric turbitidy units; WS, water supply; dates given in month/day/year format]

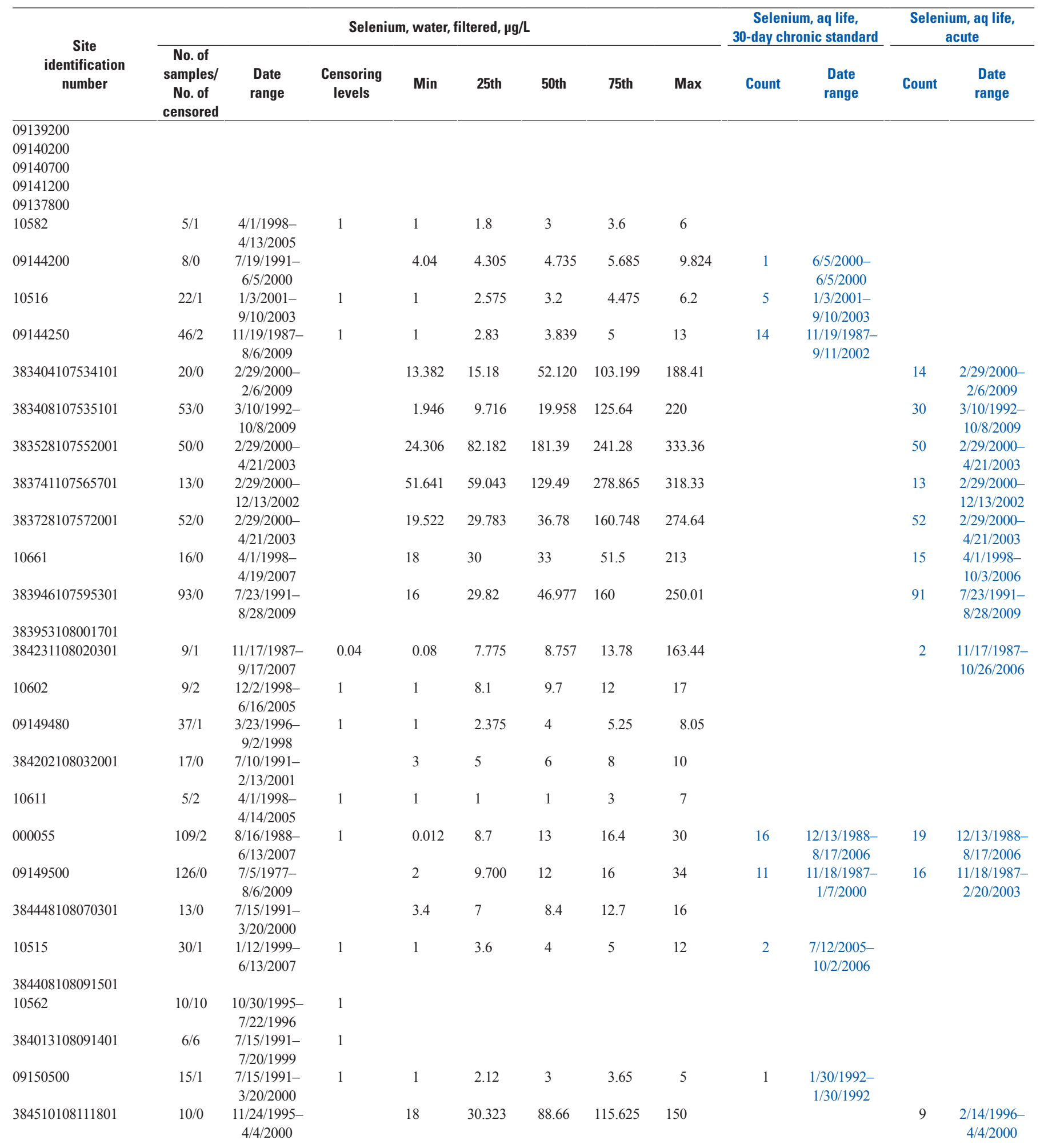


Appendix 1. Summary of surface-water-quality data and comparison to water-quality standards by site, by constituent, Piceance study area, western Colorado. Water-quality standards comparisons follow data summaries and are in blue text; standards are provided in table 3.-Continued

[CDPHE segment, Colorado Department of Health and the Environment stream segment as referred to in tables 2 and 3; latitude and longitude are in North American Datum of 1983; downstream order number assigned as part of analysis. $\mu \mathrm{g} / \mathrm{L}$, micrograms per liter; $\mu \mathrm{S} / \mathrm{cm}$, microsiemens per centimeter; mg/L, milligrams per liter; mL, milliliters; aq, aquatic; CO, Colorado; EPA, U.S. Environmental Protection Agency; Max, maximum; Min, minimum; NA, not applicable; No., number; NTU, nephelometric turbitidy units; WS, water supply; dates given in month/day/year format]

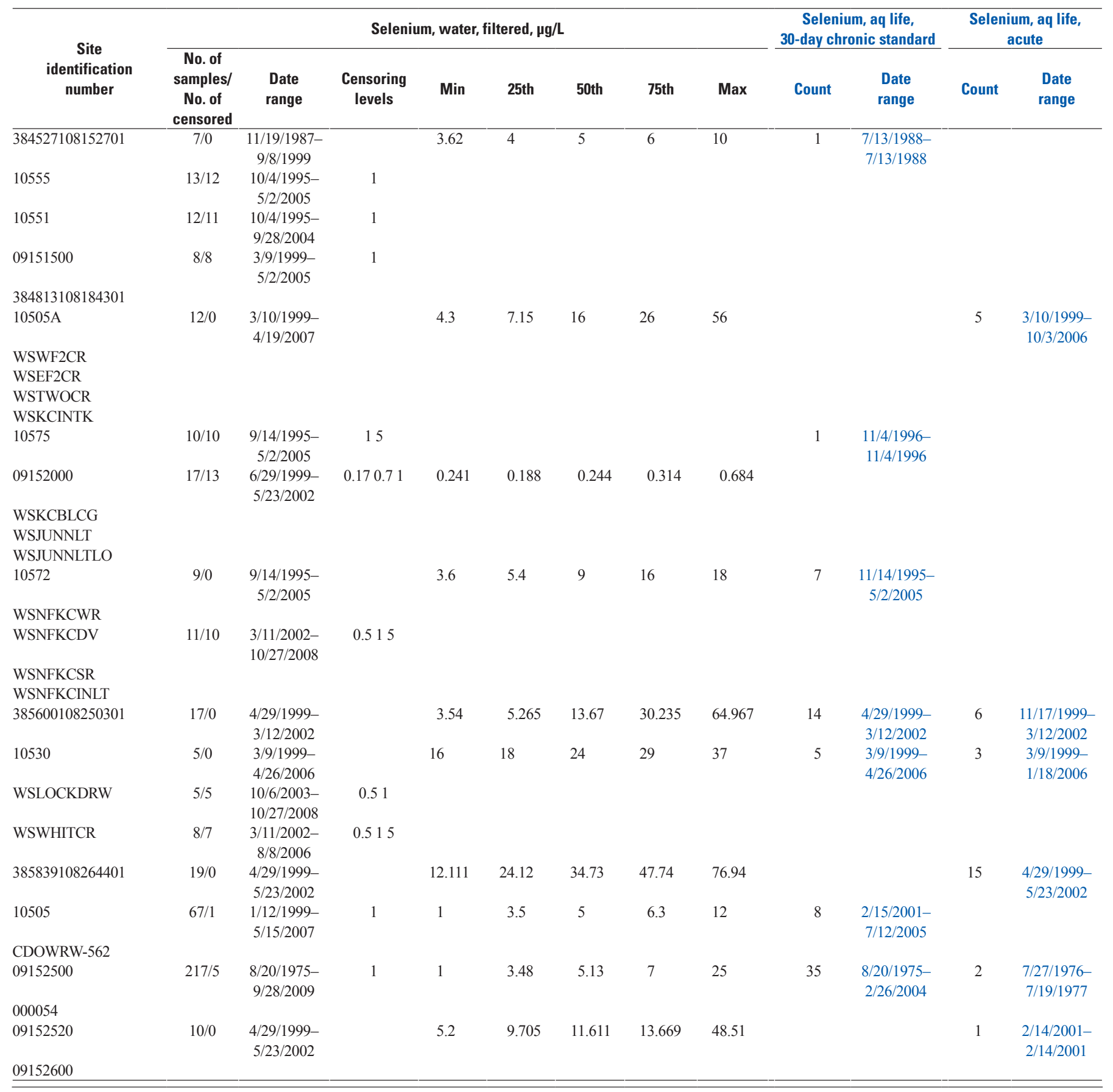


Appendix 1. Summary of surface-water-quality data and comparison to water-quality standards by site, by constituent, Piceance study area, western Colorado. Water-quality standards comparisons follow data summaries and are in blue text; standards are provided in table 3.-Continued

[CDPHE segment, Colorado Department of Health and the Environment stream segment as referred to in tables 2 and 3; latitude and longitude are in North American Datum of 1983; downstream order number assigned as part of analysis. $\mu \mathrm{g} / \mathrm{L}$, micrograms per liter; $\mu \mathrm{S} / \mathrm{cm}$, microsiemens per centimeter; $\mathrm{mg} / \mathrm{L}$, milligrams per liter; mL, milliliters; aq, aquatic; CO, Colorado; EPA, U.S. Environmental Protection Agency; Max, maximum; Min, minimum; NA, not applicable; No., number; NTU, nephelometric turbitidy units; WS, water supply; dates given in month/day/year format]

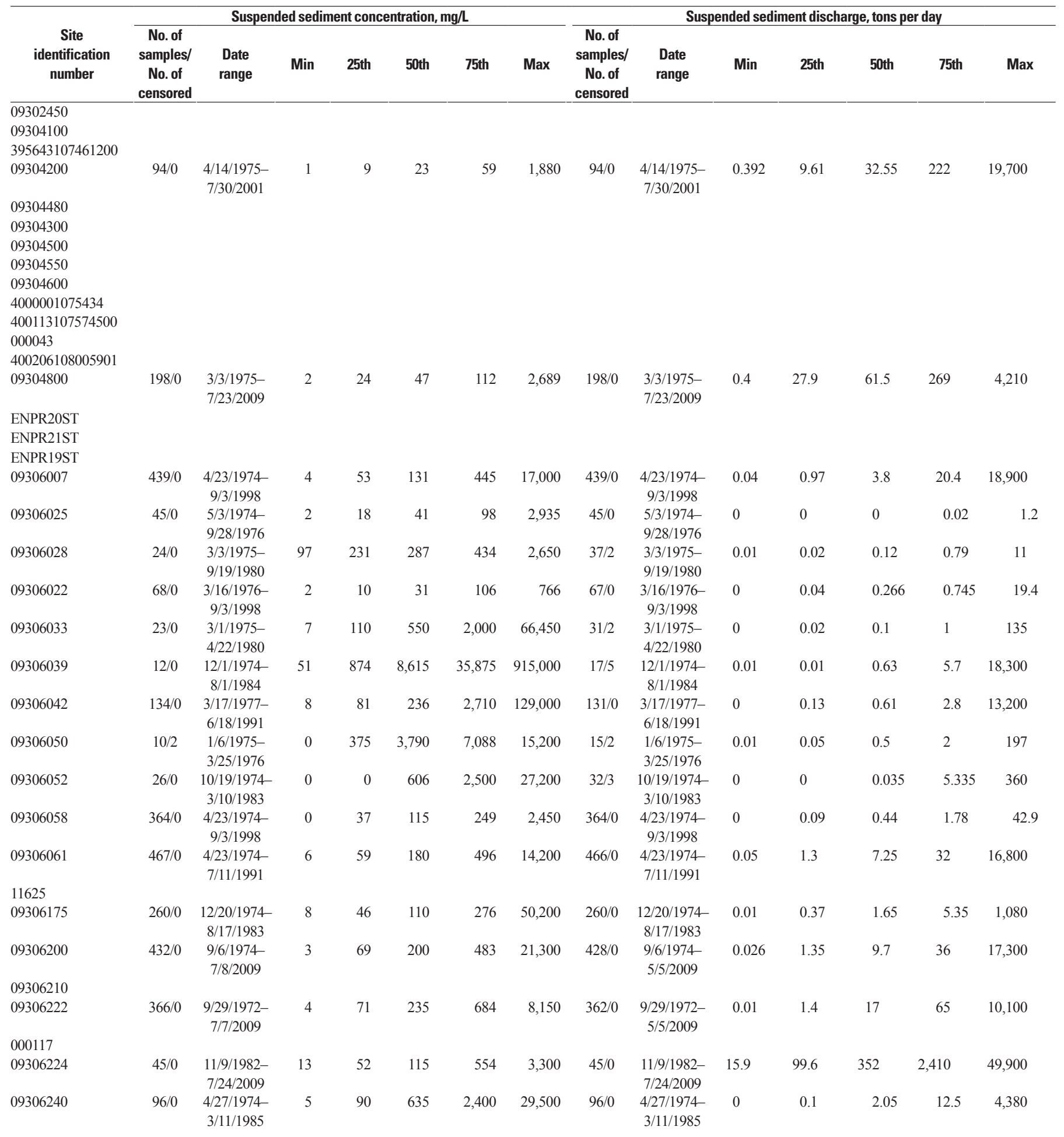


Appendix 1. Summary of surface-water-quality data and comparison to water-quality standards by site, by constituent, Piceance study area, western Colorado. Water-quality standards comparisons follow data summaries and are in blue text; standards are provided in table 3.-Continued

[CDPHE segment, Colorado Department of Health and the Environment stream segment as referred to in tables 2 and 3; latitude and longitude are in North American Datum of 1983; downstream order number assigned as part of analysis. $\mu \mathrm{g} / \mathrm{L}$, micrograms per liter; $\mu \mathrm{S} / \mathrm{cm}$, microsiemens per centimeter; mg/L, milligrams per liter; mL, milliliters; aq, aquatic; CO, Colorado; EPA, U.S. Environmental Protection Agency; Max, maximum; Min, minimum; NA, not applicable; No., number; NTU, nephelometric turbitidy units; WS, water supply; dates given in month/day/year format]

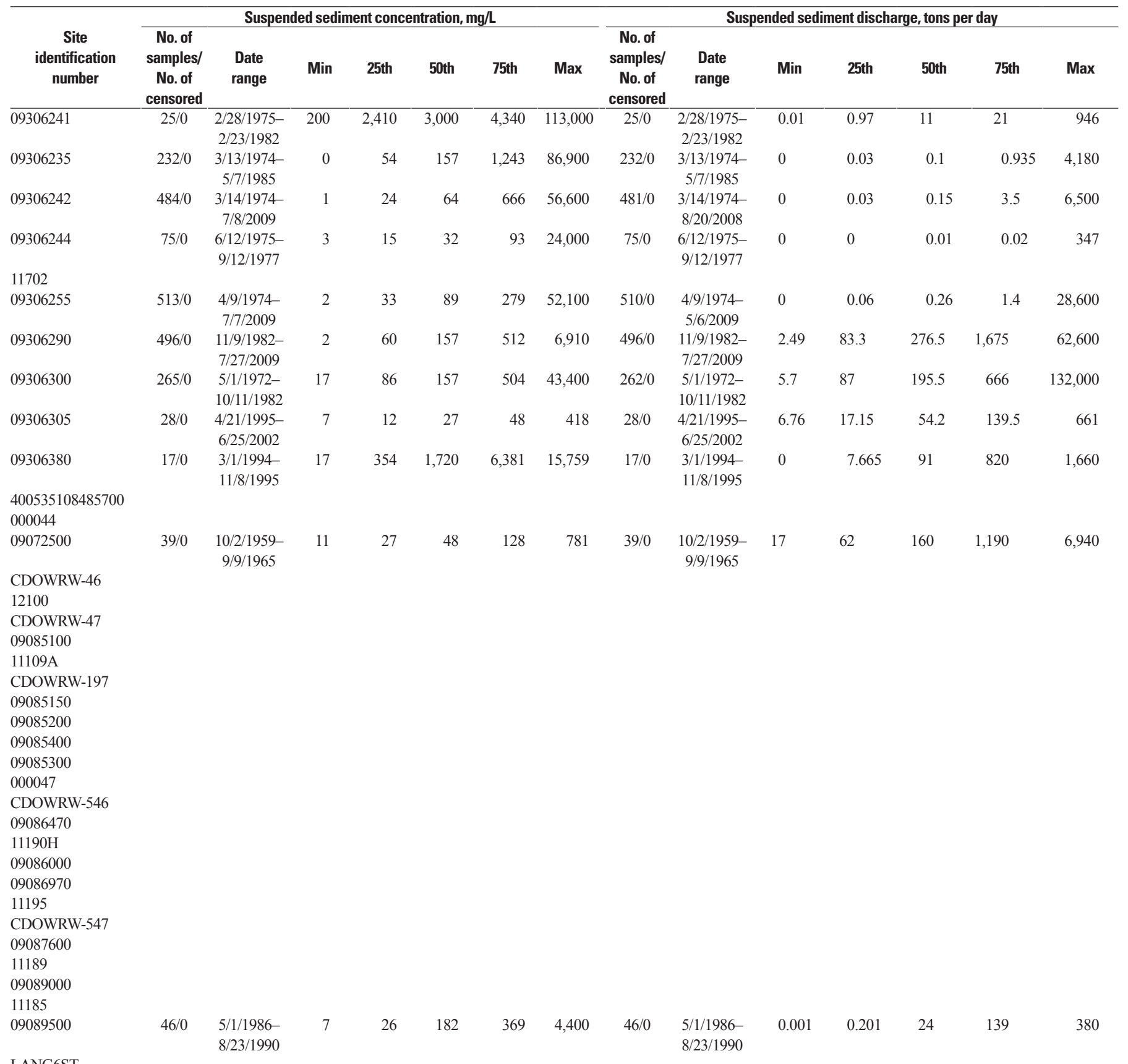

LANG5ST

LANG4ST

LANG3ST

LANG7ST

LANG8ST

LANG9ST 
Appendix 1. Summary of surface-water-quality data and comparison to water-quality standards by site, by constituent, Piceance study area, western Colorado. Water-quality standards comparisons follow data summaries and are in blue text; standards are provided in table 3.-Continued

[CDPHE segment, Colorado Department of Health and the Environment stream segment as referred to in tables 2 and 3; latitude and longitude are in North American Datum of 1983; downstream order number assigned as part of analysis. $\mu \mathrm{g} / \mathrm{L}$, micrograms per liter; $\mu \mathrm{S} / \mathrm{cm}$, microsiemens per centimeter; $\mathrm{mg} / \mathrm{L}$, milligrams per liter; mL, milliliters; aq, aquatic; CO, Colorado; EPA, U.S. Environmental Protection Agency; Max, maximum; Min, minimum; NA, not applicable; No., number; NTU, nephelometric turbitidy units; WS, water supply; dates given in month/day/year format]

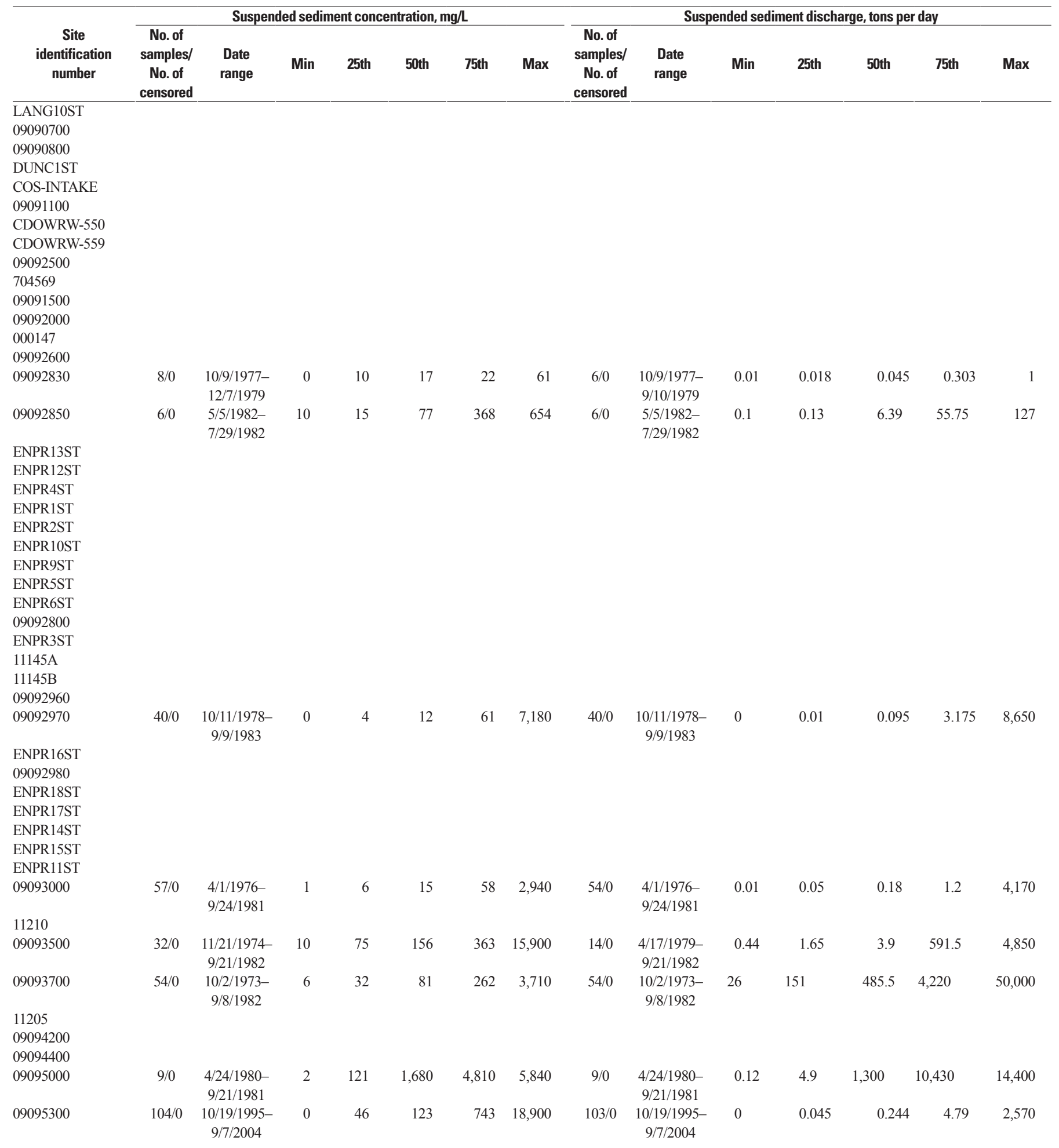


Appendix 1. Summary of surface-water-quality data and comparison to water-quality standards by site, by constituent, Piceance study area, western Colorado. Water-quality standards comparisons follow data summaries and are in blue text; standards are provided in table 3.-Continued

[CDPHE segment, Colorado Department of Health and the Environment stream segment as referred to in tables 2 and 3; latitude and longitude are in North American Datum of 1983; downstream order number assigned as part of analysis. $\mu \mathrm{g} / \mathrm{L}$, micrograms per liter; $\mu \mathrm{S} / \mathrm{cm}$, microsiemens per centimeter; $\mathrm{mg} / \mathrm{L}$, milligrams per liter; mL, milliliters; aq, aquatic; CO, Colorado; EPA, U.S. Environmental Protection Agency; Max, maximum; Min, minimum; NA, not applicable; No., number; NTU, nephelometric turbitidy units; WS, water supply; dates given in month/day/year format]

\begin{tabular}{|c|c|c|c|c|c|c|c|c|c|c|c|c|c|c|}
\hline \multirow[b]{2}{*}{$\begin{array}{c}\text { Site } \\
\text { identification } \\
\text { number }\end{array}$} & \multicolumn{7}{|c|}{ Suspended sediment concentration, $\mathrm{mg} / \mathrm{L}$} & \multicolumn{7}{|c|}{ Suspended sediment discharge, tons per day } \\
\hline & $\begin{array}{c}\text { No. of } \\
\text { samples/ } \\
\text { No. of } \\
\text { censored }\end{array}$ & $\begin{array}{c}\text { Date } \\
\text { range }\end{array}$ & Min & 25th & 50th & 75th & Max & $\begin{array}{c}\text { No. of } \\
\text { samples/ } \\
\text { No. of } \\
\text { censored }\end{array}$ & $\begin{array}{c}\text { Date } \\
\text { range }\end{array}$ & Min & 25th & 50th & 75th & Max \\
\hline 09095400 & $20 / 0$ & $\begin{array}{c}1 / 24 / 1980 \\
9 / 23 / 1982\end{array}$ & 8 & 34 & 471 & 6,795 & 37,100 & $20 / 0$ & $\begin{array}{c}1 / 24 / 1980- \\
9 / 23 / 1982\end{array}$ & 0.01 & 0.213 & 20.5 & 348.25 & 3,790 \\
\hline $\begin{array}{l}11202 \\
000148\end{array}$ & & & & & & & & & & & & & & \\
\hline 09095500 & $563 / 0$ & $\begin{array}{c}10 / 4 / 1982- \\
9 / 9 / 1998\end{array}$ & 4 & 33 & 92 & 278 & 10,500 & $563 / 0$ & $\begin{array}{c}\text { 10/4/1982- } \\
9 / 9 / 1998\end{array}$ & 26.7 & 216 & 668 & 3,520 & 310,000 \\
\hline
\end{tabular}

09097500

11155

09097600

09095800

09096500

391507107550601

CDOWRW-56

CDOWRW-55

09097900

CDOWRW-54

CDOWRW-53

09105000

11103

UP RAPID CRK

INTAKE

RC-2

RC-3

LOWER RAPID

CRK

L COTTONWOOD

INTAKE

11151

390622108205400

09106150

CDOWRW-553

CDOWRW-555

390322108253401

390348108265601

CDOWRW-556

390319108273200

390318108273200

CDOWRW-557

09106200

390324108291301

390326108291601

390323108291601

390303108291601

390322108292301

390318108293301

390302108293801

390319108312501

390320108315901

CDOWRW-558

CDOWRW-560

09106500

390337108342800

CDOWRW-563 
Appendix 1. Summary of surface-water-quality data and comparison to water-quality standards by site, by constituent, Piceance study area, western Colorado. Water-quality standards comparisons follow data summaries and are in blue text; standards are provided in table 3.-Continued

[CDPHE segment, Colorado Department of Health and the Environment stream segment as referred to in tables 2 and 3; latitude and longitude are in North American Datum of 1983; downstream order number assigned as part of analysis. $\mu \mathrm{g} / \mathrm{L}$, micrograms per liter; $\mu \mathrm{S} / \mathrm{cm}$, microsiemens per centimeter; mg/L, milligrams per liter; mL, milliliters; aq, aquatic; CO, Colorado; EPA, U.S. Environmental Protection Agency; Max, maximum; Min, minimum; NA, not applicable; No., number; NTU, nephelometric turbitidy units; WS, water supply; dates given in month/day/year format]

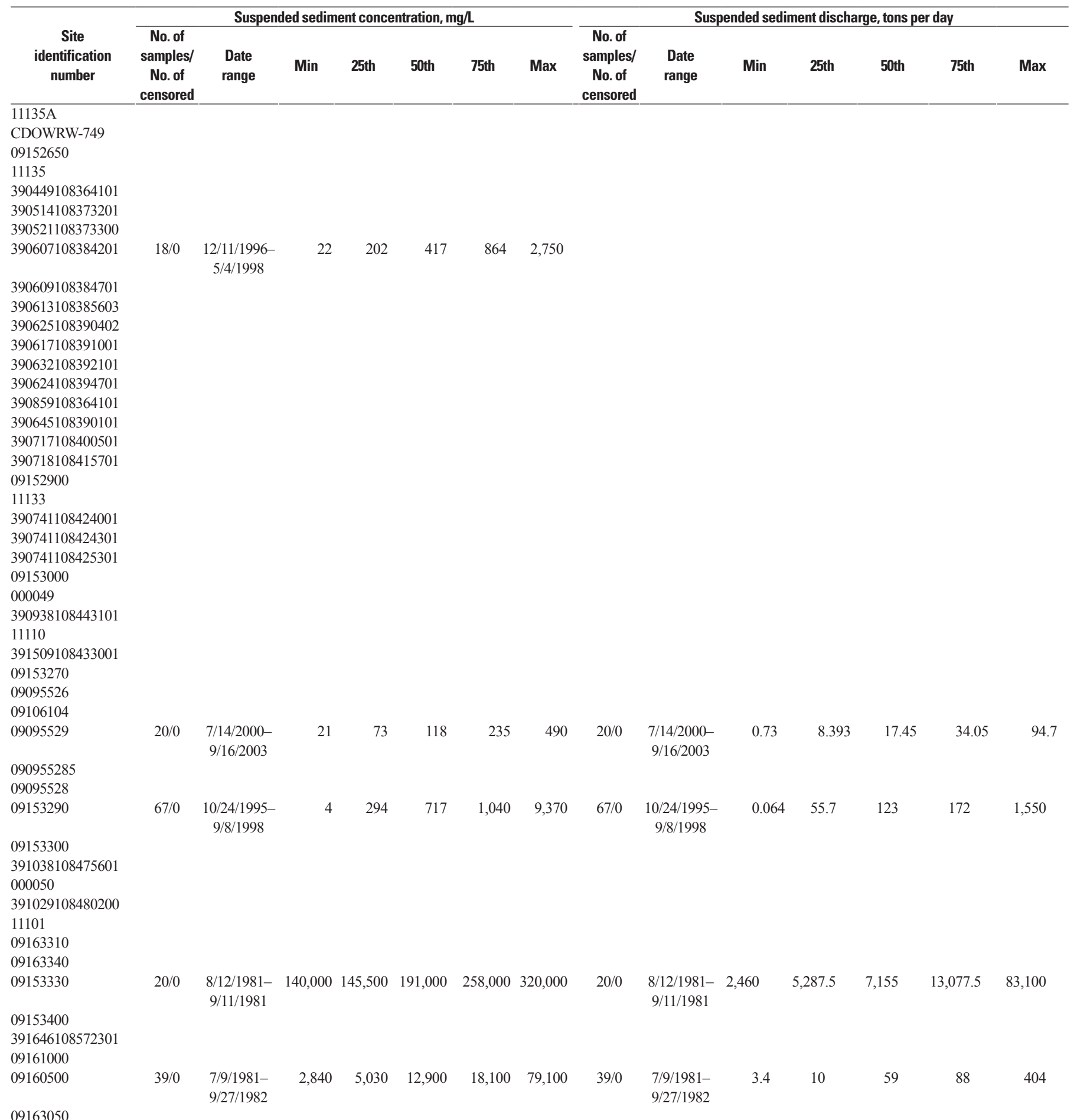


Appendix 1. Summary of surface-water-quality data and comparison to water-quality standards by site, by constituent, Piceance study area, western Colorado. Water-quality standards comparisons follow data summaries and are in blue text; standards are provided in table 3.-Continued

[CDPHE segment, Colorado Department of Health and the Environment stream segment as referred to in tables 2 and 3; latitude and longitude are in North American Datum of 1983; downstream order number assigned as part of analysis. $\mu \mathrm{g} / \mathrm{L}$, micrograms per liter; $\mu \mathrm{S} / \mathrm{cm}$, microsiemens per centimeter; $\mathrm{mg} / \mathrm{L}$, milligrams per liter; mL, milliliters; aq, aquatic; CO, Colorado; EPA, U.S. Environmental Protection Agency; Max, maximum; Min, minimum; NA, not applicable; No., number; NTU, nephelometric turbitidy units; WS, water supply; dates given in month/day/year format]

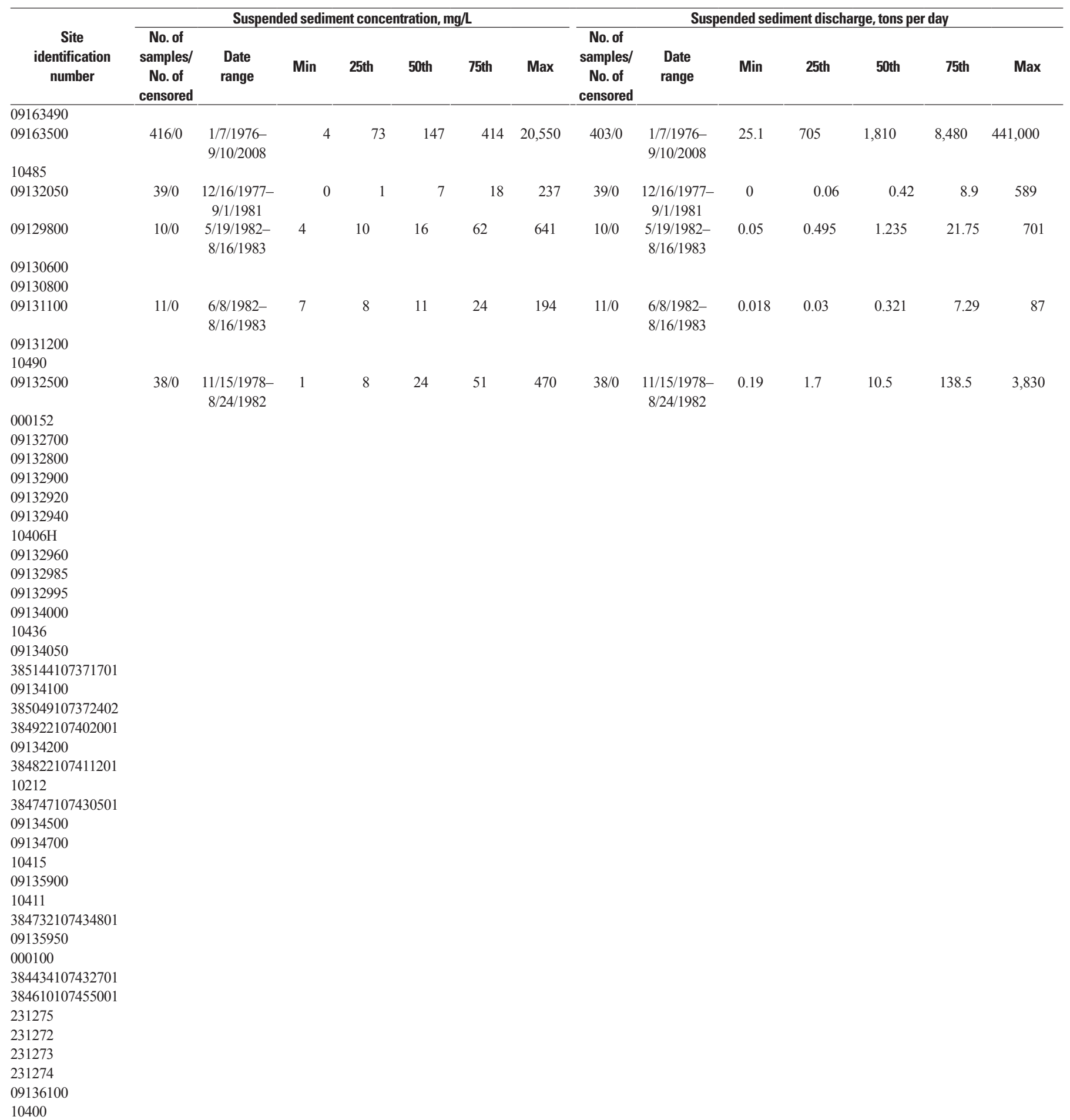


Appendix 1. Summary of surface-water-quality data and comparison to water-quality standards by site, by constituent, Piceance study area, western Colorado. Water-quality standards comparisons follow data summaries and are in blue text; standards are provided in table 3.-Continued

[CDPHE segment, Colorado Department of Health and the Environment stream segment as referred to in tables 2 and 3; latitude and longitude are in North American Datum of 1983; downstream order number assigned as part of analysis. $\mu \mathrm{g} / \mathrm{L}$, micrograms per liter; $\mu \mathrm{S} / \mathrm{cm}$, microsiemens per centimeter; mg/L, milligrams per liter; mL, milliliters; aq, aquatic; CO, Colorado; EPA, U.S. Environmental Protection Agency; Max, maximum; Min, minimum; NA, not applicable; No., number; NTU, nephelometric turbitidy units; WS, water supply; dates given in month/day/year format]

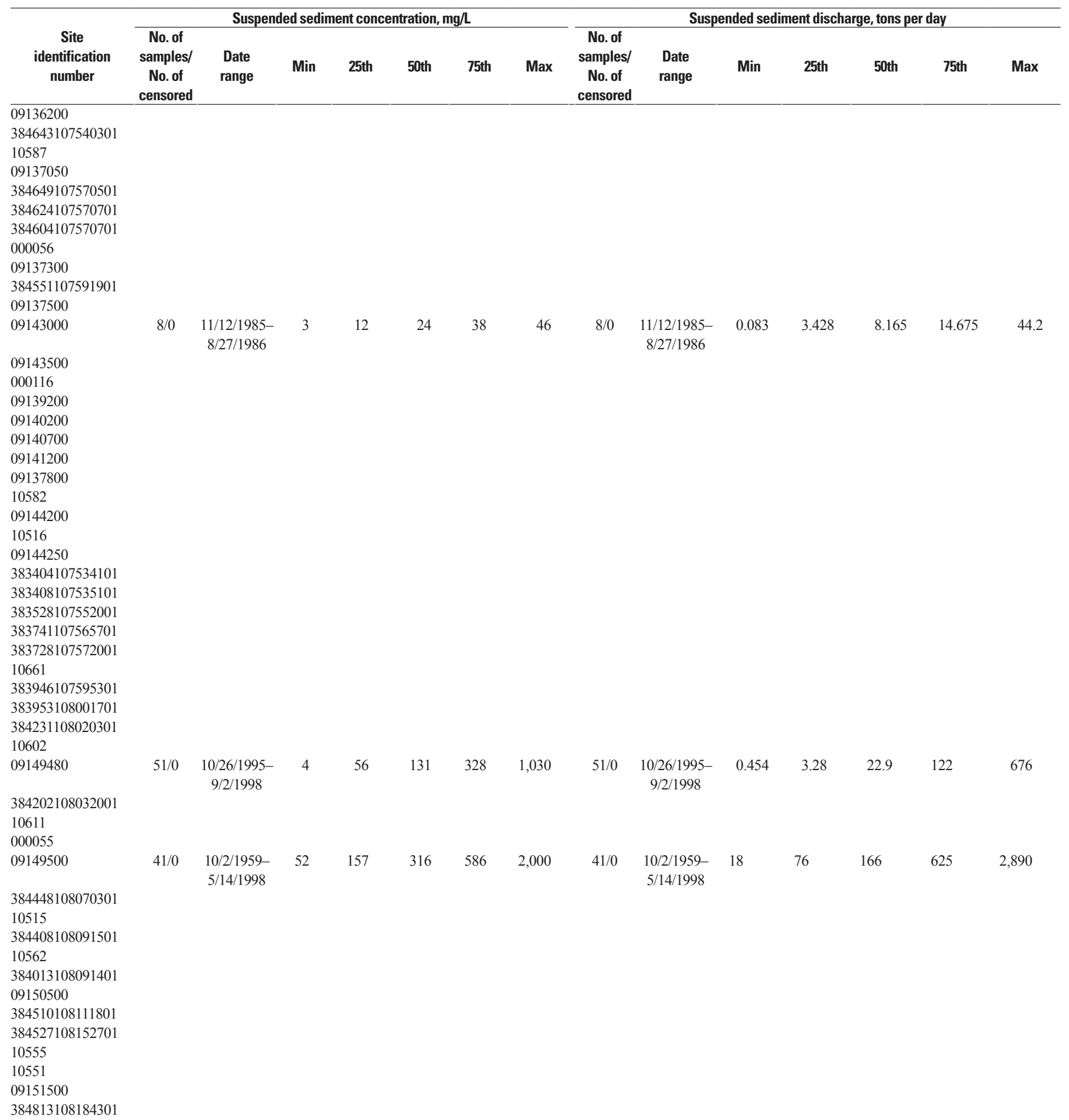


Appendix 1. Summary of surface-water-quality data and comparison to water-quality standards by site, by constituent, Piceance study area, western Colorado. Water-quality standards comparisons follow data summaries and are in blue text; standards are provided in table 3.-Continued

[CDPHE segment, Colorado Department of Health and the Environment stream segment as referred to in tables 2 and 3; latitude and longitude are in North American Datum of 1983; downstream order number assigned as part of analysis. $\mu \mathrm{g} / \mathrm{L}$, micrograms per liter; $\mu \mathrm{S} / \mathrm{cm}$, microsiemens per centimeter; $\mathrm{mg} / \mathrm{L}$, milligrams per liter; mL, milliliters; aq, aquatic; CO, Colorado; EPA, U.S. Environmental Protection Agency; Max, maximum; Min, minimum; NA, not applicable; No., number; NTU, nephelometric turbitidy units; WS, water supply; dates given in month/day/year format]

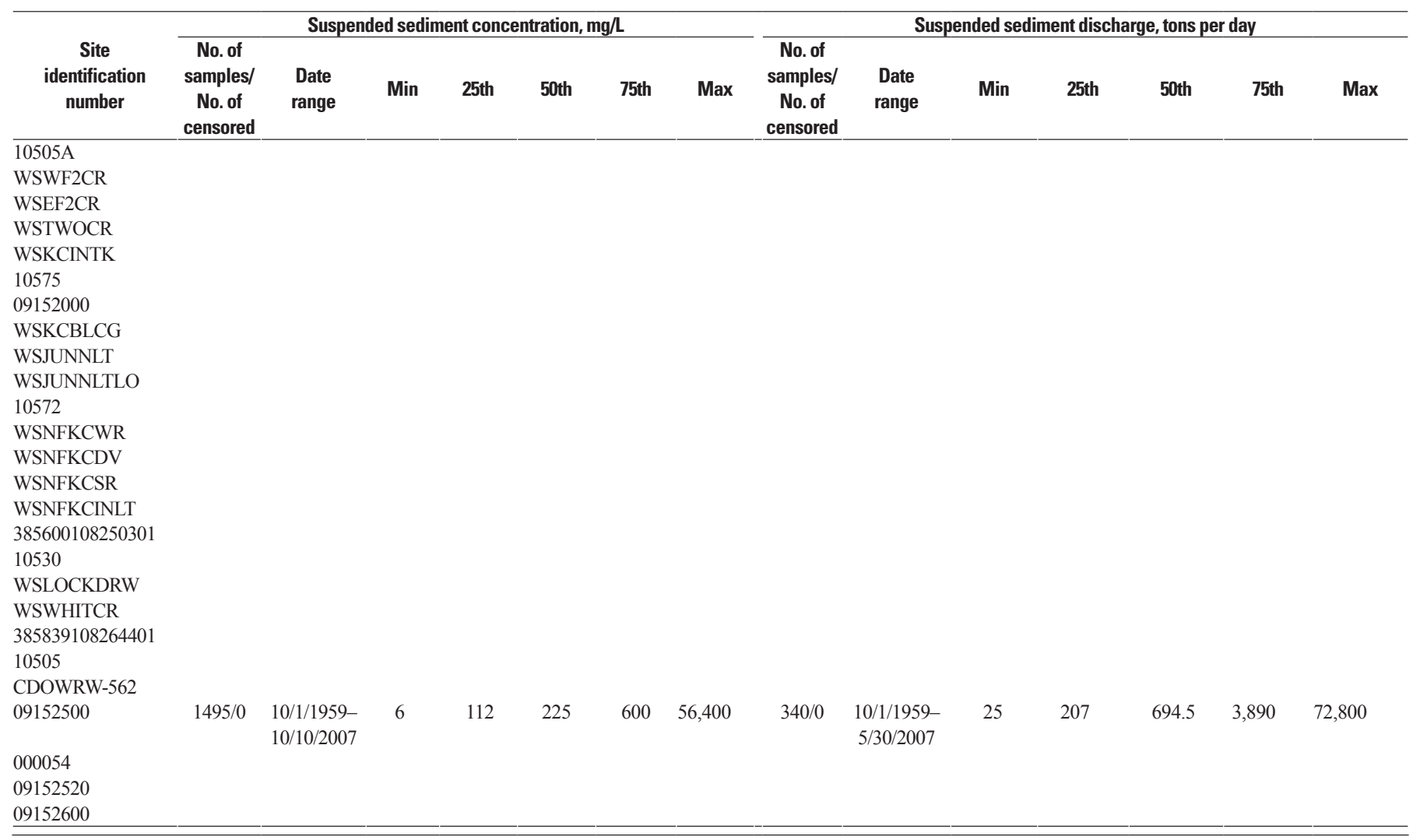


Appendix 1. Summary of surface-water-quality data and comparison to water-quality standards by site, by constituent, Piceance study area, western Colorado. Water-quality standards comparisons follow data summaries and are in blue text; standards are provided in table 3.-Continued

[CDPHE segment, Colorado Department of Health and the Environment stream segment as referred to in tables 2 and 3; latitude and longitude are in North American Datum of 1983; downstream order number assigned as part of analysis. $\mu \mathrm{g} / \mathrm{L}$, micrograms per liter; $\mu \mathrm{S} / \mathrm{cm}$, microsiemens per centimeter; mg/L, milligrams per liter; mL, milliliters; aq, aquatic; CO, Colorado; EPA, U.S. Environmental Protection Agency; Max, maximum; Min, minimum; NA, not applicable; No., number; NTU, nephelometric turbitidy units; WS, water supply; dates given in month/day/year format]

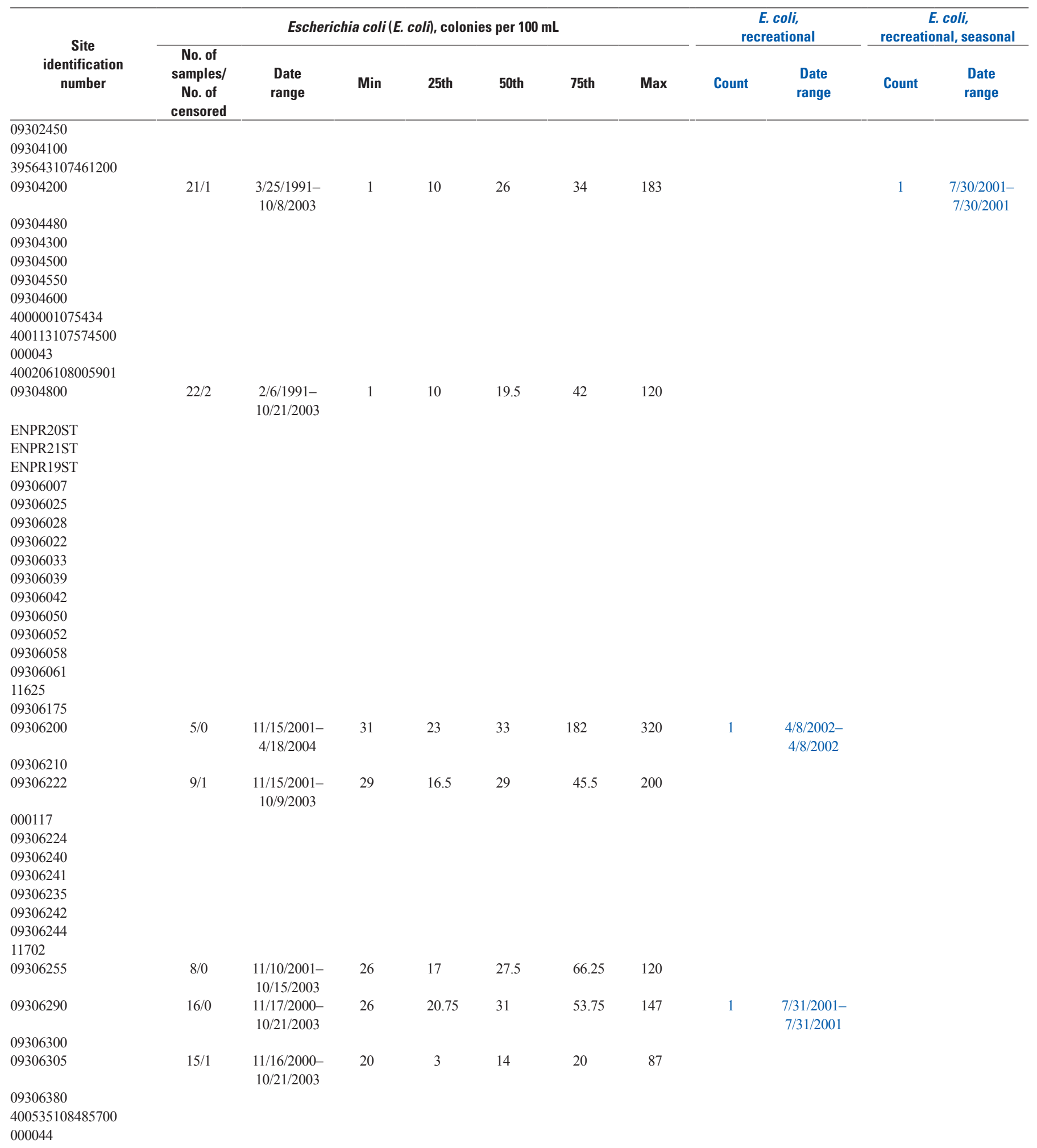


Appendix 1. Summary of surface-water-quality data and comparison to water-quality standards by site, by constituent, Piceance study area, western Colorado. Water-quality standards comparisons follow data summaries and are in blue text; standards are provided in table 3.-Continued

[CDPHE segment, Colorado Department of Health and the Environment stream segment as referred to in tables 2 and 3; latitude and longitude are in North American Datum of 1983; downstream order number assigned as part of analysis. $\mu \mathrm{g} / \mathrm{L}$, micrograms per liter; $\mu \mathrm{S} / \mathrm{cm}$, microsiemens per centimeter; mg/L, milligrams per liter; mL, milliliters; aq, aquatic; CO, Colorado; EPA, U.S. Environmental Protection Agency; Max, maximum; Min, minimum; NA, not applicable; No., number; NTU, nephelometric turbitidy units; WS, water supply; dates given in month/day/year format]

\begin{tabular}{|c|c|c|c|c|c|c|c|c|c|c|c|}
\hline \multirow[b]{2}{*}{$\begin{array}{c}\text { Site } \\
\text { identification } \\
\text { number }\end{array}$} & \multicolumn{7}{|c|}{ Escherichia coli(E. coli), colonies per $100 \mathrm{~mL}$} & \multicolumn{2}{|c|}{$\begin{array}{c}\text { E. coli, } \\
\text { recreational }\end{array}$} & \multicolumn{2}{|c|}{$\begin{array}{c}\text { E. coli, } \\
\text { recreational, seasonal }\end{array}$} \\
\hline & $\begin{array}{c}\text { No. of } \\
\text { samples/ } \\
\text { No. of } \\
\text { censored }\end{array}$ & $\begin{array}{l}\text { Date } \\
\text { range }\end{array}$ & Min & 25th & 50th & 75th & Max & Count & $\begin{array}{l}\text { Date } \\
\text { range }\end{array}$ & Count & $\begin{array}{l}\text { Date } \\
\text { range }\end{array}$ \\
\hline \multicolumn{12}{|l|}{09072500} \\
\hline \multicolumn{12}{|l|}{ CDOWRW-46 } \\
\hline \multicolumn{12}{|l|}{12100} \\
\hline \multicolumn{12}{|l|}{ CDOWRW-47 } \\
\hline 09085100 & $12 / 1$ & $\begin{array}{c}12 / 18 / 1990- \\
8 / 11 / 1993\end{array}$ & 8 & 3 & 9 & 38.25 & 84 & 1 & $\begin{array}{c}3 / 17 / 1992- \\
3 / 17 / 1992\end{array}$ & & \\
\hline
\end{tabular}

11109A

CDOWRW-197

09085150

09085200

09085400

09085300

000047

CDOWRW-546

09086470

$11190 \mathrm{H}$

09086000

09086970

11195

CDOWRW-547

09087600

11189

09089000

11185

09089500

LANG6ST

LANG5ST

LANG4ST

LANG3ST

LANG7ST

LANG8ST

LANG9ST

LANG10ST

09090700

09090800

DUNC1ST

COS-INTAKE

09091100

CDOWRW-550

CDOWRW-559

09092500

704569

09091500

09092000

000147

09092600

09092830

09092850

ENPR13ST

ENPR12ST

ENPR4ST

ENPR1ST

ENPR2ST

ENPR10ST

ENPR9ST 
Appendix 1. Summary of surface-water-quality data and comparison to water-quality standards by site, by constituent, Piceance study area, western Colorado. Water-quality standards comparisons follow data summaries and are in blue text; standards are provided in table 3.-Continued

[CDPHE segment, Colorado Department of Health and the Environment stream segment as referred to in tables 2 and 3; latitude and longitude are in North American Datum of 1983; downstream order number assigned as part of analysis. $\mu \mathrm{g} / \mathrm{L}$, micrograms per liter; $\mu \mathrm{S} / \mathrm{cm}$, microsiemens per centimeter; mg/L, milligrams per liter; mL, milliliters; aq, aquatic; CO, Colorado; EPA, U.S. Environmental Protection Agency; Max, maximum; Min, minimum; NA, not applicable; No., number; NTU, nephelometric turbitidy units; WS, water supply; dates given in month/day/year format]

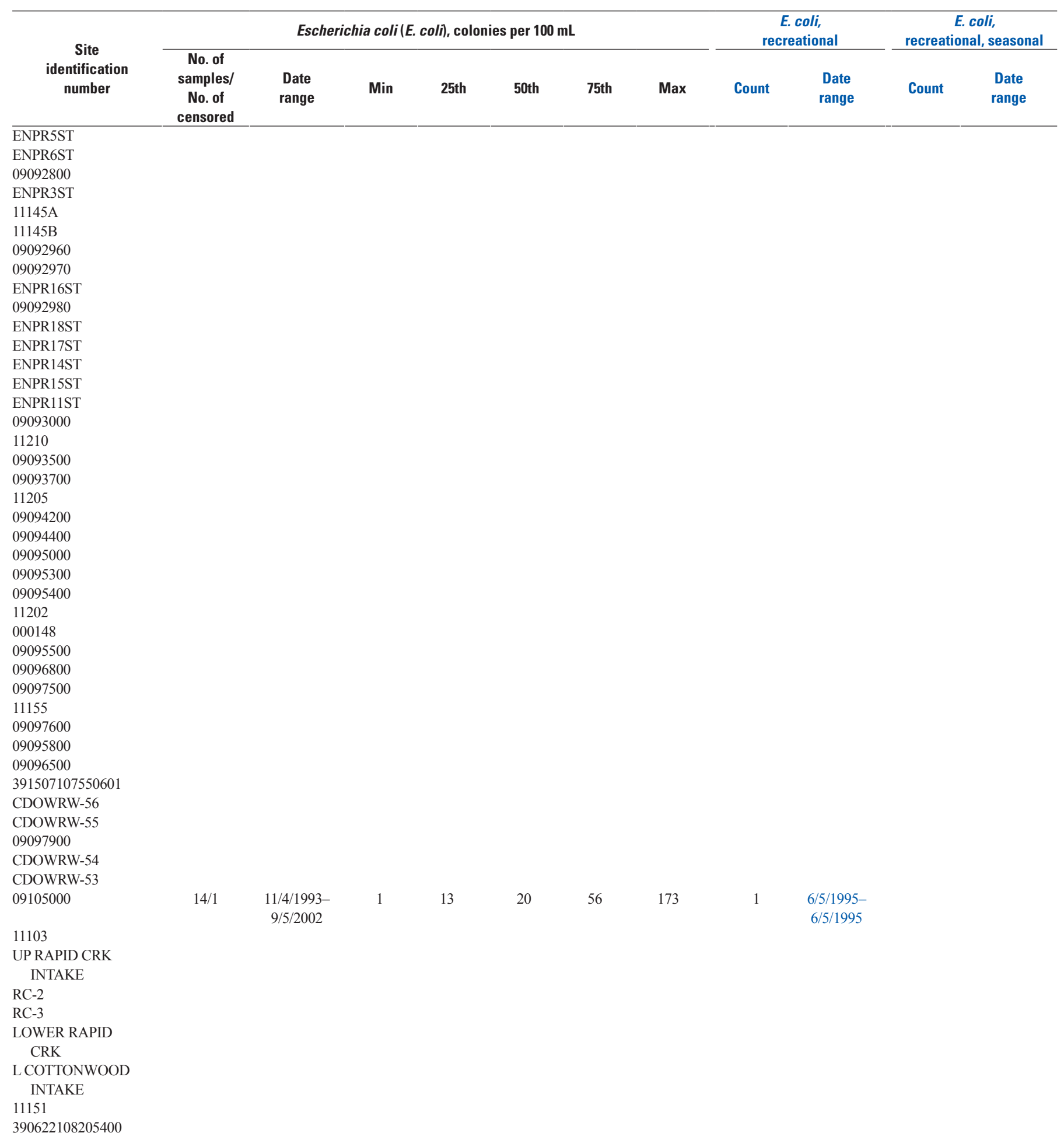


Appendix 1. Summary of surface-water-quality data and comparison to water-quality standards by site, by constituent, Piceance study area, western Colorado. Water-quality standards comparisons follow data summaries and are in blue text; standards are provided in table 3.-Continued

[CDPHE segment, Colorado Department of Health and the Environment stream segment as referred to in tables 2 and 3; latitude and longitude are in North American Datum of 1983; downstream order number assigned as part of analysis. $\mu \mathrm{g} / \mathrm{L}$, micrograms per liter; $\mu \mathrm{S} / \mathrm{cm}$, microsiemens per centimeter; mg/L, milligrams per liter; mL, milliliters; aq, aquatic; CO, Colorado; EPA, U.S. Environmental Protection Agency; Max, maximum; Min, minimum; NA, not applicable; No., number; NTU, nephelometric turbitidy units; WS, water supply; dates given in month/day/year format]

\begin{tabular}{|c|c|c|c|c|c|c|c|c|c|c|c|}
\hline \multirow[b]{2}{*}{$\begin{array}{c}\text { Site } \\
\text { identification } \\
\text { number }\end{array}$} & \multicolumn{7}{|c|}{ Escherichia coli (E. coli), colonies per $100 \mathrm{~mL}$} & \multicolumn{2}{|c|}{$\begin{array}{c}\text { E. coli, } \\
\text { recreational }\end{array}$} & \multicolumn{2}{|c|}{$\begin{array}{c}\text { E. coli, } \\
\text { recreational, seasonal }\end{array}$} \\
\hline & $\begin{array}{c}\text { No. of } \\
\text { samples/ } \\
\text { No. of } \\
\text { censored }\end{array}$ & $\begin{array}{l}\text { Date } \\
\text { range }\end{array}$ & Min & 25th & 50th & 75th & Max & Count & $\begin{array}{l}\text { Date } \\
\text { range }\end{array}$ & Count & $\begin{array}{c}\text { Date } \\
\text { range }\end{array}$ \\
\hline 09106150 & $12 / 0$ & $\begin{array}{l}11 / 4 / 1993- \\
8 / 13 / 1996\end{array}$ & 50 & 7.25 & 42 & 114.5 & 520 & 2 & $\begin{array}{l}6 / 6 / 1995- \\
8 / 25 / 1995\end{array}$ & & \\
\hline
\end{tabular}

CDOWRW-553

CDOWRW-555

390322108253401

390348108265601

CDOWRW-556

390319108273200

390318108273200

CDOWRW-557

09106200

390324108291301

390326108291601

390323108291601

390303108291601

390322108292301

390318108293301

390302108293801

390319108312501

390320108315901

CDOWRW-558

CDOWRW-560

09106500

390337108342800

CDOWRW-563

$11135 \mathrm{~A}$

CDOWRW-749

09152650

11135

390449108364101

390514108373201

390521108373300

390607108384201

390609108384701

390613108385603

390625108390402

390617108391001

390632108392101

390624108394701

390859108364101

390645108390101

390717108400501

390718108415701

09152900

11133

390741108424001

390741108424301

390741108425301

09153000

000049

390938108443101

11110 
Appendix 1. Summary of surface-water-quality data and comparison to water-quality standards by site, by constituent, Piceance study area, western Colorado. Water-quality standards comparisons follow data summaries and are in blue text; standards are provided in table 3.-Continued

[CDPHE segment, Colorado Department of Health and the Environment stream segment as referred to in tables 2 and 3; latitude and longitude are in North American Datum of 1983; downstream order number assigned as part of analysis. $\mu \mathrm{g} / \mathrm{L}$, micrograms per liter; $\mu \mathrm{S} / \mathrm{cm}$, microsiemens per centimeter; mg/L, milligrams per liter; mL, milliliters; aq, aquatic; CO, Colorado; EPA, U.S. Environmental Protection Agency; Max, maximum; Min, minimum; NA, not applicable; No., number; NTU, nephelometric turbitidy units; WS, water supply; dates given in month/day/year format]

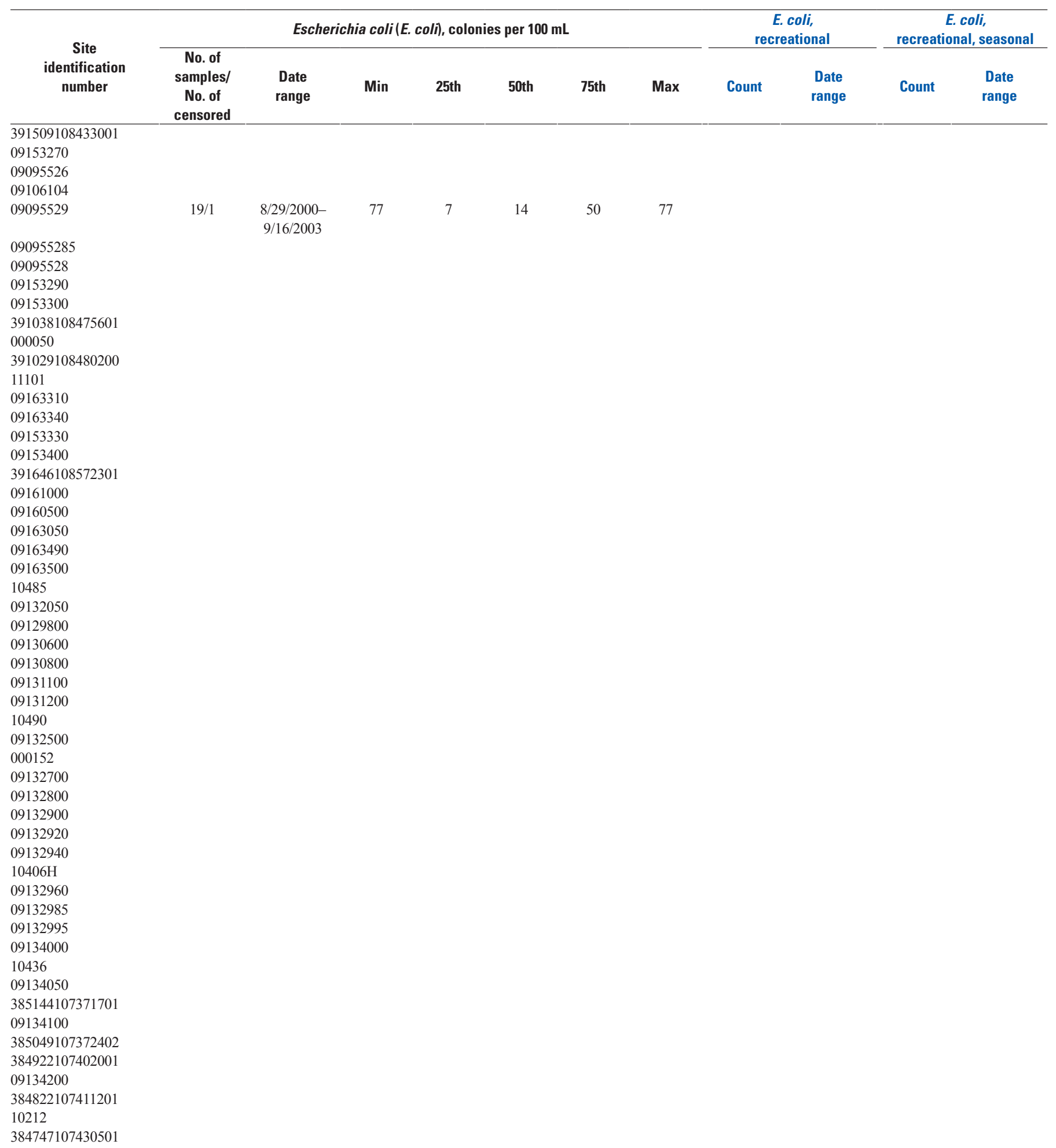


Appendix 1. Summary of surface-water-quality data and comparison to water-quality standards by site, by constituent, Piceance study area, western Colorado. Water-quality standards comparisons follow data summaries and are in blue text; standards are provided in table 3.-Continued

[CDPHE segment, Colorado Department of Health and the Environment stream segment as referred to in tables 2 and 3; latitude and longitude are in North American Datum of 1983; downstream order number assigned as part of analysis. $\mu \mathrm{g} / \mathrm{L}$, micrograms per liter; $\mu \mathrm{S} / \mathrm{cm}$, microsiemens per centimeter; $\mathrm{mg} / \mathrm{L}$, milligrams per liter; mL, milliliters; aq, aquatic; CO, Colorado; EPA, U.S. Environmental Protection Agency; Max, maximum; Min, minimum; NA, not applicable; No., number; NTU, nephelometric turbitidy units; WS, water supply; dates given in month/day/year format]

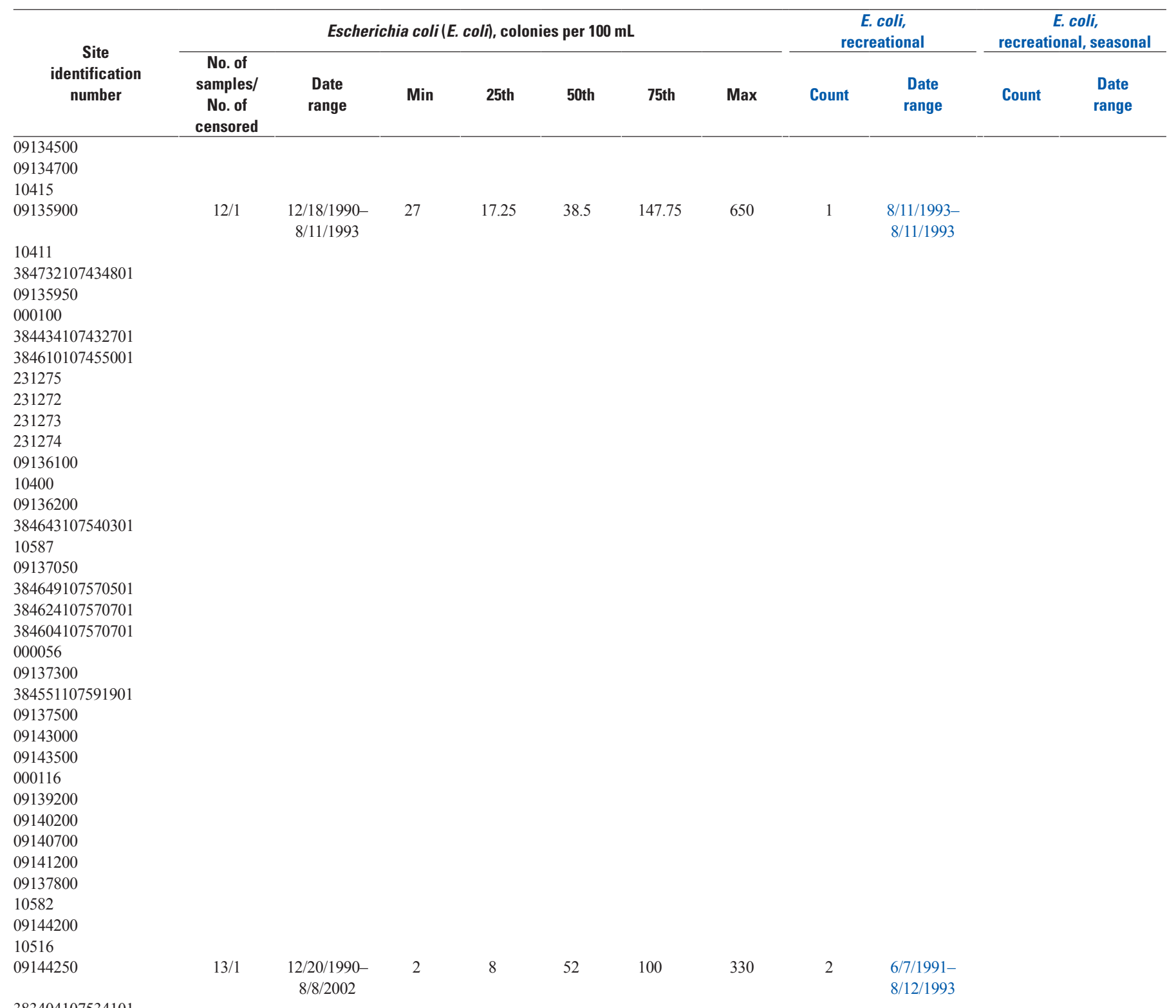

383404107534101

383408107535101

383528107552001

383741107565701

383728107572001

10661

383946107595301

383953108001701

38423110802030

10602

09149480

384202108032001

10611

000055 
Appendix 1. Summary of surface-water-quality data and comparison to water-quality standards by site, by constituent, Piceance study area, western Colorado. Water-quality standards comparisons follow data summaries and are in blue text; standards are provided in table 3.-Continued

[CDPHE segment, Colorado Department of Health and the Environment stream segment as referred to in tables 2 and 3; latitude and longitude are in North American Datum of 1983; downstream order number assigned as part of analysis. $\mu \mathrm{g} / \mathrm{L}$, micrograms per liter; $\mu \mathrm{S} / \mathrm{cm}$, microsiemens per centimeter; mg/L, milligrams per liter; mL, milliliters; aq, aquatic; CO, Colorado; EPA, U.S. Environmental Protection Agency; Max, maximum; Min, minimum; NA, not applicable; No., number; NTU, nephelometric turbitidy units; WS, water supply; dates given in month/day/year format]

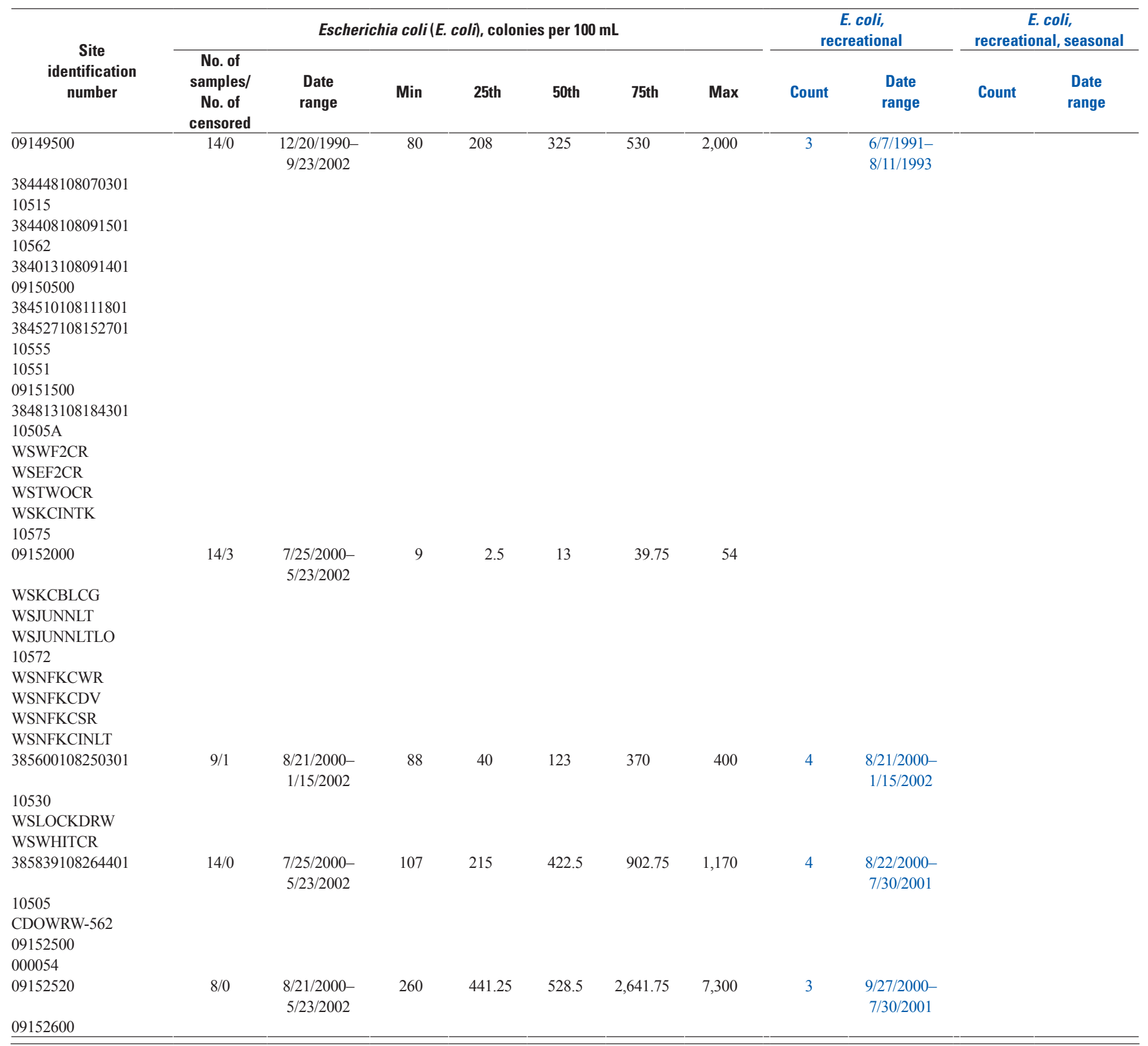


Appendix 1. Summary of surface-water-quality data and comparison to water-quality standards by site, by constituent, Piceance study area, western Colorado. Water-quality standards comparisons follow data summaries and are in blue text; standards are provided in table 3.-Continued

[CDPHE segment, Colorado Department of Health and the Environment stream segment as referred to in tables 2 and 3; latitude and longitude are in North American Datum of 1983; downstream order number assigned as part of analysis. $\mu \mathrm{g} / \mathrm{L}$, micrograms per liter; $\mu \mathrm{S} / \mathrm{cm}$, microsiemens per centimeter; mg/L, milligrams per liter; mL, milliliters; aq, aquatic; CO, Colorado; EPA, U.S. Environmental Protection Agency; Max, maximum; Min, minimum; NA, not applicable; No., number; NTU, nephelometric turbitidy units; WS, water supply; dates given in month/day/year format]

\begin{tabular}{|c|c|c|c|c|c|c|c|c|c|c|c|c|c|c|c|c|}
\hline \multirow[b]{2}{*}{$\begin{array}{c}\text { Site } \\
\text { identification } \\
\text { number }\end{array}$} & \multicolumn{8}{|c|}{ Toluene, water, unfiltered, recoverable, mg/L } & \multicolumn{8}{|c|}{ Benzene, water, unfiltered, recoverable, mg/L } \\
\hline & $\begin{array}{c}\text { No. of } \\
\text { samples/ } \\
\text { No. of } \\
\text { censored }\end{array}$ & $\begin{array}{c}\text { Date } \\
\text { range }\end{array}$ & $\begin{array}{l}\text { Censoring } \\
\text { levels }\end{array}$ & Min & 25th & 50th & 75th & Max & $\begin{array}{c}\text { No. of } \\
\text { samples/ } \\
\text { No. of } \\
\text { censored }\end{array}$ & $\begin{array}{c}\text { Date } \\
\text { range }\end{array}$ & $\begin{array}{c}\text { Censoring } \\
\text { levels }\end{array}$ & Min & 25th & 50th & 75th & Max \\
\hline
\end{tabular}

09302450

09304100

395643107461200

09304200

09304480

09304300

09304500

09304550

09304600

4000001075434

400113107574500

000043

400206108005901

09304800

ENPR20ST

ENPR21ST

ENPR19ST

09306007

09306025

09306028

09306022

09306033

09306039

09306042

09306050

09306052

09306058

09306061

11625

09306175

09306200

09306210

09306222

000117

09306224

09306240

09306241

09306235

09306242

09306244

11702

09306255

09306290

09306300

09306305

09306380

400535108485700

000044

09072500

CDOWRW-46

12100

CDOWRW-47

09085100

11109A

CDOWRW-197

09085150 
Appendix 1. Summary of surface-water-quality data and comparison to water-quality standards by site, by constituent, Piceance study area, western Colorado. Water-quality standards comparisons follow data summaries and are in blue text; standards are provided in table 3.-Continued

[CDPHE segment, Colorado Department of Health and the Environment stream segment as referred to in tables 2 and 3; latitude and longitude are in North American Datum of 1983; downstream order number assigned as part of analysis. $\mu \mathrm{g} / \mathrm{L}$, micrograms per liter; $\mu \mathrm{S} / \mathrm{cm}$, microsiemens per centimeter; mg/L, milligrams per liter; mL, milliliters; aq, aquatic; CO, Colorado; EPA, U.S. Environmental Protection Agency; Max, maximum; Min, minimum; NA, not applicable; No., number; NTU, nephelometric turbitidy units; WS, water supply; dates given in month/day/year format]

\begin{tabular}{|c|c|c|c|c|c|c|c|c|c|c|c|c|c|c|c|c|}
\hline \multirow[b]{2}{*}{$\begin{array}{c}\text { Site } \\
\text { identification } \\
\text { number }\end{array}$} & \multicolumn{8}{|c|}{ Toluene, water, unfiltered, recoverable, mg/L } & \multicolumn{8}{|c|}{ Benzene, water, unfiltered, recoverable, mg/L } \\
\hline & $\begin{array}{c}\text { No. of } \\
\text { samples/ } \\
\text { No. of } \\
\text { censored }\end{array}$ & $\begin{array}{l}\text { Date } \\
\text { range }\end{array}$ & $\begin{array}{l}\text { Censoring } \\
\text { levels }\end{array}$ & Min & 25th & 50th & 75th & Max & $\begin{array}{c}\text { No. of } \\
\text { samples/ } \\
\text { No. of } \\
\text { censored }\end{array}$ & $\begin{array}{l}\text { Date } \\
\text { range }\end{array}$ & $\begin{array}{c}\text { Censoring } \\
\text { levels }\end{array}$ & Min & 25th & 50th & 75th & Max \\
\hline \multicolumn{17}{|l|}{09085200} \\
\hline \multicolumn{17}{|l|}{09085400} \\
\hline \multicolumn{17}{|l|}{09085300} \\
\hline \multicolumn{17}{|l|}{000047} \\
\hline \multicolumn{17}{|l|}{ CDOWRW-546 } \\
\hline \multicolumn{17}{|l|}{09086470} \\
\hline \multicolumn{17}{|l|}{$11190 \mathrm{H}$} \\
\hline \multicolumn{17}{|l|}{09086000} \\
\hline \multicolumn{17}{|l|}{09086970} \\
\hline \multicolumn{17}{|l|}{11195} \\
\hline \multirow{2}{*}{\multicolumn{17}{|c|}{$\begin{array}{l}\text { CDOWRW-547 } \\
09087600\end{array}$}} \\
\hline & & & & & & & & & & & & & & & & \\
\hline \multicolumn{17}{|l|}{11189} \\
\hline \multicolumn{17}{|l|}{09089000} \\
\hline \multicolumn{17}{|l|}{11185} \\
\hline \multicolumn{17}{|l|}{09089500} \\
\hline LANG6ST & & & & & & & & & $23 / 0$ & $\begin{array}{c}4 / 15 / 2004 \\
12 / 2 / 2004\end{array}$ & & 1 & 1.1 & 1.3 & 1.7 & 9.8 \\
\hline LANG5ST & $5 / 0$ & $\begin{array}{c}4 / 13 / 2004 \\
4 / 18 / 2004\end{array}$ & & 2.6 & 3.4 & 4.7 & 6.1 & 7 & $31 / 0$ & $\begin{array}{c}4 / 13 / 2004 \\
4 / 11 / 2005\end{array}$ & & 1.2 & 3.9 & 5.5 & 6.4 & 12 \\
\hline LANG4ST & & & & & & & & & $31 / 0$ & $\begin{array}{c}4 / 13 / 2004 \\
4 / 11 / 2005\end{array}$ & & 1 & 2.2 & 3.2 & 4.2 & 360 \\
\hline \multicolumn{17}{|l|}{ LANG3ST } \\
\hline LANG7ST & & & & & & & & & $5 / 0$ & $\begin{array}{c}4 / 15 / 2004 \\
12 / 2 / 2004\end{array}$ & & 1.1 & 1.15 & 1.3 & 2.45 & 3.6 \\
\hline \multicolumn{17}{|l|}{ LANG8ST } \\
\hline \multicolumn{17}{|l|}{ LANG9ST } \\
\hline \multicolumn{17}{|l|}{ LANG10ST } \\
\hline \multicolumn{17}{|l|}{09090700} \\
\hline \multicolumn{17}{|l|}{09090800} \\
\hline DUNC1ST & & & & & & & & & & & & & & & & \\
\hline COS-INTAKE & $13 / 13$ & $\begin{array}{c}5 / 25 / 2006- \\
5 / 14 / 2009\end{array}$ & 0.005 & & & & & & $13 / 13$ & $\begin{array}{c}5 / 25 / 2006- \\
5 / 14 / 2009\end{array}$ & 0.001 & & & & & \\
\hline
\end{tabular}

CDOWRW-550

CDOWRW-559

09092500

704569

09091500

09092000

000147

09092600

09092830

09092850

ENPR13ST

ENPR12ST

ENPR4ST

ENPR1ST

ENPR2ST

ENPR10ST

ENPR9ST

ENPR5ST

ENPR6ST

09092800 
Appendix 1. Summary of surface-water-quality data and comparison to water-quality standards by site, by constituent, Piceance study area, western Colorado. Water-quality standards comparisons follow data summaries and are in blue text; standards are provided in table 3.-Continued

[CDPHE segment, Colorado Department of Health and the Environment stream segment as referred to in tables 2 and 3; latitude and longitude are in North American Datum of 1983; downstream order number assigned as part of analysis. $\mu \mathrm{g} / \mathrm{L}$, micrograms per liter; $\mu \mathrm{S} / \mathrm{cm}$, microsiemens per centimeter; mg/L, milligrams per liter; mL, milliliters; aq, aquatic; CO, Colorado; EPA, U.S. Environmental Protection Agency; Max, maximum; Min, minimum; NA, not applicable; No., number; NTU, nephelometric turbitidy units; WS, water supply; dates given in month/day/year format]

\begin{tabular}{|c|c|c|c|c|c|c|c|c|c|c|c|c|c|c|c|c|}
\hline \multirow[b]{2}{*}{$\begin{array}{c}\text { Site } \\
\text { identification } \\
\text { number }\end{array}$} & \multicolumn{8}{|c|}{ Toluene, water, unfiltered, recoverable, mg/L } & \multicolumn{8}{|c|}{ Benzene, water, unfiltered, recoverable, mg/L } \\
\hline & $\begin{array}{c}\text { No. of } \\
\text { samples/ } \\
\text { No. of } \\
\text { censored }\end{array}$ & $\begin{array}{l}\text { Date } \\
\text { range }\end{array}$ & $\begin{array}{l}\text { Censoring } \\
\text { levels }\end{array}$ & Min & 25th & 50th & 75th & Max & $\begin{array}{c}\text { No. of } \\
\text { samples/ } \\
\text { No. of } \\
\text { censored }\end{array}$ & $\begin{array}{c}\text { Date } \\
\text { range }\end{array}$ & $\begin{array}{l}\text { Censoring } \\
\text { levels }\end{array}$ & Min & 25th & 50th & 75th & Max \\
\hline
\end{tabular}

$11145 \mathrm{~A}$

$11145 \mathrm{~B}$

09092960

09092970

ENPR16ST

09092980

ENPR18ST

ENPR17ST

ENPR14ST

ENPR15ST

ENPR11ST

09093000

11210

09093500

09093700

11205

09094200

09094400

09095000

09095300

09095400

11202

000148

09095500

09096800

09097500

11155

09097600

09095800

09096500

391507107550601

CDOWRW-56

CDOWRW-55

09097900

CDOWRW-54

CDOWRW-53

09105000

11103

UP RAPID CRK

INTAKE

RC-2

RC-3

LOWER RAPID

CRK

L COTTONWOOD

INTAKE

11151

390622108205400

09106150

CDOWRW-553

CDOWRW-555

390322108253401

390348108265601 
Appendix 1. Summary of surface-water-quality data and comparison to water-quality standards by site, by constituent, Piceance study area, western Colorado. Water-quality standards comparisons follow data summaries and are in blue text; standards are provided in table 3.-Continued

[CDPHE segment, Colorado Department of Health and the Environment stream segment as referred to in tables 2 and 3; latitude and longitude are in North American Datum of 1983; downstream order number assigned as part of analysis. $\mu \mathrm{g} / \mathrm{L}$, micrograms per liter; $\mu \mathrm{S} / \mathrm{cm}$, microsiemens per centimeter; mg/L, milligrams per liter; mL, milliliters; aq, aquatic; CO, Colorado; EPA, U.S. Environmental Protection Agency; Max, maximum; Min, minimum; NA, not applicable; No., number; NTU, nephelometric turbitidy units; WS, water supply; dates given in month/day/year format]

\begin{tabular}{|c|c|c|c|c|c|c|c|c|c|c|c|c|c|c|c|c|}
\hline \multirow[b]{2}{*}{$\begin{array}{c}\text { Site } \\
\text { identification } \\
\text { number }\end{array}$} & \multicolumn{8}{|c|}{ Toluene, water, unfiltered, recoverable, $\mathrm{mg} / \mathrm{L}$} & \multicolumn{8}{|c|}{ Benzene, water, unfiltered, recoverable, mg/L } \\
\hline & $\begin{array}{c}\text { No. of } \\
\text { samples/ } \\
\text { No. of } \\
\text { censored }\end{array}$ & $\begin{array}{l}\text { Date } \\
\text { range }\end{array}$ & $\begin{array}{l}\text { Censoring } \\
\text { levels }\end{array}$ & Min & 25th & 50th & 75th & Max & $\begin{array}{c}\text { No. of } \\
\text { samples/ } \\
\text { No. of } \\
\text { censored }\end{array}$ & $\begin{array}{l}\text { Date } \\
\text { range }\end{array}$ & $\begin{array}{l}\text { Censoring } \\
\text { levels }\end{array}$ & Min & 25th & 50th & 75th & $\operatorname{Max}$ \\
\hline
\end{tabular}

390319108273200

390318108273200

CDOWRW-557

09106200

390324108291301

390326108291601

390323108291601

390303108291601

390322108292301

390318108293301

390302108293801

390319108312501

390320108315901

CDOWRW-558

CDOWRW-560

09106500

390337108342800

CDOWRW-563

$11135 \mathrm{~A}$

CDOWRW-749

09152650

11135

390449108364101

390514108373201

390521108373300

390607108384201

390609108384701

390613108385603

390625108390402

390617108391001

390632108392101

390624108394701

390859108364101

390645108390101

390717108400501

390718108415701

09152900

11133

390741108424001

390741108424301

390741108425301

09153000

000049

390938108443101

11110

391509108433001

09153270

09095526

09106104

09095529

090955285

09095528 
Appendix 1. Summary of surface-water-quality data and comparison to water-quality standards by site, by constituent, Piceance study area, western Colorado. Water-quality standards comparisons follow data summaries and are in blue text; standards are provided in table 3.-Continued

[CDPHE segment, Colorado Department of Health and the Environment stream segment as referred to in tables 2 and 3; latitude and longitude are in North American Datum of 1983; downstream order number assigned as part of analysis. $\mu \mathrm{g} / \mathrm{L}$, micrograms per liter; $\mu \mathrm{S} / \mathrm{cm}$, microsiemens per centimeter; $\mathrm{mg} / \mathrm{L}$, milligrams per liter; mL, milliliters; aq, aquatic; CO, Colorado; EPA, U.S. Environmental Protection Agency; Max, maximum; Min, minimum; NA, not applicable; No., number; NTU, nephelometric turbitidy units; WS, water supply; dates given in month/day/year format]

\begin{tabular}{|c|c|c|c|c|c|c|c|c|c|c|c|c|c|c|c|c|}
\hline \multirow[b]{2}{*}{$\begin{array}{c}\text { Site } \\
\text { identification } \\
\text { number }\end{array}$} & \multicolumn{8}{|c|}{ Toluene, water, unfiltered, recoverable, mg/L } & \multicolumn{8}{|c|}{ Benzene, water, unfiltered, recoverable, mg/L } \\
\hline & $\begin{array}{c}\text { No. of } \\
\text { samples/ } \\
\text { No. of } \\
\text { censored }\end{array}$ & $\begin{array}{l}\text { Date } \\
\text { range }\end{array}$ & $\begin{array}{l}\text { Censoring } \\
\text { levels }\end{array}$ & Min & 25th & 50th & 75th & Max & $\begin{array}{c}\text { No. of } \\
\text { samples/ } \\
\text { No. of } \\
\text { censored }\end{array}$ & $\begin{array}{c}\text { Date } \\
\text { range }\end{array}$ & $\begin{array}{l}\text { Censoring } \\
\text { levels }\end{array}$ & Min & 25th & 50th & 75th & Max \\
\hline
\end{tabular}

09153300

391038108475601

000050

391029108480200

11101

09163310

09163340

09153330

09153400

391646108572301

09161000

09160500

09163050

09163490

09163500

10485

09132050

09129800

09130600

09130800

09131100

09131200

10490

09132500

000152

09132700

09132800

09132900

09132920

09132940

$10406 \mathrm{H}$

09132960

09132985

09132995

09134000

10436

09134050

385144107371701

09134100

385049107372402

384922107402001

09134200

384822107411201

10212

384747107430501

09134500

09134700

10415

09135900

10411

384732107434801

09135950 
Appendix 1. Summary of surface-water-quality data and comparison to water-quality standards by site, by constituent, Piceance study area, western Colorado. Water-quality standards comparisons follow data summaries and are in blue text; standards are provided in table 3.-Continued

[CDPHE segment, Colorado Department of Health and the Environment stream segment as referred to in tables 2 and 3; latitude and longitude are in North American Datum of 1983; downstream order number assigned as part of analysis. $\mu \mathrm{g} / \mathrm{L}$, micrograms per liter; $\mu \mathrm{S} / \mathrm{cm}$, microsiemens per centimeter; mg/L, milligrams per liter; mL, milliliters; aq, aquatic; CO, Colorado; EPA, U.S. Environmental Protection Agency; Max, maximum; Min, minimum; NA, not applicable; No., number; NTU, nephelometric turbitidy units; WS, water supply; dates given in month/day/year format]

\begin{tabular}{|c|c|c|c|c|c|c|c|c|c|c|c|c|c|c|c|c|}
\hline \multirow[b]{2}{*}{$\begin{array}{c}\text { Site } \\
\text { identification } \\
\text { number }\end{array}$} & \multicolumn{8}{|c|}{ Toluene, water, unfiltered, recoverable, $\mathrm{mg} / \mathrm{L}$} & \multicolumn{8}{|c|}{ Benzene, water, unfiltered, recoverable, $\mathrm{mg} / \mathrm{L}$} \\
\hline & $\begin{array}{c}\text { No. of } \\
\text { samples/ } \\
\text { No. of } \\
\text { censored }\end{array}$ & $\begin{array}{l}\text { Date } \\
\text { range }\end{array}$ & $\begin{array}{l}\text { Censoring } \\
\text { levels }\end{array}$ & Min & 25th & 50th & 75th & Max & $\begin{array}{c}\text { No. of } \\
\text { samples/ } \\
\text { No. of } \\
\text { censored }\end{array}$ & $\begin{array}{l}\text { Date } \\
\text { range }\end{array}$ & $\begin{array}{l}\text { Censoring } \\
\text { levels }\end{array}$ & Min & 25th & 50th & 75th & Max \\
\hline
\end{tabular}

\section{0}

384434107432701

384610107455001

231275

231272

231273

231274

09136100

10400

09136200

384643107540301

10587

09137050

384649107570501

384624107570701

384604107570701

000056

09137300

384551107591901

09137500

09143000

09143500

000116

09139200

09140200

09140700

09141200

09137800

10582

09144200

10516

09144250

383404107534101

383408107535101

383528107552001

383741107565701

383728107572001

10661

383946107595301

383953108001701

384231108020301

10602

09149480

384202108032001

10611

000055

09149500

384448108070301

10515

384408108091501

10562

384013108091401 09150500

384510108111801

384527108152701

10555 
Appendix 1. Summary of surface-water-quality data and comparison to water-quality standards by site, by constituent, Piceance study area, western Colorado. Water-quality standards comparisons follow data summaries and are in blue text; standards are provided in table 3.-Continued

[CDPHE segment, Colorado Department of Health and the Environment stream segment as referred to in tables 2 and 3; latitude and longitude are in North American Datum of 1983; downstream order number assigned as part of analysis. $\mu \mathrm{g} / \mathrm{L}$, micrograms per liter; $\mu \mathrm{S} / \mathrm{cm}$, microsiemens per centimeter; $\mathrm{mg} / \mathrm{L}$, milligrams per liter; mL, milliliters; aq, aquatic; CO, Colorado; EPA, U.S. Environmental Protection Agency; Max, maximum; Min, minimum; NA, not applicable; No., number; NTU, nephelometric turbitidy units; WS, water supply; dates given in month/day/year format]

\begin{tabular}{|c|c|c|c|c|c|c|c|c|c|c|c|c|c|c|c|c|}
\hline \multirow[b]{2}{*}{$\begin{array}{c}\text { Site } \\
\text { identification } \\
\text { number }\end{array}$} & \multicolumn{8}{|c|}{ Toluene, water, unfiltered, recoverable, mg/L } & \multicolumn{8}{|c|}{ Benzene, water, unfiltered, recoverable, mg/L } \\
\hline & $\begin{array}{c}\text { No. of } \\
\text { samples/ } \\
\text { No. of } \\
\text { censored }\end{array}$ & $\begin{array}{l}\text { Date } \\
\text { range }\end{array}$ & $\begin{array}{l}\text { Censoring } \\
\text { levels }\end{array}$ & Min & 25th & 50th & 75th & Max & $\begin{array}{c}\text { No. of } \\
\text { samples/ } \\
\text { No. of } \\
\text { censored }\end{array}$ & $\begin{array}{l}\text { Date } \\
\text { range }\end{array}$ & $\begin{array}{l}\text { Censoring } \\
\text { levels }\end{array}$ & Min & 25th & 50th & 75th & Max \\
\hline \multicolumn{17}{|l|}{09151500} \\
\hline \multicolumn{17}{|l|}{384813108184301} \\
\hline \multicolumn{17}{|l|}{$10505 \mathrm{~A}$} \\
\hline \multicolumn{17}{|l|}{ WSTWOCR } \\
\hline \multicolumn{17}{|l|}{ WSKCINTK } \\
\hline \multicolumn{17}{|l|}{10575} \\
\hline \multicolumn{17}{|l|}{09152000} \\
\hline \multirow{2}{*}{\multicolumn{17}{|c|}{ WSKCBLCG }} \\
\hline \multicolumn{16}{|l|}{ WSJUNNLT } & \\
\hline \multicolumn{17}{|l|}{ WSJUNNLTLO } \\
\hline \multicolumn{17}{|l|}{10572} \\
\hline \multicolumn{17}{|l|}{ WSNFKCINLT } \\
\hline \multicolumn{17}{|l|}{385600108250301} \\
\hline \multicolumn{17}{|l|}{10530} \\
\hline \multicolumn{17}{|l|}{ WSLOCKDRW } \\
\hline \multicolumn{17}{|l|}{ WSWHITCR } \\
\hline 385839108264401 & & & & & & & & & & & & & & & & \\
\hline 10505 & & & & & & & & & & & & & & & & \\
\hline CDOWRW-562 & & & & & & & & & & & & & & & & \\
\hline 09152500 & & & & & & & & & & & & & & & & \\
\hline 000054 & & & & & & & & & & & & & & & & \\
\hline 09152520 & & & & & & & & & & & & & & & & \\
\hline 09152600 & & & & & & & & & & & & & & & & \\
\hline
\end{tabular}


Appendix 1. Summary of surface-water-quality data and comparison to water-quality standards by site, by constituent, Piceance study area, western Colorado. Water-quality standards comparisons follow data summaries and are in blue text; standards are provided in table 3.-Continued

[CDPHE segment, Colorado Department of Health and the Environment stream segment as referred to in tables 2 and 3; latitude and longitude are in North American Datum of 1983; downstream order number assigned as part of analysis. $\mu \mathrm{g} / \mathrm{L}$, micrograms per liter; $\mu \mathrm{S} / \mathrm{cm}$, microsiemens per centimeter; mg/L, milligrams per liter; mL, milliliters; aq, aquatic; CO, Colorado; EPA, U.S. Environmental Protection Agency; Max, maximum; Min, minimum; NA, not applicable; No., number; NTU, nephelometric turbitidy units; WS, water supply; dates given in month/day/year format]

\begin{tabular}{|c|c|c|c|c|c|c|c|c|c|c|c|c|c|c|c|c|}
\hline \multirow[b]{2}{*}{$\begin{array}{c}\text { Site } \\
\text { identification } \\
\text { number }\end{array}$} & \multicolumn{8}{|c|}{$\begin{array}{c}\text { Ethylbenzene, water, unfiltered, } \\
\text { recoverable, } \mathrm{mg} / \mathrm{L}\end{array}$} & \multicolumn{8}{|c|}{$\begin{array}{c}\text { Xylene (all isomers), } \\
\text { water, unfiltered, recoverable, } \mathrm{mg} / \mathrm{L}\end{array}$} \\
\hline & $\begin{array}{c}\text { No. of } \\
\text { samples/ } \\
\text { No. of } \\
\text { censored }\end{array}$ & $\begin{array}{l}\text { Date } \\
\text { range }\end{array}$ & $\begin{array}{l}\text { Censoring } \\
\text { levels }\end{array}$ & Min & 25th & 50th & 75th & Max & $\begin{array}{c}\text { No. of } \\
\text { samples/ } \\
\text { No. of } \\
\text { censored }\end{array}$ & $\begin{array}{l}\text { Date } \\
\text { range }\end{array}$ & $\begin{array}{l}\text { Censoring } \\
\text { levels }\end{array}$ & Min & 25th & 50th & 75th & Max \\
\hline
\end{tabular}

\section{0}

09304100

395643107461200

09304200

09304480

09304300

09304500

09304550

09304600

4000001075434

400113107574500

000043

400206108005901

09304800

ENPR20ST

ENPR21ST

ENPR19ST

09306007

09306025

09306028

09306022

09306033

09306039

09306042

09306050

09306052

09306058

09306061

11625

09306175

09306200

09306210

09306222

000117

09306224

09306240

09306241

09306235

09306242

09306244

11702

09306255

09306290

09306300

09306305

09306380

400535108485700

000044

09072500

CDOWRW-46

12100

CDOWRW-47

09085100 
Appendix 1. Summary of surface-water-quality data and comparison to water-quality standards by site, by constituent, Piceance study area, western Colorado. Water-quality standards comparisons follow data summaries and are in blue text; standards are provided in table 3.-Continued

[CDPHE segment, Colorado Department of Health and the Environment stream segment as referred to in tables 2 and 3; latitude and longitude are in North American Datum of 1983; downstream order number assigned as part of analysis. $\mu \mathrm{g} / \mathrm{L}$, micrograms per liter; $\mu \mathrm{S} / \mathrm{cm}$, microsiemens per centimeter; $\mathrm{mg} / \mathrm{L}$, milligrams per liter; mL, milliliters; aq, aquatic; CO, Colorado; EPA, U.S. Environmental Protection Agency; Max, maximum; Min, minimum; NA, not applicable; No., number; NTU, nephelometric turbitidy units; WS, water supply; dates given in month/day/year format]

\begin{tabular}{|c|c|c|c|c|c|c|c|c|c|c|c|c|c|c|c|c|}
\hline \multirow[b]{2}{*}{$\begin{array}{c}\text { Site } \\
\text { identification } \\
\text { number }\end{array}$} & \multicolumn{8}{|c|}{$\begin{array}{c}\text { Ethylbenzene, water, unfiltered, } \\
\text { recoverable, } \mathrm{mg} / \mathrm{L}\end{array}$} & \multicolumn{8}{|c|}{$\begin{array}{c}\text { Xylene (all isomers), } \\
\text { water, unfiltered, recoverable, } \mathrm{mg} / \mathrm{L}\end{array}$} \\
\hline & $\begin{array}{c}\text { No. of } \\
\text { samples/ } \\
\text { No. of } \\
\text { censored }\end{array}$ & $\begin{array}{l}\text { Date } \\
\text { range }\end{array}$ & $\begin{array}{l}\text { Censoring } \\
\text { levels }\end{array}$ & Min & 25th & 50th & 75th & Max & $\begin{array}{c}\text { No. of } \\
\text { samples/ } \\
\text { No. of } \\
\text { censored }\end{array}$ & $\begin{array}{l}\text { Date } \\
\text { range }\end{array}$ & $\begin{array}{l}\text { Censoring } \\
\text { levels }\end{array}$ & Min & 25th & 50th & 75th & Max \\
\hline
\end{tabular}

$11109 \mathrm{~A}$

CDOWRW-197

09085150

09085200

09085400

09085300

000047

CDOWRW-546

09086470

$11190 \mathrm{H}$

09086000

09086970

11195

CDOWRW-547

09087600

11189

09089000

11185

09089500

LANG6ST

LANG5ST

LANG4ST

LANG3ST

LANG7ST

LANG8ST

LANG9ST

LANG10ST

09090700

09090800

DUNC1ST

COS-INTAKE

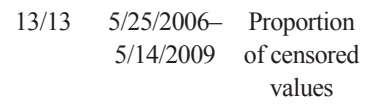

exceeds 0.90

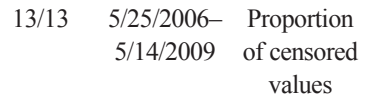

exceeds 0.90 .

09091100

CDOWRW-550

CDOWRW-559

09092500

704569

09091500

09092000

000147

09092600

09092830

09092850

ENPR13ST

ENPR12ST

ENPR4ST

ENPR1ST

ENPR2ST

ENPR10ST

ENPR9ST

ENPR5ST 
Appendix 1. Summary of surface-water-quality data and comparison to water-quality standards by site, by constituent, Piceance study area, western Colorado. Water-quality standards comparisons follow data summaries and are in blue text; standards are provided in table 3.-Continued

[CDPHE segment, Colorado Department of Health and the Environment stream segment as referred to in tables 2 and 3; latitude and longitude are in North American Datum of 1983; downstream order number assigned as part of analysis. $\mu \mathrm{g} / \mathrm{L}$, micrograms per liter; $\mu \mathrm{S} / \mathrm{cm}$, microsiemens per centimeter; mg/L, milligrams per liter; mL, milliliters; aq, aquatic; CO, Colorado; EPA, U.S. Environmental Protection Agency; Max, maximum; Min, minimum; NA, not applicable; No., number; NTU, nephelometric turbitidy units; WS, water supply; dates given in month/day/year format]

\begin{tabular}{|c|c|c|c|c|c|c|c|c|c|c|c|c|c|c|c|c|}
\hline \multirow[b]{2}{*}{$\begin{array}{c}\text { Site } \\
\text { identification } \\
\text { number }\end{array}$} & \multicolumn{8}{|c|}{$\begin{array}{c}\text { Ethylbenzene, water, unfiltered, } \\
\text { recoverable, mg/L }\end{array}$} & \multicolumn{8}{|c|}{$\begin{array}{c}\text { Xylene (all isomers), } \\
\text { water, unfiltered, recoverable, } \mathrm{mg} / \mathrm{L}\end{array}$} \\
\hline & $\begin{array}{c}\text { No. of } \\
\text { samples/ } \\
\text { No. of } \\
\text { censored }\end{array}$ & $\begin{array}{l}\text { Date } \\
\text { range }\end{array}$ & $\begin{array}{l}\text { Censoring } \\
\text { levels }\end{array}$ & Min & 25th & 50th & 75th & Max & $\begin{array}{c}\text { No. of } \\
\text { samples/ } \\
\text { No. of } \\
\text { censored }\end{array}$ & $\begin{array}{l}\text { Date } \\
\text { range }\end{array}$ & $\begin{array}{l}\text { Censoring } \\
\text { levels }\end{array}$ & Min & 25th & 50th & 75th & Max \\
\hline
\end{tabular}

ENPR6ST

09092800

ENPR3ST

11145A

11145B

09092960

09092970

ENPR16ST

09092980

ENPR18ST

ENPR17ST

ENPR14ST

ENPR15ST

ENPR11ST

09093000

11210

09093500

09093700

11205

09094200

09094400

09095000

09095300

09095400

11202

000148

09095500

09096800

09097500

11155

09097600

09095800

09096500

391507107550601

CDOWRW-56

CDOWRW-55

09097900

CDOWRW-54

CDOWRW-53

09105000

11103

UP RAPID CRK

INTAKE

RC-2

RC-3

LOWER RAPID

CRK

L COTTONWOOD

INTAKE

11151

390622108205400

09106150

CDOWRW-553 
Appendix 1. Summary of surface-water-quality data and comparison to water-quality standards by site, by constituent, Piceance study area, western Colorado. Water-quality standards comparisons follow data summaries and are in blue text; standards are provided in table 3.-Continued

[CDPHE segment, Colorado Department of Health and the Environment stream segment as referred to in tables 2 and 3; latitude and longitude are in North American Datum of 1983; downstream order number assigned as part of analysis. $\mu \mathrm{g} / \mathrm{L}$, micrograms per liter; $\mu \mathrm{S} / \mathrm{cm}$, microsiemens per centimeter; $\mathrm{mg} / \mathrm{L}$, milligrams per liter; mL, milliliters; aq, aquatic; CO, Colorado; EPA, U.S. Environmental Protection Agency; Max, maximum; Min, minimum; NA, not applicable; No., number; NTU, nephelometric turbitidy units; WS, water supply; dates given in month/day/year format]

\begin{tabular}{|c|c|c|c|c|c|c|c|c|c|c|c|c|c|c|c|c|}
\hline \multirow[b]{2}{*}{$\begin{array}{c}\text { Site } \\
\text { identification } \\
\text { number }\end{array}$} & \multicolumn{8}{|c|}{$\begin{array}{c}\text { Ethylbenzene, water, unfiltered, } \\
\text { recoverable, } \mathrm{mg} / \mathrm{L}\end{array}$} & \multicolumn{8}{|c|}{$\begin{array}{c}\text { Xylene (all isomers), } \\
\text { water, unfiltered, recoverable, } \mathrm{mg} / \mathrm{L}\end{array}$} \\
\hline & $\begin{array}{c}\text { No. of } \\
\text { samples/ } \\
\text { No. of } \\
\text { censored }\end{array}$ & $\begin{array}{l}\text { Date } \\
\text { range }\end{array}$ & $\begin{array}{l}\text { Censoring } \\
\text { levels }\end{array}$ & Min & 25th & 50th & 75th & Max & $\begin{array}{c}\text { No. of } \\
\text { samples/ } \\
\text { No. of } \\
\text { censored }\end{array}$ & $\begin{array}{l}\text { Date } \\
\text { range }\end{array}$ & $\begin{array}{l}\text { Censoring } \\
\text { levels }\end{array}$ & Min & 25th & 50th & 75th & Max \\
\hline
\end{tabular}

\section{CDOWRW-555}

390322108253401

390348108265601

CDOWRW-556

390319108273200

390318108273200

CDOWRW-557

09106200

390324108291301

390326108291601

390323108291601

390303108291601

390322108292301

39031810829330

390302108293801

39031910831250

390320108315901

CDOWRW-558

CDOWRW-560

09106500

390337108342800

CDOWRW-563

11135A

CDOWRW-749

09152650

11135

390449108364101

390514108373201

390521108373300

390607108384201

390609108384701

390613108385603

390625108390402

390617108391001

390632108392101

39062410839470

390859108364101

39064510839010

390717108400501

390718108415701

09152900

11133

390741108424001

390741108424301

390741108425301

09153000

000049

390938108443101

11110

391509108433001

09153270

09095526

09106104 
Appendix 1. Summary of surface-water-quality data and comparison to water-quality standards by site, by constituent, Piceance study area, western Colorado. Water-quality standards comparisons follow data summaries and are in blue text; standards are provided in table 3.-Continued

[CDPHE segment, Colorado Department of Health and the Environment stream segment as referred to in tables 2 and 3; latitude and longitude are in North American Datum of 1983; downstream order number assigned as part of analysis. $\mu \mathrm{g} / \mathrm{L}$, micrograms per liter; $\mu \mathrm{S} / \mathrm{cm}$, microsiemens per centimeter; mg/L, milligrams per liter; mL, milliliters; aq, aquatic; CO, Colorado; EPA, U.S. Environmental Protection Agency; Max, maximum; Min, minimum; NA, not applicable; No., number; NTU, nephelometric turbitidy units; WS, water supply; dates given in month/day/year format]

\begin{tabular}{|c|c|c|c|c|c|c|c|c|c|c|c|c|c|c|c|c|}
\hline \multirow[b]{2}{*}{$\begin{array}{c}\text { Site } \\
\text { identification } \\
\text { number }\end{array}$} & \multicolumn{8}{|c|}{$\begin{array}{c}\text { Ethylbenzene, water, unfiltered, } \\
\text { recoverable, } \mathrm{mg} / \mathrm{L}\end{array}$} & \multicolumn{8}{|c|}{$\begin{array}{c}\text { Xylene (all isomers), } \\
\text { water, unfiltered, recoverable, mg/L }\end{array}$} \\
\hline & $\begin{array}{c}\text { No. of } \\
\text { samples/ } \\
\text { No. of } \\
\text { censored }\end{array}$ & $\begin{array}{l}\text { Date } \\
\text { range }\end{array}$ & $\begin{array}{l}\text { Censoring } \\
\text { levels }\end{array}$ & Min & 25th & 50th & 75th & Max & $\begin{array}{c}\text { No. of } \\
\text { samples/ } \\
\text { No. of } \\
\text { censored }\end{array}$ & $\begin{array}{l}\text { Date } \\
\text { range }\end{array}$ & $\begin{array}{l}\text { Censoring } \\
\text { levels }\end{array}$ & Min & 25th & 50th & 75th & Max \\
\hline
\end{tabular}

\section{9}

090955285

09095528

09153290

09153300

391038108475601

000050

391029108480200

11101

09163310

09163340

09153330

09153400

391646108572301

09161000

09160500

09163050

09163490

09163500

10485

09132050

09129800

09130600

09130800

09131100

09131200

10490

09132500

000152

09132700

09132800

09132900

09132920

09132940

$10406 \mathrm{H}$

09132960

09132985

09132995

09134000

10436

09134050

385144107371701

09134100

385049107372402

384922107402001

09134200

384822107411201

10212

384747107430501

09134500

09134700

10415

09135900 
Appendix 1. Summary of surface-water-quality data and comparison to water-quality standards by site, by constituent, Piceance study area, western Colorado. Water-quality standards comparisons follow data summaries and are in blue text; standards are provided in table 3.-Continued

[CDPHE segment, Colorado Department of Health and the Environment stream segment as referred to in tables 2 and 3; latitude and longitude are in North American Datum of 1983; downstream order number assigned as part of analysis. $\mu \mathrm{g} / \mathrm{L}$, micrograms per liter; $\mu \mathrm{S} / \mathrm{cm}$, microsiemens per centimeter; $\mathrm{mg} / \mathrm{L}$, milligrams per liter; mL, milliliters; aq, aquatic; CO, Colorado; EPA, U.S. Environmental Protection Agency; Max, maximum; Min, minimum; NA, not applicable; No., number; NTU, nephelometric turbitidy units; WS, water supply; dates given in month/day/year format]

\begin{tabular}{|c|c|c|c|c|c|c|c|c|c|c|c|c|c|c|c|c|}
\hline \multirow[b]{2}{*}{$\begin{array}{c}\text { Site } \\
\text { identification } \\
\text { number }\end{array}$} & \multicolumn{8}{|c|}{$\begin{array}{c}\text { Ethylbenzene, water, unfiltered, } \\
\text { recoverable, } \mathrm{mg} / \mathrm{L}\end{array}$} & \multicolumn{8}{|c|}{$\begin{array}{c}\text { Xylene (all isomers), } \\
\text { water, unfiltered, recoverable, } \mathrm{mg} / \mathrm{L}\end{array}$} \\
\hline & $\begin{array}{c}\text { No. of } \\
\text { samples/ } \\
\text { No. of } \\
\text { censored }\end{array}$ & $\begin{array}{l}\text { Date } \\
\text { range }\end{array}$ & $\begin{array}{l}\text { Censoring } \\
\text { levels }\end{array}$ & Min & 25th & 50th & 75th & Max & $\begin{array}{c}\text { No. of } \\
\text { samples/ } \\
\text { No. of } \\
\text { censored }\end{array}$ & $\begin{array}{l}\text { Date } \\
\text { range }\end{array}$ & $\begin{array}{l}\text { Censoring } \\
\text { levels }\end{array}$ & Min & 25th & 50th & 75th & Max \\
\hline
\end{tabular}

\section{1}

384732107434801

09135950

000100

384434107432701

384610107455001

231275

231272

231273

231274

09136100

10400

09136200

384643107540301

10587

09137050

384649107570501

38462410757070

384604107570701

000056

09137300

384551107591901

09137500

09143000

09143500

000116

09139200

09140200

09140700

09141200

09137800

10582

09144200

10516

09144250

383404107534101

383408107535101

38352810755200

383741107565701

383728107572001

10661

383946107595301

383953108001701

384231108020301

10602

09149480

384202108032001

10611

000055

09149500

384448108070301 10515

384408108091501 
Appendix 1. Summary of surface-water-quality data and comparison to water-quality standards by site, by constituent, Piceance study area, western Colorado. Water-quality standards comparisons follow data summaries and are in blue text; standards are provided in table 3.-Continued

[CDPHE segment, Colorado Department of Health and the Environment stream segment as referred to in tables 2 and 3; latitude and longitude are in North American Datum of 1983; downstream order number assigned as part of analysis. $\mu \mathrm{g} / \mathrm{L}$, micrograms per liter; $\mu \mathrm{S} / \mathrm{cm}$, microsiemens per centimeter; mg/L, milligrams per liter; mL, milliliters; aq, aquatic; CO, Colorado; EPA, U.S. Environmental Protection Agency; Max, maximum; Min, minimum; NA, not applicable; No., number; NTU, nephelometric turbitidy units; WS, water supply; dates given in month/day/year format]

\begin{tabular}{|c|c|c|c|c|c|c|c|c|c|c|c|c|c|c|c|c|}
\hline \multirow[b]{2}{*}{$\begin{array}{c}\text { Site } \\
\text { identification } \\
\text { number }\end{array}$} & \multicolumn{8}{|c|}{$\begin{array}{c}\text { Ethylbenzene, water, unfiltered, } \\
\text { recoverable, mg/L }\end{array}$} & \multicolumn{8}{|c|}{$\begin{array}{c}\text { Xylene (all isomers), } \\
\text { water, unfiltered, recoverable, } \mathrm{mg} / \mathrm{L}\end{array}$} \\
\hline & $\begin{array}{c}\text { No. of } \\
\text { samples/ } \\
\text { No. of } \\
\text { censored }\end{array}$ & $\begin{array}{l}\text { Date } \\
\text { range }\end{array}$ & $\begin{array}{l}\text { Censoring } \\
\text { levels }\end{array}$ & Min & 25th & 50th & 75th & Max & $\begin{array}{c}\text { No. of } \\
\text { samples/ } \\
\text { No. of } \\
\text { censored }\end{array}$ & $\begin{array}{l}\text { Date } \\
\text { range }\end{array}$ & $\begin{array}{l}\text { Censoring } \\
\text { levels }\end{array}$ & Min & 25th & 50th & 75th & Max \\
\hline
\end{tabular}

\section{2}

384013108091401

09150500

384510108111801

384527108152701

10555

10551

09151500

384813108184301

10505A

WSWF2CR

WSEF2CR

WSTWOCR

WSKCINTK

10575

09152000

WSKCBLCG

WSJUNNLT

WSJUNNLTLO

10572

WSNFKCWR

WSNFKCDV

WSNFKCSR

WSNFKCINLT

385600108250301

10530

WSLOCKDRW

WSWHITCR

385839108264401

10505

CDOWRW-562

09152500

000054

09152520

09152600 
Appendix 2. Model coefficients and statistical diagnostics from regression models used for trend analysis in the Piceance study area, Colorado.

[ERV, estimated residual variance; $\mathrm{R}^{2}$, coefficient of determination; SCR, serial correlation of residual; Ln, natural logarithm; $\mathrm{Q}$, streamflow; $t$, decimal time in decimal years; Sin, sine function; Cos, cosine function; VIF, variation inflation factor; *, centered values; N, number of data points. Empty cells indicate variables not used in the regression because they were not statistically significant (p-value $>0.05$ ). Shaded cells indicate variables not statistically significant but included in the final regression. All constituents are dissolved unless otherwise stated]

\begin{tabular}{|c|c|c|c|c|c|c|c|c|c|c|c|c|c|c|c|}
\hline \multirow{2}{*}{$\begin{array}{l}\text { U.S. Geological } \\
\text { Survey } \\
\text { streamflow- } \\
\text { gaging stations } \\
\text { (all figures) }\end{array}$} & \multirow[b]{2}{*}{ Constituents } & \multirow[b]{2}{*}{ ERV } & \multirow[b]{2}{*}{$\mathbf{R}^{2}$} & \multirow[b]{2}{*}{ SCR } & \multirow[b]{2}{*}{$\begin{array}{c}\text { Y-axis } \\
\text { intercept } \\
\text { (Ln load) }\end{array}$} & \multicolumn{2}{|c|}{ Ln Streamflow } & \multirow[b]{2}{*}{$\mathbf{t}$} & \multirow[b]{2}{*}{$t^{2}$} & \multirow[b]{2}{*}{ Sin } & \multirow[b]{2}{*}{ Cos } & \multirow[b]{2}{*}{$\begin{array}{l}\text { Maximum } \\
\text { VIF }\end{array}$} & \multirow[b]{2}{*}{$\begin{array}{c}\mathbf{0}^{*} \\
\text { central } \\
\text { value }\end{array}$} & \multirow[b]{2}{*}{$\begin{array}{c}\mathbf{t}^{*} \\
\text { central } \\
\text { value }\end{array}$} & \multirow[b]{2}{*}{$\mathbf{N}$} \\
\hline & & & & & & $\begin{array}{c}0 \\
\text { (Ln load) }\end{array}$ & $\mathbf{0}^{2}$ & & & & & & & & \\
\hline 09085150 & Selenium & 0.101 & 82.5 & -0.418 & 2.118 & 0.878 & & & & 0.213 & 0.172 & 3.320 & 4,158 & 2008 & 21 \\
\hline \multirow[t]{5}{*}{09095300} & Alkalinity & 0.059 & 98.6 & 0.217 & -0.498 & 0.913 & -0.030 & -0.035 & -0.013 & -0.018 & 0.061 & 1.892 & 0.44 & 2000 & 74 \\
\hline & Chloride & 0.074 & 97.7 & -0.015 & -3.997 & 0.819 & -0.028 & & & & & 1.000 & 0.44 & 2000 & 74 \\
\hline & Nitrate & 0.960 & 90.0 & 0.423 & -6.713 & 0.930 & -0.092 & -0.368 & -0.107 & 0.101 & 0.508 & 1.900 & 0.44 & 2000 & 73 \\
\hline & Orthophosphate & 0.293 & 93.0 & 0.009 & -7.737 & 1.280 & & & & 0.091 & 0.384 & 1.223 & 3.04 & 2000 & 25 \\
\hline & Sulfate & 0.060 & 98.1 & 0.081 & 0.776 & 0.776 & -0.043 & -0.021 & -0.020 & 0.000 & -0.028 & 1.890 & 0.44 & 2000 & 74 \\
\hline \multirow[t]{11}{*}{09095500} & Alkalinity & 0.010 & 97.3 & 0.319 & 7.229 & 0.778 & & & & 0.033 & 0.038 & 1.857 & 4,742 & 2002 & 119 \\
\hline & Calicium & 0.005 & 97.9 & 0.286 & 6.416 & 0.668 & 0.011 & -0.002 & 0.000 & -0.040 & 0.035 & 2.130 & 4,596 & 1999 & 198 \\
\hline & Chloride & 0.008 & 23.4 & 0.356 & 6.814 & 0.051 & -0.065 & 0.002 & & -0.037 & 0.045 & 2.097 & 4,596 & 1999 & 198 \\
\hline & Dissolved solids & 0.007 & 92.9 & 0.421 & 8.374 & 0.436 & 0.017 & -0.003 & & -0.028 & 0.054 & 2.000 & 4,602 & 1999 & 212 \\
\hline & Iron, dissolved & 0.330 & 86.5 & 0.078 & 5.584 & 1.758 & -0.123 & -0.162 & 0.097 & -0.121 & 0.138 & 4.776 & 5,746 & 1998 & 53 \\
\hline & Magnesium & 0.014 & 93.5 & 0.411 & 4.975 & 0.652 & & & & 0.008 & 0.113 & 1.902 & 4,596 & 1999 & 198 \\
\hline & Potassium & 0.015 & 90.4 & 0.211 & 3.335 & 0.495 & 0.033 & & & & & 1.000 & 4,596 & 1999 & 198 \\
\hline & Selenium & 0.113 & 76.2 & 0.311 & 2.544 & 0.772 & & & & 0.311 & 0.236 & 1.727 & 4,604 & 2000 & 76 \\
\hline & Silica & 0.031 & 95.0 & 0.269 & 4.592 & 1.083 & -0.047 & -0.007 & & 0.024 & 0.101 & 2.089 & 4,596 & 1999 & 196 \\
\hline & Sodium & 0.009 & 47.2 & 0.411 & 6.541 & 0.150 & -0.032 & & & -0.019 & 0.056 & 2.096 & 4,596 & 1999 & 198 \\
\hline & Sulfate & 0.013 & 87.2 & 0.350 & 6.896 & 0.451 & -0.031 & -0.011 & & -0.037 & 0.107 & 2.097 & 4,596 & 1999 & 197 \\
\hline \multirow{10}{*}{09105000} & Alkalinity & 0.011 & 98.3 & -0.015 & 4.462 & 0.742 & -0.065 & 0.006 & 0.002 & -0.071 & 0.087 & 1.373 & 128.50 & 2004 & 87 \\
\hline & Calicium & 0.017 & 98.0 & 0.050 & 3.183 & 0.894 & -0.084 & & & -0.038 & 0.121 & 1.229 & 178.40 & 2000 & 151 \\
\hline & Chloride & 0.038 & 90.6 & 0.079 & 0.763 & 0.560 & -0.064 & -0.016 & 0.002 & 0.004 & 0.172 & 1.235 & 178.40 & 2000 & 151 \\
\hline & Dissolved solids & 0.024 & 95.7 & 0.116 & 5.106 & 0.719 & -0.051 & -0.008 & & -0.081 & 0.107 & 1.232 & 178.40 & 2000 & 151 \\
\hline & Fluoride & 0.058 & 87.1 & 0.100 & -1.566 & 0.666 & -0.051 & & & -0.216 & 0.064 & 1.218 & 199.80 & 2000 & 149 \\
\hline & Magnesium & 0.030 & 92.7 & 0.034 & 2.447 & 0.634 & -0.051 & & & -0.165 & 0.129 & 1.229 & 178.40 & 2000 & 151 \\
\hline & Potassium & 0.021 & 95.8 & 0.130 & 0.545 & 0.699 & -0.023 & & & -0.158 & -0.015 & 1.229 & 178.40 & 2000 & 151 \\
\hline & Silica & 0.015 & 98.0 & 0.175 & 2.401 & 0.868 & -0.032 & 0.004 & & -0.186 & 0.051 & 1.229 & 178.20 & 2000 & 150 \\
\hline & Sodium & 0.057 & 84.7 & 0.022 & 2.874 & 0.546 & -0.053 & -0.016 & & -0.070 & 0.126 & 1.232 & 178.40 & 2000 & 151 \\
\hline & Sulfate & 0.078 & 81.7 & 0.007 & 3.220 & 0.542 & -0.070 & -0.025 & -0.002 & -0.009 & 0.186 & 1.235 & 178.40 & 2000 & 151 \\
\hline 09106150 & Calicium & 0.007 & 99.3 & 0.229 & 5.694 & 0.821 & -0.029 & & & -0.034 & 0.164 & 1.588 & 1,845 & 1998 & 28 \\
\hline & Chloride & 0.019 & 96.4 & -0.101 & 6.332 & 0.472 & -0.090 & & & 0.041 & 0.356 & 1.588 & 1,845 & 1998 & 28 \\
\hline & Dissolved solids & 0.008 & 98.8 & 0.037 & 7.797 & 0.689 & -0.052 & & & 0.030 & 0.234 & 1.341 & 1,843 & 1997 & 43 \\
\hline & Magnesium & 0.017 & 98.4 & 0.171 & 4.306 & 0.796 & -0.040 & & & 0.039 & 0.233 & 1.588 & 1,845 & 1998 & 28 \\
\hline & Potassium & 0.021 & 97.7 & -0.207 & 2.748 & 0.728 & -0.038 & & & 0.046 & 0.201 & 1.588 & 1,845 & 1998 & 28 \\
\hline & Silica & 0.018 & 98.9 & 0.191 & 3.769 & 0.980 & & & & 0.083 & 0.024 & 1.246 & 1,845 & 1998 & 28 \\
\hline & Sodium & 0.018 & 96.9 & 0.023 & 6.066 & 0.534 & -0.078 & & & 0.058 & 0.328 & 1.588 & 1,845 & 1998 & 28 \\
\hline & Sulfate & 0.015 & 98.2 & -0.210 & 6.307 & 0.698 & -0.062 & & & 0.002 & 0.286 & 1.588 & 1,845 & 1998 & 28 \\
\hline 09106200 & Alkalinity & 0.023 & 99.5 & -0.195 & -0.527 & 0.934 & & & & -0.054 & 0.294 & 3.856 & 1.21 & 2002 & 23 \\
\hline & Calicium & 0.147 & 92.1 & -0.031 & -0.655 & 0.706 & & & & -0.074 & 0.454 & 3.560 & 1.27 & 1998 & 34 \\
\hline & Dissolved solids & 0.105 & 93.6 & 0.004 & 1.447 & 0.689 & & & & -0.054 & 0.509 & 3.560 & 1.27 & 1998 & 34 \\
\hline & Fluoride & 0.069 & 98.1 & -0.026 & -6.779 & 0.891 & & & & -0.114 & 0.151 & 3.560 & 1.27 & 1998 & 34 \\
\hline & Magnesium & 0.149 & 86.0 & -0.026 & -1.509 & 0.564 & & -0.033 & & 0.018 & 0.586 & 3.579 & 1.27 & 1998 & 34 \\
\hline & Potassium & 0.097 & 97.0 & -0.109 & -4.082 & 0.881 & & & & -0.091 & 0.324 & 3.560 & 1.27 & 1998 & 34 \\
\hline & Selenium & 0.134 & 75.0 & 0.316 & -3.307 & 0.447 & -0.054 & -0.039 & 0.012 & 0.107 & 0.681 & 4.938 & 1.40 & 1999 & 40 \\
\hline & Silica & 0.103 & 98.1 & -0.128 & -3.575 & 1.076 & & -0.024 & & -0.166 & 0.264 & 3.579 & 1.27 & 1998 & 34 \\
\hline & Sodium & 0.228 & 91.3 & -0.062 & -0.669 & 0.795 & & & & -0.121 & 0.407 & 3.560 & 1.27 & 1998 & 34 \\
\hline & Sulfate & 0.107 & 86.9 & 0.184 & 0.578 & 0.509 & & -0.031 & & -0.059 & 0.618 & 3.579 & 1.27 & 1998 & 34 \\
\hline
\end{tabular}


Appendix 2. Model coefficients and statistical diagnostics from regression models used for trend analysis in the Piceance study area, Colorado.-Continued

[ERV, estimated residual variance; $\mathrm{R}^{2}$, coefficient of determination; SCR, serial correlation of residual; Ln, natural logarithm; $\mathrm{Q}$, streamflow; t, decimal time in decimal years; Sin, sine function; Cos, cosine function; VIF, variation inflation factor; *, centered values; N, number of data points. Empty cells indicate variables not used in the regression because they were not statistically significant (p-value $>0.05)$. Shaded cells indicate variables not statistically significant but included in the final regression. All constituents are dissolved unless otherwise stated]

\begin{tabular}{|c|c|c|c|c|c|c|c|c|c|c|c|c|c|c|c|}
\hline \multirow{2}{*}{$\begin{array}{l}\text { U.S. Geological } \\
\text { Survey } \\
\text { streamflow- } \\
\text { gaging stations } \\
\text { (all figures) }\end{array}$} & \multirow[b]{2}{*}{ Constituents } & \multirow[b]{2}{*}{ ERV } & \multirow[b]{2}{*}{$\mathbf{R}^{2}$} & \multirow[b]{2}{*}{ SCR } & \multirow[b]{2}{*}{$\begin{array}{l}\text { Y-axis } \\
\text { intercept } \\
\text { (Ln load) }\end{array}$} & \multicolumn{2}{|c|}{ Ln Streamflow } & \multirow[b]{2}{*}{$\mathbf{t}$} & \multirow[b]{2}{*}{$t^{2}$} & \multirow[b]{2}{*}{ Sin } & \multirow[b]{2}{*}{ Cos } & \multirow[b]{2}{*}{$\begin{array}{l}\text { Maximum } \\
\text { VIF }\end{array}$} & \multirow[b]{2}{*}{$\begin{array}{c}\mathbf{Q}^{*} \\
\text { central } \\
\text { value }\end{array}$} & \multirow[b]{2}{*}{$\begin{array}{c}\mathrm{t}^{*} \\
\text { central } \\
\text { value }\end{array}$} & \multirow[b]{2}{*}{$\mathbf{N}$} \\
\hline & & & & & & $\begin{array}{c}0 \\
\text { (Ln load) }\end{array}$ & $\mathbf{0}^{2}$ & & & & & & & & \\
\hline \multirow[t]{10}{*}{09136100} & Alkalinity & 0.013 & 98.0 & -0.076 & 4.758 & 0.565 & -0.033 & 0.017 & 0.030 & -0.109 & 0.051 & 2.766 & 522.30 & 2005 & 24 \\
\hline & Calicium & 0.033 & 89.3 & 0.355 & 4.493 & 0.551 & & -0.024 & & -0.263 & -0.056 & 1.983 & 497 & 2001 & 40 \\
\hline & Dissolved solids & 0.040 & 83.2 & 0.251 & 6.337 & 0.487 & & -0.031 & & -0.224 & -0.015 & 1.983 & 497 & 2001 & 40 \\
\hline & Fluoride & 0.036 & 89.1 & 0.386 & -0.996 & 0.571 & & & & -0.237 & 0.023 & 1.673 & 497 & 2001 & 40 \\
\hline & Magnesium & 0.049 & 73.5 & 0.206 & 3.569 & 0.428 & & -0.039 & & -0.228 & 0.020 & 1.983 & 497 & 2001 & 40 \\
\hline & Potassium & 0.040 & 86.1 & 0.078 & 1.402 & 0.511 & & & & -0.176 & 0.005 & 1.673 & 497 & 2001 & 40 \\
\hline & Selenium & 0.124 & 61.3 & -0.124 & 1.428 & 0.441 & -0.068 & & & -0.169 & 0.087 & 1.456 & 441 & 2001 & 45 \\
\hline & Silica & 0.010 & 98.7 & 0.361 & 2.956 & 0.795 & 0.030 & 0.011 & -0.001 & -0.125 & 0.034 & 2.232 & 497 & 2001 & 40 \\
\hline & Sodium & 0.048 & 77.2 & 0.201 & 3.707 & 0.449 & & -0.030 & & -0.137 & 0.067 & 1.983 & 497 & 2001 & 40 \\
\hline & Sulfate & 0.073 & 61.7 & 0.171 & 5.464 & 0.375 & & -0.056 & & -0.276 & -0.045 & 1.983 & 497 & 2001 & 40 \\
\hline \multirow{4}{*}{09144250} & Magnesium & 0.013 & 92.5 & -0.235 & 4.548 & 0.585 & -0.081 & -0.019 & & -0.110 & -0.001 & 1.166 & 1,865 & 1999 & 26 \\
\hline & Potassium & 0.084 & 61.7 & -0.047 & 2.479 & 0.621 & & & & & & & 1,865 & 1999 & 26 \\
\hline & Selenium & 0.071 & 67.5 & 0.136 & 3.153 & 0.396 & -0.166 & -0.024 & & -0.132 & -0.118 & 1.161 & 1,418 & 1999 & 42 \\
\hline & Silica & 0.005 & 98.8 & -0.085 & 4.171 & 1.047 & & & & & & & 1,865 & 1999 & 26 \\
\hline \multirow[t]{11}{*}{09149500} & Alkalinity & 0.017 & 93.9 & 0.321 & 4.927 & 0.797 & & & & -0.084 & 0.015 & 1.077 & 271 & 2004 & 58 \\
\hline & Calicium & 0.011 & 94.7 & 0.141 & 4.839 & 0.663 & 0.022 & -0.005 & 0.001 & -0.166 & 0.010 & 1.272 & 313 & 1998 & 120 \\
\hline & Chloride & 0.051 & 75.1 & 0.080 & 2.062 & 0.665 & 0.035 & -0.011 & 0.003 & 0.057 & 0.180 & 1.270 & 313 & 1998 & 119 \\
\hline & Dissolved solids & 0.028 & 84.5 & -0.079 & 6.679 & 0.599 & -0.052 & -0.008 & 0.002 & -0.112 & 0.083 & 1.270 & 313 & 1998 & 119 \\
\hline & Fluoride & 0.020 & 92.1 & -0.019 & -0.734 & 0.691 & & 0.007 & & -0.188 & -0.083 & 1.181 & 315 & 1998 & 118 \\
\hline & Magnesium & 0.015 & 91.4 & 0.022 & 3.599 & 0.651 & 0.022 & -0.004 & 0.002 & -0.091 & 0.169 & 1.272 & 313 & 1998 & 120 \\
\hline & Potassium & 0.018 & 93.7 & 0.039 & 1.125 & 0.872 & & & & 0.017 & 0.041 & 1.120 & 313 & 1998 & 120 \\
\hline & Selenium & 0.045 & 81.7 & 0.104 & 2.997 & 0.728 & -0.089 & -0.013 & 0.002 & -0.014 & 0.253 & 1.275 & 313 & 1998 & 121 \\
\hline & Silica & 0.009 & 97.8 & 0.210 & 2.520 & 0.931 & -0.022 & 0.008 & -0.001 & -0.122 & -0.081 & 1.270 & 313 & 1998 & 119 \\
\hline & Sodium & 0.022 & 86.4 & -0.081 & 4.242 & 0.620 & 0.010 & -0.007 & 0.002 & -0.057 & 0.178 & 1.272 & 313 & 1998 & 120 \\
\hline & Sulfate & 0.019 & 88.8 & 0.002 & 6.080 & 0.609 & 0.014 & -0.007 & 0.002 & -0.118 & 0.102 & 1.277 & 313 & 1998 & 120 \\
\hline \multirow{15}{*}{09152500} & Alkalinity & 0.014 & 94.5 & 0.125 & 6.739 & 0.698 & -0.019 & 0.001 & 0.001 & -0.080 & 0.024 & 1.242 & 2,699 & 2000 & 152 \\
\hline & Calicium & 0.017 & 91.2 & 0.063 & 6.226 & 0.536 & 0.005 & -0.004 & 0.001 & -0.260 & -0.075 & 1.236 & 2,734 & 2000 & 169 \\
\hline & Chloride & 0.021 & 77.4 & 0.090 & 3.618 & 0.394 & -0.004 & -0.006 & 0.001 & -0.068 & 0.040 & 1.236 & 2,734 & 2000 & 169 \\
\hline & Dissolved solids & 0.018 & 87.7 & 0.027 & 8.043 & 0.478 & 0.001 & -0.008 & 0.001 & -0.223 & -0.016 & 1.236 & 2,734 & 2000 & 169 \\
\hline & Fluoride & 0.034 & 86.9 & 0.015 & 0.822 & 0.646 & & 0.005 & & -0.262 & -0.055 & 1.223 & 2,754 & 2000 & 167 \\
\hline & Iron, dissolved & 0.491 & 77.8 & 0.309 & 4.770 & 1.862 & 0.396 & -0.216 & 0.032 & 0.033 & 0.280 & 1.838 & 3,306 & 1995 & 71 \\
\hline & Magnesium & 0.018 & 85.9 & 0.026 & 5.077 & 0.484 & 0.002 & -0.006 & 0.001 & -0.187 & 0.063 & 1.236 & 2,734 & 2000 & 169 \\
\hline & Nitrate & 0.051 & 73.6 & 0.076 & 1.510 & 0.347 & & & & -0.397 & -0.224 & 1.334 & 3,109 & 1995 & 75 \\
\hline & Organic carbon & 0.016 & 97.5 & 0.029 & 3.444 & 1.150 & 0.086 & 0.026 & & -0.062 & -0.146 & 1.704 & 3,518 & 1999 & 46 \\
\hline & Orthophosphate & 0.159 & 73.9 & -0.015 & -0.549 & 0.979 & & & & & & & 4,305 & 1995 & 74 \\
\hline & Potassium & 0.021 & 91.9 & 0.124 & 2.933 & 0.703 & 0.049 & -0.001 & 0.001 & -0.122 & -0.009 & 1.236 & 2,734 & 2000 & 169 \\
\hline & Selenium & 0.056 & 52.2 & 0.181 & 3.963 & 0.315 & 0.064 & -0.014 & & -0.194 & 0.052 & 1.229 & 2,784 & 2000 & 159 \\
\hline & Silica & 0.014 & 97.5 & 0.163 & 4.538 & 1.030 & -0.054 & -0.003 & & -0.082 & -0.020 & 1.226 & 2,734 & 2000 & 169 \\
\hline & Sodium & 0.024 & 75.7 & 0.015 & 5.518 & 0.384 & 0.016 & -0.008 & 0.001 & -0.176 & 0.055 & 1.236 & 2,734 & 2000 & 169 \\
\hline & Sulfate & 0.027 & 78.1 & 0.021 & 7.326 & 0.350 & & -0.012 & & -0.278 & -0.029 & 1.219 & 2,734 & 2000 & 169 \\
\hline
\end{tabular}


Appendix 2. Model coefficients and statistical diagnostics from regression models used for trend analysis in the Piceance study area, Colorado.-Continued

[ERV, estimated residual variance; $\mathrm{R}^{2}$, coefficient of determination; SCR, serial correlation of residual; Ln, natural logarithm; $\mathrm{Q}$, streamflow; t, decimal time in decimal years; Sin, sine function; Cos, cosine function; VIF, variation inflation factor; *, centered values; N, number of data points. Empty cells indicate variables not used in the regression because they were not statistically significant (p-value $>0.05$ ). Shaded cells indicate variables not statistically significant but included in the final regression. All constituents are dissolved unless otherwise stated]

\begin{tabular}{|c|c|c|c|c|c|c|c|c|c|c|c|c|c|c|c|}
\hline \multirow{2}{*}{$\begin{array}{l}\text { U.S. Geological } \\
\text { Survey } \\
\text { streamflow- } \\
\text { gaging stations } \\
\text { (all figures) }\end{array}$} & \multirow[b]{2}{*}{ Constituents } & \multirow[b]{2}{*}{ ERV } & \multirow[b]{2}{*}{$\mathbf{R}^{2}$} & \multirow[b]{2}{*}{ SCR } & \multirow[b]{2}{*}{$\begin{array}{l}\text { Y-axis } \\
\text { intercept } \\
\text { (Ln load) }\end{array}$} & \multicolumn{2}{|c|}{ Ln Streamflow } & \multirow[b]{2}{*}{$\mathbf{t}$} & \multirow[b]{2}{*}{$\mathbf{t}^{2}$} & \multirow[b]{2}{*}{ Sin } & \multirow[b]{2}{*}{ Cos } & \multirow[b]{2}{*}{$\begin{array}{l}\text { Maximum } \\
\text { VIF }\end{array}$} & \multirow[b]{2}{*}{$\begin{array}{c}0^{*} \\
\text { central } \\
\text { value }\end{array}$} & \multirow[b]{2}{*}{$\begin{array}{c}\mathbf{t}^{*} \\
\text { central } \\
\text { value }\end{array}$} & \multirow[b]{2}{*}{$\mathbf{N}$} \\
\hline & & & & & & $\begin{array}{c}0 \\
\text { (Ln load) }\end{array}$ & $\mathbf{0}^{2}$ & & & & & & & & \\
\hline \multirow[t]{16}{*}{09163500} & Alkalinity & 0.009 & 96.7 & 0.247 & 7.731 & 0.765 & 0.002 & -0.002 & 0.001 & -0.064 & 0.076 & 1.527 & 7,237 & 2000 & 190 \\
\hline & Ammonia & 0.953 & 53.0 & 0.232 & -1.144 & 1.015 & -0.149 & -0.039 & 0.007 & 0.773 & 0.055 & 1.506 & 7,101 & 1999 & 168 \\
\hline & Calicium & 0.007 & 95.8 & 0.093 & 7.144 & 0.552 & 0.007 & -0.003 & 0.001 & -0.204 & -0.046 & 1.499 & 7,097 & 1999 & 214 \\
\hline & Chloride & 0.012 & 57.8 & 0.122 & 6.889 & 0.200 & -0.065 & 0.002 & 0.000 & -0.048 & 0.167 & 1.499 & 7,128 & 1999 & 219 \\
\hline & Dissolved solids & 0.007 & 92.5 & 0.049 & 9.068 & 0.449 & -0.002 & -0.007 & 0.001 & -0.159 & 0.039 & 1.499 & 7,100 & 1999 & 213 \\
\hline & Fluoride & 0.059 & 79.6 & 0.057 & 1.730 & 0.740 & -0.058 & & & -0.179 & 0.056 & 1.521 & 7,235 & 1999 & 212 \\
\hline & Iron, dissolved & 0.345 & 79.4 & 0.425 & 5.449 & 1.830 & 0.240 & -0.023 & 0.029 & 0.133 & 0.311 & 2.200 & 7,907 & 1996 & 114 \\
\hline & Magnesium & 0.010 & 91.3 & 0.170 & 5.942 & 0.488 & -0.005 & -0.006 & 0.001 & -0.159 & 0.045 & 1.499 & 7,097 & 1999 & 214 \\
\hline & Nitrate & 0.069 & 72.9 & 0.030 & 2.103 & 0.560 & & -0.014 & & -0.263 & -0.069 & 1.483 & 7,096 & 1999 & 169 \\
\hline & Organic carbon & 0.016 & 97.7 & -0.060 & 4.186 & 1.040 & 0.080 & 0.024 & & 0.020 & -0.160 & 2.077 & 8,532 & 1999 & 76 \\
\hline & Orthophosphate & 0.187 & 78.4 & 0.115 & -0.126 & 0.884 & -0.153 & -0.017 & & 0.145 & -0.282 & 1.549 & 7,570 & 2000 & 113 \\
\hline & Potassium & 0.017 & 90.4 & 0.010 & 3.947 & 0.611 & 0.007 & 0.000 & 0.001 & -0.084 & 0.041 & 1.499 & 7,097 & 1999 & 214 \\
\hline & Selenium & 0.048 & 59.8 & 0.172 & 4.616 & 0.263 & & -0.010 & & -0.253 & -0.079 & 1.496 & 7,193 & 2000 & 188 \\
\hline & Sodium & 0.011 & 74.6 & 0.060 & 6.976 & 0.308 & -0.034 & -0.004 & 0.001 & -0.081 & 0.142 & 1.499 & 7,097 & 1999 & 214 \\
\hline & Sulfate & 0.011 & 87.5 & 0.045 & 8.093 & 0.337 & -0.032 & -0.012 & 0.001 & -0.242 & -0.021 & 1.499 & 7,128 & 1999 & 219 \\
\hline & Total phosphorus & 0.835 & 65.1 & 0.201 & 0.652 & 1.139 & & 0.024 & & 0.101 & -0.862 & 1.466 & 7,116 & 1999 & 166 \\
\hline \multirow[t]{13}{*}{09304200} & Calicium & 0.009 & 99.0 & 0.078 & 4.051 & 0.797 & & & & -0.010 & 0.192 & 1.714 & 372.00 & 1996 & 30 \\
\hline & Chloride & 0.067 & 83.5 & 0.007 & 0.455 & 0.473 & & & & 0.050 & -0.198 & 1.499 & 415.30 & 2000 & 60 \\
\hline & Dissolved solids & 0.006 & 99.4 & -0.133 & 5.294 & 0.770 & -0.024 & 0.009 & & 0.011 & 0.113 & 2.250 & 294.70 & 1995 & 21 \\
\hline & Ecoli & 0.848 & 82.9 & 0.206 & 10.143 & 1.143 & & 0.166 & & -0.042 & -1.612 & 1.380 & 170.60 & 1997 & 21 \\
\hline & $\begin{array}{l}\text { Iron, total } \\
\quad \text { recoverable }\end{array}$ & 0.307 & 93.4 & -0.156 & 5.751 & 1.763 & 0.256 & -0.085 & & & & 1.079 & 551.00 & 1996 & 23 \\
\hline & Magnesium & 0.006 & 99.4 & 0.017 & 2.351 & 0.807 & & & & -0.020 & 0.127 & 1.714 & 372.00 & 1996 & 30 \\
\hline & Nitrate & 0.902 & 85.9 & -0.050 & -4.293 & 1.910 & 0.155 & 0.082 & -0.022 & 0.432 & 0.646 & 1.276 & 294.80 & 2000 & 81 \\
\hline & Orthophosphate & 0.182 & 89.2 & 0.246 & -3.845 & 0.894 & 0.046 & -0.041 & & & & 1.000 & 241.00 & 2001 & 45 \\
\hline & Silica & 0.004 & 99.7 & -0.142 & 2.511 & 0.900 & -0.015 & & & 0.014 & 0.057 & 2.152 & 294.70 & 1995 & 21 \\
\hline & Sodium & 0.004 & 99.3 & -0.048 & 1.122 & 0.521 & 0.041 & -0.029 & -0.005 & -0.006 & -0.085 & 3.063 & 294.70 & 1995 & 21 \\
\hline & Sulfate & 0.013 & 98.1 & -0.031 & 4.213 & 0.627 & -0.091 & & & 0.031 & 0.200 & 2.152 & 294.70 & 1995 & 21 \\
\hline & $\begin{array}{l}\text { Suspended } \\
\text { sediment }\end{array}$ & 0.561 & 87.0 & 0.127 & 2.908 & 1.640 & 0.405 & & & 0.446 & 0.566 & 1.880 & 506.80 & 1996 & 32 \\
\hline & Total phosphorus & 0.640 & 74.8 & 0.262 & -4.598 & 1.177 & 0.214 & 0.076 & & & & 1.007 & 300.30 & 2001 & 78 \\
\hline \multirow[t]{12}{*}{09304800} & Calicium & 0.005 & 98.6 & -0.135 & 4.871 & 0.670 & & & & & & & 836.30 & 2000 & 52 \\
\hline & Chloride & 0.025 & 80.9 & 0.035 & 2.231 & 0.296 & -0.046 & -0.021 & & 0.070 & -0.054 & 1.845 & 828.00 & 2000 & 66 \\
\hline & Dissolved solids & 0.010 & 95.6 & -0.109 & 6.309 & 0.547 & & & & 0.025 & -0.087 & 1.807 & 745.40 & 2001 & 32 \\
\hline & Fluoride & 0.178 & 63.2 & -0.007 & -1.328 & 0.638 & & & & -0.195 & -0.139 & 1.807 & 745.20 & 2001 & 32 \\
\hline & Iron, dissolved & 0.093 & 92.3 & -0.332 & 3.833 & 0.904 & 0.190 & & & -0.132 & -0.490 & 1.605 & 792.30 & 2002 & 28 \\
\hline & $\begin{array}{l}\text { Iron, total } \\
\quad \text { recoverable }\end{array}$ & 0.571 & 85.7 & 0.091 & 7.370 & 1.898 & & & & & & & 883.00 & 1997 & 24 \\
\hline & Magnesium & 0.017 & 94.7 & -0.090 & 3.491 & 0.551 & & & & 0.010 & -0.126 & 1.979 & 836.30 & 2000 & 52 \\
\hline & Orthophosphate & 0.226 & 83.0 & -0.088 & -2.497 & 0.845 & 0.190 & -0.030 & -0.004 & 0.174 & -0.258 & 1.628 & 802.90 & 2001 & 50 \\
\hline & Potassium & 0.025 & 92.6 & 0.022 & 0.744 & 0.590 & 0.086 & & & 0.030 & -0.183 & 1.825 & 745.20 & 2001 & 31 \\
\hline & Silica & 0.004 & 99.2 & -0.045 & 3.309 & 0.896 & & -0.003 & & & & 1.009 & 745.20 & 2001 & 31 \\
\hline & Sodium & 0.035 & 73.9 & -0.028 & 3.059 & 0.261 & & -0.008 & & 0.103 & -0.179 & 1.840 & 745.20 & 2001 & 31 \\
\hline & Sulfate & 0.017 & 83.2 & 0.061 & 5.178 & 0.324 & & & & 0.090 & -0.052 & 1.807 & 745.20 & 2001 & 32 \\
\hline
\end{tabular}


Appendix 2. Model coefficients and statistical diagnostics from regression models used for trend analysis in the Piceance study area, Colorado.—Continued

[ERV, estimated residual variance; $\mathrm{R}^{2}$, coefficient of determination; SCR, serial correlation of residual; Ln, natural logarithm; $\mathrm{Q}$, streamflow; t, decimal time in decimal years; Sin, sine function; Cos, cosine function; VIF, variation inflation factor; *, centered values; N, number of data points. Empty cells indicate variables not used in the regression because they were not statistically significant (p-value $>0.05$ ). Shaded cells indicate variables not statistically significant but included in the final regression. All constituents are dissolved unless otherwise stated]

\begin{tabular}{|c|c|c|c|c|c|c|c|c|c|c|c|c|c|c|c|}
\hline \multirow{2}{*}{$\begin{array}{l}\text { U.S. Geological } \\
\text { Survey } \\
\text { streamflow- } \\
\text { gaging stations } \\
\text { (all figures) }\end{array}$} & \multirow[b]{2}{*}{ Constituents } & \multirow[b]{2}{*}{ ERV } & \multirow[b]{2}{*}{$\mathbf{R}^{2}$} & \multirow[b]{2}{*}{ SCR } & \multirow[b]{2}{*}{$\begin{array}{c}\text { Y-axis } \\
\text { intercept } \\
\text { (Ln load) }\end{array}$} & \multicolumn{2}{|c|}{ Ln Streamflow } & \multirow[b]{2}{*}{$\mathbf{t}$} & \multirow[b]{2}{*}{$\mathbf{t}^{2}$} & \multirow[b]{2}{*}{$\operatorname{Sin}$} & \multirow[b]{2}{*}{ Cos } & \multirow[b]{2}{*}{$\begin{array}{c}\text { Maximum } \\
\text { VIF }\end{array}$} & \multirow[b]{2}{*}{$\begin{array}{c}0^{*} \\
\text { central } \\
\text { value }\end{array}$} & \multirow[b]{2}{*}{$\begin{array}{c}\mathbf{t}^{*} \\
\text { central } \\
\text { value }\end{array}$} & \multirow[b]{2}{*}{$\mathbf{N}$} \\
\hline & & & & & & $\begin{array}{c}0 \\
\text { (Ln load) }\end{array}$ & $\mathbf{0}^{2}$ & & & & & & & & \\
\hline \multirow[t]{19}{*}{09306200} & Alkalinity & 0.025 & 97.2 & 0.252 & 2.386 & 0.888 & 0.024 & & & & & 1.000 & 8.56 & 2004 & 38 \\
\hline & Ammonia & 0.991 & 70.5 & -0.090 & -7.071 & 1.173 & 0.124 & & & 0.432 & 0.869 & 1.155 & 14.00 & 1999 & 70 \\
\hline & Calicium & 0.011 & 99.0 & 0.210 & 1.121 & 0.986 & -0.014 & 0.005 & 0.001 & 0.005 & 0.088 & 1.182 & 14.01 & 1999 & 72 \\
\hline & Chloride & 0.016 & 98.0 & 0.208 & -0.468 & 0.816 & 0.000 & -0.014 & 0.002 & -0.062 & -0.036 & 1.168 & 14.01 & 1999 & 72 \\
\hline & Copper & 0.240 & 83.2 & -0.011 & -2.463 & 1.069 & -0.029 & -0.184 & -0.045 & 0.202 & -0.413 & 1.627 & 8.56 & 2004 & 38 \\
\hline & $\begin{array}{l}\text { Dissolved } \\
\text { solids }\end{array}$ & 0.009 & 98.9 & 0.234 & 3.663 & 0.834 & -0.004 & -0.007 & 0.001 & -0.053 & 0.003 & 1.128 & 14.01 & 1999 & 72 \\
\hline & Fluoride & 0.031 & 96.3 & -0.071 & -3.668 & 0.862 & & & & -0.077 & -0.032 & 1.077 & 14.01 & 1999 & 72 \\
\hline & Iron, dissolved & 0.381 & 59.3 & 0.555 & -0.261 & 0.636 & 0.075 & & & & & 1.000 & 14.00 & 2000 & 54 \\
\hline & Magnesium & 0.011 & 98.5 & 0.271 & 1.149 & 0.815 & -0.017 & & & -0.047 & 0.005 & 1.157 & 14.01 & 1999 & 72 \\
\hline & Nitrate & 0.675 & 92.2 & -0.192 & -4.910 & 2.352 & -0.202 & -0.026 & & 0.359 & 0.807 & 1.157 & 14.00 & 1999 & 70 \\
\hline & Organic carbon & 0.025 & 98.2 & -0.166 & -1.764 & 0.924 & 0.046 & -0.012 & & -0.038 & -0.183 & 1.204 & 13.80 & 2002 & 47 \\
\hline & Orthophosphate & 0.203 & 80.8 & 0.032 & -5.773 & 0.793 & 0.071 & -0.029 & & & & 1.059 & 14.20 & 1999 & 65 \\
\hline & Potassium & 0.024 & 97.5 & 0.122 & -2.244 & 0.914 & & -0.005 & & & & 1.043 & 14.01 & 1999 & 72 \\
\hline & Selenium & 0.044 & 97.1 & 0.138 & -2.946 & 1.176 & & & & & & & 8.57 & 2004 & 38 \\
\hline & Silica & 0.025 & 97.9 & 0.078 & -0.555 & 0.996 & & & & 0.012 & 0.076 & 1.077 & 14.01 & 1999 & 72 \\
\hline & Sodium & 0.013 & 98.0 & -0.001 & 1.830 & 0.742 & -0.003 & -0.011 & 0.001 & -0.080 & -0.043 & 1.128 & 14.01 & 1999 & 72 \\
\hline & Sulfate & 0.010 & 98.8 & 0.307 & 2.740 & 0.811 & -0.021 & -0.008 & & -0.059 & 0.020 & 1.158 & 14.01 & 1999 & 72 \\
\hline & $\begin{array}{l}\text { Suspended } \\
\text { sediment }\end{array}$ & 0.578 & 89.9 & 0.079 & 1.266 & 1.824 & 0.142 & -0.050 & & 0.635 & 0.555 & 1.158 & 14.01 & 1999 & 72 \\
\hline & Zinc & 0.515 & 80.1 & 0.309 & -1.850 & 0.905 & & -0.138 & & & & 1.070 & 14.00 & 2000 & 54 \\
\hline \multirow{19}{*}{09306222} & Alkalinity & 0.028 & 94.5 & 0.015 & 3.343 & 0.630 & 0.048 & & & & & 1.000 & 13.18 & 2004 & 40 \\
\hline & Ammonia & 0.800 & 88.2 & -0.175 & -6.806 & 1.354 & -0.041 & -0.029 & 0.012 & 0.581 & 1.291 & 1.432 & 16.20 & 2000 & 57 \\
\hline & Calicium & 0.037 & 98.7 & 0.103 & 0.817 & 1.206 & -0.037 & -0.001 & 0.002 & 0.061 & 0.279 & 1.655 & 15.69 & 2000 & 73 \\
\hline & Chloride & 0.027 & 93.4 & -0.004 & 0.749 & 0.473 & 0.029 & -0.009 & & & & 1.050 & 15.69 & 2000 & 73 \\
\hline & Copper & 0.169 & 83.9 & 0.103 & -1.707 & 1.064 & -0.073 & -0.156 & -0.045 & 0.043 & -0.482 & 2.537 & 12.98 & 2004 & 38 \\
\hline & Dissolved solids & 0.008 & 99.0 & 0.046 & 4.177 & 0.709 & & -0.005 & & & & 1.016 & 15.69 & 2000 & 73 \\
\hline & Fluoride & 0.022 & 96.8 & -0.044 & -3.006 & 0.633 & 0.027 & 0.005 & & & & 1.050 & 15.69 & 2000 & 73 \\
\hline & Iron, dissolved & 0.510 & 63.7 & 0.181 & -0.191 & 0.553 & 0.105 & -0.009 & 0.011 & 0.072 & 0.290 & 1.432 & 18.42 & 2001 & 52 \\
\hline & Lead & 0.369 & 63.3 & 0.269 & -5.312 & 0.693 & -0.547 & & & 0.087 & -0.522 & 1.867 & 12.98 & 2004 & 38 \\
\hline & Magnesium & 0.008 & 99.4 & 0.196 & 1.278 & 0.860 & -0.017 & 0.001 & 0.001 & -0.041 & 0.090 & 1.655 & 15.69 & 2000 & 73 \\
\hline & Organic carbon & 0.046 & 96.8 & 0.385 & -1.243 & 0.913 & 0.033 & & & -0.037 & -0.182 & 1.352 & 18.29 & 2001 & 52 \\
\hline & Orthophosphate & 0.221 & 88.8 & 0.259 & -5.366 & 0.923 & & & & 0.192 & 0.161 & 1.189 & 16.20 & 2000 & 56 \\
\hline & Potassium & 0.022 & 98.1 & 0.230 & -1.987 & 0.847 & 0.030 & & & & & 1.000 & 15.69 & 2000 & 73 \\
\hline & Selenium & 0.097 & 94.5 & 0.339 & -2.634 & 1.210 & & & & 0.187 & -0.189 & 1.303 & 12.98 & 2004 & 38 \\
\hline & Silica & 0.180 & 93.4 & 0.030 & -0.691 & 1.178 & & & & 0.089 & 0.263 & 1.270 & 15.69 & 2000 & 73 \\
\hline & Sodium & 0.016 & 96.7 & 0.056 & 2.779 & 0.544 & & -0.004 & & & & 1.016 & 15.69 & 2000 & 73 \\
\hline & Sulfate & 0.011 & 99.2 & 0.196 & 2.897 & 0.841 & -0.014 & -0.007 & 0.001 & -0.055 & 0.066 & 1.655 & 15.69 & 2000 & 73 \\
\hline & $\begin{array}{l}\text { Suspended } \\
\text { sediment }\end{array}$ & 0.735 & 90.7 & -0.144 & 1.226 & 1.825 & 0.066 & -0.065 & 0.012 & 0.634 & 0.181 & 1.596 & 15.30 & 2000 & 75 \\
\hline & Zinc & 0.492 & 79.0 & 0.258 & -1.621 & 0.881 & & -0.102 & & & & 1.061 & 18.42 & 2001 & 52 \\
\hline
\end{tabular}


Appendix 2. Model coefficients and statistical diagnostics from regression models used for trend analysis in the Piceance study area, Colorado.—Continued

[ERV, estimated residual variance; $\mathrm{R}^{2}$, coefficient of determination; SCR, serial correlation of residual; Ln, natural logarithm; Q, streamflow; t, decimal time in decimal years; Sin, sine function; Cos, cosine function; VIF, variation inflation factor; *, centered values; N, number of data points. Empty cells indicate variables not used in the regression because they were not statistically significant (p-value $>0.05$ ). Shaded cells indicate variables not statistically significant but included in the final regression. All constituents are dissolved unless otherwise stated]

\begin{tabular}{|c|c|c|c|c|c|c|c|c|c|c|c|c|c|c|c|}
\hline \multirow{2}{*}{$\begin{array}{l}\text { U.S. Geological } \\
\text { Survey } \\
\text { streamflow- } \\
\text { gaging stations } \\
\text { (all figures) }\end{array}$} & \multirow[b]{2}{*}{ Constituents } & \multirow[b]{2}{*}{ ERV } & \multirow[b]{2}{*}{$\mathbf{R}^{2}$} & \multirow[b]{2}{*}{ SCR } & \multirow[b]{2}{*}{$\begin{array}{l}\text { Y-axis } \\
\text { intercept } \\
\text { (Ln load) }\end{array}$} & \multicolumn{2}{|c|}{ Ln Streamflow } & \multirow[b]{2}{*}{$\mathbf{t}$} & \multirow[b]{2}{*}{$t^{2}$} & \multirow[b]{2}{*}{$\operatorname{Sin}$} & \multirow[b]{2}{*}{ Cos } & \multirow[b]{2}{*}{$\begin{array}{c}\text { Maximum } \\
\text { VIF }\end{array}$} & \multirow[b]{2}{*}{$\begin{array}{c}0^{*} \\
\text { central } \\
\text { value }\end{array}$} & \multirow[b]{2}{*}{$\begin{array}{c}\mathbf{t}^{*} \\
\text { central } \\
\text { value }\end{array}$} & \multirow[b]{2}{*}{$\mathbf{N}$} \\
\hline & & & & & & $\begin{array}{c}0 \\
\text { (Ln load) }\end{array}$ & $\mathbf{0}^{2}$ & & & & & & & & \\
\hline \multirow{11}{*}{09306242} & Alkalinity & 0.011 & 98.24 & -0.229 & -0.717 & 0.879 & & -0.022 & & & & 1.382 & 0.47 & 2004 & 29 \\
\hline & Calicium & 0.003 & 99.8 & 0.025 & -1.385 & 0.956 & 0.010 & -0.004 & -0.001 & 0.041 & 0.057 & 1.444 & 0.92 & 1999 & 58 \\
\hline & Chloride & 0.014 & 98.7 & 0.278 & -3.428 & 0.954 & -0.014 & -0.007 & 0.001 & -0.041 & -0.039 & 1.444 & 0.92 & 1999 & 58 \\
\hline & Dissolved solids & 0.004 & 99.6 & 0.335 & 0.863 & 0.934 & -0.004 & -0.009 & -0.001 & 0.014 & 0.045 & 1.444 & 0.92 & 1999 & 58 \\
\hline & Fluoride & & & & & & & & & & & & 0.92 & 1999 & 58 \\
\hline & Magnesium & 0.005 & 99.6 & 0.370 & -1.649 & 0.936 & -0.004 & -0.005 & -0.001 & 0.019 & 0.052 & 1.444 & 0.92 & 1999 & 58 \\
\hline & Nitrate & 0.781 & 89.4 & 0.120 & -6.090 & 2.285 & -0.177 & & & -0.220 & 1.193 & 1.286 & 1.09 & 1999 & 41 \\
\hline & Orthophosphate & 0.139 & 89.5 & -0.236 & -8.899 & 0.950 & & & & & & & 1.10 & 2000 & 28 \\
\hline & Potassium & 0.051 & 95.2 & 0.106 & -5.737 & 0.946 & & 0.008 & & & & 1.048 & 0.92 & 1999 & 58 \\
\hline & Silica & 0.006 & 99.54 & -0.052 & -2.908 & 0.981 & 0.006 & -0.001 & -0.002 & 0.061 & 0.044 & 1.444 & 0.92 & 1999 & 58 \\
\hline & Sodium & 0.008 & 99.2 & 0.305 & -1.264 & 0.903 & -0.018 & -0.010 & & 0.012 & 0.052 & 1.233 & 0.92 & 1999 & 58 \\
\hline \multirow[t]{9}{*}{09306255} & Calicium & 0.045 & 96.75 & 0.242 & -0.622 & 1.157 & -0.129 & & & 0.004 & 0.279 & 1.172 & 3.57 & 1999 & 75 \\
\hline & Chloride & 0.010 & 96.89 & -0.003 & -0.295 & 0.611 & -0.051 & 0.003 & 0.001 & -0.010 & -0.040 & 2.249 & 3.57 & 1999 & 75 \\
\hline & Fluoride & 0.030 & 92.52 & 0.197 & -4.336 & 0.617 & -0.023 & 0.003 & -0.003 & -0.032 & 0.006 & 2.249 & 3.57 & 1999 & 75 \\
\hline & Iron, dissolved & 0.203 & 84.39 & -0.029 & -0.972 & 0.995 & 0.093 & 0.039 & & & & 1.654 & 4.76 & 2000 & 36 \\
\hline & Organic carbon & 0.017 & 97.97 & -0.131 & -2.259 & 0.826 & -0.023 & & & -0.007 & -0.140 & 1.126 & 4.69 & 2000 & 37 \\
\hline & Potassium & 0.043 & 94.12 & 0.014 & -3.504 & 0.912 & 0.047 & & & & & 1.000 & 3.57 & 1999 & 75 \\
\hline & Silica & 0.172 & 88.16 & 0.245 & -2.117 & 1.131 & -0.083 & & & 0.031 & 0.298 & 1.172 & 3.57 & 1999 & 75 \\
\hline & Sodium & 0.008 & 98.08 & 0.174 & 1.687 & 0.676 & -0.062 & & & & & 1.000 & 3.57 & 1999 & 75 \\
\hline & Sulfate & 0.031 & 96.18 & 0.348 & 2.155 & 0.927 & -0.140 & & & & & 1.000 & 3.57 & 1999 & 75 \\
\hline \multirow[t]{15}{*}{09306290} & Calicium & 0.005 & 98.82 & -0.324 & 4.935 & 0.724 & -0.051 & & & 0.026 & 0.038 & 1.693 & 854.60 & 2000 & 44 \\
\hline & Chloride & 0.021 & 80.8 & 0.044 & 2.724 & 0.287 & & -0.015 & & 0.196 & 0.119 & 1.448 & 758 & 2000 & 35 \\
\hline & Dissolved solids & 0.011 & 95.4 & -0.163 & 6.704 & 0.601 & -0.037 & -0.007 & -0.001 & 0.103 & 0.108 & 1.473 & 758.20 & 2000 & 35 \\
\hline & Fluoride & 0.142 & 56.64 & -0.023 & -1.095 & 0.577 & 0.243 & & & & & 1.000 & 804 & 2000 & 34 \\
\hline & Iron, dissolved & 0.662 & 68.6 & -0.201 & 4.364 & 1.548 & -0.448 & & & & & 1.000 & 762.50 & 2000 & 32 \\
\hline & $\begin{array}{l}\text { Iron, total } \\
\quad \text { recoverable }\end{array}$ & 0.964 & 80.46 & -0.066 & 9.532 & 1.747 & & & & 1.083 & 1.211 & 3.142 & 962.00 & 1997 & 23 \\
\hline & Magnesium & 0.021 & 92.47 & -0.065 & 3.930 & 0.564 & -0.029 & -0.005 & -0.002 & 0.070 & 0.097 & 1.839 & 854.60 & 2000 & 44 \\
\hline & Organic carbon & 0.034 & 95.37 & -0.091 & 1.940 & 0.940 & 0.093 & -0.014 & -0.005 & 0.159 & -0.259 & 1.769 & 720.70 & 2000 & 27 \\
\hline & Orthophosphate & 0.182 & 90 & -0.114 & -2.240 & 1.308 & -0.244 & -0.054 & & & & 1.118 & 958.30 & 2001 & 40 \\
\hline & Potassium & 0.025 & 92.65 & 0.159 & 1.190 & 0.645 & -0.022 & -0.005 & -0.003 & 0.127 & -0.016 & 1.481 & 757 & 2000 & 34 \\
\hline & Selenium & 0.346 & 57.37 & 0.048 & 1.573 & 0.607 & -0.580 & & & 0.354 & 0.354 & 2.200 & 958.00 & 2001 & 35 \\
\hline & Silica & 0.012 & 97.78 & -0.408 & 3.287 & 0.986 & -0.060 & & & & & 1.000 & 757 & 2000 & 34 \\
\hline & Sodium & 0.040 & 80.28 & -0.112 & 4.355 & 0.404 & -0.034 & -0.013 & -0.003 & 0.211 & 0.283 & 1.481 & 757 & 2000 & 34 \\
\hline & Sulfate & 0.020 & 86.45 & -0.126 & 5.634 & 0.401 & -0.059 & -0.011 & -0.001 & 0.157 & 0.157 & 1.473 & 758 & 2000 & 35 \\
\hline & $\begin{array}{l}\text { Suspended } \\
\text { sediment }\end{array}$ & 0.989 & 68.6 & 0.141 & 5.419 & 1.814 & 1.814 & -0.041 & & 0.244 & 0.106 & 1.440 & 750 & 2000 & 208 \\
\hline
\end{tabular}


Appendix 2. Model coefficients and statistical diagnostics from regression models used for trend analysis in the Piceance study area, Colorado.-Continued

[ERV, estimated residual variance; $\mathrm{R}^{2}$, coefficient of determination; SCR, serial correlation of residual; Ln, natural logarithm; Q, streamflow; t, decimal time in decimal years; Sin, sine function; Cos, cosine function; VIF, variation inflation factor; *, centered values; N, number of data points. Empty cells indicate variables not used in the regression because they were not statistically significant (p-value $>0.05$ ). Shaded cells indicate variables not statistically significant but included in the final regression. All constituents are dissolved unless otherwise stated]

\begin{tabular}{|c|c|c|c|c|c|c|c|c|c|c|c|c|c|c|c|}
\hline \multirow{2}{*}{$\begin{array}{l}\text { U.S. Geological } \\
\text { Survey } \\
\text { streamflow- } \\
\text { gaging stations } \\
\text { (all figures) }\end{array}$} & \multirow[b]{2}{*}{ Constituents } & \multirow[b]{2}{*}{ ERV } & \multirow[b]{2}{*}{$\mathbf{R}^{2}$} & \multirow[b]{2}{*}{ SCR } & \multirow[b]{2}{*}{$\begin{array}{c}\text { Y-axis } \\
\text { intercept } \\
\text { (Ln load) }\end{array}$} & \multicolumn{2}{|c|}{ Ln Streamflow } & \multirow[b]{2}{*}{$\mathbf{t}$} & \multirow[b]{2}{*}{$t^{2}$} & \multirow[b]{2}{*}{ Sin } & \multirow[b]{2}{*}{ Cos } & \multirow[b]{2}{*}{$\begin{array}{l}\text { Maximum } \\
\text { VIF }\end{array}$} & \multirow[b]{2}{*}{$\begin{array}{c}\mathbf{Q}^{*} \\
\text { central } \\
\text { value }\end{array}$} & \multirow[b]{2}{*}{$\begin{array}{c}\mathbf{t}^{*} \\
\text { central } \\
\text { value }\end{array}$} & \multirow[b]{2}{*}{$\mathbf{N}$} \\
\hline & & & & & & $\begin{array}{c}0 \\
\text { (Ln load) }\end{array}$ & $\mathbf{0}^{2}$ & & & & & & & & \\
\hline \multirow[t]{11}{*}{383946107595301} & Alkalinity & 0.008 & 97.9 & -0.119 & 3.056 & 0.650 & & & & -0.144 & -0.042 & & 32 & 2006 & 35 \\
\hline & Calicium & 0.014 & 95.2 & 0.215 & 3.209 & 0.458 & & & & -0.186 & -0.055 & 4.806 & 34 & 2000 & 83 \\
\hline & Chloride & 0.026 & 74.8 & -0.093 & 0.846 & 0.325 & & -0.006 & & -0.084 & 0.117 & 4.873 & 34 & 2000 & 83 \\
\hline & Dissolved solids & 0.015 & 88.8 & -0.022 & 5.338 & 0.320 & & & & -0.174 & 0.033 & 4.729 & 34.14 & 2000 & 84 \\
\hline & Fluoride & 0.033 & 96.0 & 0.067 & -3.092 & 0.820 & -0.116 & -0.007 & 0.001 & -0.043 & -0.114 & 5.108 & 34 & 2000 & 83 \\
\hline & Magnesium & 0.017 & 82.6 & -0.051 & 2.343 & 0.269 & & & & -0.181 & 0.077 & 4.806 & 34 & 2000 & 83 \\
\hline & Potassium & 0.046 & 86.1 & -0.048 & -0.280 & 0.568 & -0.076 & & & & & 1.000 & 34 & 2000 & 83 \\
\hline & Selenium & 0.050 & 38.2 & 0.227 & 2.620 & 0.120 & & 0.013 & & -0.159 & 0.063 & 4.491 & 34 & 2000 & 92 \\
\hline & Silica & 0.018 & 98.4 & 0.305 & 0.101 & 1.096 & & 0.011 & & -0.086 & -0.009 & 4.873 & 34 & 2000 & 83 \\
\hline & Sodium & 0.024 & 65.1 & -0.120 & 3.205 & 0.246 & & & & -0.131 & 0.148 & 4.806 & 34 & 2000 & 83 \\
\hline & Sulfate & 0.017 & 85.1 & -0.024 & 4.855 & 0.273 & & & & -0.190 & 0.038 & 4.806 & 34 & 2000 & 83 \\
\hline \multirow[t]{10}{*}{384551107591901} & Calicium & 0.032 & 95.7 & 0.250 & 1.855 & 0.543 & 0.070 & & & -0.232 & -0.021 & 3.519 & 12.02 & 1998 & 101 \\
\hline & Chloride & 0.051 & 81.2 & 0.221 & -0.503 & 0.390 & 0.086 & & & -0.082 & 0.220 & 3.475 & 12.02 & 1998 & 100 \\
\hline & Dissolved solids & 0.045 & 86.9 & 0.234 & 4.178 & 0.379 & 0.089 & & & -0.198 & 0.109 & 3.505 & 12.05 & 1998 & 103 \\
\hline & Fluoride & 0.022 & 98.9 & -0.030 & -4.535 & 0.951 & 0.021 & 0.014 & 0.003 & -0.091 & -0.137 & 3.564 & 12.02 & 1998 & 100 \\
\hline & Magnesium & 0.046 & 87.6 & 0.180 & 1.043 & 0.386 & 0.084 & & & -0.231 & 0.119 & 3.519 & 12.02 & 1998 & 101 \\
\hline & Potassium & 0.060 & 92.2 & 0.232 & -1.503 & 0.597 & 0.052 & & & -0.102 & 0.012 & 3.475 & 12.02 & 1998 & 101 \\
\hline & Selenium & 0.119 & 64.1 & 0.217 & 0.892 & 0.274 & 0.094 & -0.024 & & -0.271 & 0.144 & 3.542 & 12.02 & 1998 & 106 \\
\hline & Silica & 0.016 & 99.4 & 0.252 & -1.030 & 1.127 & -0.051 & 0.015 & & -0.110 & -0.138 & 3.476 & 12.02 & 1998 & 100 \\
\hline & Sodium & 0.061 & 68.8 & 0.162 & 2.288 & 0.282 & 0.080 & & & -0.151 & 0.222 & 3.519 & 12.02 & 1998 & 101 \\
\hline & Sulfate & 0.052 & 82.8 & 0.215 & 3.684 & 0.332 & 0.089 & & & -0.227 & 0.118 & 3.475 & 12.02 & 1998 & 100 \\
\hline
\end{tabular}



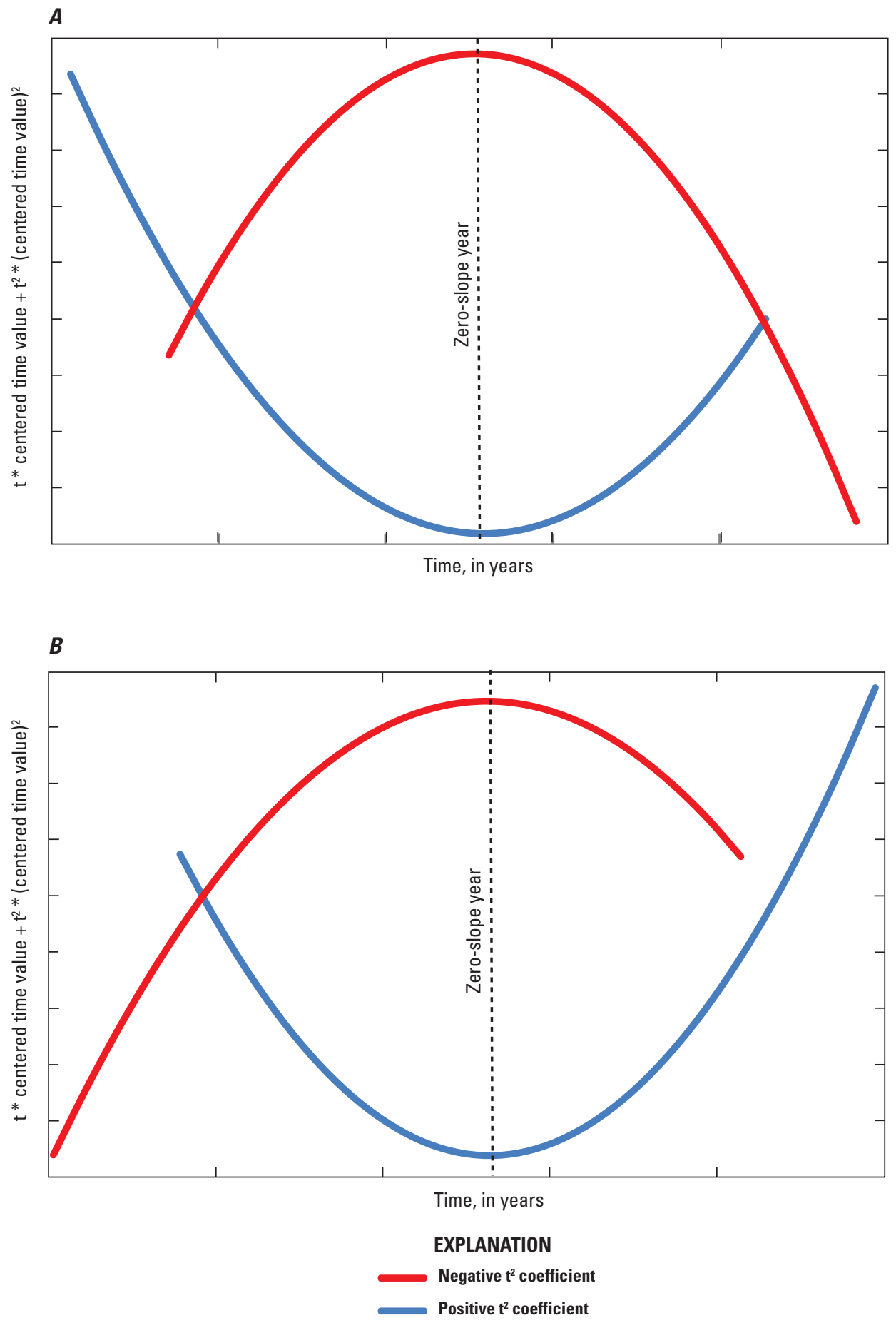

Appendix 3. Schematic diagrams of the model line without streamflow or seasonality terms to facilitate the determination of zeroslope year, net trend direction, and direction of the trend before and after the zero-slope year, $(A)$ illustrates net, downward trends where quadratic term $\left(t^{2}\right)$ is either positive or negative, and $(B)$ illustrates a net, upward trend where quadratic term $\left(t^{2}\right)$ is either positive or negative. $\left[t, t^{2}\right.$, and $t^{*}$ central value available in appendix 2 ; time, years from period of record available in tables 5,6 , and 7 ; centered time value $=$ time $-t^{*}$ central value $]$ 



\section{Plates}




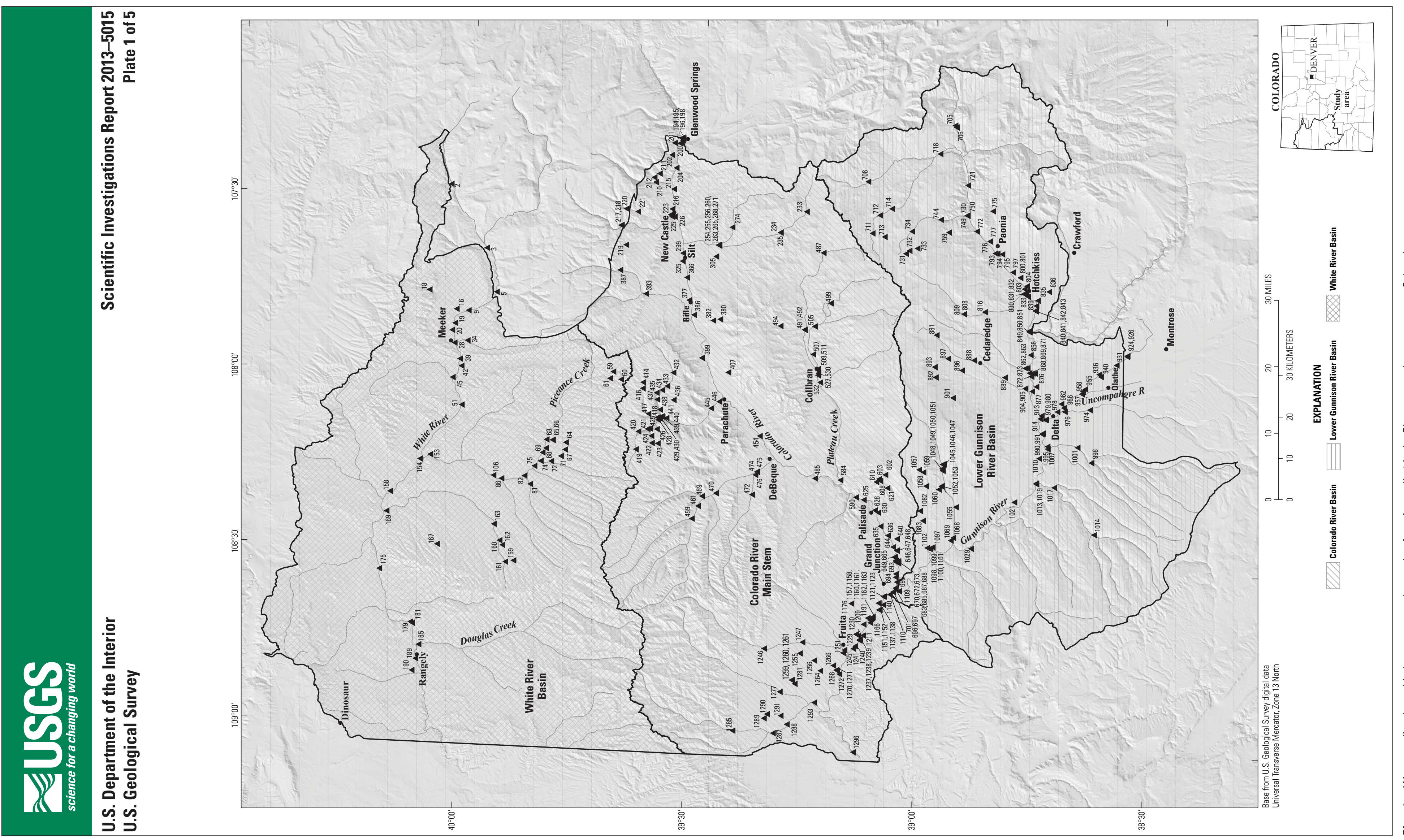




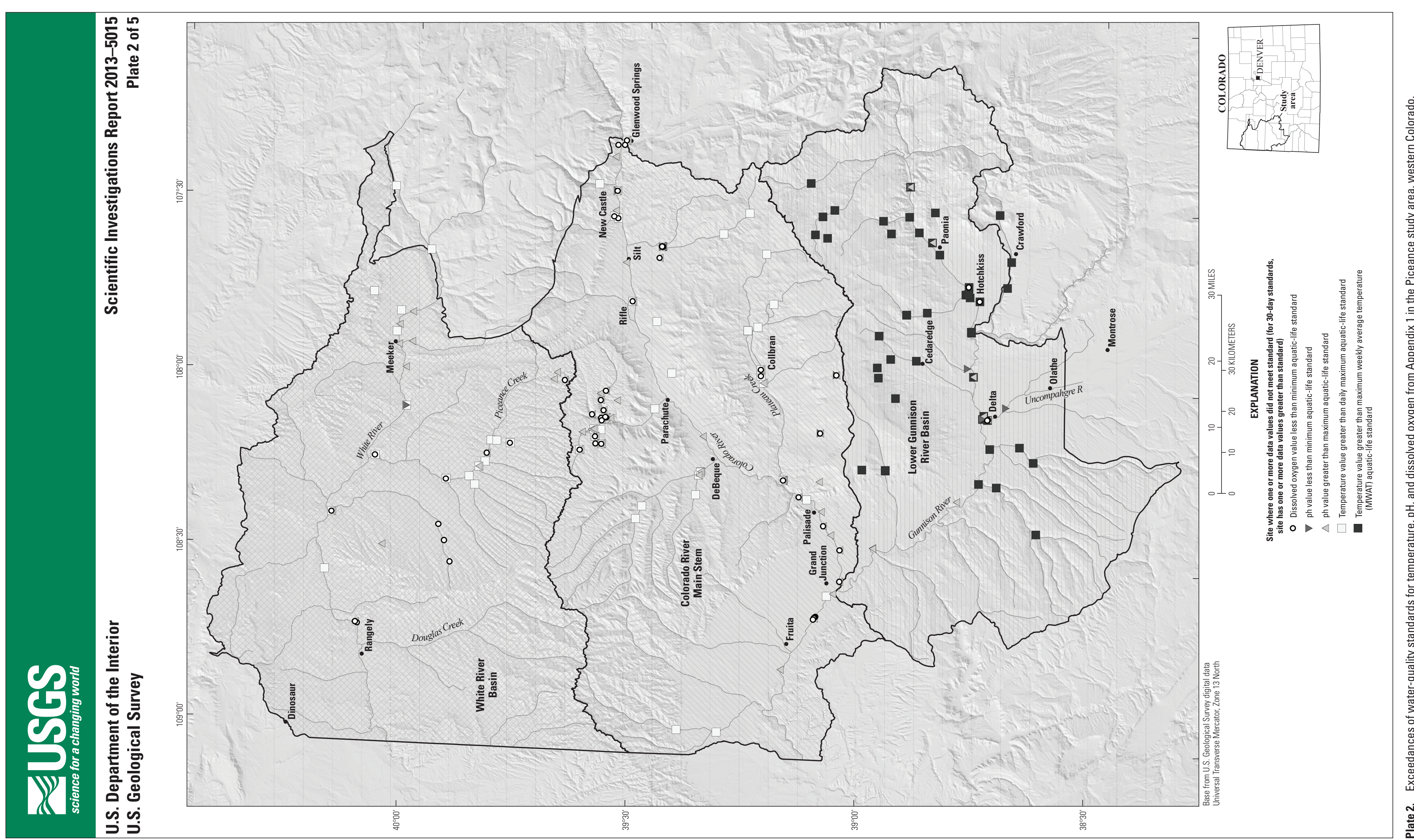



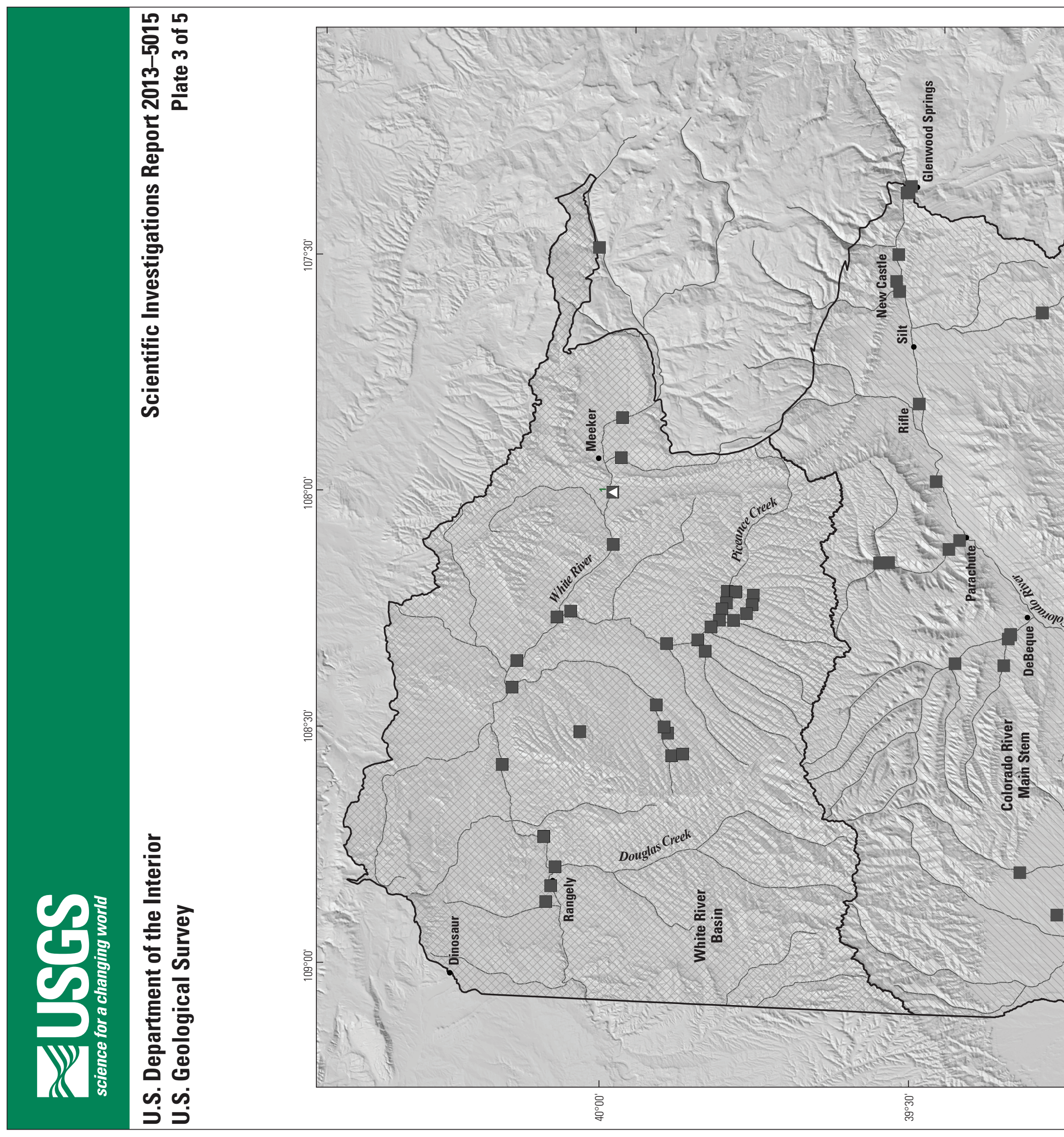

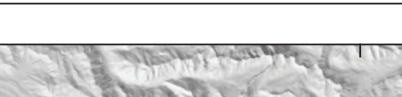

and $3 \int^{-3}$

?

$=2$

s.
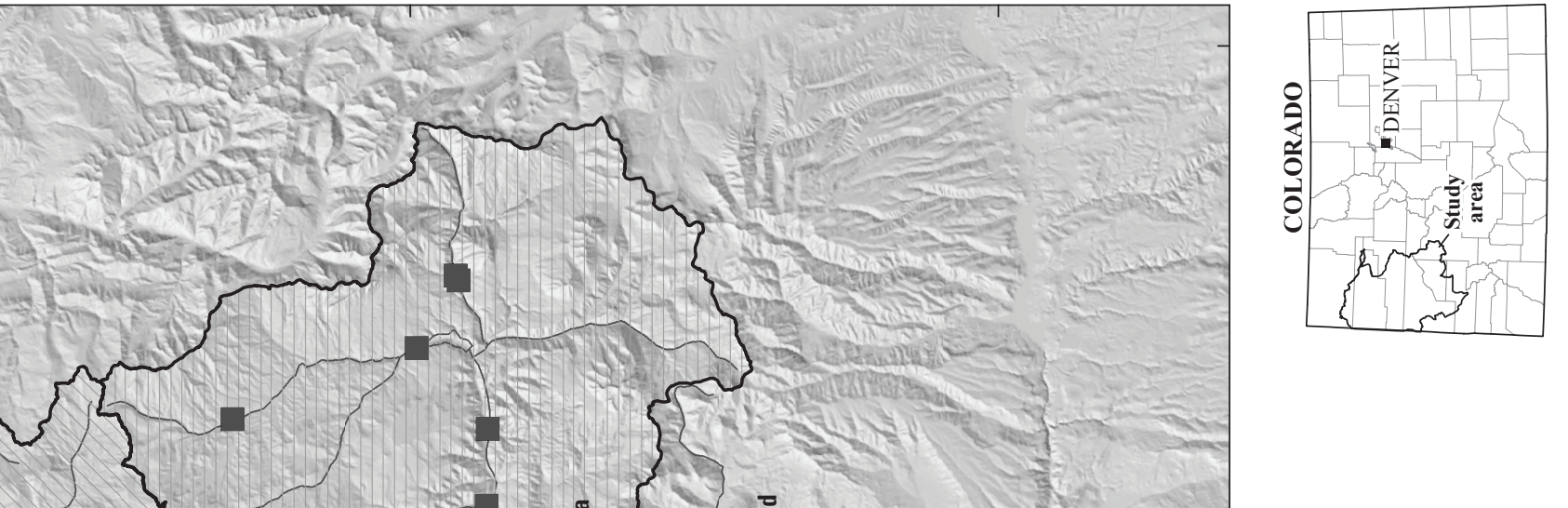

14.
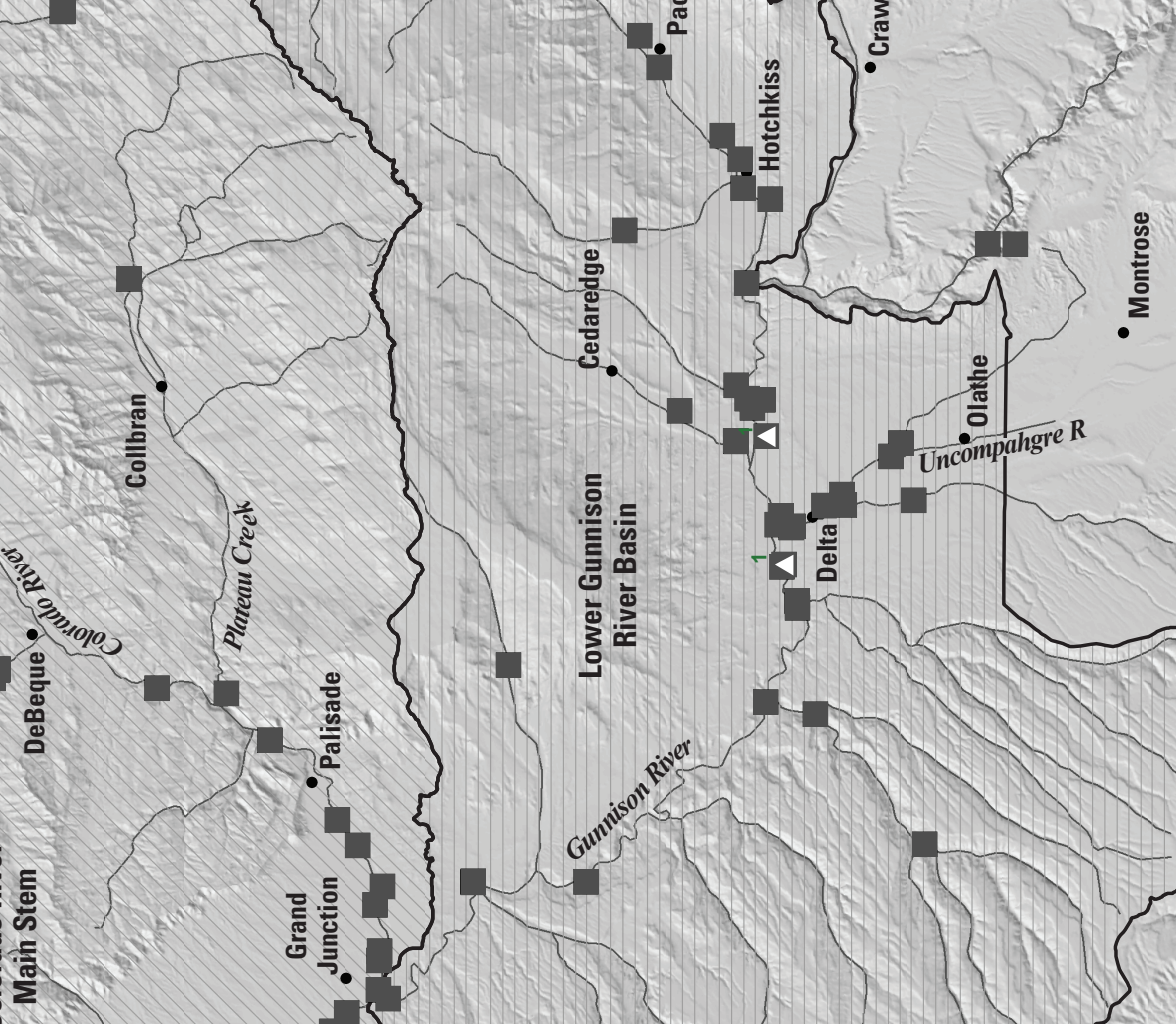

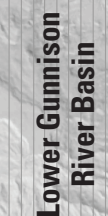
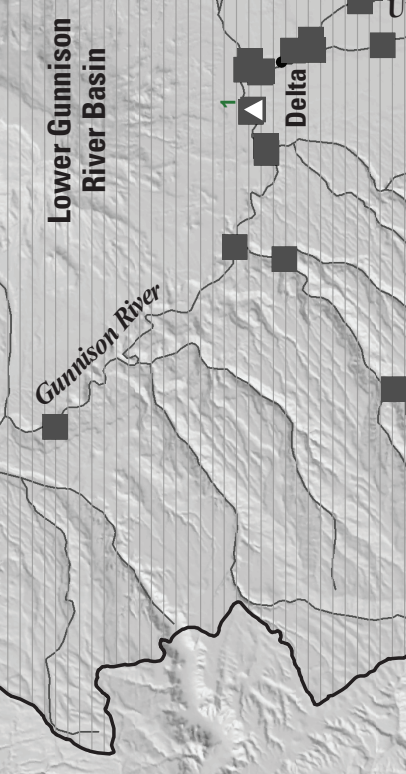

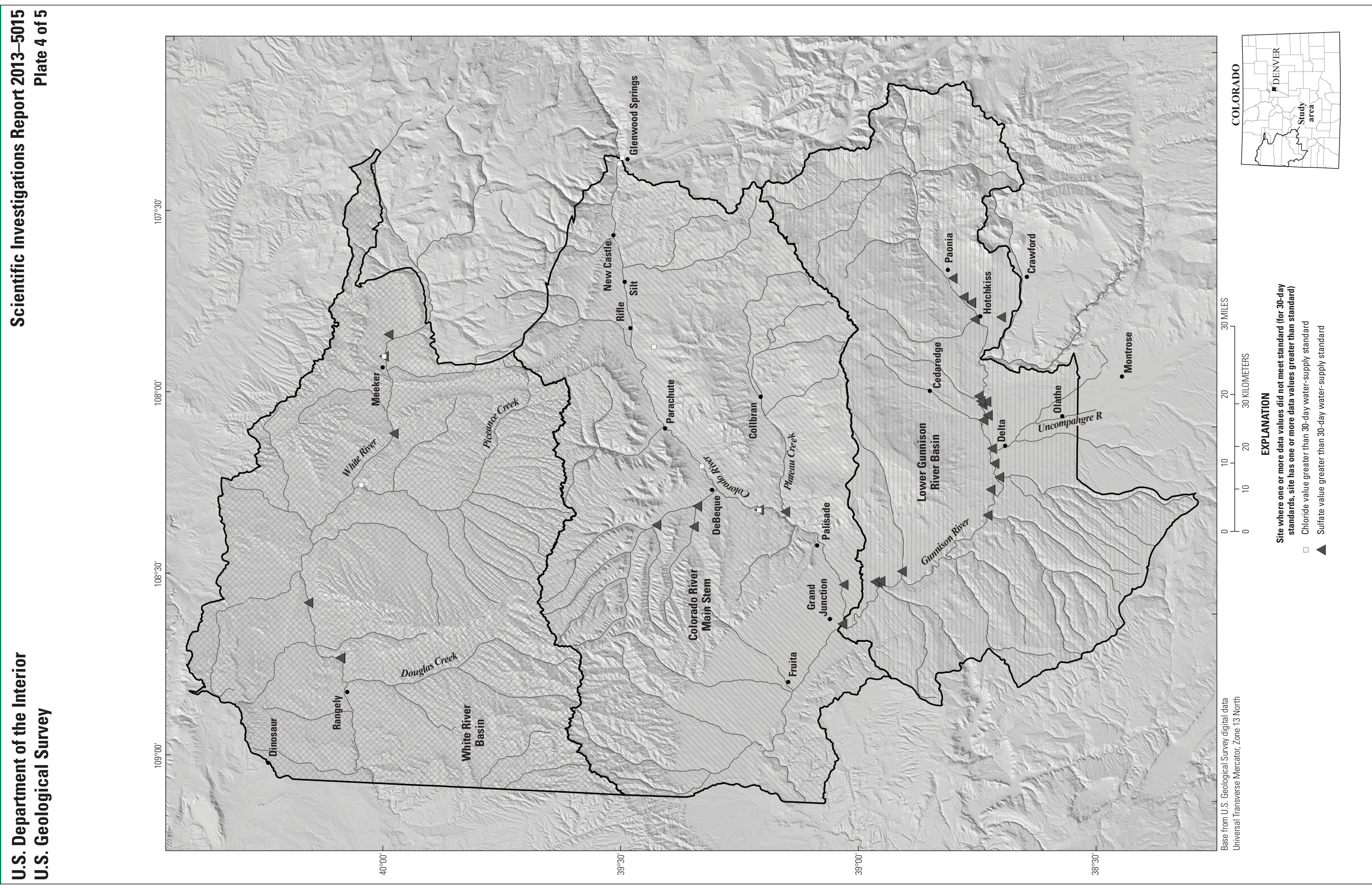


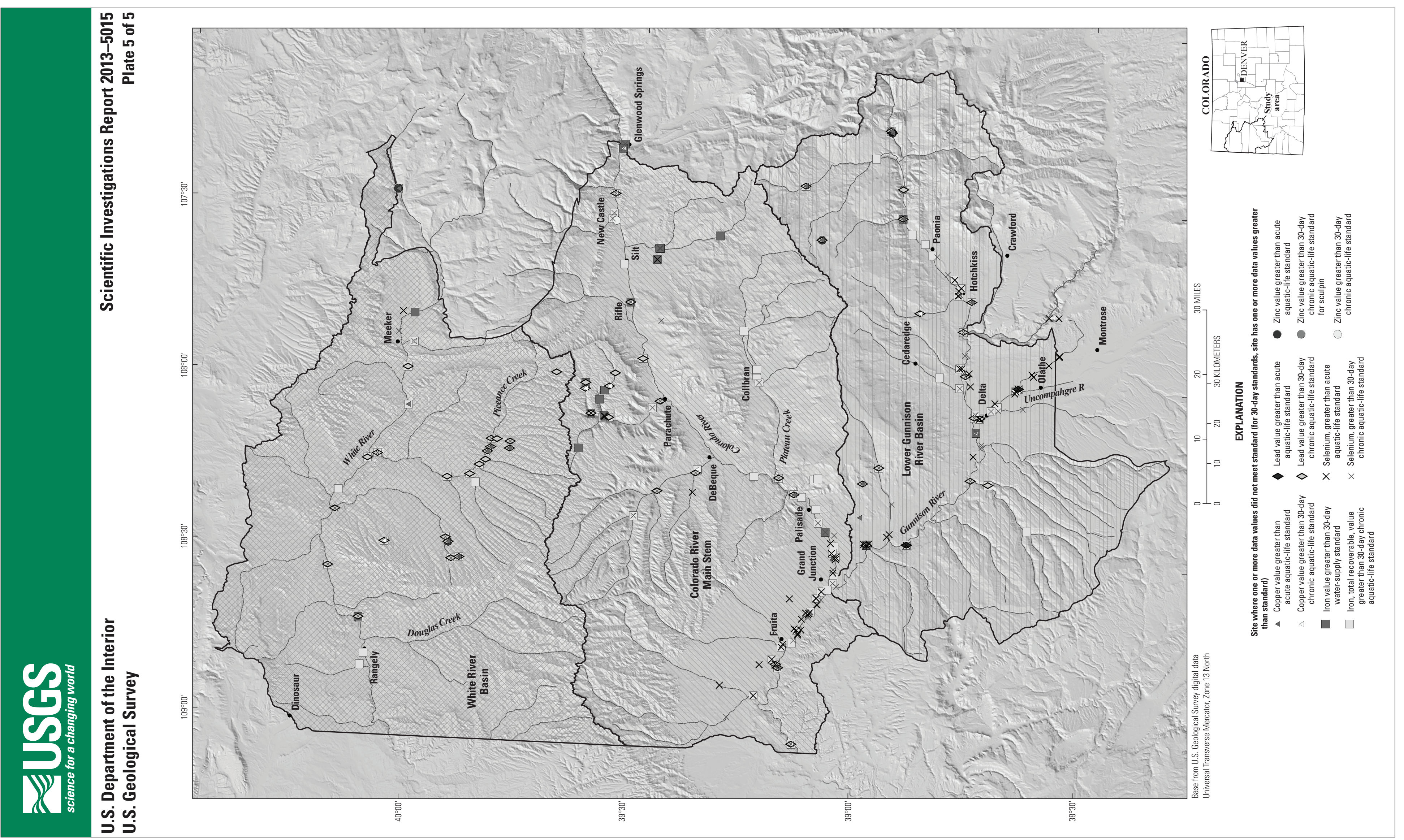


Publishing support provided by:

Denver Publishing Service Center, Denver, Colorado

For more information concerning this publication, contact:

Director, USGS Colorado Water Science Center

Box 25046, Mail Stop 415

Denver, C0 80225

(303) 236-4882

Or visit the Colorado Water Science Center Web site at: http://co.water.usgs.gov/

This publication is available online at: http://pubs.usgs.gov/sir/2013/5015/ 
